$$
\text { UNIVERSIDADE DE SÃO PAULO }
$$

FACULDADE DE FILOSOFIA, LETRAS E CIÊNCIAS HUMANAS

$$
\text { DEPARTAMENTO DE HISTÓRIA }
$$
PROGRAMA DE PÓS-GRADUAÇÃO EM HISTÓRIA

\title{
COLONIALISMO EM AÇÃO \\ Fiscalismo, Economia e Sociedade na Capitania da Paraíba
} (1647 - 1755) 


\title{
UNIVERSIDADE DE SÃO PAULO \\ FACULDADE DE FILOSOFIA, LETRAS E CIÊNCIAS HUMANAS \\ DEPARTAMENTO DE HISTÓRIA PROGRAMA DE PÓS-GRADUAÇÃO EM HISTÓRIA
}

\author{
COLONIALISMO EM AÇÃO \\ Fiscalismo, Economia e Sociedade na Capitania da Paraíba \\ (1647 - 1755)
}

MOZART VERGETTI DE MENEZES

Tese apresentada ao Programa de Pós-Graduação em História Econômica, do Departamento de História da Faculdade de Filosofia, Letras e Ciências Humanas da Universidade de São Paulo, para obtenção do título de doutor em História.

Orientação: Prof. Dr. José Jobson de Andrade Arruda

São Paulo

2005 

Para José Laudelino, meu filho. 


\section{ÍNDICE}

$\begin{array}{ll}\text { Lista de Quadros } & 7\end{array}$

Agradecimentos 9

$\begin{array}{ll}\text { Resumo/Abstract } & 10\end{array}$

$\begin{array}{ll}\text { Introdução } & 12\end{array}$

\section{CAPÍTULO I:}

O ENQUADRAMENTO ESPAÇO JURISDICIONAL

E POLÍTICO-ADMINISTRATIVO DA FAZENDA REAL PARAIBANA.

1.1. A administração fazendária central e periférica no reino

1.2 Administração financeira na colônia: legislação e especificação 35

1.3. Os limites jurisdicionais nas capitanias do norte

1.3.1. A jurisdição político-militar

1.3.2. A jurisdição eclesiástica 57

1.3.3. A jurisdição judiciária

1.3.4. A jurisdição fazendária

\section{CAPÍTULO II:}

O BUTIM DA GUERRA BRASÍLICA: A ADMINISTRAÇÃO

DA FAZENDA REAL PARAIBANA COMO ESPÓLIO DA CONQUISTA

2.1. Laços de sangue e alianças

2.1.1. As escrivanias: Garro ou Bandeira?

2.1.3. A Provedoria da Fazenda: os Dourados

2.1.3.1. O retraimento da jurisdição: a criação da Ouvidoria Geral 86

2.1.3.2. O retraimento da jurisdição: Defuntos e Ausentes

2.1.3.3. Sobrevivência em uma capitania deficitária 


\section{CAPÍTULO III:}

AS AGRURAS ECONÔMICAS DA CAPITANIA DA PARAÍBA E OS PRÓDROMOS DA ANEXAÇÃO

3.1. Receitas da Provedoria da Fazenda Real da Capitania da Paraíba

3.1.1. Os Dízimos

118

3.1.2. O Subsídio do Açúcar

3.1.3. Outros impostos sobre o açúcar

3.1.4. O Subsídio da Carne

132

3.1.5. Os direitos dos impostos reais sobre os escravos

3.1.6. Os Novos Direitos

3.1.7. A Dízima

3.1.8. Tomadias

155

3.2. Despesas

158

3.2.1. A evolução dos ofícios da Provedoria da Fazenda Real da Paraíba

3.2.1.1. Os ofícios da Provedoria: ordenados, propinas e emolumentos

3.2.3. O restante da Folha Secular

3.2.4. A Folha Eclesiástica 172

3.2.5. A Folha Militar $\quad \mathbf{1 7 5}$

3.2.6. A Fortaleza do Cabedelo, as despesas miúdas e o casamento dos príncipes

3.2.7. As despesas da Fazenda: uma relação entre as folhas de pessoal

\section{CAPÍTULO IV:}

A FAZENDA COMO RECURSO DA AUTONOMIA:

4.2. O atrelamento das provedorias: 
4.2.1. Pedro Monteiro: sonhos, estratégias fiscais e o corolário das dívidas novas e velhas

4.2.2. Dívida Nova e Dívida Velha

4.2.3. Lemos de Brito e o ônus da anexação

4.3. Epílogo: o ocaso dos conselheiros:

a anexação da Paraíba, um projeto pombalino?

CONCLUSÃO 


\section{LISTA DE QUADROS:}

QUADRO 1. Capitania da Paraíba / Receita: Dízimo. $\quad \mathbf{1 2 0}$

QUADRO 2. Capitania da Paraíba / Receita: Subsídio do Açúcar. 127

QUADRO 3. Capitania da Paraíba / Receita: Dízimo \& Subsídio do Açúcar. 130

QUADRO 4. Capitania da Paraíba / Receita: Cruzado e $\$ 80$ réis das Caixas de Açúcar.

QUADRO 5. Capitania da Paraíba / Receita: Subsídio da Carne. 137

QUADRO 6. Capitania da Paraíba / Receita: Dízimo \& Subsídio da Carne. 139

QUADRO 7. Capitania da Paraíba / Receita: Imposto dos $3 \$ 500$ réis que pagam os Escravos provenientes da Costa da Mina e os 12 tostões para a Feitoria de Ajudá.

QUADRO 8. Capitania da Paraíba / Receita: Recolhimento da Dízima. 153

QUADRO 9. Capitania da Paraíba / Receita: Tomadias de Escravos e fazendas.

QUADRO 10. Capitania da Paraíba / Receita: Arrendamento do Engenho Santo André. $\quad 157$

QUADRO 11. Capitania da Paraíba / Despesa: propinas e ordenados dos oficiais $\begin{array}{ll}\text { da Fazenda da Paraíba. } & 168\end{array}$

QUADRO 12. Capitania da Paraíba / Despesa: O restante da Folha Executiva / Secular. 172

QUADRO 13. Capitania da Paraíba / Despesa: Folha Eclesiástica. 175

QUADRO 14. Capitania da Paraíba / Despesa: Folha Militar, anterior a 1724.

QUADRO 15. Capitania da Paraíba / Despesa: Folha Militar, posterior a 1724.

QUADRO 16. Capitania da Paraíba / Despesa: Folhas de Pagamento em \%. 186

QUADRO 17. Capitania da Paraíba / Despesa: Folhas de Pagamento em decênio 1695 - 1755.187

QUADRO 18. Capitania da Paraíba / Totais de Receita \& Despesa. 189 


\section{AGRADECIMENTOS}

Muitas pessoas estiveram presentes na minha vida durante os anos deste doutorado. Primeiramente, gostaria de agradecer ao professor Jobson Arruda, meu orientador, suas críticas e sugestões foram fundamentais, tanto durante a pesquisa como na redação final. Amigos e parentes me ajudaram de diferentes maneiras, por isso os agradecimentos também são sentimentais. Getúlio, Júlia, Vanda, Aurélio, Lucila e Erlick sempre agüentaram este caçula nas estadas do Recife, fazendo de suas casas a minha casa. Élio, Jonas, Íris, Rosa, Jorge, Regina Célia e Barroso, amigos de todas as horas, obrigados a ouvir e compartilhar, às vezes a contragosto, as minhas idiossincrasias. Regina Behar, meia-irmã adotiva, que a vida me fez o prazer de encontrar na Paraíba. E Alcione, cuja serenidade, carinho e amor, nos dois últimos anos recentes, deram um sabor especial.

Tenho também que agradecer a Ana Cláudia e Eduardo, que me acolheram em São Paulo. Como aos amigos de Lisboa: Sintra, Otávio e Jorge que sempre facultaram o acesso ao material do Arquivo Histórico Ultramarino. Da mesma forma, não posso esquecer de agradecer a atenção de Dona Waldice, do Instituto Histórico Paraibano.

Por fim, agradeço ao apoio dos colegas do departamento de História da UFPB, Campus 1, pela presteza de cobrir as minhas obrigações e também à CAPES, que durante quatro anos patrocinou a pesquisa, através de bolsa PICDT.

Como é de praxe o lembrete, só ao autor cabe a responsabilidade pelo presente escrito. 


\title{
RESUMO
}

O trabalho versa sobre o processo de montagem e falência de um órgão administrativo, a Provedoria da Fazenda Real da Capitania da Paraíba (1647 - 1755). Através da análise sistêmica, política-administrativa, do órgão fazendário paraibano, podese entender a relação contraditória entre o funcionamento, na esfera fiscal, da estrutura patrimonialista montada desde a expulsão dos holandeses da Paraíba, e as investidas centralizadoras do fiscalismo régio. Tais investidas foram sentidas: a) na busca da diminuição de privilégios dos administradores da Fazenda paraibana; b) na constante centralização dos vários pontos de receita existentes na capitania para o seio da Provedoria da Fazenda; e c) na radical intervenção do Marquês de Pombal, quando do decreto da anexação e subordinação da Capitania da Paraíba à de Pernambuco. Destaca-se ainda, a trajetória da falência econômica da Capitania da Paraíba, cuja asfixia repercutiu na crise fiscal e na subordinação.

Palavras chave: 1. Capitania da Paraíba; 2 Patrimonialismo; 3. Provedoria da Fazenda; 4. Fiscalismo Régio; 5. Capitania Subordinada.

\begin{abstract}
This work studies the process of setting as well as bankruptcy of an administrative organ, the department of the royal treasury Captaincy of Paraíba (1647 - 1755). Throughout the analysis of the political and administrative system of this organ, the research points out a contradictory relationship between the patrimonial structure that was built on the occasion of the expulsion of the Dutch from Paraíba, and the attempts to centralize the charge of tributes under the royal control. Such attempts may be characterized by the following actions: a) trying to diminish the privileges of the administrators; b) centralizing the various points of receipts under the department of royal
\end{abstract}


treasury control; c) annexing and subordinating Captaincy of Paraíba to Pernambuco one, a radical intervention by Marquis of Pombal. In addition, the work emphasizes the course of economic bankruptcy of Captaincy of Paraíba, resulting in the crisis of the charge of tributes as well as in the subordination.

Key words: 1. Captaincy of Paraíba; 2. Patrimonial structure; 3. Department of the royal treasury; 3. Royal fisc; Subordinate captaincy. 


\section{INTRODUÇÃO}

As Provedorias de Fazenda Real nas capitanias, com os seus provedores à testa, foram estabelecimentos que enraizaram e asseguraram o domínio do Estado português na colônia brasileira. ${ }^{1}$ Foram também, pode-se dizer, a pedra angular que determinou os níveis e as possibilidades de ação autônoma dos governadores, na correlação de forças entre as várias capitanias que compunham uma determinada região. ${ }^{2}$ A existência ou não de uma capitania autônoma estava condicionada à necessária e irremediável possibilidade de ser a Provedoria da Fazenda capaz de gerir todos os gastos com pessoal e segurança, além de atender às exigências dos eternos socorros à Coroa portuguesa, como os pagamentos de donativos, novos direitos e compromissos diplomáticos. A falta constante no cumprimento dessas obrigações poderia acarretar a perda da autonomia, com a conseqüente anexação do governo a outra capitania.

A Provedoria da Fazenda Real da Capitania da Paraíba, quando da sua remontagem, após o fim do período de beligerância contra os batavos, c.1647, até a decretação de sua falência por D. José I, em dezembro de 1755, quando se assistiu à anexação da Paraíba à capitania de Pernambuco, objeto deste trabalho, presta-se à defesa da premissa anunciada acima.

Este estudo desenvolve-se a partir de uma abordagem sistêmica, políticoadministrativa, do órgão fazendário, valorizando, na atuação-gestão da Fazenda Real paraibana, as relações entre o governo e a sociedade. Tal perspectiva está articulada aos

\footnotetext{
${ }^{1}$ Essa premissa tem base nas idéias formuladas pela professora Bellotto que, em 1984, há exatos vinte e um anos, apresentou uma proposta de pesquisa que então desenvolvia, sobre as juntas de Fazendas existentes no Brasil Colônia, durante o governo pombalino. Cf: Heloísa Liberalli Bellotto. “Administração Fazendária no Brasil Colonial: A junta de Fazenda da Fazenda da Capitania de São Paulo (1762 - 1808)”. São Paulo; Anais da III Reunião da SBPC, 1984.p. 121-124 .

${ }^{2} \mathrm{O}$ uso do termo região refere-se aqui à divisão geopolítica do espaço brasileiro que, em alguns lugares, expressa ainda no processo de expansão e conquista da colônia e, em outros, estrategicamente efetivado por Lisboa, passou a ter algumas capitanias, ascendência militar e econômica sobre uma determinada região: Maranhão (Estado do Grão Pará), Pernambuco (Capitanias do Norte), Bahia (Governo Geral, que se bastava a Sergipe, Ilhéus e Porto Seguro) e Rio de Janeiro (Repartição Sul). Exemplos disso são as designações das frotas, as quais tomaram os nomes das respectivas capitanias. Por outro lado, Acioli, por exemplo, asseverando o exposto, diz que os governadores de Pernambuco sempre argumentavam ao rei que, isentar o restante das capitanias do Norte das suas jurisdições, era o mesmo que inverter a relação de poder, pois "estariam elas subordinando-o para dele lhes tirar socorro de gente, fazenda, munições e armas, sem dar razão de despesa, nem obediência." Cf: Vera Lúcia Costa Acioli. Jurisdição e conflito: a força política do senhor de engenho. Recife: UFPE / Departamento de História, 1989. p. 93.
} 
fenômenos estruturais do funcionamento do colonialismo português, que encontra nas proposições teóricas do Antigo Sistema Colonial o seu sentido e as possibilidades de sua explicação. ${ }^{3}$

Desta forma, o antigo sistema colonial compreende: $1^{\circ}$ - que o capital mercantil ascendente, após a desagregação do feudalismo, impulsionou a expansão comercial da Europa, orientando-se pela formulação da política econômica do mercantilismo; $2^{\circ}$ - que a competição internacional e a necessidade de executar a política mercantilista favoreceram o desenvolvimento de Estados Absolutistas na Europa; $3^{\circ}$ - que a colonização européia da época moderna, protagonista da expansão comercial ultramarina que, a princípio, limitava-se ao extrativismo de matérias primas e comercialização no ultramar, transitou, no Brasil, para área de produção, pressupondo a montagem de uma nova sociedade: uma sociedade escravista colonial; $4^{\circ}$ - que a formação e desenvolvimento das economias periféricas do antigo sistema colonial tiveram, na história do capitalismo, a função de promover a aceleração da acumulação primitiva na Europa; e $5^{\circ}$ - que "a relação metrópole (Portugal) e a colônia (Brasil), realizava-se sob a égide da noção de exclusivismo comercial, ou seja, o monopólio do fluxo mercantil reservado unicamente para a metrópole, cuja efetividade tornava imprescindivel a adoção de uma forte política protecionista que exigia, por seu turno, ações de natureza fiscal e militar para sua consecução." 4

A efetividade e pleno funcionamento desse quadro estrutural teórico-histórico de relações entre a metrópole e sua colônia, administrativamente falando, ancorava-se, portanto, nos organismos reguladores e fiscais do regime de comércio monopolista, eixo do sistema da colonização moderna. ${ }^{5}$ A máquina montada para a exeqüibilidade da malha fiscal, como qualquer outro organismo administrativo do Estado imperialista português, obedeceu, mesmo sem todos os encaixes nos momentos e manifestações do antigo sistema colonial, aos limites impostos pela estrutura política do período. Estrutura essa que, no seu âmago, fazia interagir reversivamente, isto é, num estado de quase equilíbrio, absolutismo,

\footnotetext{
${ }^{3}$ Fernando A. Novais. Portugal e Brasil na crise do Antigo Sistema Colonial (1777-1808). 7 ed. São Paulo; HUCITEC, 2001.

${ }^{4}$ José Jobson de A. Arruda. "O sentido da Colônia, revisitando a crise do Antigo Sistema Colonial”. In: José Tengarrinha. (org.) História de Portugal. 2 ed. Bauru, EDUSC; São Paulo, UNESP; Lisboa, Instituto Camões, 2001. p. 2.

5 José Ribeiro Júnior. Colonização e monopólio no Nordeste Brasileiro: a Companhia Geral de Comércio de Pernambuco e Paraíba (1759-1780). São Paulo; HUCITEC, 1976. p. 3.
} 
sociedade estamental, patrimonialismo, capitalismo comercial, política mercantilista, colonialismo, expansão ultramarina e colonial, num complexo que se poderia chamar, mantendo um termo da tradição, de Antigo Regime. ${ }^{6}$

Desta forma, durante a vigência do Antigo Regime em Portugal, e independentemente da característica de governo que tomou a monarquia portuguesa - se absolutista, coorporativa, ${ }^{7}$ patrimonial $^{8}$ ou burocrático mercantilista ${ }^{9}$ - esta se fez fortalecer, na colônia brasileira, através de um crescente grau de centralização, na medida em que transferia para as mãos das Provedorias de Fazenda Real das capitanias, antigos tipos de impostos tradicionalmente administrados pelas Câmaras Municipais. O fiscalismo

\footnotetext{
${ }^{6}$ Fernando A. Novais. Portugal e Brasil na crise do Antigo Sistema Colonial (1777-1808)... Op. cit. p. 66 ${ }^{7}$ A fórmula mais acabada sobre a existência de uma monarquia corporativa em Portugal encontra-se nas proposições de Antonio Manuel Hespanha. Para ele, seria impossível se falar em Estado, pelo menos até meados do século XVIII, tornando-se um anacronismo conceitual pensar que a centralização ali existente tivesse levado à separação da sociedade política, ou seja, do Estado - entidade que detém em exclusivo o poder de coação e a quem compete a mediação do interesse público dos interesses particulares - da sociedade civil - domínio de realização dos interesses particulares. Pelo contrário, no Portugal do Antigo Regime, o poder fôra extremamente repartido através de uma miríade de concessões em forma de mercês e doação de benefícios, ou de articulações de amizades e relações clientelares. Essas concessões, portanto, criaram uma infinidade de células sociais - pluralismo - que mantinha com o poder real uma articulação horizontal polissinodal -, a quem e para quem era atribuída uma simples superioridade e não a exclusividade do poder, daí, para Hespanha, ser mais apropriado pensar numa monarquia corporativa que absoluta. Ver do autor: Poder e instituições na Europa do Antigo Regime (coletânea de textos). Lisboa: Fundação Calouste Gulbenkian, 1984; Às vésperas do Leviathan: instituições e poder político, Portugal - século XVII. Coimbra: Almedina, 1994; “As estruturas políticas em Portugal na Época Moderna”. In: José Tengarrinha (org.). História de Portugal. Bauru, EDUSC; São Paulo: UNESP; Lisboa, Instituto Camões, 2001. p. 117 - 182; e, "A constituição do Império português. Revisão de alguns enviesamentos". In: João Fragoso, Maria Fernanda Bicalho \& Maria de Fátima Govêa. O Antigo Regime nos Trópicos: a dinâmica imperial portuguesa, séculos XVI - XVIII. Rio de Janeiro: Civilização Brasileira, 2001. p. 163 - 187. José Mattoso (dir.). História de Portugal. Vol IV. Antônio Manuel Hespanha (coord.). O antigo Regime - 1620-1807. Lisboa, Editorial Estampa, 1988.

${ }^{8}$ A constituição de um Estado Patrimonial em Portugal, como bem demonstrou Eduardo d'Oliveira França, deu-se ainda no bojo da Reconquista e guerra contra os mouros. Neste sentido, no processo de centralização política monárquica, passou-se a associar à idéia da patrimonialidade régia, isto é, que o poder do rei se colocava acima do patrimonium e poder dos particulares, à idéia da patrimonialidade da autoridade. "A conseqüência dessa associação é que, gradativamente, foram se processando o fortalecimento do poder real e a centralização da monarquia, ao mesmo tempo em que a aristocracia foi perdendo espaço político. Ou seja, o patrimonialismo teria cumprido um papel determinante no processo de construção do poder real rumo à formação do Estado centralizado, com o seu corpo de leis traduzidos na tentativa da normatização, que resultou nas Ordenações Manuelinas (1514) e nas Ordenações Filipinas (1603), e sua burocracia, que passou a ter o objetivo de administrar e salvaguardar a 'coisa pública'. Processava-se, assim, a separação entre o público e o privado”. Cf: Eduardo d'Oliveira França. O poder real em Portugal e as origens do absolutismo. São Paulo. USP, 1946, apud Regina Célia Gonçalves. Guerras e Açucares. Política e Economia na Capitania da Paraíba (1585-1630). São Paulo. Tese de Doutoramento/FFLCH/USP (Departamento de História), 2003. p. 170.

${ }^{9}$ Sobre o estado Burocrático Mercantilista ver: Vitório Magalhães Godinho. "Finanças públicas e estrutura do Estado". In: Joel Serrão (dir.). Dicionário de História de Portugal. Porto: Livraria Figueirinhas, 1971. v. 2 . p. 244-264.
} 
régio, portanto, essa preocupação excessiva da Coroa com a administração dos recursos tributáveis, receita e despesa, foi um dos mecanismos sobre os quais se estruturaram a política e a prática colonizadora dos Estados Modernos. ${ }^{10}$

Ainda, porém, no que tange à discussão acerca da administração, devem ser levados em conta alguns aspectos da teoria weberiana, que se mostram da maior importância para o presente estudo. É sabido que os estudos sobre a administração têm sua origem nas proposições teóricas fundadas por Max Weber. Coube, ao teórico alemão a primazia de chamar a atenção para o fato de que: se "toda dominação manifesta-se e funciona como administração", logo, "toda administração, de alguma forma, precisa da dominação, pois, para dirigi-la, é mister que certos poderes de mando se encontrem nas mãos de alguém." Portanto, as formas de dominação - entendidas como os mecanismos de legitimação do poder - e a administração - entendida como os meios que possibilitam engendrar $e$ reproduzir a dominação -, são elementos inseparáveis. ${ }^{11}$

Deste modo, haveria uma correspondência entre a forma de administração, seja ela tradicional (doméstica ou patrimonial) ou burocrática e os sistemas de dominação (patriarcal, patrimonial e racional legal), que se legitimariam na representação destes mesmos tipos administrativos. Esquematicamente, enquanto nos modelos pré-burocráticos, as relações entre o governante e os subordinados se dariam numa dimensão pessoal, no modelo burocrático haveria a impessoalidade. As diferenças seguem daí por diante: para as relações de piedade, haveriam as normas abstratas; para as normas pautadas na experiência (instruídas na crença da tradição), haveriam as normas pautadas na razão (legalidade abstrata, instruída pela técnica); para a legitimidade da norma não-estatuída, sagrada pela tradição, onde o potentado concreto é o senhor (poder ilimitado e arbitrário), haveria a legitimidade estatuída, que se apoiaria numa competência especial (o especialista), estabelecida mediante uma regra; para a falta de fixidez nas atribuições do cargo, haveria a regra disciplinadora da hierarquia; para a remuneração mediante o pagamento de emolumentos por atos realizados, muitas vezes atribuídos casuisticamente, haveria o

\footnotetext{
${ }^{10}$ Um bom manual sobre o desenvolvimento dos tributos no Brasil é o trabalho de Fernando José Amed \& José Labriola de Campos Negereiro. História dos tributos no Brasil. São Paulo: Edições SINAFRESP, 2000. 11 Weber, Max. Economia e sociedade: fundamentos da sociologia compreensiva. Brasília. Editora Universidade de Brasília, 1999. p. 193.
} 
emolumento ou o salário, fixado pela responsabilidade do cargo; para o compromisso do exercício do poder, lastreado na fidelidade à pessoa do senhor, haveria o exercício do poder voltado para o bem público. $^{12}$

Claro que uma abordagem que visasse estabelecer o enquadramento neste ou naquele estágio de dominação ou padrão administrativo, deveria partir de um estudo comparativo: enfocar, quadro a quadro, realidades históricas distintas, confrontá-las e registrar, passo a passo, os detalhes que pudessem, genericamente, definir em que tipo ideal - patriarcal, patrimonial ou burocrático - poderia ser emoldurado o plano de dominação administrativa que lhe fosse característico. Mas tal recurso metodológico, como enfatiza Schwartz, dificilmente se encaixaria ao mundo luso-colonial moderno. Não só pela inconveniência em tratar do "Império Português que se desenvolveu num período histórico de transição e, portanto, continha elementos de pelo menos dois dos estágios de Weber e não se encaixava corretamente em nenhum", mas, também, por ter sido a "administração brasileira caracterizada por mudanças constantes e grande flexibilidade (...) com os elementos mais profissionalizados da burocracia, continuando a ter valores e perseguir fins contrários àqueles da administração profissional." 13

Sublinhe-se, entretanto, que o próprio Weber se preocupa em evidenciar que a transição da estrutura pré-burocrática para a burocrática pura - característica, no Ocidente, do período monárquico absolutista - não pode ser "compreendida de forma demasiadamente mecânica", sendo comum que "germes de uma autêntica burocracia já se encontrem em forma pouco complicada na administração do Estado patrimonial sendo, em geral, nada abrupta a transição do cargo patrimonial ao burocrático...". 14 Neste caso, o problema levantado por Schwartz deve ser minimizado, pois, para Weber, a "via revolucionária" para a transição burocrática, que "aniquilou formas estruturais da dominação que não tinham caráter racional”, foi característica de formações históricas bastante específicas. ${ }^{15}$

\footnotetext{
${ }^{12}$ Idem ibidem. Op. cit. p. 303

${ }^{13}$ Stuart B. Schwartz. Burocracia e sociedade no Brasil colonial. São Paulo; Editora Perspectiva, 1979. p. xiv-xv.

${ }^{14}$ Max Weber. Economia e sociedade: fundamentos da sociologia compreensiva.... Op. cit. p. 303.

${ }^{15}$ Idem ibidem. Op. cit. p. 233. Para Sergio Holanda, "o funcionalismo patrimonial pode, com a progressiva divisão das funções e com a racionalização, adquirir traços burocráticos. Mas em sua essência ele é tanto mais diferente do burocrático, quanto mais caracterizados estejam os dois tipos." E continua, "é possivel acompanhar, ao longo da nossa história, o predomínio constante das vontades particulares que encontram
} 
Contudo, isto não quer dizer que tomaremos a tipologia administrativa weberiana na sua totalidade. Na verdade, este trabalho lançará mão de conceitos weberianos, como parâmetros de alcance teórico, na medida em que, na investigação histórica empírica, se mostrarem profícuos para a compreensão da experiência temporal sob exame. Conceitos como controle patrimonial, no qual a "administração é tratada como assunto puramente pessoal do senhor" e onde falta, sobretudo, a "distinção burocrática entre esfera pública e a oficial, "16 podendo tomar o cargo a expressão privada do seu ocupante, são extremamente fecundos para a nossa análise. Tal perspectiva compreende a possibilidade de se perscrutar, na distinção ou indistinção do público-privado, as soluções de continuidade ou ruptura que se fizeram presentes nas relações de poder, entre as elites locais ou ultramarinas, no trato com a coisa administrativa. É desta aparente fissura - da imbricação entre o público-privado $-{ }^{17}$ que se pode abrir um leque de questões sobre o nexo de relações entre o sujeito - nomeadamente, o funcionário colonial, seus valores, relações pessoais e interesses no espaço paraibano - e a estrutura - nomeadamente, os projetos, fins e interesses da burocracia metropolitana nas áreas ultramarinas ${ }^{18}$. É, enfim, a possibilidade de se indagar, tendo em vista as transformações por que passou o órgão fazendário - no caminho de sua racionalidade, no dizer weberiano -, como e por que os atos e realizações dos sujeitos diretamente responsáveis pelo comando da Fazenda Real da Paraíba - em sua interatividade com os homens do seu tempo -, se mostraram, às vezes, em sintonia e, às vezes, contrários, aos projetos advindos da metrópole.

seu ambiente próprio em círculos fechados e pouco acessíveis a uma ordenação impessoal. Dentre esses círculos, foi sem dúvida o da família aquele que exprimiu com mais força e desenvoltura em nossa sociedade." Sérgio Buarque de Holanda. Raízes do Brasil. 26a edição. São Paulo: Cia das Letras, 1995. p. 146

${ }^{16}$ Max Weber. Economia e Sociedade: fundamentos da sociologia compreensiva...Op. cit. p. 253.

17 Tais formulações acerca da imbricação tomada pela relação do público e privado na "Época Moderna" devem ser credenciadas ao diapasão teórico formulado por Fernando Novais, que conseguiu dar o amálgama para o período, chamando-o de "zona incerta". A Época Moderna, diz Novais, "revela sempre essa posição intermediária; em todas as instâncias, de todos os ângulos, é sempre essa sua característica definidora (...) um período em que as esferas do público e do privado não estão indistintas mais ainda não estão separadas estão imbricadas". Cf: Fernando A. Novais (direção). História da vida privada no Brasil: cotidiano e vida privada na América portuguesa. São Paulo: Cia das Letras, 2001. Introdução. p. 15-16

${ }^{18}$ Como enfatizou Schwartz, a relação entre governo e a sociedade estava estruturada a partir da articulação de dois sistemas interligados de organização: "em um nível havia a administração controlada e dirigida pela metrópole, caracterizada por normas burocráticas e relações impessoais, que amarrava os indivíduos e os grupos às instituições políticas do governo formal. Paralelamente, existia uma teia de relações interpessoais primárias baseadas em interesse, parentesco ou objetivos comuns que embora não menos formal, não contava com o reconhecimento oficial”. Stuart B. Schwartz. Burocracia e sociedade no Brasil colonial... Op. cit. pp. XI - XII (grifo nosso). 
É nesta perspectiva, portanto, que filtraremos o olhar para a documentação selecionada. Além da seleção de documentos organizados por Irineu Pinto no seu Datas e Notas para a História da Paraíba ${ }^{19}$ e das obras de cronistas coloniais já publicadas, o grosso de nossa documentação está ligado àquilo que se convencionou chamar de fontes de primeira-mão. Nossa documentação foi coligida no acervo do Arquivo Histórico Ultramarino de Lisboa e no Instituto Histórico e Geográfico Paraibano. ${ }^{20}$

$\mathrm{Na}$ documentação do Arquivo Histórico Ultramarino, encontramos os documentos pertencentes às secretarias de Estado - Conselho da Fazenda e Guerra - e o importantíssimo acervo do Conselho Ultramarino. Este último órgão, criado em 1642, era o responsável pela mediação oficial entre o rei e as colônias, através da elaboração das Consultas ao rei, a partir das correspondências chegadas em Lisboa e provindas do ultramar.

Essas Consultas, como o próprio nome determina, são documentos ascendentes nos quais se apresentam, para deliberação real, as sínteses de diversos processos relativos ao mundo ultramarino. ${ }^{21}$ Nestes processos, muitas vezes, havia uma torrente de documentos que lhes compunham as partes e que iam com eles ajuntados, com os quais os conselheiros se esforçavam em sumariar, na confecção da Consulta, todo o assunto que importava. Porém, na seletividade dos assuntos, muitas informações ficavam perdidas nas páginas dos anexos. Esses anexos, com os documentos que não chegaram a se transformar em Consulta, podendo ser compostos por uma variedade de petições, requerimentos, avisos, instrumentos de justificações, mapas econômicos, partes de livros de almoxarifes, devassas, ou cartas em geral (de ouvidores, eclesiásticos, capitães-mores, provedores, senado da câmara, etc.), são

\footnotetext{
${ }^{19}$ Irineu Ferreira Pinto. Datas e notas para a História da Paraíba. João Pessoa: Editora Universitária / UFPB, 1977. $2 \mathrm{v}$.

${ }^{20}$ A coleção de Documentos Históricos da Biblioteca Nacional também foi compulsada, contudo, os poucos documentos de nosso interesse, ali encontrados, eram cópias de documentos por nós já trabalhados.

${ }^{21}$ Um bom estudo sobre a diplomática Luso-brasileira para o período colonial encontra-se em: Heloísa Liberali Bellotto. Arquivos permanentes: tratamento documental. São Paulo: T. A. Queiroz, 1991.
} 
os documentos que se intitulam como avulsos, ou seja, o grosso daquilo que foi, e do que não foi, protocolado nos Códices.

Dos Códices encontrados no Arquivo Histórico Ultramarino, salienta-se o de número 1805, por nele constar a Relação Geral dos Contratos e Rendas Reais que foram administrados pela Fazenda Real da Paraíba, para os anos de 1731 a 1736. Quanto aos documentos avulsos, contudo, verdadeiros feixes de anexos, procuramos sempre observar os despachos ou resoluções reais no entorno dos mesmos, única forma de descobrir se tiveram ou não a atenção do Conselho Ultramarino e o rumo que tomaram em meio à administração do Reino ou do ultramar. Tal cuidado em reconstruir os labirintos do trâmite burocrático com o controle sobre a produção de documentos que compõem o conjunto da diplomática lusa, permitiu-nos perceber, na tão criticada e malfadada morosidade dos processos, o porquê das interrupções e favorecimentos de certos grupos ou pessoas que se envolveram, especialmente no nosso caso, nos assuntos da Fazenda.

Quanto à documentação dos Códices do Instituto Histórico e Geográfico Paraibano, é ela composta pelo registro da correspondência real chegada na Secretaria do Governo da Capitania da Paraíba e da Ouvidoria Geral da Paraíba. Esse registro permitiu-nos identificar como, no andamento dos processos relativos à Fazenda paraibana, foram se incorporando os vários pareceres de autoridades locais, ao assunto tratado, até o seu desfecho e se outras instâncias tomavam conhecimento ou não do assunto, ou se este deveria ser tratado de forma secreta. Esses códices permitiram conhecer o elenco das ordens régias, compostas por alvarás, provisões e decretos que podiam compor assuntos, específicos ou não, acerca do andamento da administração da Fazenda paraibana. Possibilitaram, também, a checagem acerca de alguns problemas que podiam aparecer nestes registros e que não faziam parte dos papéis avulsos do Arquivo Ultramarino, talvez por terem se perdido por algum motivo intencional ou alguma trivialidade.

Este trabalho está dividido em quatro capítulos. No primeiro capítulo, discutimos a administração fazendária no Reino e o seu alargamento para o Brasil, realçando as 
hierarquias no plano fiscal e as possibilidades de autonomia alcançadas pelos órgãos fazendários e por seus oficiais frente às outras esferas institucionais de poder. Ainda na mesma seção, damos relevo à montagem da provedoria-mor do Estado do Brasil, priorizando, nos aspectos jurisdicionais, as relações dos poderes militar, jurídico, fazendário e eclesiástico, na área compreendida pelas capitanias do Norte. A idéia aqui é entender e visualizar, nas descrições das jurisdições, o limite territorial factível à Provedoria da Fazenda Real paraibana.

No segundo capítulo, discutimos a recriação da Provedoria da Fazenda Real da Paraíba, após a expulsão dos holandeses, analisando, transversalmente, neste processo, como se deram as relações entre a sociedade paraibana e o Conselho Ultramarino. Para tanto, visualizamos, detalhadamente, as trajetórias administrativas de alguns personagens que ocuparam postos-chaves na Provedoria da Fazenda. Personagens como Salvador Quaresma Dourado, que ocupou o cargo de provedor na Paraíba, por exatos cinqüenta anos, e os membros da família Bandeira de Mello, que se eternizaram na escrivania do órgão. Tal análise, que teve como propósito compreender as redes de poder e privilégios mantidos pelos administradores da Fazenda, descortinou, também, as diversas tramas postas em prática pelos oficiais que visavam proteger interesses pessoais e dos seus familiares, os quais abrangiam um universo que exercia e que sofria, ao mesmo tempo, a pressão de outros grupos e de instituições locais e reinóis. Subjacente a essa discussão, percebeu-se, também, como as manifestações do poder da Coroa foram se fortalecendo na capitania da Paraíba e ocupando, institucionalmente, os espaços políticos-administrativos, que antes eram redutos do controle concelhio ou dos grupos locais.

No terceiro capítulo, nos debruçamos sobre o processo de centralização, na Provedoria da Fazenda Real paraibana, das atividades tanto de arrecadação como as de prodigalizar a despesa para a reprodução da vida administrativa da capitania. Quanto à receita, centramos a pesquisa na leitura sobre a criação e evolução do desempenho arrecadador de cada fonte tributária, com a sua respectiva contra-face: a atividade econômica que lhe dava sustentação. Neste levantamento, procuramos captar, mesmo que em dados dispersos e resumidos, a linha evolutiva do dízimo, dos subsídios do açúcar e carne, dos impostos sobre comércio de escravos e dos processos de arrestos e confisco de bens por dívidas à Fazenda, criando, assim, um amplo quadro sobre a situação econômica 
interna da capitania. Por outro lado, quanto à despesa, o enfoque, apesar de amplo, foi centrado mais na demonstração do peso que acarretavam para os cofres da Fazenda as despesas com as folhas de serviço. Tal procedimento permitiu-nos mapear os raios de ação da Provedoria da Fazenda paraibana no interior da capitania, com cada um dos órgãos institucionais: ouvidoria, milícia e Igreja, além da Câmara Municipal. Com a análise desses dados, foi possível vislumbrar as reais possibilidades econômicas de que dispunha a Fazenda real paraibana para manter um governo autônomo.

No quarto e último capítulo, aprofundamos algumas questões já levantadas no capítulo anterior quanto à questão tributária, principalmente no que diz respeito à junção do imposto da dízima em um só contrato, envolvendo as capitanias da Paraíba e de Pernambuco, em 1723, e à análise das implicações desta medida para o processo de anexação e perda da autonomia da capitania paraibana, em 1755. Ainda neste capítulo, discutimos alguns projetos de governadores da Paraíba preocupados em erguer a economia local, tanto no aspecto da produção ou do comércio, como, mais precisamente, no aspecto fiscal, como forma de garantir a sobrevivência da Provedoria da Fazenda Real da Paraíba e manter o governo autônomo. A radicalidade de um ou outro capitão-mor, no sentido de alcançar seus intentos, abria, muitas vezes, sérias feridas na sua relação com a elite local ou reinol. Ferir interesses de antigos moradores, proprietários ou comerciantes, intrometer-se em jurisdições alheias, compor com certos grupos em detrimentos de outros, poderiam provocar reações nada agradáveis ou inimizades mortais. Para concluir esta discussão, levantamos alguns indicativos basilares sobre as possíveis condicionantes e influências que a gestão pombalina trouxe para a consolidação da anexação da Paraíba a Pernambuco.

Este trabalho, enfim, se preocupa fundamentalmente com a história da montagem e falência de um órgão administrativo, a Provedoria da Fazenda Real da Paraíba, e que busca apreender, no colonialismo em ação, imerso nesse processo, os encontros e desencontros entre os objetivos fiscais propostos e a possibilidade real de efetivá-los. Além disso, procurou não perder de vista, nas articulações entre os dois mundos do Atlântico, a rede de relacionamentos sociais e econômicos que constituíam a trama do viver em colônia; isto é, o cadinho de relações humanas que se efetivavam tanto no aspecto formal e hierárquico, entre cargos e jurisdições, como no terreno dimensionado por valores, costumes e tradições, que permeavam os que se envolviam nos tentáculos da Fazenda paraibana. 


\section{CAPÍTULO I}

\section{O ENQUADRAMENTO DO ESPAÇO JURISDICIONAL E POLÍTICO- ADMINISTRATIVO DA FAZENDA REAL DA PARAÍBA}

O Estado Moderno português, moldado e legitimado em face da guerra, do tributo e do comércio, criou uma uniformização político-administrativa em meio à diversidade espacial - física, cultural, econômica e política - do seu território, sobre a qual buscou exercer o poder : a obra da centralização. Grosso modo, esse Estado recortou e classificou - como fruto da tradição antiga romana e que a Igreja havia preservado e adaptado às suas necessidades durante a Idade Média $^{1}$ - toda a extensão do Reino em circunscrições político- administrativas hierarquizadas entre si, organizando-as, as mais importantes, em Províncias, Comarcas, Correições, Provedorias e numerosos Concelhos. ${ }^{2}$

Nessas circunscrições, as competências jurisdicionais - militar, jurídica e fiscal estavam doutrinadas e regidas por códigos escritos que ordenavam - legislando, disciplinando, executando - as ações dos Agentes da Coroa, ou dos Funcionários Régios, ou, simplesmente, como lhes chamavam os coevos e cujo termo usaremos daqui para frente, dos Oficiais. $^{3}$ Do conjunto de leis consolidadas nas Ordenações - Afonsinas, Manuelinas e Filipinas - outros regulamentos, como os Regimentos, ${ }^{4}$ apareciam diplomando os diversos órgãos oficiais e seus quadros, instruindo-os, ampliando-os e

\footnotetext{
${ }^{1}$ Paulo César da Costa Gomes. "O conceito de região e sua discussão". In: Iná Elias da Costa, Paulo César da Costa Gomes \& Roberto Lobato Corrêa. Geografia: conceitos e temas. Rio de Janeiro; Bertrand Brasil, 1995. p. $49-75$

${ }^{2}$ Antonio Manuel Hespanha. Às vésperas do Leviathan. Instituições e poder político Portugal, século XVII. Lisboa. Livraria Almedina, 1994. Primeiro capítulo: "A arqueologia do poder”, particularmente a secção 3: "A estrutura político- geográfica. Espaço e poder" . p. 85-111.

3 “'A palavra 'funcionário', associada ao serviço público, foi criada no século XVIII. Durante a idade moderna, na Europa como na América colonial, dizia-se em diferentes línguas, 'o ofício'. O detentor do oficio era um 'oficial', o que tanto podia significar ocupações como a de tecelão ou ferreiro, como um cago público". Cf: Arno Wehling \& Maria José Weling. "O funcionário colonial entre a sociedade e o rei". In: Revisão do Paraíso. Mary Del Priore (org.). Os brasileiros e o Estado em 500 anos de História. Rio de Janeiro; Editora Campus, 2000. p. 141.

${ }^{4}$ Diversos regimentos aqui utilizados se encontram em Marcos Carneiro de Mendonça. Raízes da formação administrativa do Brasil. Rio de Janeiro: IHGB / CFC, 1972.
} 
colocando limites à sua área de atuação, quer na perspectiva hierárquica no interior do próprio órgão, quer nas dimensões limítrofes espaço jurisdicional.

Ao transpor para a Colônia esta experiência institucional, as competências político-administrativas tiveram que sofrer alguns ajustes, a fim de tornar possível o projeto colonizador. Nessas adaptações, destacou-se a produção e uso corrente dos Regimentos, já que se destinavam, tal e qual serviam no Reino, como diz Graça Salgado, a "instruir os funcionários em suas respectivas áreas de atuação, bem como determinar as atribuições, obrigações e jurisdição dos diversos cargos incumbidos de gerir a administração colonial. ", Desta forma,

tais diplomas legais eram baixados a cada um dos funcionários mais importantes, traçando minuciosamente as suas competências e dos oficiais subalternos. Eram em sua maioria personalizados, em consonância com os critérios de lealdade $e$ confiança, além dos estritos mecanismos de vigilância e controle que marcavam as regras do poder absolutista. ${ }^{6}$

A acentuação dos mecanismos institucionais de vigilância e controle, a que se refere a coordenadora de Fiscais \& Meirinhos, e que atuavam na Colônia brasileira, foram sentidos já na segunda intervenção político-administrativa, quando da criação do Governo Geral, em 1548, que intencionou coordenar a ação mais presente dos representantes da Coroa junto aos colonos. Neste sentido, Capitanias Reais, Ouvidorias, Provedorias da Fazenda e Almoxarifados foram sendo montados, durante ao processo de expansão territorial que perduraria mais de uma centúria à frente, transformando o antigo mapeamento inicial das perfeitas linhas horizontais formatadas nas Capitanias

\footnotetext{
${ }^{5}$ Graça Salgado (org.) Fiscais e Meirinhos. A administração no Brasil colonial. 2 ed. São Paulo; Editora Nova Fronteira, 1985. p. 16

${ }^{6}$ Idem ibidem.
} 
Hereditárias. Interesses econômicos diversos, de reinóis e colonos desbravadores, comerciantes, proprietários de terras, de engenhos e de escravos, fracionaram o espaço, colonial no afã de vencer os perigos externos e internos, configurando um novo mapa político-jurisdicional que moldou, militar e economicamente, em regiões factícias, uma outra geopolítica. Tais regiões, pelas barreiras institucionais impostas à consecução de um mercado interno - caracterizando-as no complexo de uma Colônia de exploração -, tiveram de se interligar majoritariamente ao mercado externo, por meio da exportação de matérias-primas. ${ }^{7}$ Desta forma, mesmo que se considere o peso da imensa força econômica provocada pela mineração no interior da Colônia, zonas de hinterlândia, como o porto do Recife, por exemplo, continuaram hegemonizando o fluxo de circulação de mercadorias para a Metrópole, garantindo a reprodução do pacto colonial.

Portanto, o objetivo deste capítulo será o de mapear, a partir do desenvolvimento das jurisdições da Milícia, Justiça, Igreja e Fazenda, em meio às Capitanias do Norte, a singularidade dos limites e abrangências da circunscrição espaço jurisdicional da Provedoria da Fazenda Real paraibana. Para tanto, é importante que se determine, primeiramente, e tendo por base alguns Regimentos, como estava formalmente montado o mecanismo de controle que legislava as competências fiscais, tanto no Reino, como na Colônia.

\section{A ADMINISTRAÇÃO FAZENDÁRIA CENTRAL E PERIFÉRICA NO REINO}

A importância da unificação territorial para a criação dos meios de ação burocráticos e financeiros que deram origem ao Estado Português, é identificada por Vitório Magalhães Godinho ${ }^{8}$ na instituição de dois alicerces: a) na criação dos dois ofícios dos Vedores de Fazenda, uma espécie de Ministério das Finanças, em c.1370; e b) na generalização do imposto das sisas - originalmente um imposto de origem

\footnotetext{
${ }^{7}$ Rosa Maria Godoy Silveira. O regionalismo nordestino. São Paulo: Moderna, 1984.

${ }^{8}$ Vitorino Magalhães Godinho. "Finanças públicas e estrutura do Estado". In: Joel Serrão (dir.). Dicionário de História de Portugal. Porto: Livraria Figueirinhas, 1971. v. 2 . p. 244-264.
} 
concelhia - para o âmbito nacional, por ter alargado a concepção de comunidade e a noção de concelho para todo o Reino, após a revolução de 1383-85.

Que o Estado português teve nesta fonte de renda um forte alicerce por onde pôde mover-se para completar a obra da unificação, segundo Godinho, não resta dúvida, pois, já em 1402, as sisas representavam cerca de $3 / 4$ da receita total do Reino. Todavia, ao longo do século $\mathrm{XV}$, motivos de força maior, como epidemias e más colheitas, fizeram recair na economia toda a sorte de infortúnios, levando a níveis de contrações insuportáveis. A diminuição da mão-de-obra e a baixa real dos preços trouxeram a inflação monetária nominal (quebra da moeda), que afetou as rendas fundiárias e obrigou os meios comerciais a buscarem novos fornecimentos de metais. Nestas condições, o Estado transformou-se em agente econômico, buscando fora do Reino, nos empreendimentos comerciais marítimos, as rendas que a terra lhe negava no mercado interno ${ }^{9}$ :

\footnotetext{
${ }^{9}$ Idem ibidem. Op. cit., p. 255.
}

Assim, o Estado vai se beneficiar do incremento mercantil através dos mares graças às Alfândegas, $e$ será ele próprio armador, e mercador com sua rede de feitorias através de todo o globo, explorando monopólios (estancos) ou fazendo-os explorar por companhias capitalistas concessionárias; o rei, a família real e a nobreza participam nessas companhias, colocam dinheiro nos negócios, auferem pingues proventos mercantis. Não só o âmbito geográfico do Estado se alarga espantosamente além-mar [colônias], como no próprio Reino [Metrópole] as suas malhas tendem agora a apertar todo o território, por meio de uma máquina burocrática e numa centralização que não extinguem senhorios nem aprestamos, mas os modificam, 
integrando-os em novo contexto. A ordem jurídica emanando do poder central organiza-se, precisa-se, codifica-se. Há agora não só uma administração da justiça perfeitamente escalonada, como uma administração financeira e econômica.$^{10}$

Essa administração organizada, precisa e codificada, de que fala o historiador português, estava respaldada nas Ordenações Afonsinas, de meados do século XV, que sistematizou a ordem jurídica e assentou um "primeiro plano de estrutura do Estado"; e nas Ordenações Manuelinas que, nas primeiras décadas do século XVI, completara à organização financeira e o direito fiscal. Na vigência das Ordenações Manuelinas foram publicados, em 1516, os Regimentos e Ordenações da Fazenda, que regulamentaram o primeiro regimento dos Vedores da Fazenda. Estava pronto, enfim, o "Estado Burocrático Mercantilista". ${ }^{11}$

Mesmo sem entrar nos méritos da concepção burocrática do Estado, na forma como o compreende Godinho, acreditamos existir, nesta definição, uma pressa em enxergar, ainda para o século XVI, o fechamento e a coroação desse processo com modelos de desempenho estritamente burocráticos de administração. Todavia, compreendemos que haja aí, principalmente no bojo das reformas filipinas, como detecta Antônio Hespanha, "o objetivo [nas ações da Coroa] que já então prosseguia ... [de] evitar a pulverização da gestão financeira”. ${ }^{12}$ Como aponta Virginia Rau, foi durante a gestão filipina que se assistiu aos "reajustamentos internos da repartição ou do seu pessoal" - como na criação do Conselho da Fazenda de 1591, para onde passaram os três Vedores da Fazenda -, e à publicação do Regimento dos Contos do Reino e Casa, em 1627, resultado da "compilação modernizada e expurgada da legislação que de longos anos se usava nos Contos". 13

\footnotetext{
${ }^{10}$ Idem ibidem.

${ }^{11}$ Idem ibidem. Op. cit. p. 256.

12 Antonio Manuel Hespanha. As vésperas do Leviathan. Instituições e poder político Portugal, século XVII... Op. cit. p 255.

${ }^{13}$ Houve tentativas de melhorar o ajuste das contas, de "simplificar e abreviar os processos e promover a cobrança das dividas ao tesouro." Porém, além da contenção sobre os poderes dos Vedores da Fazenda,
} 
Mais ainda, o Regimento dos Contos do Reino e Casa - por sinal, oriundo do reinado de D. Dinis (1279-1325), desiderato da complexidade da contabilidade real e da sedentarização dos organismos régios em Lisboa - assistiu, na União Ibérica, a passagem da jurisdição voluntária ou contenciosa dos seus assuntos para as mãos do Conselho da Fazenda. Segundo Antonio Hespanha, constatando Filipe I que, na prática, existiam três tribunais distintos, cabendo a cada um dos vedores uma leva de oficiais, "aplicou a este domínio o regime sinodal, integrando os três vedores no conselho, sujeito a um vedor presidente". 14

Contudo, já em 1603, com a promulgação das Ordenações Filipinas, dava-se à transferência de todas as questões contenciosas do Conselho da Fazenda para a alçada da justiça na Casa de Suplicação, centralizando-as nas mãos do Juizo dos Feitos da Fazenda. Os litígios envolvendo "financeiros e juristas," como ressalta Hespanha, "se seguem até ao meados do século XVII ... de que são sintomas sucessivas providências legislativas, a propósito da separação de competências quanto à jurisdição contenciosa em matérias de fazenda entre a Casa da Suplicação e o Conselho da Fazenda”. O desfecho disso, ao que parece, segundo o historiador português, é o reconhecimento, nos primeiros anos após a Restauração, da impossibilidade do Juízo dos Feitos da Fazenda, julgar matérias pertinentes aos assuntos da Fazenda, "pelo prejuízo que isso causava à Coroa." 15

Em função disso, o Conselho da Fazenda, "por processos que se sobrepunham já, em muitos casos, a simples via do recurso," cobriu uma enorme área administrativa,

\footnotetext{
em quem recaiu as maiores mudanças - pois lhes ficou proibido " prover pessoa alguma nas serventias de provedor, contador e escrivão por mais de seis meses, nem mudá-los de uma serventia a outra sem prévia consulta a el-rei e se lhes passar para isso provisão" -, se organizara toda uma estrutura de fundo burocrático bastante avançado passando a se observar os horários de expediente "sob pena de se descontar do ordenado o dia que faltasse" e também a se prestar atenção nas prerrogativas de cada função. Virgínia Rau. A Casa dos Contos. Coimbra: FLUC, 1951. p. 89. O Regimento dos Contos, de 1627, se encontra em Marcos Carneiro de Mendonça. Raizes da formação administrativa do Brasil. p. 493 - 503.

${ }^{14}$ Antonio Manuel Hespanha. As vésperas do Leviathan. Instituições e poder político Portugal, século XVII... Op. cit. p. 236-238.

${ }^{15}$ Idem ibidem. p. 239. É importante ressaltar que foi criado também, no Brasil, um Conselho da Fazenda na Bahia, em fins do século XVII. Era composto pelo governador-geral, como presidente, o provedor-mor, o juiz dos feitos da Fazenda, o procurador da Fazenda e dois desembargadores dos Agravos do Tribunal da Relação da Bahia. Nesta estrutura, ao que tudo indica, a orçada antes restrita ao provedor-mor passou a ser distribuída entre esses oficiais. Cf: Graça Salgado (org.). Fiscais e Meirinhos A administração no Brasil colonial...Op. cit. p. 85-86. Contudo, ao menos no que diz respeito às relações com a provedoria da Paraíba, os contatos com este tribunal, até meados do século XVIII, inexistiram.
} 
como a "Casa Real, a Contadoria-mor da Corte e Reino, as Casas da Alfândega de Lisboa, a Casa da Moeda, as alfândegas e portos secos do Reino, os contadores e os almoxarifados do reino, o Conselho da Índia" ${ }^{\text {"16 }}$ e, após seu desmantelamento, o Conselho Ultramarino. Aos Contos do Reino e Casa ficaram restritas apenas as questões de ordem contábil, como agir sobre o traslado da documentação de prestação de contas que os tesoureiros, almoxarifes e recebedores faziam no Reino, ao contador-mor. ${ }^{17}$ Além dessas mudanças, no plano da administração central, dois outros momentos singularizaram novas orientações na organização das finanças. Um deles foi a criação, em 1736, da Secretária de Estado dos Negócios da Marinha e Domínios Ultramarinos, que pouco ou nenhum efeito teve até a segunda metade do século XVIII; e o outro, de forma mais contundente, foi a efetivação, finalmente, da dimensão pública das finanças, mediante a criação do Erário Régio, em 1761.

Voltando, ao Conselho da Fazenda, conforme presente no seu Regimento, no domínio da "administração, competia-lhe:

arrecadar as rendas reais; administrar o comércio ultramarino e decidir sobre temas com ele conexos (como o abastecimento, defesa e obras das conquistas); tomar as contas dos almoxarifes $e$ contadores das comarcas, bem como a outros oficiais que lhas devessem, passando as devidas cartas de quitação; administrar os bens próprios do rei (lezírias, paços, casas, armazéns, terecenas, fortalezas); preparar a decisão real em todos os assuntos de graça que tocassem a fazenda, nomeadamente os próprios, tenças, ordenados, padrões; dar condicionalmente rendas reais; dar oficios das sisas, estancos e direitos reais. No

\footnotetext{
${ }^{16}$ Antonio Manuel Hespanha. As vésperas do Leviathan. Instituições e poder político Portugal, século XVII. p. 239- 256.

${ }^{17}$ Marcos Carneiro de Mendonça. Raízes da formação administrativa do Brasil...Op. cit. p. 493.
} 
domínio da jurisdição voluntária, cabia-lhe: arrendar e aforar propriedades; arrendar rendas reais; despachar, por si ou por consulta ao rei, todas as cartas em matérias de fazenda. No domínio da jurisdição contenciosa, estava-lhe atribuido o conhecimento: dos recursos em matérias de sisas; dos feitos em que fossem parte os rendeiros de rendas da coroa; dos erros dos oficiais da fazenda; das apelações das decisões de almoxarifes, recebedores e rendeiros; e, em geral, de 'todas as cousas que pertencem à nossa fazenda, \& della dependerem por qualquer via que seja, quer por acção nova', quer por apelação. $^{18}$

Por outro lado, no plano da administração financeira periférica, no Reino, as relações entre esses organismos contábeis centrais e os poderes locais se davam na delimitação das jurisdições das comarcas, através da ação dos provedores. ${ }^{19}$ Esses oficiais, que acumulavam o domínio da Provedoria dos Defuntos e Ausentes, tutelando os interesses individuais de quem não estivesse "em condições de os administrar por si nem controlar a administração que deles fosse feita - defuntos ausentes, órfãos, cativos; mas também o de pessoas coletivas que, por razões teóricas ou práticas a eles devessem ser equilibrados - confrarias, capelas, hospitais, conselhos, ..."20 acumulavam, também, no domínio da Fazenda, as funções de contadores, ficando sob sua responsabilidade:

\footnotetext{
${ }^{18}$ Antonio Manuel Hespanha. As vésperas do Leviathan. Instituições e poder político Portugal, século XVII... Op. cit. p. 237-238. O Regimento do Conselho da Fazenda encontra-se em Marcos Carneiro de Mendonça. Raizes da formação administrativa do Brasil... p. 731-737.

${ }^{19}$ Antonio Manuel Hespanha. As vésperas do Leviathan. Instituições e poder político Portugal, século XVII... Op. cit. p. 209. Acresce, no entanto, informar que, segundo o mesmo autor, nas comarcas em que não apareciam os provedores, a função que deveria ser por eles exercida, passava para as mãos dos Corregedores, ou seja, magistrados ordinários da administração real periférica, nomeados trienalmente pelo rei.

${ }^{20}$ Idem ibidem. p. 206.
} 
i) quanto às contas dos conselhos: verificar os livros de receita e despesas dos escrivães e tomar-lhes as contas; tomar as terças e entregá-las aos respectivos recebedores; cuidar do arrendamento das rendas reais e da cobrança das que não tenham sido arrendadas; prover sobre os pagamentos a fazer pelos almoxarifes; tomar as contas dos almoxarifes $e$ dos recebedores; e julgar certas questões ao arrendamento de rendas reais, dando apelação $e$ agravo para o Conselho da Fazenda, a quem também prestam contas; ii) quanto às obras: prover na reparação das fortificações e lançar fintas para obras em igrejas até certo montante; iii) quanto à defesa dos direitos reais: fazer o tombo dos bens da Coroa; averiguar da legitimidade dos direitos reais; controlar o direito a tenças e superintender na cobrança dos reais d'água. ${ }^{21}$

Como sublinha Hespanha, esse número de atribuições dos provedores nas matérias das finanças, aumentava-lhe em muito o volume da jurisdição em que se repartiam as correspondências voluntárias ou contenciosas. Assim, além da relação com o tribunal da Mesa da Consciência e Ordens, nomeadamente ao tratar dos Defuntos e Ausentes, há de se atentar, também, para o contato com o Desembargo do Paço, no que respeita às matérias de supervisão dos conselhos, ou para a Casa de Suplicação, para os efeitos judicantes de casos de apelação e agravo sobre testamentária. Um dado interessante, quanto às relações hierárquicas entre o provedor e esses outros escalões de tribunais, como em todas as outras esferas hierárquicas no Antigo Regime, é que elas se davam “antes em relações de tutela, em que o funcionário de escalão superior se limita a

${ }^{21}$ Idem ibidem. Op. cit., p. 208-209. 
controlar a atividade do de escalão inferior através da reapreciação dos seus atos quando de recurso ou da inspeção ou residência”, do que no rigor hierárquico políticoadministrativo próprio, como se assistia mais precisamente nas relações com o Conselho da Fazenda. ${ }^{22}$

No caso específico do Conselho da Fazenda, havia uma aproximação maior com aquilo que podemos encontrar numa administração moderna, e isto acontecia, ainda com o historiador português, por duas ordens de fatores. Primeiro porque, tanto nos acompanhamentos dos processos dos arrendamentos reais quanto nas relações com os almoxarifes, ou mesmo nas visitas bienais que os provedores estavam obrigados a fazer ao Conselho da Fazenda, em Lisboa, fazia-se a inspeção nos livros, sob o crivo sistemático e periódico da tomada de conta. A tomada de conta se ajustava a instruções regimentalmente definidas e não ao regime da residência, que só acontecia quando do término do exercício do cargo ou morte do seu ocupante - neste caso, a inspeção seria feita pelo sucessor direto ou por um juiz corregedor previamente indicado. Segundo, porque, conforme o Regimento dos Contos do Reino e Casa, de 1627, todos os oficiais da Fazenda, inclusive o provedor, estavam sujeitos aos cortes nos seus estipêndios caso cometessem qualquer falha. ${ }^{23}$

$\mathrm{Na}$ hierarquia formal da administração fazendária, dentro do próprio órgão, abaixo dos provedores ficavam os almoxarifes, que tinham como função:

i) receber as rendas dos rendeiros $e$ as quantias entregues aos recebedores das sisas ou dos direitos reais ou entradas nas 'távolas' (repartições de cobrança) dos vários tributos ou rendas; ii) pagar as despesas inscritas nas folhas (tenças, ordenados dos 'filhos das folhas,' etc.), arrecadando $1 \%$ de cada despesa para as obras pias; iii) decidir, na falta do contador [sendo ele o próprio provedor], dos feitos

\footnotetext{
${ }^{22}$ Idem ibidem. p. 213.

${ }^{23}$ Idem ibidem.
} 
civeis e crimes em que sejam partes os rendeiros, dando apelação e agravo para o Conselho da Fazenda. $^{24}$

Além desses dois oficiais, provedores e almoxarifes, havia os escrivães, que trabalhavam junto a um e outro, e mais uma gama de outros oficiais vinculados à provedoria, que se envolviam na administração alfandegária ocupando postos nas "alfândegas (maritimas), nos portos secos (alfândegas terrestres) e nos portos molhados (alfândegas fluviais da raia), onde se cobravam ... as dízimas de entrada”. Nestes órgãos, hierarquicamente abaixo do provedor, estavam os feitores, os escrivães, os tesoureiros, os guardas, os juízes dos direitos alfandegários e mais um número relativo de oficiais especializados nas cobranças de tributos. ${ }^{25}$ Todos, vale ressaltar, eram providos apenas por nomeação régia.

Quanto ao número das provedorias e alfândegas existentes no Reino, sabemos que eram dezenas, e que se espalhavam nas generalidades das comarcas, sendo as suas circunscrições, em geral, coincidentes com o distrito de jurisdição dos provedores. Para as provedorias fluíam as receitas levantadas nas respectivas comarcas - através dos almoxarifados e alfândegas - para dali seguirem até a tesouraria-mor no Conselho da Fazenda. As receitas estavam divididas em cinco categorias: os próprios (produtos das rendas e foros dos reguengos), os tributos (sisas, dízimas das alfândegas, terça parte dos concelhos, etc), os estancos (provindos dos arrendamentos dos direitos reais: sabão ${ }^{26}$, pimenta, pau-brasil, sal, tabaco, etc.), condenações (confiscos de bens de condenados) e, finalmente, as rendas relativas ao padroado (que vinham "dos rendimentos das capelas da coroa, das comandas das ordens em que o rei era grão-mestre e da Bula da Santa

\footnotetext{
${ }^{24}$ Idem ibidem.

${ }^{25}$ Idem ibidem. p. 216.

${ }^{26}$ Segundo Hespanha, o rendimento dos direitos sob o sabão preto estava doado desde 1455, primeiro ao Infante D. Henrique e depois aos Castros. O sabão branco foi doado aos condes de Castelo Melhor, em 1708. Todavia, ambos foram revertidos à Coroa, em 1766. Idem ibidem. p. 122.
} 
Cruzada, concessão regular dos pontífices a partir de 1591, destinada à conservação e defesa das praças do norte de África)." 27

O grande número de provedorias, com cada uma reservando para si uma margem de consignação de receitas para satisfação de certas despesas - como pagamento de pessoal e socorro de algumas obras essenciais ao bem comum -, acabava por fomentar “uma 'feudalização' das finanças, [com] cada tesouraria ou almoxarifado defendendo as suas receitas como coisa própria sua e reagindo aberta ou surdamente contra o assentamento a seu cargo de novas despesas e procurando esconder e impedir o retorno ao tesoureiro-mor dos saldos próprios". Assim, mesmo com as tentativas uniformizadoras, traduzidas nos Regimentos e Ordenações da Fazenda, de 1516, e na publicação do Regimento dos Contos do Reino e Casa, de 1627, os “múltiplos fundos orçamentais com tendências particularistas e dificilmente integráveis numa estratégia financeira comum”, limitavam, na leitura de Hespanha, "os meios financeiros indispensáveis para uma politica de efetiva centralização". ${ }^{28}$ Essa condição só seria transposta com a reforma financeira de 1761, com a criação do Erário Régio, para onde, obrigatoriamente, passaram a se dirigir todos os orçamentos das diversas repartições, que se arrecadavam as receitas, para, a partir daí, se comandarem as despesas.

Essa feudalização orçamental, inibidora da gestão unificada das receitas e tendencialmente incentivadora dos particularismos, não deixava de ser, também, um estímulo ao afrouxamento dos laços entre os organismos periféricos e centrais no Reino. E isto acontecia, continua Hespanha, como resultado de duas ordens de fatores. De um lado, era provocado pelo efeito da "miniaturização do espaço político de poder”, ou seja, pela sobrevida de formas arcaicas de "condições de contigüidade e de estabilidade da

\footnotetext{
27 Idem ibidem. Op. cit., p. 123. Sobre o tabaco, vale a pena ressaltar que, na Colônia, um órgão alfandegário especial fora criado, a Superintendência do Tabaco, em 18 de outubro de 1712, cabendo-lhe administrar o comércio do tabaco, zelando pela sua qualidade e agindo sobre os que contrabandeavam o produto. Havia uma superintendência em Salvador e outra em Pernambuco, ambas, porém, subordinadas às determinações da Junta da Administração do Tabaco, da Metrópole. Cf: Graça Salgado. Fiscais e Meirinhos. A administração no Brasil colonial... Op. cit.p. 88. Na Paraíba, por conseguinte, o ouvidor geral da capitania assumia o encargo de Superintendente do Tabaco por comissão da Superintendência de Pernambuco. Cf: AHU_ACL_CU_015, Cx. 81, Doc. 6700. (Avulsos, Capitania de Pernambuco)

${ }_{28}$ Antonio Manuel Hespanha. As vésperas do Leviathan Instituições e poder político Portugal, século XVII... Op. cit. p. 130-131.
} 
vida comunitária”,29, que reproduzia e legitimava a patrimonialização de funções e cargos administrativos:

A superioridade jurisdicional, quando existe (v.g., no caso do rei), não corresponde a um laço de subordinação/hierarquia que possa, nomeadamente, fundar a idéia de um território unificado, projeção do poder único e não dividido da unidade política superior. Pelo contrário, ele consiste somente no poder de controle ou de harmonização dos poderes inferiores. Dai que nos domínios dos poderes jurisdicionais estes poderes inferiores mantenham a sua autonomia e, por aí, uma expressão políticoterritorial autônoma. Nos seus subtipos patrimonial e corporativo - nos quais a estrutura administrativa se funda na concessão patrimonial dos cargos -, o sistema tradicional do poder ganha uma dinâmica de cissiparidade política e territorial que provoca uma progressiva miniaturização do espaço político. ${ }^{30}$

Por outro lado, quanto ao segundo efeito indutor da pulverização das finanças no reino, ela estaria resguardada na própria modéstia das receitas do reino, pois, enquanto as coroas de paises como a França, a Prússia e a Áustria dependiam, quase que inteiramente, das receitas internas, "portanto um interesse vital em o organizar e o controlar," em Portugal, pelo contrário, a maior parte das suas receitas provinham mesmo do ultramar e das alfândegas: "as receitas internas, em contrapartida, quase não cresciam desde os meados do século XVI e eram cada vez menos importantes no contexto

\footnotetext{
${ }^{29}$ Idem ibidem. p. 90.

${ }^{30}$ Idem ibidem.
} 
orçamental global". ${ }^{31}$ Daí a necessidade de se espiar mais atentamente os procedimentos fiscais nas colônias e das suas entradas na Metrópole, pelas alfândegas.

Ainda sobre a ação fiscal nas colônias portuguesas, cabe ressaltar a ponderação e contextualização que dela faz Arno Wehling, para o fato de ser o fenômeno do fiscalismo não "propriamente ibérico, (...) mas absolutista, onerando conforme o país, o centro - França, Inglaterra, Países Baixos - ou a periferia colonial - Espanha e Portugal. O desnível entre os objetivos políticos-administrativos e recursos financeiros, no caso de Portugal, onera desigualmente império e metrópole; e no império é ao Brasil - e não a África ou Índias - que cabe a maior parcela". Por isso, ainda segundo este autor, o autoconsumo na Metrópole só era amenizado pelas reexportações coloniais, compreendendo-se, assim, “que o peso da máquina estatal seja sentido de forma muito mais intensa na colônia do que na metrópole: os centros da riqueza precisam ser controlados, pois é deles que depende a prosperidade nacional e o sustento do Estado absolutista." 32

Mesmo sendo superficial e ligeira, essa descrição sobre a administração fazendária em Portugal traz alguns parâmetros sobre a sua lógica de funcionamento, que ajudarão a entender o comportamento dessa mesma área administrava, quando a experiência foi transportada para o além-mar.

\section{A ADMINISTRAÇÃO FINANCEIRA NA COLÔNIA}

No bojo da fundação do Governo-geral, teve início a administração fazendária em terras brasileiras, com a criação do cargo de Provedor-mor da Provedoria da Fazenda Real do Brasil, em 17 de dezembro de 1548. Um regimento composto de trinta artigos foi entregue a Antônio Cardoso de Barros que, como titular do cargo, tinha por missão colocar em ordem a mui desordenada administração da Fazenda. A esse regimento, um outro foi anexado, contendo cinqüenta e três artigos e que deveria servir aos provedores

\footnotetext{
${ }^{31}$ Idem ibidem. Op. cit., p. 202.

32 Arno Wehling. História administrativa do Brasil - A administração portuguesa no Brasil de Pombal a D. João (1777 - 1808). Coord. Vicente Tapajoós. Brasília; FUNCEP, 1986. Vol. 6. p. 27.
} 
das capitanias. ${ }^{33}$ Os dois regimentos mantiveram-se, com algumas poucas alterações pontuais, de caráter transitório, até os fins do período colonial. ${ }^{34}$

No que diz respeito à composição hierárquica entre este órgão fazendário e os outros existentes no Reino, a Provedoria da Fazenda Real do Brasil, na época de sua criação, atrelava-se apenas aos Contos do Reino e Casa, em Lisboa. Todavia, em 1591, como vimos, o órgão dos Contos do Reino foi subdividido, dando origem ao Conselho da Fazenda que o encimou, tomando, então, a seguinte configuração hierárquica descendente: Conselho da Fazenda $\leftrightarrow$ Contos do Reino e Casa $\rightarrow$ Provedorias da Fazenda. A partir de 1642, com a criação do Conselho Ultramarino, todas as correspondências das colônias passaram a ter este endereçamento. As reuniões deste órgão passaram, assim, a contar com a participação de um procurador da Fazenda, que emitia pareceres em matérias de sua competência. Esta composição preservou-se até a extinção dos Contos do Reino e Casa, em 1761, quando teve origem o Erário Régio, que passou a centralizar todas as atividades financeiras do Império português. A partir daí, as fazendas reais, nas várias capitanias do Brasil, foram sendo extintas, assistindo-se, então, ao processo de estabelecimento das Juntas de Fazenda e, com a perda de poder dos provedores, deu-se a paulatina, mas inexorável, supressão desses cargos. ${ }^{35}$

\footnotetext{
${ }^{33}$ O Regimento de Cardoso de Barros se encontra em Marcos Carneiro de Mendonça. Raízes da formação administrativa do Brasil... p. 89-116.

${ }^{34}$ Em dezembro de 1754, num AVISO do secretário de Estado da Marinha e Ultramar, Diogo de Mendonça Corte Real, onde ordenava a remessa dos ordenados e propinas dos ministros e oficiais da Fazenda da Paraíba para confecção de um novo regimento, enviava, também, em anexo, o dito regimento de Cardoso de Barros, para que o provedor da capitania da Paraíba se guiasse nos assuntos relativos a sua orçada. Haviam se passado 206 anos desde a sua confecção. Cf: AHU_ACL_CU_014, Cx.17, D 1419.

${ }^{35}$ Segundo, Virgínia Rau, para o caso dos oficiais da Casa dos Contos em Lisboa, quanto da sua extinção, expressa que "descontentes houve muitos, mas calaram-se, enquanto os louvores dos novos contemplados e admiradores subiam altissonantes. Todavia, com retidão e justiça, foram conservados os ordenados de todos os funcionários da velha repartição, até serem providos em outros lugares, e se indenizarem os que na Casa tinham oficios de propriedade”. Cf: Virgínia Rau. A Casa dos Contos. Op. cit. p. 160. E, sobre a extinção dos ofícios de provedores e criação das juntas no Brasil, diz Arno Wehling que "a provedoria teve suas características alteradas, até desaparecer, com funções caldeadas nos demais órgãos (...) A confusão entre os cargos de provedor-mor de capitania parece ter induzido vários historiadores à afirmação de que estas funções teriam sido extintas com a criação das juntas, ou logo após. Um documento de 1807 deixa claro, porém, que somente aí foi extinta a provedoria do Rio de Janeiro." Arno Wehling. História administrativa do Brasil - A administração portuguesa no Brasil de Pombal a D. João (1777 - 1808)... Op. cit. p. 115 e p. 116. Em outras capitanias, a Paraíba, por exemplo, sua provedoria e o respectivo cargo de provedor foram extintos somente em 1799, através de uma carta régia de 24 e janeiro, colocando em seu lugar uma Junta de Administração, subordinada ao Real Erário. Cf: AHU_ACL_CU_014, Cx. 34, Doc. 2476.
} 
Todavia, durante o tempo em que foi possível assistir à influência dos provedores e das suas fazendas reais no Brasil, houve o estímulo à montagem de toda uma aparelhagem administrativa composta por uma gama de oficias - escrivães, almoxarifes, contadores, meirinhos, guarda-livros, etc.-, que deviam conduzir as tarefas de recolher os impostos e promover os recursos suficientes para o funcionamento dos vários ramos da administração.

Resguardando o aspecto da extensão das jurisdições - geral ou local -, tanto o provedor-mor quanto os provedores de capitania, possuíam, como revelam os regimentos, um grande número de incumbências semelhantes. Em geral, atribuições como organizar as alfândegas, zelar pelos monopólios para o recebimento dos tributos, lavrar os livros de contas e despender a sustentação dos segmentos dos filhos da folha eclesiástica, executiva e militar, além da responsabilidade pelos repasses de numerários para a Coroa, eram prerrogativas, por excelência, dos provedores.

Neste sentido, ao provedor-mor coube a primazia de percorrer e efetivar nas capitanias, por nomeação sua e reconhecimento do governador-geral, os ditos provedores de capitanias e emulá-los a levantar as Alfândegas e as Casas dos Contos da mesma forma como estava obrigado a fazer na Bahia. ${ }^{36}$ Esses escritórios deveriam conter livros devidamente escriturados, como o dos Forais, Regimentos e Provisões, o dos Direitos e Rendas e Contratos de Arrendamentos, e o do Pessoal da Armadas e Navios, cabendo ao provedor-mor, neste primeiro momento, nomear um porteiro para a guarda, um escrivão para as escrivaninhas da Alfândega, Fazenda e Almoxarifado, além do próprio almoxarife e do alealdador, "isto é, do despachante, o que despachava os papéis para o pagamento dos direitos". 37 Junto a esses oficiais, vários outros escrivães, feitores e tesoureiros deveriam existir em número suficiente para o desempenho de inúmeras funções, "pois deviam proceder a levantamento das mercadorias na Alfândega e nos navios, cobrar os dízimos do açúcar, no próprio local do fabrico, processar anualmente o pregão das rendas da Coroa, até a arrematação pelo que mais desse, tomando desse fiança de dez

\footnotetext{
36 "Regimento do Provedor-Mor". In: Marcos Carneiro de Mendonça. Raízes da formação administrativa do Brasil... Op. cit., p. 99 (parágrafo $1^{\circ}$ ).

${ }^{37}$ Rodolfo Garcia. História administrativa e política do Brasil. Rio de Janeiro: José Olímpio, 1956. p. 188.
} 
por cento da quantia avaliada para a dita renda, de que devia fazer um depósito, e a tomada de contas dos mesmos ao fim do Ano Fiscal. "38

Ao provedor, estaria submetida a jurisdição da Fazenda, na qual margeava, de forma híbrida, entre as comarcas e as capitanias, os casos contenciosos ou voluntários de toda apelação e agravo, envolvendo oficiais e rendeiros nas quantias inferiores a dez mil réis e ultrapassando esse valor, deveria remeter recurso para o provedor-mor na Bahia. ${ }^{39}$

O provedor acumulava, também, o conhecimento sobre o juízo da Alfândega ${ }^{40}$, onde julgava todas as pendengas sobre o recolhimento das dízimas nos portos e todas as causas de descaminhos em que estivesse envolvida a tripulação do navio, ou existissem dos erros dos oficiais. Mais ainda, conhecia todos os feitos, causas e dúvidas que se movessem sobre dadas de sesmarias de terras e águas, que os capitães donatários fizessem, processando sem apelação ou agravo até o mesmo limite de dez mil réis. ${ }^{41}$ Além disso, cabia ao provedor, mesmo que de forma temporária, o juízo sobre a Provedoria dos Defuntos e Ausentes - afinal, a ressalva do rei esclarecia que isto só duraria "enquanto eu não dispuser dela em outra maneira ou não mandar em contrário. " 42

\footnotetext{
${ }^{38}$ Nas capitanias, no correr dos meses de novembro a janeiro, separaria o provedor, como contador, as rendas em ramos e, por pregão, tentaria arrematá-las às pessoas que dessem o melhor lanço - observando, entretanto, que nos anos subseqüentes, os lanços não poderiam ser menores que o do primeiro. Feita, então, a arrematação, era tomada a fiança de dez por cento do valor do arremate carregando o almoxarife em livro, tanto esse valor, como de todos os termos do contrato com os prazos em que se devia dar conta do arrecadado. Em janeiro e fevereiro do ano subseqüente, deveria o rendeiro quitar os débitos junto ao almoxarife. Esse oficial, então, prestaria as contas, anualmente, desses recebimentos ao provedor e, qüinqüenalmente, ao provedor-mor na Bahia. Fosse, porém, o almoxarife alcançado seria o provedor encarregado de prendê-lo e fazer a execução nos seus bens. Contudo, acaso houvesse de não ter arrematador para algum ramo, dariam os provedores nomeação a pessoas da terra, fiéis e abonadas, para, sob juramento, procederem à arrecadação dando ao final do mês de fevereiro do ano subseqüente, conta ao almoxarife. Cf: Marcos Carneiro de Mendonça. Raizes da formação administrativa do Brasil... op cit. p. 101 (Parágrafo $5^{\circ}$ ), e p. $99-103$ (Parágrafos $3^{\circ}, 4^{\circ}, 5^{\circ}, 6^{\circ}, 7^{\circ}, 8^{\circ}, 9^{\circ}$ ).

${ }^{39}$ Idem ibidem. p. 101-103 (Parágrafos $7^{\circ}, 8^{\circ}, 9^{\circ}$ ).

${ }^{40}$ Idem ibidem. "Regimento dos Provedores de Capitania" : Parágrafo 11, p. 103. Segundo Graça Salgado, "na instância da capitania[ordenado pela Carta Régia de 4. 10. 1704], o cargo de Juiz da Alfândega tornou-se distinto do de provedor, pois este anteriormente acumulava ambas as atribuições." Cf: Graça Salgado (org.) Fiscais e Meirinhos. A administração no Brasil colonial... Op. cit. p. 88. Todavia, e apesar da distinção, os provedores continuaram a acumular as funções.

${ }^{41}$ Idem ibidem. Parágrafo 41, p. 111. Segundo Regina Gonçalves, registros na Provedoria da Fazenda, sobre dada de terra, duraram até 1699 (Regina Célia Gonçalves. Guerra e Açúcares. Política e Economia na Capitania da Parába 1585-1630. São Paulo, Tese de Doutoramento/FFLCH/USP (Departamento de História. p. 185). Todavia, em documentos referentes à Paraíba, encontramos, para o ano de 1739, o retorno dessa atividade para as mãos dos provedores. AHU_ACL_CU_014, Cx. 11, Doc. 882.

${ }^{42}$ Marcos Carneiro de Mendonça. Raizes da formação administrativa do Brasil...Op. cit. p. 110 (Parágrafo 39).
} 
Por outro lado, dividia o provedor com o governador ou donatário, onde este último existisse, o poder de dar licença para o deslocamento por terra para as pessoas poderem transitar entre as capitanias ${ }^{43}$, bem como, e aí sob sua única prerrogativa, conceder licença para as "pessoas que desejassem sair a tratar e negociar suas fazendas por mar. "44 Da mesma forma, e abaixo do governador, o provedor seria o responsável pela permissão para a fabricação de navios ${ }^{45}$, como pelas diligências sobre o número de armas existentes na capitania, tanto das que estivessem em mãos dos particulares, como nos armazéns militares, buscando prover as que faltassem. ${ }^{46}$

Portanto, os provedores de Fazenda eram senhores de uma dada jurisdição de difícil definição pois, além de serem, por algum tempo, provedores dos Defuntos e Ausentes, eram, também, juizes da Alfândega, Vedores e Contadores da Fazenda, situação que os colocava, na observação do Marquês do Lavradio, praticamente como árbitros de sua própria pessoa. ${ }^{47} \mathrm{O}$ parágrafo 38 do regimento dos provedores de capitania possibilita uma aproximação sobre a autonomia alcançada por estes oficiais:

E mando aos ditos Capitães e pessoas que por eles estiverem nas ditas Capitanias, e a todas as outras justiças das ditas terras, que não conheçam das coisas de que por este Regimento hão de conhecer os ditos Provedores, nem se intrometam nelas, nem em outra alguma que toque a minha Fazenda ou dela dependa, sob pena de suspensão de suas jurisdições, até minha mercê, salvo daquelas em que lhe é dado por este Regimento, que provejam; e mando aos ditos provedores que querendo eles conhecer, prover ou intrometer-se em algumas delas, lhes não consintam e façam disso autos, os quais enviarão a este Reino e à

\footnotetext{
${ }^{43}$ Idem ibidem. p. 112 (Parágrafo 43).

${ }^{44}$ Idem ibidem. op cit. p. 112 (Parágrafo 44).

${ }^{45}$ Idem ibidem. p. 113 (Parágrafos, 46, 47 e 48).

${ }^{46}$ Idem ibidem. p. 115 (Parágrafo 51).

47 Dauril Alden. Royal government in Colonial Brazil. With special reference to the administration of the Marquis of Lavradio, viceroy, 1769 - 1779. Berkley and Los Angeles: University of California Press, 1968. p. 24.
} 
minha Fazenda do negócio da Índia, para nela se despacharem como for justiça. ${ }^{48}$

Neste caso, a lógica que informa é a mesma que explica, pois estaríamos assistindo à fundação jurisdicional de uma expressão político-administrativa autônoma, onde a tendência à patrimonialização da função lhe foi inerente. Nesse setor nevrálgico da administração que foi a Fazenda, o provedor, colocado como gestor dos assuntos de arrecadação e mantenedor dos serviços reais, principalmente dos filhos da folha, teve nas mãos uma ordem de saberes mais ou menos especializados que o faziam, em muitos momentos, tão superior que não se subordinava ao governador, ou aos outros poderes que corriam em paralelo. E mesmo que recordemos que as relações hierárquicas no Antigo Regime podiam ser explicadas pelo poder de controle ou de harmonização dos poderes inferiores e não pelo rigor hierárquico, é bom ressaltar a crítica feita por um coevo, como o Marques do Lavradio, a respeito da situação por que passava o Império português, por volta da década 1770. Para ele era bastante claro que a excessiva jurisdição dos provedores, antes da vigência e criação do Erário Régio, foi a "principal causa da ruína do tesouro"49 Qual era então, a raiz para a autonomização do espaço político e jurisdicional dos ofícios?

A argumentação sobre a eficiência ou ineficiência da ação administrativa metropolitana na Colônia, procura levantar, na historiografia colonial, questões que mantém um rasgo de ponderações, ao mesmo tempo que demonstram, ainda, um tatear cauteloso acerca do tema. Sobre isso, por exemplo, as idéias dicotômicas levantadas por Caio Prado Jr., em Formação do Brasil contemporâneo ${ }^{50}$ e Raimundo Faoro, em Os donos do poder $^{51}$ - em que pese o lapso de tempo entre um e outro trabalho, $1942 \mathrm{e}$ 1957, respectivamente -, tiveram a primazia de alimentar o debate mais recente. As citações abaixo expressam bem as duas vertentes opostas.

\footnotetext{
${ }^{48}$ Marcos Carneiro de Mendonça. Raízes da formação administrativa do Brasil... Op. cit. p. 110.

${ }^{49}$ Dauril Auden. Royal government in Colonial Brazil. With special reference to the administration of the Marquis of Lavradio, viceroy, 1769 - 1779... op cit. p. 24.

${ }^{50}$ Caio Prado Junior. Formação do Brasil Contemporâneo. 21 ed. São Paulo: Brasiliense, 1989.

51 Raimundo Faoro. Os donos do poder:formação do patronato político brasileiro.8ed. Rio de Janeiro:Globo,1989. v. 1.
} 
Para Caio Prado, “a complexidade dos órgãos, a confusão de funções e competência; a ausência de método e clareza na confecção das leis, a regulamentação esparsa, desencontrada e contraditória que a caracteriza; o excesso de burocracia nos órgãos centrais em que se acumula um funcionalismo inútil e numeroso, de caráter mais deliberativo, enquanto os agentes efetivos, os executores rareiam; a centralização administrativa que faz de Lisboa a cabeça pensante única em negócios passados a centenas de léguas que se percorrem em lentos barcos à vela, ... não poderia resultar noutra coisa, senão naquela monstruosa, emperrada e ineficiente máquina burocrática que é a administração colonial. (...) Sobra assim boa margem para a autonomia e mesmo arbitrio dos governadores. E se ... as inovações [na colônia] são insignificantes e não alteram o sistema da administração ... o que se encontrará de diferente se deverá mais às condições particulares, tão profundamente diversas das da metrópole, a que tal organização administrativa teve de se ajustar; ajustamento que se processará de 'fato', e não regulado por normas legais; espontâneo e forçado pelas circunstâncias. " 52

\footnotetext{
${ }^{52}$ Caio Prado Junior. Formação do Brasil Contemporâneo. Op. cit. p. 302, 310 e 333.
} 
Para Faoro, todavia,

A colonização foi obra do Estado, como as capitanias representaram delegação pública dos poderes, sem exclusão da realeza. ... A colonização é negócio seu, dentro do quadro marítimo e universal, sob o controle financeiro da Coroa. ... Com as vilas se instaurava, nas praias e no sertão, a palavra rígida, inviolável e hierática das Ordenações. A colonização e a conquista do território avançam pela vontade da burocracia, expressa na atividade legislativa $e$ parlamentar. Desde o primeiro século da realidade brasileira, a realidade se faz e se constrói com um decreto, alvarás e ordens régias. ... Com estas medidas [implementadas com o governo-geral], completava-se a obra da incorporação e absorção dos assuntos públicos da colônia à autoridade real, por meio dos seus agentes diretos. Era a unidade administrativa, judicial e financeira, assentadas sobre a disciplina da atividade econômica. A obra, empreendida no papel, correspondeu, em grande parte, a execução na realidade. ... Ao Sul e ao Norte, os centros de autoridade são sucursais obedientes de Lisboa: o Estado, imposto à colônia antes que ela tivesse povo, permanece integro, reforçado pela espada ultramarina. ${ }^{53}$

\footnotetext{
${ }^{53}$ Raimundo Faoro. Os donos do poder. : formação do patronato político brasileiro Op. cit. p. 109, 120, 146
} e 165. Apud. Graça Salgado (org.). Fiscais e Meirinhos. A administração no Brasil colonial... Op. cit. p. 18. 
Sobre essas afirmações, pondera Laura de Melo e Souza ${ }^{54}$, demarcando o cunho contraditório dessa discussão, pois o caráter da autonomia ou sujeição da administração colonial à Metrópole só ganharia sentido quando o teor frio da lei fosse confrontado com a realidade. Assim, sugere a autora que,

... no caso específico da administração mineira, ... a oposição entre o critério norteado pela realidade e o critério norteado pela lei, ... à luz de uma e outra interpretação, desvelam-se aspectos interessantes de sua estrutura mais profunda. Tomando a premissa de Faoro como verdadeira, pode-se notar que, de fato, ela se adapta admiravelmente ao caso mineiro: talvez nunca as leis tenham, na colônia, precedido a fixação das populações com tanta intensidade quanto as Minas. ... Por outro lado, a presença do ouro e das pedras preciosas eram uma realidade impar para a metrópole, que nunca se vira às voltas com sua exploração sistemática. As Minas criaram, assim, a necessidade de um sistema fiscal adequado, como diz Caio Prado. ${ }^{55}$

Por outro lado, dois outros aspectos devem ser lembrados na discussão sobre a autonomização dos cargos administrativos na Colônia. O primeiro diz respeito à consideração de serem os cargos administrativos parte do patrimônio real. Neste sentido,

\footnotetext{
${ }^{54}$ Laura de Melo e Souza. Os desclassificados do ouro. A pobreza mineira no século XVIII. Rio de Janeiro: Graal, 1982. p. 91-100.

${ }^{55}$ Idem ibidem. p. 95. Além dessas afirmações, chama, a autora, a atenção para o que diz Charles Boxer em O Império Colonial Português, ao "apontar a participação ativa que, apesar das proibições metropolitanas, os administradores coloniais tinham no comércio, e que tornava mais toleráveis, os baixos salários pagos a esses funcionários, fechando por isso os olhos da coroa frente às irregularidade." Idem ibidem Op. cit., p. 91.
} 
os homens que os preencheram, só o fizeram por graça de uma mercê do rei ${ }^{56}$, ou seja, foram agraciados com um benefício particular e com um regimento específico, levandoos a valorizarem, na sua investidura, o caminho do direito natural à patrimonização. Contudo, a isso se deve ponderar, como alerta José Subtil, que "na economia moral das sociedades do Antigo Regime, existe uma economia da graça, que gera deveres de dar e deveres de retribuir. O que acaba por ter muita importância para a explicação de mecanismos políticos práticos, como o regime das mercês". ${ }^{57}$ Ou seja, antes de pensarmos na total aniquilação da imagem do monarca e numa autonomização desenfreada por parte do oficial, o suscitar da presença real estaria incutido exatamente no ato da bondade e magnificência do rei, através da própria doação da mercê. Afinal, como se dizia entre os coevos, por serem as mercês "cadeias que não se rompem (...) a liberalidade fazia do príncipe duas vezes rei, porque tanto domina nas vontades como nas pessoas." 58

O segundo aspecto, surge da consideração acerca dos problemas advindos da distância percorrida e do tempo gasto pela correspondência entre a Colônia e a Metrópole ${ }^{59}$, ou seja, o tempo administrativo, no dizer de Heloisa Bellotto. ${ }^{60}$ Esse contato podia durar meses, entre a emissão de uma ordem real e o seu conhecimento pelos colonos -, paralisando, retardando, dificultando a ação administrativa da Coroa resultando na ampliação da autonomia do poder dos agentes régios na Colônia, dando

\footnotetext{
${ }^{56}$ Como veremos no próximo capítulo, toda a primeira composição dos cargos da Fazenda da Capitania da Paraíba, após a expulsão dos holandeses, foi provida a título de mercês em reconhecimento aos serviços prestados na guerra de restauração.

57 Cf: José Mattoso(dir). História de Portugal. Vol, IV.Antonio Manuel Hespanha (coord.). O antigo regime (1620-1807). Lisboa: Estampa, 1998. p. 217 (nota 4).

${ }_{58}$ Segundo Manuel Hespanha, "o oficio de reinar... desde a Antiguidade definia a liberalidade e a magnificência como qualidades reais por natureza." E citando excertos de documentos dos meados do século XVIII, alguns atribuídos a Damião de Lemos Faria e Castro, sintetiza, como os citados logo acima: "O tesouro se aumenta quando o Erário se esgota. Cada vassalo rico he um tesouro do rey" ou a "A força que vence não reina nos corações; a generosidade que obriga, domina nas vontades". Cf: Antônio Manuel Hespanha. "A Fazenda". In: José Matoso. História de Portugal. Vol. IV Antonio Manuel Hespanha (coord.). O antigo regime (1620-1807)... Op. cit. p. 183 e 188.

59 Para Rodolfo Garcia, a demora nas transações administrativas envolvendo o Conselho Ultramarino, tocava até em questões que, segundo ele, eram sem de importância mínima: "as queixas, idas da colônia, eram a elas devolvidas para serem informadas pelos governadores e outros funcionários, e tudo isso, com as dificuldades de navegação, levava anos para ter solução definitiva, mesmo quando se tratasse de negócios de natureza mínima, como um passaporte, a baixa de pobre soldado, ou contra outra cousa a esse modo insignificante." Cf: Rodolfo Garcia. História administrativa e política do Brasil ... Op. cit. p. 230.

${ }^{60}$ Cf: Heloísa Liberalli Bellotto. O Estado português no Brasil: Sistema administrativo e fiscal. In: Maria Beatriz Nizza da Silva. O império luso-brasileiro (1750-1822). Lisboa: Estampa., 1986. p. 265.
} 
cabo à confusão nas atribuições hierárquicas entre seus pares, ampliando a jurisdição de uns e diminuindo a de outros e abrindo espaço para o aprofundamento da patrimonialização dos cargos. Como diz Bellotto, entretanto, caso esse problema seja encarado como fruto da ineficiência da Coroa, por não ser capaz de estender de forma absoluta para a Colônia a autoridade real, há de ponderar esta idéia com as considerações de Stuart Schwartz e Maria Fernanda Bicalho. Para o brasilianista, havia nesta demora uma conseqüência deliberada do órgão central em colocar os seus agentes, inclusive os eclesiásticos, numa posição de desconfiança mútua, alimentando uma físcalização paranóica, inclusive com a prática das residências ${ }^{61}$. Para Maria Fernanda Bicalho, a demora dos contatos interferia diretamente na dimensão política, principalmente na justaposição de funções e atribuições pois, supostamente atribuída à ineficiência e carência do poder da Metrópole na Colônia, seria ela também uma "uma política deliberada da Coroa", uma estratégia de governo que "remetia as decisões aos conselhos e tribunais da metrópole. " 62

Sem descartarmos as considerações acima, acreditamos que a caracterização e a forma que tomou a administração na Colônia, com maior ou menor percentual de autonomia, principalmente no seu aspecto fiscal, não podem ser entendidas apenas no funcionamento dos aspectos formais da legislação, pois as condições de instalação dos mecanismos dos poderes político-administrativos oriundos de uma experiência centenária na Metrópole portuguesa, levantam o problema da recepção no ambiente colonial. Com certeza, devemos maturá-las, objetivando-as nos meios de expressão dos interesses que foram vingando, como diz Pedro Puntoni, na "tensão que germinava entre grupos reinóis e brasileiros, mediatizados pela produção que se orientava para a economia-mundo européia em expansão e fundada na presença fundamental do escravismo." 63

Neste sentido, em trabalho já citado, ao discutir sobre alguns elementos da administração no Brasil, Caio Prado Jr., é enfático ao afirmar que, em geral, o sistema de administração existente na Colônia foi um símile perfeito do que existia em Portugal, a

\footnotetext{
${ }^{61}$ Stuart B. Schwartz. Burocracia e sociedade no Brasil Colonial. São Paulo: Perspectiva, 1979. p. 215.

${ }^{62}$ Maria Fernanda Baptista Bicalho. "Centro e periferia: pacto e negociação política na administração do Brasil Colonial”, Leituras, Biblioteca Nacional de Lisboa, 6; 21, primavera 2000., apud Pedro Puntoni. O Estado do Brasil: poderes médios e administração na periferia do Império Português (1549-1720). São Paulo, USP/CEBRAP, 2002. Texto recolhido na Internet. Endereço: www.yale.edu/las/imperial_revisions/Puntoni.doc

${ }^{63}$ Idem ibidem.
} 
metrópole havia sido incapaz de "criar órgãos diferentes e adaptados a condições peculiares que não se encontravam no Reino. "64 E pelo que vimos da organização fiscal do Reino, tirante o acúmulo de poder concentrado nas mãos dos provedores das capitanias, dificilmente encontraríamos alguma proposição diferente para a Colônia brasileira: os órgãos e seus oficiais, os planos de arrecadação e a organização hierárquica, notadamente quanto às prerrogativas tutelares e à tendência à patrimonialização, em nada diferiam da Metrópole. Todavia, continua o historiador paulista, em que pese tanta similaridade, não raramente, seria "só no regime fiscal, quando se tratava dos tributos e a melhor forma de arrecadá-los, que a administração portuguesa procurava sair um pouco da rotina ... [afinal, só] o objetivo fiscal, nada mais do isto, é o que anima a metrópole na colonização do Brasil”. ${ }^{65}$

Curiosamente, esta aparente contradição encerra um raciocínio perfeito. Tendo em vista a desigualdade de condição econômica em que operava a Colônia, em função da fraqueza de recursos na Metrópole, tanto de ampliação de setores existentes como de criação de novas fontes de receitas tributáveis, a Colônia não poderia ficar ossificada, pelo menos no plano fiscal, numa única legislação, os Regimentos de 1548. Assim, mesmo sendo os regimentos válidos para todo o período colonial, a dinâmica da Colônia brasileira catalisou conjeturas dando vazão a experiências ajustadas pelo espontâneo $e$ forçadas pelas circunstâncias. Mas como podia ser diferente, quando pensamos nas diversidades espaciais, históricas, econômicas e culturais da Colônia brasileira?

Desta forma, em que pese o transplante dos órgãos do Estado português sem maiores adaptações, como diz Caio Prado Jr., muitas das soluções foram orquestradas não só através dos Regimentos, mas também de várias leis complementares, que foram sendo baixadas para a Colônia, criando, fundindo e extinguindo órgãos e cargos para o plano fiscal. Essas soluções provinham tanto de demandas externas, isto é, dos ajustamentos da ação do Estado português, frente aos desafios diplomáticos com outras nações, quanto das exigências locais, como sugere Pedro Puntoni, ou seja, de satisfação de necessidades gestadas na Colônia.

\footnotetext{
${ }^{64}$ Caio Prado Junior. Formação do Brasil Contemporâneo... Op. cit. p. 302.

${ }^{65}$ Idem ibidem.
} 
Por conseguinte, quanto às questões endógenas da Colônia, um dúbio valor prático e simbólico foi aí expressado. Por um lado, havia a necessidade que a Coroa tinha de responder aos encargos político-administrativos advindos dos realinhamentos da política fiscal, como garantir, simplesmente, um regime fiscal mais eficiente, enquanto que, por outro lado, devia dar recompensas aos colonos, por meio da distribuição de cargos. ${ }^{66}$ Exemplo disso estava nas diversas interferências da Coroa transferindo, criando e ajustando cargos e órgãos para a Região das $\operatorname{Minas}^{67}$ ou, como veremos nos capítulos adiante, na criação, às vezes de forma claramente inútil, de várias escrivaninhas, juizados de balanças e feitorias edificadas nas alfândegas da zona açucareira.

$\mathrm{Na}$ tentativa de compreensão do processo de transplante/adaptação da instituição administrativa, há se de pensar, também, que a dimensão dos espaços jurisdicionais que cada oficial maior detinha e defendia, respectivamente, nas suas áreas de atuação, não estava apenas circunscrita na correlação de força jurídica, entre tribunais e indivíduos, mas, também, se constituía a partir de um raio concreto de atuação territorial. Neste sentido, a título de comparação, por exemplo, entre os objetivos propostos e a exeqüibilidade da dimensão de uma dada jurisdição, isto é, uma área territorial dentro da qual uma autoridade exerce o poder na Colônia e na Metrópole, vemos, então, que no Reino, segundo Manuel Hespanha, a jurisdição estava doutrinada no antigo padrão romano fixado na dieta, isto é, a distância que podia ser percorrida em um dia, medida que não deveria ultrapassar a 5 léguas, ou seja, a 30 quilômetros:

\footnotetext{
${ }^{66}$ Stuart B. Schwartz. Burocracia e sociedade ... Op. cit. p. 295.

${ }^{67}$ Várias transformações ocorreram na região mineradora. O grande impulso do segmento administrativo, contudo, deu-se no início do século XVIII em diante, quando a atividade mineradora se intensificou. Em Fiscais e Meirinhos, Graça Salgado nos traz uma síntese acerca desse desenvolvimento: em 19 de abril de 1702, são criados os cargos de Superintendente e Guarda-Mor das Minas, com poderes para investigar crimes de contrabando e regulamentação das datas de terras. Esse superintendente também podia prover guardas-menores, ficando estes subordinados a suas ordens diretas. Por volta de 1700, foram criados cargos de Provedores de Registro, responsáveis pela fiscalização da saída e entrada de mercadorias, inclusive de ouro, nos territórios das minas. Entre 1735 e 1736, criaram-se as Intendências do Ouro, substitutas da Superintendência das Minas, para onde eram designados um Intendente e mais um corpo de oficiais para ajudá- lo, ou seja, um fiscal, um tesoureiro, um escrivão e seu ajudante. Após 1750, foram criados: em 1751, a Intendência Geral do Ouro; em 1803, a Real Junta Administrativa de Mineração e Moedagem. Ainda, porém, em 1734 até o final dessa década, foi criada a Intendência dos Diamantes, com um intendente, um escrivão, um fiscal e um meirinho. Cf: Graça Salgado (org.). Fiscais e Meirinhos. A administração no Brasil colonial... Op. cit. p. 88-93.
} 
Na legislação portuguesa, o padrão de avaliação da relevância jurídica do espaço, nomeadamente para o fim da divisão das competências jurisdicionais, era correspondente a isto. As Ordenações Filipinas fixavam o limite da jurisdição do tribunal da corte em cinco léguas; enquanto que a amplitude espacial da jurisdição dos ouvidores era também de cinco léguas. 68

Ainda que, para o Reino, esta determinação se tornasse demasiadamente grande quando ultrapassava dez léguas, ao ser transportada para as dimensões continentais do Brasil, mesmo se supondo o uso de meios de comunicação e transporte mais ágeis, como o cavalo ou as embarcações na costa, ela não obedecia à mesma doutrina da dieta, excedendo, em muito, o raio jurisdicional previsto. Isto acontecia porque, para além do espaço compreendido de uma dada jurisdição, que poderia ultrapassar a medida das cinco léguas recomendadas, a ela se poderiam somar outras anexas, agravando ainda mais a situação. Assim, do transplante original das capitanias hereditárias com seus donatários, às capitanias reais com seus capitães- governadores das armas, passando pelas comarcas adstritas aos ouvidores ou à jurisdição da provedoria, que se limitava, de maneira híbrida, nas dimensões das comarcas ou nas capitanias da Colônia, a experiência do Reino estaria, literalmente, muito distante e incapaz de solver esse imbróglio territorial:

Mas em vez de obviar aqueles inconvenientes com uma dispersão máxima de agentes, a administração metropolitana, repetindo fielmente o que se praticava no minúsculo Reino, deixava-as todas, ou a maior parte delas, nos centros principais onde sua ação se

\footnotetext{
${ }^{68}$ Antonio Manuel Hespanha. As vésperas do Leviathan. Instituições e poder político Portugal, século XVII... Op. cit. p. 91.
} 
tornava quase inútil pela distância que ficavam de seus administrados. ${ }^{69}$

Uma vez avaliadas as questões que a distância da Metrópole podia trazer para a administração da Colônia, faz-se necessário pontuar a relevância desse jogo em um terreno concreto de atuação. Para isso, é preciso ampliar o recorte geopolítico formado pela jurisdição da Fazenda, Justiça, Igreja e Milícia, no território compreendido pelas Capitanias do Norte, demarcando de maneira mais específica, os limites de ação da Provedoria da Fazenda Real da Paraíba.

\section{OS LIMITES JURISDICIONAIS NAS CAPITANIAS DO NORTE}

Desde o fim do século XVI que das Capitanias de Itamaracá e, principalmente, de Pernambuco, se irradiaram os planos de conquista na direção do Norte do Estado do Brasil. Segundo Regina Gonçalves, os passos dessa conquista que foram abrindo espaços em expedições permanentes, estavam vinculados diretamente aos interesses da sociedade colonial instalada em Pernambuco e cuja empresa se ancorava no negócio do açúcar e no tráfico de escravos indígenas. Neste sentido, a elite que se instalou nas áreas de expansão dessas atividades, principalmente na Paraíba, deve ser compreendida como uma extensão da nobreza da terra de Pernambuco que, de certa forma, fazia parte de uma nova geração de filhos de antigos senhores de engenho pernambucanos, mas sem oportunidade de enriquecimento quer na atividade produtiva, quer na ocupação dos cargos na administração. Assim, a rede de solidariedade e de interesses comuns, que os unia contra o inimigo comum, os índios hostis, ou na defesa da agromanufatura do açúcar, só começou a ser rompida quando da ocupação holandesa. A partir daí é que se pôde assistir ao fracionamento interno dessa elite, devido às posições diferentes assumidas diante dos novos conquistadores. ${ }^{70}$

\footnotetext{
${ }^{69}$ Caio Prado Jr. Formação do Brasil Contemporâneo ... Op. cit. p. 302-303.

${ }^{70}$ Regina Célia Gonçalves. Guerras e açúcares: Política e Economia na Capitania da Paraíba 1585-1630... p 88-111. Sobre a ultima questão, acerca das posições assumidas pela elite pernambucana na relação com os invasores, durante o conflito e após a restauração, consultar: Evaldo Cabral de Mello. Olinda
} 
O retorno à estabilidade, após o período de beligerância, lançou a elite paraibana, ela mesma restauradora, na reativação econômica da capitania e nas ocupações dos cargos administrativos ali existentes. Entretanto, a perda do contingente populacional e a destruição dos engenhos, acrescidos das baixas do açúcar no mercado internacional, deixaram a economia da Paraíba num estado desolador. ${ }^{71}$ Como esses problemas não eram sentidos apenas nessa capitania, as mesmas mazelas, mesmo que numa dimensão mais branda, envolveram também a vizinha, de Pernambuco.

Esse quadro, nada promissor, era agravado pelo fato de Portugal estar em guerra contra a Espanha, levando o desgastado Reino a se limitar apenas a ajudas fiscais, não executando os senhores de engenhos por dívidas, nas suas propriedades e fábricas. Neste sentido, o capital para a reconstrução e reativação da economia em Pernambuco passaria a sair de uma nova classe de homens de negócios, majoritariamente formada por uma população recém-chegada do Norte de Portugal, e que formaria a elite mascatal do Recife. $^{72}$ É certo que as desavenças no conflito envolvendo a nobreza olindense e a mascataria recifense rasparam levemente em algumas ações de João Maia da Gama, governador da Paraíba à época, e cujo apoio aos mascates, na leitura dos camaristas da Paraíba, foi um dos motivos da retaliação da nobreza pernambucana que a levaram a desejar a anexação nos fins do ano de 1755. Mas como a nossa intenção não é levar ao cabo a história da Guerra dos Mascates, procuramos reter, deste fato, apenas o processo de contínua transformação da cidade do Recife.

Tornando-se não apenas a sede de capital e comércio, mas também a hinterlândia sobre a vasta região das Capitanias do Norte, Recife beneficiou-se, desde cedo, com os apertos do pacto colonial, já que era para aquela cidade portuária que se dirigia a nem

\footnotetext{
restaurada: guerra e açúcar no Nordeste, 1630-1654. Rio de Janeiro: Topbooks, 1998. Particularmente, o capítulo VIII, “A querela dos engenhos”. p. 386-447.

${ }^{71}$ Irene Rodrigues Fernandes \& Laura Helena Baracuí Amorim. Atividades produtivas na Paraíba. João Pessoa: Editora Universitária,/UFPB, 1999. p. 25.

72 "O financiamento da produção açucareira achava-se agora a cargo desses homens [os mascates] que adiantavam ao senhor de engenho o capital de giro com que operar até a conclusão da safra anual, quando se procedia ao ajuste de contas entre o credor e o devedor. Fora do crédito mercantil havia poucas fontes de financiamento: a família e os parentes, a Santa Casa de Misericórdia, ou então alguma ordem religiosa ou terceira mais próspera, que era, via de regra, as ordens do Recife, não as de Olinda, de modo que, em última análise, tratava-se aqui de uma forma disfarçada de crédito mascatal". Evaldo Cabral de Mello. A fronda dos mazombos. Nobres contra mascates. Pernambuco 1666-1715. São Paulo: Cia das Letras, 1995. p.125.
} 
sempre regular frota mercante portuguesa. Assim, ainda durante o último quartel do século XVII, a cidade do Recife de Pernambuco se fez prevalecer como sede e residência dos agentes que controlavam, internamente, boa parte do financiamento da produção açucareira e o movimento comercial: manejando a exportação de cargas de mais de uma centena de engenhos, além de boa parte da produção de couro e tabaco do restante das Capitanias do Norte. ${ }^{73}$

Neste sentido, o exclusivismo colonial português, quando livre do jugo espanhol, era reeditado por uma série de medidas, como se pode constatar na criação da Companhia Geral de Comércio, em 1649, no decreto determinando a exclusividade aos navios portugueses de comerciarem com o Brasil, em 1661, na proibição aos navios partidos das costas brasileiras de se dirigirem para outros portos que não os portugueses, em 1684, e no sistema de frotas, em 1690. Todas essas medidas apertavam o cerco contra o contrabando e contra o assédio de outras nações às paragens atlânticas ${ }^{74}$, restringindo, ainda mais, os contatos com a Metrópole apenas pelo porto do Recife.

As distensões provocadas na elite paraibana, entre os partidários desse contato com o comércio recifense - notadamente os grandes proprietários de engenhos - e os contrários a ele - notadamente os pequenos produtores e, principalmente, os comerciantes locais, além dos administradores reinóis e da Câmara da Paraíba, que viam se esvaírem alguns impostos -, desembocaram na intervenção da Coroa, que procurou, mesmo que de forma dúbia, regular os contatos com o porto do Recife. Assim, o Conselho Ultramarino, após pender para um lado e outro da questão, determinou, em 1711, que acaso houvesse possibilidade de chegarem navios na capitania, não consentisse o governador da Paraíba liberar as cargas para o Recife. Pelo sim, pelo não, esta medida deixou em aberto os contatos entre as duas praças e engendrou algumas quebras na percepção de parte das elites coevas paraibanas. Além de reconhecerem nesta medida um fechar de olhos da Coroa sobre a posição hegemônica do Recife, as elites paraibanas viram, também, o recrudescimento de um antigo sentimento, a saber, de que o sucesso da

\footnotetext{
${ }^{73}$ Irene Rodrigues Fernandes \& Laura Helena Baracuí Amorim. Atividades produtivas na Paraíba ... Op. cit. p. 25.

${ }^{74}$ Fernando A Novais. Portugal e Brasil na Crise do Antigo Sistema Colonial ... Op. cit. p. 81 e 82.
} 
capitania de Pernambuco era o prenúncio da decadência da Paraíba. Ambrósio Fernandes Brandão, morador na Paraíba, ainda em 1617, foi mentor desse sentimento:

E tenho por sem dúvida, que, se não estivera [a Paraíba] tão conjunta com a vizinha de Pernambuco, que já se houvera aumentado no seu crescimento ... porque, como tem Pernambuco tão chegado os seus moradores se costumam se prover dela das coisas de que se tem necessidade, fazendo levar, para esse efeito, muito açúcar que comutam pelo que compram, com o que engrandecem de vez mais a capitania de Pernambuco e diminuem a sua. E é a razão que deixam de vir naus a ela, que viriam, se os seus moradores esperassem por elas para se haverem de prover do que lhes fosse necessário, e para esse efeito reservassem seus açucares, tendo-os prestes para com eles se carregarem as ditas naus; mas, como estão já providas de Pernambuco, onde tem dependido os seus açucares, as naus que vêm ao seu porto não podem dar saída que quiserem as fazendas que trazem, nem menos carregarem com a brevidade que lhes era necessária e porque este respeito vêm poucas, sendo a capitania capaz de carregar em cada um ano vinte naus. ${ }^{75}$

Assim sendo, o significado estratégico que a capitania de Pernambuco representou em momentos históricos determinados, tanto militar - como ponto de expansão e conquista em direção ao Norte - como econômico - ao se projetar como sede financeira e de entreposto da hinterlândia das Capitanias do Norte -, foi o principal fundamento para

\footnotetext{
${ }^{75}$ Ambrósio Fernandes Brandão. Diálogos das grandezas do Brasil. Recife: Impressa Universitária, 1962. p. 44.
} 
a explicação da prevalência da hegemonia do capitão- general ali residente $^{76} \mathrm{e}$ da fundação do bispado em Olinda.

\section{A JURISDIÇÃO POLÍTICO-MILITAR}

Formalmente, os capitães-generais, hierarquicamente inferiores ao governadorgeral ou vice-rei, estes, residentes na Bahia ou Rio de Janeiro (1763), se esforçavam para fazer valer suas ordens sobre os capitães-mores das capitanias subalternas, ou sobre governadores nas suas áreas de influência. ${ }^{77}$ Isto porque, nesta hierarquia, a principal manifestação de poder estava na condição do Capitão-general nomear seus militares subordinados - pelo tempo que a legislação permitisse ${ }^{78}$-, ou levantar homenagem aos comandantes nomeados diretamente por provisão real. Também estava sob sua orçada manter o controle sobre o tribunal militar e, por força da capacidade em fazer alianças políticas com as elites locais e com os responsáveis por postos-chaves da administração, como provedores, ouvidores ou eclesiásticos, influenciar em decisões que, preferencialmente, estariam sob prerrogativa dos governadores ou capitães-mores locais. Porém, como todos os vice-reis, governadores-generais, capitães-mores e governadores possuíam um canal de contato direto com o rei e seus ministros do Conselho Ultramarino e depois com as Secretarias de Estado, por vezes prevalecia menos o rigor formal da graduação da autoridade, constante nos Regimentos, que os meios de persuasão e os

\footnotetext{
76 "O título de capitão-general tinha sido, até então, reservado para os governadores-gerais, e referia-se a a aspecto militar de sua atividade. O governador do Rio de Janeiro foi o primeiro a receber esse título em 1697; posteriormente foi concedido para outros governadores como os das capitanias de Pernambuco, São Paulo e Minas de Ouro, Maranhão”. Paulo Pedro Perides. "A organização político-administrativa e o processo de regionalização do território brasileiro". In: Revista do Depto de Geografia USP/1995 / nº 9. p. $77-91$

${ }^{77}$ Aqui fazemos a distinção entre o cargo militar, expresso na patente de capitão-mor, general, coronel, etc. e o cargo executivo de governador. Os administradores do Ceará e Rio Grande, por exemplo, nunca levam o título de governadores.

${ }^{78}$ Do lado da Colônia, cabe esclarecer que, comumente, os capitães governadores de capitania, no litoral, teriam prerrogativa para proverem serventuários por três meses; governadores generais (Maranhão, Pernambuco, Salvador, Rio de Janeiro), seis meses, o mesmo caso para governadores capitães do interior, tempo suficiente, acreditava-se, para regularizarem sua aprovação pelo rei. Cf: AHU_ACL_CU_014, Cx.7, D 625 .
} 
interesses pessoais, que ganhavam notoriedade e se consolidavam com o passar do tempo. $^{79}$

Um exemplo acerca dos inconvenientes por que passavam os vice-reis do Brasil, sobre terem de ficar lembrando as jurisdições aos governadores das capitanias, ou da sujeição desses aos governadores-gerais, encontramos em uma carta do Conde de Sabugosa, Vasco Fernandes César de Menezes, ao rei, datada de 1730. Nela Sua Majestade é alertado de que os governadores de São Paulo, Minas Gerais e, principalmente, da Paraíba, estavam provendo pessoas para a serventia dos oficios de justiça e fazenda, quando isto deveria ser prerrogativa dos governadores do Rio de Janeiro e Pernambuco e de estrito reconhecimento seu. ${ }^{80}$

Aos governadores era autorizado apenas nomear por três meses, cabendo-lhe dar parte do ato ao governador-geral e este, ao vice-rei, fechando o circuito com a aprovação ou não do rei. Havia, no entanto, uma quebra nesta articulação, lançando os governadores a contatos diretos com Lisboa e colocando sob suspeita a autoridade do vice-reinado:

Desta [dou] conta a V. Majestade, para me livrar de entrar em contendas com os ditos governadores, $e$ das conseqüencias que se podem seguir de mandar suspender todos os oficiais que estiverem servindo por provimentos seus, sem precederem as circunstâncias dispostas no meu e seus regimentos; esperando que a Real Grandeza de V. Majestade dê a este abuso a providência que for mais conveniente para que se não grave com tanta diminuição a jurisdição deste governo; aos que da tolerância daquela introdução e de outros mais descuidos que

\footnotetext{
${ }^{79}$ Contrariamente ao que pode induzir, tal perspectiva visava reforçar a centralização uma vez que, nestas condições, poder-se-ia reduzir o tempo de execução de uma ordem emanada de Lisboa, coso tivesse essa mesma ordem que tramitar através do governo-geral, e, daí, para as outras capitanias. Cf: Paulo Pedro Perides. A organização político-administrativa e o processo de regionalização do território brasileiro... e, Dauril Alden. Royal Government in Colonial Brazil. With special reference to the administration of the Marquis of Lavradio, viceroy, $1769-1779$.... Op. cit. p. 34.

${ }^{80}$ AHU_ACL_CU_014, Cx. 7, Doc. 625.
} 
tem havido se segue o dano de se constituírem os ditos governadores só dependentes das resoluções de V. Majestade, por cuja causa não sei das dependências das capitanias ... senão curiosamente por pessoas particulares. ${ }^{81}$

O motivo maior da indignação de Vasco de Menezes estava no que the respondera, dias antes, o governador da Paraíba, Francisco Pedro de Mendonça Gurjão, quando o vice-rei o advertiu para agir de acordo com o seu regimento. Na capitania da Paraíba era uma prática comum do governador prover os ofícios não apenas da justiça e da fazenda, mas também dos postos milicianos. Por isso, o governador dizia estar bastante cônscio dos seus deveres e direitos, incluindo aqueles de caráter consuetudinário, isto é, pousado nos costumes, que lhe haviam deixado seus antecessores. Entre esses direitos estava, por exemplo, o de prover os cargos da capitania e dar pronto reconhecimento ao rei e seu Conselho Ultramarino, afinal, "a regalia [de prover os postos vagos na Paraíba] é do lugar e não da pessoa”. Não reconhecia, enfim, no governador de Pernambuco, como queria fazer-lhe crer o vice-rei, "nem mais nem menos regalia ... porque as mesmas ordens que a este governo se passam se passam também aos mais da América”. ${ }^{82}$

Nesses conflitos de jurisdição entre as Capitanias do Norte, pode-se perceber que a relação de subordinação da Paraíba com Pernambuco - diferentemente do Ceará que, desde 1656, quando foi separado do Maranhão, ligou-se a Pernambuco e do Rio Grande, subordinado à mesma capitania, em 1701 - não se firmou formalmente antes de dezembro de $1755 .{ }^{83} \mathrm{Na}$ verdade, além dos problemas com a administração, envolvendo questões de provimento e nomeações, as tensões e disputas de jurisdição estritamente militar não foram poucas, podendo-se encontrar, já em 1661, o primeiro entrevero nas capitanias do Norte.

\footnotetext{
${ }^{81}$ Idem.

${ }^{82}$ Idem.

${ }^{83}$ José Ribeiro Júnior. Colonização e monopólio no Nordeste brasileiro ... Op. cit. p. 63.
} 
Tal fato aconteceu quando Francisco de Brito Freire, governador de Pernambuco, no afã de fazer valer sua patente de general, enviou para as capitanias de Itamaracá, Paraíba e Ceará, algumas companhias de infantaria com seus comandantes, para que nelas dessem voz ao seu comando. Mas , se em duas capitanias obteve êxito ${ }^{84}$, na Paraíba seus planos foram frustrados.

À Paraíba, enviara Brito Freire uma companhia de infantaria com duzentos homens, sob o comando de João do Rego Barros. O intuito de Brito Freire era render as companhias da praça da Paraíba - que eram compostas por moradores e parentes próximos do lugar - e afirmar o seu poder com pessoas de sua inteira confiança. A resposta de Mathias de Albuquerque Maranhão, governador da Paraíba, acalmou a ira dos moradores e soldados que já se amotinavam tomando armas. Para tanto, a sua estratégia foi receber a tropa enviada por Brito Freire, como se acatasse a sua ordem e resolver a questão direto com Francisco Barreto, governador-geral, na Bahia, e com o rei, através do Conselho Ultramarino. Segundo Mathias Maranhão, sendo ele

mais velho e com larga experiência, não era razão que com um mancebo apaixonado [como Brito Freire,] pusesse em risco o serviço de Vossa majestade em poder haver uma guerra civil entre uma e outra capitania, e quis antes que esse mancebo se vangloriasse de lhe parecer que estava vitorioso e que eu cedera de alguma maneira, do que pudesse dizer, que sendo velho lhe não soubera botar água na fervura. $^{85}$

\footnotetext{
${ }^{84}$ Numa carta do capitão-mor do Ceará, Diogo Coelho de Albuquerque, ao rei [D. Afonso VI], em 16 de maio de 1661, queixava-se do procedimento do governador de Pernambuco, Francisco de Brito Freire, que, ao enviar um ajudante seu para o socorro da capitania, acabou por tirar-lhe toda a jurisdição. AHU_ACL_CU_017, Cx. 1, Doc. 18. (Avulsos, Capitania do Ceará) Sobre Itamaracá, ver a carta dos oficiaì da Câmara da Vila de N. S. da Conceição informado dos atos de Brito Freire. Cf: AHU_ACL_CU_015, Cx. 7, Doc. 704. (Avulsos, Capitania de Pernambuco)

${ }^{85}$ AH $\bar{H}{ }_{-} A \bar{C} L \_\bar{C} U \_014$, Cx. 1, Doc. 47.
} 
O resultado disso tudo não passou de um estranhamento muito comedido diante das ações de Brito Freire, por parte da Coroa. ${ }^{86}$ Em resumo, a Coroa fez crer ao mancebo que a ele não se havia dado permissão alguma para consecução de "tal novidade", pois a Capitania de Itamaracá era de donatário enquanto as outras três capitanias eram reais e, como tais, subordinadas apenas à Bahia. Afora isto, não se removeu uma palha do que já estava feito - afinal, as tropas de infantaria acantonadas no Rio Grande e Ceará, ficaram compostas com um contingente oriundo de Pernambuco e a responsabilidade da manutenção das fortificações da Paraíba passou para a Provedoria pernambucana, que perduraria até $1704 .{ }^{87}$ Nessa disputa, como em muitas outras, a Coroa sempre se colocava por trás de uma enorme pendenga, fazendo avolumar no tempo uma pilha de recursos, até que as partes se acomodassem. No caso em destaque, porém, a ação do governador da Paraíba, ao pôr freios em Brito Freire, fez arrastar por muito tempo a autonomia administrativa da capitania. Política e militarmente, portanto, a capitania de Pernambuco abrangia, além da área que lhe corresponde, a capitania de Itamaracá ${ }^{88}$, Ceará e Rio Grande.

\section{A JURISDIÇÃO ECLESIÁSTICA}

Não foi apenas o problema com a jurisdição militar que perturbou a gestão de Mathias de Albuquerque Maranhão. Mal se havia refeito dos entreveros com o governador de Pernambuco, e já tornava a se comunicar com Lisboa, apelando para não ser submetido a mais um poder que passava a se irradiar da capitania vizinha. Em 1662,

\footnotetext{
86 Todavia, além desses problemas, confusões aprontadas pelo governador contra a elite local pernambucana resultaram no término antecipado do seu governo, sendo preso e deportado para Lisboa. Cf: Vera Lúcia Costa Acioli. Jurisdição e conflito: a força política do senhor de engenho. Recife: UFPE / Departamento de História, 1989. p. 96

${ }^{87}$ Idem. Segundo Kalina Silva, após a reforma feita por Francisco de Brito Freire, em 1663, quando introduziu no Brasil a Milícia Auxiliar - a tropa de linha de Pernambuco -, isto é, a tropa profissional, passou a contar com uma força reserva dividida entre o Ceará e o Rio Grande. Cf. Kalina Vanderlei Silva. O miserável soldo \& a boa ordem da sociedade colonial - Pernambuco séculos XVII e XVIII. Recife: Fundação de Cultura da Cidade do Recife, 2001. p. 90.

${ }^{88}$ Em dezembro de 1688 , por conta de uma contenda sobre a quem cabia a jurisdição, se ao novo ouvidor da Paraíba ou ao governador de Pernambuco, acerca da suspensão aos oficiais da capitania de Itamaracá que ali estivessem servindo sem pagar os novos direitos, alertava o rei que "o governador de Pernambuco não tem jurisdição em Itamaracá, mais que no militar pela cercania...” IHGP/ PB Códice: 1816 Ouvidoria, folha $14 \mathrm{v}$.
} 
um ano após o episódio com Brito Freire, o governador escreveu a Coroa, juntamente com os oficiais da câmara paraibana, pedindo para que não ficassem sujeitos à Vigariaria Geral de Pernambuco. Alegavam que antes da retirada do Vigário da Matriz da cidade da Paraíba, por conta dos conquistadores batavos, o povo paraibano havia se acostumado a ver o seu vigário investido com os poderes de Provisor, Vigário Geral e Visitador das capitanias da Paraíba e do Rio Grande. Além disso, tinham a lhes perturbar um motivo bastante prático: a falta de condições para o traslado do Vigário de Pernambuco - afinal, a distância de mais de 25 léguas, entre as cidades de Olinda e Paraíba, com muitos rios e riscos, iria trazer à capitania paraibana grandes dispêndios que não se poderia aturar, principalmente devido ao estado miserável em que a guerra a deixara. Pediam, então, ao rei, a mercê de mandar passar ordem para o Cabido da Bahia fazer a separação na forma antiga, ficando, finalmente, restituída a jurisdição do eclesiástico ao "primeiro Estado", ou seja, a Bahia. ${ }^{89}$

Passados quatro anos, contudo, sem que houvesse um posicionamento da Mesa de Consciência e Ordens, para aonde tinha corrido a solicitação, chegou à Paraíba, em 1676, o comunicado da fundação do bispado de Pernambuco, por Bula do Papa Inocêncio XI. A notícia, que não deve ter agradado aos paraibanos, pareceu como mais um ferrete às suas costas, indicando a consolidação do poder clerical em Olinda. E, se antes, com a presença do Vigário Geral em Pernambuco, as despesas com as visitações já apareciam como algo impeditivo aos cofres da Fazenda da Paraíba, agora lhe somava um encargo extra e inesperado, a contribuição para o pagamento do Bispo e Cabido da Sé de Olinda. Uma provisão real, datada de 15 de janeiro de 1678, comunicava ao capitão-mor governador da Paraíba e ao seu provedor que, doravante, caberia à capitania de Itamaracá o dispêndio anual de 400\$000 réis, e à Fazenda Real da Paraíba, a soma de $300 \$ 000$ réis, cujos valores deveriam ser retirados dos sobejos dos dízimos das respectivas capitanias e passados para a Provedoria de Pernambuco. ${ }^{90}$

Porém, a falta de recursos na provedoria da Paraíba não demorou a ser sentida, e, ao cabo de dez anos, o provedor daquela capitania, Salvador Quaresma Dourado, no ano de 1688, enviou uma carta ao rei, dizendo ser impossível continuar a atender a esta

\footnotetext{
${ }^{89}$ AHU_ACL_CU_014, Cx. 1, Doc. 50.

${ }^{90}$ AHU_ACL_CU_014, Cx. 2, Doc. 105.
} 
despesa, que já corria com cinco anos de atraso. Nesta carta, o provedor alegava que o arrendamento dos dízimos reais feitos a Martin Correia, no ano de 1687, chegara a render perto de 1:800\$000 réis, e que tal receita deveria atender aos anos de atraso do fardamento da Infantaria e, especialmente para aquele ano, financiar as propinas para as munições. Além disso, também cabia- lhe os gastos das campanhas contra os gentios e com o socorro da própria Infantaria pois, tendo em vista os poucos rendimentos dos subsídios do açúcar administrados pela câmara municipal, tudo acabava mesmo sobrecarregando a consignação do dízimo. ${ }^{91}$

Desta forma, Salvador Dourado lastimava não ter como se virar com o pouco dinheiro de contado que chegava às suas mãos. Afinal, os pagamentos dos contratos dos dízimos do açúcar seguiam a mesma fórmula de todos os outros contratos que corriam na capitania, ou seja, eram divididos em três quartéis: o primeiro em dinheiro, o segundo em fazenda e o terceiro em açúcar. Assim, se o dinheiro não era bastante para as despesas com os filhos da folha, a fazenda não chegava para todas as fardas e o açúcar acumulava-se nos passos reais - ora por faltar gente de cabedal para arrematá-lo, ora por não ter ordem do rei ou do governador-geral para levar o açúcar até Pernambuco -, como, então, desatar o nó e pagar aqueles que só aceitavam seus ordenados em dinheiro $?^{92} \mathrm{O}$ jeito era partir para o confronto e vencer pela exaustão, mas com o bispo de Pernambuco foi diferente. As sugestivas características provocadas pelo desenrolar dos contatos entre os provedores das duas capitanias, Pernambuco e Paraíba, para solucionar este fato, trazem à superfície um complicado jogo de emulação entre os provedores, como meio de salvaguardarem os compromissos assumidos. Além disso, revelam como as formas de pressão do poder eclesiástico se colocavam acima da jurisdição das capitanias, para fazer valer os ordenados dos seus prelados.

Como referimos acima, em 1688 o atraso somava cinco anos e o numerário já passava da casa dos cinco mil cruzados, ou seja, pouco mais do total dos dízimos arrematados. Boa parte da renda havia, mas não na espécie que queria o bispo. Estocado em açúcar, o produto estava à espera que o prelado se dignasse a mandar buscá-lo "por sua conta e risco”. Já fazia meses que Salvador Dourado, repetidamente, colocara o

\footnotetext{
91 Idem.

92 Idem.
} 
açúcar em pregão, mas os lanços eram bem abaixo do valor alcançado na última arrematação, $\$ 960$ réis a arroba. ${ }^{93}$

Acresce esclarecer que, para o bispo, até então, nada faltara. Na verdade, os anos em atraso haviam sido cobertos pelo provedor de Pernambuco, João do Rego Barros, que só agora passava a régua nos valores represados e pressionava o bispo a mover-se para cobrar a fatura. O padre, contudo, além de se mostrar bastante intolerante, fazendo uso de censuras, foi mais incisivo, e, de pronto, excomungou Salvador Dourado. ${ }^{94}$

Embora o recurso da censura pelos clérigos fosse algo recorrente no mundo luso ou na América Espanhola, principalmente quanto aos embates sobre a licitude ou não da tributação dos bens ou renda da Igreja ${ }^{95}$, a excomunhão do provedor da Paraíba soou

\footnotetext{
93 Idem.

${ }^{94}$ AHU_ACL_CU_014, Cx.2, Doc. 166.

95 O clero regular, muito comumente, quando pressionado pelos oficiais da Câmara da Paraíba para responderem positivamente à cobrança dos subsídios do açúcar fabricados em seus engenhos, costumavam ameaçar os fiscais com censuras. Cf: AHU_ACL_CU_014, Cx.2,Doc. 168. Quanto à questão da América Espanhola, dizia o procurador da Coroa neste caso em destaque, "que, não havia muitos anos, que estes procedimentos de censuras se mandaram estranhar nas Índias de Castela”. Cf: AHU_ACL_CU_014, Cx.2, Doc. 166. Quanto à licitude ou não da tributação dos bens da Igreja, vemos que esta questão envolvia dois aspectos: "Um o da licitude in abstracto, por assim dizer, do tributo, face à ordem étnicojurídica comum. Outro, o da sua ilicitude no plano de uma ordem jurídica concreta, v. g., a portuguesa, com as suas limitações específicas que a ela contivesse ao poder tributário do rei. No primeiro plano -o da moral do direito comum -, a doutrina tinha como guia dois princípios. $O$ do caráter odioso de novos tributos e o de que, de qualquer modo, estes (como os antigos) tinham que ser legítimos..., sob pena de excomunhão para quem os impusesse e de recusa justificada de pagamento pelos tributados... Assim, os tributos (novos) podiam ser ilícitos e levar à excomunhão: 1) ex causa efficiente, ou seja, por falta de poder tributário de quem os criou; 2) ex causa finale, por não terem em vista o bem comum; 3) ex causa materiale, se incidem sobre bens de sustento - mas naõ de mercadorias objeto de comércio...;e, 4) ex causa formale, se não fossem iguais ou proporcionados, sobrecarregando mais os pobres que os ricos... Em face do ordenamento jurídico concreto, o que levanta desde logo. [é] o problema da obrigatoriedade ou não do consentimento dos povos. Em Portugal, a opinião geralmente recebida até o início do século XVIII é a da necessidade do consentimento do Reino, reunido em cortes... Caso particular ... era o da tributação da Igreja... Na verdade, o $\$ 18$ da Bula da Ceia feria de excomunhão todos os que impusessem, sem licença expressa do papa, quaisquer coletas, décimas, talhas contribuições ou ônus, sobre os eclesiásticos, instituições da Igreja, beneficios eclesiásticos ou bens patrimoniais adquiridos de qualquer modo pela Igreja ..., embora se admitisse que, quando se tratasse de ônus exigidos pela utilidade publica [os subsídios], os clérigos estivessem obrigados a eles, podendo ser coagidos pelo juízo secular ou eclesiástico... No direito nacional, a discussão girava em torno de três textos das ordenações: o das Ordenações Filipinas, II, 1, 19, que estabelecia a sua sujeição ao foro comum (e, implicitamente, aos respectivos tributos) no caso de questões levantadas pela aplicação dos tributos das alfândegas, sisas, dízimas, postagens e aduanas, 'nos casos em que conforme nossas Ordenações, e direito os deverem'; um outro era o das Ordenações Filipinas, II, 11, 1, em que expressamente se isentavam os clérigos de dízima (do pescado, das sentenças, das alfândegas), postagens e, em parte, da sisa; o último era o das Ordenações Filipinas, II, 33, 8, que estabelecia a sujeição do príncipio dos clérigos em relação às julgadas. Tudo combinado ... o balanço era muito favorável aos eclesiásticos ... que podiam vender sem receio de sisa, portagens ou aduanas, vender os seus bens móveis e imóveis, bem como as rebdas dos seus
} 
como uma ação anômala, tanto para os conselheiros do Ultramarino como para o procurador da Coroa. Ambos entenderam que se deveria estranhar o bispo e os cônegos, pois

se não podiam cobrar dos oficiais de Vossa Majestade por censuras porque Vossa Majestade os mandava pagar de suas rendas seculares, $e$ os oficiais que os haviam de pagar não eram obrigados a este pagamento, senão pela obediência que deviam aos preceitos de Vossa Majestade e a seus mandos, mas não se obrigavam ao Bispo, nem aos cônegos, $e$ assim, nestes termos, não residia à jurisdição de os constranger. ${ }^{96}$

Portanto, não houve contra Salvador Dourado lesão em matéria de fé, nem desacato ao representante eclesiástico que justificasse as censuras morais. A jurisdição para obrigar o oficial da Fazenda a fazer o pagamento só cabia ao rei e a mais ninguém. Tal interferência do poder eclesiástico nas rendas seculares de sua majestade, subtendese, atacava não a pessoa do oficial, mas ao cargo, cujo investido devia obediência aos preceitos do monarca e a seus mandos, ou seja, o ataque celeste acabava por resvalar na figura do rei.

O estranhamento, não foi direcionado apenas ao padre. Por ter instigado o bispo a cobrar por uma dívida que era sua e não do prelado - afinal, a mesma já havia sido paga pelo próprio João de Barros -, o provedor de Pernambuco, foi penalizado por desvio de conduta, com a perda do dinheiro. A Provedoria da Paraíba não lhe devia mais nada. Porém, isto não livrou Salvador Dourado das obrigações futuras, com o envio

\footnotetext{
beneficios...” Cf: Antônio Manuel Hespanha. “A Fazenda”. In: Mattoso, José. História de Portugal. O antigo regime. Vol. IV... Op. cit. p. 183-184

${ }^{96}$ AHU_ACL_CU_014, Cx.2, Doc. 166. Luis Filipe Alencastro, ao narrar o processo de embate entre Fernandes Vieira, quando governou Angola, e os jesuítas, nas querelas para controle do tráfico de escravos, comenta que este mestre de campo também acaba sendo excomungado. Cf: Luiz Filipe Alencastro. O trato dos viventes. Formação do Brasil no Atlântico Sul. São Paulo; Cia das Letras, 2000. p. 283.
} 
anual dos $300 \$ 000$ réis. ${ }^{97}$ Comprova isto uma correspondência do mesmo provedor paraibano, dez anos após, 1698, maldizendo a terra por faltar gente de cabedal para arrematar, em dinheiro, seiscentas arrobas de açúcar que serviria à côngrua do bispo. ${ }^{98}$ Neste caso, o volume do açúcar como o valor do arremate, orçado em \$960 réis, coincidia, mais ou menos, com cerca de dois anos de atraso. E como não aparecia quem desse mais que $\$ 840$ réis na arroba, "não livrando a Fazenda do dano da diminuição", veio um mercador, a fiado de Manoel Feitosa Machado, garantindo que pagaria o valor maior do arremate caso lhe fosse ofertado o prazo de um ano, tempo suficiente para a chegada da próxima frota. ${ }^{99}$ Como parece, se assim foi realmente efetivado, este teria sido o último envio para o bispado de Pernambuco, já que as reclamações, assim como os registros desse pagamento, somem dessa data em diante.

Independentemente de ter havido ou não o envio dessa contribuição, uma coisa é certa: o Bispado de Pernambuco era uma realidade e sua jurisdição abrangia desde a sua fundação uma área que, segundo Jorge Siqueira ${ }^{100}$, estendia-se, no litoral, da foz do São Francisco até Fortaleza no Ceará. Quanto ao interior, curiosamente, delimitava-se no horizonte, ou seja, era indicado pelo impreciso termo de "pela terra a dentro". Um relatório datado de 1745, de autoria do bispo olindense D. Fr. Luis de Santa Tereza e transcrito por Siqueira, dá a noção da imensidão espacial que cobria o bispado de Olinda:

Ao oriente é banhado pelo oceano, ao Norte estendese quase ao imenso e divide-se do bispado do Maranhão pela longa cadeia de montes que são chamados dos cocos e termina na divisão das águas abundantes naquelas serras. Do bispado do Pará separa-se pelos lugares chamados Terra Nova. Do bispado do Rio de Janeiro pelo riacho chamado das Areias. Assim, estende-se a diocese para o Norte 700

\footnotetext{
${ }^{97}$ Idem ibidem.

${ }^{98}$ AHU_ACL_CU_014, Cx.3, Doc. 217.

${ }^{99}$ Idem.

${ }^{100}$ Antônio Jorge de Siqueira. Ilustração e descolonização: o clero na Revolução Pernambucana de 1817. São Paulo, Tese de Doutorado/FFCH/USP (Departamento de História) 1980.
} 
léguas, tendo de largura, ora 80, ora 100 léguas. Ao Sul limita-se com o arcebispado da Bahia pelo famoso Rio São Francisco que corre entre as duas terras e as separa e que tem 100 léguas de comprimento. $^{101}$

\section{A JURISDIÇÃO JUDICIÁRIA}

Criada em 25 de janeiro de 1688, a jurisdição da Ouvidoria Geral da Paraíba ultrapassava, significativamente, as dimensões geográficas estipuladas como os limites da noção espacial e política da capitania. Assim se expressava o rei quanto à extensão e os motivos da sua criação:

Hei por bem mandar assinar por território a ouvidor da Paraíba, que mandei criar de novo, o Rio Grande e Itamaracá, para concorrerem nestas mesmas razões para se unirem, que me moveram a criar na Paraíba ouvidor letrado, e por entender ser nelas melhor administrada a justiça do que agora foi pelo da Bahia a quem competiam não chegarem nunca em correição os corregedores pela sua distância. ${ }^{102}$

\footnotetext{
${ }^{101}$ Idem ibidem. p. 113. Registre- se, entretanto, que tal configuração espacial desta diocese parecia inalterada ainda nos inícios do século XIX. A afirmação é do cônego José Barata, que, no seu "Apontamentos para a história eclesiástica de Pernambuco", afirmara que, durante a administração do bispo Azeredo Coutinho à frente do Seminário de Olinda, "a diocese de Olinda abrangia ainda todo o antigo território da Ibiapaba ao São Francisco pela costa e estendendo a sua jurisdição a novos núcleos fundados no interior". Segundo este mesmo autor, "este imenso território estava dividido em 120 paróquias inamoviveis além de inúmeros curatos amovíveis. As paróquias inamovíveis estavam distribuídas do seguinte modo: no Ceará, 24; no Rio Grande do Norte, 11; na Paraíba, 22; na Comarca das Alagoas, 14; na do Rio São Francisco, 18; no distrito de Pernambuco, 26 e no de Minas Gerais, 6." Idem ibidem. p 115.

${ }^{102}$ Provisão passada a Diogo Rangel Castelo Branco, em 25 de janeiro de 1688. IHGP/ PB Códice: 1816 Ouvidoria, folha 4.
} 
Apesar de não constar nesta provisão real, existe o registro de que a Capitania do Ceará, pelo menos até o final do primeiro quartel do século XVIII, também esteve submetida à jurisdição da Ouvidoria da Paraíba. Uma provisão régia, datada de $7 \mathrm{de}$ janeiro de 1723, extinguiu esta anexação, criando uma ouvidoria independente para o território cearense. ${ }^{103}$

É interessante constatar como tal conformação geográfica inverte a ordem dos fatores até então compreendidos nos jogos da determinação espacial das jurisdições presentes nas Capitanias do Norte. Nomeadamente, quanto à questão judiciária, a Comarca da Paraíba teve, como suas anexas, as comarcas de Itamaracá, Rio Grande e, durante o período acima referido, também a comarca do Ceará. Todavia, quando a capitania de Itamaracá foi comprada por D. João V, aos herdeiros de Pero Lopes de Souza, em 22 de setembro de $1723^{104}$ e, finalmente, quando da sua extinção e incorporação em definitivo a Pernambuco, pelos anos de 1752-54, ${ }^{105}$ extinguiu-se a anexação judiciária de Itamaracá à comarca da Paraíba. Isto se infere a partir de um ofício encaminhado pelo ouvidor geral da Paraíba ao secretário de Estado e Ultramar, informando a extensão das comarcas, distritos e rios da sua jurisdição, em 1757, para o caso de vir a sofrer alguma mudança por conta da anexação da capitania da Paraíba à de Pernambuco, onde já não há mais referência à comarca de Itamaracá. ${ }^{106}$

Desta forma, no âmbito das Capitanias do Norte, além da ouvidoria da Paraíba, teríamos a do Ceará e a Ouvidoria de Pernambuco, que abrangia a comarca de Alagoas e Itamaracá, sendo, esta última, anexada em meados do século XVIII.

\footnotetext{
103 “D. João por graça de Deus faço saber a vos capitão-mor da capitania da Paraíba que por ser conveniente ao meu serviço e a boa administração da justiça dos meus vassalos conviventes na Capitania do Ceará e se atalharem os insultos que eram freqüentes nas terras dela, houve por bem criar o lugar de Ouvidor Geral para a dita capitania (...), Lisboa Ocidental, a 7 de janeiro de 1723. ” Irineu Ferreira Pinto. Datas e notas para a História da Paraíba. Op. cit. p. 120.

104 Ângelo Jordão Filho. Povoamento, hegemonia e declínio de Goiana. Recife: Companhia Editorial de Pernambuco, 1977. p. 144.

${ }^{105}$ Paulo Pedro Perides. A organização político-administrativa e o processo de regionalização do território brasileiro... Op. cit. p. 83.

${ }^{106}$ AHU_ACL_CU_014, Cx. 20, Doc. 1564.
} 


\section{A JURISDIÇÃO FAZENDÁRIA}

Dentre as jurisdições até agora apresentadas, talvez a mais difícil de definição seja a dos provedores. Ligadas às capitanias como órgãos arrecadadores e de provimento, as provedorias da Fazenda foram sendo recriadas nas capitanias do Norte por volta das primeiras décadas, após consolidada a vitória sobre os holandeses. Diferentemente disso, contudo, a Capitania do Ceará só veio a conhecer uma provedoria quando da criação de sua comarca, em 1723, já que a provedoria do Rio Grande a englobava. ${ }^{107}$

O limite espacial da arrecadação das provedorias da Fazenda, apesar de não ultrapassar os termos da demarcação territorial das capitanias, poderia revelar algumas exceções, pois como poderemos constatar nos capítulos seguintes, o imposto da dízima da Paraíba foi, durante muito tempo, arrecadado pela alfândega pernambucana. Por outro lado, quando nos aproximamos das despesas, ou seja, das atividades de pagamento, municiamento e abastecimento a que estavam obrigadas as provedorias, isto tende a se acentuar, elevando em demasia o número de contato entre as capitanias. Desta forma, diferentemente do que supôs Dauril Alden para o Brasil Colônia, a ajuda financeira entre as capitanias foi um fator tão importante quanto o existente no Império Espanhol. Para este historiador, tal expediente havia sido apenas abundantemente experimentado na América Espanhola, onde as partes mais ricas, como o vice-reinado da Nova Espanha, davam suporte aos distritos menos prósperos como a Flórida, a Venezuela ou as Filipinas. $^{108}$

\footnotetext{
${ }^{107}$ No provimento do Ouvidor do Ceará, em 1723, lê-se: ... "houve por bem criar o lugar de Ouvidor Geral para a Capitania do Ceará, mandando unir ao seu lugar o de Provedor da fazenda e separando o da Provedoria do Rio Grande a que andava anexo atendendo a que, por este meio, não só aumentarão as minhas rendas mas que os emolumentos dados a ocupação..." Irineu Ferreira Pinto. Datas e notas para a História da Paraíba... Op. cit. p. 120. É oportuno dizer que a provedoria do Rio Grande estava anexa à Ouvidoria Geral da Paraíba, confundindo ainda mais as jurisdições.

${ }^{108}$ No Brasil, este autor cita apenas um caso, o do subsídio de Santos. A origem do subsídio de Santos, uma consignação anual de quatro mil cruzados remonta ao início do século XVII. Quando a Coroa criou a capitania-geral de São Paulo e Minas Gerais como sendo uma (1709), foi perguntado ao governo do Rio de Janeiro se ele concordava que a praça de Santos fosse unificada à nova capitania geral. Desde que nenhum administrador real poderia admitir que uma autoridade rival governasse um território disputado, os oficiais cariocas protestaram, e em 1711 Lisboa anunciou que dali em diante Santos seria parte da capitania geral do Rio de Janeiro. Esse anúncio inevitavelmente provocou protestos em São Paulo, que argumentava que Santos estava mais próxima de si e que era a única saída para o mar, mas esses protestos foram ignorados. No entanto, quando São Paulo e Minas passaram a ser governados
} 
No Brasil, além do envolvimento da provedoria paraibana no pagamento do bispo residente em Olinda, maiores, ainda, e constantes, foram os dispêndios financeiros empreendidos pela provedoria de Pernambuco com as capitanias do Norte. O epíteto de capitania-geral reconhecido entre as suas anexas e as correlações de forças políticomilitares, anunciavam, também, a relação de dependência econômica do restante das capitanias para com a provedoria de Pernambuco.

Desta forma, durante todo o período que vai dos fins do século XVII à primeira metade dos setecentos, Ceará, Rio Grande e Itamaracá dependeram, sob diversos aspectos, da provedoria da Capitania de Pernambuco. Fosse para o pagamento dos clérigos e militares ou mesmo para manutenção e construção de fortalezas nos limites compreendidos dessas capitanias, era a provedoria de Pernambuco que despendia muitos dos recursos necessários para a reprodução da vida administrativa. ${ }^{109}$

Todavia, de acordo com os Regimentos de 1548, a jurisdição dos provedores não deveria ir além de suas capitanias, sendo sempre sugestionados pelo Conselho Ultramarino os riscos administrativos que poderiam advir da mistura das receitas e despesas entre as capitanias. Por outro lado, boa parte das capitanias do Norte, como o Ceará, Rio Grande e Itamaracá, e por menos tempo a Paraíba, permaneceram, durante praticamente toda a primeira metade do século XVIII, sob o regime da dupla jurisdição. Por esse regime ficavam justapostas, nas mãos do ouvidor, as duas áreas de atuação, Justiça e Fazenda - confundindo ainda mais as atribuições desses oficiais, quando as próprias ouvidorias acabavam por se fundir em outras comarcas.

\footnotetext{
separadamente, em 1720, a corte transferiu a jurisdição sobre o porto do Rio de Janeiro para São Paulo. Uma grande fortaleza passou a ser construída em Santos, e desde que os recursos de São Paulo tornaramse insuficientes, a coroa depositou em juizo, em 1722, uma parte das remessas da alfândega coletada no Rio de Janeiro a fim de por cabo à obra. A intenção dessa ação era de ser temporária, mas tornou-se permanente. Com pagamentos (contas a pagar) freqüentemente atrasados, o subsídio de Santos continuou sendo uma fonte de disputas entre autoridades nas duas capitanias gerais durante todo o século XVIII. Dauril Alden. Royal Government in Colonial Brazil, With special reference to the administration of the Marquis of Lavradio, 1776-1779 ... Op. cit. p. 300

${ }^{109}$ Em 1726, o superior do hospício dos jesuítas no Ceará, padre João Guedes, requereu ao rei que seus ordenados anuais fossem pagos pela Fazenda de Pernambuco. Cf: AHU_ACL_CU_017, Cx. 2, Doc. 88 (Avulsos, Capitania do Ceará); Nas mesmas, condições solicitou ajuda de custo o cirurgião da fortaleza do Ceará, Cosme Gomes Pereira. AHU_ACL_CU_017, Cx. , Doc. 89 (Avulsos, Capitania do Ceará)
} 
Vemos, pois, que esta forma emaranhada de conceber os espaços das jurisdições, tanto no plano formal como na força do costume, tornava latente a sintonia organizacional entre os poderes, deixando transparecer, também, brechas de articulação que revelavam uma forte disjunção, mais do que aproximação, entre os comandos. Eram, portanto, teias de organização e manifestação de poderes distintos, porém imbricados, com ares de autonomia mas, ao mesmo tempo, centralizados e comandados por instâncias provenientes da Metrópole.

O tênue fio, então, que separava os interesses e vontades dos homens, na imensidão do espaço Atlântico, animou e deu vozes, através de correspondência oficial, aos atores que barganharam os ofícios, disputando os favores e a proximidade de Sua Majestade e do seu Conselho Ultramarino. Nos requerimentos e mercês, envoltos numa pilha de cartas, alvarás e ordens régias, ficaram traçados os escritos dos destinos dos oficiais da Provedoria da Fazenda Real da Paraíba. 


\section{CAPÍTULO II}

\section{O BUTIM DA GUERRA BRASÍLICA: A ADMINISTRAÇÃO DA FAZENDA REAL PARAIBANA COMO ESPÓLIO DA CONQUISTA}

Como um dos palcos da guerra de restauração contra o domínio holandês, a Capitania da Paraíba encontrava-se, em 1655, devastada. Nas palavras do seu governador, João Fernandes Vieira, um dos principais líderes da vitoriosa força lusobrasileira e proprietário de vários engenhos na capitania ${ }^{1}$, a miséria era tanta que "não ficara pedra sobre pedra" do que ali anteriormente havia. ${ }^{2}$ A tática de terra arrasada empreendida contra o invasor e que fez ruir prédios e toda a estrutura produtiva da capitania $^{3}$, deveria agora ser refeita. Paralelamente a isso, urgia a remontagem do aparelho administrativo.

Para os restauradores da Paraíba, que alardeavam terem feito a "guerra por muitos anos às suas custas", os cargos da administração deveriam lhes pertencer como um direito natural de conquista. ${ }^{4}$ Os agraciados com os escalões da administração paraibana: na Justiça - exceto o cargo de ouvidor ${ }^{5}$-, na Milícia e na Fazenda, após o período da restauração holandesa, foram providos como prêmio, tendo em vista os merecimentos pelo reconhecimento ao sangue derramado em nome da Coroa, como fiéis vassalos de Sua Majestade.

A Fazenda Real paraibana se reiniciava, portanto, como um espólio da conquista:

\footnotetext{
${ }^{1}$ As propriedades de João Fenandes Vieira na Paraíba eram os engenhos Inhobim, São Gabriel, Garjaú, Tibiri de Cima, Tibiri de Baixo, Santo André e São João. Além destes, possuía mais três em Recife (na Várzea), um em Jaboatão, dois em Goiana e Igarassu e mais dois com localização ignorada. Cf: Vera Lúcia Costa Acioli. Jurisdição e conflito: a força política do senhor de engenho. Recife: UFPE / Departamento de História, 1989. p. 151

${ }^{2}$ AHU_ACL_CU_014, Cx.1, D 37.

${ }^{3}$ Em carta dirigida ao rei, em 1656, diziam os oficiais da câmara da Paraíba que "tomando as armas juntamente com os moradores da capitania de Pernambuco e vendo que (...) nem um nem outro poderiam reduzir o grande poder do inimigo, se deliberaram como fiéis vassalos de V. Majestade de se retirarem para Pernambuco (...) queimaram e arrasaram suas casas, engenhos e canaviais de açúcar..." Cf: AHU_ACL_CU_014, Cx.1, D 40.

${ }^{4}$ Idem.

${ }^{5}$ O lugar de ouvidor geral da Paraíba é criado em 25 de janeiro de 1688, onde é provido o Bacharel Diogo Rangel de Castelo Branco. Cf: IHGP/ PB Códice: 1816 - Ouvidoria. Folha. 2.
} 
Necessário, é que haja prêmios para que haja soldados; e que os prêmios entrem pela porta do merecimento; dêem-se pelo sangue derramado, e não ao herdado somente; dêem-se ao valor e não à valia. ${ }^{l}$

Passados alguns anos, antigos soldados ajustaram contas com a Coroa de olho nas gratificações que consideravam merecer pelos anos de guerra. Pilhas de documentos, cartas de serviço, singraram o Atlântico em direção ao Reino, relatando feitos heróicos dos interessados na partilha dos ofícios que cobririam a administração na Paraíba. Possuir um cargo no ultramar simbolizava, quer fosse ou não proprietário de engenhos e escravos, uma marca de nobreza que infundia ao titular, no dizer de Raimundo Faoro, o "acatamento aristocrático." 2

Mesmo que a Guerra do Brasil ainda se estendesse até 1654 no território pernambucano, na Paraíba, há exatos nove anos antes, praticamente fora consolidada a expulsão do inimigo, reduzindo o efetivo invasor a alguns soldados isolados nas fortalezas do Cabedelo e Santo Antônio. Diante desse quadro, entregou-se El-Rei, D. João IV, ao exercício da sua magnificência, distribuindo para os restauradores paraibanos os cargos da administração. Assim, considerando que o acúmulo de cargos evitava a dispersão de funções e garantia uma melhor remuneração para os agraciados, Sua Majestade doou para o capitão Manuel Queiroz de Siqueira, em 1647, o ofício de Provedor da Fazenda Real e os que mais lhe fossem anexos, como os ofícios de Contador

\footnotetext{
${ }^{1}$ Excerto do Sermão da Visitação de Nossa Senhora, pregado pelo padre Antônio Vieira no Hospital da Misericórdia da Bahia, pela chegada àquela cidade do Marquês de Montalvão, vice-rei do Brasil. Cf: Cleonir Xavier de Albuquerque. A remuneração de serviços na guerra holandesa. Recife: Impressa Universitária / UFPE, 1968. p.119-132

2 "O cargo público em sentido amplo, a comissão do rei, transforma o titular em portador de autoridade. Confere-lhe a marca de nobreza, por um fenômeno de interpretação inversa de valores. Como o emprego público era, ainda no século XVI, atributo do nobre de sangue ou do Cortesão criado nas dobras do manto real, o exercício infunde o acatamento aristocrático aos súditos". Raimundo Faoro. Os donos do poder: formação do patronato político brasileiro. 8 ed. Rio de Janeiro: Globo, 1980. p. 175.
} 
e Provedor dos Defuntos e Ausentes. ${ }^{3}$ Em 1653, passou alvará para o capitão Lopo Curado Garro - um dos três comandantes das tropas na Paraíba -, garantindo a propriedade da escrivania da Fazenda, como dote para quem casasse com sua filha. ${ }^{4}$ Por outro lado, quando consolidada a restauração em todo território das capitanias do Norte, D. João IV ampliou os privilégios nas doações e concedeu aos mestres de campo, entre eles Francisco Barreto de Menezes, em janeiro de 1654, a faculdade do provimento dos ofícios da Justiça e Fazenda, com a vitaliciedade aos oficiais e soldados que serviram na guerra. ${ }^{5}$ Com esta medida, o monarca dividia com os mestres de campo restauradores, o poder do exercício generoso de conceder e doar, em seu nome, as presas da guerra.

Assim, o comandante chefe da restauração e mestre de campo, general Francisco Barreto de Menezes, ${ }^{6}$ encontrou no espólio da Fazenda paraibana o ofício de almoxarife, que doou ao soldado e capitão Júlio Farinha ${ }^{7}$, em 1654. Dois anos depois, em 1656, curiosamente, tornou a doar o ofício de escrivão da Provedoria da Fazenda Real (pois o rei já o havia doado para Lopo Garro), e os mais a ele anexos, para Bento Bandeira de Melo. ${ }^{8}$ É provável que, anos antes, o mestre de campo tivesse conhecido a Lopo Curado Garro, pois, além de provavelmente terem pelejado lado a lado em diversas batalhas contra os holandeses, Curado Garro era, naquela época, homenageado como governador na Paraíba e como um dos principais restauradores nesta capitania. Da mesma forma, Barreto de Menezes não devia ignorar o fato de Curado Garro ser cunhado daquele que, futuramente, seria apresentado pela história como seu grande dissabor, o restaurador

\footnotetext{
${ }^{3}$ Alvará de 24 de Maio de 1647. Cf.: Pinto, Irineu Ferreira. Datas e notas para a História da Paraíba. João Pessoa: Editora Universitária. 1977. v. 1, p. 62.

4 AHU_ACL_CU_014, Cx.1, D 63. Lopo Curado Garro formou o triunvirato que governou a Paraíba de 1645 até $165 \overline{5}$, juntamente com Francisco Gomes Muniz e Jerônimo Cadena, até ser passado o governo a João Fernandes Vieira.

5 Ordem Régia de 23 de abril de 1654. Cf: Antônio José Vitoriano Borges da Fonseca. Nobilarquia Pernambucana. Rio de Janeiro; Biblioteca Nacional, 1935. p. 191. "Indo Francisco Barreto por Mestre da Campo, governador de Pernambuco, levou provisão, para com os mais Mestres de Campo, repartirem as terras que haviam deixado os holandeses e proverem por uma vez os oficios que se houvessem presentes." Cf: AHU_ACL_CU_014, Cx.3, Doc. 204.

${ }^{6}$ O Mestre de $\bar{C}$ ampo General Francisco Barreto de Menezes aportou em Pernambuco em 1648, a mando de D. João IV, e assumiu, das mãos de Fernandes Vieira, o comando da insurreição. Cf: Antônio José Vitoriano Borges da Fonseca. Nobilarquia Pernambucana... Op. cit. p. 191.

${ }^{7}$ A propriedade do ofício de almoxarife da Fazenda paraibana foi passada, por D. Pedro II, a Simão Farinha do Amaral, em 1684, após o falecimento do seu pai, Júlio Farinha. Cf: AHU_ACL_CU_014, Cx.2, D 130.

${ }^{8}$ AHU_ACL_CU_014, Cx.1, D 63. Junto à escrivania da Fazenda, estavam as escrivanias do Almoxarifado e Alfândega.
} 
paraibano e mestre de campo, André Vidal de Negreiros. ${ }^{9}$ Neste sentido, é crível asseverar que os conhecidos conflitos de jurisdição envolvendo Vidal de Negreiros, quando governou Pernambuco, e Barreto de Menezes, quando chegou no topo da hierarquia no governo geral da Bahia ${ }^{10}$, tenham sua origem na repartição dos ofícios que vagaram com a reconquista da terra pelos batavos.

Essa dupla doação da escrivania da Fazenda, feita tanto pelo rei quanto pelo mestre de campo Barreto de Menezes, resultou em dois momentos bastante significativos para a história da Fazenda da Paraíba. Primeiro, por gerar uma extraordinária contenda jurídica entre os dois agraciados, Lopo Curado Garro e Bento Bandeira de Melo, que consumiu dezenas de anos e muitas horas de idas e vindas, ao ultramar, das mais diversas peças documentais. Segundo, por ter desencadeado a possibilidade de controle, tanto da escrivania como da cabeça da Provedoria da Fazenda paraibana, por duas famílias de antigos colonos povoadores da Paraíba - os Bandeira de Melo, que se tornaram senhores da escrivania da Fazenda, Almoxarifado e Alfândega, por todo o tempo que durou a Provedoria da Paraíba, 1647 - 1798; e os Quaresma Dourado, que controlaram a cabeça do órgão, donde sobressai a figura de Salvador Quaresma Dourado, provedor proprietário da Fazenda paraibana ao longo de cinqüenta anos (1683-1733).

No centro dos enlaces e negociações para a manutenção do controle sobre o órgão fazendário por essas famílias, figuras como o próprio Bento Bandeira de Melo, agindo localmente com sua parentela e Feliciano Dourado, estendendo o raio dessa política ao Conselho Ultramarino, engendraram um circuito de contatos que ultrapassou as franjas litorâneas da Paraíba. Para a efetivação disso, colocaram em prática uma gama de ações, fazendo aflorar redes de solidariedade por dentro e fora do circuito do ambiente formal do poder. Em última instância, tencionavam influir em assuntos diversos, como indicar quem deveria assumir este ou aquele cargo ou garantir certas regalias e privilégios para determinados indivíduos ou grupos. Neste ambiente, onde se desconheciam os valores do mérito técnico, o respeito às relações de “amizade, parentesco, honra” e, principalmente

\footnotetext{
${ }^{9}$ Juntamente com João Fernandes Vieira, André Vidal de Negreiros foi um dos homens mais ricos nas capitanias do Norte. Governou o Estado do Grão-Pará Maranhão, de maio de 1655 a setembro de 1656, e foi o segundo governador de Pernambuco depois da restauração, onde cumpriu o triênio de mandato 1657 1660. Cf: Irineo Ferreira Pinto. Datas e notas... Op.cit. p. 67-80;

${ }^{10}$ Sobre os conflitos de jurisdição envolvendo esses personagens, ver: Vera Lúcia Costa Acioli. Jurisdição e Conflito. A força política dos senhores de engenho....Op. cit. p. 74 -111.
} 
de "serviço," o agraciamento de beneficios e sinecuras.

Tais considerações parecem configurar um universo de relações sociais em que o poder se legitimou através de uma forma de dominação a que Weber chamava de patrimonial. $^{12}$ Nesta forma de dominação, a administração, ao ser tratada como um assunto puramente pessoal do senhor e não permitir a eclosão da distinção entre as esferas do público e do privado, pode levar o cargo a assumir a expressão privada do seu ocupante. Desta forma, o cargo é desejado tanto pela sua valoração simbólica - na medida em que o acesso ao benefício se confunde com uma certa proximidade com o soberano -, como pela expressão da reputação individual do poder, quando a racionalidade e o valor profissional, elementos fundantes da burocracia, ficam secundarizados pelo valor das paixões e dos interesses pessoais.

Portanto, o longo período que se estendeu da doação do ofício de provedor da Fazenda a Manuel Queiroz de Siqueira, em 1647, até o desfecho da administração de Salvador Dourado, em 1733, quando ocorreu o fechamento da gestão do último provedor proprietário da Provedoria da Fazenda Real da Paraíba, se reveste de uma importância capital para a história da administração fazendária colonial. Tal período tem importância primeiramente, por nele se dar a trajetória de negociações e conquistas, por alguns personagens pertencentes a famílias de antigos colonos da Paraíba, com o fim de adquirirem um lugar no corpo dos ofícios do ultramar. Além disso, serve para mostrar as maneiras pelas quais os beneficiados teceram na fissura aberta entre as ordens da Coroa e os ditames do costume local, suas estratégias para tirarem vantagem da moldura institucional patrimonialista.

Porém, frise-se, que esta fissura aberta não se caracterizava como um vazio de poder, em função da qual a vontade do mando local se expressasse em completo desacordo com a onipresença real. Pelo contrário, o poder real, mesmo construído numa espiral de relações, dos escalões do Reino até a Colônia, finalizava-se, ao fim e ao cabo, no cumpra-se. Por mais que agigantasse a sombra dos seus interesses pessoais sobre o

\footnotetext{
${ }^{11}$ Cf: Ângela Barreto Xavier e Antônio Manuel Hespanha. “As redes clientelares”. In: José Mattoso (dir.). História de Portugal. V. IV. Antônio Manuel Hespanha. (org.). O Antigo Regime 1621 - 1807. Lisboa: Editorial Estampa, 1998. p. 339 - 349.

12 Max Weber. Economia e sociedade: fundamentos da sociologia compreensiva. Brasília. Editora Universidade de Brasília, 1999. p. 253
} 
restante da sociedade na Colônia, o oficial em ação não tinha como descolar, da sua imagem, a luz do rei. Neste sentido, tomar como correta a interpretação de que inexistiu um projeto colonizador organizado e dirigido por um poder absoluto centralizado em Lisboa, onde a noção patrimonial do bem comum foi o leme da governança e das mercês, não nega a noção do estatuto colonial para o Brasil. ${ }^{13}$ Quer no plano do capital mercantil, quer no plano da administração, a concessão do monopólio confundia-se com a concessão dos cargos e ofícios: passado o período do uso e exploração do objeto de desfrute, retornaria este para as mãos soberanas do rei. Se, na reprodução deste sistema, o entrechoque para o alcance da nova doação ou conquista se dava numa teia de interesses múltiplos, o teor concreto da sua garantia estava, contudo, na emanação do poder, ou seja, no rei e fora da Colônia. ${ }^{14}$

A tolerância da Coroa com as denúncias de corrupção, descaminhos ou malversação do bem público, cometidos pelos oficiais ultramarinos, deve ser entendida com base tanto nos baixos e atrasados estipêndios ou na distância que enfraquecia o feixe de luz do soberano, como na certeza que tinha o monarca de que o exercício do poder deveria ser legitimado no cotidiano e em seu nome: emanação/execução. A resposta a esses problemas se foi montando, gradualmente, com a compreensão da necessidade de superar uma má administração. Assim, quando a Coroa rompeu paulatinamente com a ingerência de algumas famílias sobre a Fazenda paraibana - a criação da Ouvidoria Geral da Paraíba é exemplo disso - estava simplesmente tentando abandonar práticas consuetudinárias vindas e legitimadas ainda no butim da Guerra Brasílica.

Neste sentido, a finalização do recorte temporal, com a quebra da tradição no ofício da propriedade de provedor da Fazenda Real da Paraíba, em 1733, quando da

\footnotetext{
${ }^{13}$ A discussão sobre o caráter polisinodal da monarquia portuguesa , até cerca de 1750 , ter comprometido ou não o estatuto colonial encontra-se nos artigos de José Jobson de Andrade Arruda "Primas da história de Portugal" . p. 11-30; "O sentido da Colônia. Revisitando o antigo sistema colonial no Brasil" . p. 245-264, e no artigo de Antônio Manuel Hespanha "As estruturas políticas de Portugal na Época Moderna”. p. 117 182, contidos no livro de José Tengarinha (org.) História de Portugal. 2 ed. Bauru, SP: EDUSC, SP; Portugal, PT: Instituto Camões, 2001.

${ }^{14}$ Sobre a projeção da imagem e personificação do rei nas capitanias da América portuguesa, conferir o trabalho de Rodrigo N. Bentes Monteiro. O rei no espelho. A monarquia portuguesa e a colonização da América 1640 - 1720. São Paulo. Tese de Doutoramento/FFLCH/USP (Dpº de História), 1998. Da mesma forma para a França, ver: Jean-Marie Apostolidès. O rei-máquina: espetáculo e política no tempo de Luís XIV. Rio de Janeiro: José Olímpio; Brasília, DF: Edunb, 1993.
} 
morte de Salvador Quaresma Dourado, é tida como uma ação intencional da Coroa, pois visava despir este órgão, das interferências e idiossincrasias locais. O uso deste ofício não deveria mais servir como proveito de barganha política para colocar parentes em postos de proeminência social, perseguir inimigos ou dispor de estilos para se engordar com emolumentos. Iniciava-se então, o desfile trienal de provedores colhidos alhures e, como desejava a Coroa, mesmo que à custa do insucesso, assépticos às influências da sociedade paraibana.

Guardando, contudo, as devidas proporções acerca da determinação que os valores patrimoniais têm nas sociedades de Antigo Regime, o certo é que um mínimo de viés burocrático influiu na administração da Fazenda paraibana. Mesmo que tardia, a aplicação de preceitos técnicos por aqueles que lidavam na prática com o cotidiano da Fazenda - como a escolha de oficiais mais afeitos ao cálculo financeiro e a exigência de cofres para a guarda das verbas arrecadadas -, pode ser creditada como uma medida posológica, no intuito de superação de práticas tradicionais que determinavam os rumos do órgão fazendário.

Da mesma forma, o assédio aos cargos administrativos não se justificava apenas pelo valor simbólico que eles guardavam. Muitos cargos podiam ficar à mingua ou mesmo sofrer constantes mudanças de oficiais, por não representarem nenhum atrativo econômico para os possíveis pretendentes. Em 1719, por exemplo, o tesoureiro da dízima na Paraíba, que percebia sessenta mil réis de ordenado anual, vivia ameaçando desistir do cargo, já que em Recife se pagava duzentos mil réis e, no Rio de Janeiro, trezentos mil réis pelo mesmo serviço. ${ }^{15}$ Outros cargos eram bastante concorridos, pela possibilidade de oferecerem uma vida abastada ao seu oficial, principalmente se viessem recheados com gordas gratificações. Todavia, é arriscado estabelecer um juízo de valor, lançando condições de atração para este ou aquele cargo pelo tipo de representação, simbólica ou econômica, que, em abstrato, poderia representar. Neste sentido, talvez seja mais prudente dar uma idéia da economia da Paraíba, para tentar avaliar qual a importância material que representavam os ofícios naquela capitania e em sua sociedade.

\footnotetext{
${ }^{15}$ AHU_ACL_CU_014, Cx.5,Doc. 365.
} 
$\mathrm{Na}$ Paraíba, a paisagem do pós-guerra, com engenhos destroçados, canaviais queimados e casas destruídas, tão cedo não foi apagada da memória dos paraibanos. Pelo menos até meados da segunda metade do século XVIII, a sua economia ficou num estado de letargia profunda, em que a precariedade era a regra. Numa situação dessas, o valor econômico do cargo, para um oficial da Fazenda na Paraíba, talvez se vinculasse mais à dependência em relação ao seu ordenado direto do que em relação aos valores agregados em propinas e emolumentos. Isso era diferente do que o cago poderia render em áreas de comércio ativo como, por exemplo, Recife ou Rio de Janeiro. ${ }^{16}$

Com apenas dezoito engenhos, a pequena produção da Paraíba pouco atraía os navios da frota de Pernambuco para seus portos. Sem barcos no horizonte, lavradores e senhores de engenho se desesperavam, assistindo os açúcares apodrecerem nos paços do Tiberi e Varadouro. Cartas eram enviadas pelos oficiais da Câmara ao governador geral ou ao rei, dramatizando em favor do povo e do bem comum, pedindo liberdade para os produtores comandarem sua produção até o Recife ${ }^{17}$ - mas os salvo-condutos eram muito difíceis de se conseguir.

Para a Coroa, a licença do envio de açúcar para Recife, além de comprometer o rendimento da Fazenda Real, filtrando as amarras do pacto colonial, também poderia contrariar os interesses de outros segmentos da elite local. Na leitura da Coroa, ceder à vontade dos produtores era desmerecer os comerciantes e a administração, uma vez que o comércio a dinheiro de contado e o escambo com as mercadorias provindas do Reino sofreriam a intermediação dos mercadores da praça de Recife. Diminuía, assim, não só a

16 "O provedor da fazenda do Rio de Janeiro, por exemplo, recebia dos cofres da Coroa apenas $80 \$ 000$ por ano; contudo, tal quantia somada as propinas e, principalmente, aos emolumentos chegava a algo estimado por Lisboa, em 1697, em 800\$000”.Cf: Maria Fernanda Bicalho; João Fragoso e Maria de Fátima Gouveia. Uma leitura do Brasil colonial: bases da materialidade e da governabilidade no Império. In: Penélope. Fazer e Desfazer a História, n 23. Oeiras, Celta Editora. Novembro, 2000: 67-88 p. 69.

${ }^{17} \mathrm{Na}$ falta das ditas ordens, restava apenas a desobediência. As ordens se sucediam: Resolução Régia de 13 de março de 1665, determinando que o açúcar fosse direto para o Reino, contrariando o costume dos senhores de embarcar por Pernambuco. Nova ordem, dez anos após, em 13 de setembro de 1675, recrudescendo a anterior pelo descumprimento dos senhores; Resolução Régia de 23 de novembro de 1685, determinando, tendo em vista a pressão dos senhores de engenho, lavradores e da Câmara da capitania, a permissão para que qualquer gênero de produção da capitania da Paraíba pudesse passar livremente para Recife; e, finalmente, Resolução Régia de 24 de janeiro de 1711, determinando que, enquanto houvesse prenúncio da vinda de navios ao porto da Paraíba, não consentisse o governador a saída dos gêneros para Pernambuco. Cf: Maximiliano Lopes Machado. História da Província da Paraíba. João Pessoa: Editora Universitária / UFPB, 1977. v. II. p. 326 e 327; e Irineu Ferreira Pinto. Datas e Notas para a História da Paraíba. Op. cit. v. I. p. 64 e 65. Outras investidas na direção da abertura do porto por parte dos senhores de engenho, em 1722 e 1752-53, veremos no capítulo IV. 
arrecadação tributária, fonte de pagamento dos filhos da folha, como também o comércio local, dado o valor agregado dos transportes na mercadoria para a travessia da Paraíba a Recife. $^{18}$

Tal paradoxo colocava em choque os interesses de senhores de engenho e comerciantes da Paraíba. A situação de penúria na falta de numerário e crédito se expressava nas mais diversas situações. Como se não bastasse a pequena quantidade de engenhos (dezoito, em 1671), apenas seis deles, distribuídos entre André Vidal de Negreiros e João Fernandes Vieira ${ }^{19}$, conseguiam funcionar com plena capacidade. Isto é, esses senhores possuíam cabedais suficientes para manterem o plantel de escravos e o maquinário necessário para o trabalho regular. ${ }^{20}$

Em 1724, cinqüenta anos após, o quadro parecia não ter mudado. A partir de uma denúncia feita por um morador da capitania, ${ }^{21}$ acerca de uma venda ilícita de 27 escravos trazidos da Costa da Mina por um comissário de Pernambuco, o provedor da Fazenda, Salvador Quaresma Dourado, após ter tirado a devassa e prendido o comissário, colocou os escravos à venda em praça pública. Porém, tendo em vista “ não haver quem os arrematasse nem ainda a como dar em fiado, porque os senhores de engenho e lavradores não os podiam pagar por não terem safra, nem menos se podiam sustentar a si e aos escravos que tem pela necessidade e carestia dos mantimentos..." 22 , conseguiu vender apenas nove a alguns mineiros que andavam nos portos do Brasil a comprar escravos. ${ }^{23}$ Diante desse débil quadro econômico, as propinas e emolumentos levantados

\footnotetext{
18 " Retirada a navegação direta do porto da Paraíba, os gêneros de consumo, importados da metrópole passariam aos armazéns daquela praça [Recife], e dai, somente por preços mais elevados, pelos fretes e riscos do mar, poderiam chegar ao seu destino e satisfazer as necessidades do consumidor. E assim, ao passo que o açúcar e outros gêneros de produção diminuíam de valor nos preços correntes subiam os gêneros de consumo para os moradores da Paraiba, sendo eles obrigados a comprá-los mais caros pelo aumento das despesas de transporte." Cf: Maximiliano Lopes Machado. História da província... Op. cit. p. 327.

${ }^{19}$ Com um agravante, esses senhores se negavam constantemente a recolherem qualquer tipo de impostos, alegando retribuição ao despojamento dos seus bens no combate aos holandeses. Cf: Vera Lúcia Costa Acioli. Jurisdição e Conflitos: a força política do senhor de engenho.... Op. cit. p. 151; e Borges da Fonseca. Nobilarquia Pernambucana... Op. cit.v. II. p. 62.

${ }^{20}$ AHU ACL CU 014, Cx.1, Doc. 79.

${ }^{21}$ As denúncias contra descaminhos que lesavam a Fazenda Real, sempre foram estimuladas por todo o período colonial. Importando sempre para o denunciante cinqüenta por cento do montante apreendido ou confiscado. Por outro lado, apesar do ano de 1724 ser um ano duro de seca, essas mazelas não eram apenas conjunturais, eram, isto sim, crônicas.

${ }^{22}$ AHU_ACL_CU_014, Cx.5, Doc. 410.

${ }^{23}$ Idem.
} 
pelos administradores da Fazenda eram estritamente limitados, como também ocorria com as próprias atividades econômicas na Paraíba.

A título de exemplo, seccionando o ofício de escrivão da Provedoria da Fazenda Real, Alfândega e Almoxarifado da Paraíba do conjunto do órgão fazendário, percebe-se que esse oficial, apenas em remuneração da sua atividade como escrivão da Fazenda, percebia cem mil réis de ordenado anual. ${ }^{24}$ Das outras escrivanias, não havia ordenado algum. Todavia, entre emolumentos e propinas auferidos através da escrivania da Alfândega e da própria Fazenda, o oficial alcançava algo em torno de cinqüenta mil réis. ${ }^{25}$ Assim, o escrivão poderia totalizar, nos bons anos de produção ou de arrematação dos vários contratos que corriam na capitania, cento e cinqüenta mil réis. Considerando a realidade da capitania, este valor não era nada desprezível para os seus oficiais.

Neste sentido, contíguo à representação simbólica que a investidura do cargo carregava, como se sentir pertencente a um estrato social de qualidade superior, possuir um ofício nestas circunstâncias, mesmo com apenas um ordenado razoavelmente previsível, era um formidável fator de diferenciação econômica na Paraíba. Desta forma, valia a pena lutar com unhas e dentes por esta benesse. Feliciano Dourado e Bento Bandeira de Melo souberam garantir isso para as suas famílias.

\section{LAÇOS DE SANGUE E ALIANÇAS}

O primeiro provedor da Provedoria da Fazenda Real da Paraíba, Miguel de Siqueira, tomou assento em 1647, pela vontade de Dom João IV, e ficou no cargo até falecer, por volta de 1664. Dois anos após, atendendo a uma solicitação vinda da Paraíba, D. Afonso VI fez mercê da propriedade do dito ofício para o também restaurador Luís Quaresma.

Vindo ao Brasil por conta da guerra, Luís Quaresma, natural da vila de Santarém, Portugal, combateu como soldado os holandeses na Bahia, junto ao terço do

\footnotetext{
${ }^{24}$ Mesmo que os administradores da Fazenda privilegiassem o pagamento dos ordenado, isto não quer dizer que os atrasos não acontecessem. Se, no pagamento da Infantaria era freqüente o atraso, como veremos no capítulo seguinte, houve momentos em que tanto a falta como a má gestão dos recursos comprometiam os pagamentos das folhas executiva e eclesiástica.

${ }^{25}$ Estes valores têm por base duas avaliações: uma de 1743 e outra, de 1755. Cf: AHU_ACL_CU_014, Cx.11, Doc. 936 e Cx.18, Doc. 1442, respectivamente.
} 
conde da Torre. Depois de ter debelado o inimigo naquelas bandas, foi com o mestre de campo André Vidal de Negreiros para Pernambuco e Paraíba, em 1645, onde se casou com Dona Maria Dourado de Bulhões. ${ }^{26}$ As agruras das batalhas contra o invasor em Pernambuco, entretanto, deixaram sérias marcas em Luís Quaresma; ferido de morte, veio a falecer em 1669.

Em um requerimento feito ao rei, em 1665, Dona Maria Dourado de Bulhões já relatava o perigo pelo qual passava o marido e, por isso mesmo, solicitava que se the fizesse a propriedade da Provedoria da Fazenda Real da Paraíba pelo seu primogênito, Salvador Quaresma Dourado. ${ }^{27}$ À primeira vista, não havia nada de extraordinário no alcance desta mercê. Prática corrente, cabia ao rei agraciar seus vassalos através de sua magnificência, na medida daquilo que, em retribuição, achasse por bem contemplar os esforços dos soldados. ${ }^{28}$ Entretanto, pelo que temos conhecimento dos feitos de Luís Quaresma, seus serviços apenas o capacitavam à outorga do posto de capitão, "patente que depois da guerra se praticou com vários outros oficiais. " ${ }^{29}$ Desta forma, o capitão precisava possuir um catalisador no seu costado, que favorecesse o alcance da graça. Não resta dúvida que, neste caso, as recomendações do padre Antônio Vieira, para que se desse mais pelo sangue derramado, e não ao herdado; mais ao valor e não à valia, valeu, mais o peso da linhagem da mulher que as feridas do marido. Dona Maria Dourado de Bulhões era irmã carnal de Feliciano Dourado e unida por relações de alianças a Bento Bandeira de Melo, de quem foi irmã colaça. ${ }^{30}$

\footnotetext{
${ }^{26}$ AHU ACL CU 014, Cx.05, Doc. 275.

${ }^{27}$ Idem.

${ }^{28}$ Isto não quer dizer necessariamente, que os beneficiados se sentiam plenamente atendidos. Segundo Vera Acioli, na análise sobre os pedidos de mercês remuneratórias doadas aos restauradores, "mesmo aqueles agraciados com mão mais generosa por parte da Coroa, não consideraram seus serviços plenamente recompensados já que freqüentemente replicavam firmando de novo seus direitos e insistindo por mercês mais honrosas." Cf: Jurisdição e conflito: a força política do senhor de engenho... Op. cit. p. 52 . Ver também Cleonir Xavier de Albuquerque. A remuneração de serviços na guerra holandesa... Op. cit. p.91103.

${ }^{29}$ José Vitoriano Borges da Fonseca. Nobilarquia Pernambucana... Op. cit. p. 191.

${ }^{30}$ Irmãos colaços são filhos de mães diferentes, embora amamentados pela mesma mulher. No traçado genealógico dessas famílias, vemos que Maria Dourado de Bulhões e Feliciano Dourado eram filhos do primeiro casamento de Gaspar Fernandes Dourado com Isabel Nunes de Bulhões. Quando Gaspar Dourado ficou viúvo (com os filhos ainda crianças), casou-se pela segunda vez com Clara Freitas de Azevedo, no convívio de quem veio a falecer.. Viúva, Clara Azevedo contraiu matrimônio com Antônio Malheiros de Melo, donde descende, como filho desse casamento, Bento Bandeira de Melo. Ou seja, Feliciano e Bento eram irmãos colaços e cunhados de Luis Quaresma.
} 
Os Bandeira de Melo entraram na Colônia por volta de 1532 quando os dois irmãos Pedro e Felipe Bandeira de Melo, "obrigados por razões de parentesco que tinham com Duarte Coelho, primeiro donatário da dita capitania, o acompanharam quando veio povoar Pernambuco". ${ }^{11}$ Portanto, Bento, o escrivão da Fazenda descendia da quarta geração do costado de Pedro Bandeira de Melo. Os Dourado, por outro lado, descendiam todos do Dr. Gaspar Fernandes Dourado que, em 1611, apareceu na Paraíba como juiz dos Órfãos, provindo de Portalegre, Portugal. ${ }^{32}$ Seu filho, Feliciano Dourado, "paraibano de nascença que, apesar de mazombo, fizera uma carreira triunfante, primeiro nas embaixadas dos Países Baixos e na França, depois nos conselhos de Sua Majestade, ${ }^{, 33}$, foi um dos homens fortes no Reino e nunca titubeou nos apoios à sua parentela. Desta forma, quando Dona Maria Dourado de Bulhões encaminhou seu requerimento ao rei, em nome dos serviços prestados pelo marido, pretendendo a cabeça da provedoria local, estava não apenas bem informada sobre a vacância do posto, mas também respaldada pela mão de um influente conselheiro.

Todavia, se para assumir a provedoria da Paraíba, a viúva de Luís Quaresma contava, então, com a proteção de Feliciano Dourado, junto à Coroa, e com as informações de Bento Bandeira de Melo, este último, apesar de conhecedor das coisas da Fazenda paraibana, ainda tinha um grande desafio a superar para ocupar definitivamente a escrivania da Fazenda, vencer as batalhas judiciais contra o também provido Lopo Garro.

\section{AS ESCRIVANIAS: GARRO OU BANDEIRA?}

Como falamos anteriormente, o ofício de escrivão da Fazenda Real da Paraíba e dos que lhe andavam juntos, como a escrivania da Alfândega e Almoxarifado, foi doado tanto pelo rei, em 1653, a Lopo Curado Garro, como dote para quem casasse com sua

\footnotetext{
${ }^{31}$ José Vitoriano Borges da Fonseca. Nobilarquia Pernambucana... Op. cit. p. 184.

32 Antônio Henrique da Cunha Bueno \& Carlos Eduardo de Almeida Barata. Dicionário das Famílias Brasileiras. São Paulo: Litografia Tucano, s.d.. p. 875.

${ }^{33}$ Evaldo Cabral de Mello. A fronda dos mazombos: nobres contra mascates - Pernambuco 1666 - 1715. São Paulo: Cia das Letras, 1995. p. 31.
} 
filha, como também, pelo mestre de campo Francisco Barreto de Menezes, a Bento Bandeira de Melo, em $1656 .^{34}$

A escrivania da Fazenda, feita em doação como dote para a filha de Lopo Curado Garro, não excluía o direito de assentar ele próprio como escrivão ou de delegar o poder a um serventuário que lhe pagasse a terça parte daquilo que rendesse o ofício, até que a filha casasse. ${ }^{35}$ Contudo, como este ofício da escrivania da Paraíba não fora o almejado - afinal, o restaurador Lopo Garro pretendia a escrivania da Fazenda de Pernambuco ${ }^{36}$ - , talvez ele tenha deixado de tomar os devidos cuidados com a mercê conquistada. Mais atento, Bento Bandeira, assim que alcançou a graça feita pelo mestre de campo, assumiu de pronto a escrivania em 1656 e deve ter trabalhado durante sete anos consecutivos, sem atropelos de nenhuma sorte, juntamente com Manuel de Siqueira e Júlio Farinha, na reorganização da Fazenda, Almoxarifado e Alfândega na Paraíba. ${ }^{37}$ Mas este período de calmaria teve fim em 1663, quando finalmente Lopo Garro voltou-se contra Bento Bandeira na busca da validação da antiga doação que lhe fora feita por D. João IV.

Neste sentido, conseguindo Lopo Garro levantar "sinistras informações envolvendo Bento Bandeira em negócios escusos ${ }^{, 38}$, remeteu inúmeros documentos tanto para o Conselho Ultramarino como para o Governo Geral, com fortes acusações ao então escrivão da Fazenda. Por uma razão qualquer, a maioria dos documentos enviados ao

\footnotetext{
${ }^{34}$ A promoção de Bento dá- se em 22 de maio de 1656 e a de Lopo Curado, em 3 de novembro de 1654. Cf: AHU_ACL_CU 014, Cx.1, Doc. 63.

${ }^{35} \mathrm{O}$ alvará real de 11 de agosto de 1667 proibiu que se cobrasse dos serventuários mais que a terça parte que rendesse o ofício. Cf: Cleonir Xavier de Albuquerque. A remuneração de serviços na guerra holandesa... Op. cit. p. 81.

36 "Lopo Curado Garro pedira o fôro de fidalgo, o hábito de Cristo com comenda de $200 \$ 000$ e a capitania do forte do Cabedelo, além de dois hábitos de Cristo com $80 \$ 000$ de tença para seus filhos e o ofício de escrivão da Fazenda de Pernambuco para casamento de uma filha. Ao lhe ser concedido apenas o hábito de Santiago com pensão de $40 \$ 000$ e o oficio de escrivão da Paraíba..., fez petição de réplica ao rei. Nesta, acrescenta aos seus 32 anos de serviços os de sua tio Antônio Morais repetindo os pedidos feitos. O Conselho opinando a respeito, sugeriu apenas o aumento do valor da comenda que lhe fôra concedida". Cf: Cleonir Xavier de Albuquerque. A remuneração dos serviços na guerra holandesa... Op. cit. p. 96. Ver também: Consulta do Conselho Ultramarino de 10.12.1653. A.H.U., Códice 82, fls 282 e 283.

37 Paulatinamente, a Fazenda fôra se reconstituindo. Em 1655, por exemplo, o mestre de campo João Fernandes Vieira, indo governar a Paraíba, solicitava a D. João IV que os seus soldos vencidos e os que viessem a vencer, fossem sendo pagos por Pernambuco, enquanto não houvesse rendimentos na Fazenda da Paraíba. Cf: AHU_ACL_CU_014, Cx.1, Doc.38. Vinte e seis anos depois, em 1681, os capitães de infantaria e mais oficiais da milícia paraibana requeriam que seus soldos fossem pagos dos sobejos da Fazenda Real da Capitania da Paraíba. Cf: AHU_ACL_CU_014, Cx.5, Doc. 113 .

${ }^{38}$ AHU_ACL_CU_014, Cx.1, D 63.
} 
Conselho veio a se perder nas estantes do órgão ${ }^{39}$. Mas os que conseguiram chegar às mãos do vice-rei do Brasil foram suficientes para que o Conde de Óbidos afastasse Bento Bandeira da escrivania da Fazenda ${ }^{40}$ e provesse Lopo Garro nos ofícios.

Por dois anos, Lopo Garro ficou na escrivania da Fazenda. Porém, em 1665, Cosme de Barros Marinho, morador na Paraíba, contraiu matrimônio com Maria Ramos Curado (filha de Lopo Garro) e, sem perda de tempo, enviou para o rei D. Afonso VI o Alvará de Lembrança, reivindicando a mercê de ofício em carta de propriedade da escrivania da Fazenda e os mais a ele anexos. ${ }^{41}$ A causa dificilmente tomaria outro rumo além do reconhecimento dos direitos do genro beneficiário, uma vez que se cumpriria a ordem passada em 1654.

Mas, como todos os documentos deveriam passar necessariamente pelo Conselho Ultramarino - órgão este, ao que parece, não muito afeito ao sigilo com os seus processos -, Bento Bandeira soube da passagem dos papéis de Cosme Marinho pela Chancelaria. De pronto encaminhamento, Bento opôs alguns embargos ao processo. Primeiramente alegou a ilegitimidade do mesmo por sub-reptício - isto é, o processo teria sido obtido de forma fraudulenta, pois o encaminhamento de Currado Garro ao vice-rei fora equivocado. Em função disso, reivindicou a seu favor, sentença de ab-rogação - ou seja, fazer cessar a obrigatoriedade do alvará em favor de Curado Garro. Por fim, requereu sentença de sub-rogação - isto é, transferir para ele, Bento, todas as qualidades jurídicas que encerrava a doação do ofício de escrivão da Fazenda, Alfândega e Almoxarifado. ${ }^{42}$

No retorno deste processo ao Conselho Ultramarino para realização da consulta ao rei, em 16 de abril de $1666^{43}$, os conselheiros, por unanimidade, preferiram modificar um pouco as coisas: readmitir Bento Bandeira na escrivania da alfândega e almoxarifado e manter Cosme Marinho apenas como escrivão da Fazenda, já que o alvará, segundo diziam, não fazia menção aos outros ofícios. Todavia, como a matéria era bastante controversa e contrária ao que rezava a tradição, pois, afinal, esses ofícios "sempre

\footnotetext{
${ }^{39}$ AHU_ACL_CU_014, Cx.3, Doc. 204.

${ }^{40}$ Idem.

${ }^{41}$ Idem.

${ }^{42}$ AHU_ACL_CU_014, Cx.1, Doc. 63; e Cx.3, Doc. 204.

${ }^{43}$ Idem.
} 
andavam todos juntos", o Conselho resolveu, também, encaminhar o pleito para os juizes dos Feitos da Coroa ${ }^{44}$, "onde se julgará a favor da parte que tiver justiça”. ${ }^{45}$

Esta situação se estendeu por vinte e três anos, de 1666, ano do parecer ${ }^{46}$, até 1689, sem que houvesse sentença. Durante todo este tempo, Bento e Marinho viveram em litígio, disputando o ofício com serventuários ao sabor do provimento dos governadores que, "aproveitando-se da melhor fortuna",47, faziam dessa situação uma fácil fonte de renda. ${ }^{48}$ A situação só tomou outro rumo pelos idos de 1690 , quando Bento Bandeira conseguiu que o direito reservado fosse resolvido a seu favor, no Juízo da Coroa. Porém, não foi mais possível para Bento exercer o ofício, já que veio a falecer poucos anos depois.

Neste ínterim, seu filho mais velho, Hipólito Bandeira de Melo, tentou manter as escrivanias sob a guarda da família, quando conseguiu ser encartado no ofício, mas, para sua desgraça, foi tornado prisioneiro pelos mouros em Salé, onde então combatia. ${ }^{49}$

A situação tinha, portanto, dois componentes principais. Por um lado, Bento Bandeira estava morto ${ }^{50}$, com o seu filho mais velho preso nas masmorras de Salé, sem que houvesse certeza do seu estado. Por outro, ficava resolvida a querela sobre a quem caberia o ofício - sabendo que o mesmo fôra doado pelo mestre de campo Francisco Barreto por apenas uma vez, isto é, durante uma vida presente, à qual Bento não mais

\footnotetext{
${ }^{44}$ Os juizes dos Feitos da Coroa estavam lotados na Casa de Suplicação e julgavam, entre outras, as matérias pertinentes às ordens de mercês.

${ }^{45}$ AHU_ACL_CU_014, Cx.3, Doc. 204.

${ }^{46}$ Idem.

47 Idem.

48 "Governar significava nomear, o que constituía uma fonte substancial de poder e também de renda, pois freqüentimente os cargos eram, por baixo do pano, literalmente comprados pelos interessados não legalmente como na França, mas ilegalmente aos governadores". Evaldo Cabral de Mello. A fronda dos mazombos ... Op. cit. p. 28.. Nas Ordenações Filipinas (Ord. Fil.., L. I, t. XCVII, 3) "quando o titular não podia continuar a exercer seu posto, para que o oficio não ficasse vago, o Governador ou outra autoridade podia, provisoriamente, concedê-lo em serventia." João Fragoso. "A formação da economia colonial no Rio de Janeiro e de sua primeira elite senhorial (séc. XVI e XVII)" In: João Fragoso, Maria Fernanda Bicalho \& Fátima Govêa. O antigo regime nos trópicos. Rio de Janeiro: Civilização Brasileira. 2001. p. 56. ${ }^{49}$ Hipólito Bandeira de Melo esteve cativo por quatorze anos e foi dado como morto. Todavia, sua mãe conseguira, a partir da vitória do marido no pleito contra Marinho, reaver os emolumentos ganhos pelo próprio Marinho quando do seu exercício no cargo de escrivão. Este dinheiro serviu para o pagamento do resgate de Hipólito, que retornará para a Paraíba em 1703, quando assumiu a escrivania da Fazenda. Cf: AHU_ACL_CU_014, Cx.3, D 204.

${ }^{50}$ Nos últimos anos de vida, Bento Bandeira de Melo, já sem condições para exercer o ofício, conseguira ainda prover alguns serventuários, pelo valor de setenta mil réis anuais pagos a sua mulher Antônia Barbosa de Freitas, que foi filha de um antigo lavrador de cana na Paraíba. Cf: AHU_ACL_CU_014, Cx.3,Doc. 203
} 
pertencia. Por essas razões, o ofício retornou ao poder de Sua Majestade, para fazer mercê a quem o achasse de direito.

Nesta situação, Cosme de Barros Marinho voltou à carga em 1694 e, enviando requerimento ao rei, solicitava ser encartado nas escrivanias, uma vez que os impedimentos contra ele haviam sido extintos com a morte de Bento Bandeira. Assim, Cosme Marinho poderia, finalmente, usar da mercê de ofício que D. João IV fizera ao seu sogro em nome da filha. ${ }^{51}$

Mas as coisas não eram tão fáceis assim. Simultaneamente à petição de Cosme Marinho, outros requerimentos também chegaram às mãos de Sua Majestade. Desta feita, a viúva de Bento Bandeira, Dona Antônia Barbosa de Freitas, e a mulher do seu filho Hipólito Bandeira, Dona Maria da Conceição, entravam na disputa pela propriedade do ofício. Se já tinha sido dispendioso para Cosme Marinho se livrar das amarras processuais para se mostrar merecedor do ofício - pois, anos antes, fora obrigado a pagar a estas mulheres os emolumentos por ele recebidos durante o tempo que estivera à frente da escrivania -, mais uma vez, via suas chances se esvaírem. Ademais, os argumentos a favor das mulheres eram irrefutáveis e a mercê do ofício dificilmente, tomaria outro rumo.

Ainda indeciso, o Conselho Ultramarino ordenou, em meados do ano de 1695, que o ouvidor geral da Paraíba, Cristovam Soares Reimão ${ }^{52}$, providenciasse uma averiguação, ouvindo as partes interessadas e mais testemunhas e emitisse parecer sobre a quem caberia o ofício. A opinião do ouvidor não foi diferente da esperada. $\mathrm{Na}$ oportunidade, Cristovam Reimão disse que Cosme Marinho se encontrava ausente da capitania, pois era, já há alguns anos, morador na Bahia e não tivera filho homem que pudesse sucedê-lo. ${ }^{53}$ Já Dona Maria da Conceição amargava, além da falta do marido preso em Salé, ter de sustentar quatro filhos menores. Desse modo, opinava o ouvidor, no que seria seguido pelo Conselho e sancionado pelo rei, o ofício deveria ser passado em

\footnotetext{
${ }^{51}$ Idem.

${ }^{52}$ AHU_ACL_CU_014, Cx.3, D 204.

${ }^{53}$ Era esta a prática corrente, e não apenas para as artes chamadas mecânicas, que os filhos aprendessem os ofícios, inclusive os de letras como os contábeis, através da experiência dos pais. Como eram os provedores e/ou contadores que abalizavam todos os procedimentos contábeis através dos seus escrivães, havia claramente a exigência, para todos envolvidos com a Fazenda, do treinamento de longos anos. Ver sobre os procedimentos e tradição da recomposição dos quadros na estrutura fazendária do Reino: Virgínia Rau. $A$ Casa dos Contos. Coimbra: FLUC, 1951. Toda a $2^{\mathrm{a}}$ parte.
} 
nome do filho mais velho de Hipólito, Bento Bandeira de Melo [o neto], de apenas oito anos. A guarda do cargo ficaria com a mãe, a quem caberia o poder de prover serventuário no ofício, até a maior idade do agraciado, para ter de onde tirar o seu sustento ao longo dos anos. ${ }^{54}$

A vitória de Bento Bandeira, ao cabo dos quarenta anos de disputa, não representou uma mera façanha de apenas um homem em garantir seus direitos via a bondade do seu príncipe. Os rastros deixados no caminho não deixam dúvida de que, por dentro do Conselho Ultramarino, seu irmão colaço, Feliciano Dourado, juntamente com o corpo dos conselheiros, o tenham ajudado. A "armadura ministerial", como a denominou Faoro, que enfumaçava a "ordem monocrática" do rei, sofreria "com os órgãos colegiados limitações drásticas, retardando as decisões, orientando-as e distorcendo-as, ao sabor das suas deliberações."

Bastante sintomático foi o sumiço, no interior do próprio Conselho, dos papéis enviados por Lopo Curado Garro, incriminando Bento em sinistras simulações contra a Fazenda Real. Além disso, o meticuloso e necessário acompanhamento do desenrolar do pleito - saber das instâncias por onde tramitava o processo, levantar questões precisas e nos momentos mais pertinentes -, só seria possível com um ótimo procurador advogado e, obviamente, com dinheiro suficiente para gastar em subornos com secretários e escrivães. Entretanto, algo assim sairia por demais oneroso e, na situação em que se encontrava a capitania da Paraíba, dinheiro era o que faltava.

Não fosse da forma habitual, de mau grado seriam acolhidos os processos dos apressados. Assim aconteceu no indeferimento do pleito da sentença de direito, dada em contrário aos interesses de Lopo Garro, no Juízo da Coroa. Na alegação dos juízes, a sua

\footnotetext{
${ }^{54}$ AHU_ACL_CU_014, Cx.3, Doc. 204. A magnificência do rei exemplificava- se através dessas doações, onde a simbologia buscava expressar a gratidão aos que devotavam seus serviços a Sua Majestade. Entretanto, não eram apenas as viúvas de oficiais que tinham seus pleitos atendidos. A política de conceder mercês, através do canal de correspondência com o soberano, via o envio de petições e requerimentos, ultrapassava aos que formalmente detinham o controle do saber formal. São por demais recorrentes, na documentação, apelações de pessoas comuns: índios, negros, brancos pobres, inclusive mulheres, demonstrando uma crescente redescoberta do ser súdito na Colônia. Para um brasilianista, isto "sugere o argumento de que os não europeus não eram tão desavisados assim da natureza mais particular do sistema legal e de seus mecanismos de funcionamento, como tem sido aventado pela historiografia". Cf.: RussellWood. "Centro e periferia no mundo luso-brasileiro. In: Revista Brasileira de História. São Paulo: ANPUH / Humanitas, v. 18, n ${ }^{\circ}$ 36. p. 202 e 203. Um outro estudo sobre a dimesão discusiva envolto nos requerimentos está em Pedro Cardim. Cortes e cultura política no Portugal do Antigo Regime. Lisboa: Edição Cosmos, 1998.

${ }^{55}$ Raimundo Faoro. Os donos do poder formação do patronato político brasileiro... Op.cit., p. 175.
} 
condenação, por sub-reptícia, dava-se por ter sido ele "mal aconselhado e, com menos acerto, [ter] recorrido ao Conde de Óbidos que naquele tempo era vice-rei do Brasil, e sem lhe declarar o estado em que estava o oficio lhe pediu a serventia e dele tomou-lhe posse..." 56

Neste sentido, o fato de Lopo Garro estar mal aconselhado sobre o funcionamento dos mecanismos do sistema legal, foi algo lesivo aos interesses de Cosme Marinho, seu genro. Para quem quisesse navegar nos meandros da administração no Antigo Regime português, era necessário contar com uma proteção política, ou, digamos assim, com um reforço do direito.

Consolidada, portanto, a propriedade das escrivanias da Provedoria da Fazenda, Alfândega e Almoxarifado nas mãos dos Bandeira de Melo, fincou-se uma trajetória que, nascida em 1656, seguiu adiante, numa saga de bentos e hipólitos, por quase século e meio, e cujo rol de sucessões pode ser sintetizado dessa forma:

a) Bento Bandeira de Melo (? - morreu pelos anos de 1693-94), nomeado pelo mestre de campo Francisco Barreto de Menezes, em 1656;

b) Hipólito Bandeira de Melo (? - 1723), esteve cativo em Salé por quatorze anos. Retornou em 1703, quando assumiu a propriedade da escrivania ${ }^{57}$;

c) Bento Bandeira de Melo (1687 - 1769), escrivão desde 1708. Assumiu a propriedade em 1723 com a morte do pai (b);

d) Hipólito Bandeira de Melo (? - 1764) estava à frente da escrivania quando veio a falecer, com o pai (c) ainda em vida;

e) Bento Bandeira de Melo (1753 - ?), escrivão desde 1774 no lugar do avô (c), alcançou a propriedade em 1778. Ficou até a extinção, em definitivo, da Provedoria da Paraíba, em 1798.

\footnotetext{
${ }^{56}$ AHU_ACL_CU_014, Cx.3, Doc 203.

${ }^{57}$ AHU_ACL_CU_014, Cx.34, Doc. 2476. O papel exercido pela família Bandeira de Melo (pelo menos até ao ingresso do primeiro Hipólito) na escrivania da Fazenda é também relatado por Alden, como exemplo de controle de um grupo familiar sobre um ofício na Colônia. Cf: Dauril Alden. Royal government in colonial Brazil. With special reference to the administration of the Marquis of Lavradio, viceroy, $1769-$ 1779. Op. cit. p. 296.
} 


\section{A PROVEDORIA DA FAZENDA: OS DOURADOS}

Diferentemente da conturbada luta entre os Bandeira de Melo e os Curado Garro pelo controle da escrivania, a transmissão da propriedade do ofício de provedor, por dentro da família Dourado, mostrou-se tranqüila. ${ }^{58}$ Mas essa tranqüilidade interna não eximiu o órgão dos conflitos gerados na relação da gestão fazendária com a própria sociedade paraibana. Desde as duas primeiras gestões da família à frente da provedoria, até o longevo comando de Salvador Quaresma Dourado no órgão, acusações de diversas ordens nunca deixaram de subir à presença real. Inúmeras foram as estratégias montadas pela família Quaresma Dourado e pelo seu grupo parental, para tirar proveito da estrutura patrimonial da Fazenda real. Foram muitas também as formas de debelar estas ações, quer através de outros agentes da própria Coroa, como ouvidores ou governadores, quer através da checagem de denúncias de pessoas, moradoras ou não da capitania, lesadas ou inimigas. Neste sentido, a preocupação nesta secção será visualizar, através de um mosaico de histórias lineares, a trajetória administrativa de Salvador Dourado, com o objetivo de exemplificar a dinâmica do ofício de provedor e do próprio órgão fazendário na relação com a sociedade paraibana. Ou seja, assinalar os avanços e recuos nos limites da sua jurisdição - com a criação da Ouvidoria Geral - e os recursos, por vezes escusos, colocados em prática como forma de atender as necessidades materiais mais imediatas dos oficiais da Fazenda.

\section{O RETRAIMENTO DA JURISDIÇÃO: A CRIAÇÃO DA OUVIDORIA GERAL}

Salvador Dourado assumiu a propriedade da provedoria em 13 de fevereiro de 1682 , com vinte e cinco anos de idade. ${ }^{59} \mathrm{Na}$ altura de 1684 , para a sua infelicidade,

\footnotetext{
${ }^{58}$ A sequiência é a seguinte: Luís Quaresma (proprietário) > Alberto Dourado de Azevedo (serventuário, cunhado do proprietário) $>$ Salvador Quaresma Dourado (por herança, proprietário).

${ }^{59}$ AHU_ACL_CU_014, Cx. 4, Doc. 275.
} 
desapareceu da cena política o seu tio, Feliciano Dourado. ${ }^{60}$ Desde jovem, quando contava os anos para assumir a provedoria, pôde Salvador Dourado conhecer o tio, conselheiro em Lisboa, e certificar de perto a influência que este tinha no Conselho Ultramarino. $^{61}$

De longa data, Salvador ouvira falar de como Feliciano Dourado atendia aos apelos da sua parentela residente na capitania da Paraíba. Não apenas através de pareceres favoráveis aos muitos pedidos de seu grupo familiar para assumir o governo da capitania, como se deu com Martins de Bulhões Muniz, em 1666, nome que repetiria em 1670 e Manuel Muniz, em 1677. ${ }^{62}$ Da mesma forma, também não era estranho para Salvador o jeito com que o tio conselheiro buscava encobrir alguns crimes de seus primos. Foi o que Feliciano Dourado fez, ao não dar continuidade às cartas acusatórias do governador da capitania Luís Nunes de Carvalho, em 1667, contra alguns senhores de engenho e lavradores de cana e de outras pessoas principais da terra ${ }^{63}$. Essas pessoas estavam contrabandeando a produção de açúcar para o porto de Pernambuco e mantendo as arrematações do subsídio de açúcar e dízimo da capitania bem abaixo do que se poderia alcançar, fustigando com violência quem viesse a dar mais que a estimativa oficial. Era um mecanismo engenhoso para garantir o controle dos impostos por aqueles que deveriam pagar, reduzindo a arrecadação ao limite do arrematado que cabia à Fazenda Real. Tal prática levava ao desespero o governador Luis Carvalho. Inutilmente, o governador criticava a concordância "de alguns ministros poderosos desta Corte, parentes destes homens, principalmente Feliciano Dourado, do Conselho Ultramarino [que] se não vêem estes papéis com a consideração que convém, [atendem] mais a

\footnotetext{
60 A partir desse ano, as assinaturas de Feliciano Dourado (que já se encontrava com idade avançada) desaparecem dos pareceres do Conselho Ultramarino.

${ }^{61}$ AHU_ACL_CU_014, Cx.1, Doc. 128.

${ }^{62}$ No caso do parecer sobre Manuel Muniz, reconhecia Feliciano Dourado que apesar de ser "Manuel Muniz parente seu de grau conhecido mas que ele conselheiro pelo que deve a obrigação do posto que exercita, como pelo juramento que tomou na Chancelaria está mais obrigado ao serviço de V. Majestade ... informar dos sujeitos que convém para o bom governo daquela pobre capitania, a qual necessita de um capitão mor que seja homem de respeito, de verdadeiro valor e desinteressado”. Cf: AHU_ACL_CU_014, Cx.1,Doc. 62; Doc. 70 e Cx2, Doc. 104.

${ }^{63}$ AHU_ACL_CU_014, Cx.1, Doc. 77. Luís Nunes de Carvalho, foi o primeiro governador da Paraíba fora do grupo dos restauradores. Além disso, no seu processo de nomeação para ir governar a Paraíba teve o infortúnio de concorrer com Martinho Bulhões Muniz, restaurador e preferido de Feliciano Dourado, seu parente. Fato este que, por si só, não devia trazer bons presságios ao novo governador, antipatizando-o com os homens principais da terra. Cf: AHU_ACL_CU_014, Cx.1, Doc. 62.
} 
falsidades que estes homens mandam dizer para com eles dissimularem suas maldades". 64

Portanto, ao contar apenas com o apoio da parentela restrita à capitania, desde a morte do tio, Salvador Dourado sabia que se tornaria presa fácil nos embates políticos com membros da elite local ou com os agentes mais graduados da administração imperial. Ciente dos riscos que isso acarretava, procurou estabelecer contatos na Corte, recrudescendo antigas amizades. Numa missiva ao então secretário do Conselho Ultramarino, André Lopes de Lavre, em meados de 1684, comentava com certa proximidade:

Senhor meu, como vivo tão lembrado daquela amizade que quando estive nesta Corte me contou tem vossa mercê com Feliciano Dourado, meu tio, e do muito que me consta tem vossa mercê amparar a quem solicita seus favores, tiro destas razões o motivo para a confiança de o procurar... ${ }^{65}$

Confiança e amparo, era este o código que "introduzia benfeitor e beneficiado numa economia de favores ... de gratidão e serviço. "66 Moeda corrente, a troca de favores, enquanto norma estatuída, se manifestava entre amigos num tipo de relação não necessariamente horizontal, mas, marcadamente, no sentido aristotélico do termo, predominantemente desigual. "Para o polo dominante (credor), se traduzia na disponibilidade de quem dava um benefício e não exigia uma contrapartida expressa e/ou imediata e, do lado do polo dominado (do devedor), estava associada às idéias de 'respeito', 'serviço', 'atenção', significando a disponibilidade para prestar serviços

\footnotetext{
${ }^{64}$ AHU ACL CU 014, Cx.1, Doc. 75.

${ }^{65}$ AHU_ACL_CU_014, Cx.1, Doc. 128.

${ }^{66}$ XAVIER, Angela Barreto \& HESPANHA, Antônio Manuel. “As redes clientelares”. In: José Mattoso (dir.). História de Portugal. V. IV. Antônio Manuel Hespanha. (org.). O Antigo Regime $1621-1807$... Op.cit., p. 340.
} 
futuros e incertos", ${ }^{67}$ Por isso mesmo, ainda sem completar um ano no cargo, mas já envolto em uma situação de confronto com um outro governador, Alexandre e Souza Azevedo, Salvador Quaresma Dourado recorreu a Lopes de Lavre pedindo que ele intercedesse a seu favor, pois ...

...tenho neste Conselho meus requerimentos sobre os capitães-mores desta capitania quererem se intrometer na jurisdição destes ofícios de provedor da Fazenda Real de que sua majestade me fez mercê da propriedade (...) Folgarei muito que vossa mercê, como meu amo, queira ser servido tomar-lhe muito por sua conta para que fique eu devendo ao patrocínio de vossa mercê todo o bom sucesso que nele tiver... ${ }^{68}$

Não sabemos qual a atenção dada pelo secretário a esta carta, correspondência pessoal e curiosamente largada (intencionalmente ou não) entre os documentos do Conselho. O certo é que a reclamação de Salvador procedia, já que Souza de Azevedo havia mandado alguns soldados da Infantaria entrarem nos armazéns do Forte Velho e da Fortaleza do Cabedelo - espaços estes de responsabilidade dos almoxarifes, mas controlados pelo provedor -, para tirar algumas peças de artilharia que lhe interessavam, e levá-las para o seu navio. ${ }^{69}$ Os autos de investigação sobre o caso se estenderam até a saída do governador, em meados de 1684. Sentindo-se ameaçado por esta demora no processo, Salvador Dourado buscou apoio em Lopes de Lavre. No decorrer do ano de 1685, contudo, na residência tirada pelo ouvidor geral de Pernambuco, Dionízio de Ávila Vareiro sobre o governo de Alexandre e Souza, concluiu-se pela limpeza de mãos do governador. Porém, como denunciou em carta ao rei o juiz ordinário da Paraíba, Antônio

\footnotetext{
${ }^{67}$ Idem ibidem. Na citação, os verbos que não se encontram em itálico, foram propositalmente por nós transformados do presente, como se encontra originalmente, para o pretérito imperfeito do indicativo.

${ }^{68}$ AHU ACL CU 014, Cx 2, Doc. 128.

${ }^{69}$ AHU_ACL_CU_014, Cx.2, Doc. 121.
} 
de Souza Figueiroa, ficou revelado que o provedor da Paraíba agira corretamente, pois havia fortes indícios de prática de suborno, promovida pelos procuradores do exgovernador. Entre os envolvidos estavam João do Rego Barros (também ex-governador da Paraíba) e mais testemunhas arroladas para depor sobre o caso. ${ }^{70}$

Este fato, se não levou à invalidação da residência do governador, ao menos deu asas a Salvador Dourado, fazendo-o acreditar que, a partir desse confronto com a autoridade máxima da capitania, poderia agir impunemente, dentro ou fora da esfera de sua jurisdição. Foi um mero engano, a julgar pelas diversas cartas enviadas ao rei pelos moradores paraibanos, a respeito da necessidade da Paraíba possuir um ouvidor letrado, dado o freqüente abuso de poder por parte dos governantes e homens poderosos da terra $^{71}$. Fazendo coro a essas reivindicações, já se dizia há muito tempo, nas capitanias vizinhas, que a Paraíba era um covil de malfeitores e homiziados. ${ }^{72}$ Neste sentido, a gota d'água para a criação da Ouvidoria Geral da Paraíba, pondo fim à espera da população e à apreensão pelo aumento de despesas com a nomeação de um novo escritório, veio por causa de uma denúncia de usurpação notória da Fazenda Real. Desta feita, foi um morador da capitania, o capitão Antônio Cardoso de Carvalho, que descortinou os excessos praticados por Salvador Dourado em conluio com seu escrivão Pedro Borges de Macedo, o Almoxarife Simão de Vasconcelos e mais dois primos do provedor: Martinho de Bulhões, o moço, e Hipólito Bandeira de Melo, futuro escrivão da Fazenda. ${ }^{73}$

\footnotetext{
70 AHU_ACL_CU_014, Cx.,2 Doc.133. Acresce registrar que, após esta denúncia, Francisco do Rego Barros, fillho de João do Rego Barros (provedor em Pernambuco), que estava servindo de ouvidor na Paraíba, suspende o juiz ordinário, Antônio de Souza Figueiroa, por problemas na sua eleição para o cargo que ocupava. Cf: AHU_ACL_CU_014, Cx.2, Doc.135.

${ }^{71}$ Diziam os vereadores do senado da Câmara da cidade de Nossa Senhora das Neves da Paraíba, em 1675, que o povo padecia de justiça no "judicial e contencioso por não haver ouvidor letrado na capitania de Pernambuco e nas mais [capitanias] daquele estado (...). E por terem só um ouvidor de capa e espada [isto é, secular, que tem emprego civil, sem beca] e dista nomeado pelo Governador Geral do Estado, sem ser da mesma capitania se fazem grandes incidencias como de presente estavam experimentando." Cf: AHU_ACL_CU_014, Cx.1, D 91. Ver também os Doc.135; 139; 142 e 144.

${ }^{72}$ Vera Lúcia Costa Acioli. Jurisdição e conflitos. A força política do senhor de engenho...Op. cit., p.102.

${ }^{73} \mathrm{Na}$ consulta sobre o requerimento do capitão, opinava "o Conselho que pelos capítulos que faz presente o requerente, fazer presente a vossa majestade o muito que precisa de ouvidor letrado essa capitania, como tem apresentado em consulta desde 1675, pelas muitas insolências, roubos e mortes que sucedem todos os dias naquela capitania de que se queixa neste Conselho um Ouvidor Geral ” para a Paraíba. Cf: AHU_ACL_CU_014, Cx.2, Doc.142.
} 
Segundo o capitão Antônio de Carvalho, Salvador Dourado agia conforme seu "capricho" e não assentado no regimento que lhe passara Sua Majestade, "mostrando-se fervoroso em muitas causas e omisso demasiado em outras". ${ }^{74}$

Como já foi dito, Salvador Dourado acumulava a Provedoria dos Defuntos e Ausentes - a qual the dava competência para atuar sobre os "resíduos de deixas testamentárias, fazenda de órfãos, curatela de ausentes e tutela de capelas e albergarias, desde que não fossem de administração eclesiástica, ou estivessem sobre proteção direta do rei." "75 Era um órgão que exigia do seu gestor um trato especial com aqueles que solicitavam seus serviços. Pois, subtende-se que a situação dos que entravam na necessidade de buscar o auxílio da Provedoria dos Ausentes, era quase sempre vexatória. Mas não era bem isso que Salvador Dourado fazia - afinal, quando deveria ser diligente com o expediente das partes, praticava exatamente o contrário, como alertava o capitão Antônio de Carvalho:

$$
\begin{aligned}
& \text { tendo os pretendentes, aposta [o provedor] } \\
& \text { demasiado tempo sem reparar em qualidade de } \\
& \text { pessoa.. E as petições as retém três, quatro dias e } \\
& \text { mais. E alguma houve de três meses e depois para a } \\
& \text { maior parte sai com despachos mais de capricho que } \\
& \text { dejustiça, com que as partes [se] desgastam e deixam } \\
& \text { suas pretensões, principalmente se são de cousa } \\
& \text { pouca. }{ }^{76}
\end{aligned}
$$

Torna-se difícil supor que os bens abandonados pelas partes, mesmo que sendo de pouca coisa, tivessem como destino os cofres da Fazenda. Por certo pode-se creditar à imbricada administração lusa a demora com o andamento dos processos de peticionários $^{77}$. Nesse caso porém, há que se considerar também a demora como um

\footnotetext{
${ }^{74}$ Idem.

${ }^{75}$ Antônio Manuel Hespanha. As vésperas do Leviathan. Coimbra; Livraria Almedina, 1994. p. 208.

${ }^{76}$ Cf: AHU_ACL_CU_014, Cx.2, Doc.142.

${ }^{77}$ Cf: Dauril Alden. Royal Government With special reference to the administration of the Marquis of Lavradio, viceroy, $1769-1779$... Op.cit.,p. 289.
} 
recurso utilizado para engabelar inimigos e desafetos, como forma de levá-los à exaustão, fazendo as coisas da administração parecerem eternas.

Entretanto, não era apenas nessa esfera que Salvador Dourado agia, aproveitando a falta de ouvidor letrado na capitania. Atuando impunemente e em conjunto com o seu escrivão, o provedor da Fazenda fazia o que bem entendia na Alfândega paraibana. Assim, o capitão Antônio de Carvalho continuava o seu rosário de acusações, agora sobre o tratamento dispensado pelo provedor aos mestres dos navios que aportavam na Paraíba. O capitão dizia que o provedor pressionava os mestres " $a$ lançar dobrado o dinheiro dos despachos", majorando o valor da "marca", em mais de dois terços, embolsando a sua parte e impossibilitando que os mestres pudessem emitir qualquer recurso. Pois, caso assim quisessem, teriam que reclamar ao Tribunal da Relação da Bahia. ${ }^{78}$

A distância deste tribunal, não era o único motivo a desestimular a voz dos mestres dos navios contra a extorsão dos agentes do fisco no porto da Paraíba. Para Antônio de Carvalho, os navegadores também tinham o seu preço no embuço. Neste caso, tanto os oficiais como os mestres de navios se locupletavam "botando amizade" com o dinheiro "das forças", ou seja, com os oitenta réis arrecadados por cada caixa de açúcar embarcada e que deveria servir para os reparos e construção das fortalezas e pagamento das tropas:

porque se um navio leva trezentas ou quatrocentas caixas de que há de pagar oitenta réis [por] cada uma, botam amizade $e$ lhe abatem a metade ou o que lhe parecer e fazem termo de que leva o navio cento $e$ vinte caixas, embolsando o que deveria servir para as forças. ${ }^{79}$

\footnotetext{
78 "Nos despachos se pagam oitenta réis por caixa [de açúcar], aplicada as despesas e justificações para o provedor e seu escrivão pagam duzentos e vinte réis. Pela marca deles, que pode importar vinte ou trinta marcas, o provedor faz pagar cento e vinte e mais marcas e ele e seu escrivão embolsam a parte deles (...) e como o recurso é longe, [os mestres] pagam e calam." AHU_ACL_CU_014, Cx.2, Doc. 142.

${ }^{79}$ Idem. Grifo nosso.
} 
Apesar de Salvador Dourador agir fraudulentamente com a Provedoria dos Ausentes, usar seu poder na Fazenda contra os mestres dos navios e mesmo abusar com a consignação destinada ao pagamento dos $\operatorname{soldados}^{80}$, não eram essas ações propriamente que mais escandalizaram o capitão Antônio Cardoso. Na verdade, o motivo do seu desconforto, e que o fizera concentrar toda a sua ira contra Salvador, encontravase na forma humilhante com que eram tratados os seus pares pelo temido provedor. Antônio Cardoso alegava que, diferentemente de Salvador Dourado, os seus parentes que o antecederam, como aconteceu com Alberto Dourado de Azevedo, sempre buscaram tratar com complacência os fiadores das arrematações dos dízimos e subsídio do açúcar, alargando os prazos e evitando que a obrigação do pagamento do fiado levasse esses homens à ruína. ${ }^{81}$ Mas o novo provedor, pelo contrário, mostrava-se impiedoso:

entrando no cargo [Salvador Dourado] logo mandou prender os ditos fiadores na enxovia e ali lhe fizeram vender muitos escravos de suas lavouras. Fizeram na fazenda do capitão Carlos Oliveira seqüestro e lhe deram depositário. Deixou ao Almoxarife [Simão de Vasconcelos] que então servia, ir com o capitão Carlos de Oliveira a Pernambuco a remediar o que devia. Para o fazer, vendeu mais de vinte mil cruzados que se lhe haviam de dar em fazendas de raiz por menos de cinco mil cruzados em pagamentos (...) Foram aqueles dias com rigores de calma a Pernambuco (...) e deste abalo e aflição morreu em

\footnotetext{
${ }^{80}$ Por sinal, noticiava-se na capitania que a falta de pagamento das tropas, pelo provedor, tinha levado a alguns soldados da capitania a se amotinarem na cidade saindo, na confusão, um soldado baleado por acidente, que veio a falecer tempos depois. Cf: AHU_ACL_CU_014, Cx.2, D 139.

81 "Sendo nesta capitania contratador dos dízimos Estevão Soares, durante os anos de oitenta e hum e oitenta e dois, perdeu considerável Fazenda no último ano e foram seus fiadores Manuel Lopes Pimentel e o capitão Carlos de Oliveira. O provedor que era [o serventuário, Alberto Dourado de Azevedo] tendo segura a Fazenda Real e vendo que os fiadores tinham que pagar pelo grande fiado mais de cinco mil cruzados, cobrou deles o que foi possível, ficando encaminhado a se cobrar o mais no cargo do [futuro] provedor" Cf: AHU_ACL_CU_014, Cx. 2, Doc. 142.
} 
breve dias o capitão Carlos de Oliveira, com que o provedor, parece, ficou satisfeito. ${ }^{82}$

Torna-se impossível saber se os valores das propinas cobradas aos mestres dos navios estavam ou não majorados pela escrita do acusador, ou se essas formas violentas de cobrança, aos fiadores, eram verdadeiras - afinal, não houve impedimento algum a Salvador Dourado durante toda a sua gestão. Mesmo assim, pode-se encontrar nestas passagens, quer a auto-afirmação do exercício do provedor, caso se creditassem serem as acusações verdadeiras, quer o poder de barganha que os coevos acreditavam que um agente da Coroa, investido em um ofício de caráter fiscal no ultramar, possuía. Com efeito, apesar de ambas as possibilidades se sustentarem na premissa de que os atos de Salvador Dourado foram um meio de penetração nas práticas daqueles que copiosamente acumulavam o poder, temos que, em contrapartida, remediar o plano de acusação do capitão Cardoso de Carvalho.

Como elemento claramente ligado à classe produtora da capitania, o capitão Cardoso procurava fazer eco contra qualquer afirmação de poder que viesse comprometer os interesses daqueles que queriam transportar o açúcar livremente para Pernambuco e controlar o processo de arrematação do subsídio do açúcar e dízimo da capitania, como faziam os Bulhões antes da gestão do governador Luís Nunes. Isto ficou claro quando um parecerista, a pedido do Conselho Ultramarino, disse que essas queixas contra os agentes da Coroa eram provenientes de pessoas "nobres da capitania da Paraíba que, afetadas mais por ódio que por razão", se mostravam contrárias a esta "proibição" do comércio com o Recife, não faltando "violências nos seus recursos". ${ }^{83}$

Mesmo sabendo das manhas da nobreza da terra, a Coroa não se furtava de se informar das suas ações contra aqueles que ocupavam os cargos nas capitanias. Em contrapartida, não deixava de encorajar os próprios agentes a não perdoarem os recalcitrantes. Tal posicionamento indicava que a Coroa mobilizava forças opostas para

\footnotetext{
${ }^{82}$ Idem.

${ }^{83}$ O parecerista fora o ex-governador de Pernambuco João de Souza. Cf: AHU_ACL_CU_014, Cx.2, D 139.
} 
poder equilibrá-las em proveito próprio. ${ }^{84}$ Colocando-se as coisas desta maneira, e contrariando o raciocínio do capitão Cardoso de Carvalho, é justo reconhecer que o serviço do provedor era mais útil que nocivo aos interesses da Coroa.

Desta feita, é claro que o provedor tinha plena consciência de que, independentemente da proporção da força que tomasse, o Conselho dificilmente se colocaria contrário às medidas de cobrança aos devedores da Fazenda Real. Esta posição fora exacerbada pelo órgão, dois anos após os fatos levantados por Cardoso de Carvalho, quando o fraco governador da Paraíba, Antônio da Silva Barbosa, fora repreendido ao tentar se desculpar ao rei por não ter dado execução às cobranças das dívidas na capitania. ${ }^{85}$ Atarefado, devido aos constantes conflitos com os índios no interior da Paraíba, o governador mostrou-se negligente com a gestão executiva e jurídica da capitania e, expondo suas debilidades ao solicitar ouvidor letrado, pois sozinho não poderia por freios aos paraibanos e tornar mais suave o seu governo ${ }^{86}$, abriu caminho para Salvador dourar o seu nome. Contudo, mesmo para os casos dessa natureza, como a cobrança de dívidas à Fazenda, não seria prudente deixar que os provedores ultrapassem determinados níveis de tolerância, pois, alongando demais a corda, se correria o risco da completa perda de limites.

Assim, além de corrupto e violento, Salvador Dourado ganhava a fama de se exceder para além dos ditames das provedorias. Pouco antes de Silva Barbosa assumir o poder, em 1684, o provedor tomou ares de governador e passou a assentar praça de soldado a um criado seu e a mais dois irmãos, Francisco Quaresma Dourado e Manuel Quaresma Dourado. E, colocando-se acima do Tribunal da Relação ou da Provedoriamor, tratou de determinar que só aceitaria recursos contra os seus procedimentos se eles fossem dirigidos diretamente ao Conselho Ultramarino. ${ }^{87}$

\footnotetext{
${ }^{84}$ Sobre a dubiedade nas ações da Coroa, como forma de garantir o exercício de poder. Cf: Stuart B. Schwartz. Burocracia e Sociedade no Brasil Colonial. São Paulo: Perspectiva, 1979. p. 58.

${ }^{85}$ AHU_ACL_CU_014, Cx.2, D 154.

${ }^{86}$ AHU ACL CU 014, Cx.2, D 145; Em uma consulta datada de 15 de novembro de 1685, sobre a reclamação que faziam os oficiais da câmara da Paraíba sobre a negligência do governador, constava o parecer do ex-governador de Pernambuco, João de Souza, onde afirmava que o "talento do capitão maior Silva Barbosa não era o mais discursivo, porque no tempo em que fora seu súdito, o julgava sempre mais apto dos empregos militares pelo seu valor, do que suficiente para os governos políticos pela sua disposição”. Cf: AHU_ACL_CU_014, Cx.2, D 139.

${ }^{87}$ AHU_ACL_CU_014, Cx. 2, D 142.
} 
Como resultado disso, o rosário de acusações e mais abusos, em relação aos limites de jurisdição, se avolumaram tanto no Conselho Ultramarino que terminaram por contrariar a expectativa do provedor. Era necessário colocar freios nas ações de Salvador Quaresma e, ao mesmo tempo, em fazer cessar as práticas de crimes de malfeitores $e$ homiziados, com a presença da justiça. A criação da Ouvidoria Geral da Paraíba se deu, enfim, na consulta ao rei, em 25 de janeiro de $1688 .{ }^{88}$

\section{O RETRAIMENTO DA JURISDIÇÃO: DEFUNTOS E AUSENTES}

A assunção da Ouvidoria Geral na Paraíba englobando, entre suas comarcas, Itamaracá, Rio Grande e, mais tarde, também o Ceará, promoveu uma mudança substancial na relação entre os poderes institucionais existentes na capitania. Além da esperada transferência das prerrogativas dos juízes ordinários para as mãos do ouvidor letrado, outras disposições passaram a ampliar as atribuições da nova ouvidoria, ocasionando perda significativa na jurisdição de Salvador Dourado.

Entre as perdas de prerrogativas do provedor da Fazenda, estava a ambicionada Provedoria dos Defuntos e Ausentes, cobiçada menos pelo seu ordenado do que pela possibilidade de enriquecimento dos seus oficiais, já que, em época de epidemias, a morte não discriminava e ceifava, também, muita gente de cabedal.

A notícia da recriação da Ouvidoria Geral da Paraíba provocou uma certa excitação no tribunal da Mesa da Consciência e Ordens que requereu, em 1688, a nomeação da Provedoria dos Defuntos e Ausentes para a pessoa do ouvidor geral da Paraíba, Diogo Rangel de Castel Branco, sob a alegação de que tal escolha estava restrita à sua jurisdição.

Ao chegar a petição do tribunal da Mesa da Consciência no Conselho Ultramarino, os conselheiros trataram de lembrar ao rei um despacho real datado de 19 de dezembro 1687, dado como resposta a uma consulta sobre os maus procedimentos do provedor da Fazenda da Ilha de Cabo Verde. A partir daquela data do despacho, com

\footnotetext{
${ }^{88}$ Provisão passada a Diogo Rangel Castelo Branco, em 25 de janeiro de 1688. IHGP/ PB. Códice: $1816-$ Ouvidoria, folha 4.
} 
efeito, ficou determinado que, os ouvidores gerais fossem também provedores dos Defuntos e Ausentes nas demais conquistas ultramarinas, observando, entretanto, que

o Desembargo do Paço consultaria os ouvidores ... e que ao tempo das consultas mandaria ... dar parte ao Conselho dos sujeitos que neles lhes são propostos para que lhe possa dizer qual será mais conveniente para exercitar o dito oficio de provedor. ${ }^{89}$

Baseados nesta prerrogativa, os conselheiros transformaram a petição da Mesa em consulta e afirmaram, em seu parecer, serem terminantemente contrários ao desmembramento dos ofícios. Segundo os pareceristas, a união das provedorias era antiqüíssima e o provimento, além de responder a uma necessidade econômica do investido, dado o parco rendimento que representava cada uma das provedorias, era feito através de uma só carta, sem contradição alguma de um ou do outro tribunal. Não mexer na mercê de Salvador Dourado seria, portanto, o momento ideal para o Conselho Ultramarino por fim a qualquer questionamento de jurisdição por parte da Mesa da Consciência. $^{90}$

Mas o despacho real não foi favorável ao Conselho Ultramarino. Desta forma, Salvador Dourado não foi apenas lesado em sua jurisdição, como logrou perda significativa no seu ordenado. Dos cento e setenta mil réis anuais recebidos pelo provedor da Paraíba, restaram- lhe setenta mil. Acuado, Salvador Dourado interpôs recurso quatro meses depois, em novembro de 1689, requerendo ao menos um abono pela perda. Alegando a grande defasagem entre o ordenado pago na Paraíba em relação ao de Pernambuco - estimava-se que o provedor da capitania vizinha recebesse trezentos e cinqüenta mil réis -, requereu uma ordinária de cem mil réis anuais. Como o valor

\footnotetext{
${ }^{89}$ A partir desta data, abria-se a possibilidade do acúmulo dos ofícios da Fazenda pelo ouvidor geral, não mais de forma interina mas, reconhecidamente, com um aparato legal AHU_ACL_CU_014, Cx.2, D 162. ${ }^{90}$ Idem.
} 
repercutiu exagerado no Conselho, inclusive com veto do procurador da Coroa, Salvador alcançou, apenas, uma ordinária de trinta mil réis anuais. ${ }^{91}$

Entretanto, esta não foi a última vez que Salvador viu sua jurisdição diminuída. Em 1693, mais uma parcela de suas prerrogativas foi suprimida, com o Juízo dos Homens do Mar indo parar nas mãos do Ouvidor Geral. É verdade que Salvador Dourado conseguiu segurar os vinte cruzados ( $8 \$ 000$ réis) de emolumentos anuais que o cargo lhe possibilitava, agora acrescido ao ordenado. Mas nada impediu uma má repercussão na sociedade paraibana com a notória perda de poder e influência do provedor no Conselho Ultramarino e, por extensão, onde mais importava, na sua localidade. ${ }^{92}$

Em resposta a isso, Salvador Dourado conseguiu, em 1697, se eleger provedor da Casa de Misericórdia da Paraíba. Por representação real, foi prestigiado, como era de estilo antigo em Recife e Rio de Janeiro, com a prerrogativa de sentar nas solenidades públicas em cadeira de espalmar, logo abaixo do governador e acima do ouvidor ${ }^{93}$. Tais etiquetas eram necessárias, pois "o povo não acredita em um poder que, embora existindo de fato, não apareça explicitamente na figura do seu possuidor. É preciso ver para crer". 94 Salvador Dourado tentou ainda alcançar, em 1705, o hábito de Cristo e duas tenças como dote para quem casasse com suas filhas, em satisfação dos serviços do seu irmão, o capitão Francisco Quaresma Dourado. Numa época em que o espólio de herança ainda se fazia oralmente, o provedor alegou que o seu irmão lhe passara os direitos pelos serviços por ele praticados à Coroa. Além do hábito de Cristo, Salvador Dourado conseguiu uma tença de doze mil réis, que lhe foram pagos anualmente até a sua morte. Para suas filhas, entretanto, nada foi garantido. ${ }^{95}$

Tirante, contudo, estas questões ligadas à simbologia da representação social do ofício do provedor e às jurisdições reduzidas pela presença da ouvidoria, outro problema para Salvador era administrar a falta de dinheiro e renda e dar cabo do próprio trabalho de escrituração das contas, que cresciam com o passar do tempo, complexificando o manuseio dos livros. E esta foi a trajetória administrativa deste provedor até sua morte, no início dos anos trinta: ministrar uma receita minúscula e duplamente dependente. Com

\footnotetext{
${ }^{91}$ AHU ACL CU 014, Cx.2,D 163 e 177.

${ }^{92} \mathrm{AHU}^{-} \mathrm{ACL}{ }^{-} \mathrm{CU}^{-} 014, \mathrm{Cx} .2$, Doc. 190.

${ }^{93}$ Irineo Pinto. Datas e notas para a história da Paraíba... p. 89.

${ }^{94}$ Norbert Elias. A sociedade de Corte. Rio de Janeiro; Jorge Zahar Editor, 2001. Op. cit. p. 133.

95 AHU_ACL_CU_014, Cx.4, Doc. 275.
} 
efeito, se ora essa receita dependia dos pequenos resultados da economia, sujeita às calamidades naturais, como toda e qualquer economia tradicional, ora dependia, como veremos nos capítulos seguintes, dos incertos envios dos vinte mil cruzados da dízima da Alfândega que se cobrava por Pernambuco.

\section{SOBREVIVÊNCIA EM UMA CAPITANIA DEFICITÁRIA}

Parte das mazelas que comprometiam a economia paraibana, era expressa nas repetidas cartas de moradores e autoridades dando conta ao rei sobre as epidemias, secas, falta de escravos e engenhos de fogo morto. Nessa situação, a festejada criação do um novo escritório, a Ouvidoria Geral, repercutiu negativamente sobre os cofres da Fazenda. Nem ao menos completara dois anos de existência e o ouvidor-geral já sentia o primeiro atraso nos seus duzentos mil réis de ordenado. Salvador Dourado até tentou uma saída negociável junto ao Conselho, que seria dividir as despesas da Ouvidoria com as capitanias anexas à comarca da Paraíba, Itamaracá e Rio Grande, mas não logrou êxito. ${ }^{96}$ Da mesma forma, foi mal inspirado quando tentou livrar a Fazenda paraibana das responsabilidades com o bispado vizinho. Como resultado, amargou o desconforto de ser excomungado pelo bispo de Pernambuco, dado o atraso no envio dos trezentos mil réis anuais que deveriam servir como complemento para o pagamento da côngrua do referido padre e cabido da Sé de Olinda. ${ }^{97}$ Portanto, garantir, os ordenados dos filhos da folha executiva, militar e eclesiástica, além dos pagamentos aos empreiteiros e mais trabalhadores da Fortaleza do Cabedelo e das despesas extraordinárias para manutenção da Fazenda, não era tarefa fácil.

Para os oficiais da Fazenda paraibana ao contrário do que acontecia em outras paragens, os pros e percalços ${ }^{98}$ soavam mais como estorvos da labuta do que como vantagens que a profissão poderia auferir. Os próprios governadores da Paraíba

\footnotetext{
${ }^{96}$ AHU_ACL_CU_014, Cx.2, Doc. 166.

${ }^{97}$ Idem. O atraso no envio desse pagamento ultrapassava, em 1688, cinco anos, já que o bispo não aceitava ter o seu pagamento em açúcar.

${ }^{98}$ Devido o caráter prebendário no regime patrimonial de ofícios, as propinas não podem ser vistas como puro ato de suborno como hoje nos parece. Em verdade, era não apenas tolerado como um donativo voluntário, como havia quem, no Conselho Ultramarino, propusesse oficializá-la para que não houvesse excessos. Cf: Vera Lúcia Costa Acioli. Jurisdição e Conflito: a força política do senhor de engenho... Op. cit. p. 59-60.
} 
reconheciam, como o fez João de Abreu Castel Branco, em 1726, que a Fazenda Real paraibana não podia suprir a todos os oficiais que se sentissem prejudicados pelas poucas chances em conseguirem fazer render seus emolumentos e propinas. ${ }^{99}$ Mas, se o motivo e a finalidade da Fazenda das capitanias eram garantir a sobrevivência e a reprodução material aos administradores, quer nas suas repartições, amealhadas entre as capitanias do Norte, quer transferindo riquezas para a Coroa, como, então, prover a tantos com uma receita minúscula ? Ao menos no plano individual, a prática de extorsão era uma das maneiras de se resolver isso. Desde o início do mandato do provedor Salvador Dourado, havia suspeita desse tipo de conduta contra os mestres de navios, quando das cobranças nos despachos para liberação das naus carregadas com açúcar nos portos da Paraíba. Longe de acreditar que tal problema fosse exclusivo do porto paraibano ${ }^{100}$, o certo é que este tipo de acusação sumiu após a criação da Ouvidoria Geral. Todavia, outras reclamações passaram a chegar no Conselho Ultramarino, principalmente depois da criação do imposto de dez por cento sobre os produtos importados, em $1711 .^{101}$ Neste caso, Salvador Dourado descobriu como agir na fissura da lei, ao se aproveitar da falta de regimento para a Alfândega paraibana. Por isso mesmo, para alguns mestres de navios, chegar ao porto da Paraíba para comerciar ou arribar, por algum problema na embarcação, poderia significar um motivo de insatisfação.

Para Salvador Dourado, entretanto, pouco importava a motivação que levara o navio à visita ao porto. Acossado com as folhas de serviço para saldar, o jeito era não desperdiçar nenhuma chance de garantir, aos seus oficiais da Fazenda, os difíceis emolumentos. Portanto, cair nas redes do porto paraibano era, para os mestres e capitães dos navios, verem fisgados seus últimos vinténs nas gratificações aos oficiais.

\footnotetext{
${ }^{99}$ Tratava, na oportunidade o governador, em dar um parecer sobre a solicitação do escrivão da Abertura da Alfândega da Paraíba, Antônio Carneiro de Albuquerque, que pedia um ordenado de $120 \$ 000$ réis anuais, valor que recebia o mesmo oficial em Pernambuco, fora os emolumentos; Antônio Albuquerque acabou alcançando $80 \$ 000$, visto não ter como "granjear" sua vida com outras atividades - afinal, como alegava o oficial, dedicava-se integralmente ao serviço mesmo com um emolumento irrisório. Cf: AHU_ACL_CU_014, Cx.6, Doc.530. Retomaremos esta questão no capítulo seguinte.

${ }^{100}$ Temos, entretanto, para outras capitanias, como, por exemplo, a da Bahia, apenas notícia da prática de contrabando, onde oficiais da administração portuária se prestavam a facilitar o ingresso de mercadorias importadas, as quais eram comercializadas livremente pelas ruas da capital. Cf: José Roberto do Amaral Lapa. A Bahia e carreira da Índia. São Paulo; Hucitec/Unicamp, 2000. (principalmente o capítulo 9) p. 229-252.

${ }^{101}$ Ordem Real de 04.02.1711 Cf: AHU_ACL_CU_014, Cx.6, Doc. 519.
} 
Vítimas dessa política, assim aconteceu com os oito navios pertencentes à "Mesa do Espírito Santo dos Homens de Negócio de Lisboa." Partindo de Portugal em 1723, com destino à Capitania de Pernambuco, esses navios se perderam do "comboio de Sua Majestade" por conta do mau tempo, indo parar na barra da capitania da Paraíba, “debaixo da proteção de sua fortaleza”. Quando os capitães dos navios requereram a Salvador Dourado carta de franquia para poderem sair da barra e seguir viagem a Pernambuco, não apenas lhes foi negada a franquia, como foram obrigados a atracar e dar entrada de todos os produtos na Alfândega da capital. Procuradores e deputados da Mesa dos Homens de Negócio se expressaram contrários ao comportamento do provedor da Fazenda denunciando, também, a conivência e participação direta do governador da capitania no fato:

Deste procedimento na verdade injusto intentaram agravar os capitães e além de lhes impedir o recurso os intimidou de sorte o capitão-mor da capitania para que se espoliarem todos os que não se satisfizessem a dar entrada naquela Alfândega, descarregando nelas as fazendas que levavam para Pernambuco sem atender a que foram àquele porto da necessidade $e$ caso fortuito do contratempo que experimentavam. ${ }^{102}$

A compreensão que os deputados da Mesa dos Homens de Negócios pediam era a de que o provedor Salvador Dourado levasse em conta e respeitasse "as matérias pertencentes às coisas náuticas”. Segundo os deputados, a concessão de franquia, que estava “fundada no regimento da alfândega da Corte e mais partes do Reino”, admitia a liberdade de atracar "a todos os navios de qualquer qualidade que por ocasião fortuita entrarem da barra para dentro constando que vão despachados para outro porto". Assim, se havia um despacho régio em Pernambuco, que desde 12 de novembro de 1692 concedia franquia para todos os navios "não só portugueses, mas ainda estrangeiros",

${ }^{102}$ AHU_ACL_CU_014, Cx.5, Doc. 423 
deveria o porto da Paraíba se reger por ele; "não só pela graduação em que se acha de maior comércio, mas também porque quando nos Reinos e cidades faltam leis para decisão nos casos, se sujeitam esses ao Reino vizinho”. Para o provedor da Fazenda paraibana, entretanto, o que importava era "que os navios descarregassem, lotando cada um deles no que quisessem e fazendo pagar a todos os despachos, pros e percalços ... como se despachassem nova carga", ${ }^{103}$

Mas não foram apenas esses homens que sofreram o infortúnio de arribar ao porto da Paraíba. A mesma falta de sorte tiveram os senhores do bergantim Santo Antônio e Almas, por ter Salvador Dourado mais uma vez desrespeitado as ordens de concessão de franquias em momento de socorro. Na alegação dos senhores, o bergantim, que partira do Maranhão, em julho de 1721, com destino ao Rio de Janeiro, mas com escala no Recife, onde deveria despachar a carga de algodão que transportava, "como lhe sobreviesse uma rigorosa tormenta, e se visse com água aberta e a verga do traquete [mastro] quebrada, se achou precisado a tomar de arribada o porto da Paraíba". ${ }^{104}$ Após atracar o barco, o mestre do bergantim, José Coelho Lopes, já em segurança, encaminhou o pedido de franquia para o governador da capitania, que o remeteu a Salvador Dourado. De posse do documento, entretanto, o provedor, além de negar a franquia, "ainda constrangeu [o

\footnotetext{
${ }^{103}$ Idem. Segundo Amaral Lapa, para o caso de solicitação de franquias em Salvador, havia muita esperteza dos mestres de navios, pois costumavam burlar o regimento da Alfândega baiana, ingressando no porto sem autorização, alegando que o navio estava aberto. Cf: José R. do Amaral Lapa A Bahia e a carreira da Índia... Op. cit. p. 10.

${ }^{104}$ AHU_ACL_CU_014, Cx.6, Doc. 501. É muito provável que esta carga fosse despachada junto com a produção da capitania de Pernambuco para a Europa. Segundo Amaral Lapa, "é de se lembrar ainda que as balanças de comércio de Portugal com seus domínios ultramarinos, dado o monopólio que se praticava, poucos elementos nos dão para verificarmos o seu montante entre uma possessão e outra, mas apenas entre a metrópole e estas e vice-versa". Cf: José R. do Amaral Lapa A Bahia e a carreira da Índia... Op. cit. p. 230. Sobre as balanças de comércio, ver José Jobson de A Arruda. O Brasil no comércio colonial. São Paulo: Ática, 1980. É oportuno, também, ressaltar que alguns estudos hoje em dia já privilegiam exatamente as trajetórias comerciais entre as possessões no Império português, como é o caso do trabalho de João L. R. Fragoso. Homens de grossa ventura: acumulação e hierarquia na praça mercantil do Rio de Janeiro (1790 - 1830). Rio de Janeiro: Arquivo Nacional, 1992. Apesar de inovarem quanto à descoberta de novos parâmetros de desenvolvimento econômico, inclusive descortinando processos de acumulação nas áreas fora do eixo Lisboa - Europa, deslocando a relação preponderante do exterior da colônia para seu interior, estes estudos em nada invalidam a dimensão do monopólio que se praticava pela metrópole. Ou seja, não excluem "a compreensão global desse processo histórico particular [que] envolve a captação [da] interação dialética entre a condição colonial articulada a metrópole e a formação social escravista da colônia (...) condição colonial [que] não significa, contudo, a exclusão permanente e definitiva da ação dos homens coloniais na busca de sua autodeterminação." Cf: José Jobson de Arruda. "O sentido da colônia..." In: José Tengarinha (org). História de Portugal... Op. cit. p. 248.
} 
mestre do navio] a descarregar o dito bergantim obrigando-o por força a assinar termo de entrada". 105

As reclamações se sucediam, sem que a Coroa colocasse freios nos agentes do fisco paraibano. Todos os oficiais diziam possuir uma ordem real garantindo a cobrança deste ou daquele emolumento ou propina. A "malícia" consistia, segundo os navegadores, em fazer a cobrança na véspera da partida da frota, impedindo que houvesse tempo para qualquer recurso, pois na vexação pagavam e, só passado algum tempo, é que pediam restituição. ${ }^{106}$

É certo que o problema com a insatisfação dos mestres, proprietários de navios e sindicatos de comerciantes, deveria perdurar até o momento em que a Coroa resolvesse assegurar um regimento para a Alfândega da Paraíba. Sem ele, seria difícil, ou mesmo impossível, determinar se Salvador Dourado agira ou não com honestidade. Desta forma, fundado na fissura da lei, o oficial podia agir à revelia do esperneio dos mestres dos navios, pois as alfândegas de Pernambuco, Bahia e Rio de Janeiro ofereciam os regimentos por onde, casuisticamente, a Alfândega paraibana podia atuar. ${ }^{107}$ Contraditoriamente, apesar de reconhecer o ato escrito como o meio e fim do princípio administrativo - afinal, sempre o estimulou e exigiu dos seus oficiais -, a Coroa faltava, em muitos momentos, com a sua parte. A demora no envio de regimentos era um exemplo.

Talvez a Coroa visse aí um mecanismo de arrefecimento das insatisfações dos oficiais da Fazenda, na medida que exaltava as tensões e discórdias destes com aqueles que sofriam diretamente suas ações. Caso assim fosse, estaria em jogo um destino perigoso, mas ao mesmo tempo bastante eficiente, pois mesmo que a mão pesada da ação fiscal revelasse, em última instância, a presença real, a perda de controle sobre os agentes, principalmente para os que detinham bens de raiz no local onde exercitavam

\footnotetext{
${ }^{105}$ AHU_ACL_CU_014, Cx.6, Doc. 501

${ }^{106}$ Sem solução para seu pleito, o mestre e o capitão da Charrua Nossa Senhora e Almas, Manuel João e João Gonçalves Lima, clamaram em 1728 que o rei obrigasse ao escrivão da Fazenda, Bento Bandeira de Melo (o neto) a devolver os emolumentos pagos a ele na vistoria que havia feito ao navio; pois já os haviam pago a quem deveria, ao escrivão da Abertura da Alfândega e meirinho dela. Cf: AHU ACL CU 014, Cx. 7, Doc. 562; 572; 586; e 647.

107 Baseado também na formula de auto-regulação, Bento Bandeira de Melo (o neto) como escrivão da Fazenda nos anos de 1730, praticava, segundo o ouvidor Salter de Mendonça, valores extorsivos na cobrança dos seus emolumentos com a alegação de que se assim não agisse não teria como pagar os novos direitos. Cf: AHU_ACL_CU_014, Cx. 9, Doc. 747.
} 
suas funções, era sempre uma evidência. Assim, mesmo correndo este risco, a administração fazendária paraibana seguiu numa mescla de ordem e desordem, em que a confusão dos livros, em meio a registros e omissões, caracterizou a gestão de Salvador Dourado.

\section{OS LIVROS DE REGISTROS, ABUSOS E OMISSÕES}

Até a criação do Erário Régio, em 1761, quando se assistiu à obrigatoriedade do uso das partidas dobradas - "método que a prática comercial espalhara por toda a contabilidade européia" 108 -, as normas exigidas para a escrituração com a contabilidade pública no interior do Reino ou mesmo no Império português, não passavam apenas de uma preocupação. ${ }^{109}$ As transformações no ato de registrar, com o uso dos algarismos arábicos, que se generalizou ao longo do século XVII por todo o Império, se deram, primordialmente, por obra de uma disseminação, em virtude da exigência empírica de se tornar mais simples e ágil a prática contábil. Mas aconteceram, também, pelo esforço dos oficiais da Casa dos Contos, em Lisboa, ao reconhecerem a necessidade de aprimoramento técnico. ${ }^{110}$

Mesmo assim, a opção pelo empírico suplantou a técnica, no sentido de privilegiar o costume, isto é, os estilos locais, tanto ao nível do próprio ato da escrita, a forma do registro contábil ${ }^{111}$, como dos suportes suficientes para receberem esses escritos, os livros. Por isso, não se deve estranhar a liberdade dada ao próprio provedor da capitania da Paraíba, Salvador Dourado, em 1713, de determinar quantos livros seriam "necessários para servirem a arrecadação da Fazenda Real”. Segundo o provedor,

\footnotetext{
${ }^{108}$ Virgínia Rau. A Casa dos Contos... Op. cit. p. 416.

${ }^{109}$ Idem; Op.cit. p. 414.

110 "Ainda em 1633 os provedores da Fazenda em Lisboa declaram que 'se não pode dar crédito ao caderno que veio das ditas despesas da Índia por virem em algarismos' e exigem que Goa remeta os livros originais, com os registros feitos segundo a norma tradicional dos Contos: por extenso e em numeração romano peninsular." Vitorino Magalhães Godinho. "Finanças Públicas e estrutura do Estado". In: Joel Serrão (dir.). Dicionário de História de Portugal. Porto: Livraria Figueirinhas, s/d. Op. cit. p. 256.

${ }^{111}$ Durante o século XVII, se dizia nos Contos que, das contas que davam os almoxarifes, pelo emaranhado dos registros contábeis, seria impossível saber o que se gastava em cada ano separadamente, "pois as despesas estão místicas". Idem ibidem.
} 
eram seis: a saber: um para se carregar nele ao almoxarife todos os efeitos da Fazenda Real, outro para a saída deles, outro para se carregarem o dito almoxarife os efeitos pertencentes às fortificações, outro para a saída deles, e outro para se carregar o procedimento da dízima da alfândega ao tesoureiro dela e outro para se carregarem os direitos dos contratos dos dízimos. ${ }^{112}$

Pela quantidade de livros, percebe-se o que diferenciou tal procedimento do avanço representado pelo uso do método de partidas dobradas. Enquanto, na partida dobrada, as entradas acompanhavam pari passu o registro da saída em um único livro, no outro método os registros eram feitos aleatoriamente em livros diferentes, sem nenhuma referência entre débito e crédito. Este procedimento gerava uma grande confusão nos estoques dos armazéns, principalmente nos trens de munições, resultando em alguma perda para a Fazenda, podendo acarretar o acúmulo de alguns itens e a falta de outros. ${ }^{113}$ Da mesma forma, podiam se acumular informações sem registros de entrada e saída nos livros dos efeitos da Fazenda Real, como acontecia quando os almoxarifes ou tesoureiros não passavam recibos e, sem comprovantes, registravam, como se dizia na época, de memória. Outras vezes, mesmo com recibos, era comum o empilhamento de maneira avulsa, sem que houvesse a atenção em transportar os dados para os livros. Nesses casos, era um tormento fazer certos balanços. Foi o que ocorreu com a ordem dada pela Coroa, em 1712, para que o governador enviasse

\footnotetext{
${ }^{112}$ Cf: AHU_ACL_CU_014, Cx.5, Doc. 338. Colocar a quantidade de Livros necessários conforme o exigido no Regimento.

${ }^{113}$ Quanto às diferenças entre um procedimento e outro, ver os pertinentes comentários de Dauril Alden. Royal government in colonial Brazil. With special reference to the administration of the Marquis of Lavradio, viceroy, 1769 - 1779...Op.cit., p. 289-290.
} 
uma relação dos últimos dez anos de todas as letras e efeitos que dessa capitania se enviaram ao Conselho Ultramarino ... contanto o dia, mês e ano em que se passaram, detalhando as folhas dos livros de receita que se carregaram e por quem foram feitas $e$ assinadas. ${ }^{114}$

Foi uma mera ilusão da Coroa. Na resposta do governador João Maia da Gama, dois anos depois, se sentia o estado da organização da gestão de Salvador Dourado. Segundo o governador, não havia "livros em que se passassem as letras, nem nos livros da Fazenda se [achavam] declaração delas". E alegava: ao constatar "a pouca e má forma que aqui havia nas coisas da Fazenda ... me vi perplexo e tive que puxar pelas terceiras vias que ficam em poder [dos almoxarifes]". 115 Ao concluir, se dizia insatisfeito, por ter ciência do que enviava “ainda não ser o que basta”. Deixava para outro momento o envio de outras notícias, primeiro sobre certas despesas surpreendentes "de que [até então] não tinha notícia"; e, segundo, no que não faltava uma centelha de suspeita contra o provedor, sobre seu estranhamento por estarem "os requerimentos dos oficiais da Fazenda com o contrário do que consta dos ditos livros”. 116

A falta de transparência nos atos e a desorganização dos livros não poderia levar a outra interpretação a respeito daqueles que dependiam diretamente da Fazenda para sobreviver, do que colocar em dúvida a honestidade e limpeza de mãos do provedor. Os soldados da Infantaria, por exemplo, cansados de esperar pelo seu fardamento e soldo em dinheiro, que já entrava no quinto ano de atraso em 1718, pediam ao rei que obrigasse ao provedor da Fazenda a apresentação dos registros dos subsídios nos últimos quatro anos. A revolta dos soldados era grande, pois sabiam que alguns soldados mais próximos do provedor recebiam em dia os seus vencimentos. Em contraste com isso, a quase totalidade dos que mantinham guarda na fortaleza do Cabedelo ou no presídio da Bahia

${ }^{114}$ AHU_ACL_CU_014, Cx.5, Doc. 341.

115 Idem;

116 Idem; 
da Traição, vivia na iminência da mendicância, já que, na falta de hospital e quartéis, eram obrigados a pagar para morarem em casas. ${ }^{117}$

As respostas para estes fatos iam sempre na demonstração de que a situação calamitosa da capitania impossibilitava fazer o pagamento para todos os soldados. Todavia, o provedor tratava de tirar daí a justificativa para comandar, através de ordens suas ou do próprio governador da capitania, o direito de "mesmo sem ter tirado mostra, dar a muitos soldados e oficiais dinheiro ... para se lhes descontar nos ditos socorros quando se passar mostra deles". O registro "dos pés das listas", ou livro de mostras, onde constavam os nomes daqueles soldados que haviam recebido o pagamento ou o adiantamento, era feito de tal forma que, às vezes, ficava impossível saber quem já havia recebido. Em um desses registros percebe-se, em meio a uma enxurrada de nomes, o do ajudante-supra Luís Quaresma Dourado, irmão de Salvador Dourado, que recebeu cinqüenta e oito mil e oitocentos réis de adiantamento, segundo valor mais alto do total do despendido em $1717 .^{118}$

Esta confusão nos pés das listas acarretava dois tipos de problemas curiosos: primeiro, a possibilidade do soldado dizer que não havia recebido e ter seu ordenado pago por mais de uma vez ${ }^{119}$ e, segundo, pela desconfiança que esta prática levantava na população. Em relação a este segundo ponto, como expressou o procurador da Fazenda Real, num parecer dado a uma consulta em 1719, tanto o empréstimo levantava "dúvida tão falivel como esta cobrança é duvidosa". Por isso, achava melhor que "Vossa Majestade ordenasse se não faça pagamento algum, sem que o possa chegar a todos". ${ }^{120}$ Talvez por estar acostumado com semelhantes experiências em outras capitanias, pode-se ver, anos à frente, que a preocupação do procurador procedia. Como o costume não orientava passar recibos, cabendo apenas ao provedor e ao seu escrivão o total controle do que era despendido, os dois podiam ajustarem a adição levando em

\footnotetext{
${ }^{117}$ AHU_ACL_CU_014, Cx.5, Doc. 366

118 Idem;

${ }^{119}$ Idem; Esta era a dúvida de João Maia da Gama, ex-governador da Paraíba e residente na Corte em 1720, sobre a quantidade de soldados que diziam nada terem recebido por cinco anos seguidos.

${ }^{120}$ Idem;
} 
conta apenas seus interesses particulares, tanto no adiantamento como no pagamento do que ainda haveria de saldar. ${ }^{121}$

Neste sentido, ou os filhos da folha se sujeitavam ao pagamento de propinas para o provedor, para terem seus ordenados ou adiantamentos, ou podiam ficar à mingua por vários anos. Isto foi denunciado pelo padre Inácio Pereira de Azevedo, coadjutor da paróquia da Paraíba e escrivão da provedoria da Casa de Misericórdia, que amargou três anos sem côngrua, $1722-25,{ }^{122}$ por ter destruído as intenções do filho homônimo e bastardo de Salvador Dourado, também padre, de permanecer na capelania da mesma Misericórdia. ${ }^{123}$ Segundo Inácio Azevedo, o esquema envolvia, além de Salvador “homem soberbo, descortês e absoluto-," seu tesoureiro da décima, Jácome dos Santos "homem muito ambicioso e interesseiro" - e o ajudante Francisco Quaresma Dourado "filho bastardo do provedor". Montados os nomes, a trama se desenvolvia no pagamento de uma pequena parte do que se teria de receber dos ordenados, ajustando-se a conta com o ajudante Francisco Dourado, "que fingia ser procurador [dos oficiais, eclesiásticos e soldados], assinando os recibos". ${ }^{124}$

\footnotetext{
${ }^{121}$ A revolta de Caio Prado Jr. sobre a administração das rendas na Colônia é bem ilustrativa: ... "As finanças não estão em melhor postura ... O manejo delas não é de melhor qualidade. Nunca se viveu, em todas as capitanias, cidades e vilas de cujas finanças temos notícias, senão em regime de déficit. E um déficit desorganizado, se podermos, sem pleonasmo acrescentar este qualificativo para caracterizar o sistema financeiro da colônia, onde a falta de rendimentos para cobrir as despesas se resolvia sumariamente com o calote, não se pagando nem com as boas intenções, os credores que não fossem protegidos das autoridades. Nem o soldo das tropas se satisfazia regularmente, e o espetáculo dos soldados mendigando pelas ruas era comum." Caio Prado Junior. Formação do Brasil Contemporâneo. $21^{\text {a }}$. ed. Brasiliense: São Paulo, 1989. p. 334

${ }^{122}$ Segundo Alden, para a efetivação do pagamento dos filhos da folha, o oficial ou eclesiástico entregava seu requerimento ao escritório do executivo (governador, vice-rei ou governador geral) e, a partir daí, incorria num elaborado e demorado procedimento, cujos passos principais eram: $1^{\circ}$ o vice-rei [no nosso caso, o governador] escrevia ao provedor confirmando a obrigação; $2^{\circ}$ o provedor solicitava ao escrivão para assegurar a reivindicação; $3^{\circ}$ o escrivão, então, fazia uma busca nos confusos registros dos livros; $4^{\circ}$ seguindo o recibo do escrivão ao autenticar a reivindicação, o provedor enviava a confirmação da obrigação ao vice-rei; $5^{\circ}$ esse então autorizava ao provedor o pagamento; $6^{\circ}$ o provedor emitia uma ordem de pagamento ao seu escrivão. Mas, como o escritório era aberto apenas duas tardes por semana, certamente passariam semanas, meses e até anos, entre a data da petição e o pagamento. Dauril Auden. Royal Government. With special reference to the administration of the Marquis of Lavradio, viceroy, 1769 -1779 ... Op. cit. p. 289.

${ }^{123}$ Dizia o governador Pedro de Gusmão, "achei os irmãos da Mesa da Misericórdia desta cidade com discórdia e desunião entre si o qual os reduziu o escrivão dela o padre Inácio Pereira de Azevedo ... [ que ] cego de sua ambição ou apossado da inimizade com o provedor da Fazenda de V. Majestade, quis ultrajálo com o poder do cargo de escrivão da Misericórdia intentando expulsar de capelão da dita Misericórdia ao padre Salvador Quaresma Dourado, filho do dito provedor da Fazenda de V. Majestade”. Cf: AHU_ACL_CU_014, Cx. 8, Doc. 650 .

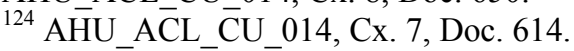


Certeza para uns, dúvida para outros, o certo é que a população da praça da Paraíba desconfiava que, com apenas o ordenado de provedor, em uma capitania sem recursos, dificilmente Salvador Dourado poderia garantir a subsistência da enorme família que possuía. O padre Inácio Pereira reverberou isto publicamente nas suas homilias $^{125}$, afetando a moral do provedor :

é o dito [Salvador Dourado] pobre, sem possuir bens algum ou propriedade de que se remedeie; e se vale da Fazenda Real de Sua Majestade com muita largueza, por vezes muito continuada com o pretexto de que o faz a conta dos seus ordenados com a confiança de que ninguém lhe toma as contas. Sendo estes que não chegam para sustentar uma grande familia de porta a dentro e de porta a fora. ${ }^{126}$

Estas denúncias não provinham apenas do mundo alheio às contas e somas da Fazenda. Por dentro do próprio órgão fazendário, os oficiais tinham suas queixas. $\mathrm{O}$ próprio tesoureiro da dízima, Jácome dos Santos, que executava o ofício de contador dos contos, dizia "não ter fé nas contas que fazia", pois tanto o provedor como seu escrivão, Bento Bandeira de Melo, mexiam nelas escrevendo nos recibos como bem entendiam. ${ }^{127}$ Da mesma forma, o almoxarife Caetano Francisco Gomes alegava que Salvador Dourado, além de guardar sobre "seu poder os livros e mais papéis pertencentes ao Almoxarifado", costumava "tirar dinheiro do cofre amontoando com o pretexto de serem por conta dos seus ordenados sem estes jamais serem ajustados". 128

\footnotetext{
${ }^{125}$ Segundo o governador Pedro de Gusmão, "foi tão público nesta cidade ... o escandaloso procedimento com que o padre Inácio P. de Azevedo se animou .. com o fim de se introduzir na Casa de Misericórdia como capelão pela via da expulsão que fez fazer ao padre Salvador Quaresma Dourado". Cf: AHU_ACL_CU_014, Cx. 8, Doc. 650

${ }^{126}$ IAHU ACL CU 014, Cx. 7, Doc. 614.

${ }^{127}$ AHU ACL CU 014, Cx. 8, Doc. 701.

${ }^{128}$ AHU_ACL_CU_014, Cx. 8, Doc. 710.
} 
Apesar dessas acusações, e considerando a posição que ocupava, Salvador Dourado morreu na pobreza em 1733. No seqüestro dos seus bens, feito provisoriamente, em virtude das suspeitas traçadas, se percebe o pequeno espólio do provedor. Como herança, deixava apenas três escravas para serem divididas com a viúva e duas filhas; o que não provocou ao que parece, nenhum sentimento de revolta e inveja nos seus filhos bastardos. ${ }^{129}$ Para vergonha de sua família, seu enterro teve que ser feito com a "ajuda dos religiosos e mais pessoas eclesiásticas, pelo sufrágio pelo amor de Deus". ${ }^{130}$ Isto não o livrou nem das observações do seu amigo, o governador Francisco Pedro de Mendonça Gurjão, para quem, apesar de reconhecer a honestidade do falecido, constava que

"no decurso de cinqüenta e um para cinqüenta e dois anos em que serviu esta ocupação houvesse peita de retroceder ao que era lícito ... tirando algum dinheiro a conta do seu ordenado". ${ }^{131}$

Com a morte de Salvador Dourado, sua família quis ainda manter a propriedade do ofício sob seu controle. Feliciano Dourado, sobrinho e genro do falecido, bem que tentou transferir o ofício para seu filho, Salvador Antônio, ainda com sete anos de idade, mas a Coroa preferiu intervir de maneira contundente. Como prescrevia a ordem real de 19 de janeiro de 1719, a qual determinava que "na ausência ou impedimento do provedor da Fazenda Real servisse o escrivão dela," a Coroa alçou Bento Bandeira de Melo ao cargo. ${ }^{132}$ Mas a gestão do novo provedor teve vôo curto: não ultrapassando o ano de 1734, ele foi logo substituído pelo Ouvidor Geral Jorge Salter de Mendonça.

\footnotetext{
${ }^{129}$ Como vimos, ao menos dois destes filhos transparecem nos documentos, fazendo justiça à informação de que Salvador Dourado havia deixado uma grande família, o homônimo, capelão da Misericórdia e o ajudante Francisco Dourado.

${ }^{130}$ AHU_ACL_CU_014, Cx. 8, Doc. 696.

${ }^{131}$ AHU_ACL_CU_014, Cx. 8, Doc. 692.

132 Bento Bandeira tomou posse no cargo, mesmo que a contragosto do governador "pois [este] não reconhecia [nele] todos os requisitos", Cf: AHU_ACL_CU_014, Cx. 8, Doc. 692.
} 
Mesmo que não se tenha conhecimento do conteúdo da ordem efetivando Salter de Mendonça no cargo, e que poderia conter os objetivos para o seu mandato, o certo é que sua gestão durou sete anos e se orientou, basicamente, no sentido da busca de esvaziamento das influências locais sobre o órgão. Durante o primeiro ano que esteve à frente do cargo, todas as suas ações foram louvadas pela Coroa. Primeiramente, conseguiu “reduzir os livros à forma que deviam ter," acabando com os emolumentos e propinas escorchantes praticadas pelos oficiais da Fazenda. ${ }^{133}$ Em segundo lugar, logrou "fazer um cofre com três chaves para guardar o dinheiro proveniente da dízima da Alfândega, " que corria por Pernambuco. ${ }^{134}$ Por fim, promoveu a renovação de boa parte do quadro dos oficiais do órgão - como fez com o almoxarife, o tesoureiro da dízima, o oficial dos contos e o escrivão da Fazenda Bento Bandeira de Melo; este último foi afastado, temporariamente, pelo que subtraíra do dinheiro da Fazenda, quando assumiu a cabeça da provedoria. ${ }^{135}$

Portanto, havia um entendimento da Coroa sobre a necessidade de adoção de uma postura mais desfavorável, ou mesmo contrária, ao abrasileiramento da administração isto é, o entrelaçamento dos oficiais de comando com a sociedade local. ${ }^{136}$ Apesar de não simbolizar uma quebra total com o empirismo administrativo que caracterizou toda a fase anterior a Pombal, ${ }^{137}$ tal entendimento sepultou um período de comando sobre a cabeça da Provedoria da Fazenda Real da Paraíba, que havia se iniciado desde a partilha da Guerra Brasílica. Apesar de ter privilegiado doravante o ingresso trienal de provedores já experimentados nas lides dos contos, essa iniciativa não resultou no sucesso econômico da capitania. Os problemas perduraram e a Fazenda paraibana, analogamente à pobreza

\footnotetext{
${ }^{133}$ Salter, em verdade, não requereu regimentos para os oficiais da Fazenda, porém, exigiu que todos os escrivões se guiassem pelas pautas que haviam na Ouvidoria e, na falta de determinados assuntos que fossem específicos da Fazenda ou Alfândega, levassem em conta apenas o que rezavam os regimentos de Pernambuco. Cf: AHU_ACL_CU_014, Cx. 9, Doc. 747.

${ }^{134}$ AHU ACL CU 01 $\overline{4}$, Cx. $\overline{9}$, Doc. 742.

${ }^{135}$ Durante o período de apenas um ano que esteve à frente da provedoria, 1733, Bento Bandeira de Melo "gastou mais de cinco mil cruzados em fardas ... não sobrando do contrato dos dízimos um vintém para pagamento dos filhos da folha", já que pagava aos soldados sem saber "se lhe devia a Fazenda ou eles" AHU_ACL_CU_014, Cx. 9, Doc. 747. Da mesma forma, foi acusado de antecipar, em vários anos, seus ordenados: duzentos e três mil e novecentos e vinte e dois réis como escrivão, e quatrocentos e quarenta e nove mil réis do seu ordenado como provedor. Cf: Ordens Régias IHGP / Códice 1733 - 1744. Doc.

${ }^{136}$ Stuart B. Schwartz. Burocracia e sociedade ... p. 251-295.

${ }^{137}$ Lourival Gomes Machado. Política e administração sob os últimos vice-reis. In: Sérgio Buarque de Holanda. História Geral da Civilização Brasileira. 7a. ed. São Paulo: Bertrand Brasil. 1993. Tomo I; Vol II. p. 360 .
} 
do último proprietário da provedoria, prorrogou sua agonia, caminhando inexoravelmente rumo à falência. 
Capítulo III

\section{AS AGRURAS ECONÔMICAS DA CAPITANIA DA PARAÍbA E OS PRÓDROMOS DA ANEXAÇÃO}

As fases pelas quais passou a Provedoria da Fazenda Real da Paraíba, até a sua falência e a sua anexação ao governo de Pernambuco, em 1755, gravaram na sua história um processo imbricado de centralização aos ditames da metrópole. Por um lado, como vimos no capítulo anterior, este processo se esboçou na implosão da ingerência de poderes locais fincados internamente na própria Fazenda. Por outro lado, como será visto agora, o caminho da centralização pode ser compreendido na busca da ampliação e reunião dos vários pontos de receitas - que se encontravam distribuídos nas esferas formais de poder da capitania, como na Câmara ou Ouvidoria - em torno da Fazenda Real paraibana.

Ao se referir à receita, inevitavelmente tem-se que pensar na despesa e, neste sentido, o custeio da administração também será visto aqui.

Todavia, não se tratará da despesa com toda a administração, uma vez que a Fazenda paraibana era responsável por um leque muito amplo de obrigações, que envolviam desde as despesas miúdas, incluindo a manutenção ordinária da administração e gastos com papel, tinta, e outros, até o pagamento dos empreiteiros ligados às obras da Fortaleza do Cabedelo. Pelo fato dessas despesas serem notadamente incertas, em função do caráter inconstante com que podiam ser contratadas, dar-se-á uma maior atenção aos ordenados das folhas de serviço militar, eclesiástica e executiva. Tal escolha se deve ao foco permanente que as folhas de pagamento podem dar à despesa. A partir desse foco pode-se objetivar uma discussão a propósito do peso que as folhas de pagamento representavam para a receita da Fazenda paraibana, embora a objetividade e a regularidade não sejam isentas de dificuldades na sua leitura e composição.

A dificuldade em vislumbrar o aspecto quantitativo dos gastos com as folhas de serviço na capitania da Paraíba se dá não apenas pela falta que havia na regularidade do envio das contas anuais de receitas e despesas da capitania para o Reino. Mesmo quando os registros apareciam pormenorizadamente, os dados deixavam dúvidas sobre o valor 
real dos ordenados - principalmente dos soldos e fardas da infantaria e da côngrua dos clérigos, pois dificilmente se repetiam. Mesmo com espaçamento de um ano a outro, essa inconstância nos valores impede qualquer possibilidade de estabelecimento de uma média que representasse os percentuais, ao menos dos gastos fixos, com as folhas executiva, militar e clerical. A solução encontrada para desfazer esse nó foi perfazer o caminho mais longo e estabelecer pari passu a evolução dos ofícios, cuja execução de pagamento estivesse sob a obrigação da Fazenda Real.

Neste sentido, com o estabelecimento da linha evolutiva e cumulativa dos cargos em cada folha, duas coisas passaram a ter explicação. Primeiro, que a falta de precisão nos ordenados arrolados pelas folhas, para mais ou para menos, era causada pelo número de meses a que corresponderia aquele pagamento, ou seja, apesar da conta fazer referência e representar seu valor anual, ele estava pautado na distribuição mensal. Assim, muitas vezes, sem nenhum aviso prévio, o pagamento do oficial que corresponderia a vinte meses, trazia no termo de abertura o anúncio do interregno da despesa geral do ano; precisamente, do primeiro dia do mês de agosto ... até o último dia do mês de julho. Isso correspondia ao início e fim das arrematações dos dízimos - pela tradição, o principal contrato dos direitos reais -, data a que estavam obrigados os arrematadores a prestarem suas contas. Segundo, como desdobramento desse registro, explicava-se também o porquê de se encontrar, após alguns anos de déficit, a simetria entre receita e despesa, já que se buscava pagar no limite as contas em atraso.

Portanto, este capítulo terá dois objetivos principais: investigar o processo de centralização, na Fazenda Real da Paraíba, dos vários impostos que existiam na capitania, e b) analisar, a partir da apresentação da criação e evolução do desempenho arrecadador de cada fonte tributária, a contra-face da atividade econômica que a sustentava. Nesses moldes, o estudo da receita tende a proporcionar sugestões para pesquisas futuras acerca da história da economia colonial paraibana. Por outro lado, quanto à despesa, o enfoque será o de demonstrar, através da análise dos quadros das despesas com as folhas de serviço, o peso que isso acarretava para os cofres da Fazenda da capitania.

Dada a quantidade razoável de quadros, tabelas e gráficos, optou-se pela divisão do capítulo em duas partes: receita e despesa. Por fim, vale ressaltar que, por se tratar de um estudo sobre a Provedoria da Fazenda Real da Paraíba, resguardou-se para a 
composição dos ofícios desse órgão uma descrição completa dos pros e percalços que acompanhavam os seus rendimentos.

\section{RECEITAS DA PROVEDORIA DA FAZENDA REAL DA CAPITANIA DA PARAÍBA}

As receitas da Fazenda Real paraibana estavam atreladas a uma série de impostos que tributavam: a) toda a produção, como os dízimos; b) o consumo interno, como o subsidio da carne; ${ }^{1}$ c) a exportação, como o subsídio do açúcar (que cobrava $\$ 60$ réis por arroba do açúcar branco e $\$ 30$ réis do mascavado), o cruzado das caixas (\$400 réis por cada caixa) e os dois tostões ( $\$ 200$ por feixe) $)^{2}$, além dos $\$ 80$ réis por caixa e $\$ 40$ réis por feixe, sobre o açúcar exportado exclusivamente para o Reino; d) a importação, como a dízima e os três mil e quinhentos réis mais os dez (ou doze) tostões por cabeça dos escravos provenientes da Costa da Mina, São Tomé e Príncipe ${ }^{3}$; e) o imposto pelo exercício de atividades administrativas, os novos direitos, importando a um terço do que excedesse a quantia de $200 \$ 000$ réis por ano.

Todos esses impostos tinham uma consignação certa. O dízimo, entendido como a principal fonte de arrecadação, servia para o pagamento da folha eclesiástica e executiva, devendo o seu sobejo servir, também, para as despesas miúdas da Fazenda e para o complemento da folha militar. As taxas sobre a exportação do açúcar, bem como o imposto da dízima, se prestavam às obras da Fortaleza do Cabedelo, à folha militar, e ainda ajudavam no pagamento do governador. Os novos direitos destinavam-se ao pagamento do ouvidor, enquanto que os impostos sobre a importação dos escravos deviam: a) os dez tostões, ser remetidos para o Reino e, de lá, para a construção da feitoria da Ajuda em Príncipe; e b) os $3 \$ 500$ réis, servir para o pagamento das côngruas da Sé de São Tomé. Por fim, o subsídio da carne, subordinado à Fazenda Real a partir de

\footnotetext{
${ }^{1}$ Subsídio aqui entendido como uma quantia que deveria ser recolhida em algumas atividades produtivas ou de comércio - como foi com o açúcar exportado ou com a carne - que a Câmara Municipal ou a Fazenda Real arbitravam para obras de interesse público.

${ }^{2}$ Esse tributo também era cobrado em outras capitanias como na Bahia no valor de $\$ 380$ réis por caixa e que servia, como na Paraíba, para o sustento da Infantaria. Cf: Stuart B. Schwartz. Segredos internos: engenhos e escravos na sociedade colonial. São Paulo: Cia das Letras, 1988. p. 165.

${ }^{3}$ Mais um imposto corria sobre o transporte dos escravos, só que este voltado para o tráfico interno, o imposto de $4 \$ 500$ por cabeça de escravo transportado de Pernambuco, Paraíba e anexas para as Minas, instituído por volta do ano de 1715. Cf: AHU_ACL_CU_014, Cx. 6, Docs. 431; 438; 484.
} 
1732, devia servir para as despesas da Câmara mais algumas outras aplicações na Capitania, acaso houvesse sobejos.

O processo de arrematação desses impostos podia ser feito no Conselho Ultramarino ou nas capitanias. Ambos respeitavam datas e rituais de arrematação que a tradição costumava resguardar, divulgando-os da melhor forma possível. ${ }^{4}$ A divulgação podia ser feita por via impressa, através de editais pregados nos lugares públicos, ou por proclamação, com o meirinho saindo às ruas munido de um tambor, anunciando em pregão a abertura dos trabalhos. Passado um mês na capitania de origem, este mesmo processo corria para a Provedoria-mor, na Bahia, onde se executavam os mesmos procedimentos. Recolhidos os lanços daquela praça, o arremate retornava para a mesma capitania, tornando a se por em praça por mais um mês. ${ }^{5}$ Todavia, caso o contrato fosse realizado no Conselho Ultramarino, o processo se resolvia no próprio Reino.

Quando os processos corriam nas capitanias, geralmente no primeiro arremate os arrematadores locais mantinham o lanço bem abaixo do real - resguardando para si o último lanço com folga e evitando a concorrência de interesses estrangeiros. Mas as informações sobre os processos, datas e locais em que corriam e sobre a economia das capitanias, era algo corrente à disposição dos interessados, fazendo pesar nos seus arremates um universo de conhecimento bem maior do que se possa imaginar. ${ }^{6}$ Por isso, não é de estranhar que Rafael Nunes Paz apareça como pretendente a arrematador dos dízimos na Paraíba, em 1727, quando um ano antes e em conjunto com Manuel Rodrigues Costa, contratou os dízimos em Pernambuco por cinqüenta mil cruzados ${ }^{7}$. Da mesma forma, vermos um Manuel Correia Bandeira aperreado, em 1725, “com a notícia de um decreto que havia sua majestade baixado ao Conselho de sua Real Fazenda, para que não pudesse arrematar um contrato a quem já tivesse outro”. Dessa feita, o

\footnotetext{
${ }^{4}$ As datas em que corriam as arrematações dos contratos reais tinham um calendário praticamente fixo. Os contratos dos dízimos e subsídios dos açúcares, por exemplo, começavam no último dia do mês de julho e terminavam no primeiro de agosto. O contrato do subsídio das carnes tinha por início e término as comemorações do dia da Páscoa. Enquanto o contrato da dízima, tinha seu início marcado para o mês de janeiro. Cf: AHU_ACL_CU_014, Cx. 16, Doc. 1303.

${ }^{5}$ AHU ACL CU $014, \bar{C} x .6$, Doc. 458.

${ }^{6}$ Sobre o contratador, diz Schwartz que "ele tinha uma idéia aproximada da produtividade da região, mas não podia prever secas, inundações ou guerras. Ele tinha provavelmente uma capacidade muito melhor de estimar o preço dos bens produzidos. Sabia que se a produção dobrasse mas o preço caísse pela metade o valor do contrato não seria maior do que fora antes das alterações". Stuart B. Schwartz. Segredos internos: engenhos e escravos na sociedade colonial... Op.cit. p. 154.

${ }^{7}$ AHU ACL CU 014, Cx. 7, Doc. 541.
} 
arrematador temia perder o contrato do direito real de cobrar os $3 \$ 500$ réis sobre "os escravos que se resgatam em toda a Costa da Mina, Cacheu, São Tomé e mais partes para a Paraíba, Pernambuco e anexas", pois já acumulava com este o “direito aplicado para a Guarda-Costa do Rio de Janeiro", 8

Quanto à arrecadação desses direitos e ao pagamento dos valores acertados, podiam ser feitos de duas formas: uma, por iniciativa de particulares - que arrematavam em hasta pública por um valor fixo, pelo prazo de um ou de três anos e que poderia ser repassado à Fazenda em açúcar, fazendas ou dinheiro; e outra, através da própria Fazenda Real. Esta segunda opção só prevalecia quando, na avaliação dos interessados, a atividade não se mostrava rentável. Nesses casos, quando a cobrança passava para as mãos dos oficiais da Fazenda, dizia-se que o "contrato estava sob administração". 9

Todavia, quando acontecia do imposto ser arrematado em contrato, o que era mais comum, o contratador entregava carta fiança de 10\%, assinada por terceiros, assegurando o compromisso de saldar não só o valor do arremate, como também o pagamento de todas as propinas aos oficiais que se beneficiavam com o processo. Em contrapartida, o contratador recebia um alvará para, durante o tempo de vigência do contrato, poder nomear pessoas em seu nome ou do seu procurador para fazerem o trabalho da cobrança. ${ }^{10}$

O curioso em todo este processo é que, para além do efetivamente saldado pelo contratador, nada se sabia sobre o lucro real obtido por ele durante a arrecadação dos impostos. Esta relação era mais tranqüila para a Coroa, como contratante, por já ter antecipado, em tese, o valor que lhe entraria nos cofres, por bem do contratador ou pelo

\footnotetext{
${ }^{8}$ Neste caso, o temor da Coroa era que o acúmulo de contratos levasse o contratador à ruína e, consigo, os seus fiadores. Manuel Bandeira, contudo, além de ser homem afortunado, tinha um bom leque de fiadores. Tinha o mesmo uma "propriedade de casas em que vive e aluga na freguesia de São Miguel em Alfama," apresentava, como seus fiadores, Domingos de Miranda, "Provedor dos Contos da Sereníssima Casa de Bragança e superior deles e da Casa do Infantado, possui várias fazendas, em que entra sua quinta no termo de Sintra, e duas no termo desta cidade, uma no Carnanixe e outra no Lumiar”; Mais outro, João Antunes, "é ourives rico e tem uma morada de casas em Castel Picão, e outra no Alegrete, na freguesia de São Miguel, e uma outra morada de casas na rua da Madragoa e, por fim a "Antônio Bernardes, ourives rico e reputado na rua”.Cf: AHU_ACL_CU_014, Cx. 6, Doc. 431.

${ }^{9}$ Caio Prado Junior. Formação do Brasil Contemporâneo. 21a. edição; São Paulo: Brasiliense, 1989. p. 321.

${ }^{10}$ Em 1735, por exemplo, Francisco de Leite de Morais, arrematador do contrato da dízima de Pernambuco e Paraíba, solicitava ao rei que os provedores das ditas capitanias agissem conforme o alvará e o admitissem, não colocando entraves aos trabalhos dos seus procuradores e feitores nas Alfândegas (Cf: AHU_ACL_CU_014, Cx. 9, Doc. 788).
} 
incômodo do fiador. ${ }^{11}$ Mas os riscos embutidos na transação, tornando o contratador sujeito a mudanças repentinas na economia - calamidades naturais, guerras, desvalorizações de moedas, queda nos preços dos produtos, e outras - podiam ser compensados pela expectativa de lucro fabuloso, caso o período do contrato fosse vencido sem intempéries. ${ }^{12}$

Assim, se os dados relativos aos contratos reais que corriam na capitania da Paraíba foram escassos na segunda metade do XVII, eles se mostraram mais generosos com relação ao século seguinte. Isto se deveu a uma guinada protagonizada pela Coroa, em 1724, determinando que se enviasse, pela provedoria da Paraíba e Câmara, "uma relação do preço por que se tem arrendado de alguns anos e as condições com que se arremataram," para passar a fazer as arrematações no Conselho Ultramarino. ${ }^{13}$ Dos documentos que responderam a essa ordem e de alguns dados já publicados por Elza Regis de Oliveira ${ }^{14}$, singularizando os rendimentos dos direitos reais para o século XVIII, partimos para avaliar as receitas da capitania da Paraíba.

\section{OS DÍZIMOS}

Segundo Schwartz, "o dízimo era o imposto de um décimo de toda a produção pago à Igreja, mas no Brasil era arrecadado pelo monarca em sua condição de grão-

\footnotetext{
${ }^{11}$ Independentemente do lugar onde o contratador desse suas fianças a ordem era a mesma, executar o fiador caso os prazos do contrato não fossem observados. Cf: AHU_ACL_CU_014, Cx. 13, Doc. 1064.

${ }^{12}$ Osório, num artigo sobre a presença de comerciantes de grosso trato cariocas no processo de arrematação dos contratos reais no Rio Grande do Sul, no último quartel do dezoito, propõe algumas possibilidades de leitura sobre os lucros obtidos pelos contratadores. Uma delas estaria na diferença dos valores obtidos pela Fazenda Real, quando transferia os processos de arrematação das capitanias para Lisboa. Nos casos por ela avaliados, para os anos de 1780-90, os aumentos chegavam, muitas vezes, a ultrapassar a casa dos $60 \%$, demonstrando que os itens estavam, em verdade, subavaliados e embutindo um lucro fantástico para o contratador. Cf: Helem Osório."As elites econômicas e a arrematação dos contratos reais: o exemplo do Rio Grande do Sul (século XVIII).” In: João Fragoso; Fernanda Bicalho e Maria de Fátima Govêa (org). $O$ antigo regime nos trópicos: a dinâmica imperial portuguesa ( séculos XVI - XVII). Rio de Janeiro: Civilização Brasileira, 2001. p. 107-137.

${ }^{13} \mathrm{Na}$ oportunidade, o governador João de Abreu Castel Branco ordenava ao Provedor, Salvador Dourado, a confecção de uma relação dos últimos vinte anos. Cf: AHU_ACL_CU_014, Cx. 6, Doc. 458; Sobre a Câmara ver: AHU ACL CU 014, Cx. 6, Doc. 455.

${ }^{14}$ Elza Regis de Oliveira. A Paraíba na crise do século XVIII. Subordinação e autonomia (1755-1799). Fortaleza: BNB, 1985.
} 
mestre da Ordem de Cristo "15. Mesmo incidindo sobre todos os bens produzidos nas capitanias, o dízimo, como qualquer outro tipo de imposto que pesava sobre bens específicos ou serviços, deve ser tomado apenas como uma estimativa das atividades, principalmente produtivas, e não como um valor exato da totalidade dos bens produzidos. $^{16}$ Isto porque, tendo em vista as circunstâncias do processo de arrematação/cobrança dos direitos reais na Colônia brasileira, a arrecadação, quando arrematada, foi sempre uma parcela declarada pelo contratador e não o montante da arrecadação em si. Porém, como esclarece Stuart Schwartz:

"embora não seja o dízimo uma medida substituta da produção, é um valor provável desta última, baseado na melhor estimativa de um observador interessado [o contratador dos direitos reais] e, como tal, é um indice razoavelmente bom da situação econômica". ${ }^{17}$

Desta forma, mesmo considerando que o dízimo na Paraíba pesava sobre todos os produtos de consumo interno e para exportação, além de serviços - onde até os empreiteiros da Fortaleza do Cabedelo eram tributados ${ }^{18}$-, iremos pautar a discussão sobre a evolução do rendimento desse direito real a partir de dois produtos específicos: o açúcar e a carne. A carne contribuiu com uma parcela da produção e do consumo interno nada desprezível. Basta lembrar que, nos portos da Paraíba, o couro e o algodão se mantiveram sem expressão até os fins do terceiro quartel do século XVIII, quando as

\footnotetext{
${ }^{15}$ Stuart B. Schwartz. Segredos internos. engenhos e escravos na sociedade colonial... Op.cit. p. 154

${ }^{16}$ Idem, Ibidem; Arno Wehling observa que em muitas capitanias, o dízimo poderia vir arrematado em ramos (lotes colocados em leilão), ou seja, por segmento de produção, dado o valor elevado do conjunto da arrematação. Cf: Arno Wehling. História administrativa do Brasil. Administração portuguesa no Brasil de Pombal a D. João (1777 - 1808). Brasília; FUNCEP, 1986. p. 130. Todavia é interessante ponderar, contudo, que as propriedades eclesiásticas, desde que proviessem da sua fundação no local e não por herança ou compra, estaria reservado o direito à isenção do dízimo. Cf: AHU_ACL_CU_015, Cx. 35, Doc. 3210 (Avulsos, Capitania de Pernambuco).

${ }_{17}^{17}$ Stuart B. Schwartz. Segredos internos: engenhos e escravos na sociedade colonial... Op.cit. p. 154.

${ }^{18}$ Em uma carta ao governador da Paraíba, no ano de 1713, ordenava o rei fazer presente ao Provedor da capitania que os empreiteiros da fortaleza não estavam livres da cobrança do dízimo. Cf: AHU_ACL_CU_014, Cx. 5, Doc. 339. Segundo Wehling, “deveriam pagá-los todos os lavradores, criadores e pescadores, os sesmeiros, os membros das ordens militares, os funcionários civis, os índios e os religiosos". Cf: Arno Wehling. História administrativa do Brasil: Administração portuguesa no Brasil de Pombal a D. João (1777 - 1808).... Op.cit. p. 130
} 
fábricas inglesas exigiram correias para a tração das máquinas e o têxtil nativo inundou o mundo de branco. Nessa circunstância, foi a produção da carne que alimentou, de forma significativa, a vida da economia local, segurando as cotações dos dízimos durante o tempo de dificuldades por que passou a produção do açúcar. ${ }^{19}$

Contudo, o açúcar representa o produto mais importante da Paraíba, além de envolver na sua economia a principal força política e social de poder da capitania, que são os senhores de engenho e os lavradores de cana. Por isso, o açúcar pode ser o escolhido para principiar as discussões sobre as cotações da arrematação do dízimo.

\section{QUADRO 1}

Capitania da Paraíba / Receita: Dízimos

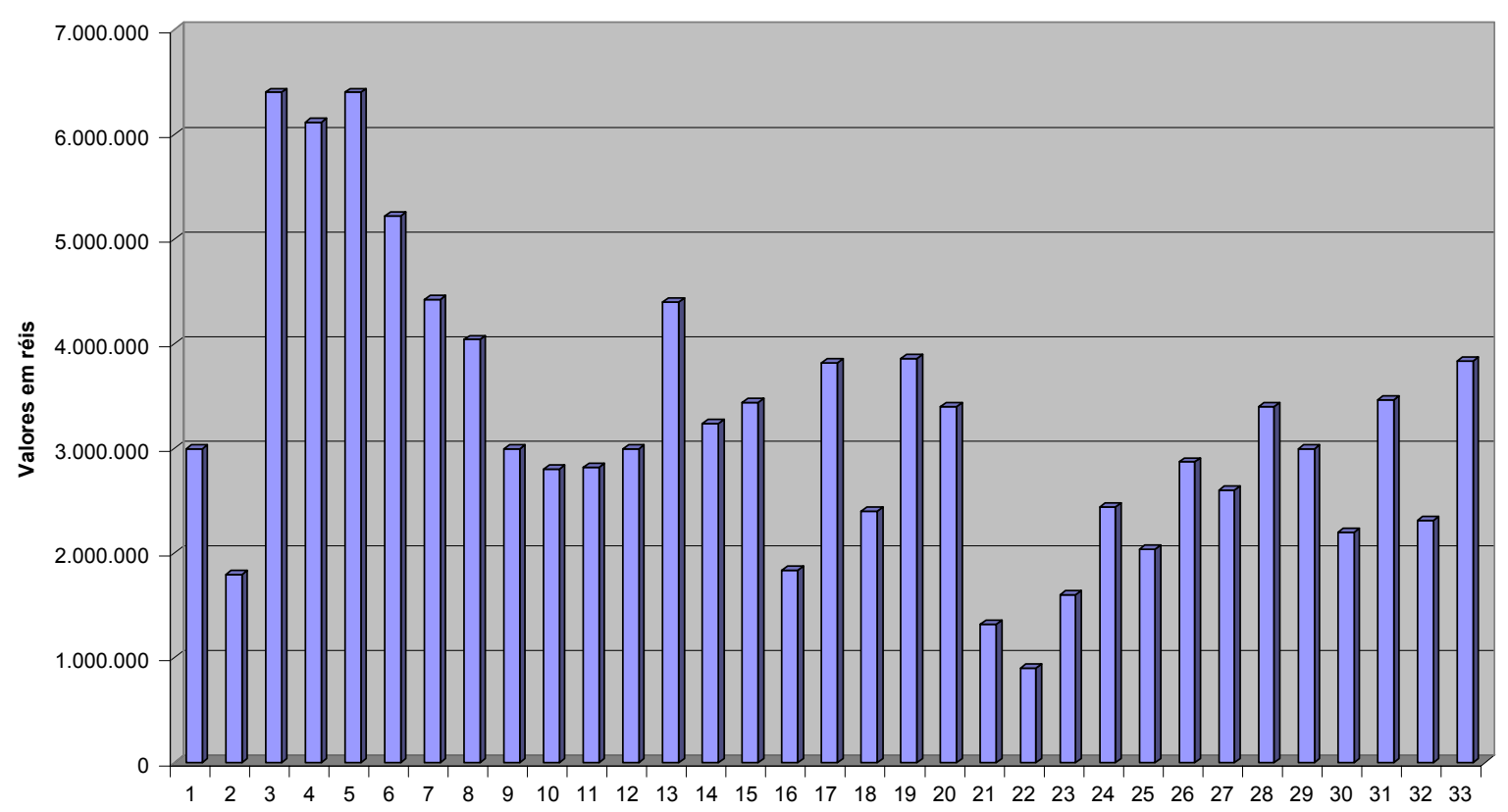

\footnotetext{
${ }^{19}$ A pouca importância do couro em sola embarcado pelo porto da Paraíba, nos anos anteriores à segunda metade do século XVIII, pode ser constatada através de um documento datado de primeiro de abril de 1710, o qual detalha o embarque da produção local em seis navios. Desses, apenas dois levaram carga de couro que não ultrapassara a 550 meios de sola. AHU_ACL_CU_014, Cx. 4, Doc. 302 . O contraste desse volume de exportado pela Paraíba pode ser atestado pela estimativa de Antonil, que calculava em torno de 90 mil meios de solas o couro exportado por Pernambuco, em 1711, provindo de todo o sertão. Cf: André João Antonil. Cultura e opulência do Brasil, por suas drogas e minas, etc. Lismoa, 1711, p. 187-8. Apud, Pedro Puntoni. A guerra dos bárbaros. Povos indígenas e a colonização do sertão do Brasil, 1620-1720. São Paulo: Hucitec: Edusp: Fapesp, 2002. p. 22
} 


\begin{tabular}{|c|c|c|c|c|c|c|c|c|c|}
\hline $\begin{array}{c}(1) \\
1670-1671\end{array}$ & $\begin{array}{c}(2) \\
1687-1688\end{array}$ & $\begin{array}{c}(3) \\
1705-1706\end{array}$ & $\underset{1706-1707}{\left(\begin{array}{c}4\end{array}\right)}$ & $\underset{1707-1708}{\left(\begin{array}{c}5 \\
)\end{array}\right)}$ & $\left(\begin{array}{c}\mathbf{6} \\
1708-1709\end{array}\right)$ & $\left(\begin{array}{c}7 \\
1709-1710\end{array}\right)$ & $\underset{1710-1711}{\left(\begin{array}{c}8 \\
)\end{array}\right)}$ & 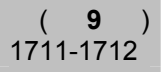 & $\underset{1712-1713}{\left(\begin{array}{c}10 \\
)\end{array}\right)}$ \\
\hline 3: $000 \$ 000$ & 1: $800 \$ 000$ & $6: 400 \$ 000$ & $6: 112 \$ 000$ & $6: 400 \$ 000$ & 5: $220 \$ 000$ & 4: $424 \$ 000$ & 4: $040 \$ 000$ & 3: $000 \$ 000$ & 2: $800 \$ 000$ \\
\hline
\end{tabular}

\begin{tabular}{|c|c|c|c|c|c|c|c|c|c|}
\hline $\begin{array}{c}(11) \\
1713-1714\end{array}$ & $\underset{1714-1715}{(\mathbf{1 2}})$ & $\underset{1715-1716}{(13})$ & $\underset{1716-1717}{(14})$ & $\underset{1717-1718}{(15})$ & $\underset{1718-1719}{(16})$ & $\underset{1719-1720}{(17})$ & $\underset{1720-1721}{(} 18)$ & $\underset{1721-1722}{(19})$ & $\underset{1722-1723}{(\mathbf{2 0}})$ \\
\hline 2: $820 \$ 000$ & 3: $000 \$ 000$ & 4: $400 \$ 000$ & 3: $236 \$ 000$ & 3: $440 \$ 000$ & 1: $840 \$ 000$ & 3: $820 \$ 000$ & 2: $400 \$ 000$ & 3: $860 \$ 000$ & 3: $400 \$ 000$ \\
\hline
\end{tabular}

\begin{tabular}{|c|c|c|c|c|c|c|c|c|c|}
\hline 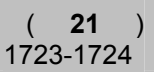 & $\underset{1724-1725}{(22})$ & $\underset{1725-1726}{(\mathbf{2 3}})$ & $\underset{1726-1727}{(24})$ & $\begin{array}{c}\left(\begin{array}{r}25 \\
1727-1728\end{array}\right)\end{array}$ & $\left.\begin{array}{c}(\mathbf{2 6} \\
1728-1729\end{array}\right)$ & $\underset{1731-1732}{(\mathbf{2 7}})$ & $\underset{1732-1733}{(\mathbf{2 8}})$ & $\underset{1733-1734}{(29})$ & $\underset{1741-1742}{(30})$ \\
\hline $1: 320 \$ 000$ & $900 \$ 000$ & 1: $600 \$ 000$ & 2: $440 \$ 000$ & 2: $040: 000$ & 2: $872 \$ 000$ & 2: $600 \$ 000$ & 3: $400 \$ 000$ & 3: $000 \$ 000$ & $2:: 200 \$ 000$ \\
\hline
\end{tabular}

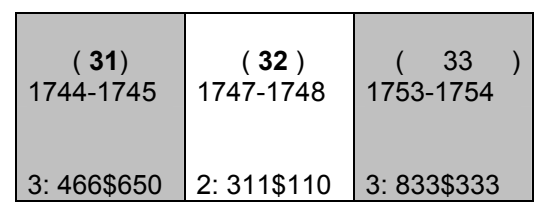

\section{Fonte: Arquivo Histórico Ultramarino}

$\mathrm{Na}$ evolução geral do desempenho da arrecadação do dízimo ${ }^{20}$, em comparação com outras capitanias do Norte, vemos que a situação da Capitania da Paraíba não era das melhores. ${ }^{21}$ Apesar de não possuirmos a mesma quantidade de dados para as outras capitanias, sujeitando essa comparação pontualmente para alguns anos, vemos que: primeiro, mesmo em anos de seca e baixa produção do açúcar (como 1725, 1729, 1732), o resultado em Pernambuco alcançou um rendimento de cerca de oitenta por cento a mais do observado na Paraíba ${ }^{22}$; segundo, mesmo quando confrontado com a capitania subordinada do Ceará, o rendimento para o ano de 1730, alcançou quase cinco contos de

\footnotetext{
${ }^{20}$ Dispomos apenas de duas datas no século XVII (1670 e 1687) e nos faltam alguns anos do início do dezoito e entre as décadas de 30 e 40 . Os valores apresentados, em praticamente todas as datas, estão pautados nos lançamentos dos almoxarifes, ou seja, no efetivamente saldado e não na arrematação do contrato.

${ }^{21}$ Nos fins do século XVIII e início do XIX, mesmo quando a Paraíba conseguiu se mostrar mais eficiente na tábua de exportação entre as capitanias, com a presença de importantes produtos de exportação, com o algodão, o couro e o açúcar, rivalizou com Santos nas últimas colocações. Cf: José Jobson de Arruda. $O$ Brasil no comércio colonial. São Paulo: Ática, 1980. p. 271 a 275.

${ }^{22}$ Nos três anos, em Pernambuco, o resultado é o seguinte: 1725= 20:000\$000 (AHU_ACL_CU_014, Cx. 7, Doc. 541); 1729= 20:000\$000 (AHU_ACL_CU_015, Cx. 39, Doc. 3510. Avulsos da Capitania de Pernambuco); e, para 1732=20:500\$000 (AHU_ACL_CU_015, Cx. 43, Doc. 3874. Avulsos da Capitania de Pernambuco)
} 
réis, valor muito difícil de se alcançar na Paraíba ${ }^{23}$; terceiro: observamos, nos anos de 1719, 1721 e 1725, que o dízimo em Itamaracá e Goiana se manteve no mesmo patamar que a Paraíba ${ }^{24}$; e, quarto: só na comparação com o Rio Grande a Paraíba leva realmente alguma vantagem. ${ }^{25}$

Mas, apesar dessas comparações, os altos e baixos da arrecadação do dízimo na Paraíba podem ser acompanhados tendo em vista a situação da economia açucareira, tanto ao nível interno, privilegiando a arrecadação do subsídio do açúcar, como ao nível do seu desempenho no cenário brasileiro e internacional. Neste sentido, os bons índices alcançados no início do século XVIII, entre os anos de 1705 e 1709, coincidem com o alívio que os anos da guerra da Sucessão Espanhola, 1701-1714, trouxeram para o setor açucareiro do Brasil (Quadro 1). Porém, a partir de 1710 o refluxo tomou a cena, empurrando os valores para baixo, bem aquém dos propiciados até então. A partir daí os índices se mantiveram próximos aos observados no século XVII, especialmente nos anos de 1670 e 1688. Nesses períodos, o efeito do impacto da produção antilhana - que ocupou espaços no comércio europeu e penetrou nas bases de fornecimento de cativos africanos - proporcionou uma forte depressão nas áreas de grande lavoura açucareira da Colônia brasileira. ${ }^{26}$

\footnotetext{
${ }^{23}$ Esse rendimento da Capitania do Ceará foi apresentado pelo governador de Pernambuco Duarte Sodré Pereira, em 1730, como forma de demonstrar a necessidade de anexar a capitania da Paraíba ao governo de Pernambuco. Cf: AHU_ACL_CU_015, Cx. 41, Doc. 3670 (Pernambuco).

${ }^{24}$ Os valores para Itamaracá foram: $1719=2: 040 \$ 000$ (AHU_ACL_CU_015, Cx. 28, Doc. 2557 Pernambuco) e 1721=2:351\$120 (AHU_ACL_CU_015, Cx. 32, Doc. 2882 Pernambuco).

${ }^{25}$ Para uma comparação com o Rio Grande, temos de arrecadação dos dízimos: $(1670-71)=100 \$ 000$; $(1687-88)=265 \$ 000 ; \quad(1705-06)=1: 415 \$ 000 ; \quad(1707-08)=1: 950 \$ 000 ; \quad(1708-09)=1: 840 \$ 000 ; \quad(1709-$ $10)=2: 016 \$ 000 ;(1711-12)=1: 024 \$ 000 ;(1712-13)=1: 024 \$ 000 ;(1713-14)=1: 112 \$ 000 ;(1714-15)=828 \$ 000$; $(1716-17)=1: 200 \$ 000 ; \quad(1717-18)=1: 520 \$ 000 ; \quad(1718-19)=856 \$ 000 ; \quad(1719-20)=856 \$ 000 ; \quad(1720-$ $21)=856 \$ 000 ; \quad(1721-22)=984 \$ 00 ; \quad(1722-23)=1: 200 \$ 000 ; \quad(1723-24)=450 \$ 000 ; \quad(1724-25)=1: 047 \$ 000 ;$ $(1725-26)=1: 181 \$ 000 ; \quad(1726-27)=1: 329 \$ 000 ; \quad(1727-28)=1: 329 \$ 000 ; \quad(1728-29)=1: 329 \$ 000 ; \quad(1729-$ $30)=1: 471 \$ 000 ;(1730-31)=1: 919 \$ 000 ;(1731-32)=2: 435 \$ 000$. Cf: AHU_ACL_CU_018, Cx. 2, Doc. 156 (Rio Grande).

26 "Com suas próprias colônias produtoras de açúcar estabelecidas nas Antilhas, os principais consumidores europeus, França e Inglaterra, começaram a excluir o açúcar e outros produtos brasileiros dos seus portos. A política instituída por Colbert, na França, e os atos de navegação britânicos de 1651, 1660, 1661 e 1673 excluiram efetivamente muitos artigos brasileiros de seus mercados tradicionais. Entre 1650 e 1710, a quantidade do açúcar brasileiro no mercado europeu diminuiu em cerca de 40\%. Josiah Child escreveu em 1669 que os açucares portugueses mascavado e panela haviam praticamente desaparecido do mercado europeu e que o preço do açúcar branco fora reduzido consideravelmente. $\mathrm{Na}$ década de 1630, aproximadamente 80\% do açúcar vendido em Londres provinha do Brasil. Em 1670, essa participação caiu para 40\% e, em 1690, para apenas 10\%”. CF: Stuart Schwartz. Segredos internos: engenhos e escravos na sociedade colonial... Op.cit. p. 162
} 
No plano interno, corroborando esse cenário, havia a concorrência da região mineradora, também consumidora de mão-de-obra escrava, fazendo elevar os custos da aquisição de boçais africanos. Além disso as calamidades naturais, com secas prolongadas - como a que durou de 1710 a $1715^{27}$, ou a de 1723 a $1727^{28}$ - e enchentes devastadoras - como a de 1729-30 ${ }^{29}$-, afetavam diretamente senhores de engenho, lavradores e a população pobre da capitania da Paraíba. ${ }^{30}$

Como conseqüência desses problemas, percebe-se que, mesmo com a permanência de um pequeno recolhimento do dízimo nestes períodos de calamidades, a produção da Paraíba absorveu melhor as intempéries da segunda década - quando se manteve bem próxima da média ponderada de 3:250\$000 réis de recolhimento dos dízimos - do que os momentos experimentados nos anos vinte. Tal fato se deve, com certeza, à sobrevida dos bons anos de produção e comércio proporcionados pelo açúcar no início do século XVIII. Deve-se atentar, também, para uma pequena tendência de melhora da arrecadação do dízimo, mesmo que pontual, nos anos trinta e nos anos cinqüenta. A questão é saber se esta leve recuperação pode ser creditada também ao açúcar ou à presença de um outro produto. Por ora, analisemos mais proximamente a evolução do desempenho da produção açucareira, através dos resultados da cobrança do seu subsídio.

\section{O SUBSÍDIO DO AÇÚCAR}

A cobrança dos subsídios do açúcar na Paraíba teve início em 1665, quando foi atendida uma solicitação da Câmara e do povo da capitania, pelo vice-rei do Brasil, para

\footnotetext{
${ }^{27}$ AHU_ACL_CU_014, Cx. 5, Doc. 353 e Doc. 392.

${ }^{28}$ AHU_ACL_CU_014, Cx. 5, Doc. 416 e Cx 6, Docs. 452; 470; 481; 535.

${ }^{29}$ AHU_ACL_CU_014, Cx. 7, Doc. 606.

${ }^{30}$ Nessa situação, era comum se desencadear uma onda especulativa sobre os alimentos, como a farinha de mandioca e o trigo importado, levando levas de famintos para os caminhos do sertão e à proliferação de doenças e mortes, principalmente de escravos. Em uma carta datada de 25 de junho de 1724, em meio a uma seca desastrosa, João de Abreu Castel Branco, governador da Paraíba, fazia referência à especulação patrocinada por alguns produtores locais, que elevavam o preço dos gêneros comestíveis, como o praticado com a farinha de mandioca que, normalmente vendida a $\$ 420$ réis a arroba, chegava a custar cerca de seis mil réis. Da mesma forma, os comerciantes faziam a farinha do Reino, o trigo, chegar ao consumidor na base de cinco mil réis a arroba. Ainda nesta mesma carta, dizia o governador ter lançado bandos para punir vadios e malfeitores, além de mostrar-se bastante preocupado com a quantidade de escravos mortos. Cf: AHU_ACL_CU_014, Cx. 5, Doc. 416.
} 
socorrer as necessidades das companhias de Infantaria ali instaladas. ${ }^{31}$ Ao que parece, o trabalho funcionou a contento, pois, passados dez anos, já havia em pleno funcionamento uma balança no passo do Tiberí, ${ }^{32}$ distante três léguas da cidade, onde se aferiam os pesos das caixas e se taxava o açúcar exportado para o Reino, cobrando-se por arroba de açúcar branco $\$ 60$ réis e a metade desse valor para o mascavado. ${ }^{33}$ Contudo, ainda por volta da década de setenta, conforme solicitação de moradores paraibanos, a balança foi conduzida para o porto da cidade, no Varadouro, onde ficaria mais "à vista dos oficiais da Fazenda e do governo de sua majestade". ${ }^{34}$

A princípio, a administração e a arrematação desse imposto ficavam a cargo da Câmara Municipal, que o arrecadavam através de dois exatores, um fiel da balança e seu escrivão. Esses exatores também se incumbiam da cobrança dos $\$ 400$ e \$200 réis por caixa e feixes de açúcar que serviam para as obras da Fortaleza, além dos $\$ 120$ réis pelo uso da balança. ${ }^{35}$ Dos valores levantados com o subsídio, se descontavam a propina para o secretário e os conselheiros do Conselho Ultramarino, no valor de $125 \$ 000$ réis, e o pagamento dos dois exatores, a saber: $50 \$ 000$ réis para o fiel e $25 \$ 000$ réis para o escrivão. O restante era repassado para a Câmara, que descontava suas despesas e, caso

\footnotetext{
${ }^{31}$ Ordem do vice-rei do Brasil, Dom Vasco Mascarenhas, Conde de Obidos, de 22 de maio de 1665. Cf: AHU / Códice 1805 / Relação Geral dos Contratos que se administram pela Fazenda Real da Paraíba 1731-1733. Folha. 31. Segundo Bicalho, “... nas colônias foram as câmaras, pelo menos durante todo o século XVII, os órgãos fundamentais no gerenciamento de boa parcela, se não do comércio, ao menos da defesa e das rendas reais - tributos e donativos impostos pela metrópole”. Poderio que se manteve até, mais ou menos, os fins dos anos vinte do século XVIII. Cf: Maria Fernanda Bicalho. A cidade e o Império. O Rio de Janeiro no século XVIII. Rio de Janeiro: Civilização Brasileira, 2003. p. 304.

${ }^{32}$ AHU_ACL_CU_014, Cx. 1, Doc. 96.

${ }^{33}$ Sobre o peso das caixas de açúcar, até o ano de 1697 , se praticava na Paraíba o uso de grandes caixões contendo cerca de 40 a 45 arrobas. Contudo, a partir dessa data, baixou a Coroa alvará de lei, determinando a uniformização para o açúcar produzido no Brasil, ordenando que as caixas não excedessem a 35 arrobas. Cf: AHU_ACL_CU_014, Cx. 3, Doc. 203. Sobre a localização do Engenho Tiberí, onde certamente deveria haver o seu passo, ver Guilherme Gomes da Silveira D'Avila Lins. Páginas de história da Paraíba: revisão crítica sobre a localização dos dois primeiros engenhos de açúcar da Paraíba. João Pessoa: Empório dos Livros, 1999

${ }^{34}$ Alguns senhores poderosos da capitania eram contrários à transferência da balança, pois mantinham contatos estreitos com a praça do Recife, para onde encaminhavam sua produção sem os entreveros dos impostos locais. Entre eles, estavam André Vidal de Negreiros, Antônio Curado Vidal e João Fernandes Vieira. Cf: AHU_ACL_CU_014, Cx. 1, Doc. 96 Consta, também, a existência de uma outra balança, pelo menos até 1725, funcionando num lugar chamado Portinho, próximo ao Varadouro. AHU_ACL_CU_014, Cx. 6, Doc. 458.

${ }^{35}$ Comumente, a Câmara arrematava por contrato pelo prazo de um ano o direito da cobrança pelo uso da balança por $22 \$ 000$ a 25\$000 réis. Cf: AHU_ACL_CU_014, Cx. 8, Doc. 697.
} 
houvesse sobejos, remetia-os para o Almoxarifado da Fazenda, para o pagamento da Infantaria e mais consignáveis. ${ }^{36}$

A transferência da administração do subsídio do açúcar para as mãos da Provedoria da Fazenda Real paraibana foi solicitada à rainha pela própria Câmara Municipal, em 27 de fevereiro de $1704 .{ }^{37} \mathrm{O}$ intuito dos oficiais da Câmara, nessa transação, era manter o recebimento do aluguel da balança nas mãos do órgão municipal $^{38}$, deixando os outros ônus para a Fazenda, o que foi aceito e confirmado em agosto de 1705. Daí por diante, por determinação real, a cobrança desse direito ficou restrita aos fiéis do passo e sem arrematação até o ano de 1744, já que o pequeno volume de trabalho podia ser realizado pela própria Fazenda. ${ }^{39}$

Todavia, uma vez que esse imposto era também um direito real, com todas as mazelas que envolviam o processo de arrematação/arrecadação na Colônia, os dados dos subsídios também requerem certos exercícios de filtragens no seu manuseio. Mesmo que o risco do mascaramento produzido pelo contratador estivesse diminuído, tendo em vista o tempo que o direito desse subsídio passou sem arrematação na Paraíba (1705-1744), há, pelo menos, dois outros motivos que podiam falsear a leitura dos dados.

O primeiro se refere à liberdade de que gozavam os contratadores dos dízimos da Paraíba, de não pagarem o subsídio sobre as caixas de açúcar que serviam para o abatimento do valor do contrato dos dízimos. Muitas vezes, essa liberdade, podia ser estendida a alguns senhores de engenho, desde que o contratador liberasse o uso do seu selo. Mas essa prática só perdurou até 1710, quando o governador da Paraíba, João Maia

\footnotetext{
${ }^{36}$ Lembrando, ainda, que esses dois oficiais recebiam $80 \$ 000$ réis de propina, além dos $75 \$ 000$, quando havia contratador. Cf: AHU ACL CU 014, Cx. 6, Doc. 455 e Cx. 8 Doc. 746.

${ }^{37}$ AHU_ACL_CU_014, Cx. 9, Doc. $7 \overline{46}$.

${ }^{38}$ Um parecer do governador da Paraíba Pedro Monteiro de Macedo, em 1735, sobre quererem os exatores da balança remuneração por este serviço, da conta de que os $\$ 120$ réis pelo uso da balança se manteve sob controle da Câmara e que ficaria ao critério deste órgão ofertar um valor a esses oficiais, sem que excedesse a quantia de $16 \$ 000$ réis pelo pouco trabalho que tinham em fazer essa cobrança. Cf: IHGPPB / Ordens Régias / Códice: 1733-1744 / Doc. 30.

${ }^{39}$ Dessa data de 1705 em diante, só conseguimos encontrar um outro contrato de arrematação do subsídio do açúcar em 1744, que fôra realizado no Conselho Ultramarino e arrematado por João da Silva Chaves pelo prazo de 3 anos, no valor de $480 \$ 000$ réis. Cf: IHGPPB / Ordens Régias / Códice 1733-1744 / Doc. 177.
} 
da Gama, a descobriu e fez com que fosse suprimido esse privilégio para os contratadores dos dízimos. $^{40}$

Outro problema que podia inibir a relação mais direta entre o pagamento do subsídio e a produção do açúcar, estava no acúmulo de caixas não negociadas nos trapiches, de um ano para outro. O risco estava na possibilidade de se creditar a um determinado ano, de grande embarque, uma produção que não lhe competia. $\mathrm{O}$ ajuntamento das caixas de açúcar nos passos podia estar respaldado em três principais motivos: a) a insatisfação de algum senhor de engenho com o preço do açúcar ${ }^{41}$; b) a crônica falta de navios nos portos paraibanos; e c) a carência da produção em si. $^{42} \mathrm{O}$ terceiro motivo, que parece mais plausível, acarretou uma política deliberada por parte da Fazenda Real, no sentido de resguardar a produção do açúcar, por alguns anos, como um meio de aumentar a receita e saldar dívidas atrasadas.

\footnotetext{
${ }^{40}$ Os contratadores dos dízimos, jurando aos santos evangelhos, indicavam nos trapiches quais as caixas que serviriam para abatimento do contrato. Assim, nesse meio, costumavam acrescentar caixas de alguns amigos. Cf: AHU_ACL_CU_014, Cx. 4, Doc. 302.

${ }^{41} \mathrm{O}$ preço do açúcar, tal como o praticado em outras capitanias, era feito na Paraíba em sessão na Câmara por avaliação, louvado, como se dizia, envolvendo na negociação as partes interessadas: comerciantes e produtores. Cf: AHU_ACL_CU_014, Cx. 11, Doc. 881. Uma ordem de 1697 mandava observar que, caso não se ajustasse o preço até 15 dias da chegada dos navios, deveriam os Oficiais da Câmara nomearem três louvados de cada parte para, avaliando o açúcar segundo as suas qualidades e considerando as circunstâncias do tempo, determinarem o seu justo preço. Passados então três dias e não se chegando a uma conclusão, que se colocasse o valor corrente em Pernambuco, acrescentado um tostão a mais, tendo em vista "a maior bondade do açúcar desta capitania". Essa forma, no entanto, foi modificada em 1705, pois era comum os senhores de engenho levarem o processo à exaustão, colocando no prejuízo os comerciantes, não só quanto ao valor, mas, principalmente, na qualidade do açúcar, já que acabavam por misturar o mascavado com o branco, lacrando as caixas. Após 1705, então, passados os 18 dias e não se acertando o valor, o Capitão-Mor deveria nomear mais três louvados das partes, para que se elegesse um, e este, finalmente, determinaria o valor que deveria ser respeitado por todos. Cf: AHU_ACL_CU_014, Cx. 4, Doc. 273.

${ }^{42}$ Segundo Oliveira, a Paraíba não conseguiu sequer produzir, durante a primeira metade do século XVIII, a quarta parte do que experimentara nos momentos anteriores a invasão holandesa. Cf: Elza Regis de Oliveira. A Paraíba na crise do século XVIII... Op.cit., p. 77.
} 


\section{QUADRO 2}

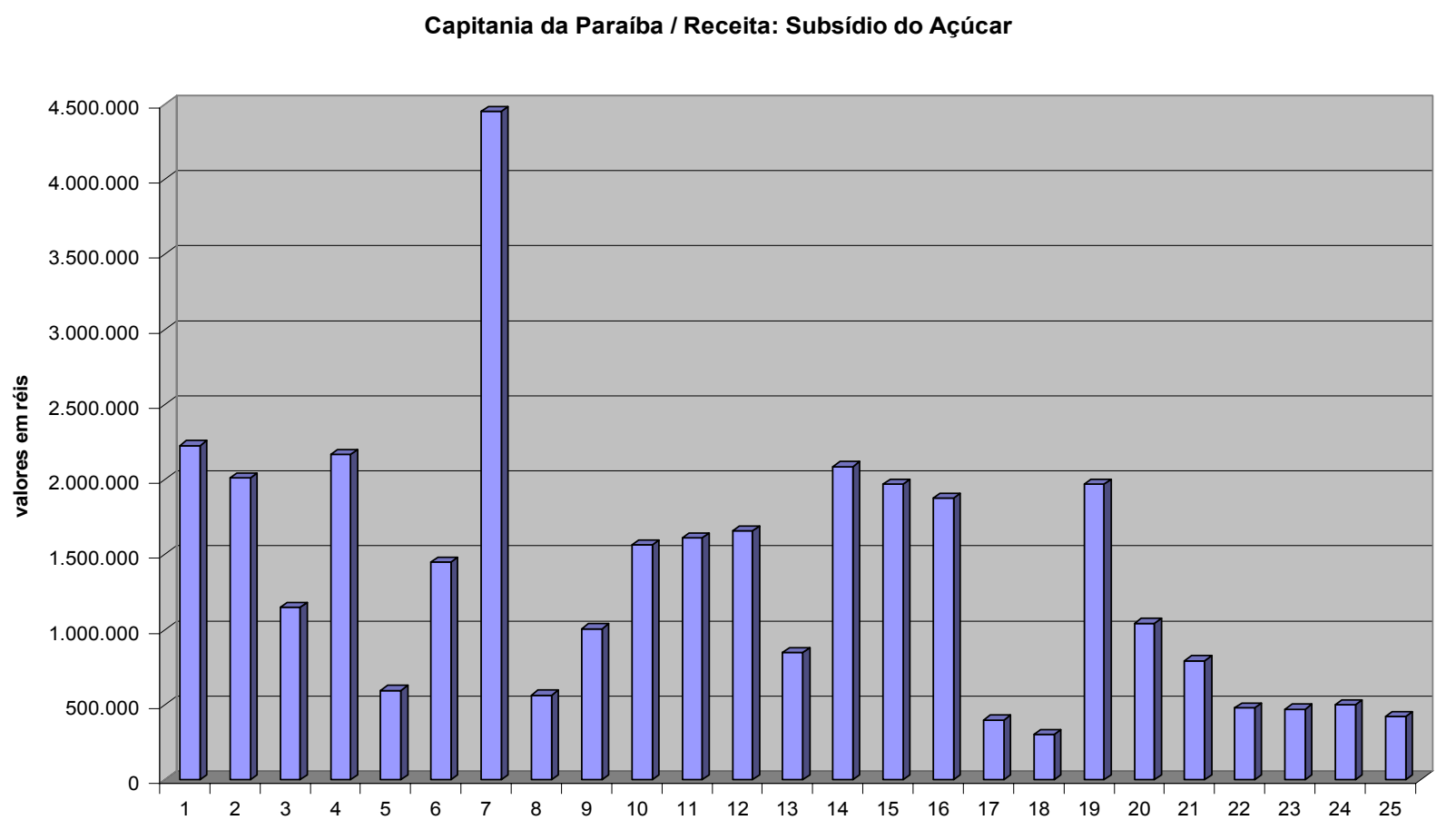

\begin{tabular}{|r|c|c|c|c|c|c|c|c|}
\hline (1) 1702 & (2) 1705 & $(3) 1706$ & (4) 1707 & (5) 1708 & (6) 1709 & (7) 1710 & (8) 1712 & (9) 1713 \\
$2: 225 \$ 280$ & $2: 012 \$ 000$ & $1: 476 \$ 540$ & $2: 166 \$ 102$ & $595 \$ 678$ & $1: 451 \$ 265$ & $4: 451 \$ 775$ & $564 \$ 915$ & $1: 006 \$ 005$ \\
\hline
\end{tabular}

\begin{tabular}{|r|l|l|l|l|l|l|l|l|}
\hline $\mathbf{1 0}) 1715$ & $\mathbf{( 1 1 )} 1917$ & $\mathbf{( 1 2}) 1718$ & $\mathbf{( 1 3}) 1720$ & $\mathbf{( 1 4 )} 1722$ & $\mathbf{( 1 5}) 1723$ & $\mathbf{( 1 6 )} 1724$ & (17) 1726 & $\mathbf{( 1 8 )} 1728$ \\
$1: 564 \$ 530$ & $1: 609 \$ 725$ & $1: 656 \$ 260$ & $847 \$ 365$ & $2: 086 \$ 185$ & $1: 970 \$ 055$ & $1: 875 \$ 055$ & $399 \$ 000$ & $301 \$ 345$ \\
\hline
\end{tabular}

\begin{tabular}{|l|l|l|l|l|l|l|}
\hline$(\mathbf{1 9}) 1731$ & $(\mathbf{2 0}) 1733$ & $(\mathbf{2 1}) 1741$ & $\mathbf{( 2 2}) 1744$ & $(\mathbf{2 3}) 1747$ & $(\mathbf{2 4}) 1749$ & $(\mathbf{2 5}) 1753$ \\
$1: 969 \$ 155$ & $1: 041 \$ 675$ & $791 \$ 937$ & $480 \$ 000$ & $470 \$ 665$ & $500 \$ 000$ & $420 \$ 000$ \\
\hline
\end{tabular}

\section{Fonte: Arquivo Histórico Ultramarino}

Observando o Quadro 2, pode-se notar que o ano de 1710, constituiu um momento bastante singular no que concerne ao subsídio do açúcar na Paraíba. Pico de toda a exportação nos anos apresentados, 1710 revela não apenas a quebra das liberdades dos contratadores dos dízimos, como também, a primeira e bem sucedida venda 
acumulada do açúcar represado nos passos paraibanos, que garantiu o pagamento integral das folhas de pessoal. Neste mesmo ano, saíram, pelo passo do Portinho, 1:565\$985 réis e, pelo Varadouro, 2:885\$790 réis. Segundo o governador João Maia da Gama, isso só foi possível porque se pode contar com as sobras das caixas de açúcar provenientes das boas safras dos anos de 1706 a 1709, mesmo levando em conta a baixa do ano de 1708, no qual entrou apenas um navio no porto da Paraíba. ${ }^{43}$

Para os anos imediatamente posteriores a 1710, os sintomas de uma seca, que começou no verão de 1711 , fizeram diminuir o valor do subsídio e abalar os pagamentos das folhas de pessoal da capitania. Deve-se considerar que os anos de 1712 e 1713 ainda sobreviveram das caixas carreadas de 1710; e que em 1715 e em 1717, a Fazenda paraibana respirou mais aliviada com a política de ajuntamento das caixas. Mesmo assim, o pagamento das folhas de pessoal, principalmente com a infantaria - motivo das quebras das Fazendas, "como acontece com todas as capitanias do Brasil", no dizer do conselheiro ultramarino José Carvalho de Abreu - começaram a amargar "sempre um ano de dívida". 44 Apenas em 1722 a arrecadação alcançou a casa dos dois contos, com suas caixas somando com os dois anos precedentes. Mas o hiato provocado pela grande seca de 1723-1727, e pela cheia de 1729, impediu um melhor desempenho, tal como o observado na primeira década dos setecentos. Depois disso, somente em 1731 o subsídio do açúcar conseguiu chegar perto dos dois contos de réis.

Nem os coevos desconheciam os motivos que enfraqueciam os índices de desempenho do açúcar nas áreas produtoras do Brasil, tanto ao nível interno quanto ao nível externo. Mas as respostas a esses problemas eram a adoção de moratórias para os senhores $^{45}$ e a determinação de que não se arrematasse por um valor aquém daquele que facilmente se conseguiria na administração do direito pela Fazenda Real. As

\footnotetext{
${ }^{43}$ AHU ACL CU 014, Cx. 6, Doc. 458.

${ }^{44}$ AHU_ACL_CU_014, Cx. 5, Doc. 353 .

${ }^{45}$ A saída sempre praticada pela Coroa, em comum acordo com os senhores de engenho, era a decretação de moratórias durante um certo tempo, geralmente seis anos, para que não fossem executadas as suas dívidas sobre as fábricas e engenhos, mas apenas na produção. Com a destruição provocada com a expulsão dos holandeses, tiveram os senhores de engenho, no processo de remontagem do parque açucareiro, esses mesmos socorros, como se verificou nos anos de 1658, 1663, 1674, 1699 e 1700 - privilégio que também se repetia em Pernambuco e por outros motivos na Bahia e Rio de Janeiro. Cf: Elza Regis de Oliveira. $A$ Paraíba na crise do século XVIII... Op.cit. p. 69. Sobre as calamidades comentadas, é importante salientar que fôra concedida moratória por seis anos, em 1717 e em 1729. Conferir, respectivamente: AHU_ACL_CU_014, Cx. 5, Doc. 360; e Cx. 7, Doc. 606.
} 
justificativas eram compreensíveis: primeiro, manter a todo custo a produção mesmo que em escala ínfima, garantindo uma sobre-vida ao produtor e, segundo, evitando um sangramento ainda maior da arrecadação, acumular por dois ou três anos os estoques do açúcar, na esperança de saldar as dívidas atrasadas.

No cômputo geral, a prática da administração do direito do subsídio, envolvendo o ajuntamento de cargas de alguns anos, adotada após 1705, não foi de todo desastrosa. Conseguiu, com isso, evitar uma maior sangria da arrecadação do subsídio, quer garantindo que ela não fosse dividida com os contratadores, quer evitando o desvio das cargas para os portos de Pernambuco ou alhures.

Porém, mesmo com a arrecadação diminuta se conseguiu, nos anos de 1744 e 1748 estabelecer contratos. Dois tipos de explicação podem ser arrolados para explicação desse fato. Em primeiro lugar, se poderia estar diante de uma retomada da produção açucareira, contrariando o movimento de queda representado nas torres 20 a 23, do Quadro 2. Pela outra explicação, se poderia estar contrariando a determinação real de não proceder à arrematação, caso o valor levantado com ela não fosse facilmente compensado com a administração do direito, ou seja, deixá-lo sob o controle da Fazenda.

O contrato de 1748, firmado no Conselho Ultramarino, possui algumas nuanças que levam a crer que os interesses dos conselheiros, mirando as propinas provenientes do processo de arrematação, convergiram com os interesses do arrematador.

No início do ano de 1748, o contrato dos subsídios do açúcar da Paraíba foi arrematado por três anos ou três safras a João Henriques Martins, pelo valor de $500 \$ 000$ réis. ${ }^{46}$ Esse contratador e os conselheiros ultramarinos sabiam que nesse ano a frota só sairia de Lisboa em setembro e que parte da safra anterior, 1746-47, ainda se encontrava nos passos paraibanos. Afinal, o próprio João Henriques Martins era também contratador dos dízimos na Paraíba. ${ }^{47}$ Fechado o contrato e passado o alvará, o contratador tinha praticamente garantido para si quatro safras, com o uma delas já estando pronta para o embarque, nos passos paraibanos.

Em abril de 1749, o provedor da Paraíba, Teotônio Fernandes Temudo, escreveu à Coroa se posicionando contra o que estava acontecendo. Tentava convencer os

${ }^{46}$ AHU_ACL_CU_014, Cx. 15, Doc. 1266.

${ }^{47}$ AHU_ACL_CU_014, Cx. 16, Doc. 1312. 
conselheiros de que o contrato, assinado em 1748, só deveria ter validade para a safra 1748-49, ficando sob administração as caixas que restavam da safra 1746-47, e as que se aprontavam de 1747-48.

Alheios a isso, os feitores do contratador, que atuavam na Paraíba, iam medindo o peso e as taras das caixas sem distinção alguma. No fim, os apelos de Temudo foram escusados no âmbito do próprio Conselho Ultramarino. Desta forma, o valor do contrato, que deveria ser repartido em três anos, pôde ser pago numa única estocada, ficando ainda, de crédito para o contratador, mais duas safras adiante. ${ }^{48}$ Os interesses privados colocavam a perder a já combalida Fazenda Real paraibana, alimentando ainda mais a tendência de queda do subsídio do açúcar. Isto pode ser constatado no Quadro 3, no qual se compara o desempenho do dízimo com o subsídio do açúcar.

\section{QUADRO 3}

Capitania da Paraíba / Receita: Dízimo \& Subsídio do Açúcar

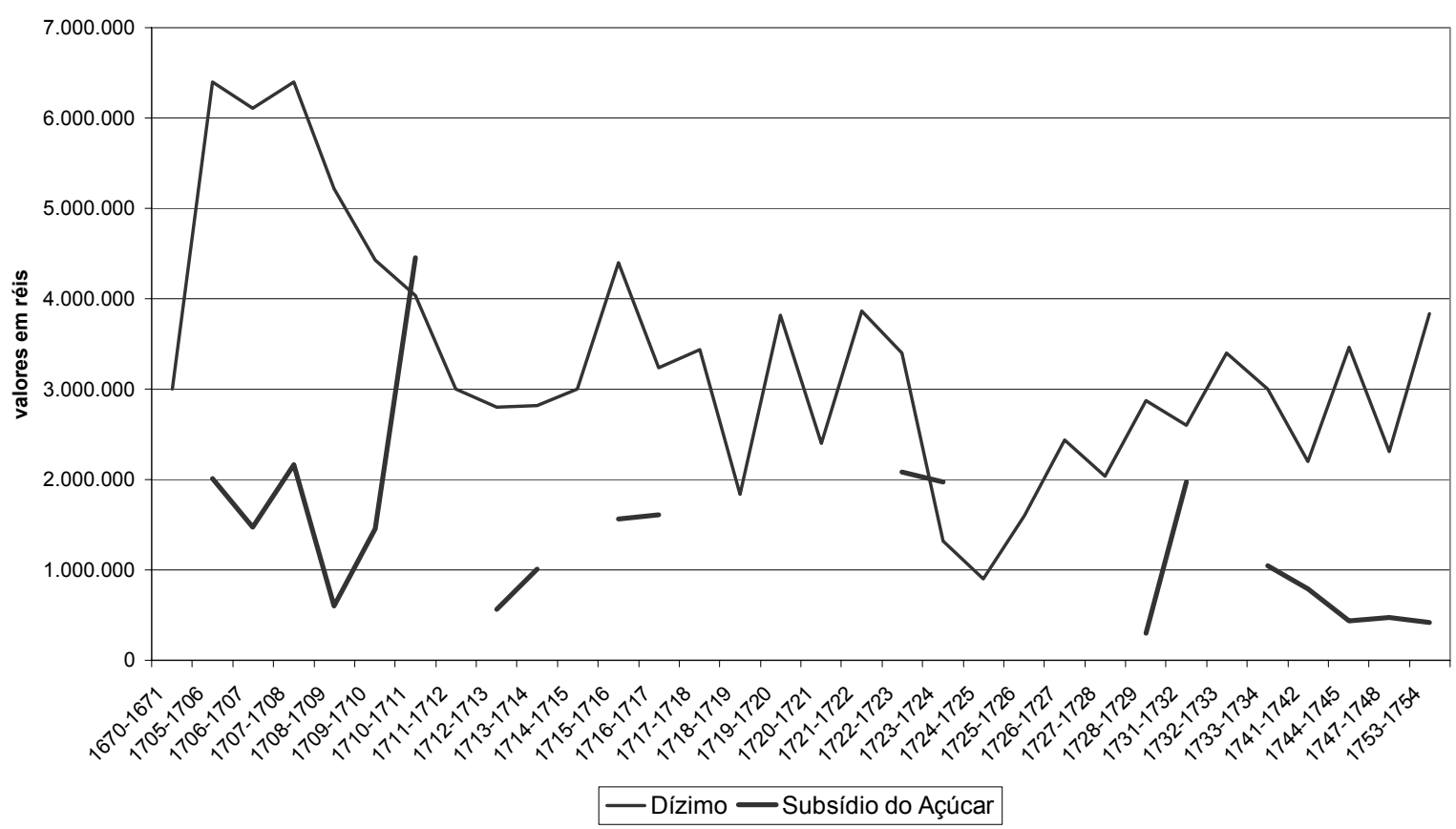

Fonte: Arquivo Histórico Ultramarino

${ }^{48}$ AHU_ACL_CU_014, Cx. 15, Doc. 1266. 
Pode-se perceber que existe um relativo paralelismo do tracejo que identifica o subsídio do açúcar com a descrição da linha do dízimo - excluindo o atípico ano de 1710, que elevou o subsídio à casa dos quatro contos, tendo em vista a exagerada contenção de caixas nos passos paraibanos. Esse paralelismo, contrasta com a dispersão discretamente apresentada nos fins dos anos 30 e que vai se acentuando até o fim do período trabalhado.

As condições praticadas no contrato de 1748 ajudaram a derrubar o subsídio do açúcar, mas não há como negar que esse movimento de dispersão acusa a entrada em cena de outro componente econômico. Mesmo encoberta pela tradição dos engenhos, a produção da pecuária também desempenhou um papel importante na economia local. Ela deu condições para sustentar a arrecadação do dízimo e trouxe um alento para o vazio deixado pelos baixos índices do açúcar. A importância da produção da pecuária para a economia e para a receita da Fazenda paraibana pode ser atestada através dos dados dos contratos do subsídio da carne e da penetração do gado pelo interior da capitania. Porém, antes merecem destaque dois outros impostos relacionados com a exportação do açúcar. O primeiro era formado pelo cruzado das caixas e os dois tostões por feixe de açúcar, e o segundo abrangia os $\$ 80$ e $\$ 40$ réis por caixa e feixe de açúcar. Esses dois impostos serviam ao soldo das tropas e às obras de construção, manutenção e reparo das fortalezas, respectivamente.

\section{OUTROS IMPOSTOS SOBRE O AÇÚCAR}

O cruzado das caixas e os dois tostões por feixe incidiam, indistintamente, sobre todos os volumes exportados pela Paraíba. Diferentemente deles, os $\$ 80$ e $\$ 40$ réis não eram cobrados dos volumes que se dirigiam para o porto de Pernambuco, em virtude de ser cobrado apenas no local de embarque para o Reino. ${ }^{49}$

Em função do pequeno número de dados disponíveis, os valores relacionados a esses impostos se mostram quase inexpressivos, para o cômputo geral da receita. Entretanto, eles ganham em importância quando comparados com os dados até aqui trabalhados sobre o subsídio do açúcar. Isto por recrudescerem os resultados

\footnotetext{
${ }^{49}$ AHU / Códice 1805 / Relação Geral dos Contratos que se administram pela Fazenda Real da Paraíba 1731-1733; p. 49. Há, também, um problema que impede de usarmos todos os dados do cruzado das caixas pois, algumas vezes, os provedores misturavam todos os impostos em uma única alínea, como aconteceu no relatório sobre o rendimento dos anos de 1753 e 1754. Cf: AHU_ACL_CU_014, Cx. 18, Doc. 1434.
} 
apresentados, no que dizem respeito tanto aos números de arrecadação dos subsídios, quanto à certeza do sucesso com a política de ajuntamento de caixas para se fazer comércio diretamente com o Reino, evitando o desvio de cargas pelo porto de Pernambuco. O sucesso com a política de ajuntamento das caixas de açúcar pode ser exemplificado quando se divide o cômputo de cada ano por um ou outro imposto e se percebe que o volume exportado pela Paraíba somente foi superado uma única vez, em 1728, pois representou menos de um terço das caixas transportadas para Pernambuco.

\section{$4^{\circ}$ QUADRO}

Capitania da Paraíba / cruzado e $\$ 80$ réis das caixas de açúcar

\begin{tabular}{|l|l|l|}
\hline Ano & Cruzado e dois tostões & $\$ 80$ e $\$ 40$ réis caixas e feixes \\
\hline 1723 & & $95 \$ 760(1197$ caixas $)$ \\
\hline $17 *$ \\
\hline 1726 & $384 \$ 760(961,9$ caixas $) *$ & \\
\hline 1727 & & $22 \$ 240(278$ caixas $)$ \\
\hline 1728 & $84 \$ 200(210,5$ caixas $)$ & \\
\hline 1731 & $240 \$ 200(600,50$ caixas $)$ & $33 \$ 760(422$ caixas $)$ \\
\hline 1733 & $416 \$ 400(1041$ caixas $)$ & $89 \$ 280(1116$ caixas $)$ \\
\hline 1741 & $220 \$ 800(552$ caixas $)$ & $44 \$ 160(552$ caixas $)$ \\
\hline 1744 & $201 \$ 600(504$ caixas $)$ & $45 \$ 900(573,7$ caixas $)$ \\
\hline 1753 & $198 \$ 000(495$ caixas $)$ & $39 \$ 600(495$ caixas $)$ \\
\hline
\end{tabular}

Fonte: Arquivo Histórico Ultramarino

* Dividido pelo valor maior de um cruzado (\$400 réis); Com o passar do tempo, os provedores apenas fazem referência ao cruzado das caixas. Ao que parece, os feixes se tornaram anti-econômicos.

** Dividido pelo valor maior de $\$ 80$ réis; Com o passar do tempo, os provedores apenas fazem referência aos 4 vinténs por caixa, ou seja, aos oitenta réis.

\section{O SUBSÍDIO DA CARNE}

Ainda se removiam os escombros da guerra, em 1670, quando os oficiais do senado da Câmara paraibana "acordaram houvesse açougue e obrigado [isto é, um imposto] sobre o corte de carne ${ }^{, 50}$. A justificativa para a adoção do imposto estava nos gastos com

\footnotetext{
${ }^{50}$ AHU_ACL_CU_014, Cx. 13, Doc. 1112. Baseada em trabalhos de outrem, Bicalho afirma que a prática de lançar tributos pelas câmaras municipais, para custear a defesa das capitanias e outros serviços ao bem do público, adicionou-lhe, um "domínio ... sob uma das mais importantes prerrogativas reais," o direito de criar tributos. Cf: Maria Fernanda Bicalho. A cidade e o Império... Op.cit. p. 312. Ainda sobre esse assunto, é interessante destacar que, em Salvador, o Tribunal da Relação da Bahia, desde 1674, mantinha seu "próprio açougue afim de evitar os custos da compra da carne". Cf: Stuart B. Schwartz. Burocracia e sociedade no Brasil colônia...Op.cit., p. 213.
} 
a construção da igreja matriz de Nossa Senhora das Neves, para onde se destinaram três partes da receita, ficando a quarta parte dirigida para as despesas a que a Câmara estava obrigada. $^{51}$

Este imposto ficou sob o controle da Câmara até 1732, quando uma ordem régia de primeiro de setembro passou esta prerrogativa para a Fazenda da Paraíba. Essa ordem seguiu um movimento geral de transferência dos impostos e contratos administrados pelas câmaras municipais para as Fazendas, como já havia acontecido em Recife, Olinda, Rio de Janeiro e outros municípios. ${ }^{52} \mathrm{O}$ baque sofrido pela Câmara, com a supressão desse imposto, levou seus oficiais a pedirem o retorno das atividades de arrematação, em $1736^{53}$. Mas a Coroa limitou-se apenas a obrigar que a Fazenda da Paraíba repassasse para a Câmara uma ajuda de custo, proveniente do mesmo contrato, para que o órgão municipal tocasse as obras mais prementes ao público da cidade. Entre essas obras estavam, por exemplo, os consertos da fonte do Tambiá e da cadeia pública. ${ }^{54}$

\footnotetext{
${ }^{51}$ AHU_ACL_CU_014, Cx. 13, Doc. 1112.

${ }^{52}$ Segundo o governador Pedro Monteiro de Macedo, o transporte dessa arrematação para a Fazenda Real obedecia a uma ordem real de 1 de setembro de 1732, tal como já houvera sua majestade mandado fazer em Pernambuco e mais capitanias. Cf: AHU_ACL_CU_014, Cx. 9, Doc. 733. Para Alden, em 1727, o Conselho Ultramarino, atendendo a uma antiga solicitação da Câmara de Olinda, transferiu a jurisdição de alguns impostos municipais para a provedoria de Pernambuco, e escreveu ao governador do Rio de Janeiro para definir se ele achava aconselhável fazer o mesmo procedimento com uma parte ou com todos os impostos cariocas. A resposta do governador, Luis Maia Monteiro, dizia ser essa ação não apenas desejável, mas de urgentíssima causa, afinal, os registros da Câmara estavam em grande desordem e seus pagamentos em atraso. Em 1731, portanto, achando que a experiência resultara em sucesso em Pernambuco, seria o próprio Conselho Ultramarino que ordenava se passasse para as provedorias das capitanias, inclusive no Rio de Janeiro, alguns impostos, notificando as Câmaras que o rei havia decidido isentá-las da incômoda responsabilidade de manejá-los. Cf: Dauril Alden. Royal government in colonial Brasil. With special reference to the administration of the Marquis of Lavradio, viceroy, $1769-1779$. Los Angeles: University of California Press, 1968. p. 310

${ }^{53}$ Sem o ingresso do contrato das carnes, as rendas da Câmara se resumiam ao contrato das aferições da balança do passo do Varadouro, o foro de nove pesqueiras, \$500 réis de licença para os barcos que carregavam casca de mangue para a fábrica de sola, e o imposto de $8 \$$ réis que se pagava sob cada pipa de aguardente proveniente do Reino. O total do rendimento, como se apurou em 1733, chegou a $199 \$ 600$ para fazer frente às despesas das obras da cadeia e prédio da Câmara, além da restauração da bica do Tambiá. Cf: AHU ACL CU 014, Cx. 9, Doc. 733. Sobre a localização da Bica do Tambia e Varadouro, ver: Welllington Aguiar e José Octávio. Uma cidade de quatro séculos: evolução e roteiro. $2^{\mathrm{a}}$ edição. - João Pessoa: FUNCEP, 1989.

54 AHU_ACL_CU_014, Cx. 10, Doc. 813. Curiosamente, essa graça real passada para a Câmara da Paraíba, em 1734, induziu a Elza de Oliveira achar que o controle do imposto havia retornado para as mãos daquela Câmara, como aconteceu em Itamaracá. (Cf: Elza Regis de Oliveira. A Paraíba na crise... Op. cit., p. 85). Em 1754, por exemplo, a Coroa determinou que a Fazenda Real passasse para a Câmara $690 \$ 000$ réis da arrematação do subsídio da carne (Cf: Irineu Ferreira Pinto. Datas e notas para a História da Paraíba. João Pessoa: Editora Universitária. 1977. p. 156), em que pese haver também uma ordem, por volta de 1746, onde se mandava que se passasse para a Câmara dois terços dos rendimentos do contrato da carne. Cf: AHU_ACL_CU_014, Cx. 14, Doc. 1161.
} 
Esse movimento de cerceamento das ações das Câmaras Municipais no Brasil Colônia teve uma conotação tanto política, com a intervenção dos Juizes de Fora, nos fins do dezessete, quanto econômica, com o transporte dos direitos de certos impostos e contratos para a Fazenda. Na base de tudo isso estava uma política deliberada da metrópole para controlar os ímpetos das câmaras e diminuir os riscos de descaminhos das rendas reais. Dessa forma, a Coroa acreditava que o contrato da carne, sob controle da Câmara paraibana, estaria sendo arrematado por um preço aquém da realidade, no que não estava de todo errada.

No início do século XVIII, o sertão da Paraíba era por excelência uma área destinada à prática da pecuária. ${ }^{55}$ Mas isso não significou um aumento direto nem do dízimo real, nem do subsídio da carne administrada pela Câmara. Havia a anuência do poder régio para o desbravamento do interior da Paraíba, pondo fim aos possíveis riscos dos ataques dos índios às áreas agrícolas do brejo e de pecuária no agreste do rio Paraíba. Entretanto, os quinhões que deveriam pertencer à Fazenda e à Câmara paraibanas não se incorporaram imediatamente às rendas reais. O problema, nesse caso, era de ordem político-administrativa. Como o único município, em toda a capitania, era a cidade da Paraíba de Nossa Senhora das Neves, ficava difícil "fazer chegar à administração, numa forma eficiente, a todos os recantos do vasto território." ${ }^{56} \mathrm{O}$ maior exemplo disso estava exatamente na arrematação dos dízimos do gado do interior da Paraíba.

Segundo os próprios criadores do sertão paraibano, a maioria dos contratadores dos dízimos da capitania eram pessoas de fora, e compostas principalmente por comerciantes pernambucanos que tinham condições de manter seus procuradores em Lisboa. Esses comerciantes costumavam repassar a cobrança do imposto para os

\footnotetext{
${ }^{55}$ Para Irene Fernandes, o sertão paraibano já havia sido devassado pelo homem branco desde os anos vinte do século XVIII, com "as linhas de penetração para o interior da Paraíba” sendo delineadas, "a partir dos condutos principais, que interligam o espaço regional: a) de Olinda, acompanhado a costa, subindo pelos vales dos rios secos e pela vegetação de caatinga chega ao vale dos Rios Piranhas, Açu, ApodiMossoró e Jaguaribe; e b) de Salvador, ocupando a costa baiana e sergipana, chegando ao Rio São Francisco, atravessam-no e, subindo os vales da margem esquerda chegam aos Rios Piranhas, Açu, ApodiMossoró e Jaguaribe." Irene Rodrigues Fernandes. A Capitania Real da Paraiba: bases históricas da sua formação econômica. 1574 - 1799. Textos UFPB/JP. n 25 Abril / 91. p. 14. Em outro trabalho, a mesma autora chama atenção para as justificativas na solicitação da sesmarias, já que, das 55 sesmarias registradas no período de 1696 a 1745, 48 se destinaram à criação do gado, 6, ao gado/lavoura e apenas uma para a lavoura. Cf: Irene Rodrigues Fernandes \& Laura Helena Baracuhy Amorim. As atividades produtivas na Paraíba. João Pessoa: Editora Universitária UFPB/JP, 1999. p. 30.

${ }^{56}$ Caio Prado Jr. A formação do Brasil contemporâneo... Op.cit., 302.
} 
criadores, aumentando os valores do arremate original, evitando o dispêndio com o deslocamento dos seus fiscais ou procuradores nas ribeiras da Paraíba. ${ }^{57}$ A solução disso só aconteceu no fim da segunda metade do século XVIII, quando a escaramuça entre contratador e atravessador passou a ser contestada pelos moradores e por alguns governadores da Paraíba, fazendo aumentar em alguns mil réis o dízimo da capitania. ${ }^{58} \mathrm{~A}$ interiorização desse processo se deu com a ida do provedor da Paraíba e do seu escrivão às ribeiras para fazer a arrematação do dízimo, da mesma forma como era praticado nos sertões do Rio Grande e Ceará. Mas isso só seria conhecido, em 1757, na Paraíba já subordinada, quando se assistiu a um aumento nos contratos, com a contribuição efetiva dessas áreas, com valores em torno de dois contos de réis. ${ }^{59}$

Como já foi dito, a conquista do interior paraibano não elevou significativamente as rendas da Câmara da Paraíba, que administrou esse contrato até 1732. Contudo, sustentou um fornecimento de carne intermitente aos habitantes da cidade, garantindo um equilíbrio nas receitas provenientes do contrato do subsídio da carne para o órgão municipal. A importância desse feito transparece, efetivamente, entre 1670 e 1731, com os preços da carne praticados junto à população e com os valores alcançados nos contratos do seu subsídio. ${ }^{60}$ Vejamos, primeiro, como se comportaram os preços da carne para a população.

Na verdade, a população paraibana só veio a sofrer com a majoração no preço da carne durante os anos de 1707 a 1709, quando a Coroa decretou a proibição da prática do comércio aos governadores e oficiais mores. Nessa ocasião, a própria Câmara propô-

\footnotetext{
${ }^{57}$ Cf: AHU_ACL_CU_014, Cx. 17, Doc. 1407 e Cx. 18, Doc. 1434. Ribeira é uma zona rural, de pecuária bovina ou cavalar, que incorpora um determinado número de fazendas. Na Paraíba, havia as ribeiras do Piancó, Rio do Peixe, das Piranhas, do Sabogi, Patú e Espinharas e do Mamanguape.

${ }^{58}$ Numa amostragem mandada fazer pelo coronel governador, Luis Antônio Lemos de Brito, sobre quanto poderia render o contrato dos dízimos nas ribeiras da Paraíba, em 1753, chegou-se a seguinte conclusão: por um contrato de três anos, a carne de boi, vaca, 8:700\$000 réis e para as miúças, isto é, caprinos e ovelhas, 2:250\$000 reís. Cf: AHU ACL CU 014, Cx. 18, Doc. 1434. E, anos antes, em dezembro de 1739, o governador Pedro Monteiro de Monteīro já apontava alguns projetos para tornar a pecuária mais rentável à Fazenda. Cf: AHU_ACL_CU_014, Cx. 11, Doc. 897. Esses projetos serão discutidos no capítulo IV.

${ }^{59}$ A ordem para implantação dessa forma de arrematação foi dada em 20 de novembro de 1754, mas só executada em 1757, já que ainda valia o contrato da última arrematação. Cf: AHU ACL CU 014, Cx. 18 , Doc. 1434. Em 1757, rendeu 2:946\$676 AHU_ACL_CU_014, Cx. 20, Doc. 1586. Em 1759, toda as Ribeiras renderam o valor de 8:746\$800 Percebe-se, então, aproximadamente, o quanto lucravam os contratadores dos dízimos de Pernambuco com o encobrimento desses valores. Cf: AHU_ACL_CU_014, Cx. 21, Doc. 1591 e 1593.

${ }^{60}$ Os dados de que dispomos sobre esses preços, está em uma averiguação feita a mando do provedor da Paraíba, José Antônio da Cunha nos livros da Fazenda e Câmara. AHU_ACL_CU_014, Cx. 13, Doc. 1112.
} 
se a compensar a perda das liberdades desses oficiais, elevando o tributo sobre a carne e outros gêneros comestíveis.

Entre os anos de 1670 e 1707, por exemplo, a carne de boi capado e de vaca chegou à população por $\$ 20$ réis o arrátel ${ }^{61}$ ou $\$ 480$ réis a arroba, e a do novilho, por $\$ 15$ réis o arrátel ou $\$ 320$ réis a arroba. ${ }^{62}$ Durante a proibição, contudo, o preço foi majorado em torno de 17 a 50 por cento, passando a arroba da carne do boi capado e de vaca para $\$ 560$ réis, e a do novilho para $\$ 480$ réis. O retorno aos patamares praticados anteriormente veio mais pelo temor de uma convulsão popular do que pela compaixão de algum administrador, pois, como alertava um conselheiro ultramarino, "a carestia no usual sempre se faz intolerável". 63 Daí a razão pela qual a Câmara da Paraíba assistiu zelosamente a população com uma política de controle sobre o corte da carne, fiscalizando a ação de marchantes e comerciantes clandestinos, principalmente em períodos de estiagem. Assim deve ser compreendido não apenas o aumento da licença para a prática do corte da carne concedido pela Câmara, quando saltou de $\$ 150$ para $\$ 800$ réis, na grande seca dos anos vinte, mas, também, a multa de $6 \$ 000$ réis para quem praticasse o corte sem licença. ${ }^{64} \mathrm{O}$ corte indiscriminado levaria tanto a uma desorganização dos contratos com os arrematadores, como a uma possível corrida especulativa. Afinal, o controle do preço ao consumidor passava necessariamente pelo

\footnotetext{
${ }^{61}$ O arrátel corresponde a 429 gramas ou 16 onças. Cf: ACIOLI, Vera Lúcia Costa. A escrita no Brasil Colônia. Recife: Editora Massangana; Editora Universitária / UFPB, 1994. p.307.

${ }^{62}$ Desses valores, ficavam livres para o obrigado $\$ 15$ réis da carne de boi e vaca e $\$ 12$ do novilho. Observando-se, entretanto, que, a partir de 1705, o corte passou a ser contabilizado em arroba, mas se mantiveram as mesmas proporções, não só do obrigado, como do preço de venda à população, ou seja, $\$ 480$ réis a arroba do boi capado e vaca, e $\$ 320$ réis para o novilho. Cf: AHU_ACL_CU_014, Cx. 13, Doc. 1112. Para se ter uma idéia sobre os valores praticados em outras capitanias, como em Minas, por exemplo, onde "o comércio das carnes despertava a contínua atenção das Câmaras porque era um item importante no abastecimento dos núcleos urbanos, além de ser a principal fonte de impostos," o valor do arrátel chegou a $\$ 60$ réis, em 1715, e \$50 réis em 1718-20. Cf: Júnia Ferreira Furtado. Homens de negócio. A interiorização da Metrópole e do comércio nas Minas setecentistas. São Paulo: HUCITEC, 1999. Op.cit., p. 208 e 209.

${ }^{63}$ AHU_ACL_CU_014, Cx. 4, Doc. 299. Segundo Júnia Furtado, "em uma carta uma carta a Dom Lourenço de Almeida, o Rei referiu-se a um motim ocorrido em Vila Rica, causado pelo prejuízo impostos a povo, em virtude das condições adversas que a Câmara tinha arrematado o contrato da carne." Cf: Júnia Ferreira Furtado. Homens de negócios... Op.cit., p. 211; Sobre algumas outras revoltas populares no período colonial, envolvendo questões fiscais, ver: Luciano Raposo de Almeida Figueiredo. "Além dos súditos: notas sobre revoltas e identidade colonial na América Portuguesa. In: Revista Tempo / Universidade Federal Fluminense, Departamento de História - V. 5; n 10, Dez. 2000 - Rio de Janeiro: Letras, 2000. p. 81-95

${ }^{64}$ Antes, essa multa corria na capitania no valor de $2 \$ 000$ réis. Cf: AHU_ACL_CU_014, Cx. 13, Doc. 1112.
} 
controle da fonte, do contrário, nada poderia garantir que o mercado fosse se preocupar com o bem estar social, principalmente em época de escassez.

\section{QUADRO 5}

Capitania da Paraíba / Receita: Subsídio da Carne

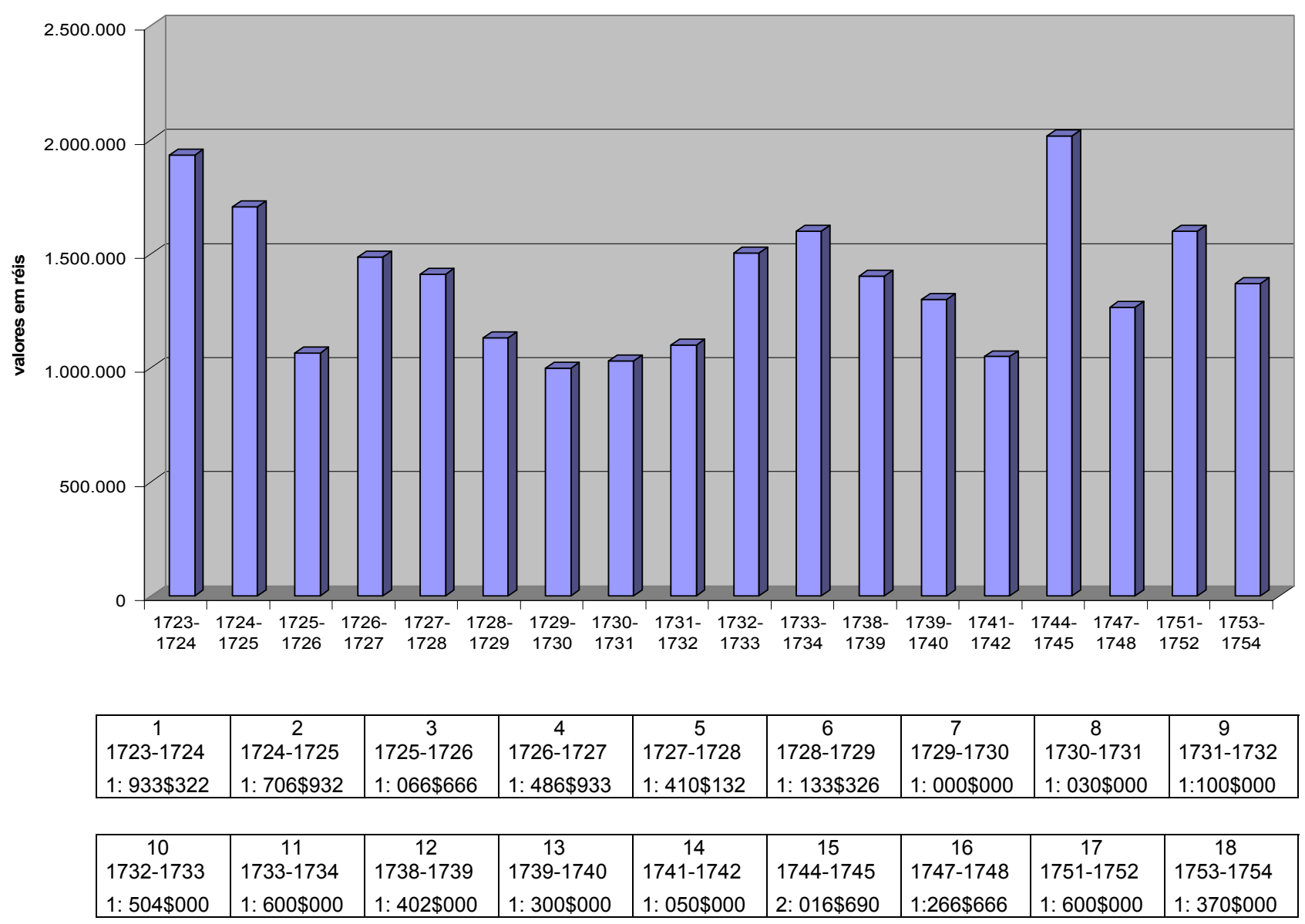

Fonte: Arquivo Histórico Ultramarino

Como pode ser observado no Quadro 5, os valores alcançados com a arrematação dos direitos do subsídio da carne, pelo menos para o período anterior à passagem para a Fazenda, também depõem nessa direção. Como conseqüência da estiagem dos anos vinte, vê-se que os preços nas arrematações foram caindo lentamente, mas isso não acarretou, como era de se esperar, um forte aumento na venda da carne no varejo. Entre 1715 e 1722, o valor das últimas arrematações havia se estabilizado com um preço baixo de $\$ 320$ réis para a arroba de boi capado e de vaca, e de \$280 réis para o novilho. Durante a estiagem, os preços acabaram ficando em $\$ 400$ réis para a carne de 
boi capado e de vaca, e em $\$ 320$ réis para o novilho, não ultrapassando os valores praticados no início do século. Daí se observa que a redução no valor dos contratos que acompanhavam a queda da produção não era seguida por aumento do preço do retalho, confirmando a clara política da Câmara paraibana de conter um viés especulativo.

Mas as suspeitas da Coroa sobre descaminhos nessas arrematações do contrato não paravam. Afinal, mesmo dois anos após a estiagem, os preços não se recuperaram ${ }^{65}$ e, pelo contrário, entrava-se na década de trinta com os piores índices já experimentados. A intervenção da Coroa, em 1732, passando a prerrogativa do arremate do subsídio das carnes para a Fazenda Real - independentemente de se saber se houve ou não uma preocupação em manter um preço acessível para a população ${ }^{66}$-, não deixa dúvidas de que suas desconfianças com os descaminhos tinham fundamento. Neste sentido, o primeiro contrato sob o controle da Fazenda (1732-1733) já acrescentava algo em torno de quarenta por cento e comprovava que os anos anteriores estavam sendo sub-avaliados. É claro que esses valores pesaram positivamente para a Fazenda Real, principalmente como contraponto para os maus resultados das arrematações do subsídio do açúcar. Como já tivemos oportunidade de salientar, os valores da arrematação do subsídio da carne não entraram livremente na Fazenda, uma vez que as despesas da Câmara permaneciam e boa parcela desse contrato devia voltar para as suas mãos. Apesar dessa ressalva, pode-se perceber que o desempenho dos contratos das carnes, após 1732, demonstrou a vitalidade de uma economia endógena, a pecuária paraibana,

\footnotetext{
${ }^{65}$ Numa carta do juiz ordinário da Paraíba, Manuel Rodrigues Coelho, ao rei, em julho de 1729, havia a denúncia de que o governador João de Abreu Castel Branco, durante sua gestão nos anos vinte, tinha incorporado a prática de coibir ao "seu arbitrio" os contratadores do subsídio das carnes para que completasse o seu soldo. Talvez o motivo para esses baixos índices tivesse amparo nas suas ações, pois poderia afugentar possíveis contratadores. Cf: AHU_ACL_CU_014, Cx. 7, Doc. 600

${ }^{66}$ Se a Fazenda se preocupava com os preços da carne para a população, não sabemos, mas com a sua fiscalização o exemplo que segue é interessante. Corria o ano de 1742 quando o contratador das carnes, João da Silva Chaves, escrevendo ao rei, pedia para que o provedor da Fazenda da capitania fosse mais rigoroso com a fiscalização, evitando a venda de carne clandestina. $\mathrm{O}$ maior perigo, dizia, residia nos soldados e nos clérigos, pois como havia "abundância de gado," todos queriam cortar carne para "vender publicamente pelas ruas da cidade". Mas quem mais lhe importunava, continuava o contratador, era um clérigo de nome Pedro Tavares, morador na cidade, que saía às ruas "com dois negros incontinente a vender carne livremente". O castigo que pediu o contratador, ao rei, para o padre - já que o governador alegava ter força apenas sobre os soldados mas não sobre os clérigos, amparados em outra jurisdição - foi a adoção de um "violento remédio". Atendido o contratador, o padre foi expulso, ainda em 1742, para Pernambuco. AHU_ACL_CU_014, Cx. 11, Doc. 959. Sete anos depois, em 1749, o padre Pedro Tavares, se sentindo injustiçado, pedia ao governador da capitania da Paraíba Antônio Borges da Fonseca, poder retornar à Paraíba para reparar a situação em que se encontrava a sua casa. Cf:AHU_ACL_CU_014, Cx. 15, Doc. 1269.
} 
principalmente quando comparada com o desenvolvimento dos índices do contrato dos dízimos na capitania, como aparece no Quadro 6.

\section{QUADRO 6}

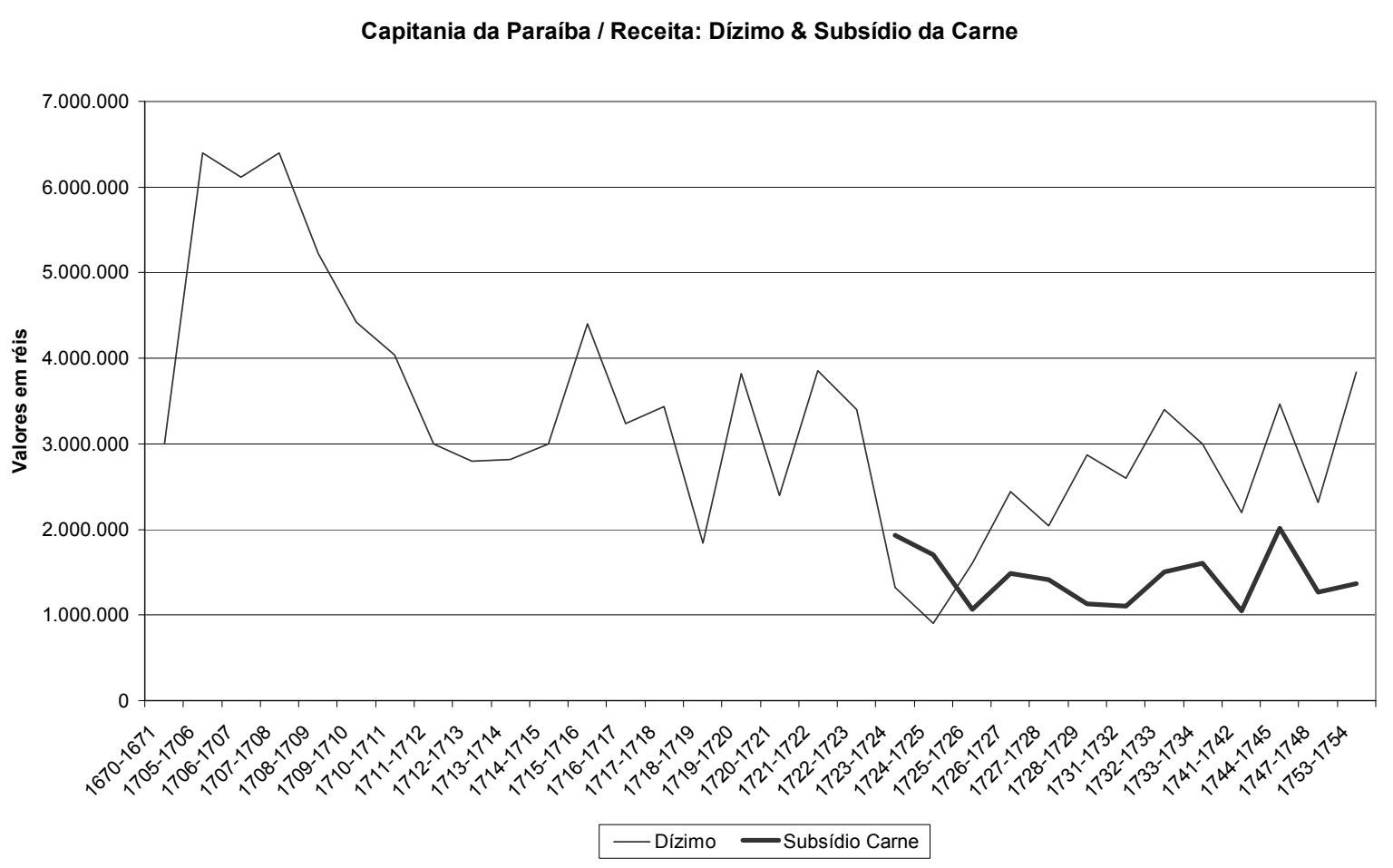

Fonte: Arquivo Histórico Ultramarino.

A partir de 1732, as oscilações correm quase que simultaneamente ligadas umas às outras, como pleno indicativo da importância que a atividade passa a desempenhar no cenário econômico nos últimos anos da segunda metade do XVIII. Essa importância não deve ser confundida com o aumento da produção do couro, que só seria experimentado no final do século. Apesar do couro, é o fornecimento da carne, como fonte de subsistência para o mercado interno, na medida em que é comercializado nas feiras da Paraíba, de Pernambuco e do Rio Grande, que influencia o traçado da linha.

A penetração da pecuária para no interior da capitania da Paraíba não promoveu apenas o desenvolvimento da sua economia, sendo também responsável pela geração da maior parte da mão-de-obra usada na própria pecuária e nas lavouras do litoral: os índios apresados na conquista do sertão. 
Durante o último quartel do século XVII, além dos muitos índios que ficavam nas mãos dos sertanistas, ou dos que iam reforçar a população das missões do interior, ${ }^{67}$ outros ficavam como prêmios ou pagamentos pelos serviços prestados aos soldados, que os vendiam aos senhores de engenho e lavradores do litoral. ${ }^{68}$ Mesmo antes dos combates encarniçados contra os índios, no processo de penetração da pecuária, foram protagonizadas algumas razias, tanto por João Fernandes Vieira, na época em que foi governador na Paraíba, 1655-1657, como por André Vidal de Negreiros. Sendo ambos restauradores, custearam tropas punitivas contra os potiguara e acabaram por trazer casais de índios, ainda brabos, do sertão paraibano, para sitiá-los em suas terras. ${ }^{69}$

Mas não eram apenas os índios existentes no interior que eram cobiçados. Os sobreviventes do litoral também atraíam o interesse dos produtores daquelas localidades. Em 1675, foi atendida uma representação do povo e dos oficiais da Câmara da Paraíba, que pediam ao rei para não se dividirem as três aldeias de "índios domésticos" do litoral - uma sob a administração dos beneditinos e outras duas sob a administração do soldado João Ribeiro. A alegação era de que os índios, através de jornais, atendiam às necessidades das obras da Fortaleza do Cabedelo e dos templos da cidade, do trabalho dos engenhos e lavouras, e até do corte de lenha e do serviço cotidiano. ${ }^{70}$

Assim, o trabalho do índio na capitania da Paraíba era disputadíssimo, com os exemplos se multiplicando com o passar do tempo. Em 1701, foi aprovado "o ato do

\footnotetext{
${ }^{67}$ Vale lembrar que as missões do interior da Paraíba como a do Boqueirão, transferida para Pilar em 1670, ou a dos Airús em Campina Grande, dos Coremas no Boqueirão do Piancó, dos Pegas na região do Piranhas e dos Icós no Rio do Peixe apesar de serem custeadas, como veremos, pela Fazenda da Paraíba, estavam subordinadas à Junta das Missões de Pernambuco. Vale acrescentar, todavia, que o quadro apresentado por Puntoni, sobre as missões no Nordeste, para o período (aproximado) do final do século XVII à segunda metade do século XVIII, grosso modo, lista 61 aldeamentos distribuídos da seguinte forma: Pernambuco, 12; Rio Grande, 9; Ceará, 3; Paraíba, 2; e 35 no sertão de dentro na Bahia. Cf: A guerra dos bárbaros. Povos indígenas e a colonização do sertão do Brasil, 1620-1720. Op. cit., p. 75

${ }^{68}$ Carta de D. Mathias da Cunha para o capitão-mor da Paraíba de 14 de março de 1688. Cf: Maria do Céu Medeiros \& Ariane Norma Meneses Sá. O trabalho na Paraiba: das origens à transição para o trabalho livre. João Pessoa: Editora Universitária UFPB/JP. p. 40

${ }^{69}$ Idem. Op.cit. p. 35

${ }^{70}$ AHU_ACL_CU_014, Cx. 1, Doc. 95. Segundo Medeiros, essa solicitação estava contemplada no Regimento das Missões de $1^{\circ}$ de dezembro de 1686, que "já havia procurado disciplinar essa busca do trabalho do índio no Pará e Maranhão. Como os problemas que procurava resolver eram os mesmos que ocorriam em outras regiões, logo o regimento se estendeu por toda a Colônia. Nele se estabelece, entre muitas outras medidas, a distribuição de indios em proporções iguais para o serviço das aldeias e dos moradores; o tempo que podiam ficar nas casas fora da aldeia (geralmente seis meses); o salário a receberem; a proibição de se retirarem indios das aldeias sem licenças das pessoas que estavam delegadas para o fazerem; a faixa etária dos índios de serviço, etc." Cf: Maria do Céu Medeiros \& Ariane Norma Meneses Sá. O trabalho na Paraiba... Op.cit. p. 41
} 
capitão-mor da Paraíba por não consentir que fossem tirados cinqüenta casais de índios de sua jurisdição, pelo governador dos índios, Sebastião Pinheiro Camarão, para fazer uma aldeia nas minas de salitre em Pernambuco" ${ }^{71}$. Em 1712, por “ordem do governo da capitania" foi ao sertão," à entrada de índios, o capitão Manoel da Cruz" ${ }^{72}$. Em 1716, as Câmara da Paraíba e Rio Grande solicitaram que a Repartição dos índios não ficasse apenas nas mãos dos missionários ou dos capitães-mores. Pediram que a responsabilidade fosse dividida entre a Câmara e os capitães, "porque aqueles [missionários] os tiram e os ocupam em suas fazendas e negociações, e estes [capitãesmores] talvez lhes dêem a quem mais lhes der",73. Por fim, em 1710, 1726, 1736 e 1753, os índios foram requisitados por governadores e Câmara para darem andamento às obras da Fortaleza do Cabedelo. ${ }^{74}$

Portanto, tanto particulares como o próprio governo da capitania, necessitavam do braço indígena, pela crucial razão de que lhes faltava cabedal para adquirir escravos provenientes do continente africano. Os números levantados sobre o direito real dos $3 \$ 500$ réis que se pagavam sobre os escravos provenientes da Costa da Mina, instituído em 1724, e dos dez ou doze tostões que se pagava por cada cabeça de escravo para a Fortaleza de Ajuda da mesma Costa da Mina, além de justificar a carestia dessa mão-deobra, trazem, por um lado, uma margem sobre os valores da arrecadação desse imposto e, por outro, uma dimensão acerca das formas de aquisição de escravos para a capitania da Paraíba.

\section{OS DIREITOS DOS IMPOSTOS REAIS SOBRE OS ESCRAVOS}

Segundo os senhores de engenho e lavradores de cana paraibanos, os preços excessivos praticados nas vendas dos cativos africanos se relacionavam com os mesmos rosários de problemas apresentados para a contenção do mercado do açúcar: a intervenção dos holandeses na África, a concorrência desleal dos mineiros e as

\footnotetext{
${ }^{71}$ Irineu Ferreira Pinto. Datas e notas para a história da Paraíba...Op.cit., p. 95

${ }^{72}$ Idem. Op.cit. p. 106

${ }^{73}$ AHU ACL CU 014, Cx. 5, Doc. 355.

${ }^{74}$ AHU_ACL_CU_014, Cx. 4, Doc. 303; Cx. 6, Doc. 525; Cx. 10, Doc. 811; e Cx.17. Doc. 1369.
} 
calamidades naturais. Em função disso, algumas tentativas foram postas em prática para, se não sanarem, ao menos amenizarem a carência de escravos na capitania.

Em 1710, estimava-se que a Paraíba estaria bem servida de escravos, caso se introduzissem entre 200 a 300 negros por ano. ${ }^{75}$ Durante a imensa mortandade de escravos, em virtude da grande seca da década de vinte, houve quem sublinhasse a necessidade de se transportar de 800 a 1000 escravos da África. ${ }^{76}$ A saída, como queriam os senhores, se pautava no socorro pela Fazenda, que deveria antecipar o valor da compra dos escravos para se abater apenas da produção - conforme se fazia com suas dívidas, ou seja, interpor moratórias. ${ }^{77}$ Para a Coroa, em contrapartida, a solução era dar liberdade para os paraibanos se organizarem em companhias, com mais pessoas interessadas no tráfico e em fazerem comércio na Costa da Mina e em Angola.

Mas, não afeitos ao comércio de risco, os senhores de engenho e lavradores da Paraíba relutavam em participar dessas empreitadas, na forma como queria a Coroa, como mostra o comentário de João Maia da Gama:

No ano de 1714 fiz armar um patacho e são tão miseráveis estes homens que somente um lavrador embarcou nele rolos de fumo e nenhum senhor de engenho; e foi só com carga de particulares desta cidade [isto é, não oficiais] e de outros da capitania de Goiana e minha, que também entrei no patacho e carga para os animar, e chegando o patacho com sucesso, gastando apenas quatro meses de ida e volta, trazendo 170 escravos, não houve senhor de engenho que comprasse nenhum. E animados com o sucesso se aparelharam para a segunda viagem, sem que estes inúteis e miseráveis senhores de engenho embarcassem coisa alguma; na segunda, o dito

\footnotetext{
${ }^{75}$ AHU ACL CU 014, Cx. 5, Doc. 360.

${ }^{76} \mathrm{AHU}^{-} \mathrm{ACL}{ }^{-} \mathrm{CU}^{-}$014, Cx. 6, Doc. 452.

${ }^{77}$ Isto já havia sido tentado em 1710 e, como a experiência não resultara a contento, talvez por conta das moratórias das dívidas dos senhores de engenho, a Coroa se negou em 1717 a tomar parte nesta proposta de antecipação. Cf: AHU_ACL_CU_014, Cx. 5, Doc. 360.
} 
patacho recolheu 270 cabeças por lhe morrerem 80; e nem com este segundo serviço se animaram os senhores de engenho. ${ }^{78}$

A adjetivação de miseráveis ressalta a mesquinhez dos senhores de engenho e lavradores da terra, principalmente quando associada à insinuação de inutilidade. Entretanto, é no fato dessas pessoas serem despossuídas, que se deve buscar, fundamentalmente, a explicação para seus atos em relação à aquisição de escravos.

Freqüentemente, a falta de cabedal dos senhores, para a aquisição dos escravos, colocava-se como um empecilho. Nos momentos mais fáceis para compra, quando havia o confisco de carga e a Fazenda colocava os escravos para vender a 97\$000 réis (normalmente o valor chegava a $120 \$ 000$ réis), diziam os senhores que o preço era excessivo. ${ }^{79}$ Para se livrarem da situação de penúria, como as experimentadas nas estiagens e alcançarem o número necessário de escravos para a lavoura e as fábricas, os senhores paraibanos chegavam a propor planos quiméricos ${ }^{80}$. Um deles, foi o de quererem saldar a compra de escravos em quatro ou cinco anos do açúcar produzido, além de ditarem o preço da venda, que deveria ficar na casa dos noventa a cem mil réis. ${ }^{81}$ Em março de 1726, Luiz Pires dos Santos, procurador da Fazenda Real, tentou colocar os pés dos senhores paraibanos sobre a terra:

Este negócio me parece tão dificultoso negociar-se

(...) por que, quem haverá de levar escravos para a

\footnotetext{
${ }^{78}$ AHU_ACL_CU_014, Cx. 5, Doc. 360.

79 AHU ACL CU 014, Cx. 5, Doc. 410.

${ }^{80}$ É interessante destacar a construção que faz Schwartz sobre a visão utópica dos senhores de engenho e lavradores de cana. "Sua idéia de utopia era um mundo onde impostos e tarifas governamentais fossem baixos ou inexistentes, onde houvesse sempre um grande número de navios para transportar o açúcar, de modo a reduzir os custos de frete, e onde fosse constante, de boa qualidade e com grande volume a oferta de mão-de-obra africana, para que os custos dessa mão-de-obra permanecessem baixos. Mercadores $e$ agentes comerciais neste mundo imaginário, participam como um mal necessário, para fornecer capital e crédito, mas os senhores de engenho sonhavam com uma moratória das dividas em tempos difíceis ou, pelo menos, com uma limitação da capacidade dos comerciantes de executar dívidas em atraso. Essencialmente sonhavam com custos e impostos baixos, crédito fácil e juros reduzidos e preços altos para o seu produto ... A política dos senhores de engenho, se é que se pode falar em tal coisa, era organizada em função desses temas, e qualquer piora nas condições acarretava freqüentemente uma intensificação de seus apelos e demandas.” Stuart Schwartz. Segredos internos: engenhos e escravos na sociedade colonial... Op.cit. p. 170.

${ }^{81}$ AHU_ACL_CU_014, Cx. 6, Doc. 520.
} 
Paraíba para os venderem pelos preços que os compradores arbitrarem e para os pagarem com seus frutos quando os quiserem (...) se do porto de Pernambuco (aquele donde se provem os moradores da Paraíba) vão todos os anos mil e quinhentos escravos (ou mais) para as Minas, por mar ou terra, destes podem os suplicantes comprar o que quiserem assim como o fazem os moradores da Bahia e Rio de Janeiro, que se submetem a pagar pelo que valem. Quanto que tenho notícias que na Paraiba há duas sumacas que navegam para a Costa da Mina armada pelos moradores da mesma terra, e me dizem que os escravos que os vão levar para a Bahia e Rio de Janeiro a buscar maior lucro. Pois se os moradores da terra vão buscar sua conveniência aonde lhes parece que haverá, quem vai levar escravos a Paraiba pelo preço que oferecem ? ${ }^{82}$

Como era de se esperar, o plano para a compra de escravos, com as facilidades sugeridas pelos produtores paraibanos, foi recusado pelo Conselho Ultramarino. E, mais uma vez, a Coroa propôs que se organizasse uma companhia composta por "senhores de engenho, lavradores de partidos deles e moradores mais principais da capitania" ${ }^{83}$, a exemplo daquela patrocinada por João Maia da Gama.

$\mathrm{Na}$ verdade, mesmo com as evasivas dos senhores de engenho, os contatos com a Costa da Mina não cessaram. Mesmo durante a estiagem, alguns escravos entraram na

\footnotetext{
${ }^{82}$ AHU ACL CU 014, Cx. 6, Doc. 506.

${ }^{83}$ A resposta da Coroa, datada de 02 de maio de 1726, dizia "ser inconcebivel nesta parte o que propondes, deveis conferir com os oficiais da Câmara, se há nessa capitania senhores de engenho, lavradores de partidos deles, moradores mais principais se lhe oferecem algum meio para que possam ter alguma embarcação própria para irem a Costa da Mina e Angola, a transportarem escravos para este porto. Lucrando por este caminho os interesses que este negócio pode dar e terem os que forem necessários para as culturas de suas terras, porque de outra maneira não será fácil, que o que tratarem semelhante comércio, vão vendê-los por um preço tão inferior no tempo presente e com pagamento tão prolongados." Cf: IHGP/PB; Ordens Régias: Códice 1720 - 1732 / Doc. 123.
} 
capitania: por volta de 140 , em 1724; e 50, em $1725 .{ }^{84}$ Apesar de pequenos, estes números comprovam a existência de uma atividade que envolvia Mathias Soares Taveira, dono do patacho, alguns comerciantes paraibanos e produtores de tabaco de Goiana. ${ }^{85}$ Talvez a razão para os senhores e lavradores paraibanos recusarem a proposta da Coroa estivesse aí. Eles não aceitavam que os comerciantes de Goiana, envolvidos nesse tráfico, fossem seus financistas e credores - afinal, possivelmente, eram esses comerciantes também seus credores em outras atividades. Contudo, a situação não colocava outra alternativa para eles.

A resposta do procurador da Fazenda tornava claro para onde seguia a maior parte dos escravos que chegavam à Alfândega da Paraíba - Bahia e Minas $^{86}$ - e responsabilizava os próprios moradores da capitania pelo vexame por que passavam. A participação no comércio de escravos, correndo os riscos no Atlântico, foi a única saída que restou para os produtores da terra. Sua entrada no tráfico foi feita ainda sob o manto protetor da Coroa, quando o rei baixou um alvará, em 1728, permitindo aos senhores de engenho e lavradores de cana produzirem tabaco em suas propriedades, sem os gastos finais dos exames, deixando-os livres para a prática do comércio com a Costa da Mina. Tal medida, pode-se supor, também visava afastar os produtores de tabaco de Goiana do tráfico e garantir maior rentabilidade aos paraibanos. ${ }^{87}$ Observando o Quadro 7, sobre as receitas dos escravos, pode-se percebe que essa medida realmente surtiu pouco efeito. Mesmo sabendo que nem todos os escravos enviados para a Paraíba permaneceram na atividade açucareira, indo para as Minas ou desviando-se para a pecuária no interior da

\footnotetext{
${ }^{84}$ Ver tabela Receita: Imposto dos $3 \$ 500$ réis que pagam os escravos provenientes da Mina e dos 12 tostões para a feitoria de Ajuda (QUADRO 7).

${ }^{85}$ Além da referência que fez João da Gama, sobre a presença de gente da cidade de Goiana na empreitada de 1714, outros momentos também enfáticos revelam alguns contatos: em 1722, a Câmara da Paraíba propõe que o tabaco de Goiana passe a ser escoado pelo porto da capitania da Paraíba; em 1725, o governador João de Abreu Castel Branco, demonstra sua satisfação em poder levar para a Paraíba Antônio Monteiro, morador de Goiana, pois era o mesmo homem de posses, com três embarcações, e que podia levar escravos e investir na cultura do tabaco na capitania, mas, quando este vira a esterilidade da terra, naquele ano, se retirara. Cf: AHU_ACL_CU_014, Cx. 6, Doc. 458. O Tribunal da Junta de Administração do Tabaco, em 1727, informava ao rei que o patacho de Mathias Soares Taveira (um dos dois patachos que faziam o tráfico no porto da Paraíba), fôra avistado negociando com produtores de tabaco em Goiana, sem que fizesse exame em presença do superintendente do tabaco, que era o ouvidor da capitania da Paraíba. Cf: IHGP / Ordens Régias: Códice: 1720 - 1732. Doc. 162.

${ }^{86}$ Não todos, mas parte deles. O próprio João da Gama, por volta de 1720, escrevia a Coroa solicitando passar seus escravos e todo seu açúcar para Pernambuco, pois os havia deixado em um engenho na Paraíba. Cf: AHU_ACL_CU_014, Cx. 5, Doc. 372.

${ }^{87}$ AHU_ACL_CU_014, Cx. 8, Doc. 661.
} 
capitania, que crescia no momento, os registros de entrada melhoram a partir de 17251726, com uma forte expansão em 1726-1727. ${ }^{88}$

\section{Quadro 7}

Capitania da Paraíba / Receita: Imposto dos $3 \$ 500$ réis que pagam os escravos provenientes da Mina e dos 12 tostões para a feitoria de Ajuda

\begin{tabular}{|l|l|l|l|}
\hline ANOS & Imposto sobre a entrada 3\$500 & $\begin{array}{l}\text { Feitoria de Ajuda: } 1 \$ 000 \\
\text { ou } 1 \$ 200\end{array}$ & $\begin{array}{l}\text { Números de entrada } \\
\text { de escravos* }\end{array}$ \\
\hline 1714 & $=$ & $=$ & 170 \\
\hline 1715 & $=$ & $=$ & 270 \\
\hline $1723-1724$ & $464 \$ 082$ & $=$ & 140 \\
\hline $1724-1725$ & $172 \$ 375$ & $=$ & 50 \\
\hline $1725-1726$ & $871 \$ 500$ & $298 \$ 800(12$ tostões $)$ & 249 \\
\hline $1726-1727$ & $2: 791 \$ 600$ & $482 \$ 400(12$ tostões $)$ & 797,6 ou 402 \\
\hline $1727-1728$ & $566 \$ 000$ & $91 \$ 200(12$ tostões $)$ & 161,7 ou 76 \\
\hline $1728-1729$ & $402 \$ 000$ & $=$ & 114,8 \\
\hline $1731-1732$ & $=$ & $112 \$ 000(12$ tostões $)$ & 94 \\
\hline $1732-1733$ & $883 \$ 600$ & $200 \$ 000(10$ tostões $)$ & 252,4 ou 200 \\
\hline $1733-1734$ & $=$ & $114 \$ 000(10$ tostões $)$ & 114 \\
\hline $1736-1737$ & $=$ & $214 \$ 000(10$ tostões $)$ & 214 \\
\hline $1739-1741$ & $=$ & $481 \$ 000(10$ tostões $)$ & 481 \\
\hline $1744-1745$ & $717 \$ 000$ & $=$ & 204,8 \\
\hline $1745-1746$ & $=$ & $182 \$ 000(10$ tostões $)$ & 182 \\
\hline $1747-1748$ & $2: 409 \$ 920$ & $=$ & 688,5 \\
\hline $1753-1754$ & $1: 968 \$ 030$ & $=$ & 562,2 \\
\hline
\end{tabular}

\section{Fonte: Arquivo Histórico Ultramarino}

* Os números de entrada dos escravos apresentam muitas discrepâncias. Para alcançá-los, dividiu-se o valor do imposto pelo montante arrecadado. Apenas no ano de 1723-24 e 1725-26 as contas foram apresentadas integralmente pelos almoxarifes, dada a necessidade de se restituirem os valores pagos à maior pelos capitães dos navios, por terem sido cobrados erradamente doze e não dez tostões. Cf: AHU_ACL_CU_014, Cx. 9, Doc. 783 e 784.

Essa euforia foi barrada já no ano de 1729, quando uma nova lei, de 15 de março, determinou que, além de "se proibir a freqüente extração de ouro, moeda e tabaco fino" para comércio na Costa da Mina com os holandeses, se deveria também observar o "número de escravos que é possível à arqueação dos navios ... pois precisariam eles navegar com armamento de guerra ." ${ }^{89}$ Como revelou o governador Francisco Gorjão ao

\footnotetext{
${ }^{88}$ AHU_ACL_CU_014, Cx. 8, Doc. 661. Registre-se que a intensidade do tráfico entre capitanias acabou por favorecer a criação de mais um imposto em 1725: o Imposto de $4 \$ 500$ réis por cabeça de escravo transportado de Pernambuco, Paraíba e anexas para a Bahia, Rio de Janeiro e Minas.

${ }^{89}$ AHU_ACL_CU_014, Cx. 8, Doc. 661. Segundo Boxer, “depois que os holandeses terem expulsado os portugueses dos fortes da Costa do Ouro em 1637-42, estes últimos mantiveram interesses limitados nessas regioos apenas durante algumas décadas. Contudo, os holandeses descobriram por excelência própria que os negros preferiam tabaco brasileiro da Bahia [de terceira categoria] a qualquer outro tipo de produtos comerciais. Permitiam portanto que os comerciantes que traziam tabaco da Bahia comprassem escravos em quatro portos ao longo do território que é hoje a costa do Daomé e que então era denominada a Costa
} 
rei, se os homens da capitania da Paraíba observassem a ordem e armassem os patachos com "espingardas, pólvoras e peças de artilharia”, não sobraria espaço para o transporte dos escravos e "seria a ruína da fábrica dos engenhos e da planta do tabaco que não havendo embarcações para a Costa não cultivará nenhum, pois a má qualidade dele faz não ter saída para outra parte". 90 Passado, o ano de 1730 sem transporte para a Costa da Mina, retomou-se a atividade de 1731 a 1736 e adentrou-se a década de 40 com as repetidas proibições da Coroa e do vice-rei. ${ }^{91}$ Como se observa entre os anos de 1742 a 1753, o transporte permaneceu de forma esporádica e casual.

Exemplos da intermitência da atividade do tráfico na Paraíba, são descritos em flashes dos registros de receitas e despesas enviadas para o Reino, quando se ressaltava a incerteza de se poder contar com os dois patachos para as viagens à Costa da Mina ${ }^{92}$. Tais exemplos apareciam também em pedidos de governadores para participarem desse tipo de comércio, com apelos de graça especial à Sua Majestade, como fez o governador Pedro Monteiro de Macedo, em 1736:

... e ouço dizer que os meus antecessores alcançaram licença de vossa majestade para mandar alguns rolos de tabaco para a Costa da Mina, que é o único negócio por que se trocam, e me pareceu pedir também licença de vossa majestade para quando se oferecer ocasião ${ }^{93}$.

\footnotetext{
dos Escravos: Grand, Popo, Whydah (Ajuda), Jaquim e Apa." Mas depois das descobertas das Minas, o processo se inverteu, e durante as primeiras décadas do século XVIII, o ouro em pó passou a ser contrabandeado por traficantes de escravos, juntamente com o tabaco de terceira, "apesar de todos os esforços feitos pelo governo da metrópole e pelas autoridades locais para porem termo a esta fuga e para limitarem a exportação comercial do tabaco.” Cf: C. R. Boxer. O Império colonial português. Textos de cultura portuguesa. Lisboa: Edições 70, 1969. Op.cit.,p.196-197. Creio que o tabaco de terceira levado para o comércio do tráfico da Costa da Mina tenha recebido a alcunha de tabaco da Bahia, apesar de não serem apenas comerciantes baianos que freqüentaram a região.

${ }^{90}$ AHU_ACL_CU_014, Cx. 8, Doc. 661.

${ }^{91}$ Em setembro de 1743 , quando da solicitação da Câmara da Paraíba para organização de uma companhia, o parecer do Conselho Ultramarino se colocava contrário a mais uma licença pois "se acha inobservável [diante] da resolução de V. Majestade, de 23 de março próximo passado [1742]". Cf: AHU_ACL_CU_014, Cx12. Doc. 1002.

${ }^{22}$ AHU_ACL_CU_014, Cx. 14, Doc. 1161; Cx. 15 Doc. 1258; e AHU / Códice 1805 / Relação Geral dos Contratos que se administram pela Fazenda Real da Paraíba - 1731-1733.

${ }^{93}$ AHU ACL CU 014, Cx. 10, Doc. 796.
} 
Levando em conta a liberdade concedida pela ordem de 1728, é possível que a atividade do tráfico possa ser uma chave para explicar como os senhores de engenho e os lavradores de cana paraibanos conseguiam os créditos e insumos necessários para manterem e reproduzirem, mesmo que no limite, a economia açucareira. ${ }^{94}$ Mas tais créditos não chegaram a enriquecer a parcela de moradores envolvidos na atividade haja vista a simplicidade dos altares das igrejas e da própria construção civil da capitania - ou a monetarizar a economia. Assim, não fizeram jus à desconfiança da Coroa sobre o uso de moedas de ouro ou de ouro em pó, pelos moradores da Paraíba, quer na aquisição de escravos na Costa da Mina quer na sua venda aos mineiros nos portos Brasil. Como explicou Francisco Gurjão:

Ainda que desta capitania [os moradores] quisessem [levar] para as partes da Mina ouro ou moeda o não podiam fazer, porque nela não há outro negócio senão o de açúcar e por este respeito não vem a esta [capitania] embarcações da Bahia ou Rio de Janeiro, nem da mesma costa vem escravos que os mineiros venham comprar, que é por este caminho que se pode entrar ouro ou moeda, e assim posso afirmar a V. Majestade que não levam ouro nem moedas as [duas] sumacas que deste porto navegam para a Costa da Mina. ${ }^{95}$

Moedas de ouro ou cobre eram difíceis de se encontrar na Paraíba. Havia reclamações sobre isso nos pagamentos das folhas de pessoal e nos valores que estava a

\footnotetext{
${ }^{94}$ Não há indícios, nas fontes consultadas, de que a liberdade concedida aos senhores de engenho e lavradores de cana paraibanos, para a prática livre da plantação e colhimento do tabaco, tenha influenciado na diminuição da produção açucareira.

${ }^{95}$ AHU ACL CU 014, Cx. 8, Doc. 661. Devido a semelhança entre a sumaca e o patacho (a sumaca era de menor mastreação), aparecem nos documentos as duas referências. "A sumaca, embora sendo um barco pequeno, parece ter tido algum papel no tráfego de longo curso.No século XVII é, em geral, um navio holandês. No Brasil, no final do século XVII e no XVIII, parece especializado no transporte de tabaco... O patacho é um pequeno navio de transporte com dois mastros, e de uma centena de toneladas. É muitas vezes holandês." Cf: Frédéric Mauro. Portugal o Brasil e o Atlântico( 1570 - 1670). Lisboa: Imprensa Universitária / Editorial Estampa, 1979.p.67
} 
Provedoria obrigada a mandar para Lisboa, como no pagamento dos livros ou nas comissões dos conselheiros, pois todos queriam em dinheiro de contado. ${ }^{96}$ Para dar cabo das necessidades do comércio miúdo, pagamento da Infantaria e dos pobres mendicantes, a Fazenda Real da capitania comprava remessas de moedas de cobre do Reino. ${ }^{97}$

Voltando aos impostos sobre direitos dos escravos, é importante ressaltar que eles eram arrematados apenas no Conselho Ultramarino, pois não se limitavam a uma única capitania. Com efeito, os impostos de entrada dos escravos importados da região da Mina (os $3 \$ 500$ réis e os 10 ou 12 tostões) ${ }^{98}$, assim como os que pesavam sobre os escravos exportados internamente para a região das Minas Gerais (os 4\$500 réis), cobriam toda a grande área das Capitanias do Norte.

Desta forma, afora algumas notícias sobre a presença de mineiros para comprar escravos na Paraíba, nada existe sobre os valores dessa arrecadação em solo paraibano que vá além do valor do contrato orçado em seis contos de réis por ano, e que foi arrematado por Jerônimo Lobo Guimarães, no Conselho Ultramarino, em 1725. ${ }^{99}$ Quanto à arrecadação dos direitos de entrada, o Quadro 7 mostra que os valores arrecadados na Alfândega paraibana permaneceram na capitania. Sobre isso falou o provedor Fernandes Temudo:

A aplicação primeira que tem os direitos dos escravos (não falando nos dez tostões de Ajuda) é para as côngruas da Sé de São Tomé, e quando lá se despacham ou na Ilha do Príncipe ficam logo lá os tais direitos, e não despachando lá, mas sim neste Brasil, vem letras para serem remetidas tais direitos a São Tomé se bem que tarde ou nunca lá chegam a

\footnotetext{
${ }^{96}$ Em 1725 e 1726, Salvador Quaresma Dourado, provedor da capitania, reclamava dizendo que os homens de negócios da capitania escondiam as poucas moedas de ouro que havia para a sua correspondência e, por isso, faria o pagamento dos livros em açúcar fino, no valor de 32\$000 réis. Cf: AHU_ACL_CU_014, Cx. 6, Doc. 462 e 533 .

${ }_{97}$ A reclamação também para a falta de moedas na Paraíba, segundo a Câmara Municipal, era a preferência dos moradores pelo comércio da praça do Recife. AHU ACL CU 014, Cx. 12, Doc. 1002.

${ }^{98}$ A mudança de 12 tostões (1\$200 réis) para 10 tostões (1\$000 réis) deveu-se à correção de um erro do escrivão que só foi reparado em 21 de agosto de 1728. A cobrança feita à maior foi mandada restituir aos capitães dos navios que a requeressem. Cf: AHU_ACL_CU_014, Cx. 9, Docs. 743; 783; e 784.

${ }^{99}$ AHU_ACL_CU_014, Cx. 6, Doc. 438 e 444.
} 
ir, por se consumirem nas necessidades desta Paraíba, tanto para fortificações como para os filhos da folha, a que não chegam as mais consignações. ${ }^{100}$

O imposto de $3 \$ 500$ réis por cabeça de escravo, que serviu para a côngrua da Sé de São Tomé, foi criado em 1723 e arrematado, pela primeira vez, no Conselho Ultramarino, em 1724, por Manuel Correia Bandeira, por 18:100\$000 réis ao ano, durante três anos. No primeiro ano, ao ser notificado de que não poderia ter mais um contrato pois já possuía outros dois, Manuel Bandeira pediu que lhe tomassem a quarta parte de sua fiança, já que não havia recebido dinheiro algum. Esse senhor possuía os contratos dos doze tostões de entrada de escravos para Pernambuco, Paraíba e anexas, como o contrato dos direitos aplicados à Guarda Costa do Rio de Janeiro. ${ }^{101}$

O imposto dos doze tostões, por conseguinte, criado pela Coroa em 1721, foi revisto em 1728, quando passou para os dez tostões. Esse imposto, que serviu para a manutenção do forte São João Batista de Ajuda, fundado em 1680, no território de Daomé, ${ }^{102}$ seguiu o mesmo destino dos $3 \$ 500$ réis, ou seja, fazer frente às despesas da Provedoria da Fazenda Real da Paraíba. Mas isso não ocorreu somente com a arrecadação dos impostos sobre o transporte de cativos. Como foi visto, parcelas da arrecadação de outros órgãos, como, por exemplo, a Câmara Municipal, passaram também a contar com o controle da Fazenda Real. Por fim, nesse rol de impostos destinados a atender a necessidades de órgãos distintos, mas que foi sendo vinculado à Fazenda, há de se introduzir mais um: os novos direitos.

\footnotetext{
${ }^{100}$ AHU_ACL_CU_014, Cx. 15, Doc. 1258.

${ }^{101}$ AHU_ACL_CU_014, Cx. 6, Doc. 431. Não temos mais informações sobre se este contrato voltou a ser arrematado no Conselho. Ao que parece, ficou mesmo sendo administrado pela Fazenda Real da Paraíba.

102 Já falamos mais acima que este contrato tinha como arrematador Manuel Correia Bandeira. Infelizmente não dispomos dos valores dessa arrematação, da mesma forma que não temos conhecimento se este contrato tornou a ser arrematado. Cf: AHU_ACL_CU_014, Cx. 6, Doc. 431; Cx. 14, Doc.1161.
} 


\section{OS NOVOS DIREITOS}

Criado em 1692, os chamados novos direitos, era uma taxa anual fixada em 10\% sobre os rendimentos dos oficiais, com o objetivo de custear as despesas da Justiça. . ${ }^{103}$ Devia ser recolhido pela chancelaria no Reino, ou pelas ouvidorias nas capitanias. Em 1723, sob a anuência das ouvidorias e tendo em vista o grande número de cargos vagos no ultramar, a Coroa ampliou em um terço o valor a ser pago pelos novos direitos, mas permitiu que qualquer pessoa considerada idônea ocupasse os cargos sem proprietários. Três anos mais tarde, em 1726, por pressão das câmaras e dos oficiais da administração, a cobrança dos novos direitos sofreu uma dupla mudança. Em primeiro lugar, o imposto foi restringido a quem percebesse mais de duzentos mil réis anuais. Além disso, com o intuito de diminuir as evasões das taxas, o pagamento foi dividido em parcelas semestrais, ao invés de ocorrer no final do ano. ${ }^{104}$

Essas mudanças, de início restritas ao Rio de Janeiro e Minas, somente passaram a ter validade na Paraíba através de uma ordem real, datada de 12 de maio de $1727 .{ }^{105}$ Passados mais cinco anos, no entanto, e seguindo a mesma orientação de centralização de toda a receita da capitania para a Fazenda Real, o controle do rendimento dos novos direitos transitou da ouvidoria para as mãos do provedor, em 1732. ${ }^{106}$

Os valores da arrecadação dos novos direitos da capitania da Paraíba foram inexpressivos, uma vez que os ordenados, mesmo quando acompanhados dos seus prós e percalços, dificilmente chegavam a ultrapassar o limite dos duzentos mil réis. ${ }^{107}$ Como

\footnotetext{
${ }^{103}$ Cf: AHU_ACL_CU_014, Cx. ,7 Doc. 570.

${ }^{104}$ Daruil Alden. Royal government in colonial Brasil With special reference to the administration of the Marquis of Lavradio, viceroy, 1769 - 1779... p. 296-297.

105 "Esta resolução se deve também estender com aqueles oficios que de sua natureza nunca se serviram de propriedades, que costumam ser trienais, como são secretários de governo das ditas capitanias, almoxarife da Fazenda Real, serviçais dos mesmos almoxarifes e outras semelhantes”. Ordens Régias / IHGPPB / Códice 1720 - 1732; Doc. 139.

${ }^{106}$ Ordem de sua majestade, de 9 de setembro de 1732, pela qual se manda aplicarem os novos direitos para o pagamento dos ouvidores gerais dessa capitania. AHU / Códice 1805 / Relação Geral dos Contratos que se administram pela Fazenda Real da Paraíba,1731-1733. p. 50. Anos antes, contudo, em 1724, o provedor da Fazenda, Salvador Dourado, solicitou ao rei e foi atendido, quando reivindicou lançar mão dos novos direitos para socorro dos filhos da folha. Na oportunidade, renderam os novos direitos renderam para a Fazenda, 414\$380 réis. AHU / Códice 1805 / Relação Geral dos Contratos que se administram pela Fazenda Real da Paraíba - 1731-1733.

${ }^{107}$ Em 1741, a solicitação feita pela Coroa para que a Câmara da Paraíba indicasse três pessoas para que fizessem, com a maior isenção, uma avaliação de todos os ofícios existentes na capitania, para o pagamento dos novos direitos, teve como resultado a negativa para praticamente todos os ofícios, ou seja, tirante o
} 
resultado, o repasse "de muitos anos quando corria pela ouvidoria", contabilizado na receita de 1732-1733, alcançou o valor de 1:033\$685 réis ${ }^{108}$. Além disso, foram conseguidas apenas mais três receitas: $151 \$ 950$ réis para os anos de $1739-1741^{109}$, $321 \$ 260$ réis para o ano de $1744-1745$, e de apenas $141 \$ 620$ réis para o ano 17531754. ${ }^{110}$

No fim das contas, todos esses impostos incluindo: dízimo, subsídio do açúcar, cruzados das caixas, subsídio da carne, transporte de cativos e os novos direitos, dificilmente chegavam para cobrir as despesas de pessoal. Afora a primeira década do século XVIII, quando o dízimo foi sustentado pela vantajosa performance da produção e do comércio do açúcar, praticamente todo o restante dos outros anos foram foi de déficit, com a dívida se transportando de um ano mal sucedido a outro. Dessa forma, a precariedade das rendas da Fazenda Real paraibana pedia um aporte externo de peso, como foi a garantia da arrematação da dízima da Alfândega de Pernambuco e Paraíba em um só contrato.

\section{A DÍZIMA}

$\mathrm{Na}$ Paraíba, o recolhimento da dízima - imposto que correspondia à cobrança de $10 \%$ dos bens importados - foi instituído em 1711. Em 1723, por decreto real, foi mandado que se fizesse a sua arrematação junto com a dízima de Pernambuco. Independentemente do valor alcançado na arrematação, a provedoria pernambucana devia remeter, anualmente, vinte mil cruzados - oito contos de réis - para a congênere paraibana. As discussões sobre essa ordem e seus desdobramentos para a relação das duas capitanias, constituem preocupações do próximo capítulo. Por ora, nos limitaremos a apresentar os valores dessas remessas, com o cuidado de esclarecer o que caberia a uma e outra Alfândega. Isso é importante porque, apesar das arrematações serem feitas em

ordenado do ouvidor, todos os outros não alcançavam os 200\$000. Cf: AHU_ACL_CU_014, Cx. 11, Doc. 936.

108 AHU / Códice 1805 / Relação Geral dos Contratos que se administram pela Fazenda Real da Paraíba,1731-1733.

${ }^{109}$ AHU ACL CU 014, Cx. 11, Doc. 939.

${ }^{110}$ AHU_ACL_CU_014, Cx. 16, Doc. 1434. 
conjunto, as Fazendas permaneciam autônomas, inclusive com o arrematador do contrato sendo obrigado a pagar propinas aos oficiais das duas capitanias. ${ }^{111}$

\section{QUADRO 8}

Capitania da Paraíba: Receita / Recolhimento da Dízima

\begin{tabular}{|c|c|c|c|}
\hline Ano & Alfândega da Paraíba & Alfândega de Pernambuco & Total \\
\hline $1725-1726$ & $979 \$ 637$ & & $979 \$ 637$ \\
\hline $1726-1727$ & $465 \$ 377$ & $8: 500 \$ 000$ & $8: 965 \$ 377$ \\
\hline $1727-1728$ & & $6: 520 \$ 360$ & $6: 520 \$ 360$ \\
\hline $1728-1729$ & $980 \$ 199$ & $7: 534 \$ 623$ & $8: 514 \$ 822$ \\
\hline $1729-1730$ & $372 \$ 802$ & $5: 915 \$ 738$ & $6: 288 \$ 540$ \\
\hline $1730-1731$ & $440 \$ 106$ & $1: 600 \$ 000$ & $2: 040 \$ 106$ \\
\hline $1731-1732$ & $107 \$ 068$ & $8: 000 \$ 000$ & $8: 107 \$ 068$ \\
\hline $1732-1733$ & $1: 092 \$ 068$ & $8: 000 \$ 000$ & $9: 092 \$ 068$ \\
\hline $1733-1734$ & $1: 756 \$ 826$ & $7: 552 \$ 340$ & $9: 309 \$ 166$ \\
\hline $1734-1735$ & & $8: 967 \$ 490$ & $8: 967 \$ 490$ \\
\hline $1735-1736$ & & $1: 394 \$ 888$ & $1: 394 \$ 888$ \\
\hline $1736-1737$ & & $4: 800 \$ 000$ & $4: 800 \$ 000$ \\
\hline $1737-1739$ & & $2: 446 \$ 000$ & $2: 446 \$ 000$ \\
\hline $1739-1741$ & & $15: 727 \$ 170$ & $15: 727 \$ 170$ \\
\hline $1741-1742$ & $2: 343 \$ 056$ & 11:600\$000 & $13: 943 \$ 056$ \\
\hline $1742-1743$ & & $545 \$ 473$ & $545 \$ 473$ \\
\hline $1743-1744$ & & $44 \$ 800$ & $44 \$ 800$ \\
\hline $1744-1745$ & & 3:601\$094 & $3: 601 \$ 094$ \\
\hline $1745-1750$ & $2: 501 \$ 060$ & $4: 878 \$ 660$ & $7: 379 \$ 720$ \\
\hline $1750-1751$ & & $355 \$ 440$ & $355 \$ 440$ \\
\hline $1751-1753$ & & $16: 350 \$ 115$ & $16: 350 \$ 115$ \\
\hline $1753-1754$ & $2: 055 \$ 915$ & $4: 623 \$ 230$ & $6: 679 \$ 145$ \\
\hline Total & $13: 094 \$ 114$ & $126: 614 \$ 365$ & $139: 708 \$ 879$ \\
\hline
\end{tabular}

\section{Fonte: Arquivo Histórico Ultramarino}

Os valores apresentados no Quadro 8 mostram que, em comparação com as outras receitas da capitania da Paraíba, o aporte externo era expressivo. Todavia, há de se considerar que, em alguns anos, não só os valores não eram repassados, como não alcançavam o pretendido, 8:000\$000 réis. Assim, mesmo que, em determinados momentos, os provedores da Paraíba reconhecessem algum esforço em ajustar a conta,

\footnotetext{
111 Ao tomar conhecimento de uma ordem de 1754, que mandava passar a arrematação das dízimas das capitanias da Paraíba e Pernambuco para esta última, retirando o controle do processo do Conselho Ultramarino, Horácio de Almeida confundiu em seu trabalho dízima por dízimo e terminou, em tom ufânico, por concluir que a Paraíba estava sendo usurpada pela capitania vizinha, inclusive porque, havia uma carta régia de 17 de novembro de 1730 obrigando a que os dízimos só pudessem ser arrematados nos lugares em que fossem pagos. Cf: Horácio de Almeida. História Paraíba.João Pessoa. Editora Universitária/UFPB/JP., 1978. V. 2; p. 74. Essa mesma interpretação é repetida por Silveira. Cf: Rosa Maria Godoy Silveira \& outros. Estrutura de Poder na Paraíba. João Pessoa: Editora Universitária / UFPB/JP, 1979. p. 29
} 
por parte da capitania vizinha ${ }^{112}$, a falta de regularidade no envio da receita das dízimas criava sérios problemas para o fechamento dos pagamentos na Fazenda da Paraíba.

A provedoria de Pernambuco se justificava afirmando que suas rendas se esvaíam nos gastos internos e que a irregularidade das frotas impediam o recolhimento da dízima $^{113}$. Quantos aos provedores da Paraíba, sem contar com os aportes anuais dos vinte mil cruzados, sentiam-se alijados nos seus direitos e tentavam, muitas vezes, se valer de precatórios. Mesmo nos momentos em que os repasses tendiam à regularidade, como se observa na primeira metade dos anos trinta, o tesoureiro Pantaleão Martins dizia que, nos vários envios de Pernambuco para a Paraíba, havia "bastante mil cruzados em fazendas e negros". Isto facilitava descaminhos e atrasos nos pagamentos, tendo em vista o tempo gasto para a conversão das fazendas e escravos em valores correntes. ${ }^{114}$

Com exceção desses impasses quanto à natureza e atraso dos valores durante os 31 anos de vigência do contrato, que antecederam à anexação, vê-se que a transferência total do rendimento da Alfândega vizinha, em comparação com o da Paraíba, significou um aporte expressivo de recursos. Mas, esses recursos, não foram suficientes para equilibrar as rendas locais.

Finalmente, afora essas fontes de receita, tradicionalmente ligadas à carga de impostos e taxas, há de considerar outra, de menor porte e também incerta, mas que contribuiu para o montante de arrecadação da receita: as tomadias.

\footnotetext{
112 Salter de Mendonça, provedor e ouvidor da Paraíba, em 1736, reconhecia que, apesar da dívida de alguns anos, não havia necessidade de se estranhar o provedor de Pernambuco, João do Rego Barros, afinal, compreendia as dificuldades no socorro ao Rio Grande e Fernando de Noronha. Cf: AHU_ACL_CU_014, Cx. 10, Doc. 805.

${ }_{113}$ A regularidade das frotas para Pernambuco, Bahia e Rio de Janeiro, podia ficar comprometida devido a guerras ou ao fato de comerciantes de Lisboa já possuírem grandes estoques e não desejarem mais produtos. Cf: Stuart Schwartz. Segredos internos: engenhos e escravos na sociedade colonial... Op.cit. p. 169

${ }^{114}$ Os envios de negros, como partes de parcelas dos vinte mil cruzados da dízima, acabou por levar a uma grave suspeita sobre o antigo tesoureiro da dízima, Antônio de Almeida Gouveia, em meados da década comentada. O que tudo indicava, era que este tesoureiro levava os escravos para fazer os serviços domésticos na sua casa e dali os transferia para engenhos e acabava por não se ter mais notícia deles. AHU_ACL_CU_014, Cx. 11, Doc. 896.
} 


\section{TOMADIAS}

Freqüentemente, a inobservância e a ação contrária a alguns preceitos legais e regulamentares das obrigações contratuais mediavam a relação súdito/soberano, como nas práticas de descaminhos - contrabando e extravios nas contas públicas. Eram faltas graves que atentavam contra os deveres sociais da República - isto é, ao bem comum e, por extensão, à diligência e lealdade à Sua Majestade - e que deviam ser punidos com rigor.

Para combater essas falhas, existia uma malha de denúncia e acusações, secretas ou não, estimulada pela Coroa e que garantia para os denunciantes cinqüenta por cento das tomadias, isto é, das apreensões efetuadas. Havia também um aparelhamento fiscalizador constante e constrangedor para os oficiais régios. Os oficiais estavam sujeitos tanto aos processos das residências - uma espécie de mini-devassa feita pelo oficial sucessor sobre o seu antecessor, aprovando ou não o seu exercício no cargo -, quanto à auto-prestação de suas contas, como era o caso dos muitos oficiais de recebimento tesoureiro e almoxarifes - ligados à Fazenda.

No caso de se haver encontrado dolo, o crime não prescrevia e mesmo que o processo durasse anos a fio, ultrapassando a morte dos acusados, seus herdeiros diretos, ou fiadores, ou mesmo os herdeiros dos fiadores, carregavam as dívidas como coresponsáveis e sofriam as execuções nos seus bens. ${ }^{115}$

Na Paraíba, fazendo jus ao pequeno movimento do seu porto, ocorreram poucas apreensões de contrabando de escravos e fazendas (Quadro 9). Elas podem ser identificadas nos relatos feitos nos livros dos almoxarifados e enviados pelos provedores da Fazenda paraibana para Lisboa: ${ }^{16}$

\footnotetext{
${ }^{115}$ Em 1754, o provedor da Fazenda Real da Paraíba, Manuel Rodrigues Coelho, escrevia ao rei dizendo-se preocupado com a falta de quitação geral das contas do almoxarife e tesoureiro da décima da capitania, pois isto poderia resultar em prejuízo à Fazenda. Todavia, apesar disto estar acontecendo, mesmo que tirasse as contas dos almoxarifes já mortos, tinha certeza que, havendo alcance, a causa não prescrevia para eles ou fiadores que ficam, mesmo seus herdeiros, pois estariam sujeitos ao seqüestro dos seus bens. Cf: AHU ACL CU 014, Cx. 17, Doc. 1384. ${ }^{116} \mathrm{~A} \bar{H} \mathrm{U}_{-} \mathrm{A} \overline{\mathrm{C}} \mathrm{C}-\overline{\mathrm{C}} \mathrm{U} \_14, \mathrm{Cx} .14$, Doc. 570.
} 


\section{QUADRO 9}

\section{Capitania da Paraíba / Receita:Tomadias de Escravos e Fazendas}

\begin{tabular}{|l|c|}
\hline Ano & Valores \\
\hline $1723-1724$ & $1: 814 \$ 570$ \\
\hline $1724-1725$ & $612 \$ 080$ \\
\hline $1726-1727$ & $30 \$ 000$ \\
\hline $1727-1728$ & $82 \$ 600$ \\
\hline
\end{tabular}

Fonte: Arquivo Histórico Ultramarino

Quanto aos arrestos de bens de oficiais, foi no seio da própria Fazenda da Paraíba que apareceram alguns casos. Um deles ocorreu em 1741, com Jácome dos Santos, tesoureiro da dízima e oficial dos contos, cujo arresto alcançou, após sua morte, o valor de 1:091\$601 réis ${ }^{117}$. Outro caso envolveu dois almoxarifes, Luis Mendonça de Sá e Simão Farinha do Amaral, alcançados em muitos contos de réis e que tinham, como fiador, o senhor de engenho e dizimeiro da capitania da Paraíba, Gaspar Acioli de Vasconcelos.

Em 1710, Gaspar Vasconcelos foi o primeiro fiador do almoxarife alcançado, Luis de Sá. Como o desfalque somava 15:188\$912 réis e o almoxarife não tinha como cobrir, o provedor da Fazenda confiscou os bens do fiador: o engenho Santo André, no valor de 5:199\$255 réis, e o engenho Podre, avaliado em 4:578\$430 réis. Ficando ainda a dever à Fazenda, Gaspar Vasconcelos teve esses mesmos bens confiscados pela segunda vez. Desta feita, foi o outro almoxarife, Simão do Amaral, que ficou alcançado em 7:361\$612 réis e, como seu primeiro fiador, Domingos da Silveira, não tinha bens, foi acionado o segundo, o mesmo Gaspar Vasconcelos. ${ }^{118}$

A dívida acumulada, devia ser saldada com o arrendamento dos engenhos a particulares ou por sua venda em hasta pública. Porém, como os valores do arremate não deveriam cobrir o prejuízo, acertou-se que os engenhos ficariam arrendados pelo prazo que fosse necessário. Acontece que, pela forma como correu a administração dos bens confiscados, envolvendo relatórios e inventários, passaram-se anos, acarretando a depreciação das propriedades por negligência, enchentes, roubos ou saques. Em meio a esse imbróglio, João Maia da Gama, em 1716, colocou os engenhos em arrendamento e solicitou permissão para vendê-los, pois não existiam outras dívidas para cobrar e vários

${ }^{117}$ AHU ACL CU 014, Cx. 11, Doc. 939.

${ }^{118}$ AHU_ACL_CU_014, Cx. 12, Doc. 1021; Cx. 16, Doc. 1348; e Cx. 18, Doc. 1423. 
pagamentos em atraso. ${ }^{119}$ A solução foi manter arrendado o engenho Santo André, já que o Podre não conseguiu sobreviver às ações das cheias e dos saques da população. ${ }^{120}$ Os valores do arrendamento, que giravam em torno de trezentos mil réis anuais, quando havia arrendatário, são registrados esporadicamente pelos provedores (Quadro 10). ${ }^{121}$

\section{QUADRO 10}

Capitania da Paraíba / Receita:

Arrendamento do Engenho Santo André

\begin{tabular}{|l|c|}
\hline Ano & Arrendamento \\
\hline $1724-1725$ & $94 \$ 413$ \\
\hline $1717-1728$ & $30 \$ 755$ \\
\hline $1728-1729$ & $300 \$ 440$ \\
\hline $1751-1752$ & $349 \$ 400$ \\
\hline $1753-1754$ & $349 \$ 400$ \\
\hline
\end{tabular}

Fonte: Arquivo Histórico Ultramarino

Uma vez identificadas as várias fontes de receita da Provedoria da Fazenda Real da Capitania da Paraíba, podemos passar para às despesas, ou seja, para as alíneas a que estavam consignadas. Como anunciamos na introdução desse capítulo, começaremos pela descrição das despesas de pagamento ao corpo dos oficiais pertencentes à Fazenda paraibana. Incluídos, nestas despesas, estão todos os prós e percalços - emolumentos ou propinas - que os oficiais recebiam, inclusive os que eram feitos através de particulares e que, por isso mesmo, se encontravam fora da alçada do órgão fazendário.

\footnotetext{
${ }^{119}$ IHGP / Ordens Régias; Códice 1709 - 1719; Doc. 149.

${ }^{120}$ Um parecer do provedor da Fazenda da Paraíba, Manuel Rodrigues Coelho, dado em 1755, sobre esses dois engenhos, aconselhava que, por ter ficado por longo tempo de fogo morto o engenho Podre, supunha ser melhor vendê-lo e investir em benfeitorias no Santo André. Reconhecia, então, o provedor, que os filhos de Gaspar Vasconcelos, seus herdeiros, queriam e muito arrematá-los tendo em vista o abandono em que se encontravam, já que o padre Mathias da Gloria, que há muitos anos, era o arrendatário, tratava-os com desleixo, chegando mesmo a passar a administração dos engenhos para terceiros. Cf: AHU_ACL_CU_014, Cx. 18, Doc. 1423 ${ }^{121}$ A $\bar{H} U$ AC $\bar{C} L \bar{C} U \_014$, Cx. 7, Doc. 570; Cx. 16; Doc. 1334; e Cx. 18; Doc. 1454.
} 


\section{DESPESAS}

\section{A EVOLUÇÃO DOS OFÍCIOS DA FAZENDA REAL DA PARAÍBA: JUNÇÕES, ORDENADOS E PROPINAS.}

O desenvolvimento do quadro dos ofícios da Fazenda Real da Paraíba estava, necessariamente, ligado à ampliação das atividades do órgão. Desde a sua recriação, após a expulsão dos holandeses do território paraibano, até o início do século XVIII - período que corresponde, também, à remontagem do parque produtivo açucareiro na capitania -, a Provedoria da Fazenda Real tomou a feição estruturada de corpo administrativo, com um número determinado de ofícios. Seu efetivo era formado por um primeiro escalão, que contava com: o Provedor da Fazenda, que acumulava os cargos de Contador e Juiz da Alfândega, Mar e Direitos Reais e Vedor Geral da Gente de Guerra ${ }^{122}$; o Escrivão da Fazenda, que acumulava também a escrivaninha do Almoxarifado, Alfândega e da Gente de Guerra; e o Almoxarife da Fazenda.

Do outro lado, estavam os cargos médios, assim definidos por não possuírem um ordenado específico, além dos emolumentos e propinas, ou ajudas de custos, e que foram criados com o passar do tempo, na medida em que foram edificadas a Casa da Alfândega e a Casa dos Contos. ${ }^{123}$ Eram os ofícios de Procurador da Fazenda e Coroa, de Meirinho do Mar e Fazenda e de Escrivão das Execuções. Este último acumulava também os ofícios de Guarda livros, Selador e Porteiro da Alfândega e da Casa dos Contos. ${ }^{124}$

Após essa estruturação inicial, outros momentos determinariam novos alargamentos no número de ofícios na Provedoria da Fazenda paraibana: um deles, por acúmulo de trabalho, e dois outros, por questões fiscais propriamente ditas.

O primeiro movimento foi provocado pela busca de incremento de uma nova fonte de receita, a dízima, em 1711. A cobrança de dez por cento sobre as mercadorias

\footnotetext{
${ }^{122}$ Como vimos no capítulo anterior, desde a primeira doação do cargo de provedor da Fazenda paraibana em 1647, que a outra provedoria, a dos Defuntos e Ausentes, andaram juntas até o ano de 1689, quando se separam com a criação da Ouvidoria Geral da Paraíba. Cf: AHU_ACL_CU_014, Cx. , Doc. 154.

${ }^{123}$ Irineu Pinto registra a existência de uma carta régia datada de 4 de setembro de 1696 , ordenando a construção de uma casa para Alfândega (Cf: Irineu Ferreira Pinto. Datas e notas... Op.cit. p. 88 e 99) Em 1704, em ma carta do governador da Paraíba, Fernando Barros de Vasconcelos, já há menção da passagem do açúcar produzido na capitania por esta Casa da Alfândega. Cf: AHU_ACL_CU_014, Cx. 04, Doc. 273 ${ }^{124}$ AHU_ACL_CU_014, Cx. 6, Doc. 530; Cx. 10, Doc. 807; Cx. 14, Doc. 1144; Cx. , Doc. 1419; e, Cx.18, Doc. 1442 .
} 
importadas que não tinham isenção real, como o azeite, provocou a necessidade de provimento de mais um oficial, o Tesoureiro da Dízima. ${ }^{125}$ No princípio, não foi abonado nenhum ordenado para este ofício, mas em 1715, quando da renovação do triênio do seu oficial, Francisco Pinto Correia, o estipêndio chegou a $60 \$ 000$ réis anuais. ${ }^{126}$

A segunda movimentação aconteceu dez anos mais tarde, em 1721, quando o provedor da Fazenda Real, Salvador Quaresma Dourado, com a idade avançada e cansado pelo volume de trabalho, justificou, perante a Coroa, a necessidade da criação de um oficio para os Contos. A idéia era que o titular pudesse agilizar as contas da Fazenda, liberando ele e o seu escrivão dessas tarefas. Para o cargo de oficial dos Contos, foi conduzido Jácome Rodrigues dos Santos, que passou a contar com um ordenado anual de $60 \$ 000$ réis. $^{127}$

Mas o aumento substancial no número de ofícios se deu no terceiro movimento, em 1723, quando a Coroa optou pela junção dos contratos da dízima das alfândegas da Paraíba e de Pernambuco. A Coroa estava preocupada em garantir a lisura com uma sonhada maior arrecadação na Alfândega da Paraíba e em evitar um possível descontrole com o que deveria chegar da Alfândega vizinha. Por isso, permitiu ao provedor da Fazenda paraibana alargar o número dos ofícios com quantos fossem necessários ao serviço, e provê-los com pessoas capazes para tal fim. Neste sentido, numa única estocada, o provedor Salvador Dourado criou, em 6 de novembro de $1723,{ }^{128}$ os ofícios de Escrivão da Mesa da Abertura da Alfândega, Feitor da Mesa da Abertura da Alfândega, Escrivão do Despacho da Descarga da Alfândega, Escrivão da Ementa da Alfândega, Juiz da Balança da Alfândega, e Escrivão da Balança da Alfândega. ${ }^{129}$

Esse último e exagerado crescimento dos ofícios, trouxe uma difícil questão para ser resolvida pela provedoria, pois os cargos com pouca remuneração não eram atrativos.

Acontece que para esses ofícios, criados em 1723, não foi dirigido ordenado algum, além de algumas propinas e emolumentos que se restringiam ao movimento no

\footnotetext{
${ }^{125}$ AHU ACL CU 014, Cx. 05, Doc. 348.

${ }^{126}$ Idem.

127 AHU_ACL_CU_014, Cx. , Doc. 365 e 382.

${ }^{128}$ AHU_ACL_CU_014, Cx.18, Doc. 1442 e Cx. 14 Doc. 1144.

129 Idem. Como já nos referimos anteriormente, Segundo Schwartz, os baixos escalões cresciam em quantidade não apenas em função da demanda de trabalho, mas também, pela necessidade que tinha a Coroa de dar recompensas. Cf: Stuart B. Schwartz. Burocracia e Sociedade no Brasil Colônia... Op. cit., p. 294.
} 
porto da Paraíba e exclusivamente à importação. Neste sentido, como dificilmente atracavam mais de dois navios por ano, mesmo em época de regularidade da frota de Pernambuco, o valor levantado pelos oficiais ligados aos ofícios de 1723 não compensava o trabalho que executavam. Segundo o governador da Paraíba, Borges da Fonseca, esse era o motivo "porque a cada passo estão entrando e saindo oficiais ..., sem haver quem os sirva, e quando os há, andam rogando-os e comprometem-se com os donos das fazendas para lhes darem $\$ 40$ réis por cada bilhete, para virem alguns pobres fazer a figura dos tais oficiais pelo pouco que se lucra, em razão de virem poucos navios a este porto.", 130

Em 1728, aconteceu uma pequena mudança no tratamento desses ofícios, quando a Coroa consignou um ordenado de $80 \$ 000$ réis anuais apenas para a escrivaninha da Mesa da Abertura da Alfândega. Isto porque o oficial que solicitou o ordenado, destoava dos pobres a que se refere Borges da Fonseca. O oficial era Antônio Carneiro de Albuquerque, filho de família nobre da Paraíba, que justificou duplamente a necessidade do ordenado. Por um lado, alegou não ter outra opção para "granjear outros serviços para com ele poder sobreviver", pois além da pouca visita de navios ao porto, a ordem real de 1719 o proibia de exercer qualquer outra atividade, inclusive o comércio. ${ }^{131}$ Por outro lado, lembrava que o oficial congênere da Alfândega de Pernambuco tinha um ordenado de $120 \$ 000$ mil réis anuais.

Mas não foram apenas esses ofícios sem ordenados e com pouca margem de gratificações que ofereceram dificuldades de provimentos. Uma das saídas mais experimentadas na administração portuguesa, para tornar os ofícios mais atrativos, proporcionando uma melhor remuneração para os oficiais, foi o recurso à sobreposição de cargos. ${ }^{132}$ Remédio simples e eficaz, valeu-se dele também a Coroa, com relação aos oficiais da Provedoria da Fazenda paraibana. Assim, para além dos ofícios que,

\footnotetext{
${ }^{130}$ AHU_ACL_CU_014, Cx. 14, Doc. 1144 .

${ }^{131}$ AHU_ACL_CU_014, Cx. 9, Doc. 716 e Cx. , Doc. 780.

132 Em uma consulta ao Conselho Ultramarino para se saber da conveniência em separar o ofício de escrivão da Alfândega da Fazenda do de escrivão da provedoria-mor da Bahia, em 1722, foi o procurador da Fazenda e Coroa de opinião de que "não lhe parecia se devia criar o ofício de novo se pretendia houvesse, nem se multiplicar oficios sem uma urgentíssima necessidade e menos dividi-los, porque ambos vêm a ficar pobres e por via de regra se dão mais dois ladrões à República..." Mesmo assim, o ofício de escrivão da Alfândega foi separado, por despacho real, em 1726. Cf: Documentos Históricos. Consultas do Conselho Ultramarino. Bahia 1724. Rio de Janeiro; Biblioteca Nacional, 1950. Códice: I-8,4,7. vol 89-90 p. $55-59$.
} 
tradicionalmente, traziam os seus tantos outros que lhe andavam juntos - vide a provedoria e sua escrivaninha -, a Fazenda da Paraíba experimentou dois ajuntamentos de ofícios bastante peculiares. O primeiro foi com a Tesouraria da Dízima, que além de absorver a Tesouraria das Fortalezas, ficou junta ao Oficio dos Contos, durante o período que foi de 1721 a 1734 , quando se separou. O segundo ajuntamento se deu em 1739, quando, a Tesouraria da Dízima se vinculou ao ofício de almoxarife, definitivamente.

O primeiro exemplo deu-se em 1715, quando o oficial Jácome Rodrigues dos Santos, que servia de Tesoureiro das Fortificações, foi obrigado pelo governador da Paraíba, João Maia da Gama, a assumir também como Tesoureiro da Dízima. ${ }^{133}$ Em 1719, esse oficial, sabedor da carência de pessoal na capitania, para resolver as contas da Fazenda, ameaçou desistir do ofício de Tesoureiro da Dízima, caso não fosse o seu ordenado aproximado ao patamar de $200 \$ 000$ réis anuais que o oficial de Pernambuco recebia. Alegava Jácome dos Santos ser impossível sobreviver com os $60 \$ 000$ réis que recebia como Tesoureiro da Dízima, além do trabalho que tinha na outra tesouraria, pois "não chegavam para compor as quebras que tem nas cobranças que faz e outras despesas miúdas". ${ }^{134}$ Como resultado, conseguiu $100 \$ 000$ réis anuais com a junção das tesourarias - afinal, não eram os ofícios incompatíveis, pois o valor arrecadado da dízima deveria servir às forças, isto é, às fortificações e soldados. Alem disso, acabou por acumular dois anos depois, o ofício dos Contos, donde adicionava aos seus estipêndios mais $60 \$ 000$ réis por ano. Jácome dos Santos manteve os dois ofícios até a sua morte, em $1734 .^{135}$

O outro exemplo teve sua origem nas preocupações do governador da Paraíba, Pedro Monteiro de Macedo. Receoso frente à possibilidade do almoxarife vir a incorrer em descaminhos, já que era "impossível viver com os $50 \$ 000$ réis de ordenado que não lhe chega para suas despesas correntes, "136 propôs ao Conselho Ultramarino, em 1739, juntar o oficio de almoxarife com a tesouraria da Dízima. Justificava que o ordenado de

\footnotetext{
133 AHU_ACL_CU_014, Cx. 5, Doc. 365.

${ }^{134}$ Em 1719, residindo na Corte, João Maia da Gama, ex-governador da Paraíba, foi de parecer favorável ao aumento de Jácome dos Santos, revelando ser esse oficial, além de "muito apto, suficiente e afamado para o emprego ... não há outra pessoa capaz” na Capitania. AHU_ACL_CU_014, Cx. 5, Doc. 365.

${ }^{135}$ AHU ACL CU 014, Cx. 9, Doc. 382.

${ }^{136}$ AHU_ACL_CU_014, Cx. 11, Doc. 917.
} 
$150 \$ 000$ réis estaria à altura da responsabilidade que os cargos exigiam. ${ }^{137} \mathrm{~A}$ princípio a Coroa relutou em acatar a idéia, "por serem ambos oficios de contas e de recebimentos diferentes". Mas terminou por aceitar a proposta, em 1740, desde que as pessoas providas contassem com bens de raiz no local do exercício do ofício e mantivessem as fianças separadas, num ofício e noutro. Doravante, a Coroa proporcionou, para o almoxarifetesoureiro da dízima, "o ordenado de 150 mil réis, com seus pros e percalços”, sem esquecer, contudo, de "sujeitar a sua liberdade sem desculpas para chegar aos descaminhos". ${ }^{138}$

Além dessas mudanças no adicionamento de cargos ou junção de ofícios já existentes, a Fazenda paraibana conheceu, até o fim da sua autonomia, em dezembro de 1755, apenas mais uma incorporação de ofício. No ano de 1739, foram introduzidos mais dois cargos aos vários que o provedor da capitania e o seu escrivão possuíam: o Juízo e a Escrivaninha das Demarcações de Terras. ${ }^{139}$ Bem antes dessa data, curiosamente, tais ofícios vinham, por vezes, no elenco de títulos que os próprios oficiais anunciavam quando passavam seus despachos ${ }^{140}$ e já constavam no primeiro regimento de 1548 . Quando foram reconhecidos oficialmente, em 1739, a escrivaninha e o juízo das demarcações, não chegaram a remunerar coisa alguma aos seus oficiais, pois as pessoas que possuíam as terras no litoral ou sertão da Paraíba, preferiam tê-las "sem forma ou divisão alguma ... [pois não] queriam consentir lhas demarcarem na forma das reais ordens". ${ }^{141}$

Feitos esses comentários acerca dos desdobramentos que tiveram os ofícios que compunham a Fazenda Real da Paraíba, podemos agora acrescentar os ordenados, propinas e emolumentos que proporcionavam aos seus oficiais. O inserto das remunerações tem como objetivo dar uma idéia sobre as atividades (ou atribuições) que

\footnotetext{
${ }^{137}$ Idem;

${ }^{138}$ Idem. É interessante ressaltar aqui que havia muitas falhas nas tomadas de contas dos tesoureiros e almoxarifes, os quais dificilmente procuravam dar quitação das suas atividades. Todavia, como já fizemos menção, quando acontecia de estes serem alcançados, até mesmo após terem morrido, ficavam seus herdeiros ou os herdeiros dos seus fiadores, sujeitos ao seqüestro dos seus bens. Cf: AHU_ACL_CU_014, Cx. 17, Doc. 1384.

${ }^{139}$ Ordem de 27 de janeiro de 1739. Cf: AHU_ACL_CU_014, Cx. 14, Doc. 1442.

${ }^{140}$ Em 1725, por exemplo, ao mandar, o provedor, que seu escrivão, Bento Bandeira, descrevesse as condições com que se arrematara o contrato do subsídio do açúcar, este dispõe, no protocolo final, o uso desta prerrogativa: “escrivão das demarcações de terras". Cf: AHU_ACL_CU_014, Cx. 5, Doc. 455.

${ }^{141}$ AHU_ACL_CU_014, Cx. 18, Doc. 1442.
} 
cada um dos oficiais devia desenvolver para levantar seus pros e percalços. Além disso, pretende tornar visível a singularidade que havia na relação hierárquica no interior do órgão, já que o ordenado, por si só, não espelhava, necessariamente, o valor políticosocial da envergadura do cargo.

Neste sentido, deve-se considerar as possibilidades de subornos e extorsões, práticas tão presentes nos cargos ligados ao fisco, e que podiam escamotear ou aumentar as propinas e emolumentos. Entretanto, era nestes últimos, isto é, nos ganhos paralelos, reconhecidos oficialmente, e não nos ordenados diretos, que ficava a verdadeira expressão econômica do ofício. Por isso, a descrição dos ordenados executados na Provedoria devem vir acompanhada dos seus penduricalhos. Pois, por se tratar de um sistema de poder de Antigo Regime, e não propriamente duma burocracia, as justificativas para a exploração estão pautadas numa dimensão extra-econômica. Na verdade, elas estão baseadas numa dimensão simbólica, em que a tradição, por costume antigo ou pela vontade do soberano, divina e natural, concedia os cargos e sua remuneração ao seu estrito desígnio e reconhecimento, com um olho que mirava menos a responsabilidade do ofício, do que o próprio beneficiado. ${ }^{142}$

\section{OS OFÍCIOS DA PROVEDORIA: ORDENADOS, PROPINAS E EMOLUMENTOS ${ }^{143}$}

\section{O provedor e seu escrivão}

Na escala hierárquica da Provedoria da Fazenda Real, o primeiro ofício era o de Provedor. Na Paraíba, o ordenado atribuído ao seu ocupante era de $78 \$ 000$ mil réis

\footnotetext{
${ }^{142}$ Sobre as gradações político-administrativas, José Subtil informa que é praticamente impossível, até meados do dezoito, estabelecer uma diferenciação baseada simplesmente no princípio do ordenado, pois "os oficios valiam sobretudo pelos seus rendimentos 'brutos', que incluíam além do salário, emolumentos e propinas, 'pros' e 'percalços' gêneros, percentagens sobre o valor das cartas ou provisões passadas pelo titular, etc.” Cf: José Subtil. “Os poderes do Centro”. In: José Mattoso (dir.). História de Portugal. V. IV. Antonio Manuel Hespanha (org.) O antigo Regime 1621-1807. Lisboa: Editorial Estampa, 1998. p. 169.

${ }^{143}$ Esta descrição, apesar de ter como base a avaliação dos ofícios realizada pelo provedor da Paraíba, Manuel Rodrigues Coelho, em 1755 - AHU ACL_CU_014, Cx. 18, Doc. 1442 -, traz uma variedade de anotações que estão presentes em uma série de outros documentos. Para evitar o cansativo número de referências que se colocariam no corpo do texto, apresentamos os documentos antecipadamente, deixando em notas, mesmo que repetidos, apenas os que foram imprescindíveis. AHU_ACL_CU_014, Cx.3, Doc. 190; Cx. 7, Doc. 570; Cx.9, Doc. 747; Cx.9, Doc 763; Cx. 10, Doc. 812; Cx. 10, Doc. 878; Cx. 12, Doc. 1021; Cx. 14, Doc. 1196; Cx. 15, Doc. 1258; Cx. 14, Doc. 1262; Cx.16, Doc. 1334; e, Cx. 18, Doc. 1454.
} 
anuais $^{144}$ - penúltimo ordenado mais baixo em toda a provedoria. ${ }^{145}$ Todavia, ao se juntar a esse ordenado aos prós e percalços do próprio ofício de provedor e dos outros que lhe andavam anexos, o valor final tendia a melhorava substancialmente. ${ }^{146}$

No que diz respeito aos contratos reais, ao provedor era garantida a propina de $40 \$ 000$ réis para cada triênio em que se realizava a arrematação do contrato dos dízimos. Durante a vigência desse contrato, ele ainda tinha o direito a oito libras de cera no dia de Nossa Senhora da Candeia, e mais quatro resmas de papel, por apenas uma vez. Pelo contrato dos subsídios das carnes, praticava $10 \$ 000$ réis de propina e, nas arrematações dos contratos do subsídio do açúcar, tinha $16 \$ 000$ réis. Contudo, esses dois últimos contratos só passaram a remunerar os oficiais da Fazenda quando deixaram de correr pela Câmara Municipal. ${ }^{147}$ O Provedor da Fazenda ainda recebia de emolumentos: a) por assinatura de um mandado executivo, $\$ 150$ réis; b) por mandado de citação ou notificação, $\$ 120$ réis; c) por cada testemunha, $\$ 80$ réis; d) por conclusão dos processos, \$200 réis.

Por outro lado, se não tinha vencimento como Vedor Geral da Gente de Guerra ou Juiz das Demarcações de Terra, recebia como Juiz da Alfândega, além de $40 \$ 000$ mil réis de propina pela arrematação do contrato da dízima, os seguintes emolumentos: a) por visita que fazia em exame nos navios, $9 \$ 600^{148}$; b) por marca de peça de fazenda que se descarregasse ou carregasse na Alfândega, $\$ 80$ réis; c) por cada caixa ou feixe de açúcar

\footnotetext{
${ }^{144}$ Com o detalhe de que o provedor Salvador Dourado (gestor de 1682 a 1733), como vimos no capítulo anterior, teve $30 \$ 000$ mil réis como mercê ordinária em compensação por ter perdido o ofício de provedor dos Defuntos e Ausentes, em 1688, cuja remuneração durou até sua morte, em 1733, mas não aderiu ao ofício. Além disso, os $78 \$ 000$ mil réis correspondiam a 70 mil réis de ordenado, mais os 8 mil réis que este mesmo provedor conseguiu quando perdeu os emolumentos do ofício de Juiz dos Homens do Mar, em 1693. Esse último aumento, sim, foi incorporado ao cargo.

${ }^{145}$ Em 1746, numa carta enviada pelo provedor da Fazenda da Paraíba, Teotônio Fernandes Temudo, ao rei, alegava que o que recebia, $78 \$ 000$ réis, era muito pouco, pois "oficiais com vinte dias de trabalho, tem $80 \$ 000$ réis, almoxarife tem de ordenado $150 \$ 000$ réis,e não tem cada um desses oficiais a vigésima parte do trabalho que tem o provedor". Cf: IHGP / Ordens Régias; Códice 1745-1755 Doc. 32.

${ }^{146}$ Vale lembrar, que foi comum aos ouvidores o acúmulo do cargo de provedor. Na Paraíba, isso se deu, efetivamente, apenas uma única vez, com o ouvidor geral Salter de Mendonça, que esteve à frente da provedoria de 1734 até 1740 após a morte de Salvador Dourado. O seu sucessor, o ouvidor Inácio de Souza Jácome Coutinho, não conseguiu manter os dois cargos por estar doente. Cf: AHU_ACL_CU_014, Cx. , Doc. 935

${ }^{147}$ Como já nos referimos, o contrato do subsídio do açúcar passou a ser administrado pela Fazenda em 1705, mas só veio a ter uma arrematação em 1744; o da carne, por conseguinte, passou à Fazenda em 1732. Cf: AHU ACL CU 014, Cx. 18, Doc. 1442.

${ }_{148}$ Alegava-se que Salvador Dourado praticava $19 \$ 200$ réis. AHU_ACL_CU_014, Cx. 9. Doc. 747; e Cx. 18, Doc. 1442.
} 
que se embarcava esclusivamente para Lisboa, \$60 réis e \$030 réis, respectivamente; d) por cada entrada e saída dos navios no porto, $\$ 70$ réis; e) por cada cabeça de escravo, $\$ 100$ réis; f) por cada despacho de navio, quando saía ao resgate de escravos na Costa da Mina, $10 \$ 000$ réis.

Logo abaixo do provedor estava o seu escrivão. Tal e qual o seu superior, esse oficial acumulava todas as outras escrivaninhas dos ofícios que diziam respeito ao provedor. Assim, ele tinha, como Escrivão da Fazenda, 100\$000 réis de ordenado anual, ao qual se acumulavam pela arrematação do contrato dos dízimos, 25\$000 réis de emolumento, quatro libras de cera por ano e quatro resmas de papel por apenas uma única vez, durante o triênio do contrato. Além disso, tinha a mais, pela propina da arrematação dos contratos dos subsídios da carne e do açúcar, $8 \$ 000$ e $12 \$ 000$ réis, respectivamente.

Como Escrivão da Alfândega, recebia a propina de $20 \$ 000$ réis pela arrematação do contrato da dízima e os seguintes emolumentos: a) pelas visitas e despachos dos navios provenientes ou despachados para Lisboa, $8 \$ 800$ réis; b) por cada caixa ou feixe de açúcar despachado exclusivamente para Lisboa, \$60 e \$30 réis, respectivamente; c) por cada marca dos carregadores, $\$ 080$ réis; d) por cada cabeça de escravo despachado na Alfândega, \$100 réis; e) por cada barco com destino Costa da Mina, para regatar escravos, $10 \$ 000$ réis.

Das outras escrivaninhas, Matrícula da Gente de Guerra, Demarcações de Terra e Almoxarifado, não recebia nenhum ordenado, apesar de ter como emolumento, no exercício desta última, $\$ 320$ réis de cada mandado de despesa, e mais $\$ 170$ réis por cada emissão de recibo.

\section{Almoxarife, tesoureiro da dízima e oficial dos contos}

Na Paraíba, a junção do ofício de Almoxarife ao de Tesoureiro da Dízima aconteceu em 1739, passando o oficial a receber um ordenado de $150 \$ 000$ réis. Além desse ordenado, o oficial manteve os rendimentos que cabiam a cada um dos ofícios, separadamente. Enquanto almoxarife, conservou a propina de $20 \$ 000$ réis da arrematação dos dízimos reais e quatro libras de cera por ano, mais as propinas de $8 \$ 000$ réis do contrato da carne e de $6 \$ 000$ réis dos subsídios do açúcar. Por outro lado, também 
recebia a propina dirigida ao Tesoureiro da Dízima, no valor de $10 \$ 000$ reais, que correspondia ao processo de arrematação do contrato da dízima da Alfândega.

Quanto ao Oficial dos Contos da Fazenda, tinha $60 \$ 000$ réis anuais de ordenado. De propina, recebia $10 \$ 000$ réis pela arrematação do contrato dos dízimos reais, e duas libras de cera, mais $8 \$ 000$ réis pelo contrato do subsídio da carne. Além disso, tinha $4 \$ 000$ réis pelo contrato do subsídio do açúcar e $8 \$ 000$ réis pelo contrato da dízima. Recebia também, de emolumentos, por exame que fazia para as partes saberem o quanto a Fazenda poderia lhes dever, $\$ 720$ réis.

\section{Procurador da fazenda e meirinho do mar e fazenda}

Mediando o universo dos ofícios mais abastados, que dispunham de um ordenado certo - exceto o Escrivão da Mesa da Abertura da Alfândega, por ser um caso à parte -, estavam os ofícios de Procurador da Fazenda e Coroa e o de Meirinho do Mar e Fazenda. Além de uma pequena ajuda de custo de $4 \$ 000$ réis por ano, pela obrigação de assistirem a todas as audiências, esses ofícios tinham direito apenas a emolumentos e propinas.

Assim, o Procurador da Coroa e Fazenda recebia de propina, pelos contratos reais: $20 \$ 000$ réis pela arrematação do contrato dos dízimos, mais duas libras de cera por ano e duas resmas de papel trienalmente; $8 \$ 000$ réis pela arrematação do contrato dos subsídios da carne; $6 \$ 000$ réis pelo subsídio do açúcar e $10 \$ 000$ réis pelo contrato da dízima. De emolumento, cobrava $\$ 720$ réis por cada consulta que lhe era feita pelas partes.

Quanto ao Meirinho do Mar e Fazenda, os valores recebidos na arrematação da carne e na quantidade de libras de cera eram os mesmos que o Procurador da Coroa e Fazenda recebia. O contrato dos dízimos lhe rendia $10 \$ 000$ réis e o subsídio do açúcar, apenas $4 \$ 000$ réis. Este oficial tinha também, como Meirinho da Fazenda, o direito a $4 \$ 000$ réis pagos pela Fazenda Real, por assistir a todas as audiências na capitania por 
costume antigo. E, como Meirinho do Mar, recebia $10 \$ 000$ réis pela arrematação do contrato da dízima, mais $4 \$ 000$ réis pela entrada e saída dos navios no porto. ${ }^{149}$

\section{Escrivão das execuções, portaria, selagem, guarda livros dos contos e os ofícios de 1723}

Finalmente, abaixo desses ofícios, vinham aqueles vinculados mais diretamente à Alfândega e que se limitavam à vigilância de navios e às emissões de bilhetes, no processo dos despachos de mercadorias. Um deles, a Escrivaninha das Execuções, Portaria e Selagem da Alfândega e Guarda-Livros dos Contos, se distinguia pela antiguidade, porque garantia um certo enobrecimento ao seu ocupante. Por seu lado, a Escrivaninha da Mesa de Abertura da Alfândega - inicialmente tão desprestigiada, como o restante dos ofícios destinados à arrecadação da dízima da Paraíba, criados em 1723 destacava-se, como já foi comentado, por ter a nobreza do seu ocupante favorecido a introdução de um ordenado, em 1728.

A rigor, o Escrivão das Execuções, Selador, Porteiro da Alfândega e Guarda Livros da Casa dos Contos da Paraíba não tinha ordenado. Mas recebia pelo ofício de Escrivão das Execuções, tal e qual o Meirinho da Fazenda, uma pequena ajuda de $4 \$ 000$ réis por ano, pagos pela Fazenda Real, como costume antigo, por assistir às audiências de arrematação dos contratos reais. Dentre os que não tinham ordenado, este oficial era o que tinha mais chance de aumentar seus estipêndios, dado o número de propinas e emolumentos que lhe eram facultados. Assim, como Escrivão das Execuções e Porteiro da Alfândega, recebia de propinas pelo contrato da arrematação do dízimo, \$400 réis a cada mil cruzados, mais duas libras de cera enquanto corria o triênio do contrato dos dízimos. Além disso, percebia $\$ 120$ réis de emolumentos, por mandados de citações e notificações em pública forma de que podiam necessitar as partes nas contendas. Ainda

\footnotetext{
${ }^{149}$ Sobre o trabalho deste oficial, certificava o escrivão da Fazenda, Bento Bandeira de Melo, em 1736, que "o meirinho do mar, Antônio Pereira Lisboa, no serviço do dito oficio, assiste as audiências que faz o provedor, nas arrematações ... nas mostras do socorro da infantaria e quando necessário vai notificar carpinas, pedreiros, ferreiros ... , notificar louvados para avaliarem as fardas que dá o contratador da dízima para a infantaria, acompanhar ao provedor quando sai fora, principalmente quando no serviço de Sua Majestade, como seja, a entrega de pólvora de um almoxarife a outro .., quando vai o provedor assistir o despacho das fazendas que vem de Lisboa a desta, com muita vigilância para que não se desencaminhem alguma coisa dos direitos. E tudo o que encarregado pelo provedor ... ou pelos oficiais maiores, tudo executa com muita prontidão, e é muito obediente aos ministros..." Cf: AHU ACL CU 014, Cx. 10, Doc. 878.
} 
como Selador e Porteiro dos Contos, tinha de emolumentos: a) 1\$000 réis, nas visitas que fazia aos navios que iam para o porto da Paraíba; b) \$10 réis, por cada selo nas fazendas que se despachavam na Alfândega, além de $\$ 170$ réis, por cada fardo; c) 1\$000 réis, por cada navio proveniente da Costa da Mina; d) \$30 réis, por cabeça de escravo.

Quanto ao Escrivão da Mesa da Abertura da Alfândega, além do ordenado de $80 \$ 000$ réis, tinha $\$ 40$ réis de emolumento por bilhete das fazendas despachadas na Alfândega. Esses emolumentos eram idênticos para todos os outros oficiais envolvidos com o recolhimento das dízimas e que não tinham ordenado, a saber: Feitor da Mesa da Abertura, Juiz da Balança, Escrivão da Mesa da Balança, Escrivão da Ementa e Escrivão do Despacho e Descarga. O Escrivão do Despacho e Descarga acumulava também, de emolumentos: $2 \$ 240$ réis dos navios que vinham despachados para a Alfândega da Paraíba, provenientes de Lisboa ou Costa da Mina; \$560 réis, por bilhete de descarga das embarcações; e $\$ 035$ réis por cabeça de escravo.

No seu conjunto, em razão do volume de negócios da capitania da Paraíba, os valores pagos aos oficiais da Provedoria da Fazenda, não deviam ir muito além dos seus ordenados diretos. Como mostra o Quadro 11, existiam as propinas provenientes das arrematações dos contratos dos direitos reais (dízimo, dízima, subsídio do açúcar, contratos das carnes) que deviam ser pagas logo no início dos trabalhos de arrecadação e a cargo do contratador - não incidindo nos valores acordados na arrematação. Com exceção dessas propinas, dificilmente poderia ser acrescida mais alguma coisa aos seus rendimentos anuais dos oficiais.

\section{QUADRO 11}

Capitania da Paraíba / Despesas : propinas e ordenados dos oficiais da Fazenda da Paraíba

\begin{tabular}{|l|l|l|l|l|c|}
\hline Cargo & Dízimo & Dízima & Carne & Açúcar & Ordenado \\
\hline Provedor & $40 \$ 000$ & $40 \$ 000$ & $10 \$ 000$ & $16 \$ 000$ & $78 \$ 000$ \\
\hline Escrivão da Fazenda & $25 \$ 000$ & $20 \$ 000$ & $8 \$ 000$ & $12 \$ 000$ & $100 \$ 000$ \\
\hline Almoxarife & $20 \$ 000$ & $10 \$ 000$ & $8 \$ 000$ & $6 \$ 000$ & $150 \$ 000$ \\
\hline Procurador & $20 \$ 000$ & $10 \$ 000$ & $8 \$ 000$ & $6 \$ 000$ & $4 \$ 000 *$ \\
\hline Oficial dos Contos & $10 \$ 000$ & $8 \$ 000$ & $8 \$ 000$ & $4 \$ 000$ & $60 \$ 000$ \\
\hline Execuções... & $\$ 400^{* *}$ & ----- & ---- & ----- & $4 \$ 000^{*}$ \\
\hline Mesa de Abertura & ----- & ----- & ----- & ---- & $60 \$ 000$ \\
\hline Meirinho: Mar e Fz. & $10 \$ 000$ & $10 \$ 000$ & ---- & ----- & $4 \$ 000^{*}$ \\
\hline
\end{tabular}

\section{Fonte: Arquivo Histórico Ultramarino}

* Ajuda de custos. contrato.

** Quatrocentos réis por cada mil cruzados, ou seja, $\$ 400$ réis a cada $400 \$ 000$ reis que render o 
Cabe esclarecer que até o ano de 1729, a propina correspondente ao direito dos dízimos era efetuada durante todos os anos de vigência do contrato. Após essa data, no entanto, passou a ser realizada de uma única vez. Essa mudança resultou de um processo de arrematação desse direito realizado no Conselho Ultramarino, para os anos de 1729 1732, que garantiu para o contratador Garcia da Ponte Coelho a condição de pagar uma só propina. Em função disso, as propinas restantes, caso os oficiais quisessem recebê-las, deviam descontar do valor da arrematação. ${ }^{150}$ Mas isso era impossível, pois, das propinas pagas na Paraíba pelo contratador do dízimo também partilhavam o governador da Paraíba (80\$000 réis) $)^{151}$, os oficiais mores da Bahia $(18 \$ 000)^{152}$ e os oficiais do Conselho Ultramarino ( $93 \$ 553$ réis $)^{153}$. Além disso, o uso da arrematação desse direito tinha uma consignação certa e dificilmente chegava para atender às demandas a que se destinava.

Sabendo-se o valor dos ordenados que cabia a cada oficial da Provedoria da Fazenda paraibana, cabe perguntar: a qual alínea da receita o pagamento desses oficiais estava consignado? Para tentar responder a esta pergunta, deve-se alargar ainda mais os horizontes e trazer à baila os outros encargos sob responsabilidade da Fazenda, como o restante da folha secular (executiva e militar) e a folha eclesiástica, com os seus gastos ordinários.

\section{O RESTANTE DA FOLHA SECULAR}

Diferentemente do caso dos ofícios da Provedoria para o século XVIII, o restante da folha secular, no que respeita à criação de novos cargos, não foi tão profícua em novidades (Quadro 12). Assim, o conjunto dos ordenados ficou assentado ainda na

\footnotetext{
${ }^{150}$ AHU_ACL_CU_014, Cx. 10, Doc. 839.

${ }^{151}$ O capitão-mor e governador da Paraíba, Pedro Monteiro de Macedo, em 1738, solicitou o pagamento dos $80 \$ 000$ réis de propinas por todos os anos da arrematação dos contratos dos dízimos, como recebiam seus antecessores. Cf: AHU_ACL_CU_014, Cx. 10, Doc. 839.

${ }^{152}$ O Provedor-mor tinha de propinas, pelas arrematações dos dízimos na Colônia: Bahia, $100 \$ 000$ e Rio de Janeiro, 100\$000. Já os das capitanias: Pernambuco, 50\$000; Itamaracá, 10\$000; Paraíba, 10\$000; Rio Grande do Norte, 8\$000; Espírito Santo, 10\$000; e São Vicente, 10\$000. Para o escrivão da Fazenda, Bahia, 80\$000; Rio de Janeiro, 80\$000; Pernambuco, 40\$000; Itamaracá, 8\$000; Paraíba, 8\$000; Rio Grande do Norte, 8\$000; Espírito Santo, 6\$000; e São Vicente, 6\$000. Cf: Alvará: Documentos Históricos. Consultas do Conselho Ultramarino. Rio de Janeiro; Biblioteca Nacional, 1950. V. 80. p. 90 - 108

${ }^{153}$ AHU_ACL_CU_014, Cx. 12, Doc. 1018.
} 
segunda metade do século XVII, da mesma forma como aconteceu com o pagamento da única tença sob responsabilidade da Fazenda paraibana: os $40 \$ 000$ réis instituídos a André Vidal de Negreiros, em 1676, pela sua participação na guerra da libertação divina e que foram transpassados para o seu filho Mathias, depois da morte do patriarca. ${ }^{154}$

Quanto aos ordenados e às provisões dos oficiais, pode-se datar com precisão apenas a designação do salário do ouvidor geral da Paraíba, que foi de $200 \$ 000$ réis, em $1687^{155}$. O restante dos pagamentos aparecem como parte da folha secular, desde o início do século XVIII, sem nenhuma especificação mais detalhada. Nestas folhas constam os ordenados do governador, que não iam além do soldo anual de $200 \$ 000$ réis, do sargentomor das ordenanças, que percebia $40 \$ 000$ réis e do patrão da barra da cidade, que alcançava $20 \$ 000$ réis anuais. Além desses, existiam os oficiais ligados à Fortaleza do Cabedelo, como o condestável, com $23 \$ 440$ réis, o capitão da fortaleza, com o estipêndio de $100 \$ 000$ réis, seu alferes, com $96 \$ 000$ réis, e o ajudante apontador das fortificações, com $36 \$ 500$ réis. $^{156}$

Se esta folha não variou no sentido da criação dos cargos, daquilo que lhe havia consignado el-Rei no século XVII, há que se considerar o volume dos aumentos que esta rubrica trouxe para a Fazenda paraibana. Por volta dos anos vinte e trinta do século XVIII, por exemplo, além dos $100 \$ 000$ réis que o ouvidor recebia de ajuda de custo, quando ia às correições nos sertões do Ceará e Rio Grande ${ }^{157}$, teve ele um outro aumento neste mesmo valor, elevando seu estipêndio para $400 \$ 000$ réis. ${ }^{158} \mathrm{Da}$ mesma forma,

\footnotetext{
154 Mathias Vidal de Negreiros era coronel de cavalaria da Capitania de Itamaracá, mas continuou recebendo a tença pela Provedoria da Fazenda paraibana. A tença a seu pai foi consignada em 15 de dezembro de 1676 e transpassada em 1688. Provisão Real de 7 de dezembro de 1688. André Vidal faleceu em 3 de fevereiro de 1680. AHU / Códice 1805 / Relação Geral dos Contratos que se administram pela Fazenda Real da Paraíba - 1731-1733.

${ }^{155}$ Irineu Ferreira Pinto. Datas e Notas para a História da Paraíba... p. 81.

${ }^{156}$ Curiosamente, chama a atenção a inclusão, nesta folha, do capitão da fortaleza e dos seus subordinados diretos, alferes, condestável e o apontador das fortificações, pois seus vencimentos deveriam se localizar na folha militar. Isso talvez se explicasse pelo caráter da nomeação desses militares serem da alçada real, pois não há indício algum de que tenham eles alguma prerrogativa executiva.

${ }^{157}$ AHU_ACL_CU_014, Cx. 5, Doc. 374; Cx. 6, D. 432; Numa Carta Régia de 6 de setembro de 1725, é ordenado ao provedor Salvador Dourado que faça o pagamento do ordenado do ouvidor e da ajuda de custo de cem mil réis (Cf: Ordens Régias / IHGP / Códice 1720-1732; Doc. 118). A partir desta data, de 1725, passa a aparecer como ordenado o valor de trezentos réis anuais. Lembrando que a Ouvidoria Geral do Ceará foi criada por provisão régia de 7 de janeiro de 1723, acabando a anexação à Paraíba. Cf: Irineu Ferreira Pinto. Datas e notas... p. 120.

${ }^{158}$ Nos mapas de receita e despesa para os anos quarenta e cinqüenta, encontramos o ouvidor da Paraíba com o ordenado de $400 \$ 000$ réis por ano. Cf: AHU_ACL_CU_014, Cx. 18, Doc. 1434 e Cx. 19; Doc. 1524.
} 
houve o aumento do capitão-mor governador da Paraíba, que teve seu ordenado elevado por duas vezes: na primeira, para 1:200\$000 réis e na segunda, para 1:600\$000. Ambos os aumentos foram atribuídos como recompensa pelas proibições da prática de comércio aos capitães-mores. Uma dessas proibições se deu em $1707^{159}$, sendo revogada em 1709; e a outra aconteceu quando se reeditou a proibição em $1720 .{ }^{160}$

Indo governar a Paraíba em 1708, João Maia da Gama acordou, em paralelo com a Câmara da Paraíba, um ordenado como recompensa pela perda da prática do comércio. Além do soldo de $200 \$ 000$ réis pagos pela Fazenda Real, a Câmara se prontificou a pagar 1:200\$000 réis por ano, que seriam custeados através de um imposto lançado sobre a população, em alguns itens de consumo da terra: azeite, sal, carnes, gibiritas e aguardente. Em 1709, em função dos dissabores dos tributos para a população, o rei terminou por revogar a lei. ${ }^{161}$ Mas essa revogação não fez retroagir o ordenado aos valores praticados antes de 1708. Pelo contrário, não só o valor de 1:200\$000 réis foi mantido, como foi repassado para a alçada da Fazenda Real e estabelecido como soldo, no lugar dos $200 \$ 000$ réis. ${ }^{162}$ Mais adiante, em 1720, a proibição ao comércio retornou, e assistiu-se a um novo aumento, agora para 1:600\$000 réis anuais. ${ }^{163}$

\footnotetext{
${ }^{159}$ Ordem de 19 de maio de 1707. Cf: AHU_ACL_CU_014, Cx. 13, Doc. 1112.

${ }^{160}$ A lei de 29 de agosto de 1720: "Lei ordenando que nenhum vice-rei, capitão-general ou governador possa comerciar, por si ou interposta pessoa, nem intrometer-se em contratos ou donativos da Câmaras, desencaminhar direitos, pôr preços a gêneros e fretes dos navios, nem mandar fazer sequestro nas fazendas dos moradores sem autoridade da Justiça, revogando-se a permissão que por resolução de 26.11.1709 se tinha dado aos governadores das conquistas negociar.” Graça Salgado (org.). Fiscais e Meirinhos. A administração no Brasil colonial. Rio de Janeiro; Arquivo Nacional. Editora Nova Fronteira, 1985. p. 429 Sobre essa lei, ver também e repercussões na Paraíba (AHU_ACL_CU_014, Cx. 5. Doc. 342; e, Cx.6, Doc. 380) no próximo capítulo IV.

${ }^{161}$ Não havia na Coroa unanimidade para a revogação dessa lei. Um procurador da Fazenda no Reino, em 1708, afirmava, em seu parecer, que "pela experiência que tive no ultramar a que passei, nenhuma coisa é mais conveniente como a proibição do negócio aos governadores, porque o poder vende e compra os gêneros e faz os preços, mas não sei se a proibição bastará; antes presumo que eles terão de lucrar os soldos acrescentado-os.” Cf: AHU_ACL_CU_014, Cx. 4, Doc. 299.

${ }^{162}$ Numa carta dos oficiais da Câmara, ao rei, em 18 de maio de 1710 , é feito agradecimento o agradecimento em nome da piedade do monarca por ter livrado o órgão de pagar os três mil cruzados de soldo ao governador. Cf: AHU ACL CU 014, Cx. 4, Doc. 303.

${ }_{163}$ É interessante ressaltar que o governador João de Abreu Castel Branco, 1722-1729, na falta de numerários na Fazenda Real, lançava mão dos rendimentos dos contratos da carne - que até então se encontravam sob o controle da Câmara - para completar o seu ordenado. Cf: AHU_ACL_CU_014, Cx. 7, Docs. 580 e 600 .
} 
QUADRO 12

Capitania da Paraíba / Despesas: Restante da Folha Executiva

\begin{tabular}{|l|l|l|l|l|l|l|l|l|}
\hline Ano & Tenças & Ouvidor & Governador & P. daBarra & Condestável & CapFortaleza & Alferes & Apontador \\
\hline Ant.1699 & $40 \$ 000$ & $200 \$ 000$ & $200 \$ 000$ & $20 \$ 000$ & $23 \$ 440$ & $100 \$ 000$ & $96 \$ 000$ & $36 \$ 000$ \\
\hline 1707 & & & $1: 200 \$ 000$ & & & & & \\
\hline 1720 & & & $1: 600 \$ 000$ & & & & & \\
\hline $1720-30$ & & $400 \$ 000$ & & & & & & \\
\hline
\end{tabular}

Fonte: Arquivo Histórico Ultramarino

\section{A FOLHA ECLESIÁSTICA}

Como diz Américo Lacombe, a concessão do direito do padroado à Ordem de Cristo em Portugal, feita através de uma série de bulas papais, terminou por tornar o grão-mestrado inerente à Coroa. ${ }^{164}$ Tal prerrogativa fez parecer ao rei português, que a cobrança e o despendimento dos dízimos eclesiásticos eram deveres intransferíveis:

Uma conseqüência da maior relevância da bula Inter Coetera de 1456 foi a cobrança dos dízimos. Por interpretação da Ordem de Cristo, não contestada pelas autoridades eclesiásticas, o encargo de

\footnotetext{
164 Segundo Américo Lacombe, as bulas papais estavam sempre valorizando o perfil cruzadista dos monarcas portugueses, primeiro contra a expansão mulçumana e, mais tarde, contra a crescente onda protestante. Linearmente, podemos conduzir a seguinte leitura das bulas: Martinho V Sane charissimus, de 4 de abril de 1418, que concedeu largas indulgências aos colaboradores de D. João I na campanha africana e recomendou, expressamente, a pregação de uma cruzada; bula Dum diversas, de Nicolau V (18 de junho de 1452) concedeu aos reis de Portugal a faculdade de adquirirem os domínios dos mulçumanos e infiéis e de possuírem seus bens públicos e particulares; bula Romanus Pontifex, de Nicolau V, de 8 de janeiro de 1455, que sintetizava o pensamento do infante Dom Henrique, porque representava a aprovação pontifícia do seu plano: o fervor missionário e o espírito mercantil; bula inter Coetera, que determinava que as terras descobertas pela Ordem de Cristo, ficariam isentas da jurisdição de qualquer bispo, e submetidas, quanto ao espiritual, ao prior do convento da Ordem de Cristo em Tomar, que tinha, aliás, direitos e honras prelatícias, e podia, assim, assumir a nova jurisdição episcopal. Mas a administração nunca passou à Ordem de Cristo ficando sob a administração temporal que competia ao rei; e as bulas Dum fidei constantium, de 7 de junho de 1514, que menciona, pela primeira vez, o Padroado Real nas colônias portuguesas e a Pro excellenti praeeminentia, de 12 de junho de 1514 ... que erige a diocese do Funchal, na Ilha da Madeira, que assume a jurisdição episcopal sobre as regiões além do Cabo Borjador, em prejuízo do prior do Convento de Tomar. Cf: Américo Jacobina Lacombe. “A igreja no Brasil Colonial.” In: Sérgio Buarque de Holanda (dir.) História Geral da civilização brasileira. A época colonial. 2 Administração, economia e sociedade. $7^{\mathrm{a}}$ Edição; São Paulo: Bertrand Brasil, 1993. Adaptado das páginas 52,53,54 e 55. Para Boxer, “o Padroado Real português pode ser vagamente definido como uma combinação de direitos, privilégios e deveres, concedidos pelo papado à Coroa portuguesa, como patrono das missões católicas e instituições eclesiásticas na África, Ásia e Brasil.” Cf: C. R. Boxer. A Igreja e a expansão ibérica. Lisboa,Edições 70.s/d.p. 99.
} 
administrar a espiritualidade teve como decorrência o recebimento dos dízimos eclesiásticos que viessem a pagar os habitantes das terras incluídas no padroado. Uma inovação, porém, introduziu-se nesta cobrança. Enquanto em certas regiões da Europa os fiéis contribuíam diretamente para o sustento do clero e do culto, a Ordem de Cristo adotou a centralização das cobranças e o orçamento único. Com a incorporação do grão-mestrado à Coroa, porém, o resultado foi a confusão dos dízimos com a renda do Estado. ${ }^{165}$

Essa confusão das rendas explicava a prerrogativa da Fazenda Real não só no processo de arrendamento para arrecadação dos dízimos, mas também dos pagamentos, tanto das côngruas como das ordinárias, ao clero regular ou secular, além das outras consignáveis ditadas ao sabor das necessidades da Fazenda.

Com a provedoria da Paraíba, não foi diferente. Porém, tendo em vista o caráter de capitania autônoma, havia outras incumbências que iam além das suas responsabilidades domésticas e exigiam alguns sacrifícios, como, por exemplo, o atendimento ao clero de outra capitania, Pernambuco. Como aparece no Quadro 13, em 1664, a obrigação com a folha eclesiástica restrita a jurisdição da Paraíba, chegava a $269 \$ 000$ réis anuais, com este valor dividido entre o vigário da Igreja Matriz Nossa Senhora das Neves $(244 \$ 000){ }^{166}$ e o seu coadjutor $(25 \$ 000) .{ }^{167}$ Mas a Provedoria tinha de

\footnotetext{
165 Américo Jacobina Lacombe. "A igreja no Brasil Colonial." In: Sérgio Buarque de Holanda (dir.) História Geral da civilização brasileira... Op.cit: p. 54 e 55. Outro detalhe a ressaltar, nesse sistema do Padroado, era o regime de provimento dos cargos eclesiásticos no período colonial: "o rei apresentava ao Papa os bispos na qualidade de chefe de Estado; e no de grão-mestre da Ordem de Cristo, apresentava aos bispos os beneficiários para os cabidos, paróquias e capelanias." (Idem Ibidem). Segundo Boxer, "a Coroa ... transferia, promovia e afastava ... clérigos; podia e decidia os limites da sua jurisdição; podia e arbitrava qualquer conflito de jurisdição entre si. Portanto, em muitos aspectos, os membros do clero colonial, ibérico podiam ser considerados, como eram freqüentemente, funcionários assalariados da Coroa...” C. R. Boxer. A Igreja e a expansão ibérica... Op.cit. p. 100.

${ }^{166}$ Cópia da provisão de 2 de abril de 1664, do vice-rei, Dom Vasco Mascarenhas por onde se paga ao vigário paroquial de Nossa Senhora das Neves da Paraíba o ordenado e ordinárias $244 \$ 000$ réis, dividido metade em dinheiro de contado e metade em açúcar. Cf: AHU / Códice 1805 / Relação Geral dos Contratos que se administram pela Fazenda Real da Paraíba - 1731-1733. Falhas, 74, 74v e 75.
} 
arcar, também, com parte do pagamento do bispo de Pernambuco e cabido da Sé de Olinda, que lhe onerava em mais $300 \$ 000$ réis por ano. ${ }^{168}$ Esta despesa não chegou a se firmar por muito tempo, não indo além do período que abrangia desde a criação do dito bispado, em 1676, até o primeiro ano do século XVIII, quando desapareceram os envios. ${ }^{169}$ Ao que tudo indica, a penetração do processo evangelizador, rumo ao interior da capitania paraibana, levou a Coroa a priorizar o movimento missionário em detrimento das contribuições destinadas ao bispo.

Em 1702, por exemplo, chegou à capitania da Paraíba uma ordem régia mandando pagar 37\$000 réis por ano a cada um dos três missionários das aldeias / missões de Campina Grande, Camaratuba e Piranhas ${ }^{170}$, o que totalizava $111 \$ 000$ réis. Este foi o primeiro indício de penetração da Provedoria da Fazenda Real paraibana rumo ao interior da capitania. E não seria o último. Em 1739, novamente, uma ordem régia mandou que se acrescentasse, à folha eclesiástica, o pagamento de mais sete missionários. Cinco deles, registrados apenas como missionários pertencentes a várias religiões e atuantes no interior da capitania, passaram a receber, cada um, $30 \$ 000$ réis por ano. Os outros dois, que tiveram acrescido ao termo de missionário o ser clérigo, tiveram direito, cada um, a $40 \$ 000$ reis por ano. ${ }^{171}$

Esses acrescentamentos à folha eclesiástica não se limitaram apenas ao sertão. $\mathrm{Na}$ cidade, os religiosos da Reforma do Carmo e os franciscanos passaram a receber, por ano, uma ordinária de $50 \$ 000$ réis, em 1717. Também os capuchos de Santo Antônio tomaram, na mesma data, uma ordinária anual de $90 \$ 000$ réis. ${ }^{172}$ Anos mais tarde, em 1729, foi fundada a vigariaria da igreja de São Pedro e São Paulo da Ribeira de Mamanguape, localizada na parte Norte da Mata da Paraíba. O vigário de Mamanguape, passou a receber uma côngrua de $50 \$ 000$ réis anuais, acrescidos de uma ordinária no

\footnotetext{
${ }^{167}$ Cópia de uma Provisão de 2 de abril de 1664, do vice-rei, Dom Vasco Mascarenhas concedendo ao coadjutor da paróquia de Nossa Senhora das Neves da Paraíba o ordenado e ordinárias de $25 \$ 000$ réis. Cf: AHU / Códice 1805 / Relação Geral dos Contratos que se administram pela Fazenda Real da Paraíba 1731-1733. Folhas 76 e 76v.

${ }^{168}$ AHU_ACL_CU_014, Cx.2, Doc. 166.

${ }^{169}$ Idem

${ }^{170}$ Carta Régia de 8 de setembro de 1702. AHU - Códice 1895.

${ }^{171}$ Ordem de 16 de abril de 1739. AHU_ACL_CU_014, Cx.18, Doc. 1434

${ }^{172}$ Carta Régia de 5 de fevereiro de $171 \overline{7}$. AHU - Códice 1895.
} 
valor de $24 \$ 000$ réis, para guisamento das missas ${ }^{173}$. Para o seu coadjutor ficou uma côngrua de $25 \$ 000$ réis por ano, a partir de $1733 .{ }^{174}$

Além de todas essas inclusões na folha eclesiástica, deve-se acrescentar o ordenado de $80 \$ 000$ réis, pago ao capelão de Santa Catarina - capela existente no interior da Fortaleza do Cabedelo. Algumas vezes, este ordenado vinha ligado às despesas que se faziam à Infantaria. Isto ocorria quando a remuneração ficava consignada à dízima, por não ter como se saldar através do dízimo, que era, por excelência, a sua consignação. ${ }^{175}$

QUADRO 13

Capitania da Paraíba / Despesas: Folha Eclesiástica

\begin{tabular}{|l|c|c|}
\hline Instituição / Ordens & Ano & Valor \\
\hline Igreja Matriz & 1664 & $269 \$ 000$ \\
\hline Capelania do Forte do Cabedelo & ---- & $80 \$ 000$ \\
\hline Bispado de Pernambuco & $1676-1701^{*}$ & $300 \$ 000$ \\
\hline Missionários (3) & $1702^{* *}$ & $111 \$ 000$ \\
\hline Missionários (7) & 1739 (indefinido) & $230 \$ 000$ \\
\hline Vigariaria de Mamanguape & 1729 & $74 \$ 000$ \\
\hline Vig. de Mamanguape (Coadjutor) & 1733 & $25 \$ 000$ \\
\hline Carmelitas Reformados & 1717 & $50 \$ 000$ \\
\hline Capuchos & 1717 & $90 \$ 000$ \\
\hline Franciscanos & 1717 & $50 \$ 000$ \\
\hline
\end{tabular}

Fonte: Arquivo Histórico Ultramarino

* Período de envio dos 300\$000 réis.

** Campina Grande, Camaratuba e Piranhas

\section{A FOLHA MILITAR}

Em 1653, baseando-se no Regimento das Fronteiras, ${ }^{176}$ a Coroa portuguesa definiu uma forma global de pagamento para as tropas estacionadas nas colônias. Estabeleceu que as Juntas do Comércio, ou as fazendas reais, deviam responder pela

\footnotetext{
${ }^{173}$ Carta Régia de 20 de agosto de 1729. AHU - Códice 1895.

${ }^{174}$ Carta Régia de 2 de fevereiro de 1733 . AHU - Códice 1895.

${ }^{175}$ Conferir alguns mapas de receita e despesas em que esse pagamento aparece em lugares distintos: em 1729 (AHU_ACL_CU_014, Cx. 7, Doc 570); 1733 (Cf: AHU / Códice 1805 / Relação Geral dos Contratos que se administram pela Fazenda Real da Paraíba - 1731-1733.); e, em 1746 (AHU_ACL_CU_014, Cx. 14, Doc. 1161).

${ }^{176}$ Elaborado em 29 de agosto de 1645, o Regimento das Fronteiras determinava uma regulamentação militar geral para Império, que incluía sistemas de pagamento, promoção, baixas e contabilidade genérica das tropas. Cf: Kalina Vanderlei Silva. O miserável soldo \& a boa ordem da sociedade colonial: militarização e marginalidade na Capitania de Pernambuco dos séculos XVII e XVIII. Recife: Fundação de Cultura da Cidade do Recife, 2001. p. 163; e Graça Salgado (org.). Fiscais e Meirinhos... Op.cit. p. 102 e 103.
} 
manutenção das tropas de linha - como a Infantaria -, ficando as milícias ou os corpos de ordenanças, quando houvessem nas capitanias, a cargo da população local. Na Capitania da Paraíba, por exemplo, a Provedoria da Fazenda Real devia ser a responsável pelo pagamento das companhias de Infantaria ali existentes. Mas quantas companhias possuía a Paraíba?

Logo após os primeiros anos da expulsão dos holandeses, o mestre de campo João Fernandes Vieira, ao ser nomeado para governar a capitania da Paraíba, em 1655, levou consigo cinco companhias do seu terço, com cerca de trezentos homens, para repovoar e garantir a segurança do lugar. Solicitou ao rei que a sua manutenção e a dos seus soldados, fossem custeadas pela Fazenda de Pernambuco, enquanto não houvesse rendimento na Fazenda da Paraíba. ${ }^{177}$

Ao cabo de dois anos, quando seguiu para governar Angola, em 1658, Fernandes Vieira levou parte do efetivo que o havia acompanhado à Paraíba - cerca de duzentos homens. ${ }^{178}$ Desta feita, o governador-geral do Brasil, Francisco Barreto de Menezes, nomeou nos postos vagos da praça da Paraíba, por volta de 1659, "dois capitães com duzentos homens, os quais fossem filhos desta capitania [da Paraíba] para assim poderem sustentar melhor nela". ${ }^{179}$

Ao que parece, esse contingente de trezentos homens constituiu as três companhias de Infantaria que guarneciam a capitania da Paraíba. Duas delas situavam-se na praça da Paraíba e a outra, no presídio da Fortaleza do Cabedelo. A essas companhias juntaram-se mais alguns soldados, como os dez homens que foram mandados para manter guarda em um fortim da Baía da Traição. Esse fortim foi construído na gestão do governador João Maia da Gama, em $1710^{180}$, mas foi desmobilizado nos idos de 1729, passando o seu efetivo a se incorporar à companhia da Fortaleza do Cabedelo. ${ }^{181}$ Outrossim, esse governador teve também, a incumbência de levantar a Casa da Pólvora,

\footnotetext{
${ }^{177}$ Cf: AHU_ACL_CU_014, Cx. 1, Doc. 39 e Doc 40.

${ }^{178}$ Afirma Alencastro que a "testemunha direta, Cardornega diz que João Fernandes Vieira desembarcou em Luanda com duzentos soldados de sua confiança. Cem acima dos permitidos pela Coroa". Cf: Luiz Felipe Alencastro. O trato dos viventes. Formação do Brasil no Atlântico Sul. São Paulo/ Cia das Letras, 2000. p. 275.

${ }^{179}$ AHU ACL_CU_014, Cx. 1, Doc. 47.

${ }^{180}$ Horácio de $\bar{A}$ lmeida. História da Paraíba... Op.cit. p. 68

${ }^{181}$ AHU / Códice 1805 / Relação Geral dos Contratos que se administram pela Fazenda Real da Paraíba $1731-1733$, p. $55,55 \mathrm{v}$ e 56.
} 
no mesmo ano de 1710 , para onde foram mandados um cabo armeiro e seu ajudante, em $1711^{182}$

Dada a volubilidade que caracteriza o comportamento de um corpo militar, com promoções, baixas e nomeações, torna-se difícil estabelecer um quadro evolutivo do seu pagamento. Dessa forma, ao singularizar o número de companhias pagas que atuavam no espaço da capitania da Paraíba, optamos por apresentar o valor que correspondia ao pagamento de uma folha militar completa - com os soldos, os números da farda e o pãode-munição (Quadros 14 e 15).

\section{$\underline{\text { Soldos }}$}

Sobre os soldos, dispõe-se de duas amostragens. A primeira foi conseguida através de uma carta do vedor geral Salvador Dourado ao rei, de 18 de agosto de 1718, falando sobre a relação das gentes de guerra pagas pela Fazenda Real. ${ }^{183}$ Os dados retirados daí podem ser alongados para os anos anteriores, pois, desde que a Coroa definiu a forma de pagamento das tropas em 1653, há indício de um único aumento de soldo na Paraíba. Foi em 1716, quando houve o provimento de um sargento-mor engenheiro, que passou a contar com um soldo de $312 \$ 000$ réis anuais. ${ }^{184}$ A outra amostragem, que se baseia numa série de listas de pagamentos, a partir de $1723,{ }^{185}$ absorveu o aumento geral para a infantaria da Paraíba, em $1724^{186}$, e pode ser estendida

\footnotetext{
${ }^{182}$ Irineu Ferreira Pinto. Datas e notas ... Op.cit. p. 105

${ }^{183}$ AHU_ACL_CU_014, Cx. 5, Doc. 362. Esta relação faz referência a um pagamento geral de doze meses, para o interregno de $1714-15$, conseguida através do acúmulo de três anos de receita, 1714-17.

${ }^{184}$ As informações sobre a folha militar para os anos anteriores a Pombal, pelo menos para as capitanias do Norte, são por demais difíceis. No ótimo trabalho de Kalina Silva, que se debruça sobre o sofrimento dos soldados de Infantaria existentes em Pernambuco, principalmente pela falta de pagamento, há apenas uma nota sobre o valor alcançado por um capitão de Infantaria, em 1716, $77 \$ 280$ réis por ano. Cf: Kalina Silva. O miserável soldo \& a boa ordem da sociedade colonial: militarização e marginalidade na Capitania de Pernambuco dos séculos XVII e XVIII... Op.cit., p. 309; nota 486.

${ }^{185}$ Dispomos de cinco listas de pagamento para os anos de 1723 a 1733: três em AHU / Códice 1805 / Relação Geral dos Contratos que se administram pela Fazenda Real da Paraíba - 1731-1733; folhas 5 a 8v para os anos de 1729-30 (inclusive com o pagamento do pão de munição); folhas 10 e 10v para os anos 1731-32, apenas com o registro do pagamento das fardas; e folhas 15 a $17 \mathrm{v}$ para os anos de $1732-33$, inclusive com o pagamento das fardas. Há mais uma folha para os anos de 1733-34 que abarca as três companhias. Cf: Irineu Ferreira Pinto. Datas e notas para a História do Brasil ... p. 135 e 136. E, por fim, para o ano de 1723 - 1724, extensivo até 1729, uma amostra de quanto se deveria pagar aos soldados de Infantaria da Paraíba. Cf: AHU_ACL_CU_014, Cx. 7, Doc. 570.

${ }^{186}$ Ordem real de 13 de maio de 1723 , registrada nos livros da provedoria da Parába no primeiro de agosto de 1724, determinava ao governador da Paraíba que, por se reconhecer na lista enviada pelo provedor-mor
} 
até o ano de 1745, quando se assistiu à equiparação dos terços do Brasil aos do Reino. ${ }^{187}$ $\mathrm{Na}$ capitania da Paraíba, por conta dessa equiparação, o rei autorizou os aumentos dos soldos de ajudante de artilharia, para $76 \$ 200$ réis, ajudante supra, para $51 \$ 000$ réis e de ajudante do número, para $100 \$ 000$ réis anuais, como se constata nos registros da secretaria de governo da capitania. ${ }^{188}$

\section{$\underline{\text { Pão-de-munição }}$}

O pão-de-munição foi instituído para as companhias de Infantaria da Paraíba a partir de 1726, com o teto de uma quarta de farinha - cerca de 9 litros - a cada dez dias, para os soldados. Cabe esclarecer, que a compra do produto ao assentista, para distribuição pelo almoxarifado à tropa, tinha como teto o valor de $\$ 400$ réis o alqueire cerca de 36 litros. Caso este valor fosse excedido, a depender do comércio, era feita a conversão em dinheiro, que era passado para os soldados como forma de evitar uma possível especulação sobre o produto. ${ }^{189}$

\section{$\underline{\text { As fardas }}$}

Quanto às fardas, sabe-se que, quando não eram enviadas pelo Reino ${ }^{190}$, cabia ao provedor, como Vedor da Gente de Guerra da Capitania, ou aos contratadores dos

\footnotetext{
como era pequeno o soldo que se praticava no estado do Brasil, procurasse igualar os soldos da Paraíba ao da capitania do Rio de Janeiro. Cf: AHU_ACL_CU_014, Cx. 13, Doc. 1127

${ }^{187}$ Ordem de 29 de outubro de 1745. Cf: Ordens Régias / IHGP / Códice 1745 -1755; Doc. 24

188 Idem.

189 Ordem régia de 8 de agosto de 1726 (Cf: AHU / Códice 1805 / Relação Geral dos Contratos que se administram pela Fazenda Real da Paraíba - 1731-1733, folhas 35 e 35v). Segundo o governador da Paraíba, Pedro Monteiro de Macedo, o processo do assentamento da farinha obedecia o seguinte ritual: "no mês de setembro ou outubro se porá em praça o assento das farinhas, por ser este o tempo mais propício para a compra, por todos desfazerem roças, e arrematado o assento, podendo ser, se adiantará ao assentista por baixo de fiança o dinheiro que for necessário a compra da metade da farinha, para que se tenha do seu provimento na Fortaleza [do Cabedelo] sempre um bom sobressalente ... e que a metam em uma das casas do governador segurando a muito sua satisfação, e será obrigado o assentista, ou por si, ou por outrem, a distribuí-las aos soldados nos dias destinados pela livrança [isto é, com registro de pagamento] na presença do sargento da companhia, e na cidade se recolherá no armazém seu, e a distribuirá da mesma forma ... de janeiro a dezembro. Cf: AHU_ACL_CU_014, Cx. 10, Doc. 824.

190 Uma carta régia, bastante danificada, de D. João V, c. 1716, sō̄re o envio dos fardamentos, argumentava que o motivo da demora dava-se exatamente "por não querer incorrer em erro quanto ao cabimento dos vestidos, e que os que agora mandava estavam de acordo com a lista inclusa”. Cf: Códice: IHGPPB / Ordens Régias 1709-1719.
} 
dízimos, a obrigação de colocar em algumas lojas da cidade, um valor determinado em "panos finos, chapéus e mais miudezas," com as quais os soldados pudessem se vestir. ${ }^{191}$ Em relação à quantia que devia caber a cada soldado, sabe-se que, para os anos posteriores a 1723 , os dados são os mesmos que foram utilizados para o pagamento dos soldos - e onde uma farda orçava em $13 \$ 440$ réis. A questão é saber se o aumento dos soldos de 1724 foi ou não estendido para esse quesito. Dois documentos sugerem algumas pistas: a) a já citada lista de pagamentos da gente de guerra, enviada ao rei, em 1718; b) um requerimento ao rei, feito pelos "soldados das companhias pagas da cidade da Paraíba e Fortaleza do Cabedelo" no início da década de vinte, mas anterior a $1723^{192}$, pedindo para serem pagos em dinheiro, na falta dos artigos para a confecção das fardas.

No primeiro documento, a confusão dos pés das listas no pagamento das fardas tornava impossível qualquer dedução sobre os valores pagos - inclusive pelo mau estado do documento, principalmente nas partes que referenciavam o assunto. ${ }^{193}$ Quanto ao segundo documento, pelo menos elucidava que havia um valor unitário para todos os soldados, equivalente a $10 \$ 000$ réis por ano. ${ }^{194}$

Como pode ser verificado nos Quadros 14 e 15, o valor correspondente a uma farda ordinária, que antes de 1723 era de $10 \$ 000$ réis, modificou-se após o aumento dos soldos em 1724, passando a valer $13 \$ 440$ réis. Resta saber se alguns oficiais de primeira plaina, como o ajudante supra e do número, ou o sargento, ou mesmo alguns cabos de esquadra que aparecem com um vencimento diferenciado após o aumento, foram ou não minimizados na argumentação dos peticionários. Na incerteza, pode-se simplesmente endossar o valor dos $10 \$ 000$ réis, generalizando-o para toda a tropa que tinha direito à farda. Responder se haveria uma diferença a maior para alguns postos, é um limite que esta pesquisa não pode ultrapassar. Contudo, se no futuro a variação nos pagamentos das

\footnotetext{
${ }^{191}$ AHU_ACL_CU_014, Cx. 5, Doc. 397.

192 Idem. Curiosamente, até fins do século XVIII, os requerimentos ou petições, endereçadas ao rei ou a qualquer outra instância superior, não eram datadas de maneira alguma pelos requerentes ou peticionários. Por isso, nas datações destes documentos, usa-se sempre a data de porta (entrada no protocolo) como referência, que é posterior à feitura do documento.

193 AHU_ACL_CU_014, Cx. 5, Doc. 362.

194 “... sem dúvida vencem esses suplicantes, por ano, dez mil réis, cujo ajuste lhes fica devendo a fazenda Real dois mil e tantos réis..." Neste ajuste de "dois mil e tanto réis" estava, exatamente, o pedido dos soldados para serem ressarcidos em dinheiro pela Fazenda Real ou pelo contratador, que lhes pagava apenas "sete mil e tantos réis" Cf: AHU_ACL_CU_014, Cx. 5, Doc. 397
} 
fardas, para o período anterior a 1723 vier a se confirmar, os números com que trabalhamos não deixarão de ter validade. Pois, considerando-se a inconstância com que se faziam os pagamentos dos soldados o valor a menor margeia uma larga faixa de segurança no conjunto do que foi efetivamente saldado com as tropas.

\section{QUADRO 14}

Capitania da Paraíba / Despesa / Folha Militar: anterior a 1723

\begin{tabular}{|c|c|c|}
\hline Posto & Soldo * & Farda $^{* *}$ \\
\hline Sargento-mor eng ${ }^{\circ} 195$ & $312 \$ 000$ & Não vence \\
\hline 2 capitães & $96 \$ 000 \times 2=192 \$ 000$ & Não vence \\
\hline 1 Ajudante do $n^{\circ}$ & $67 \$ 200$ & $10 \$ 000$ \\
\hline 1 Ajudante supra & $43 \$ 800$ & $10 \$ 000$ \\
\hline Ajud. De Artilharia & $23 \$ 040$ & $10 \$ 000$ \\
\hline 2 Alferes & $43 \$ 800 \times 2=87 \$ 600$ & $x 2=20 \$ 000$ \\
\hline 2 Embandeirados & $10 \$ 950 \times 2=21 \$ 900$ & $x 2=20 \$ 000$ \\
\hline 3 Sargentos do $n^{\circ}$ & $21 \$ 9000 \times 3=65 \$ 700$ & $x 3=30 \$ 000$ \\
\hline 3 Sargentos Supra & $16 \$ 425 \times 3=49 \$ 275$ & $x 3=30 \$ 000$ \\
\hline 12CabosdeEsquadra & $14 \$ 600 \times 12=175 \$ 200$ & $x 12=120 \$ 000$ \\
\hline 1 Condestável & Vence na folha executiva & $10 \$ 000$ \\
\hline 5 Artilheiros & $16 \$ 425 \times 5=82 \$ 125$ & $x 5=50 \$ 000$ \\
\hline 2 Pajens & $16 \$ 425 \times 2=32 \$ 850$ & $x 2=10 \$ 000$ \\
\hline 6 Tambores & $10 \$ 950 \times 6=65 \$ 700$ & $x 6=60 \$ 000$ \\
\hline 120 Praças & $10 \$ 950 \times 120=1: 314 \$ 000$ & $x 120=1: 200 \$ 000$ \\
\hline $2 \operatorname{Praças}\left(S t^{\circ} A n t^{\circ}\right)^{196}$ & $10 \$ 950 \times 2=21 \$ 900$ & $x 2=20 \$ 000$ \\
\hline 1 Praça $\left(\text { São } B t^{\circ}\right)^{197}$ & $10 \$ 950$ & $10 \$ 000$ \\
\hline 1 Capelão & $48 \$ 000$ & $10 \$ 000$ \\
\hline 1 Cirurgião & $48 \$ 000$ & Não vence \\
\hline Cabo Armeiro & $40 \$ 000$ & Não Vence \\
\hline Ajudante de Armas & $25 \$ 000$ & Não vence \\
\hline Assentista do azeite & $30 \$ 210$ (as três Cia's) & \\
\hline Total: & $\begin{array}{l}\text { Sem o eng }{ }^{\circ} 2: 444 \$ 450(1715) \\
\text { Com o eng } \\
\circ\end{array}$ & $1: 620 \$ 000$ \\
\hline
\end{tabular}

Fonte: Arquivo Histórico Ultramarino

* Praça de soldado: 10\$950 réis / ** Farda / praça soldado, 1723: 10\$000 réis

\footnotetext{
${ }^{195}$ Nesse cargo de sargento-mor engenheiro da companhia assumiu Luís Xavier Bernardes, em 4 de junho de 1716 (Cf: Irineu Ferreira Pinto. Datas e notas para a História da Paraíba ... p. 110). Por volta do ano de 1742, fôra promovido a mestre de campo general e engenheiro pelo governador de Pernambuco. Tal patente, porém, como dizia o governador da Paraíba, Pedro Monteiro de Macedo, que deveria vir acompanhada "com seus muitos mil cruzados", só teria validade em Pernambuco, uma vez que naquela capitania havia general e não na Paraíba, onde o comandante das armas era um capitão-mor. A remuneração do oficial deveria se resumir, portanto, ao cargo que lhe era reconhecido na Paraíba. Cf: AHU_ACL_CU_014, Cx. 12, Doc. 990.

${ }^{196}$ Nos documentos consultados, conseguimos apenas determinar para o ano de 1709 (13 de dezembro), a carta régia autorizando pagar dobrado o soldo de uma praça de soldado raso para o "Glorioso Santo Antônio”. Cf: Códice 1805; Folha 57 v.

${ }^{197}$ Não conseguimos determinar quando foi instituída a praça de soldado a São Bento, todavia, já aparecer esta remuneração na relação de pagamento de 1714-15 e seguintes. Cf: AHU_ACL_CU_014, Cx. 5, Doc. 362.
} 


\section{QUADRO 15}

Capitania da Paraíba / Despesa / Folha Militar: Posterior a 1724

\begin{tabular}{|c|c|c|c|}
\hline Posto & Soldo * & Farda ** & Pão-de-munição*** \\
\hline Sargento-mor eng ${ }^{\circ}$ & $312 \$ 000$ & Não vence & Não vence \\
\hline 2 capitães & $192 \$ 000 \times 2=384 \$ 000$ & Não vence & $x 4=14 \$ 600$ \\
\hline 1 Ajudante do $n^{\circ}$ & $96 \$ 000$ & $16 \$ 960$ & $3 \$ 650$ \\
\hline Ajudante supra & $48 \$ 000$ & $16 \$ 960$ & $x 2=7 \$ 300$ \\
\hline Ajud. De Artilharia & $67 \$ 200$ & $13 \$ 440$ & $7 \$ 300$ \\
\hline 2 Alferes & $72 \$ 000 \times 2=144 \$ 000$ & $X 2=26 \$ 880$ & $14 \$ 600$ \\
\hline 2 Embandeirados & $14 \$ 400 \times 2=28 \$ 800$ & $X 2=26 \$ 880$ & $7 \$ 300$ \\
\hline 3 Sargentos do $n^{\circ}$ & $30 \$ 720 \times 3=172 \$ 800$ & $17 \$ 250 \times 3=51 \$ 750$ & $10 \$ 950$ \\
\hline 3 Sargentos Supra & $19 \$ 200 \times 3=57 \$ 600$ & $14 \$ 400 \times 3=43 \$ 200$ & $10 \$ 950$ \\
\hline 12CabosdeEsquadra & $19 \$ 200 \times 12=230 \$ 400$ & $14 \$ 400 \times 12=172 \$ 800$ & $43 \$ 800$ \\
\hline 1 Condestável & Vence na folha executiva & $16 \$ 960$ & $3 \$ 650$ \\
\hline 5 Artilheiros & $19 \$ 200 \times 5=96 \$ 000$ & $14 \$ 400 \times 5=72 \$ 000$ & $18 \$ 250$ \\
\hline 2 Pajens & $19 \$ 200 \times 2=38 \$ 400$ & $x 2=26 \$ 880$ & $7 \$ 300$ \\
\hline 6 Tambores & $15 \$ 360 \times 6=92 \$ 160$ & $x 6=80 \$ 640$ & $21 \$ 900$ \\
\hline 120 Praças & $15 \$ 360 \times 120=1: 843 \$ 200$ & $x 120=1: 612 \$ 800$ & $x 120=438 \$ 000$ \\
\hline $2 \operatorname{Praças~}\left(S t^{\circ} A n t^{\circ}\right)$ & $15 \$ 360 \times 2=30 \$ 720$ & $x 2=26 \$ 880$ & $7 \$ 300$ \\
\hline 1 Praça $\left(\right.$ São $\left.B t^{\circ}\right)$ & $15 \$ 360$ & $13 \$ 440$ & $3 \$ 650$ \\
\hline 1 Capelão & $48 \$ 000$ & $13 \$ 440$ & Não Vence \\
\hline 1 Cirurgião & $48 \$ 000$ & Não vence & Não vence \\
\hline Cabo Armeiro & $40 \$ 000$ & Não Vence & Não Vence \\
\hline Ajudante de Armas & $25 \$ 000$ & Não vence & Não Vence \\
\hline Assentista do azeite & $60 \$ 000$ (as três Cia's) & & \\
\hline Total: & $3: 877 \$ 640$ & $2: 231 \$ 910$ & $620 \$ 500$ \\
\hline
\end{tabular}

\section{Fonte: Arquivo Histórico Ultramarino}

* Praça de soldado, 1724: $15 \$ 360$ réis anuais.

** Farda / praça soldado, 1724: 13\$440 réis anuais.

*** Farinha de munição, praça de soldado, teto, uma $4^{\mathrm{a}}$ a cada dez dias: $3 \$ 650$ réis anuais correspondente a um limite de $\$ 100$ réis a cada dez dias.

Conforme mostram os dados dos Quadros 14 e 15, os soldos atingiram, nos anos anteriores a 1723 , o valor de 2:444\$450 réis, antes do provimento do sargento-mor engenheiro, em 1716. Após esse provimento, o soldo da Infantaria subiu para 2:756\$450 réis, alcançando, com o aumento de 1724, o valor de 3:877\$640 réis. Além desse aumento assistiu-se, no ano de 1745 , a um pequeno acréscimo de $16 \$ 000$ réis no soldo de alguns oficiais de primeira plaina, que elevou a fatura dessa alínea para 3: 894\$930 réis.

Quanto à farda, os valores resumem-se a 1:620\$000 réis, para o período anterior a 1724, e a 2:231\$910 após o aumento geral das tropas. Sobre o pão-de-munição, tem-se 
um valor único de $620 \$ 500$ réis, para os anos posteriores a $1726 .{ }^{198}$ Além dessas despesas com as folhas de pessoal da administração, havia outros gastos ordinários de grande vulto, que, necessariamente, pelo volume de gastos envolvidos, representavam uma soma significativa nos custos para a Fazenda paraibana. A construção de fortalezas, as despesas miúdas e o casamento dos príncipes, constituem bons exemplos disso.

\section{A FORTALEZA DO CABEDELO, AS DESPESAS MIÚDAS E O CASAMENTO DOS PRÍNCIPES}

A estratégica edificação, que respondia pela defesa contra o ingresso de possíveis inimigos no rio Paraíba - em cujas margens e braços estavam edificados os engenhos de açúcar e a própria cidade de Nossa Senhora das Neves -, teve a superintendência das suas obras transferida do governo de Pernambuco para o da Paraíba, em 1704. ${ }^{199}$ A despesa com essa fortificação não se mostrou efetivamente certa durante o ano, tendo em vista o número de pessoas e tarefas que ela abarcava. Os gastos evolviam o trabalho de índios na terraplanagem, que tinham um jornal de $\$ 500$ réis $^{200}$, os presos e os escravos alugados e os pedreiros, carpinteiros e calafates, enfim, com os empreiteiros que sempre refaziam suas contas. Em função disso, dificilmente a despesa poderia ficar aquém dos quatro contos de réis por ano.

Para se ter uma idéia dos gastos com a fortaleza e sua obra interminável, quando a superintendência ficou a cargo da Fazenda paraibana, em 1704, o provedor Salvador Dourado reviu os projetos e reclamou sobre a demora da reconstrução, por lhe faltarem oficial engenheiro, escravos e um condestável mais efetivo. Segundo o provedor, já haviam se passado mais de vinte anos de trabalho sob a administração de Pernambuco e

\footnotetext{
198 Em 1747, o provedor da Fazenda, Teotônio Temudo, calcula um valor de $602 \$ 650$ para o pão-demunição. Cf: AHU_ACL_CU_014, Cx. 16, Doc. 1258

${ }_{199}$ Inicialmente a superintendência das obras das fortalezas nas capitanias do Norte havia ficado sob o comando de Fernandes Vieira. Na sua saída para Angola, entretanto, passou a superintendência para o governo de Pernambuco. Mas, em 1704, reconhecendo a necessidade de manter em caráter permanente uma administração que acompanhasse as obras, decidiu a Coroa passar a superintendência para o governador da Paraíba, Fernando de Barros Vasconcelos. Deixando claro, porém, que o governo de Pernambuco não deveria se furtar em ajudar, quando necessário, às obras daquele forte, afinal, dele dependia a manutenção da conquista na região. Cf: AHU_ACL_CU_014, Cx. 4, Doc. 266

200 Carta régia de 31 de março de 1713. Cf: Irineu Ferreira Pinto. Datas e notas... p. 107; e ,AHU_ACL_CU_014, Cx. 2, Doc. 86.
} 
nem a quarta parte do que se pretendia, estava pronto. Anos mais tarde, em 1729, o mesmo provedor disse que já tinha gastado 32:483\$475 réis com três empreiteiros, e ainda se devia 3:017\$475 réis do contrato da arrematação do serviço reiniciado em 1704, e nem por isso a obra estava em fase de conclusão. ${ }^{201}$ Pelo contrário, entrava o ano de 1731 ainda faltando cobrir "o corpo da guarda, as abóbadas das portas, quatro quartéis, a casa do capitão-mor e a casa do governador. "202 Em 1741, o governador da Paraíba, Pedro Monteiro de Macedo, reclamou que a dívida com os empreiteiros da fortaleza passava de quatro contos de réis. Dois anos depois, em 1743, foi o próprio provedor da capitania da Paraíba, José Antônio da Cunha, que disse estar consternado por ter encontrado a Fortaleza do Cabedelo ainda

com as plataformas e metade das cortinas sem lajeamento para efeito de poder laborar a artilharia, como também sem parapeitos para a parte da terra, nem ainda para o mar, e sem guaritas e outras obras interiores, precisas e necessárias, para a defesa dela (...) As carretas muitas delas expostas ao tempo sem se alcatroarem (...) A sua entrada, o corpo da guarda, imperfeito, a casa dos governadores, arruinada, (...) as traves fora do lugar e encostadas à parede (...) A contra escarpa em circunferência sem banqueta para a guarnição se poder defender de qualquer invasão terrestre (...) $O$ tijolo para o parapeito e outras obras interiores péssimo (...) $E$

\footnotetext{
${ }^{201}$ AHU ACL CU 014, Cx. 7, Doc. 577. Dinheiro para pagar os empreiteiros não havia, e em uma carta do governador da Paraíba Francisco Pedro de Gusmão, para o rei, em 22 de junho de 1729, dizia ser impossível continuar com as obras da fortaleza, pois dos oito contos de réis que se mandava de Pernambuco, pela junção do contrato da dízima, sobravam para se aplicar na obra pouco mais de 1:900\$000 réis. Cf: AHU_ACL_CU_014, Cx. 7, Doc. 576.

${ }^{202}$ Engana-se Irineu Pinto quando diz que essas obras da fortaleza estavam concluídas no ano de 1731. Elas apenas tinham sido postas em praça pelo governador. Cf: Irineu Ferreira Pinto. Datas e notas para a História da Paraíba... Op.cit. p. 134.
} 
não sei o que mais posso advertir para expor na presença de Vossa Majestade. ${ }^{203}$

As dívidas e advertências sobre o estado da fortaleza não consternavam apenas os oficiais e Sua Majestade. Com o tempo, a dívida sujeitava também os parentes que precisavam viver do suor daqueles que haviam gasto parte de sua vida e morrido durante a construção da fortaleza. Assim, em 1748, Dona Izabel da Cunha enviou junto com o seu marido João Martins Gramacho, um requerimento ao rei, pedindo que lhe pagassem 1:236\$394 réis. ${ }^{204}$ Alegou que era herdeira do seu pai, Antônio Afonso de Carvalho, um dos três empreiteiros mencionados por Salvador Dourado, em 1729. ${ }^{205}$

Mas não eram apenas as despesas com a Fortaleza do Cabedelo que preocupavam os administradores da Fazenda. Outros empreendimentos e pequenos gastos, incluídos no rol das despesas miúdas, podiam inundar as despesas extraordinárias, encarecendo mais as contas da Provedoria da Paraíba. Para a construção da igreja matriz, por exemplo, foram gastos $8 \$ 000$ réis por ano ${ }^{206}$; para a construção da capela dos presos, $100 \$ 000$ réis, em $1726^{207}$; para a morada do governador, $40 \$ 000$ réis de aluguel por ano. ${ }^{208}$ Existiam ainda os gastos com os serviços esporádicos de pedreiros para conserto da Alfândega; jornais de canoeiros e outras conduções, como, por exemplo, os trens de munição de um armazém a outro; pagamento de ajuda de custo para os soldados que entregavam a correspondência ao correio marítimo em Pernambuco; e compra de livros, papel e tinta para a Casa dos Contos da Capitania. Todos esses gastos eram contabilizados como despesas miúdas que não orçavam anualmente aquém dos dois contos de réis. Contudo, com exceção do saldo para a igreja Matriz - que tinha na consignação dos dízimos uma receita certa -, todo o restante das despesas miúdas ficava à espera das sobras de um

\footnotetext{
${ }^{203}$ AHU_ACL_CU_014, Cx. 13, Doc. 1112

204 Esse valor era relativo aos trabalhos executados pelo seu pai nos anos de 1732 a 1736 . Cf: AHU_ACL_CU_014, Cx. 15, Doc. 1242.

${ }^{205}$ Os empreiteiros eram Rafael da Silva Torres e Simão Gomes.Cf: AHU_ACL_CU_014, Cx. 7, Doc. 571 e 577 .

${ }^{206}$ Em 17 de agosto de 1717, há uma ordem real para que se socorra a edificação da Matriz, com mil cruzados por ano durante três anos (Irineu Ferreira Pinto. Datas e notas para a História da Paraíba... p. 111-112). Contudo, o que se apreende das despesas feitas ao longo do tempo pela Fazenda Real, tocando inclusive nos anos de 1749 e 1755, é que a contribuição é dobrada, para dois mil cruzados, ou seja, $8 \$ 000$ réis. Cf: AHU_ACL_CU_014, Cx. 15, Doc. 1258 e Cx. 18, Doc. 1454.

${ }^{207}$ Carta Régia de 7 de maio de 1726. Cf: Irineu Pinto. Datas e notas... p. 124

${ }^{208}$ Carta Régia de 18 de outubro de 1738 ordenando manter o aluguel. Idem. p. 142
} 
bom ano, já que, na hierarquia das quebras, os cortes eram dirigidos primeiro para esta alínea. Como se o epíteto extraordinário da despesa, em si, valesse também para o quesito do pagamento.

Por fim, devem ser destacados, os donativos de um milhão e duzentos e cinqüenta mil cruzados, que as Capitanias do Norte ficaram obrigadas a pagar por conta do casamento do príncipe Dom José com a princesa espanhola Maria Ana Vitória e do dote da princesa portuguesa Maria Bárbara, quando do seu casamento com o príncipe espanhol Dom Fernando, ambos realizados em janeiro de 1729. Tal destaque deve-se mais pela confusão que fazem alguns interpretes do período, do que pela relevância dos pagamentos. Para Silveira, ${ }^{209}$ por exemplo, o vultoso donativo, conjugado com uma conjuntura de contínua seca empobreceu os moradores da Paraíba. Para Horácio de Almeida $^{210}$, por outro lado, a falta desse pagamento foi o motivo do grande castigo: a anexação da Paraíba a Pernambuco. Na verdade, a Paraíba nunca foi castigada por nenhum dos dois motivos. Primeiro porque o donativo não poderia empobrecer os moradores, pois a capitania da Paraíba, como diz Horácio de Almeida, nunca chegou a pagá-lo. Em segundo lugar, não se pode simplesmente atrelar a anexação à falta dramática desse pagamento, já que tanto a Paraíba como a capitania do Rio Grande foram agraciadas pelo perdão real, livrando-se do encargo em reconhecimento da pobreza por que passavam. $^{211}$

\section{AS DESPESAS DA FAZENDA: RELAÇÃO ENTRE AS FOLHAS DE PESSOAL}

Feitas essas observações sobre os donativos e as despesas com a Fortaleza do Cabedelo, as discussões sobre as folhas de serviço podem ser retomadas. A intenção é

\footnotetext{
${ }^{209}$ Rosa Maria Godoy Silveira \& outros. Estrutura de Poder na Paraíba... p. 30

${ }^{210}$ Segundo o autor, "o Rio Grande do Norte ... não pagou a imposição dos donativos para os casamentos reais e nem por isso foi achado de culpa, antes [foi] justificado pela pobreza em que vivia. Só a Paraíba merecia o castigo. Acabou sendo anexada a Pernambuco, em razão da precariedade de suas rendas." Cf: Horácio de Almeida. História Paraíba. V. 2; p. 74 e 75

${ }^{211}$ Em 1739, dizia o governador Pedro Monteiro de Macedo, ter " $V$. Majestade, atendido a pobreza da terra, a isentou por vossa real piedade de contribuir com o donativo, o qual lho impôs [à] Pernambuco, para aliviar a sua vaidade”. Cf: AHU_ACL_CU_014, Cx. 11, Doc. 897. Em uma carta dos oficiais da Câmara da Paraíba, em 1741, diziam que "V. Majestade, já tem conhecido a suma pobreza dessa terra, de sorte que por sua real grandeza e piedade a livrou do donativo.” Cf: AHU_ACL_CU_014, Cx. 11, Doc. 936.
} 
fornecer um quadro síntese que as relacione e possibilite verificar o peso de cada uma delas, quer no cômputo geral do período trabalhado, quer nos recortes pontuais estabelecidos por força dos movimentos de avanço e recuo dos quadros de pessoal que as compunham. Assim, devem ser abstraídas as despesas com a Fortaleza do Cabedelo e as despesas extraordinárias, uma vez que a inconstância do pagamento destas alíneas, até mesmo pela imposição das quebras e pela variedade de serviços, impede uma margem de cálculo confiável. $\mathrm{O}$ foco deve ficar apenas nos pagamentos das folhas e especificamente naquilo que cabia à Fazenda real. Devem ser excluídas, também, as gratificações que ficavam sob a responsabilidade de particulares.

Como se vê nos Quadros 16 e 17, relativos às despesas em porcentagem e ao cômputo por decênio, respectivamente, a maior pressão sobre a folha de pagamento, ao longo de todo o período esteve na folha militar, que compreendeu nada menos que $67 \%$ do total dos custos. Junto a ela, num movimento análogo, ficou a folha executiva. Apesar de partir de um patamar inferior, a folha executiva manteve a casa dos $24 \%$ e expressou, no decorrer do tempo, o mesmo desempenho para cima, mais que dobrando as despesas no fim do período.

\section{QUADRO 16}

Capitania da Paraíba / Despesas: Folhas de Pagamento em \%

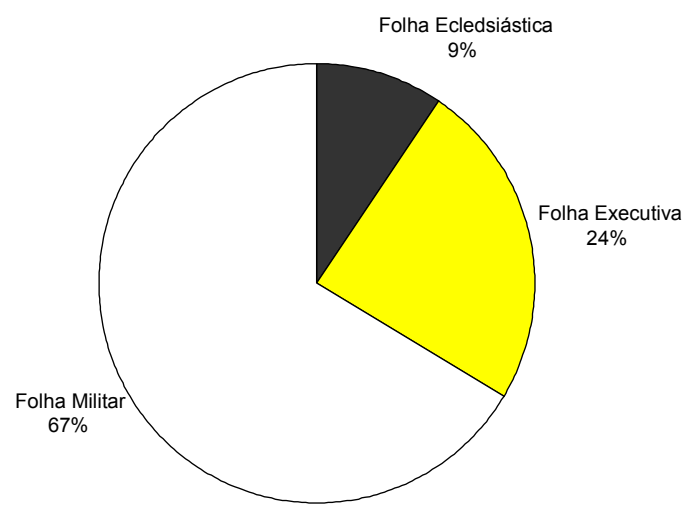


Ao contrário disso, tem-se a relativa estabilidade da folha eclesiástica que, após o desafogo inicial, ao ficar livre do peso das obrigações com o bispado de Pernambuco, alcançou uma ligeira alta a partir de 1715, mas sem exercer uma maior pressão sobre o conjunto, não ultrapassou, mesmo no fim do período, a um conto de réis. Mas, o que realmente salta aos olhos, é a significativa elevação dos pagamentos no período entre os anos de 1715 a 1735, quando ocorrem os aumentos dos governadores e dos soldos e a introdução do pão-de-munição da Infantaria. Se, no primeiro destes dois decênios, essas duas folhas passaram dos 6,6 contos para os nove contos de réis, no segundo, em comparação com o índice de partida, elas praticamente acabaram por dobrar os custos totais, alcançando um valor próximo aos dez contos de réis, em 1735.

\section{QUADRO 17}

Capitania da Paraíba / Despesas: Folha de Pagamento / 1695-1755 por decênio.

\begin{tabular}{|l|l|l|l|l|l|l|l|}
\hline Folhas / Anos & $\mathbf{1 6 9 5}$ & $\mathbf{1 7 0 5}$ & $\mathbf{1 7 1 5}$ & $\mathbf{1 7 2 5}$ & $\mathbf{1 7 3 5}$ & $\mathbf{1 7 4 5}$ & $\mathbf{1 7 5 5}$ \\
\hline Eclesiástica & $649 \$ 000$ & $460 \$ 000$ & $460 \$ 000$ & $650 \$ 000$ & $749 \$ 000$ & $979 \$ 000$ & $979 \$ 000$ \\
\hline Executiva & $921 \$ 940$ & $821 \$ 940$ & $1: 809 \$ 340$ & $2: 142 \$ 340$ & $2: 222 \$ 340$ & $2: 362 \$ 340$ & $2: 333 \$ 340$ \\
\hline Militar & $4: 064 \$ 450$ & $4: 064 \$ 450$ & $4: 376 \$ 450$ & $6: 109 \$ 550$ & $6: 730 \$ 050$ & $6: 746 \$ 350$ & $6: 746 \$ 350$ \\
\hline Total & $5: 635 \$ 390$ & $5: 346 \$ 390$ & $6: 645 \$ 790$ & $8: 901 \$ 890$ & $9: 701 \$ 390$ & $10: 008 \$ 690$ & $10: 006 \$ 690$ \\
\hline
\end{tabular}

Tal desempenho, que se manteve mais ou menos até o termino de 1755, demandou uma forte carga nas despesas da Fazenda paraibana que, acrescidas das despesas extraordinárias e com a fortaleza, comprimiram, ainda mais, a possibilidade do pagamento de pessoal. Neste sentido, cada segmento específico - militar, executivo e eclesiástico - armava-se na tentativa de receber com regularidade seus ordenados. As queixas pelo atraso nos pagamentos, excluindo os oficiais da Fazenda - fazendo jus ao adágio local de: farinha pouca, meu pirão primeiro ${ }^{212}$, , tornaram-se cada vez mais comuns. Ouvidores, governadores e até clérigos - que não se furtavam em usar da excomunhão como meio de pressão - escreveram várias cartas e petições ao rei,

\footnotetext{
${ }^{212}$ Os oficiais da Fazenda separavam um terço dos rendimentos do dízimo para a sua folha e mais despesas. Cf: AHU_ACL_CU_014, Cx. 14, Doc. 1161 e Cx. 15, Doc. 1258.
} 
cobrando seus ordenados. De todos os segmentos os militares foram os mais prejudicados. Os prejuízos não atingiram todas as patentes, mas principalmente os soldados de baixa plaina, que dificilmente entravam no rol dos mais necessitados quando se fazia um socorro à tropa. Em sentido inverso ao seu peso sobre a folha de pagamento, este segmento situava-se em último lugar na escala de prioridade daqueles que eram responsáveis pelos ordenados. ${ }^{213}$ A melhor explicação para o desprestígio dos soldados de baixa plaina pode ser colhido em Koster, quando sentenciou no início do século XIX,

"que o processo de recrutamento e o soldo desprezivel explicam completamente a má impressão que se tem dos soldados de linha, [pois] são recrutados entre os piores indivíduos da província ... [e] formados principalmente por brasileiros e gente de cor., 214

Como vimos, mesmo com todas essas intempéries, havia, estrategicamente, uma fórmula para execução dos pagamentos, que atrelava um determinado tipo de tributo a um segmento de pessoal específico, tornando menos subjetivo o destino das receitas.

\section{A CRISE FISCAL: OS PRÓDROMOS DA ANEXAÇÃO}

O Quadro 18 apresenta um resumo dos dados que foram até agora analisados, deixando perceber o impacto que as folhas de pagamento representavam sob as receitas da Provedoria da Fazenda Real da Paraíba.

\footnotetext{
${ }^{213}$ Em 1726, por exemplo, depois de amargarem um atraso de três anos nos soldos e de se ter notícia de que, "por muito menos queixa se amotinaram os regimentos de Pernambuco e conseguiram por este meio o seu pagamento," o rei finalmente ordenou “ao provedor da Fazenda Real [da Paraíba] que não mande distribuir dinheiro algum do que está ou entrar na mão dos tesoureiros sem que primeiro se faça o pagamento desta guarnição e da Fortaleza do Cabedelo”.AHU_ACL_CU_014, Cx. 6, Doc. 524.

${ }^{214}$ Henry Koster. Viagens ao Nordeste do Brasil. Recife: Editora Masangana, 2002. V. 1. Op.cit. p. 112. Observando apenas que a gente de cor a que Koster se refere, só foi aceita, segundo Caio Prado, nas tropas de linhas, em fins do século XVIII. Cf: Caio Prado Júnior. Formação do Brasil Contemporâneo... p. 310 11.
} 


\section{QUADRO 18}

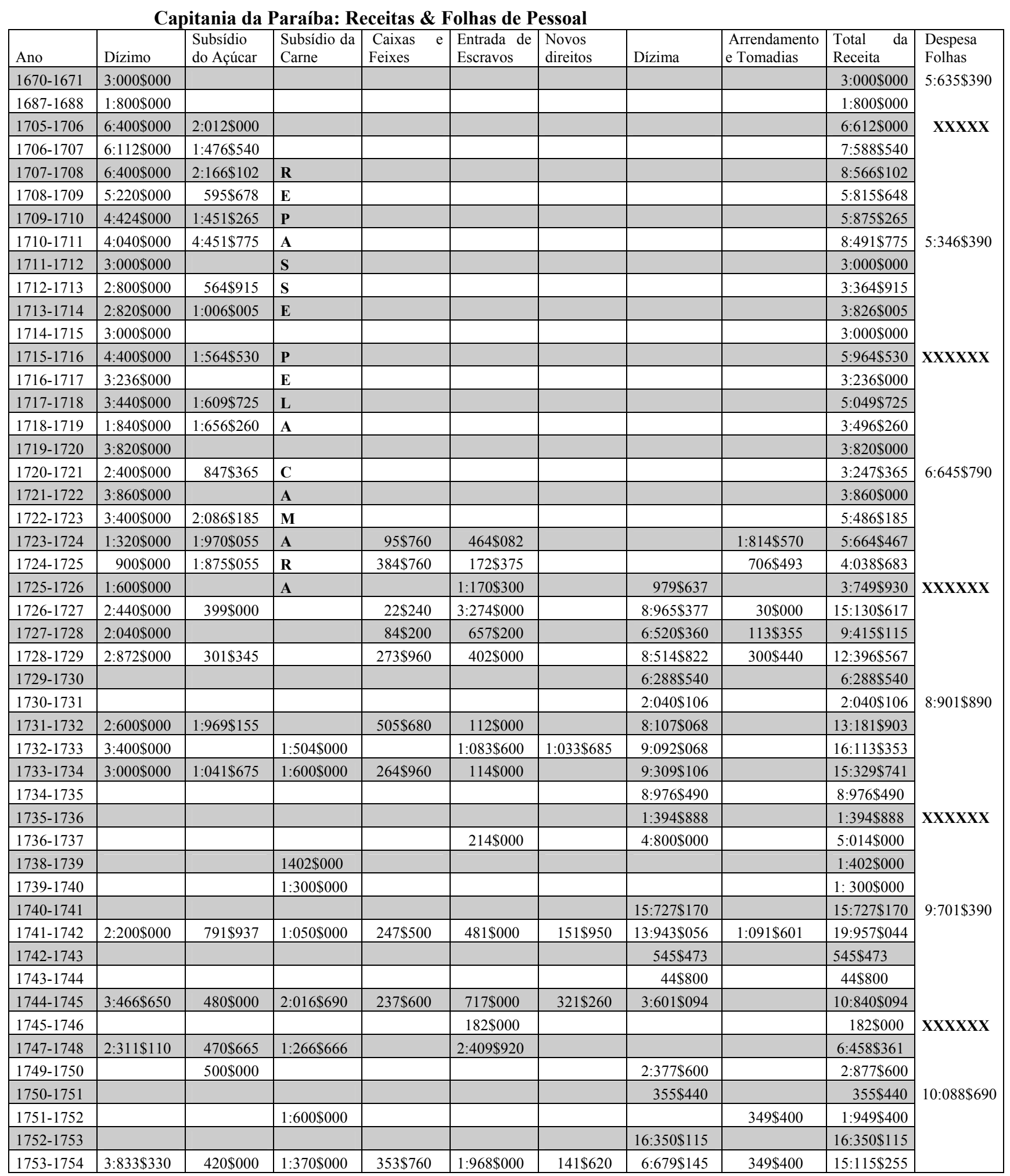


Deve-se lembrar que, para a composição tanto dos quadros sobre as despesas com pessoal, quanto desse quadro síntese, que as concentra com a receita (Quadro 18), os números das folhas executiva, clerical e militar não aparecem na forma como foram registrados e enviados pelos provedores à Coroa. Isto porque havia sempre o risco desses valores não traduzirem o que realmente cada oficial devia receber, já que os anos porventura em atraso podiam estar embutidos no valor que aparecia como o salário daquele ano. Seguindo essa orientação, optou-se pelo acompanhamento cumulativo dos ordenados, côngruas e soldos, como forma de vislumbrar aquilo que realmente devia ser pago e não o objetivamente saldado.

Por outro lado, embora nesse quadro não apareçam as despesas com a Fortaleza do Cabedelo e as despesas miúdas, elas devem ser lembradas como possíveis de margear uma estimativa para cima no custeio da administração, com algo em torno de quatro a seis contos de réis anuais. Todavia, como seus pagamentos eram incertos, a Provedoria da Fazenda se preocupou mais com as folhas de serviço - como se vê resumida no lado esquerdo do quadro, com um recorte de amostragem realizado em intervalos de dez anos. Esse resumo demonstra como o resultado dessas folhas incidiu, anualmente, sobre a receita da capitania da Paraíba.

Assim, percebe-se que, desde o início do século XVIII, quando assistiu a um pequeno período de superávit, o peso da folha de pagamento cobriu entre $60 \%$ a $90 \%$ da receita. Mas foi a partir da grande seca iniciada no verão de 1711, e que correu ao longo dos cinco anos seguintes, que a situação da Fazenda se tornou grave. Começou aí uma fase crítica na arrecadação, que só estacionou nos meados da década de vinte, com os repasses do contrato da dízima. Esses anos de déficit, foram amenizados com as contribuições provenientes dos contratos de arrematação da carne. Repassadas pela Câmara, essas contribuições serviram para complementar os ordenados dos governadores, como aconteceu com João Maia da Gama e João de Abreu Castel Branco. $^{215}$

\footnotetext{
215 Em 1709, quando se deu o retorno à liberdade de comércio para os governadores, João da Gama continuou vencendo o soldo de três mil cruzados, mesmo sem que a Fazenda tivesse disponibilidade. Para isso, conforme denunciava o provedor Salvador Dourado, cobrava da Câmara abertamente o complemento do seu vencimento, no que se justificava o governador, alegando que o dito ordenado fôra uma "mercê que $V$. Majestade fez a mim e não aos meus antecessores", pois quando foi governar a Paraíba, por conta da proibição, não havia "em Portugal ajustado sociedade, nem carregações para o negócio”. Cf:
} 
Porém, mesmo que estancados os déficits da folha com os primeiros envios da dízima a partir de 1726-27, ajudado pelo direito de entrada dos escravos, que cresceu significativamente nesses anos, a regularidade dos pagamentos teve fôlego curto. Como conseqüência, a sucessão dos anos de superávit foi se encurtando, não conseguindo ultrapassar três anos consecutivos. Somente no início da década de trinta, a Fazenda paraibana voltou a respirar insuflada pelos aportes das receitas que corriam sob o controle da ouvidoria, como os novos direitos, e da Câmara, como o subsídio da carne. Mas esses aportes não foram suficientes para alavancar as rendas da capitania. A cada ano que se aproximava do meado do século XVIII, foi ficando mais patente a dependência em relação aos envios dos vinte mil cruzados do contrato conjunto da dízima.

No geral, a produção de açúcar, que se apresentava como a principal atividade econômica da capitania, soberana do capital mercantil na Paraíba, deveria ser também a principal fonte de receita. Por isso, a sobrecarga fiscal a rondava com o subsídio do açúcar, os cruzados, os oitenta réis e os outros encargos, tidos como fundos para reconstrução da Capitania, e mais os dízimos - que deviam ser aplicados no pagamento de pessoal. O problema, no caso, é que a Fazenda se apoiava sobre um setor que precisava se autogerir financeiramente para reconstruir e expandir seu parque produtivo, destruído desde a guerra contra os holandeses, mas a carga fiscal, juntamente com as outras mazelas já comentadas, impedia qualquer saída. Criou-se, assim, um círculo vicioso, ${ }^{216}$ que reduzia as possibilidades de crescimento e expansão do setor que deveria proporcionar as rendas necessárias para a reconstrução da capitania.

Nesses momentos de queda da produção do açúcar, alguns setores de subsistência, voltados para o mercado interno, tentaram protagonizar algumas saídas. Foi o caso, por exemplo, da produção da carne, que significou uma sustentação lamentavelmente mínima na arrecadação do dízimo. Paradoxalmente, a elasticidade desta produção dependia exatamente do mau agouro do açúcar, além dos chamamentos e necessidades do mercado externo, pois:

AHU ACL CU 014, Cx. 5, Doc. 342. Para o ordenado de Casltel Branco (que ficou no cargo de 1722 a 1729), a Câmara repassou: ano $1723=1: 395 \$ 260$; ano de $1724=938 \$ 840$; ano de $1725=1: 133: 333$; ano de $1726=480 \$ 130$; ano de $1727=538 \$ 240$, quando se encerram os repasses. Cf: AHU_ACL_CU_014, Cx. 7, Doc. 580

${ }^{216}$ Stuart B. Schwartz. Segredos interno: engenhos e escravos na sociedade colonial... Op.cit. p. 158 
... ainda aqui são os mecanismos do sistema colonial que definem o conjunto e imprimem o ritmo em que se movimenta a produção. No periodo em que a procura externa se retraia, isto é, quando baixavam os preços europeus dos produtos coloniais, as unidades produtoras na colônia [, no caso do açúcar], tendiam a deslocar fatores para a produção de subsistência, [inclusive escravos,] pois diminuía sua capacidade de importar, quando ao contrário ampliava-se a procura externa, as unidades produtivas coloniais tendiam a mobilizar todos fatores na produção exportadora ... Era pois o setor de exportação que comandava o processo produtivo no seu conjunto. ${ }^{217}$

Finalmente, diante dessa situação, a mistura dos anos de déficits nas balanças de pagamentos com a incapacidade da Provedoria da Fazenda Real da Paraíba em responder aos seus compromissos, diagnosticou, claramente, um estado crônico de exaustão das suas rendas que acabou por asfixiar o órgão fazendário.

Desfalecida a Fazenda, contudo, ações e projetos de alguns governadores da Paraíba tentaram dar-lhe vivacidade, garantindo-lhe novas fontes de renda, antes que o vexame da anexação ao governo de Pernambuco se consumasse. As marchas e contramarchas dessa história são vistas no derradeiro capítulo a seguir.

\footnotetext{
${ }^{217}$ Fernando A. Novais. Portugal e Brasil na crise do Antigo Sistema Colonial (1777-1898). $7^{\mathrm{a}}$ ed. São Paulo: Hucitec, 2001. p. 96
} 


\section{CAPÍTULO IV}

\section{A FAZENDA COMO RECURSO DA AUTONOMIA: PLANOS, SONHOS E ESTRATÉGIAS FISCAIS}

Em fevereiro de 1756, os primeiros navios que atracaram no porto da Capitania de Pernambuco, portando a correspondência de Lisboa, trouxeram uma ordem real endereçada ao governador da Capitania da Paraíba, notificando aos paraibanos o que, há muito tempo, já esperavam e temiam:

Dom José, por graças de Deus, Rei de Portugal (...) Faço saber a vós, Coronel e Governador da Paraíba [Luís Antônio Lemos de Brito] que, por se ter conhecido os poucos meios que há na Provedoria da Fazenda da Paraíba para sustentar um governo separado, fui servido, em consulta do meu Conselho Ultramarino, extinguir o dito governo da Paraiba e que, acabado o vosso tempo, fique essa mesma Capitania sujeita ao governo de Pernambuco, pondose, na Paraíba, um Capitão-mor com jurisdição e soldo igual ao que tem o Capitão-mor da cidade do Rio Grande do Norte (...). Lisboa, primeiro de Janeiro de mil setecentos e cinqüenta e seis... ${ }^{1}$

O temor da subordinação já havia sido expressado pelos oficiais da Câmara da Paraíba onze anos antes, quando da morte do governador Pedro Monteiro de Macedo. Em 1744, receosos diante do irremediável destino do governador, os oficiais diziam temer

\footnotetext{
${ }^{1}$ IHGP / Ordens Régias / Códice 1745 - 1755 / Doc. 157 (grifo nosso).
} 
que o "governo da Capitania de Pernambuco, que sempre cuidou de por essa [Capitania da Paraíba] debaixo do seu governo, [viesse a] entrar nessa mesma diligência". ${ }^{2}$

A fragilidade econômica comum a todas as capitanias produtoras de açúcar no Nordeste do Brasil colonial - vulneráveis tanto às causas naturais, quanto às variações internacionais de preços, quer do produto, quer da mão-de-obra escrava -, parecia multiplicar-se na Paraíba. Qualquer ocasião de turbulência econômica interna, nutrida com fatos que pudessem por em xeque a autoridade política maior da capitania, levava o povo da Paraíba, assombrado pelo fantasma da anexação, a enaltecer, perante o monarca, o papel exercido pela capitania na região.

Assim, sempre atentos às possibilidades da anexação, os oficiais da Câmara nunca deixaram de lembrar à Sua Majestade a importância estratégica que a Paraíba tinha na composição das Capitanias do Norte, com seus "mui honrados e fieis vassalos", eternamente dispostos a conter os ânimos dos "sublevados pernambucanos". E, desse mesmo modo, faziam ver ao monarca a responsabilidade e o prestígio em ser, desde o início, uma Capitania Real e não de donatário, como a sua vizinha; "não parecendo conveniente ficar esta [cidade da Paraíba], mais antiga, sujeita a [Recife de] Pernambuco". 3

Entretanto, em plena abertura do ano de 1756, a vicissitude se fez presente e a sujeição deixou de ser uma probabilidade. Findo o tempo do governador em exercício, Luís Antônio Lemos de Brito, a Milícia e Fazenda da Paraíba foram anexadas à da Capitania de Pernambuco. Dessa forma, decretava el-Rei aos súditos paraibanos, a falência da Fazenda local. O governador saiu em abril de 1757, sendo substituído por José Henrique de Carvalho, nomeado capitão-mor da Paraíba pelo General de Pernambuco.

Os adversários da anexação sentiram o baque. A Câmara tentou persuadir o rei do contrário, mas o infortúnio consolidou-se de maneira incontestável e irreversível, com a criação da Companhia Geral de Comércio de Pernambuco e Paraíba, em 1759. A subordinação vigorou até 1799 .

\footnotetext{
${ }^{2}$ AHU_ACL_CU_014, CX.13, Doc.1084.

${ }^{3}$ Idem.
} 


\section{HISTÓRIA E ANEXAÇÃO}

Os acontecimentos que desembocaram no parecer do Conselho Ultramarino e na ordem de janeiro de 1756 são analisados, geralmente, sob duas perspectivas: sob a luz da sede expansionista dos governadores pernambucanos ou na versão com que os consolidou, no final do século XVIII, Fernando Delgado Freire de Castilho.

Como governador da Paraíba, entre os anos de 1797 a 1801, Castilho foi o responsável direto pela autonomia da Capitania da Paraíba. Seus relatórios sobre as potencialidades econômicas da capitania e as críticas ao governo da Metrópole, por manter o sistema de exploração nas bases monopolísticas, são peças de raro valor, principalmente por evidenciarem um aguçado tino propositivo nas questões administrativas. ${ }^{4}$ Como protagonista e parte interessada na valorização da área que lhe fora confiada, Castilho fez ver à rainha, D. Maria I, em ofícios dirigidos ao secretário de Estado da Marinha e Ultramar, Rodrigo de Souza Coutinho, que o parecer dos conselheiros, do qual resultou a ordem da anexação, estava equivocado. Para ele, os conhecimentos dos conselheiros sobre a situação econômica da Paraíba não os capacitavam para tal conclusão, visto apenas terem em mãos "uma simples e pouco fundamentada representação do último governador independente ,, Luis Antônio Lemos de Brito.

Essa leitura de Castilho era motivada, exclusivamente, pela intenção de impugnar as amarras a que estava submetido, pois em tudo era proibido de agir sem a expressa autorização do governador de Pernambuco.

\footnotetext{
${ }^{4}$ Fernando Delgado Freire de Castilho integraria, com outros, o movimento ilustrado luso-brasileiro do último período do Antigo Regime em Portugal. Suas propostas, para a ocupação de Fernando de Noronha por casais, o manejo das matas litorâneas da Paraíba, as leituras sobre as técnicas utilizadas na agricultura e a pecuária, os relatórios demográficos, e o levantamento de problemas sociais e econômicos da Capitania, entre outros estudos, desembocaram em propostas que tencionavam, ao fim e ao cabo, aprimorar as relações econômicas entre Portugal e Brasil. Sobre esse movimento ilustrado, Cf:: Fernando A. Novais. Portugal e Brasil na crise do Antigo Sistema Colonial (1777-1898). 7 a edição. São Paulo: Hucitec, 2001. Principalmente o capítulo IV: "Política Colonial." E de Rafael de Bivar Marquese. Administração e escravidão. Idéias sobre a gestão da agricultura escravista brasileira. São Paulo: Hucitec: Fapesp, 1999. Cabe registrar que toda a correspondência de Castilho, inclusive seus relatórios e a instrução para o seu governo, estão muito bem preservados e podem ser consultados no IHGP. Alguns podem ser encontrados na coletânea de documentos organizados por Irineu Ferreira Pinto. Datas e Notas para a história da Paraíba. João Pessoa: Editora Universitária / UFPB, 1977.

${ }^{5}$ AHU_ACL_CU_014, Cx. 34, D. 2473
} 
Como homem do seu tempo, Castilho elaborava seus argumentos com os olhos na Paraíba do final século XVIII e não nas grandes mazelas dos meados desta centúria. Afinal, as demandas e exigências do mercado externo haviam valorizado alguns produtos como o couro, a madeira e, principalmente, o algodão, os quais poderiam fazer da Paraíba uma capitania bastante pródiga. ${ }^{6}$

Endossando esta leitura de Castilho, Horácio de Almeida, partidário e divulgador da versão expansionista pernambucana, tentou demonstrar que a anexação foi fruto de um plano que tinha Pernambuco, "de levar a Capitania vizinha à exaustão para anexá-la ao seu território." Para Almeida, este plano

vinha concebido desde quando governou Pernambuco Duarte Sodré Pereira que, em carta a el-Rei [,em 1730], exagerava a pobreza da Paraíba e pedia a anexação do seu território ao de Pernambuco, alegando que nem dinheiro tinha para os donativos lançados por ocasião do casamento dos príncipes. ${ }^{\succ}$

Então, o ideal expansionista propagado pelos governadores de Pernambuco, aliado ao parecer equivocado dos conselheiros - que tinham como base uma representação mal fundamentada de Lemos de Brito - sobre a real condição econômica da Paraíba, são os elementos que permitiriam entender a anexação da Capitania da Paraíba. Particularizando os exageros expansionistas, parece mais sensato admitir a existência, nas ações dos capitães-mores, de um princípio natural militar para a expansão. Não fosse assim, seria difícil explicar o plano de anexação das capitanias do

6 "Nas instruções de 1797 ao governo da Paraíba estabelecia-se que o principal objeto de cuidado devia ser o de animar e promover as culturas já existentes, e introduzir as que possam ser novas, e venham concorrer para enriquecer esta capitania". Cf: Instrução do governo de Fernando Delgado Freire de Castilho, governador da Paraíba (1797), R.B.H.G.B., t. VI, p. 444 segs. Apud Fernando A. Novais. Portugal e Brasil na crise do Antigo Sistema Colonial (1777-1898)... Op. cit. 256. Acrescente-se ainda, que o respeito aos escritos e ações de Castilho renderam-lhe, na Paraíba, o agraciamento simbólico da cadeira número 15 do Instituto Histórico e Geográfico Paraibano - IHGP.

${ }^{7}$ Horácio de Almeida. História da Paraíba. João Pessoa, Edtora Universitária / UFPB, 1978. op cit. p. 74; A carta de Sodré Pereira encontra-se nos documentos avulsos da Capitania de Pernambuco. Cf: AHU_ACL_CU_015, Cx. 41, Doc. 3670. 
Rio Grande, Ceará e do Terço do Açú à Paraíba, como projetado pelo governador da Paraíba, João Maia da Gama, em $1711 .^{8}$ Preferentemente a serem apegados aos valores locais, os governadores tinham por objetivo fazer valer as prerrogativas inerentes ao seu cargo, pois o que os sustentava era "a manutenção das suas próprias competências (sobretudo o direito de nomear)" 9 .

Sobre o mesmo assunto, Elza Regis de Oliveira, ${ }^{10}$ interpretou o processo da anexação da Capitania da Paraíba à de Pernambuco como resultado da crise de longa duração que se abateu sobre o Nordeste açucareiro, atingindo tanto a produção do açúcar - em virtude da guerra contra os holandeses - quanto a comercialização do produto - por causa da concorrência antilhana. O que chama atenção é que, mesmo em um trabalho considerado de fôlego, Oliveira terminou por aderir às avaliações de Castilho e de Horácio de Almeida. Primeiramente, insistiu na idéia de que

houve o desejo de expansão de Pernambuco sobre as capitanias do Norte. E a Paraíba pela sua contigüidade do seu território com Pernambuco não deixava de ser cobiçada. O problema não era novo, pois a Paraíba perdera um terço de suas terras para Pernambuco, quando da conquista real: a Ilha de Itamaracá, Goiana e Igarassú... ${ }^{11}$

Em segundo lugar, acabou por minimizar, na conclusão do trabalho, seu próprio axioma, que responsabilizava a crise da economia açucareira, ao não encontrar razões fundamentais para a anexação. Como ela mesma disse,

\footnotetext{
${ }^{8}$ Carta do governador geral do Brasil, Pedro Vasconcelos de Souza, ao rei, D. João V, sobre a carta régia para que dê seu parecer acerca do que propõem João Maia da Gam, a respeito da anexação das capitanias do Rio Grande, Itamaracá e o Terço do Açu à Paraíba. Cf: AHU_ACL_CU_014, Cx.4, Doc. 330.

${ }^{9}$ Cf: Evaldo Cabral de Mello. A fronda dos mazombos. Nobres contra Māascates, Pernambuco 1666-1715. São Paulo: Cia das Letras, 1995. p. 26 -27.

${ }^{10}$ Cf: Elza Regis de Oliveira. A Paraíba na crise do século XVIII: subordinação e autonomia (1755 1799). João Pessoa: Banco do Nordeste do Brasil S/A, 1985.

${ }^{11}$ Idem ibidem. Op. cit., p. 82. Quanto a questão levantada por Oliveira, sobre Itamaracá, cabe ressaltar que a Paraíba surge do desdobramento da antiga capitania de Itamaracá e não o contrário.
} 
"apesar da difícil situação econômica da Paraíba, tudo nos leva a crer que havia interesses subjacentes à subordinação da Capitania." 12

Oliveira enxerga com razão, nos "interesses subjacentes", a mão centralizadora de Pombal e, mesmo sem um aprofundamento maior, a possibilidade da existência de uma suposta articulação de comerciantes de ambas as capitanias que seriam beneficiados com a subordinação. Mas acaba por defender que a "pobreza não era tão agressiva quanto podia parecer, pois os moradores da Paraiba ofereceram cem mil cruzados para a reconstrução de Lisboa, quando do terremoto de 1755. "14 Infelizmente, Oliveira não se deu conta de que em março de 1759, quatro anos após o compromisso firmado, os oficiais da Câmara da Paraíba informaram à Metrópole "da impossibilidade do povo em satisfazer o donativo." 15

Uma análise que pretenda investigar e concatenar os fatos que resultaram na subordinação da capitania da Paraíba, não pode hesitar quanto à dimensão da crise que se abateu sobre a economia paraibana. Mas principalmente não deve, relegar a um segundo plano a declaração do monarca, que reconheceu, a partir de um parecer do Conselho Ultramarino, a falência da Provedoria da Fazenda Real da Paraíba. Foi o que aconteceu com Castilho e aqueles que posteriormente se preocuparam com o tema da anexação. $\mathrm{Na}$ verdade, na declaração do monarca encontra-se o comprometimento de dois dos principais veículos da política administrativa do Império Português. Um deles era o Conselho Ultramarino, situado no nível mais geral do universo da sua jurisdição. O outro era constituído pelas fazendas das capitanias, representando uma espacialidade mais localizada, restrita à circunscrição responsável pela gestão econômica dos agentes reprodutores da mesma política imperial.

\footnotetext{
12 Idem. op cit., p. 93.

${ }^{13}$ Idem. Op.cit. p. 89

${ }^{14}$ Idem. Op.cit. p. 93. Conferir também: AHU_ACL_014, Cx. 19, Doc. 1483 e 1488.

${ }^{15}$ AHU_ACL_CU_014, Cx.21, Doc. $161 \overline{2}$.
} 
Dessa forma, seguindo a linha de raciocínio adotada desde o início do trabalho, no sentido de privilegiar as possibilidades de análises que a administração fazendária pode oferecer, nos debruçaremos, dessa feita, sobre os dados deixados pelos administradores da Fazenda da Paraíba, quanto à origem e desdobramento do vínculo econômico entre as capitanias de Pernambuco e Paraíba e que redundaram na subordinação da última. Para tanto, o enfoque ficou restrito ao estudo dos efeitos de um único tributo, a dízima, por ser este o principal elo de ligação tributária entre as alfândegas de ambas as capitanias.

\section{O ATRELAMENTO DAS PROVEDORIAS: A ARREMATAÇÃO DA DÍZIMA EM UM SÓ CONTRATO}

Quando o governador da Paraíba, Luís Antônio Lemos de Brito, encaminhou sua representação ao rei, no ano de 1755, fez recrudescer, de forma aguda, uma história de desentendimentos entre as provedorias de Pernambuco e Paraíba acerca de uma antiga dívida que, pela sua imensidão e comprometimento dos encargos não saldados, parecia não ter fim.

O problema começou quando o rei reeditou uma ordem, em agosto de 1720, proibindo o comércio aos governadores ultramarinos. ${ }^{16}$ Tentando acabar com a intromissão de oficiais com postos de comandos nos assuntos de mercado, esta resolução acabou por gerar um grande constrangimento nas capitanias do Norte. Se o ordenado dos governadores não era tão atrativo, doravante a impossibilidade de comerciar provocaria a adoção de medidas compensatórias, no intuito de abrandar os gastos desses oficiaismores. Afinal, como disse um membro do Conselho Ultramarino, "quem vai para as conquistas, vai na certeza de negociar." ${ }^{17}$

\footnotetext{
${ }^{16}$ Mesmo que já tenhamos feito referência em nota anterior, nunca é demais repetir: "Lei ordenando que nenhum vice-rei, capitão-general ou governador possa comerciar, por si ou interposta pessoa, nem intrometer-se em contratos ou donativos da Câmaras, desencaminhar direitos, pôr preços a gêneros e fretes dos navios, nem mandar fazer seqüestro nas fazendas dos moradores sem autoridade da Justiça, revogandose a permissão que por resolução de 26.11.1709 se tinha dado aos governadores das conquistas negociar." Graça Salgado (org.). Fiscais e Meirinhos. A administração no Brasil colonial. Rio de Janeiro; Arquivo Nacional. Editora Nova Fronteira, 1985. p. 429

17 João Fragoso. "A formação da economia colonial no Rio de Janeiro e sua atuação nos quadros do Império português (1701-1750).” In: João Fragoso, Maria Fernanda Bicalho e Maria de Fátima Govêia
} 
Primeira vítima desta medida, o provido governador da Paraíba, João de Abreu Castel Branco, ${ }^{18}$ antes mesmo de tomar posse, em 1721, se preveniu e alcançou junto ao rei um aumento razoável no seu soldo, passando seu ordenado de três para quatro mil cruzados. ${ }^{19}$ Todavia, foi alertado a tempo sobre os problemas que poderia encontrar no além-mar, para custeio desse aumento, pois era sabido no Reino que a situação econômica da capitania não era das melhores. Castel Branco sugeriu então, ao Conselho Ultramarino, uma solução para o caso, que imediatamente fez a sua proposta subir para a assinatura do monarca:

Por evitar queixas e se poder sustentar e valer seu soldo, será necessário que vossa majestade lhe mande aplicar para seu pagamento o rendimento da décima da Alfândega, além daquilo que lhe tocar na consignação aplicada ao governo e mais filhos da folha, [ou seja,] ... a terça parte do contrato dos dízimos reais mais os sobejos da Fazenda. ${ }^{20}$

O despacho real concedendo esta mercê a Castel Branco, repercutiu negativamente sobre a economia local. $\mathrm{O}$ saldo de quatro mil cruzados do ordenado do

(orgs.) O Antigo Regime nos Trópicos. A dinâmica imperial portuguesa (séc. XVI e XVIII). Rio de Janeiro; Civilização Brasileira, 2001. p. 41. João Maia da Gama, governador da Paraíba de 1708 a 1717, tornou-se um ativo traficante de escravos e comerciante de açúcar ao longo de sua gestão. No início dos anos 20 do século XVIII, já fora do governo da Paraíba e residindo no Maranhão, onde governou de 1722 a 1728 , ainda mantinha alguns negócios na Paraíba. Um requerimento seu, por essa época, pedindo ao rei que o deixasse usar as charruas reais para embarcar seus escravos e todo o seu açúcar existente na Paraíba pelo porto de Pernambuco, exemplifica isso. Cf. AHU_ACL_CU_014, Cx.5, D 372.

${ }^{18}$ João de Abreu Castel Branco governou a Paraíba de janeiro de 1722 a março de 1729.

19 Em agosto de 1721, conquistou um ordenado de 4.000 cruzados anuais, anteriormente era de 3.000 cruzados. O governador-general de Pernambuco passou a receber 6.000 cruzados anuais, anteriormente recebia 5.400 cruzados. Cf. AHU ACL CU 014, Cx.6, Doc. 380

${ }^{20}$ AHU_ACL_CU_014, Cx.6, Doc. 383 (grifo nosso). Para o caso descrito, a décima refere-se à décima da Alfândega, ou dízima, encargo tributário que remonta à tradição romana, e que foi conservado pelos Visigodos e persistiu após a Reconquista. Correspondia à décima parte sobre o valor das mercadorias importadas que entrassem pelo mar e não tivessem isenção real. Não confundir, portanto, com o imposto da décima, ou décima militar, criado por lei em 5 de setembro de 1641, para manter um exército de 20.000 homens de infantaria e 4.000 de cavalaria na defesa das fronteiras do Reino por ocasião da Restauração. Cf: Ruy de Abreu Torres. "Décima" e "Dízima" (verbetes). In: Joel Serrão. (Direção) Dicionário de História de Portugal. Porto - Livraria Figueirinhas, S/D. p. 788 e 840-41, respectivamente. 
governador, incidindo sobre o rendimento da décima, fez jogar para cima as despesas da folha. Lamentavelmente, a idéia de Castel Branco, não obstante a concordância do monarca, acabou sendo frustrada por problemas econômicos internos à própria capitania. Apesar da ignorância do governador sobre a gestão dos recursos da Paraíba, tais problemas econômicos não deveriam ser motivo de desconhecimento para os conselheiros ultramarinos. Esses conselheiros não só tinham ciência da utilização da consignação da dízima para outros fins como também tinham conhecimento acerca do uso indevido desse rendimento.

Esse encargo tributário, que será tratado daqui por diante apenas por dízima, foi criado como tributo, nas capitanias da Paraíba e Pernambuco, pela ordem real de 4 de fevereiro de $1711^{21}$ e devia destinar-se, como esperava Castel Branco, apenas para a manutenção das fortalezas. ${ }^{22}$ A partir de 1715, entretanto, Salvador Dourado, provedor da Capitania da Paraíba, deu outro rumo para o uso deste tributo. Alegando a necessidade de conter possíveis descaminhos com a consignação dos valores destinados à fortaleza, o provedor conseguiu, com a anuência do Conselho Ultramarino, transferir para o almoxarifado da Fazenda Real a administração, guarda e controle da consignação da dízima para complementar os soldos da Infantaria. ${ }^{23}$ Buscando desembaraçar esta situação, o rei oficializou, em maio de 1719, a liberdade do uso dos recursos da dízima, pois:

\footnotetext{
${ }^{21}$ AHU ACL CU 014, Cx.14, Doc. 1196.

22 AHU_ACL_CU_014, Cx.6, Doc. 519. Todos os produtos estavam sujeitos ao imposto, exceto os produtos importados que vinham para o gasto de cada pessoa, como o azeite, por exemplo. Por outro lado, a dízima, originalmente, serviria apenas como consignação para a defesa das capitanias brasileiras e fora estabelecida ao longo dos anos de 1699 a 1715 pelas principais Alfândegas. Cf: AHU_ACL_CU_014, Cx.14, Doc. 1196.

${ }^{23}$ AHU_ACL_CU_014, Cx. 5, Doc. 366. Assim, se justificava ao rei, ainda em 1718, o escrivão da Fazenda Hipólito Bandeira de Melo, sobre a autorização que tinha para o uso do rendimento da dízima para socorro da Infantaria: "Declaro que, por conta dos socorros da infantaria de que ainda lho não tenho passado mostra por não ter ainda dinheiro para poder se pagar a todos outros declarados, por conta dos ditos socorros, se tem dado a muitos soldados e oficiais dinheiro [da dízima] por ordem do governador desta praça e o provedor da Fazenda Real por conta deles, para se lhes descontar quando se passar mostra dos ditos salários como consta dos livros". Acontece que a confusão das anotações dos pés das Listas, proposital ou não, impossibilitava saber a quem havia sido adiantado. Nestes casos, a memória falhava. Cf: AHU_ACL_CU_014, Cx.5, Doc. 362.
} 
não chegando do contrato dos subsídios [do açúcar] aplicados para seu soldo, nem a Fazenda Real para o seu pagamento, para aquela que faltar se tire do direito da dízima da Alfândega que serve para a fortaleza (...), porque sem eles [os soldados] é o mesmo que não haver fortificação. ${ }^{24}$

A centralização de todas as consignações para o pagamento das folhas de pessoal no almoxarifado da Fazenda terminou por comprometer a aplicação desses recursos. Segundo diziam os oficiais e soldados das companhias de Infantaria da cidade da Paraíba, essa medida acarretou duas principais conseqüências. A primeira foi o início do atraso dos seus soldos. A segunda foi o mau hábito dos governadores e dos provedores da Fazenda de, vez por outra, "lançarem mão das suas consignações", com a desculpa de ser este o único meio de saldar os ordenados dos oficiais da Fazenda e da Justiça. ${ }^{25}$

Percebe-se, então, que tanto nos anos 1715 e 1719, como em 1721, a solução para o aperto nas consignações, na busca do custeio para o pagamento dos soldos dos soldados e para o novo ordenado do governador, respectivamente, só tinha uma direção: lançar mão da dízima.

Mesmo sem dispor dos valores que a arrecadação da dízima alcançava nos anos anteriores a 1725, vimos que os valores levantados pela Alfândega da Paraíba, em anos posteriores, eram inexpressivos. ${ }^{26}$ Neste sentido, à parte as acusações de desvios e extorsões perpetrados com o dinheiro guardado no almoxarifado da Fazenda, a tentativa

\footnotetext{
${ }^{24}$ Idem.

${ }^{25}$ Durante as primeiras décadas do setecentos, guarneciam a praça da cidade da Paraíba apenas duas companhias de Infantaria com aproximadamente 150 homens. Afora os soldados que mantinham guarda na fortaleza do Cabedelo ou no presídio da Bahia da Traição, todo o restante do efetivo vivia bastante insatisfeito pois, além da falta de hospital e quartéis, eram obrigados a pagar para morar em casas. Com o atraso nos soldos, entre os anos de 1715 a 1719, muitos já viviam na iminência da mendicância e, na falta de dinheiro, temiam se submeter à extorsão dos oficiais responsáveis pelos pagamentos dos seus soldos. Revoltados, reclamavam ao rei, o vexame de passarem por "muitos inconvenientes de ficar nas mãos dos Provedores de Fazenda, havendo disto muita fiação, pagando primeiro a quem melhor [lhes] parecer”. Cf: AHU_ACL_CU_014, Cx.5, Doc. 366. Registre-se ainda que o provedor da capitania, Salvador Dourado, já havia, em 1713, utilizado o dinheiro da Provedoria dos Defuntos e Ausentes, para completar o pagamento dos soldados. Cf: Irineu Ferreira Pinto. Datas e notas para a história da Paraíba... p. 107

${ }^{26}$ No Quadro 8 do capítulo III, sobre o recolhimento da dízima pela Alfândega da Paraíba, 1726 - 1754, essa não ultrapassou a casa dos três contos de réis.
} 
de driblar a falta de recursos, com efeitos tradicionalmente consignáveis para saldar os pagamentos das folhas de pessoal, eram sintomas evidentes do estado débil da economia paraibana. $^{27}$

O crônico e irresoluto desnível entre objetivos políticos-administrativos e recursos financeiros disponíveis, que tanto sobrecarregou a economia da colônia brasileira, se mostrou, neste caso, limpidamente. O diagnóstico da crise, por si só, deveria convencer os conselheiros do rei da incoerência em arbitrar o socorro aos soldados ou em atribuir o aumento desejado pelo capitão-mor governador. Mas não foi obstado pela certeza da exaustão em que se encontrava a Provedoria da Fazenda da Paraíba. ${ }^{28}$ A força da tradição da monarquia no Antigo Regime, que constrangia à moral e à religião todo e qualquer cálculo financeiro $^{29}$, teimava em enfocar apenas no fisco a panacéia para todos os problemas financeiros do Império. ${ }^{30}$

\footnotetext{
27 A carta de Salvador Dourado, provedor da Fazenda da Paraíba, em 1718, esclarecia ao Conselho Ultramarino sobre os problemas que a falta de escravos e queda na produção do açúcar, com a conseqüente diminuição na arrematação dos dízimos, acarretavam sobre a folha de pagamentos. Segundo Salvador Dourado, o total “das receitas e cargas vivas" que entraram na Fazenda Real da Paraíba, de 1715 até 1718 , chegaram a 17:152\$875. Número, entretanto, não suficiente para arcar com as despesas do ordenado das folhas. Cf: AHU ACL CU 014, Cx.5, Doc. 362.

${ }^{28}$ Mesmo nos casos em que ficava claro para algum parecerista o provável comprometimento da fazenda real com o aumento de ordenados, o jeito era se esconder sob o manto da corporação, justificando, também, os riscos com os possíveis descaminhos, tendo em vista os baixos estipêndios. Em resposta ao requerimento dos oficiais da fazenda, pedindo "acrescentamento nos seus ordenados", respondeu o governador Maia da Gama a uma provisão em 1710: "pois o meu parecer é, e o será sempre, que Vossa Majestade mande pagar a quem o serve de sorte que o não seja necessário furto, ou descaminho”. AHU_ACL_CU_014, Cx.4, Doc. 305

${ }^{29}$ Acerca dos elementos morais que inibiam o cálculo financeiro no Antigo Regime, ver: Antônio Manuel Hespanha. “A Fazenda.” In: José Mattoso (dir.). História de Portugal. V. IV. Antonio Manuel Hespanha (org.) O antigo Regime (1620 - 1807). Lisboa, Editorial Estampa, 1998. p. 181 - 213

${ }^{30}$ Sobre a acentuada política fiscal imposta pelo governo português no período pós-resturação, envolvendo a balança de serviços, Caldeira nos fala que "o acordo interno metropolitano, entre fidalgos $e$ representantes de uma economia agrícola já em atraso e a acomodada burguesia contratista e dependente do Estado, gerou o único agente possivel para inverter o fluxo de capital para a Colonia: o Fisco. Na falta de mecanismo de mercado capazes de gerar eficiencia acumulativa no centro do sistema, cobrar impostos tornou-se a única solução, mesmo que à custa do crescimento da economia colonial. A fórmula portuguesa da eficiência acumulativa metropolitana' pós-restauração era bem diversa da inglesa: igual a receita coloniais menos despesas coloniais do Tesouro. Em outras palavras, o grande ativo metropolitano português pós-Restauração passou a ser a capacidade de cobrar pelos precários serviços de defesa externa (já que a interna era inteiramente financiada e executada na Colônia, educação superior (vedada na Colônia - onde a educação básica era, além de desestimulada, financiada localmente), comércio exterior (na verdade transporte e distribuição para Europa, já que a navegação de cabotagem e africana eram questões locais), Justiça (somente nas causas maiores, pois as menores eram decididas em Salvador), $e$ "e cultura" (mercado garantido pela proibição de estabelecer tipografia na Colônia) muito mais do que efetivamente custava. Para que isto fosse assim, os portugueses não titubearam em enfrentar a conseqüência óbvia: baixar o nível do custo administrativo, o que se fez com denodo: fraqueza na proteção
} 
Dessa forma, Castel Branco cansou de esperar por medidas econômicas que, efetivamente, trouxessem resultados práticos e duradouros - principalmente para custearem seu ordenado e colocarem o restante da folha em dia. Em abril de 1722, acabou por elaborar um projeto em que, além de mostrar-se bastante cônscio acerca dos problemas da capitania, propunha uma solução para o estado deplorável em que ela se encontrava. $\mathrm{Na}$ oportunidade, Castel Branco alertava que o único fator de enriquecimento das "povoações marítimas" era o comércio mas, na falta deste, com a maioria dos navios indo em direitura a Pernambuco, os moradores da capitania viviam mais de "empenhos que de cabedais". Também compreendia que, para além das calamidades naturais, como as epidemias que dizimavam os trabalhadores, as secas e as freqüentes enchentes que destroçavam os engenhos, a produção na capitania era afetada, principalmente, pela falta de escravos, devido a dois fatores básicos. Primeiramente, " $o$ negócio da Costa da Mina [estava] infestado pelos piratas [que,] insultado pelos holandeses, [tinham] subido o preço dos negros a tanta exorbitância, que não ... [tinha] proporção o custo deles com o lucro do seu trabalho”. Além disso, a concorrência interna, imposta pelos mineiros na compra dos escravos, era daninha para toda a Colônia, pois, por "todos os portos do Brasil [agem os mineiros a] cada dia ... [alterando] os seus preços, de sorte que aos senhores de engenho nem lhe tem conta o comprá-los, nem podem conservar sem negros as suas fábricas. "31

Apesar desses problemas, Castel Branco alegou ter conseguido, com muito esforço, carregar e embarcar cinco navios com açúcar no porto da capitania. Para tanto, teve que se desdobrar com "todo o bom tratamento [aos capitães dos navios] para os convidar a tomar a ele" 32 o caminho da Paraíba e não o de Recife. Pode-se entender que o "bom tratamento", mesmo quando não especificado, devia ter, como contrapartida,

militar, falta de escolas, Justiça lenta e ineficiente." Jorge Caldeira. A nação mercantilista. São Paulo: Editora 34, 1999. p. 164-165.

${ }^{31}$ A queda na produção, sentida em 1722, era por demais preocupante e sobre isso dizia o governador: "os engenhos que antes fabricavam 200 caixas, hoje não chega a 50”. AHU_ACL_CU_014, Cx.5, Doc.392. Como foi comentado no capítulo anterior, a falta de escravos era motivo de preocupação, nas épocas das epidemias a mortalidade entre eles era enorme. Foi comum a pequenos comerciantes de Goiana e Paraíba, lavradores, senhores de engenho e governadores, como Maia da Gama, em 1714, por exemplo, armarem navios para resgatarem escravos na Costa da Mina, em troca de tabaco. Alguns senhores de engenho, utilizando-se da desculpa da falta de cabedais, acabavam ganhando melhor preço na venda dos escravos trazidos, negociando, não só com os paraibanos, mas, também, com os mineiros. Cf. AHU_ACL_CU_014, Cx.5, Doc. 360.

${ }^{32}$ Idem. 
vantagens fiscais. Isto ficou claro quando o Conselho Ultramarino, ao subir a carta do governador em consulta, sugeriu ao rei autorizar uma diminuição na cobrança da dízima da Alfândega. A redução deveria ser de cinqüenta por cento, durante cinco anos, sobre todos os gêneros de fazendas, inclusive os escravos, com o adendo dos navios ficarem obrigados a não tomar carga em nenhum outro porto, senão o da Paraíba.

Mesmo que a proposta se revelasse atraente para os comerciantes da praça de Lisboa, incluindo, talvez, interesses dos próprios conselheiros, o efeito desta ação, em contrapartida, poderia colocar em xeque vários privilégios de antigos arrematadores de direitos reais. Por isso, a resposta do rei, revelou ser inadmissível uma redução na alíquota de importação. A resolução fôra enfática:

Não há que deferir quanto a diminuição dos direitos das fazendas que dos Reinos vão para aquela capitania e [nem] pelo que pertence aos das fazendas que vão para a Costa das Minas. O conselho me faça presente as notas que sobre isso vierem na frota. ${ }^{33}$

Essa resposta, não acalentou, de modo algum, o pedido de socorro dos paraibanos. Necessariamente, o momento exigia uma medida que, a curto prazo, abrandasse o atraso dos ordenados. ${ }^{34}$ A solução adotada pela Coroa foi atrelar, doravante, a arrematação da dízima da Alfândega da Paraíba à de Pernambuco, em um só contrato. No entender da Coroa, em virtude de não ser freqüente a visita de navios ao porto da Paraíba, que se cobrasse de Pernambuco, aquilo que deveria ser recolhido do imposto da dízima da Alfândega na Paraíba. Se a medida se mostrou plausível para os paraibanos, as conseqüências, entretanto, a depender da recepção em Pernambuco, acabou por se tornar

\footnotetext{
${ }^{33}$ Idem.

${ }^{34}$ Até o magistrado, ouvidor geral da Paraíba, Manuel da Fonseca e Silva, reclamava, em 1725, que, apesar do aumento de ordenado que o rei concedeu por conta da proibição da prática de comércio aos oficiais, nada lhe havia acrescentado o provedor Salvador Quaresma Dourado, nem mesmo lhe pago as ajudas de custo a que tinha direito nas correições que fez ao Rio Grande e Ceará. Reconhecia os problemas da Capitania, mas gostaria que o rei pusesse freios no Provedor da Fazenda, obrigando-o a lhe pagar. AHU_ACL_CU_014, Cx.6, Doc. 432.
} 
inócuas. Esta medida não atendeu ao objetivo de colocar em dia os pagamentos da folha militar e desafogar a economia da capitania, como representou uma "anexação branca", jogando a Fazenda da Paraíba nas mãos do governo de Pernambuco. A autonomia, que correspondia à prerrogativa da Fazenda da capitania de se mostrar capaz de arcar com as despesas da administração executiva, eclesiástica e, principalmente, militar, parecia não se consolidar na Paraíba.

O primeiro contrato que inaugurou a união das duas dízimas da Alfândega, Pernambuco-Paraíba, teve início em janeiro de 1724. Foi arrematado no Conselho Ultramarino, onde corriam os lanços, por um alto comerciante da praça de Lisboa, Jerônimo Lobo Guimarães. ${ }^{35} \mathrm{O}$ valor total do contrato orçava em duzentos e quarenta e seis mil cruzados livres para a Fazenda Real. Ao longo de três anos, ou de três frotas, deveria render oitenta e dois mil cruzados anuais, sendo sessenta e dois mil para a Capitania de Pernambuco e os vinte mil restantes, para a Paraíba. Esses valores, ao que parece, foram estipulados sob a anuência do próprio Conselho, pois os vinte mil cruzados, que equivaliam a oito contos de réis, não encontram lastro na Paraíba quando comparados com outros valores de impostos ou direitos arrematados ao longo dos anos de 1724 a 1756. Na verdade, vê-se, em alguns anos, que a receita total da capitania não alcançou esta soma. Daí a importância dessa quantia para os cofres da capitania, como desafogo para os problemas mais imediatos, em que pese a criação de novas necessidades que poderiam ser atendidas por esse dinheiro.

Assim, é importante não esquecer que, uma vez que passou para as mãos da Fazenda da Paraíba administrar a dízima - quer o que fosse remetido de Pernambuco, quer o pouco que entrasse pelo seu porto -, tornavam-se necessários, como afirmou o provedor Salvador Dourado, "outros dois ou três oficiais para este efeito". ${ }^{36}$ Para tanto, seriam arbitrados emolumentos semelhantes aos dos oficiais da Alfândega da Bahia, com o valor do ordenado sendo futuramente estabelecido, assim que se mostrasse, na prática, o número de funcionários realmente necessários para o serviço. ${ }^{37}$ Mesmo que os valores

\footnotetext{
${ }^{35}$ Jeônimo Lobo Guimarães viria, futuramente, a ser também o arrematador dos direitos sobre os escravos negociados por terra e mar de Pernambuco e Paraíba que seguiam para a região das Minas. AHU ACL CU 014, Cx.6, Doc. 438.

${ }^{36}$ AHU_ACL_CU_014, Cx.6, Doc. 479.

${ }^{37}$ Idem.
} 
da dízima ainda fossem uma promessa, não se perdia a oportunidade de aumentar as sinecuras na provedoria. Afinal, os vinte mil cruzados da dízima de Pernambuco, imediatamente se transformariam em direito adquirido, pois, como alegava Castel Branco, "a frota de Pernambuco sempre se reputou como frota da Paraíba.",38

Findo, o primeiro ano do contrato, o qual correu de janeiro a dezembro de 1724, os problemas começaram a aparecer. Dando conta a Sua Majestade, em agosto de 1725, o provedor Salvador Dourado reclamou que os oficiais da Alfândega deveriam ajustar com o contratador, no fim de cada ano ou de cada frota, "os ganhos ou as perdas" da ação fiscalizadora, mas nada disso havia ocorrido. ${ }^{39}$ Apoiado pelo procurador da Coroa, Salvador Dourado intercedeu junto ao Provedor de Pernambuco, passando-lhe precatório para notificar o representante do contratador que o assistia na praça do Recife, alertandoo da obrigação de pagar os vinte mil cruzados. Mas o representante deu de ombros e, pedindo vistas, se negou a pagar na Paraíba os efeitos de uma dízima onde nenhuma mercadoria havia sido despachada. ${ }^{40}$

Este fato frustrou muitos, pois a situação de crise em que se encontrava a economia da capitania ameaçava levar ao caos a sociedade paraibana. Ao longo de todo o ano de 1724, a seca se alastrara pela Paraíba, alcançando o brejo e o litoral. Sem açúcar para embarcar, nenhum navio atracou no porto do Cabedelo. Como se isto não bastasse, uma praga de gafanhotos invadiu as roças, destruindo o que ainda restava "dos frutos da terra ... [pois tanto] as mandiocas, como legumes e frutas das árvores se extinguiram quase de todo. " A fome e a especulação sobre a farinha espalharam-se pela capitania. ${ }^{41}$

A situação só se tornou menos difícil quando começaram a chegar à Paraíba as remessas dos valores correspondentes ao dinheiro da dízima. Esse dinheiro, entretanto,

\footnotetext{
${ }^{38}$ AHU_ACL_CU_014, Cx.6, Doc. 452.

${ }^{39}$ AHU_ACL_CU_014, Cx.6, D 491.

${ }^{40}$ Idem.

${ }^{41}$ Assegurando uma parte de culpa pelas calamidades aos desvios dos homens na terra, o governador Castel Branco, para acalmar a ira dos céus, promoveu preces e novenas que foram feitas em todas as igrejas e que culminaram com o retorno da imagem de Nossa Senhora das Neves, para os destroços da igreja Matriz. Na imaginação do governador, a recompensa divina foi imediata: A procissão solene, para condução da imagem que há dezesseis anos se encontrava na Misericórdia, fora realizada “com tanta fé de todos estes povos que, brevemente, começaram a entrar algumas chuvas que deram lugar a cultivar-se a terra $e$ plantar-se as poucas sementes que se achavam”. Cf: AHU_ACL_CU_014, Cx.5, Doc. 416.
} 
era incerto. Além de espaçado e remetido em pequenas quantias, ${ }^{42}$ sua aplicação era feita ao sabor do imediato. Tudo isso porque dependia das frotas ou da chegada de navios soltos (isto é, fora das frotas) no porto de Recife. Daí o desacerto entre as capitanias quanto à compreensão do comprometimento da Alfândega de Pernambuco no envio dos vinte mil cruzados, se anual ou dependente das frotas. Nos termos dos contratos, mostrava-se claramente o cuidado que a Coroa tinha em não comprometer o ganho do contratador ou dela mesma, com a perda dos valores antecipadamente acordados. Se, a princípio, era demarcado o espaço de três anos para o cumprimento do acordo, este poderia ser estendido até o fechamento de três frotas, não contando nisso os navios soltos que, porventura, entrassem nos portos para além desse tempo estipulado. ${ }^{43}$

Contudo, percebe-se que, apesar das receitas dos vinte mil cruzados estarem atreladas a uma dimensão de tempo incerto - o cumprimento de três frotas -, a sua consignação deveria ser impreterivelmente anual. Não fosse assim, ficaria comprometido o pagamento dos soldados ou dos empreiteiros responsáveis pela condução das obras da Fortaleza do Cabedelo, além dos mais dependentes aos quais esse dinheiro deveria servir. ${ }^{44}$ Nesse sentido, as alfândegas de uma e outra capitania estabeleciam cálculos diferentes sobre a dívida que cabia a Pernambuco quanto aos valores não repassados. A dúvida acerca da base de cálculo, ano ou frota, gerava uma diferença nos números, cujos valores assustavam pela disparidade. $\mathrm{Na}$ escalada dos contratos, alguns dado podem ser tomados como referência. $\mathrm{O}$ primeiro contrato, como foi referido, iniciou em janeiro de 1724, com o lanço sendo arrematado por Jerônimo Lobo Guimarães, no valor de oitenta e dois mil cruzados por ano. Como em todos os outros contratos, a relação ano - frota também se fazia presente. O término foi previsto para 1727. Porém, ao que parece, foi prorrogado com o mesmo valor por mais um triênio. Assim, passado o tempo e não se

\footnotetext{
${ }^{42} \mathrm{O}$ número do parcelamento variava ano a ano. Anos houve em que a quantia podia chegar em três parcelas ou, como no ano de 1753, no qual contamos 17 parcelas. Cf: AHU_ACL_CU_014, Cx.17, Doc. 1394. O problema com o parcelamento, sem a devida concentração dos recursos, inviabilizava qualquer possibilidade de construção de uma dimensão orçamentária.

${ }^{43}$ Estabelecia os contratos que teriam duração "por três anos ... com condição que ele contratador the pertencerá três frotas dessa cidade de Lisboa somente ou entre os três anos ou fora deles e assim mais os direitos de todas as fazendas dos navios soltos que entrarem somente nos referidos três anos de qualquer parte que forem expedidos". Cf: AHU_ACL_CU_014, Cx.9, Doc. 788.

${ }^{44}$ Orçamento. Cf: AHU_ACL_CU_014, Cx.7,Doc. 576.
} 
completando as seis frotas devidas, só em 1731, sete anos depois, dar-se-ia o encerramento do contrato de Lobo Guimarães. ${ }^{45}$

O terceiro contrato, arrematado por Manuel Gomes de Carvalho, no valor de cento e seis mil cruzados, deveria ter início em janeiro de 1732 mas, acatando uma petição do contratador, o rei prorrogou, "por faltar rendimento," para o ano seguinte. ${ }^{46}$ Nestes termos, os três anos correram sem atropelos, de modo que, em janeiro de 1736, Francisco Leite Morais surgiu como contratador da dízima, arrendada por oitenta e seis mil cruzados, e trezentos mil réis anuais. ${ }^{47}$

Além dos desacertos quanto ao pagamento integral ou não pelos contratadores em Pernambuco, o certo é que, a defasagem ano / frota era motivo de contendas constantes entre as duas provedorias. Em 1736, por exemplo, Jorge Salter de Mendonça, ouvidor geral e provedor da Fazenda Real da Paraíba, apresentou ao rei o que havia rendido, até então, o direito da dízima para a Paraíba. De 1724 até 1736, os 62:590\$551 réis que constava terem sido recebidos de Pernambuco, somados ao que rendeu na Alfândega da Paraíba, 5:709\$753 réis, totalizavam 68:300\$304 réis. Por outro lado, multiplicando-se os doze anos pelos 8:000\$000 reis, que anualmente deveriam ser mandados de Pernambuco à Paraíba, obtinha-se o total de 96:000\$000 reis. Quando dessa quantia se subtraía o valor de 68:300\$304 réis, chegava-se ao valor real da dívida que caberia a Pernambuco, ou seja, 27:699\$096 réis. Tal valor corresponderia a cerca de três anos e meio de atraso. O problema é que, pelos cálculos efetuados pelo provedor de Pernambuco, essa dívida, se acompanhada apenas pelo registro das frotas, não ultrapassava a faixa dos 3:699\$096 réis. $^{48}$

$\mathrm{Na}$ verdade, o não-envio desse dinheiro para a Fazenda paraibana ofendia toda a economia local pois, como diziam os oficiais do Senado da Câmara da Paraíba, "se não fossem os vinte mil cruzados de Pernambuco já não haveria nesta [capitania] nenhuma casta de dinheiro". ${ }^{49}$ Com a primeira remessa do produto da dízima em 1726-1727, orçado em 8:500\$000 réis, mais os $465 \$ 377$ réis, que renderam na alfândega da Paraíba,

\footnotetext{
${ }^{45}$ AHU_ACL_CU_014, Cx. 8, D 665; 666 e 667.

${ }^{46}$ AHU_ACL_CU_014, Cx.9, D 752.

${ }^{47}$ AHU_ACL_CU_014, Cx. 9, D. 788.

${ }^{48}$ AHU ACL CU 014, Cx. 10, D 805.

${ }^{49}$ AHU_ACL_CU_014, Cx.11, Doc. 936.
} 
foi possível saldar todos os débitos com a infantaria, além de atender alguns outros débitos. ${ }^{50}$

Ainda em 1729, mesmo com o bom prenúncio do retorno das chuvas ${ }^{51}$, resquícios dos anos anteriores de seca empurraram para baixo a arrematação dos direitos dos dízimos da capitania, acarretando atrasos nos pagamentos dos "filhos de uma ou outra folha". 52 A cobertura para atender esta demanda não poderia sair simplesmente da margem de consignação dos vinte mil da dízima. Um flagrante do orçamento, para o ano de 1730, demonstrava ser insuficiente o valor da dízima, até mesmo para fazer frente às exigências dos empreiteiros responsáveis pela construção e reparos da Fortaleza de Cabedelo. ${ }^{53}$

Dessa forma, a tomada de consciência acerca do mau negócio que havia sido a junção dos contratos da dízima, passou a dar forma a propostas que pudessem fazer respirar a Provedoria da Fazenda Real da Paraíba. Neste sentido, alguns governadores, desejosos de demonstrar ao rei sua eficiência em zelar e expandir as receitas da Fazenda Real, fizeram chegar a Lisboa algumas cartas, onde evidenciaram seus projetos e estratégias fiscais para a efetiva consolidação autônoma da Paraíba.

Dentre os governadores da Paraíba, durante e após os anos 30, Pedro Monteiro de Macedo e Luís Antônio Lemos de Brito confundiram as suas gestões com os seus projetos para libertar a capitania da dízima da Alfândega que se cobrava por Pernambuco. Apesar de não conduzirem ao fim almejado, suas histórias ganham importância na medida em que desnudam os interesses dos grupos contrários a eles, que sobreviviam e alimentavam a crônica política de dependência entre as capitanias.

\footnotetext{
${ }^{50}$ Em 1727, o total do rendimento orçou em 8:965\$377 e atendeu as seguintes despesas: Infantaria: 8:035\$827; soldo do governador: $144 \$ 638$ (complemento); soldo do apontador da fortaleza: $31 \$ 000$; soldo do capitão engenheiro: 200\$000; oficial dos contos: 60\$000; tesoureiro: $100 \$ 000$. Total das despesas: 8:571\$827. Cf: AHU_ACL_CU_014, Cx. 7, Doc. 570.

${ }^{51}$ AHU_ACL_CU 014, Cx.7, Doc. 214.

${ }^{52}$ O governador da Paraíba, Francisco Pedro de Mendonça Gurjão, em 1729, falando sobre o contrato da arrematação dos dízimos da capitania alegava que, "costumando dar dezesseis mil cruzados ou mais, nem a oito tem chegado.” Cf: AHU_ACL_CU_014, Cx. 7, Doc. 576.

53 "Relação do que despende para os vinte mil cruzados. (...) Para pagamento da Infantaria _ 3:478\$560; Soldo do governador (ajustado pelo valor da dízima, por não chegarem os efeitos do Senado da Câmara) 1:200\$000; Capitão engenheiro_ 300\$000; Tesoureiro do rendimento da dízima_100\$000; Escrivão dos Contos da Fazenda _ 60\$000; Apontador das obras_ 36\$000; Farinhas para socorro das infantarias 782\$400; Resta para aplicar nas obras: 1:943\$560; Total: 8:000\$000" Cf: AHU_ACL_CU_014, Cx. 7, Doc. 576.
} 


\section{PEDRO MONTEIRO: SONHOS, ESTRATÉGIAS FISCAIS E O COROLÁRIO DAS DÍVIDAS NOVAS E VELHAS}

Provido para governar a Paraíba, por despacho real na consulta de janeiro de 1734, Pedro Monteiro de Macedo tomou posse em setembro do mesmo ano e encontrou a capitania numa situação deficitária. Ainda que a receita da capitania mostrasse, no geral, um aumento nos últimos três anos, sua despesa havia aumentado na mesma proporção. ${ }^{54}$ A falsa impressão de superávit deu-se, em primeiro lugar, pelo acréscimo, no ano de 1732, do ingresso das receitas do contrato das carnes, antes administrado pelo Senado da Câmara. ${ }^{55}$

Em segundo lugar, foi um erro pensar que a entrada dos vinte mil cruzados da dízima que se recolheu por Pernambuco, no período de três anos consecutivos, 1731-34, colocasse em dia os compromissos com os pagamentos da folha militar e dos empreiteiros envolvidos com a obra de reparo da Fortaleza do Cabedelo. ${ }^{56}$ Os anos de atraso no envio desses recursos haviam perturbado as consignações a tal ponto que, do ponto de vista da provedoria da Paraíba, a dívida de Pernambuco já ultrapassava os sessenta mil cruzados em $1733 .{ }^{57}$

Além desses problemas que se apresentaram de imediato, outros mais difíceis apareceram adiante, alargando o desafio para o governador. Ele devia cumprir o principal objetivo constante em seu regimento, isto é, garantir uma boa arrecadação para todas as mercadorias tributáveis e, conseqüentemente, aumentar os rendimentos da capitania. Entretanto, o sucesso ou o fracasso no alcance deste objetivo, estava intimamente ligado à sorte do governador em ser agraciado com bons anos de chuvas e colheitas, além de não poder dispensar a colaboração dos outros agentes da administração, principalmente do provedor da Fazenda Real. Mas, em ambos os casos, foi infeliz.

\footnotetext{
${ }^{55}$ AHU_ACL_CU_014, Cx.9, Doc. 733.

${ }^{56}$ Elza Regis de Oliveira. A Paraíba na crise... Op. cit, p. 145.

${ }^{57}$ AHU_ACL_CU_014, Cx.8, Doc. 715.
} 
Acontece que, em 1733, havia falecido o antigo proprietário da Provedoria da Fazenda paraibana, Salvador Quaresma Dourado. Dessa forma, Pedro Macedo encontrou a Fazenda sofrendo uma grande devassa em suas contas. Para o seu azar, tanto o processo investigativo como a gestão do próprio órgão tributário estavam nas mãos do Ouvidor Geral, Jorge Salter de Mendonça. Nada pior para um governador que ter de compartilhar sua administração com outro agente que, na escala hierárquica, pelo acúmulo de cargos, se prestava a confrontá-lo em suas prerrogativas. Pedro Macedo chegou a tecer elogios sobre o zelo com que o provedor / ouvidor Salter Mendonça conduzia as coisas públicas - "acabando com o abuso dos exorbitantes salários e emolumentos pagos a boa parte dos oficiais da justiça e fazenda". Mas a falta de fardas e o atraso dos soldos da infantaria alimentaram no governador a suspeita sobre os descaminhos percorridos pelo dinheiro enviado de Pernambuco, fazendo-o lembrar a Sua Majestade que a "dobrada jurisdição", isto é, o acúmulo do cargo do ouvidor com o de provedor, era prejudicial à boa administração. $^{58}$

Por isso, ainda sem traquejo como administrador, Pedro Macedo tomou talvez, a medida mais correta. Percorreu o litoral e enveredou sertão adentro em jornadas que the tomaram muitos meses do ano de $1735 .^{59}$ Como militar valoroso nas várias batalhas corridas nos anos de sua juventude, no início do setecentos ${ }^{60}$, não demorou a associar a experiência da caserna com a nova atividade administrativa. Pasmo com a violência que encontrou pelos caminhos na Paraíba, escreveu ao rei, acreditando que boa parte das mortes por conflitos de terras poderia ser resolvida, caso pudesse nomear pessoa para fazer as demarcações. Elas deviam ocorrer principalmente nas terras dos índios, com a colocação de marcos nos limites da divisa da Paraíba com Pernambuco e Rio Grande. ${ }^{61}$ Da mesma forma, percebeu a fragilidade militar no litoral brasileiro. Sabedor dos conflitos existentes no Sul, por conta da disputa pela conquista da Colônia do Sacramento, temeu uma ofensiva de Castela ou França nos mares do Norte do Brasil. Isso já havia acontecido com os navios franceses que se alojaram na ilha de Fernando de Noronha e para onde Pernambuco enviou nove embarcações, incluindo cinco naus de

\footnotetext{
${ }^{58}$ AHU_ACL_CU_014, Cx.12, Doc. 1021.

${ }^{59}$ AHU_ACL_CU_014, Cx.10, Doc. 801.

${ }^{60}$ AHU ACL CU 014, Cx.9, Doc. 730.

${ }^{61}$ AHU_ACL_CU_014, Cx.10,Doc. 800.
} 
guerra. ${ }^{62}$ Assim, fez ver à Sua Majestade quão necessário seria garantir a segurança da capitania, livrando toda essa área das possíveis invasões de nações inimigas. Para isso, incumbiu o sargento-mor engenheiro Luís Xavier Bernardo da realização de novas medições, traçando os planos para reparo de Cabedelo e construção de fortalezas na Bahia da Traição, antigo sonho dos ex-governadores João Maia da Gama e Antônio Velho Coelho. ${ }^{63}$

Homem experimentado na ciência militar, Pedro Macedo já havia dado mostras de sua capacidade prática em recuperar fortalezas, como demonstrou na fortificação de Campo Maior, ao executar com zelo o reparo de toda a bateria que estava em ruínas. Nos anos em que esteve na ativa como soldado, servira na Praça de Ceuta, Peniche, Lisboa e nas províncias de Beira e Além-Tejo, onde alçou-se ao posto de sargento-mor. Singrou o Atlântico por duas vezes, a mando de Sua Majestade, para comboiar as frotas de Pernambuco e Rio de Janeiro. ${ }^{64}$

Ao que parece, sua família não provinha da nobreza, na verdade, estava ali, na ante-sala da fidalguia. Alcançou o Hábito de Cristo e, ao solicitar as tenças para suas sobrinhas, justificando o pedido com o gesto nobre, deixou escrito que elas eram mossas da câmara, isto é, camareiras da rainha. Talvez a proximidade dele e dos seus entes queridos junto ao monarca tenha servido de ajuda quando requereu o governo da Paraíba. $\mathrm{Na}$ consulta decisória com os outros opositores para o governo da Paraíba, Pedro Macedo foi preterido por todos os conselheiros, mas a decisão real recaiu sobre o seu nome. Era o primeiro cargo executivo que assumia e queria demonstrar sua lealdade e devoção ao rei. ${ }^{65}$ Todas as suas fichas foram jogadas na construção e reparo das fortalezas da Paraíba, fezendo disso a obra de toda sua vida.

Mas o tempo parecia tramar contra Pedro Macedo. Nos anos de 1736 e 1737, duas cheias sucessivas trouxeram todas as más conseqüências possíveis: fome, diminuição do número de escravos, engenhos de fogo morto e queda do comércio. A renda tributária da

\footnotetext{
${ }^{62}$ AHU_ACL_CU_014, Cx.10, Doc. 830 e 867.

${ }^{63} \mathrm{AHU}^{-} \mathrm{ACL}^{-} \mathrm{CU}^{-} 014, \mathrm{Cx} .11$, Doc. 880.

${ }^{64}$ Idem.

${ }^{65}$ AHU_ACL_CU_014, Cx.09, Doc. 729; Cx.09, Doc. 730 e Cx. 11, Doc. 927. Sobre os ofícios da Câmara ou Casa Real; Cf: Pedro Cardim. "A Casa Real e os órgãos centrais de governo no Portugal da segunda metade de Seiscentos." In: Revista Tempo. Dossiê: política e administração no mundo luso-brasileiro. Rio de Janeiro, Departamento de História da UFF. Vol.7; nº 13; p 13 -57. Julho, 2002.
} 
capitania se exauriu e os contratos de arrematação dos dízimos, subsídio do açúcar e carne decaíram nestes anos. Os vinte mil cruzados da dízima da Alfândega de Pernambuco passaram a concorrer com outras consignações. A ajuda em dinheiro e o envio de tropas deveriam sair da capitania de Pernambuco para a nova Colônia do Sacramento. Além disso, deveria também investir na construção de uma fortaleza na Ilha de Fernando de Noronha e no reparo das forças de defesa do Rio Grande. Não deu outra, atraso dos soldos da Infantaria e, para o desespero de Pedro Macedo, as obras das fortalezas ficaram quase paradas. ${ }^{66}$

Acuado, com uma Fazenda em pedaços, o governador viu-se impossibilitado de agir. Escreveu, então, uma carta ao rei, em 1738, onde apresentou um curioso projeto sobre a taxação do transporte de gados e corte da carne. O objetivo era livrar a Paraíba, de uma vez por todas, da dependência dos vinte mil cruzados da dízima da Alfândega de Pernambuco e salvaguardar a independência do órgão fazendário da capitania. ${ }^{67}$

A partir do momento que houvesse uma quebra com o contratador, o contrato do subsídio das carnes passaria a ser administrado diretamente pela Fazenda Real. A idéia de Pedro Macedo era deixar, na concorrência, a escolha entre os criadores, no sentido de definirem onde e em qual açougue cortariam a sua carne. É verdade que o imposto a ser pago continuava no mesmo valor que era destinado ao contratador, ou seja, oitocentos réis por cabeça de gado. Mas ele incidiria apenas sobre as cabeças abatidas e não sobre o conjunto do lote, cujo valor era antecipado ao contratador para emissão da licença para o abate. Dessa forma, se beneficiaria tanto o criador, pois estaria livre das perdas com as possíveis mortes dos gados no caminho das feiras e lugarejos, quanto os mais pobres, a “respeito da barateza das carnes." Restava ainda evitar a saída indiscriminada do gado para outras capitanias que pudessem ou quisessem oferecer uma menor taxa para o corte. Por isso, Pedro Macedo propôs a universalização dessa prática, garantindo os níveis de produtividade e consumo de cada capitania. ${ }^{68}$

Contudo, mesmo com estes procedimentos, ainda não era possível conseguir um valor aproximado dos vinte mil cruzados que deviam ser transferidos da Alfândega de

\footnotetext{
${ }^{66}$ AHU_ACL_CU_014, Cx.10, Doc. 830.

${ }^{67}$ Idem;

${ }^{68}$ Idem;
} 
Pernambuco. Para se ter uma idéia, o último valor alcançado na arrematação do contrato das carnes chegara a três mil cruzados por ano. Por mais estímulo que se fizesse, seria impossível livrar a capitania da consignação de Pernambuco. Por isso, deslocando o enfoque do projeto, Pedro Macedo pretendeu criar um imposto de passagem, que incidiria sobre os gados que atravessavam a Paraíba com destino as Minas, vindos das capitanias de cima, Rio Grande e Ceará.

Nesse caso, mantendo-se os mesmos oitenta e cinco réis por cabeça de gado, incluindo também os cavalos, o governador contava poder arrecadar para além dos vinte mil cruzados. Segundo seus cálculos, passavam cerca de 10 a 12 mil cabeças pela capitania, número que poderia ser aumentado, caso fosse acrescentado o gado criado em curral paraibano e destinado as Minas. ${ }^{69}$

A repercussão do projeto e as suas seqüelas foram interessantes porque fizeram emergir diversos conflitos e animosidades, envolvendo tanto as administrações local e central quanto as sociedades paraibana e pernambucana.

Se o ouvidor e provedor da Fazenda Real da Paraíba, Salter de Mendonça, se eximiu de emitir qualquer parecer sobre o projeto, a Câmara paraibana agiu de forma diferente. No mesmo ano de 1738, seus oficiais escreveram ao rei:

Em vista da necessidade urgente de pagar aos soldados e adiantar a fortaleza e aumentar maiores defesa e companhias, não só aprovamos o dito projeto, mas humildemente prostrados aos pés de vossa majestade lhe pedimos em nome destes moradores para por em prática, por não discorremos por desconveniência a Pernambuco nem a Paraíba, que quando tivera prejuízo estamos muito prontos a sacrificar as nossas fazendas e vidas pelo serviço de vossa majestade (...) e enquanto não se põe em forma este projeto seja obrigado o contratador da dízima de

\footnotetext{
${ }^{69}$ Idem.
} 
Pernambuco a por nesta capitania 30 mil cruzados para com estes se poder remediar as necessidades que padecem, enquanto não tem efeito o projeto do nosso governador. ${ }^{70}$

Os oficiais da Câmara reconheceram os méritos do projeto do governador e aproveitaram para lembrar ao rei que não acreditavam mais na Alfândega de Pernambuco. Daí pedirem para o contratador pagar diretamente e com valor acrescido de dez mil cruzados, para adiantamento da obra da fortaleza. Prenunciando possíveis rejeições, e já calejados com os antigos entreveros entre as populações das duas capitanias, buscaram deixar claro que o importante no projeto era promover a segurança das conquistas reais, tarefa para qual estavam dispostos a qualquer sacrifício.

A resposta de Pernambuco não demorou muito. $\mathrm{O}$ argumento levantado pela administração da capitania vizinha foi apoiado pelos pernambucanos que possuíam currais na Paraíba. Tentava demonstrar que este imposto, tanto no processo do abate como de passagem para as Minas, já existia em Pernambuco e foi consignado pelo rei para o pagamento dos quarenta mil cruzados do donativo real. Diziam, também, que a Paraíba estava por "graça real especial de Sua Majestade, em reconhecimento da pobreza da terra," isenta deste donativo. Por fim, consideravam um absurdo que os criadores fossem obrigados a pagar em dois lugares um único tributo. ${ }^{71}$

Pedro de Macedo não cedeu na defesa do seu projeto e mandou o ajudante supra Francisco de Melo Moniz para Lisboa, com a missão de mostrar as reais condições da capitania e as vantagens do plano de reorganização dos tributos sobre a passagem e abate do gado na Paraíba. O governador alegou que Pernambuco podia ficar com todo o restante do dinheiro que, arrecadado na Paraíba, ultrapassasse os vinte mil cruzados. Bastava que no rio São Francisco fosse feita uma relação dos gados que atravessassem para as Minas, para que depois se pudesse confrontá-la com a relação da Paraíba.

\footnotetext{
${ }^{70}$ AHU_ACL_CU_014, Cx.10, Doc. 842.

${ }^{71}$ AHU_ACL_CU_014, Cx.11, Doc. 897.
} 
Mas os pernambucanos não eram os únicos opositores ao projeto. $\mathrm{Na}$ verdade, o plano contrariava interesses de muitos criadores paraibanos, inclusive missões religiosas, especializados no envio de gado para as Minas. ${ }^{72}$ Não se sabe ao certo se a consulta sobre este projeto chegou ao rei, ou se ficou ao nível do Conselho Ultramarino. Contudo, em meados da década de quarenta, o rei ordenou o envio de mais dez mil cruzados, para a Paraíba, provenientes dos quarenta mil cruzados do donativo real que Pernambuco estava obrigado a mandar anualmente para a Coroa. Se esse dinheiro aparecia como recompensa pela não aprovação do projeto, é certo que, de acordo com o que disse o governador da Paraíba, Antônio Borges da Fonseca, em 1749, ele nunca chegou à Paraíba. ${ }^{73}$

Dessa forma, a rejeição ao projeto se baseava exatamente nisso: se a idéia principal era desvinculação da renda tributária das capitanias, dava-se exatamente o contrário, se ampliava a margem de consignáveis entre Pernambuco e Paraíba com a promessa de mais um repasse de verba, os dez mil cruzados.

Mesmo que seus planos tenham sucumbido, Pedro Macedo não desistiu das fortalezas. Empedernido, entrou a década de 1740 empreendendo todos os esforços na causa e, segundo as várias cartas acusatórias sobre sua pessoa, que não paravam de chegar a Lisboa, declarava guerra a quem se atrevesse a cruzar seu caminho. Revoltavase ao identificar, como um dos males da terra, a falta de disposição, pois ninguém estava disposto a nenhuma cota de sacrifício, muito pelo contrário, todos almejavam tirar proveito de tudo:

E seguro V. Majestade, que só com a força da prudência, sofrimento e destreza se pode encaminhar

\footnotetext{
${ }^{72}$ Sobre o controle dos currais de gado e aldeamentos indígenas pelas missões religiosas no interior do Nordeste, ver: Maria do Céu Medeiros. Igreja e dominação escravista no Brasil: o caso dos Oratorianos de Pernambuco 1659-1830. João Pessoa: CCHLA/UFPB; Editora Idéia, 1993; e Ricardo Pinto de Medeiros. $O$ descobrimento dos outros: povos indígenas no sertão nordestino no período colonial. Recife, Tese de Doutoramento/CFCH/UFPE (Departamento de História). 2000.

${ }^{73}$ AHU_ACL_CU_014, Cx.15, Doc. 1258
} 
essa gente, e ainda para suas conveniências porque quando lhes falta a razão, lhes sobra de malícia. $^{74}$

Pedro Monteiro decidiu partir para o confronto com a sociedade. Na questão das finanças, conseguiu infiltrar-se na Fazenda Real e, com a saída de Salter de Mendonça, passou a perseguir vários oficiais do órgão. Chegou mesmo a prendê-los sem culpa formada, além de nomear para os seus lugares pessoas de sua confiança, como o "tesoureiro Manuel da Fonte, seu compadre." Usando de amizade, “conseguiu junto com o almoxarife e escrivão da Fazenda, Amaro Velho de Vasconcelos, mexer nas consignações do órgão contra as ordens de Sua Majestade." mesmo lhe sendo proibido, por ordem real, comerciar, se meteu em todo tipo de atividade. Primeiro, armou barcos, com “rolos de tabacos já beneficiados," para adquirir escravos na África e vendê-los em Minas ou “embaixo de sua própria laje”. Segundo, fazia rufar tambores pelas ruas da cidade "sob a capa do bem comum, ordenando a cada farinheiro certo número de alqueire e mandando guardar em armazéns (...) embarcava depois tantos mil alqueires para o Rio de Janeiro". Terceiro, instituiu uma finta para a população, impondo, "a cada uma das pessoas que seja pobre ou rica um patacão, com que aluga escravos para o trabalho do entulho da fortaleza." E quarto, na falta de alimentos ou animal de tração para a obra da fortaleza, mandava os "soldados apanhar gado vacum ou cavalar que se achavam nos pastos", 76 , à revelia dos donos.

Pode haver exagero nas acusações, mas o fato é que Pedro de Macedo foi se afastando do convívio dos segmentos sociais que seu cargo exigia e boa parte da população cobrava, daí os relatos intermináveis sobre seu comportamento. O governador transportou-se para um outro universo de relações sociais, que assombravam senhores de engenho, religiosos e moralistas daqueles tempos.

Já abandonara a morada do palácio que ficava a 40 passos da Casa de Misericórdia, indo morar em casa de aluguel ou na fortaleza com seus soldados. Passou a relacionar-se com duas mulatas, uma forra chamada Antônia e outra escrava, que

\footnotetext{
${ }^{74}$ AHU_ACL_CU_014, Cx.10, Doc. 843.

${ }^{75} \mathrm{AHU}^{-} \mathrm{ACL} C \mathrm{CU}^{-} 014, \mathrm{Cx} .12$, Doc. 1009.

${ }^{76}$ Idem;
} 
pertencia a D. Joana, viúva do Capitão João Ferreira Batista, com as quais passeava em seu escaler pelo rio Paraíba, em direção a Cabedelo. Segundo um dos vereadores, o governador:

não freqüentava mais as missas e procissões,
preferindo as serenatas onde entoava
desonestíssimas cantigas seguindo de dança já
impedida pelos exelentíssimos bispos, a que chamam
batuque. Nestas tocam e cantam, e o seu ajudante
Bras de Melo Muniz, e alguns soldados seus
aplicados com essa música, pertubam a cidade e
talvez em alguma ocasião estejam em oração e
louvando a Deus. Acabando o festejo fica o
governador com qualquer das duas pardas em seu
palácio que diz ser uma outra mesquita. ${ }^{77}$

No calor das acusações, um despacho real, feito em fevereiro de 1744, como resposta a uma consulta do Conselho Ultramarino sobre as razões para a substituição do governador, ordenou que se colocassem editais para provimento do novo governo da Paraíba. Isolado pela elite local, Pedro Macedo dizia apenas que, no Brasil, “quando acaba quem governa até as pedras tramam contra" ${ }^{, 78}$. Veio a falecer nos fins desse mesmo ano e, ironicamente, mandou cunhar na sua lápide: “Aqui jaz Pedro Monteiro de Macedo que por governar mal a Paraíba quer que todos o pisem e a todos pede um padre nosso e uma ave Maria". ${ }^{79}$ O recado estava entendido: o rei acendia duas velas para dois santos, mas com tamanhos diferentes. A não aprovação do projeto de Pedro Macedo, com a alocação dos dez mil cruzados do donativo pago por Pernambuco para a Paraíba, ampliando a margem de contatos entre as provedorias, visava manter as coisas sem alteração alguma.

\footnotetext{
${ }^{77}$ Idem.

${ }^{78}$ AHU_ACL_CU_014, Cx.11, D 928.

${ }^{79}$ Irineu Ferreira Pinto. Datas e notas para a história da Paraíba... Op. Cit. p. 148
} 
A inesperada morte de Pedro Monteiro de Macedo, colocou os paraibanos de sobreaviso. A ameaça da subordinação nunca foi tão nítida. $\mathrm{O}$ vácuo de poder no governo da capitania foi preenchido por uma Junta de Oficiais da Câmara, que governou a Paraíba de maio a agosto de $1744 .{ }^{80}$ Porém, mesmo com a situação política amenizada com a posse da Junta, a desorganização da Fazenda, deixada por Pedro Macedo nas suas incessantes intervenções no órgão, principalmente com a saída do ouvidor / provedor Jorge Salter de Mendonça, se fazia sentir e dela resultaria mais um realinhamento no relacionamento das provedorias.

\section{DÍVIDA NOVA E DÍVIDA VELHA}

Durante boa parte da gestão de Pedro Macedo, concomitante com a administração de Salter de Mendonça na Fazenda, o escrivão do órgão, Bento Bandeira de Melo, por diversas vezes, assumiu interinamente o cargo de provedor. Esse revezamento Salter Bento era provocado pela dupla jurisdição a que estava submetido Salter pois, como ouvidor, estava obrigado a sair em correição sertão adentro e precisava deixar alguém no cargo de provedor. ${ }^{81}$ Tal estado de coisas se prolongou até meados de 1741, quando Bento Bandeira tentou se estabilizar no cargo, já que o provedor escolhido no Conselho Ultramarino, José Antônio da Cunha, só chegou na Paraíba em 1744.

Antônio da Cunha já havia servido na Capitania da Paraíba como militar e secretário de governo durante cinco anos, até a chegada de Pedro de Macedo, que o exonerou. Ao requerer no Conselho Ultramarino a vaga de Provedor da Fazenda da Paraíba, em setembro de 1742, servia na província do Minho, no ofício de Juiz das Cizas. Porém, mesmo sendo Antônio da Cunha aceito pelos conselheiros para o cargo, Pedro Monteiro fez por onde barrar o escolhido, arrastando o provimento até a sua morte. ${ }^{82}$

\footnotetext{
${ }^{80}$ Essa Junta foi sucedida por João Lobo de Lacerda, que se manteve até agosto de 1745. Posteriormente, governou a capitania Antônio Borges da Fonseca (1745 - 1753) e, como último governador independente, Luis Antônio Lemos de Brito, de novembro de 1753 até abril de 1757.

${ }^{81}$ AHU ACL CU 014, Cx12, D. 971.

${ }^{82}$ AHU_ACL_CU_014, Cx.,11. D 962.
} 
Revoltado, Antônio da Cunha tornou a abrir as feridas deixadas pelo governador na Fazenda. Além de centrar suas denúncias na gestão imediatamente anterior, estendeu suas críticas às administrações mais antigas, não poupando nem aqueles oficiais que já tinham sofrido suas residências ou suas prestações de contas como, por exemplo, Salvador Quaresma Dourado. Segundo Antônio da Cunha, não era apenas o atraso do pagamento dos vinte mil cruzados da dízima, a virem de Pernambuco, que desgraçava as consignações. Por anos a fio, dizia ele, "descaminhos intolerantes" haviam selado o destino da fortaleza, que se encontrava "no mais deplorável estado que pode haver". Assim, em tom dramático concluía:

De que servem Senhor, superintendentes, engenheiros empreiteiros, apontadores, obreiros para haver de não cuidarem no que respeita e toca a sua obrigação; e para que são tantas e repetidas medições, para que tantas despesas. Mande $V$. majestade tirar a conseqüência de semelhante proceder e do que dele se achar mandará fazer inteiro cumprimento de justiça, porque me não atrevo fazê-lo sem expressa ordem de V. Majestade. ${ }^{83}$

Mas a intolerância do provedor mostrou-se maior que a sua paciência pela espera da resposta do monarca. Mesmo sem autorização, passou a fazer inúmeras investigações. "Fundado no capitulo 96 do foral da Alfândega, e nas mais ordens porque V. Majestade lhe recomenda a boa arrecadação," 84 começou a tirar devassas. Em virtude delas, seqüestrou os bens de Pedro Macedo e do seu almoxarife, Francisco da Costa Oliveira, responsabilizando este último pelo desvio do dinheiro da obra da nova fortaleza. Sem hesitar, mandou prender o tenente engenheiro, Luiz Xavier Bernardo, na fortaleza do Cabedelo. Obrigou o escrivão da Fazenda, Bento Bandeira de Melo, e os herdeiros do

\footnotetext{
${ }^{83}$ AHU_ACL_CU_014, Cx. 13, D 1120.

${ }^{84}$ Idem;
} 
antigo provedor, Salvador Dourado, falecido em 1733, a devolverem o que haviam tirado da Fazenda sob o pretexto de adiantamento dos seus ordenados. ${ }^{85}$ Encaminhou precatórios para a Provedoria da Fazenda de Pernambuco, obrigando o provedor daquela provedoria a observar e cumprir as ordens de Sua Majestade com o envio do dinheiro da dízima. A resposta do oficial da capitania vizinha, cheia de ironia, de que "ficaria na lembrança o envio para quando houvesse dinheiro, " foi repassada para o rei por Antônio da Cunha, que ficou a assistir as repreensões do monarca sobre o provedor de Pernambuco. ${ }^{86}$

O desmantelo das contas no Almoxarifado da Fazenda Real da Paraíba também não lhe passou desapercebido. Mostrou diferenças que existia entre os valores a que deveriam corresponder os bens in natura provenientes de Pernambuco, e os valores registrados nos Livros de Mostra da Infantaria, nos últimos trinta anos. Demonstrou que essas diferenças haviam desarrumado a tal ponto as consignações que:

Dos cem mil cruzados que a Provedoria de Pernambuco resta dever a desta do alcance da graça concedida dos vinte mil cruzados da dízima (...) ainda que tenham efeito de se arrecadar, o que duvido, não chegarão para reparo ao menos da fortaleza. ${ }^{87}$

Essas acusações não passaram sem efeito pelo Conselho Ultramarino que, endossando o parecer do procurador da Fazenda, sugeriu ao rei o andamento das investigações. Na sua avaliação, o procurador dizia poder "ser certos alguns dos descaminhos e desordens de que dá conta." ${ }^{88}$ Todavia, também não passou despercebida a forma com que havia agido o provedor:

\footnotetext{
${ }^{85}$ Idem.

${ }^{86}$ AHU_ACL_CU_014, Cx.13, D 1099.

${ }^{87}$ Idem;

${ }^{88}$ Idem;
} 
... das contas que dá o Provedor José Antônio da Cunha que com esta se remetem a V. Majestade, se mostra a sua curta capacidade e ser inábil para esta ocupação, e se verifica do que dele vaticinou Pedro Monteiro de Macedo, quando soube que pretendia este lugar; parece ao Conselho, que para se evitarem as confusões, que vai introduzindo na Provedoria, será conveniente que V. Majestade lhe haja o lugar por acabado, e nomeie novo Provedor. ${ }^{89}$

O andamento das investigações, sob o comando de Teotônio Fernandes Temudo, que tinha sido provedor da Capitania do Rio Grande, terminou por levantar todos os seqüestros e não incriminar ninguém. Dessa forma, foi o mesmo que reconhecer lisura em todos casos denunciados por Antônio da Cunha.

Porém, no início do ano de 1748, requerimentos de antigos empreiteiros envolvidos na construção da fortaleza, solicitando pagamento, passaram a chegar a Lisboa. $^{90}$ Mas não havia dinheiro para nada. Em 1749, no envio da relação de rendimentos e despesas da Fazenda da Paraíba, ao Conselho Ultramarino, Fernandes Temudo mostrava ser impossível atender a este e a outros pagamentos, principalmente aqueles consignados com o envio dos vinte mil cruzados. ${ }^{91}$

Em dois anos consecutivos, 1746 e 1747, nada havia chegado da Alfândega de Pernambuco. O último soldo foi pago aos soldados em novembro de 1745, as fardas em junho de 1747 e o pão-de-munição, em janeiro de 1748. A dívida total de Pernambuco, segundo os cálculos do provedor, chegava a 54:732\$202 réis, que convertidos em cruzados, totalizavam cento e trinta e seis mil cruzados, oitocentos e trinta mil, quinhentos e cinco réis. Nem os dez mil cruzados do donativo real, acertados à época de Pedro Macedo, haviam sido enviados. ${ }^{92}$

\footnotetext{
${ }^{89}$ Idem; Ainda sobre a exoneração e o abuso da jurisdição, conferir: AHU_ACL_CU_014, Cx13, D 1122.

${ }^{90}$ AHU_ACL_CU_014, Cx.15,D 1260.

${ }^{91}$ AHU_ACL_CU_014, Cx.15,D 1258.

${ }^{92}$ Idem.
} 
A situação chegou a tal ponto que, em 1751, Temudo enviou cartas ao provedor de Pernambuco, nas quais tentava fazê-lo compreender o comprometimento com os pagamentos. As obrigações se referiam não apenas à folha militar e à segurança da capitania (com as obras da fortaleza paradas), mas também às folhas eclesiástica e executiva, que acabavam sofrendo atrasos, pois, na falta da dízima, tinha-se que cobrir essa carência com outras consignáveis. ${ }^{93}$ Em maio de 1752, o Ouvidor Geral da Paraíba, José Ferreira Gil, escreveu ao rei relatando que, servindo há dois anos na capitania, apenas havia recebido o equivalente

a seis meses de ordenado, propinas e aposentadoria (...), nem o que me pertencia do luto que se deram pela morte do Senhor Rei, Dom João o Quinto, nem as propinas das luminárias pela proclamação de Vossa Majestade (...) Nem os oito mil réis quando se fazem correições nos sertões, dando-se por desculpa o não haver dinheiro, nem a Câmara o tem para satisfazer alguma e assim me vejo em maior consternação obrigando-me esta quase nos termos de pedir, o que é contra o respeito de um Ministro... ${ }^{94}$

Além de todos esses problemas, o escancaramento das contas, com os desajustes dos livros apresentados ainda no tempo de Antônio da Cunha, não deixava de por em xeque todos os apontamentos acerca do montante da dívida que corria entre as duas provedorias. O debate acerca da base do cálculo, se anual ou por frota, ganhou um novo elemento. A solução encontrada pelo Conselho Ultramarino, e acatada pelo rei, foi tomar o ano de 1748 como ponto de inflexão e dividir, a partir daí, a dívida da Provedoria de Pernambuco para com a da Paraíba.

\footnotetext{
${ }^{93}$ AHU ACL CU 014, Cx.16, D 1333.

${ }^{94}$ AHU_ACL_CU_014, Cx.16, D 1326
} 
A chamada divida velha, anterior a 1748, orçou com base no cálculo apresentado por Temudo. A partir dessa data, todos os repasses e recebimentos de uma e outra provedoria deviam ser feitos de imediato, com o valor, dia, mês e o ano do ingresso ou saída das receitas vivas, letras ou dinheiro, ficando registrados em livros e não mais por lembrança. Assim, encontrou-se uma saída para o malogro da ordem com o repasse dos dez mil cruzados do donativo real que deveria ir de Pernambuco para a Paraíba. Toda a arrecadação da dízima feita pela Alfândega paraibana deveria servir como abatimento da divida velha, não mais incidindo doravante sobre os vinte mil cruzados. ${ }^{95}$

Mas nem a execução desse plano minimizou os desacertos entre as provedorias. Nos quatro anos seguintes, de 1749 a 1753, não havia coincidência nos valores repassados. Se, para a Provedoria da Paraíba, a divida nova encontrava-se na casa dos 23:938\$915, para Pernambuco ela orçava em apenas 15:778\$628 réis, uma diferença de mais de oito contos. ${ }^{96}$ A confusão estava nos valores que deviam servir ou não como rebate da divida nova.

Ilustra isto o caso do recebimento, em 1747, do dinheiro de cobre em moedas de dois réis e de vinténs na Paraíba, provindo de Lisboa, e que serviu para facilitar o comércio e as despesas com o pagamento dos soldados. ${ }^{97} \mathrm{O}$ montante do cobre importado chegava a 1:809\$040 réis e devia ser pago no Conselho Ultramarino em dinheiro e não em açúcar, como comumente se fazia. Contudo, "em razão dos poucos homens de negócios que há nesta terra que quisessem trocar algum dinheiro ou tomá-lo para passar letra segura, "98 Temudo negociou com os conselheiros, alegando que o pagamento fosse feito por Pernambuco, "por conta da grande soma que aquela Provedoria deve a esta". 99 Acontece que este dinheiro só foi repassado para a Paraíba em $1752 .{ }^{100}$ Neste sentido, a

\footnotetext{
${ }^{95}$ Ordem de Sua Majestade de 14 de agosto de 1748. AHU_ACL_CU_014, Cx.17, D 1394.

${ }^{96}$ Nos registros da Alfândega da Paraíba, constavam vindo de Pernambuco: $1749=590 \$ 273$ \# $1750=$ $6: 843 \$ 360 \# 1751=355 \$ 440 \# 1752=3: 368 \$ 857 \# 1753=13: 503 \$ 155 \#$ e, $1754=$ não houve envio; Total : 24:061\$085. Nos registros de Pernambuco: $1749=7: 591 \$ 000 \# 1750=942 \$ 350 \# 1751=$ $4: 536 \$ 727$ \# $1752=3: 019 \$ 080 \# 1753=12: 652 \$ 122$ \# $1754=2: 598 \$ 590$ \# Total : 32:221\$372. Cf: AHU_ACL_CU_014, Cx.17,D 1395; 1396 e 1398. OBS: Nas nossas contas, detectamos um erro a menor nas contas de Pernambuco em $118 \$ 770$.

${ }^{97}$ AHU_ACL_CU_014, Cx.14, D 1216.

${ }^{98}$ AHU_ACL_CU_014, Cx.14, D 1209

${ }^{99}$ Idem.

${ }^{100}$ AHU_ACL_CU_014, Cx.17, D 1393 e 1394
} 
Provedoria de Pernambuco quis computar este valor como pertencente à novas despesas, no que foi expressamente contestada pela Provedoria da Paraíba. ${ }^{101}$

Assim continuaram as discussões acerca do montante da dívida e os apelos da Provedoria da Paraíba para que a Provedoria de Pernambuco cumprisse as ordens reais, quanto ao repasse anual dos vinte mil cruzados da dízima da Alfândega de Pernambuco. Elas não comprovavam outra coisa que não o insucesso da política dessa transferência fiscal criada desde 1723. O desafogo da economia paraibana, no que diz respeito à garantia de pagamentos dos filhos das folhas, não foi atingido.

Quando o último governador independente da Paraíba, Luís Antônio Lemos de Brito, encaminhou o relatório do provedor acerca das receitas e despesas da capitania sobre o ano de 1754, e uma avaliação sobre os meios de tornar útil a capitania, ou seja, livrá-la da dízima de Pernambuco, estava exatamente constando esse malogro. No conjunto de cartas em que foi enviado o relatório, encontrava-se uma representação do governador cobrando uma firme posição da Coroa pelo desrespeito ao precatório que passou, para a Provedoria de Pernambuco, a incumbência de remeter os vinte mil cruzados. Na resposta do provedor da capitania vizinha, mais uma vez era enfatizado que “o precatório ficaria na lembrança para quando houvesse dinheiro. "102 Ao contrário de Fernando Delgado Freire de Castilho, que os viu como "uma simples e pouco fundamentada representação", ${ }^{103}$ esses documentos podem ser considerados como a última possibilidade de manter a capitania ainda autônoma.

\section{LEMOS DE BRITO E O ÔNUS DA ANEXAÇÃO}

Lemos de Brito tomou posse do governo da capitania da Paraíba em novembro de 1753. ${ }^{104}$ Como de praxe, após o envio dos ofícios e cartas relatando as condições da fortificação e a situação dos apetrechos de guerra da capitania, remeteu, em atendimento

\footnotetext{
${ }^{101}$ Idem. Neste mesmo documento há a contestação também do envio de sete contos de réis por parte da Provedoria de Pernambuco que, segundo o governador da Paraíba, fazia parte do montante da frota de 1747, neste caso, como o narrado acima, anterior a 1748.

102 AHU_ACL_CU_014, Cx.18, D 1462.

${ }^{103}$ AHU ACL CU 014, Cx.34, D 2473.

${ }^{104}$ AHU_ACL_CU_014, Cx.17, D 1383.
} 
à ordem de 15 de março de 1721, "a relação dos rendimentos e despesas que teve a fazenda da capitania e mais partes de sua jurisdição”. ${ }^{105}$ Nesta relação, enviada em maio de 1755 , foi acrescentada uma resposta a uma segunda ordem, cuja novidade lhe fora apresentada nos seguintes termos:

E por se reconhecer na vossa pessoa préstimo, capacidade e zelo do meu serviço, se vos ordena que na primeira ocasião que remeteres semelhantes relações, informeis com o vosso parecer, apontando os meios que vos ocorreram para se tirar alguma utilidade dessa capitania, como também se todas as despesas que se fizeram são precisas e úteis ao meu serviço... ${ }^{106}$

Na descrição que fez o governador, em resposta à primeira ordem, foi apresentada uma receita total de 15:115\$255 réis, orçando o montante a despesa em 15:273\$111 réis. O balanço deficitário de $157 \$ 856$ réis era perfeitamente justificável para Lemos de Brito. Afinal, da Provedoria de Pernambuco, só chegara no último ano 4:623\$230 réis, dos oitos contos a que estava obrigada, acumulando a divida nova $26: 390 \$ 050$ réis. ${ }^{107}$

Somados ao valor da dízima de Pernambuco, contou o governador com 2:055\$915 réis, que rendeu a dízima da alfândega no porto da Paraíba. Entretanto, o total de 6:679\$145 réis, soma de ambas as alfândegas, não foi suficiente para fazer frente às despesas de sua consignação, que chegaram a 10:457\$391 réis. Outras despesas que não eram anuais, porém necessárias à manutenção da capitania, também ficavam apenas na lembrança e não entraram sequer no cômputo do déficit. Caso essas despesas tivessem sido integradas, o déficit passaria a muitos contos de réis. ${ }^{108}$

\footnotetext{
${ }^{105}$ AHU_ACL_CU_014, Cx.18, D 1434.

${ }^{106}$ Idem;

${ }^{107}$ Idem.

${ }^{108}$ As despesas com a consignação da dízima foram as seguintes: Ajudante apontador da fortaleza: $36 \$ 000$; Fardamento: 2:188\$576 ; Soldo do general governador: 1:600\$000; Sustento dos índios que trabalhavam
} 
No parecer dado em resposta à segunda ordem de Sua Majestade, Lemos de Brito percebeu que a única forma de se tirar alguma utilidade da capitania dependia do rompimento dos laços entre as duas provedorias. Fazer a capitania da Paraíba respirar, como dizia, passava, necessariamente, pela realização de uma reforma nos modos pelos quais, até então, se praticava no processo de arrematação dos impostos. Era preciso também alargar o estoque de açúcar nos portos da Paraíba, através da ampliação da área de fornecimento do produto com a incorporação da produção de Goiana.

A cidade de Goiana, pertencente à capitania de Itamaracá, fazia parte da comarca da Paraíba. Tal iniciativa seria facilitada não só pela maior proximidade entre as cidades da Paraíba e de Goiana, mas, também, pela correnteza das águas em favor da Paraíba, principalmente no período das frotas. ${ }^{109}$

Como esperava o governador, o impacto dessa medida incidia diretamente sobre o comércio local, valorizando a permanência do pouco dinheiro circulante. Ao invés de um ou dois navios que, ordinariamente, vinham ao porto, poder-se-ia doravante contar com cinco ou seis, quebrando o monopólio dos comerciantes pernambucanos que forneciam fazendas e gêneros comestíveis à cidade da Paraíba. ${ }^{110}$

Mas essa não era a única forma de oxigenar a economia da capitania. Além do transporte do açúcar de Goiana para os portos da Paraíba, Lemos de Brito propunha, também, deslocar todas as arrematações dos impostos que envolviam a Paraíba e que se faziam no Conselho Ultramarino, para serem realizadas na capitania. Segundo o

na fortaleza e na balsa da mesma: $398 \$ 600$; Conserto da Casa da Pólvora: 8 \$200; Condução das pedras para a fortaleza: $36 \$ 000$; Soldo e socorro da Infantaria: 5:840\$012; Ajuste do fardamento: 87\$560; Ajuste de vencimentos com alguns soldados para quem se passou letras: $215 \$ 443$; Ajuda de custo para o sargento-mor ir buscar a dízima em Pernambuco: 25\$000; Ajuda de custo para o capitão engenheiro de Pernambuco acompanhar as obras da fortaleza: $22 \$ 000$ / total: 10:457\$391 réis. No caso dos pagamentos das letras, reclamava o governador que os almoxarifes, talvez propositalmente, lançavam nos pés das listas de uma maneira tal, que era "dificil se guiar por elas". Cf: AHU_ACL_CU_014, Cx.18, D 1434.

109 As frotas "partiam de Portugal em fins de setembro, início de outubro, chegando ao Recife em fins de dezembro. Regressavam em fins de março e começo de abril do ano seguinte... Esse período de viagens não era por acaso: evitava-se temporais de inverno no hemisfério norte e, no Brasil, a safra findava, com o açúcar já pronto para o embarque, antes do período das chuvas, decorrendo a viagem de volta sempre na primavera européia". Cf: Luís Geraldo Silva. A propriedade mercantil e a propriedade colonial: uma abordagem interpretativa da economia colonial do Nordeste (1690-1750). Recife; Cadernos de História / Departamento de História : UFPE, 1987. P. 31.

${ }^{110}$ Dizia Lemos de Brito que "nesta cidade não vêm gêneros bastantes, nem fazenda, são os mercadores pernambucanos que fornecem as lojas dos mercadores da terra e que levam destes em pagamentos tanto dinheiro adquirem, e seguir-se-a em virtude dessa mutilação podermos respirar livres da Provedoria de Pernambuco". Cf:AHU ACL CU 014, Cx.18, D 1434. 
governador, na forma como se praticava, até então, "toda a conveniência era dos homens de negócio de Pernambuco que, em razão do seu comércio, conservam correspondentes no Reino por quem mandavam arrematar no Conselho Ultramarino". 111

Essa proposta, aliás, como demonstrava o governador, já mostrara ser eficaz. Em 1753, por exemplo, a arrematação dos subsídios da carne foi realizada na capitania e observou-se, apenas para aquele ano, um aumento superior a quinhentos mil réis. ${ }^{112}$ Os criadores de gado vacum ou cavalar do sertão paraibano davam mostras expressivas de sua pressão para conquistar um maior espaço na gestão da economia da capitania. Dos valores alcançados no processo de arrematação anual, isto é, com receita certa, os subsídios da carne só perdiam para a arrematação dos dízimos reais. ${ }^{113}$

Então, Lemos de Brito propôs à Sua Majestade, que obrigasse o provedor da Fazenda a por editais nos sertões do Piancó e do Cariri, e em outros lugares onde havia dízimo, determinando o tempo em que se deviam arrematar os Ramos e Ribeiras, para que todos pudessem acorrer à cidade e efetivarem seus lanços. Além disso, como medida para beneficiar quem possuísse dinheiro na capitania, o contrato devia ser executado da mesma forma como ocorria no Rio Grande e no Ceará. Ou seja, que se desse aos contratadores a possibilidade de saldar o compromisso parcelando ao longo dos três anos de contrato, "dando os arrematadores a terça parte no primeiro ano, e as duas no último que é quando já tem percebido os frutos dos dois que restam e lhes fica mais fácil". 114

Lemos de Brito sabia que a proposta de levar as arrematações para a capitania não deveria sofrer muita objeção por parte do Conselho Ultramarino. Isto porque, como os valores arrematados não eram tão expressivos, dificilmente os conselheiros se preocupariam com a lisura do pleito ou com os descaminhos, ou mesmo com as perdas de

\footnotetext{
${ }^{111}$ Idem.

${ }^{112} \mathrm{O}$ contrato dos subsídio das carnes para os anos de 1749 - 1752 (três anos, como comumente se fazia), foi arrematado no Conselho Ultramarino por João Henriques Moniz, por 1:066\$666 cada ano; O único ano de 1753 (intercalando 1752 - 1753), fôra arrematado na Paraíba a Damião de Macedo do Amaral por 1:600\$000. Voltando a ser arrematado no Conselho, em 1753, o contrato vigoraria até 1756 e foi arrematado por João da Costa Monteiro, morador em Pernambuco, no valor de 1:370\$000 o ano. Este arrematador, contudo, repassou o contrato a Antônio Pereira de Castro, talvez morador na Paraíba, por 1:680\$000, levando na transação, $930 \$ 000$ réis. Cf: AHU_ACL_CU_014, Cx.18, Doc. 1434.

113 Valores anuais: dízimo $3: 833 \$ 333$; subsídio do açúcar ${ }^{420} \overline{\$} 000$; subsídio da carne 1:370\$000 AHU ACL CU 014, Cx.19, D 1473

${ }^{114}$ Idem;
} 
propinas que esta transferência possivelmente poderia acarretar. ${ }^{115}$ Contudo, quanto o segundo ponto apresentado pelo governador - descarregar a produção de Goiana pela Paraíba - a coisa mudava inteiramente de rumo e passava a contar com outros protagonistas. Para Lemos de Brito, Pernambuco não tinha porque se queixar, pois, a capitania vizinha tinha o controle de todos os engenhos existentes entre Goiana e Porto Calvo. $^{116}$

Ao chegarem ao Conselho Ultramarino, essas propostas não tardaram a subir para a presença real. Como esperado, enquanto a condução dos lanços para arrematação dos contratos na capitania não sofreu restrição, a apreciação do segundo ponto, não transcorreu tão calmamente. Para o procurador da Fazenda, mais ponderado, fazia-se necessário que fossem ouvidos, por escrito, o governador de Pernambuco e os oficiais da Câmara de Goiana. Deveria ficar claro, na oportunidade, que o que se procurava, era uma saída para a situação por que passava a capitania da Paraíba, e não prejudicar Pernambuco. Para os conselheiros, entretanto, a negação era clara, podendo-se "escusar novas providências" além da arrematação. Todavia, o que gerou surpresa foi o despacho real que determinou que se seguisse o parecer do procurador da Fazenda. ${ }^{117}$

Ao que tudo indica, esse fato gerou uma celeuma entre os conselheiros. Por um lado, estavam em jogo, os interesses de comerciantes pernambucanos, no sentido de não perderem o escoamento da produção de Goiana pelo porto do Recife, o que não excluía a participação de agentes da Coroa nesta transação. Mas o aspecto principal é que os conselheiros se sentiram alijados em seus próprios interesses. No bojo desse processo, estava a singular transferência, para a Paraíba, da arrematação dos contratos que, com o possível ingresso do açúcar goiano, pareciam se avolumar com gordas comissões. Mas

\footnotetext{
${ }^{115}$ Segundo o procurador da Coroa, no seu parecer sobre esta proposta, alegava "que mesmo que se não deva admitir e sendo novo este conceito, prejudissialícimo nos contratos grandes, é algumas vezes nos pequenos e nas circunstâncias presentes convém este novo método, de que não pode nunca resultar dano considerável". Cf: AHU_ACL_CU_014, Cx.18, D 1462.

${ }^{116} \mathrm{Ou}$ seja, "todos os engenhos dos territórios contíguos ao Recife e da cidade de Olinda e, a além destes, os muitos que há nos territórios das capitanias sujeitas de Igarassú, de São Lourenço da Mata, de Ipojuca, de Serinhaém, de Porto Calvo e das Alagoas que é vila populosa e [, claro,] o da vila de Goiana". AHU_ACL_CU_014, Cx.21, D 1434.

${ }^{117}$ A $\bar{H} U \_A \bar{C} L \_\bar{C} U \_014, C x .18, D$ 1462. A resposta do governador de Pernambuco Luís Diogo Lobo da Silva, seguiu a sugestão dos oficiais da Câmara de Goiana, para que não fossem transportados e comercializados o açúcar para a Paraíba, tendo em vista a sujeição dos produtores goianos aos comerciantes pernambucanos. Cf: AHU_ACL_CU_015, Cx. 81, Doc. 6700 (Avulsos, Capitania de Pernambuco).
} 
havia, também, a constatação da perda de importância do próprio Conselho na condução da política ultramarina.

A nível local, além da proteção aos pecuaristas do sertão para que participassem da arrematação da carne, os ataques de Lemos de Brito contra o monopólio dos comerciantes pernambucanos, no controle do comércio da praça da Paraíba, ganharam a adesão da Câmara paraibana e resvalaram internamente nos interesses de comissários paraibanos representantes dos comerciantes da capitania vizinha. Neste sentido é que se deve entender o recrudescimento das ações da Câmara da Paraíba, durante os anos de 1752-53, em reverter uma ordem de Dom João V, confeccionada em 1722, na qual proibia a abertura do porto da Paraíba. ${ }^{118}$ A interpretação dessa ordem é curiosa, pois, contraditoriamente, ela poderia atingir a quem forçadamente parecia auxiliar, isto é, o comércio da Paraíba.

Para as classes produtoras paraibanas - representadas pela Câmara -, a ordem subjugava tanto o comércio como a própria produção. Ao não permitir o livre embarque do açúcar via Recife, ou qualquer outro porto, deixava tudo à mercê dos comissários de comerciantes pernambucanos, os quais ajustavam os preços nos trapiches locais e embarcavam depois os produtos para Pernambuco, onde os vendiam mais caros. Dessa maneira, obrigavam também os lojistas da cidade da Paraíba a se sujeitarem aos preços do mercado de Recife. ${ }^{119}$

Contrários a isso, estavam alguns homens de negócio da cidade da Paraíba, como João Gomes da Costa, Jacinto Ferreira Mendes, Manuel Pinto da Costa e outros comerciantes, que defendiam a dita ordem de 1722. Eles acreditavam que a abertura para o transporte poderia aniquilar qualquer possibilidade de atracagem de navios, fechando literalmente o porto da Paraíba. Como conseqüência, evitaria o ingresso de mercadorias

\footnotetext{
118 A ordem emanada de 1722, em verdade, recrudescia uma outra de 1711 determinando que, emquanto houvesse prenúncio da vinda de navios ao porto da Paraíba, não consentisse o governador a saída dos gêneros para Pernambuco. Sobre a celeuma acerca da abertura ou não do porto paraibano em fins do século XVII e início do XVIII, ver a nota 22 do capítulo II deste trabalho.

119 Diziam os oficiais da Câmara da Paraíba, numa representação ao rei: "É comum o clamor destes moradores pela opressão que se tem com o porto desta terra fechado, não somente por lhes ser proibido aquilo, que a todas as capitanias circulo vizinhas é lícito, mas também porque o meio que procuram para sua utilidade e sustentação lhe serve para mais se impossibilitarem e destruírem pelas despesas e trabalho de plantarem sem poder dar saída aos frutos produzidos ... Além deste prejuizo ainda há para esta mesma causa outro maior e vem a ser que os mercadores de lojas desta cidade comprar para fornecimento de suas lojas..." Cf: AHU_ACL_CU_014, Cx.16, Doc. 1328.
} 
por meio do escambo com os produtos do Reino, eliminando por completo o pequeno comércio local. $^{120}$

$\mathrm{Na}$ verdade, esses mercadores da praça da Paraíba eram, na sua maioria, comissários dos mercadores de Pernambuco - afinal, a não ida de navios já era uma realidade tal e qual a carência de gêneros. Apesar disso, o comércio interno da Paraíba, mesmo que débil, continuou a existir, principalmente através do abastecimento via Recife. Neste sentido, talvez aí se encontrem os interesses subjacentes sentidos por Oliveira, que tateou, no processo de anexação, "o controle da burguesia portuguesa instalada no Recife, havendo possibilidade de articulação da área agrária com a comercial" na Paraíba. ${ }^{121}$

$\mathrm{O}$ correr dos acontecimentos nas relações entre as provedorias, e os entreveros entre as elites local, regional e ultramarina, destarte, levaram os conselheiros a uma situação-limite. Como sobrecarga à aprovação das suas propostas, Lemos de Brito enviou à Sua Majestade, com cópia endereçada ao secretário de Estado da Marinha e Ultramar, Luís Correia de Sá, uma representação contra o general governador de Pernambuco. Nela dizia que as ordens da Coroa se tornavam inócuas, já que, em momento algum, aquele governador haveria de prestigiar o socorro à Paraíba, sem que antes atendesse primeiro as suas próprias necessidades. ${ }^{122}$

Acontece que, em 1753 e 1754, não houve recolhimento da dízima em Pernambuco, porque o rendimento daqueles anos pertenceu apenas ao contratador talvez porque o mesmo tenha satisfeito em 1752, ou nos anos anteriores, todos os valores da arrematação. Contudo, mesmo sem que houvesse dízima nestes dois anos, o rei ordenou que o provedor e o general governador de Pernambuco enviassem, sem falta, os quarenta mil cruzados que correspondiam a duas parcelas dos vinte mil cruzados da dízima para a Paraíba, como parte do pagamento da dívida nova. Sabedor disso, Lemos de Brito passou precatório à provedoria vizinha, obrigando-a a dar cumprimento à ordem.

\footnotetext{
${ }^{120}$ Declaravam estes senhores, lembrando a ordem de 1722, que não tinha "lugar a representação que a Câmara tinha feito porque se lhe concedesse a licença que pretendia seria esse o meio não só de lhe fechar o porto da Paraiba e não haver navio que se quisesse ir por que não havia carga, mas que por este meio seria o povo mais sensivel ao dano de comprar os gêneros que lhes são necessários para seu uso por muito maior valor..."'Cf: AHU_ACL_CU_014, Cx.16, Doc. 1337.

${ }^{121}$ Elza Regis de Oliveira. A Paraiba na crise do século XVIII... Op. cit. p. 93 e 94.

${ }^{122}$ AHU_ACL_CU_014, Cx.18, D 1462 e 1436.
} 
O provedor de Pernambuco respondeu que o envio ficaria na lembrança para quando houvesse dinheiro e que não remanejaria valores de outra consignação para este pagamento - porque havia ordem de Sua Majestade proibindo tal ação. Além disso, propôs que os quarenta mil cruzados para socorro da Paraíba fossem emprestados pela Bahia, pois, para piorar a situação, parte dos valores do arrendamento, já saldados em Pernambuco, haviam sido desviados pelos almoxarifes dessa alfândega, impedindo que a remessa chegasse à Paraíba. ${ }^{123}$

A réplica de Lemos de Brito foi no sentido de atiçar as relações entre o rei e o governo de Pernambuco, avivando o caráter insubordinado do provedor da capitania vizinha. O rosário de reclamações era amplo: havia falta de compaixão para com a Paraíba; o provedor de Pernambuco só respeitava a ordem para não confundir as consignações quando era do seu interesse, pois, se assim não o fosse, o dinheiro da dízima da Paraíba não se esvairia em despesas estranhas; não se podia confiar em uma provedoria que tornava as ordens de Sua Majestade inócuas, pois seus interesses estariam à frente dos verdadeiros interesses dos povos do Reino. ${ }^{124}$ Queria, enfim, que, a partir do próximo contrato, os vinte mil cruzados fossem pagos na Paraíba pelo contratador e não mais pelo tesoureiro da alfândega de Pernambuco. ${ }^{125}$

Os relatórios e cartas do governador Lemos de Brito, balizados pelo provedor da Fazenda paraibana, que nessa época era Manuel Rodrigues Coelho, não deixaram muita margem de ação para os conselheiros. Em 10 de dezembro de 1755, em consulta ao rei, duas posições subiam à presença do monarca. De um lado, o procurador da Coroa não achava que se deveria "gravar mais a provedoria da Bahia com uma divida estranha, [pois ao] sustentar uma [provedoria] com as rendas das outras ..." seria uma forma de “... se descuidarem de procurar cada uma o seu aumento, e de se empobrecerem todas brevissimamente”. Por isso mesmo, em tom conservador, dizia que

\footnotetext{
${ }^{123}$ Diziam os conselheiros, em dezembro de 1755 , que "essa falta procede dos descaminhos que fizeram os almoxarifes da Fazenda de Pernambuco, por omissão do provedor não recenciar as contas ..." Na mesma consulta, propunha ao procurador da Fazenda "que se cobrem algumas dividas do que a dita provedoria de Pernambuco é credora aos almoxarifes que fugiram e se dê a terça parte do que se cobrar à Paraíba".Cf: AHU_ACL_CU_014, Cx.18, Doc.1462

124 Idem.

${ }^{125}$ AHU_ACL_CU_014, Cx.18, Doc. 1434.
} 
... o que lhe ocorria somente era que os contratadores da dízima da alfândega dêem quatro mil cruzados cada ano na Paraíba até se completarem os quarenta mil cruzados que a provedoria de Pernambuco devia nestes dois anos, porque esta modesta quantia podese-lhe tirar com menos vexame e descômodo ... e assim se irá remediando a Paraiba até ser paga, ou esperar a melhoria dos rendimentos de Pernambuco para se lhe satisfazer por este modo... ${ }^{126}$

Por outro lado, os conselheiros não admitiam que se passasse a obrigação do pagamento dos vinte mil cruzados, ou de qualquer quantia, para a provedoria da Paraíba através do contratador, pois "o contratador não cobra o rendimento dela, mas o tesoureiro da mesma". Recomendavam que o rei procurasse encurtar as distâncias administrativas entre as provedorias de Pernambuco e Paraíba, aumentando a responsabilidade da maior sobre a menor, diminuindo os custos dos efeitos das folhas de serviço pagas pela provedoria da Paraíba. Eis, finalmente, a tônica do plano de anexação:

... fique esta capitania sujeita a de Pernambuco, pondo-se na Paraíba um capitão-mor com jurisdição e soldo ao que tem o capitão-mor da cidade de Natal e Rio Grande, que fica muito mais distante do Recife, por serem sessenta léguas..., sendo somente vinte $e$ cinco da cidade da Paraíba..., evitando-se desta forma o excesso que vai ao soldo e despesa que faz um governador, a que faz um capitão-mor subalterno, e ficando por esta forma o governador e capitão general de Pernambuco entendendo igualmente nesta provedoria da Fazenda se há de se interessar

${ }^{126}$ AHU_ACL_CU_014, Cx. 18, Doc. 1462. 


exatamente na economia e providência desta
provedoria...

Cinco meses depois, em maio de 1756, a Câmara paraibana respondeu alegando que tal ordem lhe parecera injusta em dois pontos cruciais. Primeiramente, os paraibanos sempre se comportaram como fiéis vassalos de Sua Majestade, pois, diferentemente dos seus vizinhos, nunca haviam se sublevado, como acontecera no episódio dos Mascates. ${ }^{128}$ Para os camaristas, esse acontecimento inaugurou o rancor da nobreza pernambucana, por ter o governador da Paraíba, João Maia da Gama, se intrometido em favor da mascataria recifense. Em segundo lugar, a economia de quatro mil cruzados, referente à extinção do cargo de governador, era irrelevante frente às despesas da Fazenda paraibana, porque...

as côngruas eclesiásticas do clero, das religiões $e$ missionários sempre hão de ser as mesmas, os soldados são sempre precisos, os ministros como se hão de extinguir, as obras da fortaleza como hão de parar? Os consertos públicos de fontes e cadeias são inevitáveis e tudo isto se há de tirar desta capitania ${ }^{129}$

Essa representação da Câmara repercutiu no Conselho Ultramarino, abrindo uma dissensão entre os conselheiros e os procuradores da Fazenda e da Coroa. Para o procurador da Fazenda, o correto era acompanhar o que diziam os oficiais da Câmara paraibana, pois a economia que representava o corte nas despesas "que fazia um governador" era praticamente nula. O procurador da Coroa, que também concordava

\footnotetext{
${ }^{127}$ Idem. Entre os seis conselheiros que votaram nesta proposta de anexação, dois foram votos contrários.

${ }^{128}$ AHU ACL CU_014, Cx. 13, Doc. 1071. Sobre o episódio da Guerra dos Mascates ver: Charles R. Boxer. A idade de ouro do Brasil: dores de crescimento de uma sociedade colonial. $3^{\text {a }}$ edição. Rio de Janeiro: Nova Fronteira, 2000; e Evaldo Cabral de Mello. A fronda dos mazombos. Nobres contra Mascates, Pernambuco 1666-1715...

${ }^{129}$ AHU_ACL_CU_014, Cx. 19, Doc. 1494 e 1495.
} 
com os oficiais paraibanos, acrescentava que "as supostas circunstâncias em que se achavam os moradores da Paraíba com os de Pernambuco, seria [mais] conveniente conservá-los na separação dos governos". Diante disso, resolveu o Conselho Ultramarino solicitar ao vice-rei do Brasil que informasse com o seu parecer ...

ouvindo por escrito ao governador de Pernambuco e da Paraíba e a Câmara, nobreza e povo da Paraíba, $e$ averiguando que prejuízo se segue a estes moradores em que o capitão-mor que os governar fique sujeito ao governador de Pernambuco, e averiguar também se o rendimento que a Fazenda Real tem nesta capitania a pode sustentar separada, sem a dependência dos rendimentos que tem a Fazenda Real de Pernambuco. ${ }^{130}$

Mesmo que não se tenha conhecimento do andamento dessas averiguações o resultado dificilmente poderia ser outro além do esperado pelo Conselho Ultramarino. A forma como a questão foi levantada - se a capitania poderia se sustentar separada da Fazenda de Pernambuco - não poderia conduzir a outra conclusão senão a constatação da falência da Provedoria da Fazenda Real da Paraíba. O certo é que, no início do ano seguinte, abril de 1757, cumpriu-se a ordem temida pelos paraibanos: na saída de Lemos de Brito, assumiu interinamente a capitania da Paraíba o sargento-mor José Henriques de Carvalho, nomeado pelo capitão-general de Pernambuco, Luís Diogo Lobo da Silva.

Ainda perduraram arestas, como a que se constatou ainda nesse mesmo ano, envolvendo os oficiais da Câmara da Paraíba, o governador de Pernambuco e o sargentomor, em virtude dos oficiais da Câmara quererem novamente abrir o porto da Paraíba. Mas essas querelas foram finalmente estancadas quando da criação da Companhia Geral de Comércio de Pernambuco e Paraíba, em 1759. A anexação da Paraíba tornou-se um

${ }^{130}$ Idem. 
fato e foi fruto do esfacelamento e completa falência da política de socorro implantada em 1723, quando da arrematação das dízimas das alfândegas em um só contrato.

Contudo, ampliando mais o enfoque, devemos considerar que nesse episódio, apesar de admitirem uma boa dose de intencionalidade e de acaso, as ações humanas partiam também de condições históricas determinadas. Essas condições conformavam a Paraíba, enquanto unidade político-administrativa, "como componente de um espaço vinculado, enquanto colônia, ao processo europeu de acumulação primitiva de capital (...) e submetida ao domínio do capital mercantil" internacional que ligava Portugal aos outros países europeus. De modo análogo, enquanto espaço regional, a Paraíba era marcadamente dependente do circuito de contatos com este mesmo capital mercantil, realizado hegemonicamente pelos comerciantes sediados em Recife. ${ }^{131}$ Dessa forma, a Paraíba, tal como todo o conjunto político-administrativo colonial submetido ao capital mercantil, não se autodeterminava e obedecia às demandas políticas vindas da metrópole.

Assim, no contexto da anexação da Paraíba a Pernambuco, transformações políticas de grande monta foram anunciadas em 1750, com a subida ao trono do novo monarca D. José I. A partir daí, através das intervenções do futuro marquês de Pombal, Portugal sofreu mudanças profundas na condução dos vários ramos da gestão do Reino e do Império. Essas mudanças, que chegaram inclusive ao Conselho Ultramarino, também influenciaram a tomada de decisão que levou à anexação.

\section{EPÍLOGO. O OCASO DOS CONSELHEIROS: A ANEXAÇÃO DA PARAÍBA, UM PROJETO POMBALINO?}

O Conselho Ultramarino foi criado por decreto real, em 1642, e detinha um importante papel nos despachos das matérias ligadas às conquistas. Segundo um estudioso desse órgão, "foi praxe (...) conferir sempre o título de Conselheiro

\footnotetext{
${ }^{131}$ Irene Rodrigues Fernandes. Comércio e subordinação: a associação comercial da Paraíba no processo histórico regional - 1889 - 1930." Recife; Dissertação de Mestrado / CFCH / UFPE (Departamento de História), 1985. p.7
} 
Ultramarino aos chanceleres das relações de Goa e Rio de Janeiro". ${ }^{132}$ Neste sentido, pessoas experimentadas nas coisas do ultramar sempre tiveram posição de destaque na condução das políticas ultramarinas, manejando, muitas vezes, seus pareceres de acordo com seus próprios interesses. Para Gilson Reis, "as relações existentes entre os diversos funcionários do Conselho Ultramarino e demais autoridades delegadas, que exerciam suas funções jurídico-administrativas no Brasil Colônia, estiveram vinculadas por concessões contratuais que influenciavam na apreciação dos despachos que subiam à consulta do Conselho Ultramarino". ${ }^{133}$ Todavia, a partir do governo de D. José I, essa face hegemônica dos conselheiros começou a mudar. Os secretários de Estado, que até então figuravam discretamente junto ao soberano, transformaram o Conselho Ultramarino “em mero colaborador subalterno da orientação governativa deles". ${ }^{134}$ Na queda-debraço entre conselheiros e secretários, venceu a cena centralizadora protagonizada por Sebastião José de Carvalho e Melo. E a derrota de Alexandre de Gusmão apareceu como o prenúncio de novos tempos para o Conselho.

Alexandre de Gusmão, natural de Santos, começou seus estudos no colégio jesuíta da Bahia e foi aluno de Direito nas universidades de Sorbonne e Coimbra, nesta última recebendo o título de bacharel. Ingressou no Conselho Ultramarino em 1743 e destacouse no governo de D. João $\mathrm{V}$ como seu secretário particular e diplomata. Teve participações importantes nos campos da política e da administração, principalmente nas negociações luso-espanholas que resultaram no Tratado de Utrech, em 1715, e no Tratado de Limites, assinado em janeiro de 1750, em Madri. Com a subida de D. José I ao trono português, em agosto de 1750, Gusmão viu se esvaírem seus poderes frente ao novo ministro, Sebastião José de Carvalho e Melo. Mesmo estranha aos assuntos da Colônia Americana, a secretaria dos Negócios Estrangeiros e Guerra, subordinada a Carvalho e Melo, teve a incumbência especial do monarca para resolver questões relativas à diminuição da arrecadação do ouro na região das minas do Brasil. A solução adotada, a cobrança dos quintos, era diretamente contrária ao que Gusmão havia anteriormente

\footnotetext{
${ }^{132}$ Marcelo Caetano. O Conselho Ultramarino: esboço da sua história. Lisboa. Agência Geral do Ultramar, 1967.p. 50

${ }^{133}$ Gilson Reis. "O Conselho Ultramarino". In, José Jobson de Andrade Arruda. Dumentos Manuscritos Avulsos da Capitania de São Paulo (catálogo 1 - 1644-1830). Bauru, SP : São Paulo, SP : FAPESP : IMESP, 2000. p. 293

${ }^{134}$ Marcelo Caetano. O Conselho Ultramarino: esboço da sua história... Op. cit. p.52.
} 
aconselhado. Ao tentar dissuadir o rei dessa decisão, Gusmão teve a consulta, na qual era relator, "devolvida secamente, sem resolução do monarca - o que, pela primeira vez, ao que parece, se verificava". ${ }^{135}$

A situação vexatória em que Gusmão foi colocado, se não rendeu todos os frutos esperados por Carvalho e Melo, fez explicitar aos conselheiros ultramarinos quem realmente iria mandar dali por diante. É sintomático perceber que os pareceres do Conselho nunca foram de encontro à tendência centralizadora e administrativamente racionalista conduzida pelo superministro. A adulação, que era restrita ao monarca, se estendeu também ao seu secretariado e, no caso especial de Carvalho e Melo, talvez tenha sido exercida de modo exagerado, pois todos sabiam que contrariá-lo podia trazer conseqüências imprevistas. $^{136}$

O projeto encabeçado por Carvalho e Melo teve como objetivo quebrar uma tradição político-administrativa de longo lastro. No Brasil, as ações mais imediatas de cunho centralizador, como a transferência da capital, da Bahia para o Rio de Janeiro, e a compra de várias capitanias de donatários, incorporando-as ao patrimônio régio, se entremearam com várias outras medidas. Tais medidas tocaram: a) na economia englobando um amplo espectro de atuação, desde o âmbito fiscal (Juntas de Fazenda), passando pelo comércio (Companhias Gerais) e a política pública (Erário Régio, em Lisboa), até a diversificação das culturas agrícolas na Colônia e o incentivo à industrialização no Reino ${ }^{137}$; b) na justiça - com a instalação do Tribunal da Relação do

\footnotetext{
${ }^{135}$ Marcelo Caetano. O Conselho Ultramarino: esboço de sua história... Op. cit, p. 51-52. Ver também: Jaime Cortesão. Alexandre de Gusmão e o Tratado de Madrid (Conferência), Lisboa, 1950 (Biblioteca de ajuda do AHU).

${ }^{136}$ Charles Boxer. O Império Português, textos de cultura portuguesa. Lisboa; Edições 70. 1969. Principalmente a o capítulo "A ditadura pombalina e suas conseqüências". p.203-227; Sobre o período ver também: Francisco C. Falcon. A época pombalina: política econômica e monarquia ilustrada. São Paulo; Ática, 1983; Andrée Mansui-Diniz Silva. "Portugal e o Brasil: a reorganização do império, 1750 - 1808". In: Leslie Bethell. (organizador). História da América Latina. São Paulo: Edusp; Brasília: Fundação Alexandre Gusmão, 1998. Vol. 1 pp 477 - 518; e, Kenneth Maxwell. Marquês de Pombal: paradoxo do Iluminismo. $2^{\mathrm{a}}$. edição. Rio de Janeiro; Paz e Terra, 1996.

${ }^{137}$ A amplitude dessas últimas investidas são assinaladas por Jobson Arruda: “... Pombal fez do estímulo à agricultura o epicentro de sua ação política. Seus efeitos não tardaram, expressando-se na diversificação agrícola do espaço colonial brasileiro, gerando produtos para reexportação do Reino, alimentos para a população metropolitana e matérias primas para a manufatura, enlaçando industria e agricultura, transformando a caminhada rumo a industrialização uma finalidade concreta. A criação das companhias de comércio, cuja finalidade era exatamente unir espaços agrícola e industrial, separados pelo oceano, fechava o circuito da perspectiva econômica que então se delineava para o Império Luso-brasileiro. Neste termo, a politica industrialista portuguesa não foi fruto passageiro de uma crise comercial, como ocorrera
} 
Rio de Janeiro; e, c) na composição dos quadros de pessoal da administração, onde se pretendeu dar maior racionalidade e eficiência. Exemplo disso foi a limitação do acesso aos cargos executivos àqueles que demonstrassem formação intelectual e profissional para o ofício, evitando, assim, o nepotismo e o caráter prebendário e vitalício dos ofícios e serventias.

Com rigor cartesiano, a administração fazendária lusitana seguiu os números coordenados pelo Erário Régio (abruptamente criado, já que o terremoto e o incêndio, em novembro de 1755 , destruíram a Casa dos Contos). Impôs também novos métodos de trabalho, que iam desde a escrituração dos dados de receita e despesa, como o uso dos livros com partidas dobradas, até a preocupação com a formação intelectual do quadro dos oficiais da Fazenda. Descortinava-se, aí, o início de uma política administrativa que tencionava abandonar uma longa tradição empirista e patrimonial. ${ }^{138}$ Neste sentido, o processo de anexação da Paraíba a Pernambuco, com o pretendido repasse do controle e do gerenciamento de sua Fazenda para a capitania vizinha, além de enquadrar-se perfeitamente nos marcos dessa gestão reformadora, pode também explicar a mudança de rumo dos conselheiros, na distensão provocada com o parecer dado pelos procuradores da Fazenda e da Coroa. Dessa forma, coadunava-se a insustentável situação da Provedoria da Fazenda Real da Paraíba, com a tomada de consciência acerca do malogro da política de repasse dos vinte mil cruzados.

Foi somente em 1798-99, quando o capitão-mor Fernando Delgado Freire de Castilho, demonstrou um quadro econômico favorável da capitania - onde a exportação do açúcar, do couro, do algodão e, principalmente, da extração de madeira do litoral, diversificavam e davam os indicadores necessários da vitalidade da economia local - que,

\footnotetext{
no século XVII. Tem um caráter estrutural e enorme potencial transformador, seja na metrópole, seja na colônia. José Jobson de A. Arruda. "O sentido da Colônia. Revisitando a crise do Antigo Sistema Colonial no Brasil." In: José Tengarrinha (org.). História de Portugal.2 ${ }^{\mathrm{a}}$ edição. São Paulo: ENESP; Bauru: EDUSC; Lisboa: Instituto Camões, 2001. p. 254.

${ }^{138}$ Um exemplo interessante que realça bem este corte na gestão administrava, interpondo uma face racionalizadora, encontramos na fundação da Aula de Comércio, em 1759, quando se institui o primeiro estudo de contabilidade, economia e comércio em Lisboa. Daí resultaria a consolidação da utilização de séries contínuas das balanças de comércio e que adquiriram uma uniformidade marcante a partir de 1796. Cf: José Jobson de A. Arruda. O Brasil no comércio colonial. São Paulo: Editora Ática, 1980. p. 61-76.
} 
finalmente, por determinação real, a Capitania da Paraíba tornou-se independente da vizinha Capitania de Pernambuco. ${ }^{139}$

139 Para Jobson Arruda, essa vitalidade econômica, contrasta com a noção de crise do sistema: "defrontamo-nos [,então,] com uma transformação vital. Se a metrópole avança criando fábricas, a colônia diversifica sua produção, seus mercados se integram interna e externamente. Se as rendas geradas pelo setor exportador são menores, tanto no Brasil quanto em Portugal, comparativamente ao auge da produção aurifera, compensam pela sua distribuição mais plural, refletida nos indices de renda 'per capita'. A conjuntura e econômica era de prosperidade. Não se pode falar em depressão, em decadência. E, em tais circunstâncias, engendra-se um enorme potencial transformador". Cf: José Jobson de A. Arruda. "O sentido da Colônia. Revisitando a crise do Antigo Sistema Colonial no Brasil." In: José Tengarrinha (org.). História de Portugal. Op. cit., p. 255. 


\section{CONCLUSÃO}

Neste trabalho, estudou-se a administração colonial num período em que as queixas da população local, a respeito dos cargos da administração serem exclusivos dos nascidos no reino, ainda não haviam sido evidenciadas de forma patente. Como diz Stuart Schwartz, até meados do século XVIII

os brasileiros se queixavam com freqüencia dos abusos mas raramente criticavam a natureza do governo ou o fato de que funcionários juntavam fortunas e se ligavam à sociedade local. Ao invés, os brasileiros tinham a aspiração de conseguir um lugar no funcionalismo real para os seus filhos e de casar suas filhas com um funcionário do rei. Essas oportunidades podem ter sido mais efêmeras que reais, mas enquanto a burocracia permanecesse teoricamente aberta para os nascidos na colonia e enquanto pudesse ser 'abrasileirada', a elite brasileira a aceitava como se fosse sua. O governo na colonia era muitas vezes ineficiente, de vez em quando opressivo e normalmente corrupto; raramente, porém, era visto como um instrumento de dominação estrangeira. ${ }^{1}$

Para os nascidos na Colônia, as oportunidades de trabalho na administração do Império português não necessariamente provinham da efetivação de laços matrimoniais. Relações contratuais envolvendo a Coroa - Conselho Ultramarino - beneficiaram a elite local paraibana. Os restauradores, apoiados na magnificência do rei, por quem haviam

\footnotetext{
${ }^{1}$ Stuart B. Schwartz. Burocracia e sociedade no Brasil colonial. São Paulo; Editora Perspectiva, 1979. p. 295
} 
empenhado seus patrimônios privados e suas vidas na manutenção do domínio português contra os holandeses, tiveram, em contrapartida, o acesso aos cargos da administração colonial. Todos os oficiais que compuseram os cargos da Provedoria da Fazenda Real da Paraíba, após a Guerra da Libertação Divina, ingressaram na Fazenda por esta porta. Desta forma, o caráter patrimonial e corporativo, tomado pelo órgão fazendário paraibano, foi algo duradouro e que influenciou todas as esferas da administração. Essa influência se fez sentir desde a jurisdição até a feição técnica da Fazenda: aferição dos tributos, formas das contas de receitas e despesas e levantamento de questões que envolviam o cálculo financeiro.

Contudo, no afã de restringir o controle patrimonial da Fazenda, a Coroa exerceu uma forte ingerência local sobre outras áreas da administração - como aconteceu na criação da Ouvidoria Geral e na retirada do controle da Fazenda sobre a Provedoria dos Defuntos e Ausentes, ainda no século XVII. Apesar das incursões da Coroa, foi somente no ano de 1733, e motivado pela casualidade, que se demarcou, realmente uma mudança no rumo administrativo do órgão, quando da morte do último proprietário da Provedoria da Fazenda, Salvador Quaresma Dourado. O infortúnio do provedor possibilitou o ingresso trienal de provedores letrados, mais adaptados aos princípios burocráticos, contribuindo para a limitação de uma série de vícios e abusos praticados pelos oficiais ali lotados.

Mas o ano de 1732-1733 foi também profícuo no plano fiscal. Nele se assistiu a transferência, para as mãos da Fazenda Real, do subsídio da carne, principal imposto cobrado pela câmara municipal, que alcançava níveis de desempenho semelhantes ou melhores que o atribuído ao subsídio do açúcar. Voltada para o mercado interno, a pecuária cresceu apoiando-se nos fatores de produção deslocados da economia açucareira. Tal transferência, contudo, coroou o processo de concentração de todos os impostos na Fazenda Real da Paraíba, efetivando mais uma intervenção do fiscalismo régio, antes da decretação da falência econômica da capitania.

Ora, esse processo de checagem dos valores patrimoniais na administração ou de centralização dos impostos na Fazenda Real foi algo generalizado na Colônia, tanto pelos desarranjos econômicos, como por motivos de fundo político-administrativo. Porém, na 
Capitania da Paraíba, tal construção alimentava nos coevos não apenas a tomada de consciência acerca da fragilidade econômica da capitania, que sofria com as quedas do açúcar no mercado internacional e com a elevação do preço da mão-de-obra escrava; sobretudo, deixava nos paraibanos a sensação de estarem sendo espoliados pela capitania de Pernambuco.

Os embates fiscais entre as duas capitanias autônoma e territorialmente contíguas, no âmbito das Capitanias do Norte, deixava claro para os paraibanos - na medida em que as fontes de receita ficavam exíguas e a apertura fiscal cada vez mais patente - que as decisões da Coroa não teriam outro caminho que a anexação.

A Coroa empreendeu fracassadas tentativas de oxigenar as receitas paraibanas e, por conseguinte, a sua economia. Exemplo disso foram a arrematação da dízima em um só contrato, envolvendo as provedorias de Pernambuco e Paraíba, a partir de 1723, e o repasse para a Paraíba de dez mil cruzados, retirados dos quarenta mil do donativo pagos por Pernambuco à Coroa. Essas tentativas vieram como respostas paliativas aos planos de alguns governadores paraibanos, que tencionavam encontrar uma saída fiscal definitiva para a capitania. Porém, tais propostas dos governadores contrariavam diversos interesses da elite pernambucana e até de setores da elite paraibana, as respostas da Coroa, ao invés de promoverem a solução dos problemas, garantindo os ajustes da Fazenda com os pagamentos de dívidas atrasadas, jogaram a Paraíba, cada vez mais, na dependência da provedoria pernambucana.

Finalmente, com a subida ao trono português de D. José I, em 1750, abriram-se espaços para a aplicação das medidas preconizadas pelo seu primeiro ministro, Sebastião José de Carvalho e Melo: conter gastos, concentrar recursos e dotar a máquina administrativa com uma face mais racional-burocrática. Neste sentido, quando a resolução real de 29 de dezembro de 1755 reconheceu a falência da Provedoria da Fazenda Real da Paraíba e sua falta de condição para sustentar um governo autônomo, anexando-o ao de Pernambuco, dois destinos se encontraram: a penúria econômica da capitania e a nova condição político-administrativa do Império português. O significado histórico da anexação foi, pois, o prenúncio de uma nova aplicação da política racionalizadora, com a modernização do colonialismo em novas bases. A criação da 
Companhia Geral de Comércio Pernambuco e Paraíba, foi, enfim, o seu efeito mais imediato. 


\section{BIBLIOGRAFIA E FONTES}

ACIOLI, Vera Lúcia Costa. A escrita no Brasil Colônia. Recife: Editora Massangana; Editora Universitária / UFPB, 1994.

Jurisdição e conflito: a força política do senhor de engenho.

Recife: UFPE / Departamento de História, 1989.

AGUIAR, Welllington; e OCTÁVIO, José. Uma cidade de quatro séculos: evolução e roteiro. $2^{\mathrm{a}}$ edição. - João Pessoa: FUNCEP, 1989.

ALBUQUERQUE, Cleonir Xavier de. A remuneração de serviços na guerra holandesa. Recife: Impressa Universitária / UFPE, 1968.

ALDEN, Dauril. Royal goververnment in colonial Brazil: with special reference to the administration of the Marquis of Lavradio, Viceroy, 1769 - 1779. Berkeley / Los Angeles: University of California Press, 1968.

ALENCASTRO, Luiz Felipe de. O trato dos viventes: formação do Brasil no Atlântico Sul. São Paulo: Companhia das Letras, 2000.

ALMEIDA, Horácio de. História da Paraíba. João Paulo: Editora Universitária / UFPB, 1976. 2 Vol.

AMED, Fernando José. \& NEGREIRO, José Labriola de Campos. História dos tributos no Brasil. São Paulo: Edições SINAFRESP, 2000.

APOSTOLIDÈS, Jean-Marie. O rei-máquina: espetáculo e política no tempo de Luís XIV. Rio de Janeiro: José Olímpio; Brasília, DF: Edunb, 1993.

ARRUDA, José Jobson de A. O Brasil no comércio colonial. São Paulo: Editora Ática, 1980.

Dumentos Manuscritos Avulsos da Capitania de São

Paulo (catálogo 1 - 1644-1830). Bauru, SP : São Paulo, SP : FAPESP : IMESP, 2000.

"O sentido da Colônia. Revisitando a crise do Antigo

Sistema Colonial no Brasil.” In: José Tengarrinha (org.). História de Portugal.2a edição.

São Paulo: ENESP; Bauru: EDUSC; Lisboa: Instituto Camões, 2001. 
BELLOTTO, Heloísa Liberali. A administração fazendária no Brasil colonial: a Junta da Fazenda da Capitania de São Paulo (1762 - 1808). Anais da III reunião da SBPC, São Paulo, 1984.

Arquivos permanentes: tratamento documental. São Paulo: T. A.

Queiroz, 1991.

. O Estado português no Brasil: Sistema administrativo e fiscal. In:

Maria Beatriz Nizza da Silva. O império luso-brasileiro (1750-1822). Lisboa: Estampa., 1986.

BICALHO, Maria Fernanda Baptista. A cidade e o Império. O Rio de Janeiro no século XVIII. Rio de Janeiro: Civilização Brasileira, 2003.

; FRAGOSO, João. \& GOUVEIA, Maria de Fátima. Uma

leitura do Brasil colonial: bases da materialidade e da governabilidade no Império. In: Penélope. Fazer e Desfazer a História, $\mathrm{n}^{\mathrm{o}}$ 23. Oeiras, Celta Editora. Novembro, 2000: 67-88.

BOXER, Charles R. A idade de ouro do Brasil: dores de crescimento de uma sociedade colonial. $3^{\mathrm{a}}$ edição - Rio de Janeiro: Nova Fronteira, 2000.

A Igreja e a expansão ibérica. Lisboa, Edições 70.s/d.

O Império Colonial Português: textos de cultura portuguesa.

Lisboa: Edições 70, 1969.

BUENO, Antônio Henrique da Cunha \& BARATA, Carlos Eduardo de Almeida. Dicionário das Famílias Brasileiras. São Paulo: Litografia Tucano, s.d.

CAETANO. Marcelo, O Conselho Ultramarino: esboço da sua história. Lisboa. Agência Geral do Ultramar, 1967.

CALDEIRA, Jorge. A nação mercantilista: ensaio sobre o Brasil. São Paulo: Editora 34, 1999.

CARDIM, Pedro. Cortes e cultura politica no Portugal do Antigo Regime. Lisboa: Edição Cosmos, 1998.

"A Casa Real e os órgãos centrais de governo no Portugal da segunda metade de Seiscentos.” In: Revista Tempo. Dossiê: política e administração no mundo 
luso-brasileiro. Rio de Janeiro, Departamento de História da UFF. Vol.7; n ${ }^{0} 13$; pp 13 57. Julho, 2002.

CORTESÃO. Jaime, Alexandre de Gusmão e o Tratado de Madrid (Conferência), Lisboa, 1950 (Biblioteca de ajuda do AHU).

DEL PRIORE Mary (org.). Revisão do Paraíso. Os brasileiros e o Estado em 500 anos de História. Rio de Janeiro; Editora Campus, 2000.

DINIZ-SILVA, Andrée Mansui. "Portugal e o Brasil: a reorganização do império, 1750 1808”. In: BETHELL, Leslie (organizador). História da América Latina. São Paulo: Edusp; Brasília: Fundação Alexandre Gusmão, 1998. Vol. 1 pp 477 - 518.

ELIAS, Norbert. A sociedade de Corte. Rio de Janeiro; Jorge Zahar Editor, 2001.

FALCON. Francisco C., A época pombalina: política econômica e monarquia ilustrada. São Paulo.; Ática, 1983.

FAORO, Raymundo. Os donos do poder: formação do patronato político brasileiro. $8^{\mathrm{a}}$ edição. Rio de Janeiro: Editora Globo, 1989. Vol. 1.

FERNANDES, Irene Rodrigues \& AMORIM, Laura Helena Baracuí. Atividades produtivas na Paraíba. João Pessoa: Editora Universitária,/UFPB, 1999.

FRAGOSO, João; BICALHO, Maria Fernanda Baptista; e GOVEIA, Maria de Fátima (organizadores). O Antigo Regime nos trópicos (séculos: XVI-XVIII). Rio de Janeiro: Civilização Brasileira, 2001.

e FLORENTINO, Manolo. O arcaísmo como projeto: mercado atlântico, sociedade agrária e elite mercantil no Rio de Janeiro, c. 1790 - c. 1849. Rio de Janeiro: Diadirim, 1993.

e FLORENTINO, Manolo. "Estrutura e dinâmica da praça mercantil do Rio de Janeiro". In: FURTADO, Júnia Ferreira. Diálogo Oceânicos: Minas Gerais e as novas abordagens para uma história do Império Ultramarino Português. Belo Horizonte: Editora da UFMG, 2001. pp. 155 - 179.

FERNANDES, Irene Rodrigues \& AMORIM, Laura Helena Baracuhy. Atividades produtivas na Paraíba. João Pessoa: Editora Universitária, 1999. 
- Comércio e subordinação: a associação comercial da Paraíba no processo histórico regional - 1889 - 1930." Recife; Dissertação de Mestrado / CFCH / UFPE (Departamento de História), 1985.

FIGUEIREDO, Luciano Raposo de Almeida. “Além dos súditos: notas sobre revoltas e identidade colonial na América Portuguesa. In: Revista Tempo / Universidade Federal Fluminense, Departamento de História - V. 5; n 10, Dez. 2000 - Rio de Janeiro: Letras, 2000.

FURTADO, Ferreira Júnia. Homens de negócios: a interiorização da metrópole e do comércio nas minas setecentistas. São Paulo: Hucitec, 1999.

GARCIA, Rodolfo. História administrativa e política do Brasil. Rio de Janeiro: José Olímpio, 1956.

GOMES, Paulo César da Costa. "O conceito de região e sua discussão”. In: Iná Elias da Costa, Paulo César da Costa Gomes \& Roberto Lobato Corrêa. Geografia: conceitos e temas. Rio de Janeiro; Bertrand Brasil, 1995 p. 49-75

GERALDO, Luiz. A propriedade mercantil e a propriedade colonial: uma abordagem interpretativa da economia colonial do Nordeste (1690 - 1750). Recife: Departamento de História / UFPE, 1987.

GODINHO, Vitorino Magalhães. "Finanças públicas e estrutura de Estado". In: SERRÃO, Joel. (Dir.) Dicionário de História de Portugal. Porto: Livraria Figueirinhas, 1971. pp. 244 - 264. Vol. 2.

GONÇALVES, Regina Célia. Guerra e Açúcares. Política e Economia na Capitania da Paraíba 1585-1630. São Paulo, Tese de Doutoramento/FFLCH/USP (Departamento de História).

HESPANHA. Antônio Manuel, “A Fazenda.” In: José Mattoso (dir.). História de Portugal. V. IV. Antonio Manuel Hespanha (org.) O antigo Regime (1620 - 1807). Lisboa, Editorial Estampa, 1998. p. 181 - 213. . As vésperas do Leviathan: instituições e poder politico / Portugal - séc. XVII. Coimbra: Livraria Almedina, 1994. 
"Para uma teoria da história institucional do Antigo Regime". In:

HESPANHA, Antônio Manuel. Poder e instituições na Europa do Antigo Regime: coletânea de textos. Lisboa: Fundação Caloute Gulbenkian, 1986. pp 9 - 122.

“As estruturas políticas em Portugal na Época Moderna”. In: José Tengarrinha (org.). História de Portugal. Bauru, EDUSC; São Paulo: UNESP; Lisboa, Instituto Camões, 2001. p. 117 - 182.

"A constituição do Império português. Revisão de alguns enviesamentos". In: João Fragoso, Maria Fernanda Bicalho \& Maria de Fátima Govêa. $O$ Antigo Regime nos Trópicos: a dinâmica imperial portuguesa, séculos XVI - XVIII. Rio de Janeiro: Civilização Brasileira, 2001. p. 163 - 187.

HOLANDA, Sérgio Buarque. (organizador) História geral da civilização brasileira. $7^{\mathrm{a}}$ Edição. São Paulo: Bertrand Brasil, 1993. Tomo I : 2 volumes. Raizes do Brasil. 26 edição. São Paulo: Cia das Letras, 1995.

JORDÃO FILHO, Ângelo. Povoamento, hegemonia e declínio de Goiana. Recife: edição do autor, 1978.

JUNIOR, José Ribeiro. Colonização e monopólio no Nordeste brasileiro: a Companhia de Comércio de Pernambuco e Paraíba (1759 - 1780). São Paulo: Hucitec, 1976.

KOSTER. Henry, Viagens ao Nordeste do Brasil. Recife: Editora Masangana, 2002. 2 Volumes.

LACOMBE, Américo Jacobina. "A igreja no Brasil Colonial.” In: Sérgio Buarque de Holanda (dir.) História Geral da civilização brasileira. A época colonial. 2 Administração, economia e sociedade. $7^{a}$ Edição; São Paulo: Bertrand Brasil, 1993.

LAPA, José Roberto do Amaral. A Bahia e a Carreira da Índia. São Paulo: Hucitec / Capinas: Unicamp, 2000.

LINS, Guilherme Gomes da Silveira D’Avila. Páginas de história da Paraíba: revisão crítica sobre a localização dos dois primeiros engenhos de açúcar da Paraíba. João Pessoa: Empório dos Livros, 1999.

LOBO, Eulalia Maria Lahmeyer. A administração colonial luso-espanhola nas Américas. Rio de Janeiro: Companhia Brasileira de Artes Gráficas, 1952. 
MACHADO, Lourival Gomes. "Política e administração sob os últimos vice-reis." In: Sérgio Buarque de Holanda. História Geral da Civilização Brasileira. $7^{\mathrm{a}}$. ed. São Paulo: Bertrand Brasil. 1993. Tomo I; Vol II

MACHADO, Maximiliano Lopes. História da Província da Paraíba. João Pessoa: Editora Universitária / UFPB, 19772 Vol.

MARTINHEIRA, José Sintra. Catálogo dos Códices do Fundo do Conselho Ultramarino existentes no Arquivo Histórico Ultramarino. Rio de Janeiro: Real Gabinete Português de Leitura / Fundação Calouste Gulbenkian, 2000.

MATTOSO, José. (dir) História de Portugal. Volume IV. HESPANHA, Antonio Manuel. o Antigo Regime 1620 - 1807. Lisboa: Editorial Estampa, 1998.

MAURO, Frédéric. Portugal o Brasil e o Atlântico( 1570 - 1670). Lisboa: Imprensa Universitária / Editorial Estampa, 1979.

MAXWELL. Kenneth, Marquês de Pombal: paradoxo do Iluminismo. $2^{\mathrm{a}}$. edição. Rio de Janeiro; Paz e Terra, 1996

MEDEIROS, Maria do Céu. Igreja e dominação no Brasil escravista: o caso dos oratorianos de Pernambuco (1659 - 1830). João Pessoa: Editora Idéia, 1993.

\& SÁ, Ariane de Menezes. O trabalho na Paraíba: das origens à transição para o trabalho livre. João Pessoa: Editora Universitária,1999.

MEDEIROS. Ricardo Pinto de, O descobrimento dos outros: povos indígenas no sertão nordestino no período colonial. Recife, Tese de Doutoramento/CFCH/UFPE (Departamento de História). 2000.

MELLO, Evaldo Cabral. A fronda dos mazombos: nobres contra mascates - Pernambuco, 1666 - 1715. São Paulo: Companhia das Letras, 1995.

Olinda restaurada: guerra e açúcar no Nordeste, 1630-1654. Rio de Janeiro: Topbooks, 1998.

MENEZES, Mozart Vergetti de; OLIVEIRA, Elza Regis de; e LIMA, Vitória Barbosa (organizadores). Catálogo dos documentos manuscritos referentes à capitania da Paraíba, existentes no Arquivo Histórico Ultramarino de Lisboa. João Pessoa: Editora Universitária, 2002. 
NOVAIS, Fernando A. História da vida privada no Brasil: cotidiano e vida privada na América portuguesa. Organização do volume SOUZA, Laura de Mello e. São Paulo: Companhia das Letras, 1997.

. Portugal e Brasil na crise do Antigo Sistema Colonial (1777-1808). 7 ed.

São Paulo; HUCITEC, 2001.

OLIVEIRA, Elza Regis de. A Paraíba na crise do século XVIII. Subordinação e autonomia (1755-1799). Fortaleza: BNB, 1985.

OSÓRIO, Helem."As elites econômicas e a arrematação dos contratos reais: o exemplo do Rio Grande do Sul (século XVIII).” In: FRAGOSO, João.; BICALHO, Maria Fernanda Baptista e GOVÊA, Maria de Fátima (orgs.). O antigo regime nos trópicos: a dinâmica imperial portuguesa ( séculos XVI - XVII). Rio de Janeiro: Civilização Brasileira, 2001. p. 107-137.

PEREGALLI, Enrique. Recrutamento militar no Brasil Colonial. Campinas: Editora da Únicamp, 1986.

PERIDES, Paulo Pedro. "Organização político-administrativa e o processo de regionalização do território colonial brasileiro." In: Revista do Departamento de Geografia. São Paulo: USP, 1995. № 9, p. 77 - 91.

PRADO JUNIOR, Caio. Formação do Brasil Contemporâneo. 21 ed. São Paulo:

Brasiliense, 1989.

PUNTONI, Pedro. A guerra dos bárbaros. Povos indígenas e a colonização do sertão do Brasil, 1620-1720. São Paulo: Hucitec: Edusp: Fapesp, 2002.

O Estado do Brasil: poderes médios e administração na periferia do Império

Português (1549-1720). São Paulo, USP / CEBRAP, 2002. Texto recolhido na Internet.

Endereço: http://www.yale.edu/las/imperial_revisions/Puntoni.doc

RAU, Virgínia. A casa dos Contos. Coimbra: Faculdade de Letras da Universidade de Coimbra / Instituto de Estudos Históricos Dr. Antônio de Vasconcelos, 1951.

REIS. Gilson, “O Conselho Ultramarino”. In, José Jobson de Andrade Arruda. Dumentos Manuscritos Avulsos da Capitania de São Paulo (catálogo 1 - 1644-1830). Bauru, SP : São Paulo, SP : FAPESP : IMESP, 2000. 
RIBEIRO JÚNIOR, José. Colonização e monopólio no Nordeste Brasileiro: a Companhia Geral de Comércio de Pernambuco e Paraíba (1759-1780). São Paulo; HUCITEC, 1976.

ROSSELL-WOOD, A. J. R. "Centro e periferia no mundo luso-brasileiro, 1500 - 1808". In: Revista Brasileira de História. São Paulo: ANPHU / FAPESP / Humanitas Publicações FFLCH / USP; V. 8, No 36, p. 187 - 249. 1998.

SALGADO, Graça. (organizadora) Fiscais e meirinhos: a administração no Brasil Colonial. Rio de Janeiro: Nova Fronteira, 1985.

SCHIERA, Pierangelo. “Sociedade de 'estados', de 'ordens' ou 'corporativa' ”. In: Poder e instituições na Europa do Antigo Regime: coletânea de textos. Lisboa: Fundação Caloute Gulbenkian, 1986. pp 144 - 153.

SCHWARTZ, Stuart B. Burocracia e sociedade no Brasil colonial. São Paulo: Editora Perspectiva, 1979.

Segredos Internos: engenhos e escravos na sociedade colonial.

São Paulo: Companhia das Letras, 1988.

"O Brasil colonial: as grandes lavouras e as periferias". In:

BETHELL, Leslie (organizador). História da América Latina. São Paulo: Edusp; Brasília: Fundação Alexandre Gusmão, 1998. Vol. 2 pp 339 - 421.

SERRÃO, Joel. Dicionário de História de Portugal. Porto: Livraria Figueirinhas, 1971. 4 Volumes.

SILVA, Kalina Vanderlei. O miserável soldo \& a boa ordem da sociedade colonial Pernambuco séculos XVII e XVIII. Recife: Fundação de Cultura da Cidade do Recife, 2001.

SILVA, Maria Beatriz Nizza da. O império luso-brasileiro (1750-1822). Lisboa: Estampa., 1986.

SILVEIRA, Marco Antônio. O universo do indistinto: Estado e sociedade nas minas setecentistas (1735 - 1808). São Paulo: Hucitec, 1997.

SILVEIRA. Rosa Maria Godoy, \& outros. Estrutura de Poder na Paraíba. João Pessoa: Editora Universitária / UFPB/JP, 1979. 
. Rosa Maria Godoy. O regionalismo nordestino. São Paulo: Moderna, 1984.

SIQUEIRA, Antônio Jorge. Ilustração e descolonização: o clero na revolução pernambucana de 1817. São Paulo, Tese de Doutoramento FFLCH / USP, 1980 (Departamento de História).

SOUZA, Laura de Mello e. Desclassificados do ouro: a pobreza mineira no século XVIII. $3^{\text {a }}$ edição. São Paulo: Graal, 1986.

SUBTIL, José. “Os poderes do Centro”. In: José Mattoso (dir.) História de Portugal. V. IV. Antonio Manuel Hespanha (org.) O antigo Regime 1621-1807. Lisboa: Editorial Estampa, 1998.

SZMRECSÁNYI, Tamás. (organizador) História Econômica do período colonial. São Paulo: ABPHE / FAPESP / Editora Hucitec, 1996.

TENGARRINHA, José. (organizador) História de Portugal. $2^{\text {a }}$ edição. Bauru: Edusc / São Paulo: Unesp, 2001.

WEBER, Max. Economia e sociedade: fundamentos da sociologia compreensiva. Brasília. Editora Universidade de Brasília, 1999.

WEHLING, Arno. História administrativa do Brasil: administração portuguesa no Brasil de Pombal a D. João (1777 - 1808). Brasília - DF: FUNCEP, 1986.

\& WEHLING. Maria José, "O funcionário colonial entre a sociedade e o rei”. In: Revisão do Paraíso. DEL PRIORE Mary (org.). Revisão do Paraíso. Os brasileiros e o Estado em 500 anos de História. Rio de Janeiro; Editora Campus, 2000. p. 140-159.

XAVIER, Ângela Barreto e HESPANHA, Antônio Manuel. "As redes clientelares". In: José Mattoso (dir.). História de Portugal. V. IV. Antônio Manuel Hespanha. (org.). O Antigo Regime 1621 - 1807. Lisboa: Editorial Estampa, 1998.

\section{FONTES PRIMÁRIAS}

Impressas 
BRANDÃO, Ambrósio Fernandes. Diálogos das grandezas do Brasil. Recife: Impressa Universitária, 1962.

Documentos Históricos. Consultas do Conselho Ultramarino. Bahia 1724. Rio de Janeiro; Biblioteca Nacional, 1950. Códice: I-8,4,7. vol 89-90

FONSECA, Antônio José Vitorino Borges de. Nobiliarquia pernambucana. Rio de Janeiro: Biblioteca Nacional, 1935. 2 volumes.

História da conquista da Paraíba por um da Companhia de Jesus nos fins do século XVI a mando do padre Chistovam Goveia, visitador da Companhia de Jesus, na Província do Brasil. Campina Grande: FURNE / UFPB, 1983

MENDONÇA, Marcos Carneiro de. Raízes da formação administrativa do Brasil. Rio de Janeiro: IHGB, 1972. 2 volumes [coleções de regimentos]

PINTO, Irineu Ferreira. Datas e notas para a história da Paraíba. João Pessoa: Editora da Universitária / UFPB, 1977 [coleção de documentos paraibanos]

\section{Manuscritas}

Instituto Histórico e Geográfico Paraibano

Códice / Ordens Régias 1709 - 1719

Códice / Ordens Régias 1719 - 1732

Códice / Ordens Régias 1732 - 1744

Códice / Ordens Régias 1745 - 1755

Códice / 1816 - Ouvidoria

Documentos do Arquivo Histórico Ultramarino

Códice 82 / Consulta do Conselho Ultramarino de 10.12.1653. A.H.U., fls 282 e 283. Códice 1805 / Relação Geral dos Contratos que se administram pela Fazenda Real da Paraíba - 1731-1733. 


\section{Documentos Avulsos}

\section{Capitania de Pernambuco}

1663, março, 29, vila de Nossa Senhora da Conceição

CARTA dos oficiais da Câmara da vila de Nossa Senhora da Conceição, da capitania de Itamaracá, ao rei [D. Afonso VI], informando que o governador da capitania de Pernambuco, Francisco de Brito Freire, diz ter direito em administrar a dita capitania e, pedindo que não se retire os foros de jurisdição pertencentes a esta capitania.

Anexos: 3 docs.

AHU_ACL_CU_015, Cx. 7, D. 704.

1725, agosto, 3, Recife

CARTA do provedor da Fazenda Real da capitania de Pernambuco, João do Rego Barros, ao rei [D. João V], remetendo a relação dos rendimentos do contrato dos dízimos reais da capitania de Itamaracá.

Anexos: 3 docs.

AHU ACL CU 015, Cx. 32, D. 2882.

[ant. 1727, março, 25]

REQUERIMENTO do contratador dos dízimos reais da capitania de Pernambuco, Manoel Rodrigues Costa, por seu procurador Severino de Carvalho, ao rei [D. João V], pedindo que envie provisão ao provedor da Fazenda Real da dita capitania, [João do Rego Barros], esclarecendo que só as terras e engenhos pertencentes às ordens religiosas, desde as suas devidas fundações, é que ficam isentas de pagamentos de tributos.

AHU_ACL_CU_015, Cx. 35, D. 3210.

1729, julho, 24, Recife

CARTA do provedor da Fazenda Real da capitania de Pernambuco, João do Rego Barros, ao rei [D. João V], remetendo a relação da receita das rendas reais, dos contratos que administra a Provedoria e despesas com o produto deles.

Anexo: 1 doc.

AHU_ACL_CU_015, Cx. 39, D. 3510.

1730, setembro, 7, Recife

CARTA do [governador da capitania de Pernambuco], Duarte Sodré Pereira Tibão, ao rei [D. João V], sobre os vinte mil cruzados que remete anualmente dos dízimos da Alfândega da capitania de Pernambuco para despesa com a guarnição e obras da fortaleza de Cabedelo, na Paraíba, e que julga poderiam ter outra aplicação mais útil.

Anexos: 14 docs.

Obs.: Informações sobre os rendimentos e presídios das capitanias de Pernambuco, Alagoas, Ceará, Rio Grande e Itamaracá.

AHU_ACL_CU_015, Cx. 41, D. 3670.

1732, maio, 24, Recife

CARTA do provedor da Fazenda Real da capitania de Pernambuco, João do Rego Barros, ao rei [D. João V], remetendo as relações das receitas dos contratos e rendas reais e das despesas da provedoria da dita capitania.

Anexo: 1 doc.

AHU_ACL_CU_015, Cx. 43, D. 3874.

1756, maio, 2, Recife

CARTA do [governador da capitania de Pernambuco], Luís Diogo Lobo da Silva, ao rei [D. José I], sobre a carta do governador da capitania da Paraíba pedindo para que o açúcar produzido nos engenhos do distrito de Goiana sejam transportados e comercializados naquele porto.

Anexos: 2 docs.

AHU ACL CU 015, Cx. 81, D. 6700.

\section{Capitania do Ceará}

1661, maio, 16, Lisboa

CARTA do capitão-mor do Ceará, Diogo Coelho de Albuquerque, ao rei [D. Afonso VI] queixado-se do governador de Pernambuco, Francisco de Brito Freire, que, ao enviar seu ajudante para o socorro do Ceará, acabou por lhe tirar toda a jurisdição sobre esta capitania.

AHU_ACL_CU_006, Cx.1, Doc. 18

[ant., 1716, fevereiro, 17]

REQUERIMENTO do superior do Hospício do Ceará, padre João Guedes, ao rei [D. João V] pedindo que seus ordenados anuais sejam pagos pela Fazenda Real de Pernambuco.

AHU ACL CU 006, Cx. 2, Doc. 88 
1726, agosto, 5, Pernambuco.

CARTA do governador de Pernambuco, Manuel Rolim de Moura, ao rei [D. João] em resposta a provisão de se pagar a Cosme Gomes Pereira a ajuda de custo de cirurgião da fortaleza do Ceará com soldo de soldado.

AHU_ACL_CU_006, Cx. 2, Doc. 89

\section{Capitania do Rio Grande}

1732, Março, 4, Natal

CARTA do [provedor da Fazenda Real do Rio Grande do Norte], Domingos da Silveira, ao rei [D. João V] sobre a arrematação dos dízimos da Capitania do Rio Grande do Norte.

Anexo: provisões (3, cópias); edital do provedor da Fazenda Real do Rio Grande do Norte, Domingos da Silveira (cópia) e certidão do rendimento dos dízimos reais da capitania desde 1661 até 1732.

AHU ACL_CU 018, Cx. 2, D. 156

\section{Capitania Paraíba}

1655, abril, 21, Lisboa

CONSULTA do Conselho Ultramarino, ao rei D. João IV, sobre o requerimento do mestre-de-campo, João Fernandes Vieira, solicitando levar a sua companhia de Infantaria à Paraíba e que seus soldos vencidos e os que forem vencendo, sejam pagos em Pernambuco, enquanto não houver rendimentos da Fazenda Real na capitania.

AHU ACL_CU 014, Cx. 1, D. 38

1657, junho, 20, Lisboa

CONSULTA do Conselho Ultramarino, ao rei D. Afonso VI, sobre o requerimento dos oficiais da Câmara e povo da Paraíba, solicitando decreto para liberdade de se enviar gêneros para a capitania, à semelhança do que se fez para o Rio Grande, Pará, Maranhão e praças vizinhas, devido à Junta do Comércio não o fazer.

AHU_ACL_CU_014, Cx. 1, D. 39.

1657, julho, 12, Lisboa

CONSULTA do Conselho Ultramarino, ao rei D. Afonso VI, sobre a carta dos oficiais da Câmara e povo da Paraíba em que solicitam ajuda de Pernambuco para o sustento dos soldados existentes na capitania, por se encontrarem impossibilitados com suas fazendas e engenhos, danificados em decorrência da luta contra os holandeses.

AHU_ACL_CU_014, Cx. 1, D. 40.

1661, novembro, 12, Lisboa

CONSULTA (cópia) do Conselho Ultramarino, à rainha regente D. Luísa de Gusmão, sobre as diferenças entre o capitão-mor da Paraíba, Matias de Albuquerque Maranhão, e o governador de Pernambuco, Francisco de Brito Freire, no tocante à jurisdição de suas capitanias, e o que sobre isto escreveram o governador e capitão-general do Brasil, Francisco Barreto, e os oficiais da Câmara da Paraíba.

Anexo: 2 docs.

AHU_ACL_CU_014, Cx. 1, D. 47.

1662, junho, 12, Paraíba

CARTA do capitão-mor da Paraíba, Matias de Albuquerque Maranhão, ao rei D. Afonso VI, sobre a contribuição que coube à capitania para o dote da rainha da Grã-Bretanha e paz de Holanda.

AHU ACL CU 014, Cx. 1, D. 50

1663, outubro, 26, Lisboa

CONSULTA do Conselho Ultramarino, ao rei D. Afonso VI, sobre a carta dos oficiais da Câmara da Paraíba, informando que João Fernandes Vieira não quer pagar as contribuições que lhe tocam para sustento da Infantaria.

Anexo: 1 doc.

AHU_ACL_CU_014, Cx. 1, D. 57.

1664, novembro, 24, Lisboa

CONSULTA do Conselho Ultramarino, ao rei D. Afonso VI, sobre a carta do vice-rei do Brasil, conde de Óbidos, [D. Vasco de Mascarenhas], informando da impossibilidade da Fazenda Real ajudar no restabelecimento das fortificações da Paraíba.

AHU ACL CU 014, Cx. 1, D. 59.

1666, março, 27, Lisboa

CONSULTA do Conselho Ultramarino, ao rei D. Afonso VI, sobre a nomeação de pessoas para o cargo de capitão-mor da Paraíba.

Anexo: 3 docs.

AHU_ACL_CU_014, Cx. 1, D. 62 
1666, abril, 10, Lisboa

CONSULTA do Conselho Ultramarino, ao rei D. Afonso VI, sobre os embargos que Bento Bandeira de Melo pôs à carta que se passou do ofício de escrivão da Fazenda Real da Paraíba a Cosmo de Barros Marinho.

AHU_ACL_CU_014, Cx. 1, D. 63.

1667, outubro, 10, Lisboa

CONSULTA do Conselho Ultramarino, ao rei D. Afonso VI, sobre o requerimento de Luís Quaresma, solicitando apostila à carta dos ofícios de provedor da Fazenda Real, e dos Defuntos e Ausentes da Paraíba, para passar pela Chancelaria.

AHU_ACL_CU_014, Cx. 1, D. 67.

1669, fevereiro, 26, Lisboa

CONSULTA do Conselho Ultramarino, ao rei D. Pedro II, sobre a nomeação de pessoas para o cargo de capitão-mor da Paraíba.

Anexo: 1 doc.

AHU_ACL_CU_014, Cx. 1, D. 70.

1669, setembro, 6, Lisboa

CONSULTA do Conselho Ultramarino, ao príncipe regente D. Pedro, sobre o requerimento de Maria Dourado de Bulhões, viúva do capitão Luís Quaresma Dourado, solicitando a propriedade do ofício de provedor da Fazenda Real, e dos Defuntos e Ausentes da Paraíba, que pertencia ao seu marido, para o filho Salvador Quaresma.

Anexo: 1 doc.

AHU_ACL_CU_014, Cx. 1, D. 72.

1670, agosto, 13, Paraíba

CARTA do capitão-mor da Paraíba, Luís Nunes de Carvalho, ao príncipe regente D. Pedro, sobre a administração da Justiça e da Fazenda Real, do poder e conduta dos ricos da capitania, da prisão de [Gabriel Mendonça Furtado e Antonio Cardoso de Carvalho], e da inação do vice-rei do Estado do Brasil e dos ministros da corte de Lisboa, particularmente do conselheiro do Conselho Ultramarino, Feliciano Dourado.

AHU_ACL_CU_014, Cx. 1, D. 75 .

1670, dezembro, 11, Lisboa

CONSULTA do Conselho Ultramarino, ao príncipe regente D. Pedro, sobre as diferenças que houve na Paraíba entre o capitão-mor, Luís Nunes de Carvalho, e Martinho de Bulhões Moniz, seus irmãos e parciais, e o envio de um desembargador da Relação da Bahia para fazer devassa em Pernambuco, Itamaracá e Paraíba.

Anexo: 9 doc.

AHU_ACL_CU_014, Cx. 1, D. 77

1671, agosto, 25, cidade de Nossa Senhora das Neves

CARTA dos oficiais da Câmara da Paraíba, ao príncipe regente [D. Pedro], acerca das sobras da Fazenda Real, em que pedem uma ordinária aplicada aos dízimos da capitania, para sustento dos padres da Companhia de Jesus, e uma esmola para reedificar e ornamentar a igreja matriz; e em que tecem elogios ao governador Inácio Coelho da Silva.

AHU ACL CU 014, Cx. 1, D. 78

1671, setembro, 8, Lisboa

CARTA dos lavradores e senhores de engenho da Paraíba, ao príncipe regente [D. Pedro], queixando-se dos oficiais da Câmara pela mudança da balança do açúcar de Tibiri para o passo do Varadouro e a necessidade de se fazer comércio com Pernambuco, pela falta de gêneros e navios do Reino e Angola, e escravos da Guiné

Anexo: 4 docs.

AHU_ACL_CU_014, Cx. 1, D. 79.

1673, agosto, 15, Paraíba

CARTA dos oficiais da Câmara da Paraíba, ao príncipe regente [D. Pedro], sobre o procedimento do capitão-mor da Paraíba, Inácio Coelho da Silva, e solicitando seja provido por outro triénio no governo da capitania.

AHU ACL CU 014, Cx. 1, D. 86

1675, março, 6, Lisboa

CONSULTA do Conselho Ultramarino, ao príncipe regente D. Pedro, sobre o requerimento dos juízes, vereadores e ministros do Senado da Câmara da cidade de Nossa Senhora das Neves da Paraíba, solicitando ouvidor letrado que administre justiça na capitania. AHU_ACL_CU_014, Cx. 1, D. 91.

1675 , outubro, 7, Lisboa

CONSULTA do Conselho Ultramarino, ao príncipe regente D. Pedro, sobre a representação dos moradores da Paraíba para conservarem os índios em suas aldeias, podendo, assim, usá-los em suas lavouras e fábricas de engenhos, lenhas e outros serviços, na falta de escravos de Angola.

AHU ACL CU 014, Cx. 1, D. 95. 
1675, outubro, 7, Lisboa

CONSULTA do Conselho Ultramarino, ao príncipe regente D. Pedro, sobre a representação dos moradores da Paraíba, referente ao comércio da capitania, pedindo a mudança da balança do açúcar do passo do Tibiri para o passo do Varadouro, no porto da cidade, para se evitar o desvio do produto para o porto de Pernambuco; e o pedido de esmola para o término da construção da torre dos sinos e adro da igreja de Nossa Senhora das Neves.

AHU_ACL_CU_014, Cx. 1, D. 96.

1677, novembro, 13, Lisboa

CONSULTA do Conselho Ultramarino, ao príncipe regente D. Pedro, sobre a nomeação de pessoas para o cargo de capitão-mor da Paraíba

Anexo: 4 docs.

AHU_ACL_CU_014, Cx. 2, D. 104.

1678, janeiro 15, Lisboa

PROVISÃO (cópia) do príncipe regente D. Pedro, designando as contribuições de Pernambuco, Paraíba e Itamaracá para pagamento das côngruas pertencentes às dignidades e mais pessoas do novo Bispado de Pernambuco.

AHU ACL CU 014, Cx. 2, D. 105.

1681, julho, 6, Lisboa

CONSULTA do Conselho Ultramarino, ao príncipe regente D. Pedro, sobre o requerimento dos capitães de Infantaria, e mais oficiais de milícia da Paraíba, solicitando alimentação e fardamento da mesma forma que se fez aos oficiais e soldados dos Terços da guarnição de Pernambuco.

Anexo: 1 doc.

AHU_ACL_CU_014, Cx. 2, D. 113.

1683, outubro, 9, Paraíba

CARTA do provedor da Fazenda Real da Paraíba, Salvador Quaresma Dourado, ao príncipe regente [D. Pedro], sobre o capitão-mor Alexandre de Sousa e Azevedo ter mandado tomar peças de artilharia do Forte Velho e munições do forte do Cabedelo, e os metido em um navio de seu interesse.

AHU_ACL_CU_014, Cx. 2, D. 121.

1684, agosto, 20, Paraíba

CARTA do provedor da Fazenda Real, Salvador Quaresma Dourado, ao [secretário do Conselho Ultramarino], André Lopes de Lavre, sobre os capitães-mores da Paraíba se intrometerem na jurisdição dos ofícios de provedor da Fazenda Real, de que é proprietário.

Anexo: 1 doc.

AHU ACL CU 014, Cx. 2, D. 128.

1684, novembro, 15, Lisboa

CONSULTA do Conselho Ultramarino, ao rei D. Pedro II, sobre o requerimento de Simão Farinha do Amaral, solicitando carta da propriedade do ofício de almoxarife da Fazenda Real da Paraíba.

Anexo: 1 doc.

AHU ACL CU 014, Cx. 2, D. 130.

1685, julho, 18, Paraíba

CARTA do juiz ordinário da Paraíba, António de Sousa Figueiroa, ao rei [D. Pedro II], sobre a forma como o ouvidor-geral de Pernambuco, Dionísio de Ávila Vareiro, tirou residência a Alexandre de Sousa de Azevedo, do tempo que serviu como capitão-mor da Paraíba, de que remete treslado do auto de testemunhas.

Anexo: 1 doc.

AHU_ACL_CU_014, Cx. 2, D. 133.

1685, agosto, 1, Paraíba

CARTA do ouvidor-geral da Paraíba, Francisco do Rego Barros, ao rei [D. Pedro II], sobre haver suspendido o juiz ordinário, António de Sousa Figueiroa, e ser conveniente ir em correição à Paraíba o ouvidor-geral de Pernambuco.

AHU_ACL_CU_014, Cx. 2, D. 135.

1685 , outubro, 8 , Lisboa

CONSULTA do Conselho Ultramarino, ao rei D. Pedro II, sobre a provisão do governador e capitão-geral do Estado do Brasil, marquês das Minas, [D. Antonio Luís de Sousa], passada aos moradores da Paraíba para navegarem o seu açúcar para o porto de Recife.

Anexo: 3 docs.

AHU_ACL_CU_014, Cx. 2, D. 136.

1685 , novembro, 16, Lisboa

CONSULTA do Conselho Ultramarino, ao rei D. Pedro II, sobre a carta dos oficiais da Câmara da Paraíba acerca do mau procedimento do capitão-mor, António da Silva Barbosa, no governo da capitania.

AHU ACL CU 014, Cx. 2, D. 139. 
1686, janeiro, 26, Lisboa

CONSULTA do Conselho Ultramarino, ao rei D. Pedro II, sobre o requerimento do capitão Antonio Cardoso de Carvalho, morador na cidade de Paraíba, solicitando devassa tirada por ministro letrado ao provedor da Fazenda, Salvador Quaresma Dourado, conforme os capítulos que oferece.

Anexo: 3 docs.

AHU_ACL_CU_014, Cx. 2, D. 142.

1686, fevereiro, 23, Lisboa

CONSULTA do Conselho Ultramarino, ao rei D. Pedro II, sobre a carta do capitão-mor da Paraíba, António da Silva Barbosa, solicitando ouvidor letrado para a capitania ou ir a ela em correição o ouvidor-geral de Pernambuco.

Anexo: 1 doc.

AHU_ACL_CU_014, Cx. 2, D. 144.

1687, janeiro, 27, Lisboa

CONSULTA do Conselho Ultramarino, ao rei D. Pedro II, sobre a nomeação de pessoas para o posto de sargento-mor das Ordenanças da Paraíba.

Anexo: 1 doc.

AHU ACL_CU_014, Cx. 2, D. 145.

1688, janeiro, 21, Lisboa

CONSULTA do Conselho Ultramarino, ao rei D. Pedro II, sobre a carta do capitão-mor da Paraíba, Antonio da Silva Barbosa, acerca das razões que teve, para não dar execução à ordem de pôr em arrecadação as dívidas à Fazenda Real.

AHU_ACL_CU 014, Cx. 2, D. 154.

1689, julho, 9, Lisboa

CONSULTA do Conselho Ultramarino, ao rei D. Pedro II, sobre a consulta da Mesa da Consciência e Ordens acerca do provimento do ofício de provedor dos Defuntos e Ausentes da Paraíba, atendendo à jurisdição destes tribunais e aos providos Salvador Quaresma Dourado e o ouvidor geral Diogo Rangel de Castel Branco.

Anexo: 4 docs.

AHU_ACL_CU_014, Cx. 2, D. 162.

1689, novembro, 5, Lisboa

CONSULTA do Conselho Ultramarino, ao rei D. Pedro II, sobre o requerimento de Salvador Quaresma Dourado, solicitando acrescentamento de ordenado do ofício que tem de provedor da Fazenda Real da Paraíba em recompensa de lhe terem tirado o de provedor dos Defuntos e Ausentes, que andava anexo.

Anexo: 2 docs.

AHU ACL_CU_014, Cx. 2, D. 163.

1690, janeiro, 6, Lisboa

CONSULTA do Conselho Ultramarino, ao rei D. Pedro II, sobre as cartas dos provedores da Fazenda Real da Paraíba, Salvador Quaresma Dourado e de Pernambuco, João do Rego Barros, e do Bispo de Pernambuco, acerca da censura deste para ser pago da sua côngrua na Paraíba.

Anexo: 6 docs.

AHU_ACL_CU_014, Cx. 2, D. 166.

1690, novembro, 15, Lisboa

CONSULTA do Conselho Ultramarino, ao rei D. Pedro II, sobre a carta dos oficiais da Câmara da Paraíba acerca da diminuição dos contratos e da pretensão de se isentarem os clérigos de pagar o subsídio do açúcar.

Anexo: 2 docs.

AHU_ACL_CU_014, Cx. 2, D. 168.

1692, setembro, 18 , Lisboa

CONSULTA do Conselho Ultramarino, ao rei D. Pedro II, sobre o requerimento do provedor da Fazenda Real da Paraíba, Salvador Quaresma Dourado, solicitando trinta mil réis de mercê ordinária em recompensa do prejuízo de ficar separado o ofício de provedor dos Defuntos e Ausentes do de provedor da Fazenda Real.

AHU_ACL_CU_014, Cx. 2, D. 177.

1694, outubro, 10, Lisboa

CONSULTA do Conselho Ultramarino, ao rei D. Pedro II, sobre o requerimento do provedor da Fazenda Real, Salvador Quaresma Dourado, solicitando a recompensa de vinte cruzados cada ano, do ofício de juiz das causas dos homens do mar, que foi desanexado do de provedor.

Anexo: 4 docs.

AHU_ACL_CU_014, Cx. 3, D. 190.

1696, dezembro, 12, Lisboa

CONSULTA do Conselho Ultramarino, ao rei D. Pedro II, sobre a carta dos oficiais das Câmaras da Paraíba e de Pernambuco acerca do cumprimento da ordem relativa ao peso das caixas de açúcar.

Anexo: 1 doc. 


\section{AHU_ACL_CU_014, Cx. 3, D. 203.}

1696, dezembro, 13, Lisboa

CONSULTA do Conselho Ultramarino, ao rei D. Pedro II, sobre os requerimentos do coronel Cosme de Barros Miranda e Maria da Conceição, viúva de Bento Bandeira de Melo, solicitando a propriedade do ofício de escrivão da Fazenda Real da Paraíba. Anexo: 1 doc.

AHU_ACL_CU_014, Cx. 3, D. 204.

1697, novembro, 13, Lisboa

CONSULTA do Conselho Ultramarino, ao rei D. Pedro II, sobre a cera e tochas para a festa de São Sebastião e procissão do Corpo de Deus, na Paraíba.

AHU_ACL_CU_014, Cx. 3, D. 214.

1698, junho, 8, Paraíba

CARTA do provedor da Fazenda Real da Paraíba, Salvador Quaresma Dourado, ao rei [D. Pedro II], sobre a razão de mandar rematar seiscentas arrobas de açúcar para pagamento da côngrua do Bispo de Pernambuco.

Anexo: 1 doc.

AHU_ACL_CU_014, Cx. 3, D. 217.

1700 , outubro, 19, Lisboa

CONSULTA do Conselho Ultramarino, ao rei D. Pedro II, sobre a carta do provedor da Fazenda Real da Paraíba, Salvador Quaresma Dourado, acerca da arrematação da obra da casa da Alfândega da Paraíba, e dúvidas que teve o arrematante sobre o pagamento em açúcar.

Anexo: 8 docs.

AHU_ACL_CU_014,Cx. 3, D. 236.

1701, novembro, 8, Lisboa

CONSULTA do Conselho Ultramarino, ao rei D. Pedro II, sobre a carta do capitão-mor da Paraíba, Francisco de Abreu Pereira, acerca do preço do tabaco que deveria ser vendido na capitania.

Anexo: 1 doc.

AHU_ACL_CU_014, Cx. 3, D. 245.

1704, abril, 8, Paraíba

CARTA do provedor da Fazenda Real da Paraíba, Salvador Quaresma Dourado, ao rei [D. Pedro II], sobre a demora com a construção da fortaleza de Cabedelo, por falta de oficiais, e da necessidade de aposentar o condestável, por ser ele já muito velho. AHU_ACL_CU_014, Cx. 4, D. 263.

1704, agosto, 7, Lisboa

CONSULTA do Conselho Ultramarino, à infanta regente de Portugal, D. Catarina de Bragança, sobre a carta do capitão-mor da Paraíba, Fernão de Barros de Vasconcelos, em que descreve os problemas com as obras do forte do Cabedelo.

Anexo: 1 doc.

AHU_ACL_CU_014, Cx. 4, D. 266.

1704, agosto, 11, Lisboa

CONSULTA do Conselho Ultramarino, à infanta regente de Portugal, D. Catarina de Bragança, sobre as cartas do capitão-mor da Paraíba, Fernando de Barros e Vasconcelos e do provedor da Fazenda, Salvador da Quaresma Dourado, acerca de ser necessário construir uma nova casa da Pólvora.

Anexo: 3 docs.

AHU_ACL_CU_014, Cx. 4, D. 268.

1704, Novembro, 20, Lisboa

CONSULTA do Conselho à infanta regente de Portugal, D. Catarina de Bragança, sobre a carta do capitão-mor da Paraíba, Fernão de Barros Vasconcelos, acerca dos danos que provocará nos homens de negócios o ajustamento dos preços do açúcar.

Anexo: 2 docs.

AHU_ACL_CU_014, Cx. 4, D. 273.

REQUERIMENTO do provedor da Fazenda Real da Paraíba, Salvador Quaresma Dourado ao rei [D. Pedro II], solicitando hábito s de Cristo com tença, para si e para quem casar com suas duas filhas Rosa e Isabel, em satisfação de seus serviços e dos de seu irmão Francisco Quaresma Dourado.

Anexo: 18 docs., consulta reg. CU, cód. 87, fól. 81v.

AHU_ACL_CU_014, Cx., D. 275.

1706, Agosto, 17, Lisboa

CONSULTA do Conselho Ultramarino ao rei D. Pedro II, sobre a carta do ouvidor-geral da Paraíba [Gonçalo de Freitas Barracho], acerca do rendimento que tem o ofício de escrivão da Provedoria da Paraíba, em que está provido Paulo de Almeida.

AHU_ACL_CU_014, Cx. 4, D. 279. 
1709, Junho, 17, Lisboa

CARTA RÉGIA (cópia) do rei D. João V, ao provedor da Fazenda da Paraíba ordenando por em pregão a obra da capela-mor e torre da igreja de Nossa Senhora das Neves.

AHU_ACL_CU_014, Cx. 4, D. 298.

1709, Setembro, 6, Lisboa

PARECER (minuta) do Conselho Ultramarino sobre o que escrevem o capitão-mor, oficiais da Câmara, procurador da Fazenda Real e povo da Paraíba acerca da proibição do comércio aos capitães-mor.

Anexo: 1 doc., consulta reg. CU, cód. 265, fól. 215-216v.

AHU ACL_CU 014, Cx. 4, D. 299.

1710, abril, 1, Paraíba

AUTO de uma portaria do governador da Paraíba, João da Maia da Gama, a notificar os contratadores que, sob juramento, declarem o número das caixas que têm no contrato e os mestres dos navios, a carga que levam.

Anexo: 5 docs.

AHU_ACL_CU_014, Cx. 4, D. 302.

1710, Maio, 18, Paraíba

CARTA dos oficiais da Câmara ao rei [D. João V], sobre o miserável estado das finanças da Paraíba, não possibilitando o pagamento ao capitão, oficiais, e soldados, da nova companhia a criar.

AHU ACL CU 014, Cx. 4, D. 303.

1710, maio, 26, Paraíba

CARTA do capitão-mor da Paraíba, João da Maia da Gama, ao rei [D. João V], sobre os requerimentos dos oficiais da Fazenda, solicitando aumento nos seus ordenados.

AHU_ACL_CU_014, Cx. 4, D. 305.

1710, novembro, 28, Lisboa

CONSULTA do Conselho Ultramarino, ao rei D. João V, sobre a carta do capitão-mor da Paraíba, João da Maia da Gama, acerca da ordem para arrematar o contrato dos dízimos reais da capitania com a condição de se dar aos contratadores praça para os açúcares.

Anexo: 2 docs.

AHU ACL CU 014, Cx. 4, D. 323.

1712, junho, 10, Bahia

CARTA do [governador-geral do Brasil], Pedro de Vasconcelos de Sousa, ao rei [D. João V], sobre a carta régia ordenando que dê seu parecer acerca do que propõe o capitão-mor da Paraíba, João da Maia da Gama, a respeito da anexação das capitanias do Rio Grande, de Itamaracá e o Terço de Açu à Paraíba.

AHU ACL CU 014, Cx. 4, D. 330.

1713, agosto, 31, Paraíba

CARTA do [provedor da Fazenda Real], Salvador Quaresma Dourado, ao rei [D. João V], sobre ter recebido ordem para mandar uma relação de todos os livros que forem necessários para o serviço de arrecadação da Fazenda Real.

AHU ACL CU 014, Cx. 5, D. 338.

1713, setembro, 18, Paraíba

CARTA do [provedor da Fazenda Real], Salvador Quaresma Dourado, ao rei [D. João V], sobre a ordem régia para cobrar do contratador empreiteiro do forte do Cabedelo, Simão Gomes, todo o produto do dízimo.

AHU_ACL_CU_014, Cx. 5, D. 339.

1714, abril, 13, Paraíba

CARTA do capitão-mor da Paraíba, João da Maia da Gama, ao rei [D. João V], remetendo a lista das letras e efeitos da capitania remetidos ao Conselho Ultramarino, e dos conhecimentos das despesas do tesoureiro ou almoxarife da Fazenda Real, desde 1704.

Anexo: 4 docs.

AHU_ACL_CU_014, Cx. 5, D. 341.

1714, maio, 6, Paraíba

CARTA do capitão-mor da Paraíba, João da Maia da Gama, ao rei [D. João V], sobre a informação do provedor da Fazenda Real de que havia cobrado dos oficiais da Câmara três mil cruzados do seu ordenado, desde o dia em que tomou posse da capitania, como venciam seus antecessores

AHU ACL_CU_014, Cx. 5, D. 342.

1715, janeiro, 31, Lisboa

CONSULTA do Conselho Ultramarino, ao rei D. João V, sobre a representação do capitão-mor da Paraíba, João da Maia da Gama, solicitando quatro mil cruzados de ajuda de custo, pelas diligências que fez para evitar a sublevação da capitania e de Pernambuco. Anexo: 1 doc.

AHU ACL_CU 014, Cx. 5, D. 344. 
1715, julho, 30, Lisboa

CONSULTA do Conselho Ultramarino, ao rei D. João V, sobre o requerimento de Francisco Pinto Correia, solicitando provisão da serventia do ofício de tesoureiro e recebedor dos dízimos de todas as fazendas que entram na Alfândega, pelo tempo de três anos, com ordenado de cem mil réis.

Anexo: 1 doc.

AHU_ACL_CU_014, Cx. 5, D. 348.

1716, fevereiro, 22, Lisboa

CONSULTA do Conselho Ultramarino, ao rei D. João V, sobre a carta do capitão-mor da Paraíba, em que dá conta da diminuição da renda dos subsídios de que se paga a Infantaria, em virtude das continuadas secas.

AHU_ACL_CU_014, Cx. 5, D. 353.

1716, maio, 8, Paraíba

CARTA do ouvidor-geral da Paraíba, Jerónimo Correia do Amaral, ao rei [D. João V], sobre a repartição dos índios não dever ser responsabilidade dos padres, mas ocupação dos capitães-mores junto com a Câmara.

AHU_ACL_CU_014, Cx. 5, D. 355.

1717, junho, 8, Lisboa

CONSULTA do Conselho Ultramarino, ao rei D. João V, sobre a carta do capitão-mor da Paraíba, João da Maia da Gama, a propósito da forma como se pode introduzir negros na capitania para fábrica dos engenhos.

Anexo: 1 doc.

AHU_ACL_CU_014,Cx. 5, D. 360.

1718, agosto, 12, Paraíba

CARTA do [provedor da Fazenda Real], Salvador Quaresma Dourado, ao rei [D. João V], remetendo a relação das pessoas e da gente de guerra paga pela Fazenda Real, e informando sobre a situação econômica da capitania.

Anexo: 1 doc.

AHU_ACL_CU_014, Cx. 5, D. 362.

1719 , janeiro, 24, Lisboa

CONSULTA do Conselho Ultramarino, ao rei D. João V, sobre o requerimento de José Cordeiro Machado, solicitando provisão da serventia dos ofícios de porteiro e selador da Alfầndega da Paraíba e de escrivão das Execuções, por três anos.

Anexo: 1 doc

AHU ACL CU 014, Cx. 5, D. 364.

1719, maio, 8, Lisboa

CONSULTA do Conselho Ultramarino, ao rei D. João V, sobre o requerimento de Jácome Rodrigues Santos, tesoureiro da dízima da Alfândega da Paraíba, solicitando aumento do seu ordenado.

Anexo: 3 docs.

AHU_ACL_CU_014, Cx. 5, D. 365.

1719, maio, 16, Lisboa

CONSULTA do Conselho Ultramarino, ao rei D. João V, sobre o requerimento dos oficiais e soldados das Companhias da cidade da Paraíba, solicitando a regularização dos seus soldos que se encontram com atraso de cinco anos.

Anexo: 2 docs.

AHU_ACL_CU_014, Cx. 5, D. 366.

[ant. 1720, abril, 2, Paraíba]

REQUERIMENTO de João da Maia da Gama, ao rei [D. João V], solicitando provisão para que todo o açúcar, que tiver na Paraíba, possa navegar livremente para Pernambuco.

AHU_ACL_CU_014, Cx. 5, D. 372.

1720, maio, 11, Lisboa

PARECER do Conselho Ultramarino sobre o requerimento do ouvidor geral da Paraíba, Manuel da Fonseca e Silva, solicitando a mercê de acrescentar cem mil réis ao seu ordenado, como fez com os ouvidores de outras capitanias, por serem os sertões daquela capitania desertos, e correr riscos de vida em razão dos tapuias que neles habitam.

Anexo: 2 docs.

AHU_ACL_CU_014, Cx. 5, D. 374.

1721, agosto, 8, Lisboa

CONSULTA do Conselho Ultramarino, ao rei D. João V sobre o requerimento do capitão-mor nomeado para a Paraíba, João de Abreu de Castel Branco, solicitando mandar acrescentar o seu soldo da mesma forma que fez com todos os governadores das mais conquistas.

AHU_ACL_CU_014, Cx. 5, D. 380. 
1721, outubro, 3 , Lisboa

CONSULTA do Conselho Ultramarino, ao rei D. João V, sobre a carta do provedor da Fazenda Real da Paraíba, Salvador Quaresma Dourado, informando da necessidade de um oficial com ordenado para os Contos.

AHU_ACL_CU_014, Cx. 5, D. 382.

1721, outubro, 24, Lisboa

CONSULTA do Conselho Ultramarino, ao rei D. João V, sobre o requerimento do capitão-mor nomeado para a Paraíba, João de Abreu Castel Branco, solicitando provisão para que o seu soldo seja pago não somente pela consignação dos filhos da folha, contrato dos dízimos, mas também pelos rendimentos da dízima da Alfândega e sobejos dos contratos que administra aquela Câmara.

AHU_ACL_CU_014, Cx. 5, D. 383.

1722, agosto, 4, Paraíba

CARTA do [capitão-mor da Paraíba], João de Abreu Castel Branco, ao rei [D. João V], sobre o transporte do açúcar e tabaco de Goiana no porto da capitania.

AHU ACL CU 014, Cx. 5, D. 389.

1722, outubro, 12, Lisboa

CONSULTA do Conselho Ultramarino, ao rei D. João V, sobre a carta do [capitão-mor da Paraíba], João de Abreu Castel Branco, acerca do comércio dos moradores da capitania e aumento da Fazenda Real, através do açúcar e escravos.

Anexo: 1 doc.

AHU_ACL_CU_014, Cx. 5, D. 392.

[ant. 1723, abril, 27, Paraíba]

REQUERIMENTO dos soldados das Companhias pagas da cidade da Paraíba e fortaleza do Cabedelo, ao rei [D. João V], solicitando mandar-lhes pagar as suas fardas em panos finos, chapéus e mais miudezas.

AHU ACL_CU_014, Cx. 5, D. 397.

1724, abril, 10, Paraíba

CARTA de Manuel Eusébio da Costa, ao rei [D. João V], denunciando a venda de escravos na Paraíba, provenientes da Costa da Mina, comprados com ouro na América.

AHU ACL CU 014, Cx. 5, D. 410.

1724, junho, 25, Paraíba

CARTA do [capitão-mor da Paraíba], João de Abreu Castel Branco, ao rei [D. João V], sobre a difícil situação da capitania, em conseqüência da seca e o lançamento de um bando para punir vadios e ladrões.

AHU_ACL_CU_014, Cx. 5, D. 416.

[ant. 1724, setembro, 16, Lisboa]

REQUERIMENTO do provedor e Deputados da Mesa de Espírito Santo dos homens de negócios, ao rei [D. João V], solicitando providências contra o procedimento do capitão-mor, [João de Abreu Castel Branco], e o provedor da Fazenda da Paraíba, por não lhes darem fianças quando oito navios de sua frota que ia para Pernambuco, foram parar na barra daquela capitania por causa da derrota. AHU ACL CU 014, Cx. 5, D. 423.

[ant. 1725, fevereiro, 7, Paraíba]

REQUERIMENTO de Manuel Correia Bandeira, ao rei [D. João V], solicitando mandar que o executor lhe tome fiança da quarta parte da perda do contrato da entrada dos escravos que vão da Costa da Mina e Cabo Verde a Pernambuco, Paraíba e anexas, visto o suplicante não receber dinheiro.

Anexo: 4 docs.

AHU_ACL_CU, 014, Cx. 6, D. 431.

1725, fevereiro, 9 , cidade do Natal

CARTA do ouvidor geral da Paraíba, Manuel da Fonseca e Silva, ao rei [D. João V], sobre a provisão real que manda o provedor da Fazenda, Salvador Quaresma Dourado, cumprir a ordem de conceder-lhe aumento de ordenado e pagamento de ajuda de custo.

Anexo: 1 doc.

AHU_ACL_CU_014, Cx. 6, D. 432.

1725, abril, 14, Lisboa

CARTA PRECATÓRIA do superintendente da Contadoria-Geral do Reino, João Bressane Leite, para ser feito embargo no dinheiro dos soldos ou ajuda de custo que, pelo Conselho Ultramarino, se paga a João da Maia da Gama, para pagamento da quantia de trezentos mil réis de que é devedor à Fazenda Real.

AHU_ACL_CU_014, Cx. 6, D. 436.

1725, julho, 5, Paraíba 
CARTA do [provedor da Fazenda Real da Paraíba], Salvador Quaresma Dourado, ao rei [D. João V], sobre a ordem que recebeu para assistir Jerônimo Lobo Guimarães.com o gasto necessário aos administradores do contratador dos direitos dos escravos que vão para as minas de ouro, por mar e terra.

Anexo: 1 doc.

AHU_ACL_CU_014, Cx. 6, D. 438.

1725, julho, 12, Paraíba

CARTA do [capitão-mor da Paraíba], João de Abreu Castel Branco, ao rei [D. João V], sobre o atraso do pagamento dos soldados da capitania e a informação do provedor da Fazenda, [Salvador Quaresma Dourado], de que não tem como pagar.

Anexo: 1 doc.

AHU_ACL_CU_014, Cx. 6, D. 442.

1725, julho, 15, Paraíba

CARTA do [capitão-mor da Paraíba], João de Abreu Castel Branco, ao rei [D. João V], sobre ficar advertido pela ordem que recebeu, das condições do contrato da dízima da Alfândega da Paraíba e da de Pernambuco, unidas num só contrato, que Jerônimo Lobo Guimarães mandou arrematar.

AHU_ACL_CU_014, Cx.6, D. 443.

1725, julho, 16, Paraíba

CARTA do [capitão-mor da Paraíba], João de Abreu Castel Branco, ao rei [D. João V], sobre mandar por editais para se fazer público que pertencem a Jerônimo Lobo Guimarães os direitos que se pagam dos escravos que vão para as minas, por mar e terra. AHU_ACL_CU_014, Cx. 6, D. 444.

1725, julho, 18, Paraíba

CARTA do [capitão-mor da Paraíba], João de Abreu Castel Branco, ao rei [D. João V], sobre ter mandado o ouvidor tomar as contas do almoxarife Simão Farinha do Amaral, pela incapacidade do mesmo em continuar no ofício, não sendo sua ordem executada.

AHU_ACL_CU_014, Cx. 6, D. 447.

1725, julho, 19, Paraíba

CARTA do [provedor da Fazenda Real da Paraíba], Salvador Quaresma Dourado, ao rei [D. João V], remetendo a cópia da pauta por onde se paga, na Alfầndega, o direito da dízima das fazendas e mais gêneros que vão à Paraíba.

AHU_ACL_CU_014,Cx.6, D. 451.

1725, julho, 21, Paraíba

CARTA do [capitão-mor da Paraíba], João de Abreu Castel Branco, ao rei [D. João V], sobre as dificuldades com a calamidade da seca e morte de mais da metade dos escravos, solicitando transportar de Angola à Paraíba oitocentos ou mil escravos, com ajuste antecipado do preço.

Anexo: 4 docs

AHU_ACL_CU_014, Cx. 6, D. 452.

1725, julho, 24, Paraíba

CARTA do [provedor da Fazenda Real da Paraíba], Salvador Quaresma Dourado, ao rei [D. João V], remetendo o treslado da certidão que mandaram os oficiais da Câmara da Paraíba, das condições com que arremataram o contrato dos subsídios do açúcar.

Anexo: 3 docs.

AHU_ACL_CU_014, Cx. 6, D. 455.

1725, julho, 24, Paraíba

CARTA do [capitão-mor da Paraíba], João de Abreu Castel Branco, ao rei [D. João V], sobre os procedimentos que tomou junto aos navios que, indo em direção a Pernambuco, tiveram que atracar no porto da Paraíba, por ocasião do mau tempo.

AHU_ACL_CU_014, Cx. 6, D. 456.

1725, julho, 26, Paraíba

CARTA do [capitão-mor da Paraíba], João de Abreu Castel Branco, ao rei [D. João V], remetendo relação dos contratos dos dízimos que correram pela Fazenda Real, nos últimos vinte anos.

Anexo: 4 docs.

AHU ACL CU 014, Cx. 6, D. 458.

1725, julho, 26, Paraíba

CARTA do [capitão-mor da Paraíba], João de Abreu Castel Branco, ao rei [D. João V], sobre as pessoas que pretendem os ofícios de justiça ou fazenda que não têm proprietários.

Anexo: 2 docs.

AHU ACL_CU 014, Cx. 6, D. 459.

1725, julho, 26, Paraíba 
CARTA do [provedor da Fazenda Real da Paraíba], Salvador Quaresma Dourado, ao rei [D. João V], sobre a ordem que recebeu para dar livramento ao inglês Rolan Martin, e os mais que foram culpados, na devassa que tirou por mandado do capitão-mor, relativa aos escravos levados à Paraíba pelo dito inglês.

Anexo: 2 docs., m. est.

AHU_ACL_CU_014, Cx. 6, D. 461.

1725, julho, 27, Paraíba

CARTA do [provedor da Fazenda Real da Paraíba], Salvador Quaresma Dourado, ao rei [D. João V], sobre o que importaram os cinco livros enviados à Provedoria da Paraíba e cujo pagamento será efetuado em açúcar fino, proibindo-se o pagamento em moedas de ouro.

Anexo: 1 doc

AHU_ACL_CU 014, Cx. 6, D. 462.

1725, julho, 27, Paraíba

CARTA do [provedor da Fazenda Real da Paraíba], Salvador Quaresma Dourado, ao rei [D. João V], sobre a ordem para dar, dos rendimentos dos dízimos da Paraíba, cem mil réis para construção de uma capela para que os presos possam ouvir missas.

AHU_ACL_CU_014, Cx. 6, D. 463 .

1725, julho, 27, Paraíba

CARTA do [provedor da Fazenda Real da Paraíba], Salvador Quaresma Dourado, ao rei [D. João V], sobre ter mandado ajustar a conta do que têm recebido os empreiteiros que arremataram a obra do forte de Cabedelo, desde a época em que a Superintendência corria por conta de Pernambuco.

Anexo: 1 doc.

AHU_ACL_CU_014, Cx. 6, D. 464.

1725, julho, 28, Paraíba

CARTA do [provedor da Fazenda Real da Paraíba], Salvador Quaresma Dourado, ao rei [D. João V], sobre não poder remeter com brevidade as contas do almoxarife da Fazenda Real, Simão Farinha.

AHU_ACL_CU_014, Cx. 6, D. 466.

1725, julho, 29, Paraíba

CARTA do [provedor da Fazenda Real da Paraíba], Salvador Quaresma Dourado, ao rei [D. João V], sobre a ordem para entregar ao procurador de José Ramos da Silva, a importância dos direitos da dízima de uma embarcação que, no tempo de seu contrato, saiu do Maranhão ao porto da Paraíba.

AHU_ACL_CU_014, Cx. 6, D. 469.

1725, julho, 29, Paraíba

CARTA do [provedor da Fazenda Real da Paraíba], Salvador Quaresma Dourado, ao rei [D. João V], sobre não remeter a importância dos livros enviados à Provedoria, em açúcar fino, por não ter ido ao porto da Paraíba nenhum navio.

AHU_ACL_CU_014, Cx. 6, D. 470.

1725, julho, 30, Paraíba

CARTA do [provedor da Fazenda Real da Paraíba], Salvador Quaresma Dourado, ao rei [D. João V], sobre um precatório remetido pelo provedor da Fazenda Real da Ilha de São Tomé, Manuel Pereira de Abreu, para cobrar a quantia de quatrocentos mil réis ao mestre da sumaca Domingos Rodrigues de Lima, por embarcar clandestinamente três pretos civis daquela ilha.

Anexo: 1 doc

AHU ACL CU 014, Cx. 6, D. 474.

1725, julho, 30, Paraíba

CARTA do [provedor da Fazenda Real da Paraíba], Salvador Quaresma Dourado, ao rei [D. João V], sobre não remeter a relação dos livros necessários à Fazenda Real, Alfândega e Secretaria do governo, por haver o suficiente para dois anos.

AHU ACL CU 014, Cx. 6, D. 475.

1725, julho, 31, Paraíba

CARTA do [capitão-mor da Paraíba], João de Abreu Castel Branco, ao rei [D. João V], sobre ter recebido o decreto relativo ao abuso que se pratica na Paraíba, por parte dos escrivães das mesas dos despachos, oficiais de justiça e fazenda, que levam emolumentos exorbitantes contra o regimento e ordenações.

AHU ACL CU 014, Cx. 6, D. 478.

1725, julho, 31, Paraíba

CARTA do [provedor da Fazenda Real da Paraíba], Salvador Quaresma Dourado, ao rei [D. João V], sobre a execução das condições do contrato da dízima da Alfândega, arrematada por Jerônimo Lobo Guimarães, por três anos.

AHU ACL CU 014, Cx. 6, D. 479. 
1725, julho, 31, Paraíba

CARTA do [capitão-mor da Paraíba], João de Abreu Castel Branco, ao rei [D. João V], sobre a despesa que importam as obras da fortaleza do Cabedelo.

Anexo: 3 docs.

AHU_ACL_CU_014, Cx. 6, D. 480.

1725, julho, 31, Paraíba

CARTA do [provedor da Fazenda Real da Paraíba], Salvador Quaresma Dourado, ao rei [D. João V], sobre não poder enviar os três mil cruzados que deve em açúcar, por não ter ido ao porto da Paraíba nenhum navio, em virtude de não se ter feito açúcar nos engenhos, devido à seca.

AHU_ACL_CU_014, Cx. 6, D. 481.

1725, agosto, 5, Paraíba

CARTA do [capitão-mor da Paraíba], João de Abreu Castel Branco, ao rei [D. João V], sobre os alvarás de fianças ou de fiéis carcereiros, que se concedem aos criminosos, depois de presos.

Anexo: 3 docs.

AHU_ACL_CU_014, Cx. 6, D. 484.

1725, agosto, 22, Paraíba

CARTA do [provedor da Fazenda Real da Paraíba], Salvador Quaresma Dourado, ao rei [D. João V], sobre não ter ajustado as contas com o contratador da dízima da Alfândega da Paraíba e Pernambuco, Jerônimo Lobo Guimarães, por não virem navios à capitania. AHU_ACL_CU_014, Cx. 6, D. 491.

1725, agosto, 24, Paraíba

CARTA do [capitão-mor da Paraíba], João de Abreu Castel Branco, ao rei [D. João V], sobre a situação em que se encontram as companhias de Infantaria da Guarnição da Paraíba e a necessidade de 20 mil cruzados do produto da dízima para acudi-las.

Anexo: 5 docs.

AHU_ACL_CU_014, Cx. 6, D. 492.

[ant. 1725, outubro, 27 Paraíba]

REQUERIMENTO do contratador do direito de entrada de escravos da Costa da Mina, Cacheu e Cabo Verde, Manuel Correia Bandeira, ao rei [D. João V], solicitando provisão para citar o Provedor da Fazenda Real.

Anexo: 3 docs.

AHU_ACL_CU_014, Cx.6, D. 494.

[ant. 1726, fevereiro, 17, Paraíba]

REQUERIMENTO de João Machado Gaio, João Gonçalves Rodrigues e Jerônimo Pinto, ao rei [D. João V], solicitando, enquanto senhores do bergantim Santo Antonio e Almas, que, indo do Maranhão a Pernambuco, arribou no porto da Paraíba por estar naufragando, mandar o provedor da Fazenda Real lhes restituir o dinheiro da dízima e todas as despesas cobradas.

Anexo: 1 doc.

AHU_ACL_CU_014, Cx. 6, D. 501 .

1726, fevereiro, 23, Lisboa

CARTA de Jerônimo Lobo Guimarães, ao rei [D. João V], justificando o não pagamento da dívida contraída na arrematação do contrato da dízima da Alfândega da Paraíba e Pernambuco.

AHU_ACL_CU_014, Cx. 6, D. 505.

1726, março, 6, Lisboa

CARTA de Luís Pires dos Santos, ao rei [D. João V], sobre as informações dadas pelo capitão-mor da Paraíba, [João de Abreu Castel Branco], e a súplica dos senhores de engenho e lavradores, relativas à necessidade de se introduzir mil escravos por ano na Paraíba, devido à dificuldade em fazer negócio, pois os compradores querem ditar o preço da venda.

AHU_ACL_CU_014, Cx. 6, D. 506.

1726, junho, 7, Bahia

CARTA do [vice-rei do Brasil, conde de Sabugosa], Vasco Fernandes César de Meneses, ao rei D. João V, sobre a provisão, ordenando que fique na Provedoria da Paraíba o confisco que se fez a Diogo Gonçalves Lima, por fazer resgate de vinte escravos em ouro; e a respeito do empréstimo feito pelo governador do Rio de Janeiro à Feitoria de Ajudá, para continuar o projeto de Montevidéu. AHU_ACL_CU_014, Cx. 6, D. 511.

1726, agosto, 30, Paraíba

CARTA do [provedor da Fazenda], Salvador Quaresma Dourado, ao rei [D. João V], sobre os procedimentos que se tomou com o bergantim de João Machado Gaio, João Gonçalves Reis e Jerônimo Pinto, cobrando a Alfândega da Paraíba dez por centro pela entrada das fazendas na capitania.

Anexo: 3 docs.

AHU ACL_CU 014, Cx. 6, D. 519.

1726, setembro, 2, Paraíba 
DESPACHO do Conselho Ultramarino sobre o parecer do procurador da Coroa acerca da carta do ouvidor-geral da Paraíba, Manuel da Fonseca e Silva, contra o capitão-mor João de Abreu Castel Branco.

Anexo: 2 docs.

AHU_ACL_CU_014, Cx. 6, D. 520.

1726, setembro, 9, Paraíba

CARTA do [capitão-mor da Paraíba], João de Abreu Castel Branco, ao rei [D. João V], sobre o recebimento e divulgação da provisão em que consta a obrigação de pagar nas alfândegas do Reino todo o açúcar fabricado nas conquistas.

AHU_ACL_CU_014, Cx. 6, D. 523.

1726, setembro, 9, Paraíba

CARTA do [capitão-mor da Paraíba], João de Abreu Castel Branco, ao rei [D. João V], sobre a falta de pagamento dos soldos dos oficiais e soldados da Infantaria da guarnição da Paraíba, pelo tempo de três anos; e que os soldados dos regimentos de Pernambuco se amotinaram para conseguirem seus pagamentos.

Anexo: 2 docs.

AHU_ACL_CU_014, Cx. 6, D. 524.

1726, setembro, 9, Paraíba

CARTA do [capitão-mor da Paraíba], João de Abreu Castel Branco, ao rei [D. João V], sobre as obras de recuperação da fortaleza do Cabedelo, a serem feitas com índios e soldados das companhias pagas.

AHU_ACL_CU_014, Cx. 6, D. 525.

1726, setembro, 9, Paraíba

CARTA do [provedor da Fazenda Real da Paraíba], Salvador Quaresma Dourado, ao rei [D. João V], sobre os procedimentos tomados acerca da ordem de livramento do inglês Rolan Martin, e os mais culpados na devassa tirada sobre uns escravos da Costa da Mina introduzidos na capitania.

AHU_ACL_CU_014, Cx. 6, D. 526.

1726, setembro, 11, Paraíba

CARTA do [provedor da Fazenda Real da Paraíba], Salvador Quaresma Dourado, ao rei [D. João V], sobre a ordem para enviar ao Conselho Ultramarino um mapa com os números dos livros necessários à Provedoria da Fazenda.

AHU_ACL_CU_014, Cx. 6, D. 529.

1726, setembro, 12, Paraíba

CARTA do [capitão-mor da Paraíba], João de Abreu Castel Branco, ao rei [D. João V], sobre o ordenado do escrivão da Abertura da Alfândega da Paraíba não ser igual ao de Pernambuco, tendo em vista ser menor o movimento do porto da Paraíba.

Anexo: 7 docs.

AHU ACL CU 014, Cx. 6, D. 530.

1726, setembro, 13, Paraíba

CARTA do [provedor da Fazenda Real da Paraíba], Salvador Quaresma Dourado, ao rei [D. João V], sobre a cobrança do empréstimo feito ao capitão-mor da Paraíba, João de Abreu Castel Branco.

AHU_ACL_CU_014, Cx. 6, D. 531.

1726, setembro, 14, Paraíba

CARTA do [capitão-mor da Paraíba], João de Abreu Castel Branco, ao rei [D. João V], sobre o requerimento de João Machado Gaio, João Gonçalves Rodrigues e Jerônimo Pinto, proprietários do bergantim Santo Antonio e Almas, solicitando mandar passar franquias e restituição do dinheiro gasto com a dízima e exorbitantes salários que levaram os oficiais da Alfândega.

Anexo: 3 docs.

AHU ACL CU 014, Cx. 6, D. 532.

1726, setembro, 15, Paraíba

CARTA do [provedor da Fazenda Real da Paraíba], Salvador Quaresma Dourado, ao rei [D. João V], informando que o pagamento dos livros remetidos do Reino para a Provedoria da Fazenda iria atrasar, tendo em vista a falta de moedas de ouro novas na Paraíba. AHU ACL CU 014, Cx. 6, D. 533.

1726, setembro, 20, Paraíba

CARTA do vigário da Paraíba, Antonio da Silva e Melo, ao rei [D. João V], sobre as calamidades que o povo da Paraíba padece com a retirada da imagem da Virgem da igreja da Misericórdia; e solicitando um toldo para a referida igreja. AHU_ACL_CU_014, Cx. 6, D. 535 .

1726, setembro, 23, Paraíba

CARTA do [capitão-mor da Paraíba], João de Abreu Castel Branco, ao rei [D. João V], sobre a determinação para se arrematar o contrato dos dízimos reais da capitania na corte e informando ser possível passar a renda do contrato por dez mil cruzados. AHU_ACL_CU_014, Cx. 6, D. 538.

[ant. 1727, abril, 22, Paraíba] 
REQUERIMENTO do contratador do dízimo real, Rafael Nunes Paz, ao rei [D. João V], solicitando passar ordem para agir conforme o contrato assinado, compreendendo neste o pagamento das fardas e farinha para os militares.

Anexo: 1 doc.

AHU_ACL_CU_014, Cx. 7, D. 541.

[ant. 1727, julho, 24, Paraíba]

REQUERIMENTO dos interessados no navio Nossa Senhora de Nazaré e São João Baptista, ao rei [D. João V], solicitando mandar ordem ao governador da Paraíba, [João de Abreu Castel Branco], para que não impeça a saída dos navios do porto da Paraíba ao de Pernambuco, cinco ou seis dias antes, para se incorporaram à frota.

Anexo: 1 doc.

AHU_ACL_CU_014, Cx. 7, D. 543 .

1727, dezembro, 19, Lisboa

DESPACHO do Conselho Ultramarino sobre o parecer do procurador da Coroa, relativo ao açúcar e tabaco de Goiana serem embarcados em Pernambuco e não na Paraíba

AHU_ACL_CU_014, Cx. 7, D. 546.

[ant. 1728, março, 2, Paraíba]

REQUERIMENTO do alferes da fortaleza do Cabedelo, José de Melo Moniz, ao provedor da Fazenda Real da Paraíba, [Salvador Quaresma Dourado], solicitando certidão de fé de ofício de todo o tempo que tem servido na capitania, de 1691 até a presente data.

Anexo: 9 docs.

AHU_ACL_CU_014, Cx. 7, D. 547.

1728, março, 10, Paraíba

CARTA do [provedor da Fazenda Real da Paraíba], Salvador Quaresma Dourado, ao rei [D. João V], remetendo duas caixas de açúcar branco pela galera Triunfo da Fé, do capitão João Gonçalves Lima, e pela charrua Nossa Senhora de Nazaré e São João Baptista, do mestre Manuel João, como pagamento de onze livros que foram enviados no ano anterior.

Anexo: 3 docs.

AHU ACL_CU_014, Cx. 7, D. 548.

[ant. 1728, agosto, 11, Paraíba]

REQUERIMENTO de Bento Bandeira de Melo, ao rei [D. João V], solicitando passar carta de propriedade dos ofícios de escrivão da Fazenda da Alfândega e Almoxarifado da Paraíba.

Anexo: 5 docs.

AHU ACL CU 014, Cx. 7, D. 555.

[ant. 1728, outubro, 23, Paraíba]

REQUERIMENTO do capitão inglês, Roland Martin, ao rei [D. João V], solicitando mandar que o provedor da Fazenda Real lhe entregue o dinheiro sequestrado na devassa ordenada pelo capitão-mor da Paraíba, João de Abreu Castel Branco, tendo em vista não ter culpa do fogo que ateou o seu patacho, nem na venda dos escravos sobreviventes a capitães de navios com destino à Paraíba.

Anexo: 2 docs.

AHU_ACL_CU. 014, Cx. 7, Doc. 558.

[ant. 1728, novembro, 12, Paraíba]

REQUERIMENTO do mestre e capitão da charrua Nossa Senhora de Nazaré e São João Baptista e galera Triunfo da Fé e Almas, Manuel João e João Gonçalves Lima, ao rei [D. João V], solicitando mandar passar ordem ao provedor da Alfầndega da Paraíba para lhes restituir o pagamento da visita ao navio, efetuada pelo escrivão da Abertura, Antonio Carneiro de Albuquerque.

AHU ACL CU 014, Cx. 7, D. 562.

1729, abril, 30, Paraíba

CARTA do [capitão-mor da Paraíba], Francisco Pedro de Mendonça Gorjão, ao rei [D. João V], sobre ter ordenado ao provedor da Fazenda para tomar os escravos que se acham sem senhores, para a Fazenda Real; embarcar os dois escravos existentes na cadeia da cidade e colocar editais para se arrematarem os gados de vento por contrato.

AHU ACL CU 014, Cx. 7, D. 568.

1729, maio, 27, Paraíba

CARTA do [provedor da Fazenda Real da Paraíba], Salvador Quaresma Dourado, ao rei [D. João V], solicitando mais informações acerca das condições em que o contratador, Agostinho de Andrade Silva, arrematou o sal.

Anexo: 1 doc.

AHU_ACL_CU_014, Cx. 7, D. 569.

1729, maio, 30, Paraíba

CARTA do [provedor da Fazenda Real da Paraíba], Salvador Quaresma Dourado, ao rei [D. João V], remetendo relação da receita e despesa do Almoxarifado, de 1723 a 1729, com a importância da folha secular e eclesiástica, da Infantaria, bem como o rendimento do direito da dízima da Alfândega.

Anexo: 1 doc.

AHU ACL CU 014, Cx. 7, D. 570. 
1729, junho, 2, Paraíba

CARTA do [provedor da Fazenda Real da Paraíba], Salvador Quaresma Dourado, ao rei [D. João V], sobre o andamento das obras da fortaleza do Cabedelo.

Anexo: 1 doc.

AHU_ACL_CU_014, Cx. 7, D. 571.

1729, junho, 9, Paraíba

CARTA do [provedor da Fazenda Real da Paraíba], Salvador Quaresma Dourado, ao rei [D. João V], informando que o desembarque e embarque de mercadorias para o Reino foram regidos pelas pautas que estavam em exercício.

AHU_ACL_CU_014, Cx.7, D. 572.

1729, junho, 15, Paraíba

CARTA do [provedor da Fazenda Real da Paraíba], Salvador Quaresma Dourado, ao rei [D. João V], sobre a perseguição sofrida por seu filho, Salvador Quaresma Dourado, sacerdote do hábito de São Pedro e capelão da Santa Casa de Misericórdia da cidade da Paraíba, pelos seus inimigos, Inácio Pereira de Azevedo, sacerdote e coadjutor da matriz da mesma cidade, e o ouvidor geral da capitania, João Nunes Souto.

AHU ACL CU 014, Cx. 7, D. 574.

1729, junho, 20, Paraíba

CARTA do [capitão-mor da Paraíba], Francisco Pedro de Mendonça Gorjão, ao rei [D. João V], solicitando que Jácome Rodrigues Santos continue no ofício de escrivão dos Contos da Fazenda Real.

AHU_ACL_CU_014, Cx. 7, D. 575.

1729, junho, 22, Paraíba

CARTA do [capitão-mor da Paraíba], Francisco Pedro de Mendonça Gorjão, ao rei [D. João V], sobre a necessidade de se aplicar mais dez mil cruzados, a cada ano, na fortificação do Cabedelo, e que seja proveniente da dízima de Pernambuco ou do contrato dos negros, arrematados por Jerônimo Lobo Guimarães.

Anexo: 1 doc.

AHU ACL CU 014, Cx. 7, D. 576.

1729, julho, 23, Paraíba

Carta do [capitão-mor da paraíba], francisco pedro de mendonça gorjão, ao rei [d. João v], sobre o cumprimento da ordem para o provedor da fazenda real, [salvador quaresma dourado], ajustar as contas com os empreiteros das obras da fortaleza do cabedelo.

Anexo: 2 docs.

AHU_ACL_CU_014, Cx. 7, D. 577.

1729, junho, 24, Paraíba

CARTA do [capitão-mor da Paraíba], Francisco Pedro de Mendonça Gorjão, ao rei [D. João V], enviando as contas da receita e despesa da Fazenda Real, de 1722 a 1729.

Anexo: 1 doc.

AHU_ACL_CU_014, Cx. 7, D. 580 .

1729, junho, 24, Paraíba

CARTA de Manuel Eusébio da Costa, ao rei [D. João V], sobre as injustas razões que levaram os homens da terra a suspendê-lo do cargo de procurador da Coroa e Fazenda da Paraíba, e solicitando o pagamento do resto da última provisão a que tem direito.

Anexo: 2 docs.

AHU_ACL_CU_014, Cx. 7, D. 582.

1729, junho, 30, Paraíba

Carta do [capitão-mor da paraíba], francisco pedro de mendonça gorjão, ao rei [d. João v], sobre a cobrança dos emolumentos na visita que fez o escrivão da abertura, antonio carneiro de albuquerque, aos navios dos mestres joão gonçalves lima e manuel joão.

Anexo: $2^{\mathrm{a}}$ via

AHU_ACL_CU_014, Cx. 7, D. 586 .

1729, junho, 30, Paraíba

CARTA do [capitão-mor da Paraíba], Francisco Pedro de Mendonça Gorjão, ao rei [D. João V], sobre a cobrança dos emolumentos na visita que fez o escrivão da Abertura, António Carneiro de Albuquerque, aos navios dos mestres João Gonçalves Lima e Manuel João. Anexo: $2^{\mathrm{a}}$ via

AHU_ACL_CU_014,Cx. 7, D. 586 .

1729, julho, 12, Paraíba

CARTA do juiz ordinário da Paraíba, Manuel Rodrigues Coelho, ao rei [D. João V], queixando-se que os poucos recursos existentes na Câmara da cidade são utilizados pelo capitão-mor, [Francisco Pedro de Mendonça Gorjão], impossibilitando a construção de obras públicas.

AHU ACL_CU 014, Cx. 7, D. 600.

1729, julho, 29, Paraíba 
CARTA do [capitão-mor da Paraíba], Francisco Pedro de Mendonça Gorjão, ao rei [D. João V], denunciando a trama envolvendo os padres Inácio Pereira de Azevedo e Pedro Tavares da Silva com o ouvidor geral da Paraíba, [João Nunes Souto], para a eleição de provedor e mais oficiais da mesa da Santa Casa de Misericórdia.

AHU_ACL_CU 014, Cx. 7, D. 604.

1729, outubro, 19, Paraíba

CONSULTA do Conselho Ultramarino, ao rei D. João V, sobre a carta do capitão-mor da Paraíba, Francisco Pedro de Mendonça Gorjão, informando da cheia que houve na capitania, destruindo engenhos, matando gado e pessoas; e encaminhando o requerimento dos senhores de engenho e lavradores, em que solicitam para não serem executadas em suas fábricas as dívidas que possuem.

Anexo: 3 docs.

AHU_ACL_CU_014, Cx. 7, D. 606 .

[ant. 1730, fevereiro, 10, Paraíba]

REQUERIMENTO do padre Inácio Pereira Azevedo, ao rei [D. João V], solicitando mandar, por ministro independente do provedor da Fazenda, Salvador Quaresma Dourado, fazer a conta do suplicante e pagar-lhe o que lhe deve do tempo em que foi coadjutor na paróquia da Paraíba.

Anexo: 3 docs

AHU_ACL_CU_014, Cx. 7, D. 614.

1730, maio, 6, Baía

CARTA do [vice-rei do Brasil], conde de Sabugosa, [Vasco Fernandes César de Meneses], ao rei [D. João V], sobre alguns governadores, entre os quais o da Paraíba, [Francisco Pedro de Mendonça Gorjão], estarem nomeando pessoas para a serventia dos ofícios de Justiça e Fazenda, sendo prerrogativas dos governadores do Rio de Janeiro e Pernambuco.

Anexo: 2 docs.

AHU_ACL_CU_014, Cx. 7, D. 625.

1730, outubro, 14, Paraíba

CERTIDÃO do capitão-mor da Paraíba, Francisco Pedro de Mendonça Gorjão, comprovando que há mais de um ano não se pagava a Infantaria do presídio do Cabedelo, por falta de efeitos na Fazenda Real e por não virem de Pernambuco os vinte mil cruzados da dízima aplicados a esse pagamento.

AHU_ACL_CU_014, Cx. 8, D. 645.

1730, novembro, 20, Paraíba

CARTA do capitão-mor da Paraíba, Francisco Pedro de Mendonça Gorjão, ao rei [D. João V], sobre a resposta do provedor da Fazenda Real da Paraíba, [Salvador Quaresma Dourado], e o escrivão da Fazenda e da Abertura, [Bento Bandeira de Melo], a respeito do que se pratica na capitania, nas visitas que se fazem aos navios.

Anexo: 2 docs

AHU_ACL_CU_014, Cx. 8, D. 647.

1731, janeiro, 3, Paraíba

CARTA do ouvidor geral da Paraíba, Tomás da Silva Pereira, ao rei [D. João V], sobre os requerimentos de Salvador Quaresma Dourado, do padre Inácio Pereira de Azevedo e do capitão-mor, Francisco Pedro de Mendonça Gorjão, acerca da contenda relativa à capelania da Misericórdia da cidade da Paraíba.

Anexo: 4 docs.

AHU_ACL_CU_014, Cx. 8, D. 650 .

1731, abril, 9, Paraíba

CARTA do [capitão-mor da Paraíba], Francisco Pedro de Mendonça Gorjão, ao rei [D. João V], sobre as queixas de Felix Gomes ao vice-rei do Brasil, [conde de Sabugosa, Vasco Fernandes César de Meneses], por não estar na serventia de um dos ofícios de tabelião do Público Judicial e Notas da Paraíba e a respeito da jurisdição de provimento de cargos.

Anexo: 4 docs.

AHU_ACL_CU_014, Cx. 8, D. 652.

1731, agosto, 27, Paraíba

CARTA PRECATÓRIA do provedor e contador da Fazenda Real, Salvador Quaresma Dourado, ao provedor da Fazenda Real da cidade de Olinda e vila de Santo Antonio do Recife, mandando cobrar os vinte mil cruzados da décima da capitania de Pernambuco, pertencentes à Paraíba, em cada ano, para pagamento da Infantaria, como constava da arrematação do contrato, feito na Corte. AHU_ACL_CU_014, Cx. 8, D. 655.

[ant. 1731, setembro, 18, Paraíba]

REQUERIMENTO do contratador dos dízimos reais da Paraíba, Garcia da Ponte Coelho, ao rei [D. João V], solicitando passar provisão para que o almoxarife leve em conta tudo o que pagou a mais de uma propina de que estava desobrigado.

Anexo: 15 docs. 


\section{AHU_ACL_CU_014, Cx. 8, D. 657.}

1732, fevereiro, 4, Paraíba

CARTA do [capitão-mor da Paraíba], Francisco Pedro de Mendonça Gorjão, ao rei [D. João V], sobre ter recebido a lei para se evitar a extração do ouro, moeda e tabaco fino ou alguma outra fazenda, ou género proibido, que se costuma trazer nas embarcações dos portos que da capitania navegam para a Costa da Mina.

AHU-Pernambuco, doc. 23

AHU_ACL_CU_014, Cx. 8, D. 661 .

1732, março, 29, Paraíba

CARTA do [capitão-mor da Paraíba] Francisco Pedro de Mendonça Gorjão, ao rei [D. João V], remetendo cópia da carta de João da Maia da Gama, ex-capitão-mor da capitania, ao vigário da matriz, para que fizesse sair do distrito o padre Inácio Pereira de Azevedo. Anexo: 1 doc.

AHU_ACL_CU_014,Cx. 8, D. 663.

1732, abril, 12, Recife

CARTA do provedor da Fazenda Real de Pernambuco, João do Rego Barros, ao rei [D. João V], sobre os vinte mil cruzados referentes ao contrato da dízima da Alfândega da Paraíba e Pernambuco, que devem ser remetidos àquela capitania.

Anexo: 2 docs.

AHU ACL CU 014, Cx. 8, D. 665.

1732, abril, 19, Recife

CARTA do [governador capitão-mor de Pernambuco], Duarte Sodré Pereira Tibão, ao rei [D. João], informando que tem pago à Paraíba, anualmente, os vinte mil cruzados do produto da arrecadação da dízima da Alfầndega da Paraíba e Pernambuco, feitas num só contrato, ficando sempre a dever um ano.

Anexo: 1 doc.

AHU_ACL_CU_014, Cx. 8. D. 666 .

1732, abril, 21, Paraíba

CARTA do [provedor da Fazenda da Paraíba], Salvador Quaresma Dourado, ao rei [D. João V], sobre a remessa dos vinte mil cruzados que a Provedoria de Pernambuco está obrigada a enviar anualmente à Paraíba, para pagamento da obra do forte de Cabedelo, Infantaria e mais consignações a que está aplicada.

AHU_ACL_CU_014, Cx. 8, D. 667.

1732, abril, 26, Paraíba

CARTA do [procurador da Fazenda Real], Salvador Quaresma Dourado, ao rei [D. João V], sobre o recebimento de dez mil cruzados de Pernambuco, referentes ao produto da dízima e informando, ainda, que a dívida desta capitania para com a Provedoria da Paraíba é de sessenta mil cruzados.

AHU ACL CU 014, Cx. 8, D. 672.

[ant. 1732, agosto, 21, Paraíba]

REQUERIMENTO do ajudante de Infantaria, Francisco de Melo Moniz, em seu nome e como procurador do sargento-mor Luís Xavier Bernardo e mais militares da guarnição da Paraíba, ao rei [D. João V], solicitando mandar que o provedor da Fazenda Real de Pernambuco, João do Rego Barros, remeta a quantia vencida para pagamentos dos soldos e mais consignações dos suplicantes.

AHU_ACL_CU_014, Cx. 8, D. 678 .

1733, maio, 4, Paraíba

CARTA do [capitão-mor da Paraíba], Francisco Pedro de Mendonça Gorjão, ao rei [D. João V], sobre o falecimento do provedor da Fazenda Real da Paraíba, Salvador Quaresma Dourado, e o provimento de Bento Bandeira de Melo no referido cargo, bem como o tenente-coronel Amaro Velho de Vasconcelos no de escrivão da Fazenda.

Anexo: 2 docs.

AHU_ACL_CU_014, Cx. 8, D. 692.

1733, maio, 8, Paraíba

CARTA do [capitão-mor da Paraíba], Francisco Pedro de Mendonça Gorjão, ao rei [D. João V], sobre a carta do provedor da Fazenda Real, [Bento Bandeira de Melo], solicitando ordenado para o meirinho do mar e escrivão das Execuções.

AHU_ACL_CU_014, Cx. 8, D. 693.

1733, junho, 4, Paraíba

CERTIDÃO do vigário colado da freguesia e vigararia de Nossa Senhora das Neves, da cidade da Paraíba, Dr. Antonio da Silva e Melo, comprovando que Feliciano Dourado deixou um filho homem por nome Salvador Antonio, e que Salvador Quaresma Dourado não deixou sucessor algum para o cargo que exerceu, de provedor da Fazenda Real.

Anexo: 3 docs.

AHU_ACL_CU_014, Cx. 8, D. 696. 
1733, junho, 6, Paraíba

CARTA do [capitão-mor da Paraíba], Francisco Pedro de Mendonça Gorjão, ao rei [D. João V], sobre o que a Câmara arremata por contrato da balança pública existente no passo do Varadouro.

Anexo: 1 doc.

AHU_ACL_CU_014, Cx. 8, D. 697.

1733, junho, 13, Paraíba

CARTA do escrivão dos Contos da Fazenda Real, Jácome Rodrigues Santos, ao rei [D. João V], sobre o que toca ao escrivão dos Contos da Fazenda Real e os abusos cometidos pelo ex-provedor, Salvador Quaresma Dourado.

AHU_ACL_CU_014, Cx.9, Doc. 701

1733, junho, 14, Paraíba

CARTA do escrivão dos Contos da Fazenda Real, Jácome Rodrigues Santos, ao rei [D. João V], sobre o pedido que fez ao governador da Paraíba, [Francisco Pedro de Mendonça Gurjão], desistindo do ofício que exercia.Anexo: 1 doc.

AHU ACL CU 014, Cx. 8, D. 703.

1733, junho, 21, Paraíba

CARTA do almoxarife da Provedoria da Fazenda Real, Caetano Francisco Gomes ao rei [D. João V], sobre os impedimentos postos ao cumprimento das obrigações do seu ofício, por parte do ex-provedor da Fazenda Real da Paraíba, Salvador Quaresma Dourado, tendo reclamado e requerido o escrivão dos Contos e tesoureiro da Décima, Jácome Rodrigues dos Santos, pelo dinheiro para pagamento dos militares, e solicita se dê regimento à Provedoria e aos seus oficiais.

AHU_ACL_CU_014, Cx. 8, D. 710 .

1733, junho, 30, Paraíba

CARTA do [provedor da Fazenda Real da Paraíba], Bento Bandeira de Melo, ao rei [D. João V], sugerindo um ordenado para o meirinho do mar e escrivão da Execução do Tribunal da Fazenda.

AHU_ACL_CU_014,Cx. 8, D. 714.

1733, junho, 30, Paraíba

CARTA do [provedor da Fazenda Real da Paraíba], Bento Bandeira de Melo, ao rei [D. João V], informando que mandou passar precatória à Fazenda Real de Pernambuco com a conta dos sessenta mil cruzados vencidos do contrato da dízima da Paraíba, para se remeter à Provedoria desta capitania.

Anexo: 1 doc.

AHU_ACL_CU_014,Cx. 8, D. 715.

1733, julho, 2, Paraíba

CARTA do [provedor da Fazenda Real da Paraíba], Bento Bandeira de Melo, ao rei [D. João V], sobre o ordenado do escrivão de Abertura e Descarga da Alfândega da capitania.

AHU_ACL_CU_014, Cx. 9, D. 716.

1734, janeiro, 12, Lisboa

AVISO do [secretário de estado], Diogo de Mendonça Corte Real, ao [secretário do Conselho Ultramarino], Manuel Caetano Lopes de Lavre, mandando reformar a consulta sobre o governo da Paraíba.

AHU ACL CU 014, Cx. 9, D. 729.

1734, janeiro, 19, Lisboa

CONSULTA do Conselho Ultramarino, ao rei D. João V, sobre nomeação de pessoas para o posto de capitão-mor da Paraíba.

Anexo: 2 docs.

AHU_ACL_CU_014, Cx. 9, D. 730.

1734, março, 2, Lisboa

CONSULTA do Conselho Ultramarino, ao rei D. João V, sobre a carta dos oficiais da Câmara da Paraíba, solicitando a restituição da administração do contrato do subsídio das carnes à Câmara para que, com o seu produto, possa acudir às despesas a que está obrigada. Anexo: 11 docs.

AHU ACL CU 014, Cx. 9, D. 733.

1734, julho, 19, Paraíba

CARTA do provedor da Fazenda Real da Paraíba, Jorge Salter de Mendonça, ao rei [D. João V], sobre a fabricação de um cofre de três chaves para recolher nele o dinheiro proveniente de Pernambuco, para as obras das fortificações, e pertencente à Fazenda Real. AHU_ACL_CU_014, Cx. 9, D. 742.

1734, julho, 20, Paraíba

CARTA do provedor da Fazenda Real da Paraíba, Jorge Salter de Mendonça, ao rei [D. João V], sobre a cobrança do dinheiro referente aos escravos provenientes da Costa da Mina.

Anexo: 3 docs.

AHU ACL CU 014, Cx. 9, D. 743. 
1734, agosto, 20, Paraíba

CARTA do provedor da Fazenda Real da Paraíba, Jorge Salter de Mendonça, ao rei [D. João V], sobre o exame que fez aos livros dos registros e como estes se achavam em grande confusão, causando prejuízo à Fazenda, à Infantaria e aos filhos da folha.

AHU_ACL_CU 014, Cx. 9, D. 747.

1734, agosto, 25, Paraíba

CARTA do provedor da Fazenda Real da Paraíba, Jorge Salter de Mendonça, ao rei [D. João V], remetendo relação, em anexo, de todos o rendimento e despesa da capitania.

Anexo: 2 docs.

AHU_ACL_CU_014, Cx. 9, D. 749.

1734, agosto, 26, Paraíba

CARTA do ouvidor geral da Paraíba, Jorge Salter de Mendonça, ao rei [D. João V], sobre a inquirição que fez ao escrivão da Abertura da Alfândega da cidade, Antonio Carneiro de Albuquerque, por estar servindo sem tirar provimento nem pagar novo direito, tendo 80 mil réis de ordenado.

Anexo: 1 doc

AHU_ACL_CU_014, Cx. 9, D. 750 .

1734, agosto, 26, Paraíba

CARTA do provedor da Fazenda Real da Paraíba, Jorge Salter de Mendonça, ao rei [D. João V], sobre o tesoureiro da Décima, Jácome Rodrigues Santos, não dar conta da receita e despesa; e como oficial dos contos, sem tirar provimentos nem pagar novo direito.

AHU_ACL_CU_014, Cx. 9, D. 751 .

1734, setembro, 7, Recife

CARTA do governador e capitão-general de Pernambuco, Duarte Sodré Pereira Tibão, ao rei [D. João V], sobre a remessa anual dos vinte mil cruzados do produto da dízima que está aplicado para as obras da fortaleza do Cabedelo e pagamento dos ordenados dos oficiais da mesma.

Anexo: 2 docs.

AHU_ACL_CU_014, Cx. 9, D. 752.

1734, setembro, 7, Paraíba

CARTA de Bento Bandeira de Melo, ao rei [D. João V], sobre estar servindo de provedor da Fazenda Real, no impedimento de Salvador Quaresma Dourado, contra a vontade do capitão-mor, Francisco Pedro de Mendonça Gorjão, e ter encontrado a Infantaria muito atrasada nos pagamentos.

AHU_ACL_CU_014,Cx.9, D. 753.

1734, setembro, 12, Paraíba

CARTA do provedor da Fazenda Real, Jorge Salter de Mendonça, ao rei [D. João V], solicitando ordem para declarar por onde deve ser paga a propina que têm os provedores da capitania.

Anexo: 1 doc.

AHU_ACL_CU_014, Cx. 9, D. 760 .

1734, setembro, 13, Paraíba

CARTA do capitão-mor da Paraíba, Pedro Monteiro de Macedo, ao rei [D. João V], sobre haver, no passo do Varadouro da cidade da Paraíba, uma balança pública, na qual se pesam as caixas de açúcar; informando, ainda, os valores que se pagam pela pesagem e a quem pertencia o rendimento do contrato do peso.

AHU_ACL_CU_014, Cx. 9, D. 761.

1734, setembro, 13, Recife

CARTA do provedor da Fazenda Real de Pernambuco, João do Rego Barros, informando ter remetido à Provedoria da Fazenda Real da Paraíba todo o dinheiro que foi possível cobrar dos devedores da dízima para pagamento das milícias daquela praça e fortificação, conforme ordem real.

AHU ACL CU 014, Cx. 9, D. 762.

1734, setembro, 14, Paraíba

CARTA do capitão-mor da Paraíba, Pedro Monteiro de Macedo, ao rei [D. João V], sobre o ordenado que se paga, na capitania, ao meirinho do mar e escrivão das Execuções.

AHU_ACL_CU_014, Cx. 9, D. 763 .

[ant. 1734, novembro, 4, Paraíba]

REQUERIMENTO do bacharel Teotônio Fernandes Temudo, ao rei [D. João V], solicitando uma ordinária de trinta mil réis e mandar-lhe levantar a fiança que seu sucessor lhe pediu e inteirar, pela Provedoria da Paraíba ou de Pernambuco, da quantia de cento e vinte mil réis de ordenado por ano, forma que teve quando foi provedor do Rio Grande.

AHU ACL CU 014, Cx. 9, D. 765.

[ant. 1735, fevereiro, 22, Paraíba] 
REQUERIMENTO de Francisco Pereira das Chagas, ao rei [D. João V], solicitando provimento, por tempo de um ano, da serventia do ofício de escrivão das Execuções, porteiro, selador e guarda-livros da Alfândega da Paraíba.

Anexo: 8 docs.

AHU_ACL_CU_014, Cx.9, D. 771.

[ant. 1735, maio, 2, Paraíba]

REQUERIMENTO do sargento-mor da cidade da Paraíba, ao rei [D. João V], solicitando a construção de quartéis na capitania para os soldados das duas companhias de guarnição, que estão acomodados na residência do suplicante.

AHU_ACL_CU_014, Cx. 9, D. 775 .

1735, maio, 4, Lisboa

CONSULTA do Conselho Ultramarino, ao rei D. João V, sobre a carta do provedor da Fazenda Real de Pernambuco, remetendo os rendimentos da dízima da Alfầndega da capitania.

Anexo: 5 docs.

AHU_ACL_CU_014, Cx.9, D. 776.

1735, maio, 28, Paraíba

PROVISÃO do rei D. João V, ao ouvidor geral da Paraíba, [Jorge Salter de Mendonça], mandando que o escrivão da Abertura da Alfândega, [Antonio Carneiro de Albuquerque], pague os novos direitos de todo o tempo que serviu no ofício.

Anexo: 1 doc.

AHU_ACL_CU_014, Cx. 9, D. 780.

[ant. 1735, setembro, 29, Paraíba]

REQUERIMENTO de Valério Gaspar de Oliveira, ao rei [D. João V], solicitando passar ordem ao provedor da Fazenda da Paraíba para que faça a avaliação dos ofícios de guarda-livros e selador da Alfândega, provido a Francisco Pereira das Chagas.

AHU_ACL_CU 014, Cx. 9, D. 781.

[ant. 1735, outubro, 5, Paraíba]

REQUERIMENTO do capitão do patacho Nossa Senhora do Monte do Carmo e Santa Teresa, Simão dos Santos Lisboa, ao rei [D. João V], solicitando mandar ao provedor da Fazenda Real de Paraíba restituir-lhe a quantia paga a mais no imposto dos escravos trazidos por ele da Costa da Mina.

Anexo: 3 docs.

AHU_ACL_CU_014, Cx.9, D. 783.

[ant. 1735, outubro, 6, Paraíba]

REQUERIMENTO do mestre de um bergantim, Tomé de Sousa da Ponte, ao rei [D. João V], solicitando mandar ao provedor da Fazenda da Paraíba restituir-lhe a quantia paga a mais no imposto dos escravos trazidos por ele da Costa da Mina.

Anexo: 3 docs.

AHU ACL CU 014, Cx. 9, D. 784.

[ant. 1735, outubro, 31, Lisboa]

REQUERIMENTO de Francisco Leite de Morais, arrematador do contrato da dízima da Alfândega das capitanias de Pernambuco e Paraíba, ao rei [D. João V], solicitando mandar ordenar ao Provedor da Fazenda Real das ditas capitanias [Jorge Salter de Mendonça], que admita os procuradores e feitores do suplicante.

Anexo: 5 docs.

AHU_ACL_CU_014, Cx. 9, D. 788.

1736, março, 20, Paraíba

CARTA do provedor da Fazenda Real da Paraíba, Jorge Salter de Mendonça, ao rei [D. João V], sobre a representação dos oficiais da Câmara da Paraíba, a respeito das obras da cadeia e fonte de Tambiá, necessárias à cidade.

AHU ACL CU 014, Cx. 10, D. 791

1736, maio, 23, Paraíba

CARTA do provedor da Fazenda Real da Paraíba, Jorge Salter de Mendonça, ao rei [D. João V], sobre a representação dos oficiais da Câmara da Paraíba, a respeito de se finalizar a obra da capela-mor da matriz da cidade.

AHU ACL CU 014, Cx. 10, D. 792

1736, abril, 12, Paraíba

CARTA do provedor da Fazenda Real da Paraíba, Jorge Salter de Mendonça, ao rei [D. João V], sobre o requerimento dos irmãos da Confraria de Nossa Senhora do Amparo, da Vila de Goiana, solicitando uma esmola para a obra da igreja.

Anexo: 3 docs.

AHU ACL CU 014, Cx. 10, D. 795.

1736, abril, 13, Paraíba 
CARTA do capitão-mor da Paraíba, Pedro Monteiro de Macedo, ao rei [D. João V], sobre o empréstimo que recebeu da Coroa, de quatrocentos e oitenta mil réis, para a capitania, e a dificuldade em honrar o compromisso, devido à falta de moedas de ouro, por não ser essa cidade terra de negócio, e em razão da grande seca, não virem mineiros comprar cavalos.

Anexo: 1 doc.

AHU_ACL_CU_014, Cx. 10, D. 796.

1736, abril, 20, Paraíba

CARTA do almoxarife da Fazenda Real, Gabriel da Cunha Rosa, ao rei [D. João V], sobre o procedimento do provedor Jorge Salter de Mendonça, com a sua pessoa, retirando-lhe emolumentos e propinas a que tem direito, e solicitando libertá-lo da opressão em que vive.

Anexo: 6 docs

AHU_ACL_CU_014, Cx. 10, D. 797.

1736, abril, 27, Paraíba

CARTA do capitão-mor da Paraíba, Pedro Monteiro de Macedo, ao rei [D. João V], sobre as desordens e violências decorrentes da falta de demarcação das terras, e solicitando a demarcação das terras dos índios e a colocação de marcos nos limites da capitania com a de Pernambuco e a do Rio Grande.

AHU ACL CU 014, Cx. 10, D. 800.

1736, abril, 30, Paraíba

CARTA do capitão-mor da Paraíba, Pedro Monteiro de Macedo, ao rei [D. João V], solicitando oitenta e quatro mil réis de ajuda, pelas jornadas que tem feito na capitania e assistência à fortaleza do Cabedelo.

Anexo: 1 doc.

AHU_ACL_CU_014, Cx. 10, D. 801.

1736, maio, 4, Paraíba

CARTA do provedor da Fazenda Real da Paraíba, Jorge Salter de Mendonça, ao rei [D. João V], sobre a ordem que recebeu para enviar uma relação do rendimento que tem a Fazenda Real na capitania, bem como de todos os contratos e direitos.

AHU_ACL_CU_014, Cx. 10, D. 804

1736, maio, 10, Paraíba

CARTA do provedor da Fazenda Real da Paraíba, Jorge Salter de Mendonça, ao rei [D. João V], sobre a carta do provedor da Fazenda Real de Pernambuco, [João do Rego Barros], a respeito de ter remetido vinte mil cruzados à Paraíba, referente ao produto da dízima.

AHU_ACL_CU_014, Cx. 10, D. 805.

[ant. 1736, agosto, 17, Paraíba]

REQUERIMENTO do procurador da Coroa e Fazenda Real da Paraíba, Cosme Peres de Gusmão, ao rei [D. João V], solicitando provisão para servir por mais tempo o dito cargo.

Anexo: 5 docs.

AHU_ACL_CU_014, Cx. 10, D. 807.

[ant. 1736, agosto, 29, Paraíba]

REQUERIMENTO do escrivão das Execuções da Fazenda Real, porteiro da Alfândega, selador e guarda-livros da Paraíba, Francisco Pereira das Chagas, ao rei [D. João V], solicitando mandar que o contratador das carnes, Luís Rodrigues Corrêa, pague a sua propina.

Anexo: 3 docs.

AHU_ACL_CU_014, Cx. 10, D. 808 .

1736, setembro, 17, Lisboa

CONSULTA do Conselho Ultramarino, ao rei D. João V, sobre a carta do provedor da Fazenda Real da Paraíba, Jorge Salter de Mendonça, solicitando aprovação das despesas feitas com os oficiais, índios e negros, que foram à fortaleza do Cabedelo colocar em melhores condições a pólvora que se encontrava em seu armazém.

Anexo: 2 docs.

AHU_ACL_CU_014, Cx. 10, D. 811 .

[ant. 1736, setembro, 20, Paraíba]

REQUERIMENTO de Bento Bandeira de Melo, ao rei [D. João V], solicitando mandar estranhar ao ouvidor geral da Paraíba, [Jorge Salter de Mendonça], por não deixá-lo servir o ofício de escrivão da Fazenda Real, de que é proprietário.

Anexo: 3 docs.

AHU_ACL_CU_014, Cx. 10, D. 812 .

1736, outubro, 11, Lisboa

CONSULTA do Conselho Ultramarino, ao rei D. João V, sobre a carta dos oficiais da Câmara da Paraíba acerca da necessidade de obras na cidade e do fato de não disporem de rendas, em razão do contrato das carnes, que antes era administrado pela Câmara e passou à Fazenda Real.

Anexo: 2 docs.

AHU ACL CU 014, Cx. 10, D. 813 
[ant. 1736, outubro, 17, Lisboa]

REQUERIMENTO de André da Silva da Fonseca, ao rei [D. João V], solicitando provisão, por tempo de um ano, para servir no ofício de escrivão da Abertura da Alfândega da Paraíba.

Anexo: 2 docs.

AHU_ACL_CU_014, Cx. 10, D. 814 .

[ant. 1736, outubro, 31, Paraíba]

REQUERIMENTO de Francisco Pereira das Chagas, ao rei [D. João V], solicitando provisão para servir, por mais um ano, nos ofícios de escrivão das Execuções, porteiro, guarda-livros e selador da Alfândega da Paraíba.

Anexo: 4 docs.

AHU_ACL_CU_014, Cx. 10, D. 816 .

[ant. 1736, novembro, 8, Paraíba]

REQUERIMENTO de João Pereira Baldim, ao rei [D. João V], solicitando provisão para servir o ofício de escrivão dos Órfãos da Paraíba, por tempo de um ano, visto seu pai, capitão de Infantaria paga, Diogo Pereira de Mendonça, ser proprietário do citado ofício.

Anexo: 4 docs.

AHU_ACL_CU_014, Cx. 10, D. 818

[ant. 1736, novembro, 22, Paraíba]

REQUERIMENTO de Manuel Rodrigues Portela, ao rei [D. João V], solicitando provisão para servir os ofícios de escrivão da Câmara e juiz dos Órfãos da Paraíba, por tempo de um ano.

Anexo: 3 docs.

AHU ACL CU 014, Cx. 10, D. 821.

1737, março, 30, Paraíba

CARTA (cópia) do [capitão-mor da Paraíba], Pedro Monteiro de Macedo, ao rei [D. João V], sobre a ordem para dar farinha de munição às Companhias de Infantaria da cidade de Paraíba e fortaleza do Cabedelo.

AHU_ACL_CU_014, Cx. 10, D. 824

1738, janeiro, 14, Paraíba

CARTA do capitão-mor da Paraíba, Pedro Monteiro de Macedo, ao rei [D. João V], sobre as dificuldades da capitania com uma seca, uma inundação e a falta de pagamento, por parte de Pernambuco, dos 20 mil cruzados do produto da dízima.

Anexo: 1 doc.

AHU_ACL_CU_014, Cx. 10, D. 830 .

1738, janeiro, 27, Paraíba

PORTARIA do [capitão-mor da Paraíba], Pedro Monteiro de Macedo ao Síndico dos religiosos do Convento de Santo Antonio da cidade da Paraíba, capelão Antonio dos Santos Duarte, mandando passar certidão se os padres de Santo Antonio permitem aos oficiais e soldados da fortaleza do Cabedelo, nas suas necessidades, matarem do seu gado pelo preço do contrato.

AHU_ACL_CU_014, Cx. 10, D. 831.

1738, fevereiro, 18, Paraíba

CARTA do provedor da Fazenda Real da Paraíba, Jorge Salter de Mendonça, ao rei [D. João V], sobre o recebimento e quanto importam os livros, ornamentos e apetrechos de guerra, enviados à Provedoria, matriz e Convento da Reforma do Carmo da Paraíba, através do capitão e mestre do navio Nossa Senhora da Madre de Deus e Almas, Manuel Antunes Lima.

Anexo: 3 docs.

AHU_ACL_CU_014, Cx. 10, D. 835 .

1738, fevereiro, 19, Paraíba

CARTA do provedor da Fazenda Real da Paraíba, Jorge Salter de Mendonça, ao rei [D. João V], sobre ter remetido uma relação do rendimento da Fazenda Real da Paraíba, além de todos os contratos e direitos das rendas reais, de 1736 a 1737.

AHU ACL CU 014, Cx. 10, D. 836

1738, fevereiro, 20, Paraíba

CARTA do provedor da Fazenda Real da Paraíba, Jorge Salter de Mendonça, ao rei [D. João V], sobre o contrato da carne a ser arrematado no sábado de Aleluia, e o envio da relação das propinas dos ministros e mais oficiais do Conselho Ultramarino. Anexo: 5 docs.

AHU ACL CU 014, Cx. 10, D. 837.

1738, fevereiro, 20, Paraíba

CARTA do provedor da Fazenda Real da Paraíba, Jorge Salter de Mendonça, ao rei [D. João V], sobre a ruína dos engenhos Nossa Senhora da Água de Lupe [Guadalupe] e Santo André, seqüestrados pela Fazenda Real, e o arrendamento deste último.

AHU ACL CU 014, Cx. 10, D. 838

1738, fevereiro, 20, Paraíba 
CARTA do capitão-mor da Paraíba, Pedro Monteiro de Macedo, ao rei [D. João V], solicitando pagamento dos oitenta mil réis de propina do contrato dos dízimos, arrematados por Antonio Afonso.

Anexo: 2 docs

AHU_ACL_CU_014, Cx. 10, D. 839.

[ant. 1738, fevereiro, 26, Lisboa]

REQUERIMENTO de Manuel Rodrigues Portela, ao rei [D. João V], solicitando declaração de que o suplicante não deve pagar mais propinas do contrato dos dízimos da Paraíba, que arrematou por três anos.

AHU ACL CU 014, Cx. 10, D. 840

1738, março, 3, Paraíba

CARTA dos oficiais da Câmara da Paraíba, ao rei [D. João V], sobre o projecto do capitão-mor, Pedro Monteiro de Macedo, de impor aos criadores de gado e cavalos que paguem na capitania o mesmo que oferecem, voluntariamente, aos contratadores, quando querem cortar seus lotes.

AHU ACL CU 014, Cx. 10, D. 842

1738, março, 10, Paraíba

CARTA do capitão-mor da Paraíba, Pedro Monteiro de Macedo, ao rei [D. João V], na qual diz ter mandado suprir os soldados das Companhias da cidade e fortaleza do Cabedelo com farinha de munição.

AHU ACL CU 014, Cx. 10, D. 843

1738, março, 10, Paraíba

CARTA do provedor da Fazenda Real da Paraíba, Jorge Salter de Mendonça, ao rei [D. João V], sobre a arrematação do contrato do subsídio das carnes e remetendo a folha da importância das propinas que tocam aos ministros e oficiais do Conselho Ultramarino.

Anexo: 2 docs

AHU ACL CU 014, Cx. 10, D. 844.

1738, março, 17, Paraíba

CARTA do capitão-mor da Paraíba, Pedro Monteiro de Macedo, ao rei [D. João V], sobre a ordem que recebeu para informar, ouvindo o provedor da Fazenda e o almoxafire, sobre a representação que se fez contra o tesoureiro da dízima por elevar a dez por cento o pagamento que se fez, em fazendas, aos soldados.

Anexo: 1 doc.

AHU_ACL_CU_014, Cx. 10, D. 845 .

1738, março, 20, Paraíba

CARTA do provedor da Fazenda Real da Paraíba, Jorge Salter de Mendonça, ao rei [D. João V], sobre a ordem para pagar a quantia de 480 mil réis ao capitão-mor, Pedro Monteiro de Macedo, por conta de seus soldos.

Anexo: 1 doc.

AHU_ACL_CU_014, Cx. 10, D. 846 .

1738, março, 23, Paraíba

CARTA dos oficiais da Câmara da Paraíba, ao rei [D. João V], sobre a conveniência de se prorrogar a graça de não serem executados os senhores de engenho e lavradores da capitania, em suas fábricas.

AHU_ACL_CU_014, Cx. 10, D. 848 .

1738, março, 29, Paraíba

CARTA do provedor da Fazenda Real da Paraíba, Jorge Salter de Mendonça, ao rei [D. João V], sobre a arrematação do contrato dos dízimos reais, pelo tenente-coronel Manuel Rodrigues Portela, e remetendo a folha da importância das propinas que tocam aos ministros e oficiais do Conselho Ultramarino.

Anexo: 4 docs

AHU ACL CU 014, Cx. 10, D. 849.

1738, março, 30, Paraíba

CARTA do capitão-mor da Paraíba, Pedro Monteiro de Macedo, ao rei [D. João V], sobre as arrematações dos engenhos Podre e Santo André, penhorados à Fazenda Real da capitania, pelo alcaide-mor Gaspar Acioli de Vasconcelos.

Anexo: 1 doc.

AHU ACL CU 014, Cx. 10, D. 850.

1738, abril, 7, Paraíba

CARTA do provedor da Fazenda Real da Paraíba, Jorge Salter de Mendonça, ao rei [D. João V], sobre cobrar da Santa Casa da Misericórdia o subsídio referente ao embarque das caixas provenientes das rendas de um dos engenhos, Espírito Santo ou Santo Antonio, de que a mesma possui a metade.

AHU_ACL_CU_014, Cx. 10, D. 851.

[post. 1738, abril,18, Paraíba]

REQUERIMENTO de André da Silva Fonseca, ao rei [D. João V], solicitando prorrogação da serventia do ofício de escrivão da Abertura da Alfândega da Paraíba.

Anexo: 4 docs 


\section{AHU_ACL_CU_014, Cx. 10, D. 853.}

[ant. 1738, agosto, 7, Lisboa]

REQUERIMENTO do ajudante supra, Francisco de Melo Moniz, ao rei [D. João V], solicitando mandar juntar seu requerimento à carta do capitão-mor, [Pedro Monteiro de Macedo], sobre a falta de pagamento dos soldos da Infantaria, nomeando-o representante da Paraíba na Corte e solicitando que o suplicante continue a vencer o seu soldo durante sua ausência, como estivesse na capitania.

Anexo: 2 docs.

AHU_ACL_CU_014, Cx. 10, D. 856.

1738, agosto, 11, Lisboa

AVISO do secretário do Conselho Ultramarino, Manuel Caetano Lopes de Lavre, a João Bressane Leite, sobre as cartas do capitãomor da Paraíba, [Pedro Monteiro de Macedo], e do provedor da Fazenda Real da Paraíba, Jorge Salter de Mendonça acerca da farinha que se dá aos soldados da capitania como pão de munição.

Anexo: 5 docs.

AHU_ACL_CU_014, Cx. 10, D. 859.

1738 , agosto, 29, Lisboa

OFÍCIO do vedor-geral, João Luís de Renedro, ao [secretário do Conselho Ultramarino], Manuel Caetano Lopes de Lavre, sobre as cartas do capitão-mor da Paraíba, Pedro Monteiro de Macedo, e do provedor da Fazenda Real da Paraíba, Jorge Salter de Mendonça, a respeito de se dar um cavalo e um negro ao sargento-mor engenheiro, Luís Xavier Bernardo, por conta da Fazenda Real.

Anexo: 9 docs.

AHU_ACL_CU_014, Cx. 10, D. 863 .

1738, setembro, 1, Lisboa

CONSULTA (cópia) do Conselho Ultramarino, ao rei D. João V, sobre a carta dos oficiais da Câmara da Paraíba, solicitando a prorrogação da graça de não serem os senhores de engenho e lavradores de cana executados nas fábricas mas nos seus rendimentos. Anexo: 1 doc.

AHU_ACL_CU_014, Cx. 10, D. 864.

1738, setembro, 16, Lisboa

CONSULTA do Conselho Ultramarino, ao rei D. João V, sobre a carta do capitão-mor da Paraíba, Pedro Monteiro de Macedo, a respeito da falta de pagamento dos soldos dos soldados da capitania e da remessa das consignações, enviadas por Pernambuco, destinadas às fortificações.

Anexo: 1 doc.

AHU_ACL_CU_014, Cx. 10, D. 867

[ant. 1738, setembro, 26, Paraíba]

REQUERIMENTO de Antonio Carneiro de Albuquerque, ao rei [D. João V], solicitando provisão para exercer o ofício de escrivão da Abertura da Alfândega da Paraíba.

Anexo: 8 docs.

AHU_ACL_CU_014, Cx. 10, D. 872.

[ant. 1738, outubro, 12, Lisboa]

REQUERIMENTO de Cosme Peres de Gusmão, ao rei [D. João V], solicitando provisão para continuar a servir o ofício de procurador da Coroa e Fazenda Real da Paraíba, por tempo de um ano. Anexo: 2 docs. AHU_ACL_CU_014, Cx. 10, D. 876.

[ant. 1738, novembro, 22, Paraíba]

REQUERIMENTO de Antonio Pereira Lisboa, ao rei [D. João V], solicitando mandar que lhe pague todo o ordenado e emolumentos a que tem direito como meirinho-mor da Paraíba.

Anexo: 13 docs.

AHU_ACL_CU_014, Cx. 10, D. 878 .

1739, março, 3, Lisboa

DESPACHO do Conselho Ultramarino sobre a carta do capitão-mor da Paraíba, informando da necessidade de fortificar a Baía da Traição.

Anexo: 5 docs.

AHU_ACL_CU_014, Cx. 11, D. 880.

[ant. 1739, março, 27, Lisboa]

REQUERIMENTO do contratador dos dízimos reais da Paraíba, Manuel Rodrigues Portela, ao rei [D. João V], solicitando ordenar que o preço do açúcar, que o suplicante é obrigado a pagar à Fazenda Real, em virtude do seu contrato, seja feito por louvados em Câmara.

Anexo: 1 doc.

AHU ACL_CU 014, Cx. 11, D. 881 . 
1739, março, 28, Lisboa

CONSULTA do Conselho Ultramarino, ao rei D. João V, sobre a nomeação de pessoas para o ofício de almoxarife da Fazenda Real da Paraíba, por três anos.

Anexo: 3 docs

AHU_ACL_CU_014, Cx. 11, D. 882 .

1739, dezembro, 1, Cabedelo

CARTA do capitão-mor da Paraíba, Pedro Monteiro de Macedo, ao rei [D. João V], sobre a informação do provedor da Fazenda Real e ouvidor geral da Paraíba, Jorge Salter de Mendonça, informando o quanto tem entrado da consignação de Pernambuco para as despesas da capitania.

Anexo: 3 docs.

AHU_ACL_CU_014, Cx. 11, D. 896 .

1739, dezembro, 8, Cabedelo

CARTA do capitão-mor da Paraíba, Pedro Monteiro de Macedo, ao rei [D. João V], sobre o projeto de se pagar os gados na capitania e não em Pernambuco, para o donativo e subsídio das carnes, e, no rio São Francisco, ao gado e cavalos que vão às minas.

Anexo: 2 docs.

AHU_ACL_CU_014, Cx. 11, D. 897.

1739, dezembro, 15, Paraíba

CARTA do provedor da Fazenda Real da Paraíba, Jorge Salter de Mendonça, ao rei [D. João V], sobre os rendimentos e despesas da Provedoria da Paraíba, nos anos de 1738 e 1739.

Anexo: 2 docs.

AHU_ACL_CU_014, Cx. 11, D. 898.

[ant. 1740, maio, 9, Paraíba]

REQUERIMENTO do bacharel Manuel Rodrigues Coelho, ao rei [D. João V], solicitando provisão para continuar no ofício de procurador da Coroa e Fazenda Real, na cidade de Nossa Senhora das Neves, por tempo de seis anos.

Anexo: 4 docs.

AHU_ACL_CU_014, Cx. 11, D. 906.

[ant. 1740, maio, 24, Paraíba]

REQUERIMENTO de Francisco Pereira das Chagas, ao rei [D. João V], solicitando provisão para continuar no ofício de escrivão das Execuções da Fazenda Real, porteiro da Alfândega, selador e guarda-livros da Casa dos Contos da cidade da Paraíba, por tempo de um ano.

Anexo: 2 docs.

AHU_ACL_CU_014, Cx. 11, D. 914

1740, junho, 20, Lisboa

CONSULTA do Conselho Ultramarino, ao rei D. João V, sobre a carta de capitão-mor da Paraíba, Pedro Monteiro de Macedo, informando ser conveniente a união dos ofícios de almoxarife da Fazenda Real e tesoureiro da Dízima da capitania.

Anexo: 1 doc.

AHU_ACL_CU_014, Cx. 11, D. 917.

[ant. 1740, julho, 9, Paraíba]

REQUERIMENTO do alferes da fortaleza do Cabedelo, José de Melo Moniz, ao rei [D. João V], solicitando mandar satisfazer seus soldos em dobro, na forma que se praticou com o capitão Manuel Fernandes Abrunhosa.

Anexo: 7 docs.

AHU ACL CU 014, Cx. 11, D. 919.

1740, novembro, 10, Lisboa

ESCRITO do secretário interino da Junta dos Três Estados, João dos Santos Leite Bressane, ao [secretário do Conselho Ultramarino], Manuel Caetano Lopes de Lavre, sobre a avaliação do ofício de guarda-livros da Alfândega da Paraíba, em que está provido Francisco Pereira das Chagas, e o modo de apurar o seu rendimento anual em ordenado, propinas e emolumentos, para pagar os novos direitos. AHU_ACL_CU_014, Cx. 11, D. 925.

[ant. 1740, novembro, 22, Paraíba]

REQUERIMENTO do ouvidor geral da Paraíba, Inácio de Sousa Jácome Coutinho, ao rei [D. João V], solicitando provisão para poder servir também o ofício de provedor da Fazenda Real.

Anexo: 1 doc.

AHU_ACL_CU_014, Cx. 11, D. 926.

1740, novembro, 29, Lisboa

CONSULTA do Conselho Ultramarino, ao rei D. João V, sobre a carta do capitão-mor da Paraíba, Pedro Monteiro de Macedo, solicitando o hábito de Cristo, com sua tença, informa ainda sobre o fato de alguns frades franciscanos satirizarem aos que governam, difamando-os de judeu. 
Anexo: 1 doc.

AHU_ACL_CU_014, Cx. 11, D. 927.

1740, dezembro, 9, Lisboa

CONSULTA do Conselho Ultramarino, ao rei D. João V, sobre a carta do capitão-mor, Pedro Monteiro de Macedo, a respeito dos doze mil cruzados de Pernambuco, destinados à Fazenda Real da Paraíba, para pagamento das farinhas e fardas dos oficiais e soldados da capitania.

Anexo: 3 docs.

AHU_ACL_CU_014, Cx. 11, D. 928.

1741, junho, 16, Paraíba

CARTA do [provedor da Fazenda Real da Paraíba], Bento Bandeira de Melo, ao rei [D. João V], sobre os procedimentos e administração do capitão-mor da Paraíba, [Pedro Monteiro de Macedo].

AHU_ACL_CU_014, Cx. 11, D. 934

1741, junho, 20, Paraíba

CARTA do ouvidor geral da Paraíba, Inácio de Sousa Jácome Coutinho, ao rei [D. João V], sobre a serventia do lugar de provedor da Fazenda Real da capitania.

AHU_ACL_CU_014, Cx. 11, D. 935.

1741, julho, 2, Paraíba

CARTA dos oficiais da Câmara da Paraíba, ao rei [D. João V], remetendo a relação da avaliação dos ofícios da capitania para pagamento dos novos direitos.

Anexo: 2 docs.

AHU_ACL_CU_014, Cx. 11, D. 936.

1741, setembro, 4, Paraíba

CARTA do capitão-mor da Paraíba, Pedro Monteiro de Macedo, ao rei [D. João V], remetendo a relação dos rendimentos da Fazenda Real da Paraíba, de 1739 a 1741.

Anexo: 1 doc.

AHU_ACL_CU_014, Cx. 11, D. 939.

[ant. 1742, abril, 4, Paraíba]

REQUERIMENTO do alferes de Companhia paga da guarnição da cidade de Paraíba, Manuel Gonçalves Ramalho, ao rei [D. João V], solicitando passar provisão para que o provedor da Fazenda Real pague seus soldos, fardamento e pão de munição, desde o tempo que sentou praça até a presente solicitação.

Anexo: 12 docs.

AHU_ACL_CU_014, Cx. 11, D. 954

1742, abril, 12, Lisboa

CONSULTA do Conselho Ultramarino, ao rei D. João V, sobre o requerimento do capelão da Infantaria paga da cidade da Paraíba, padre João Loureiro Viegas, solicitando uma quarta de farinha todos os dez dias, por pão de munição, como foi concedido aos capelães dos Terços da Bahia.

Anexo: 3 docs.

AHU ACL_CU 014, Cx. 11, D. 955.

1742, junho, 19, Lisboa

CONSULTA do Conselho Ultramarino, ao rei D. João V, sobre o requerimento do contratador do contrato das carnes da Paraíba, João da Silva Chaves, solicitando passar novas ordens ao capitão-mor, [Pedro Monteiro de Macedo], e ao ouvidor geral da Paraíba, para que façam observar as condições do seu contrato.

AHU_ACL_CU_014, Cx. 11, D. 959.

1742, setembro, 5 , Lisboa

CONSULTA do Conselho Ultramarino, ao rei D. João V, sobre a nomeação de pessoas para serventia do cargo de provedor da Fazenda Real da Paraíba, por três anos.

Anexo: 6 docs.

AHU_ACL_CU_014, Cx. 11, D. 962.

[ant. 1742, outubro, 3, Lisboa]

REQUERIMENTO do contratador do contrato das carnes e dízimos reais da Paraíba, José Gomes da Silveira, ao rei [D. João V], solicitando provisão para que possa transferir todos os efeitos do produto do contrato para Pernambuco, e que não impeçam a retirada dos mesmos da dita capitania.

Anexo: 4 docs.

AHU ACL_CU 014, Cx. 11, D. 968.

1743, janeiro, 30, Paraíba 
CARTA do capitão-mor da Paraíba, Pedro Monteiro de Macedo, ao rei [D. João V], sobre as razões que teve para nomear Francisco da Costa, no cargo de provedor, e Manuel de Oliveira, no ofício de escrivão da Fazenda Real.

Anexo: 3 docs.

AHU_ACL_CU_014, Cx. 12, D. 971.

1743, fevereiro, 2, Paraíba

CERTIDÃO do escrivão da Ouvidoria, Manuel Rodrigues da Fonseca, comprovando o pagamento do ordenado e côngrua do reverendo Antonio da Silva e Melo, pelo provedor da Fazenda Real da Paraíba, Bento Bandeira de Melo.

AHU_ACL_CU_014, Cx. 12, D. 972.

1743, fevereiro, 6, Paraíba

CARTA do provedor da Fazenda Real da Paraíba, Bento Bandeira de Melo, ao rei [D. João V], sobre a prisão de Cosme Peres de Gusmão e o excesso de poder praticado pelo capitão-mor da Paraíba, Pedro Monteiro de Macedo.

Anexo: 4 docs.

AHU ACL CU 014, Cx. 12, D. 974

1743, fevereiro, 24, Paraíba

CARTA do provedor da Fazenda Real da Paraíba, Bento Bandeira de Melo, ao rei [D. João V], sobre as queixas que fez aos procedimentos do capitão-mor da Paraíba, Pedro Monteiro de Macedo, mandando soltar Cosme Peres de Gusmão, sem a sua autorização.

Anexo: 1 doc

AHU_ACL_CU_014, Cx. 12, D. 980 .

1743, março, 1, Paraíba

CARTA do capitão-mor da Paraíba, Pedro Monteiro de Macedo, ao rei [D. João V], sobre a resolução ordenando que faça sair da capitania o padre Pedro Tavares, por vender carne publicamente pelas ruas da cidade.

Anexo: 7 docs.

AHU_ACL_CU_014,Cx. 12, D. 981

1743, março, 5, Paraíba

CARTA do provedor da Fazenda Real da Paraíba, Bento Bandeira de Melo, ao rei [D. João V], sobre a corrupção praticada pelo almoxarife da Fazenda Real, Amaro Velho de Vasconcelos, e pelo escrivão Francisco da Costa Silveira, no que se refere à venda de papéis; e queixando-se dos procedimentos do capitão-mor da Paraíba, Pedro Monteiro de Macedo, no tocante a sua pessoa.

Anexo: 2 docs.

AHU_ACL_CU_014, Cx. 12, D. 983

1743, março, 6, Paraíba

CARTA do provedor da Fazenda Real da Paraíba, Bento Bandeira de Melo, ao rei [D. João V], sobre os custos referentes ao envio de livros e fardamentos à Paraíba.

Anexo: 2 docs.

AHU_ACL_CU_014, Cx. 12, D. 984

1743, março, 15, Paraíba

CARTA do provedor da Fazenda Real da Paraíba, Bento Bandeira de Melo, ao rei [D. João V], sobre o modo como se procedeu a arrematação dos contratos pelo almoxarife e tesoureiro.

Anexo: 1 doc.

AHU_ACL_CU_014, Cx. 12, D. 986.

1743, março, 26, Paraíba

CARTA do capitão-mor da Paraíba, Pedro Monteiro de Macedo, ao rei [D. João V], sobre a carta dos oficiais da Câmara da Paraíba, informando a impossibilidade de se pagar a terça parte do rendimento dos ofícios.

Anexo: 1 doc.

AHU_ACL_CU_014,Cx. 12, D. 988

1743, abril, 12, Paraíba

CARTA do provedor da Fazenda Real da Paraíba, Bento Bandeira de Melo, ao rei [D. João V], sobre a arrematação do contrato do açúcar, por três anos.

Anexo: 1 doc

AHU ACL CU 014, Cx. 12, D. 989

1743, abril, 12, Paraíba

CARTA do capitão-mor da Paraíba, Pedro Monteiro de Macedo, ao rei [D. João V], sobre a administração da justiça, os atos do provedor da Fazenda Real da Paraíba, Bento Bandeira de Melo, as obras da fortaleza do Cabedelo e a despesa da Fazenda Real, de 1741 a 1742 .

Anexo: 3 docs.

AHU_ACL_CU_014, Cx. 12, D. 990 .

1743, abril, 14, Paraíba 
CARTA do provedor da Fazenda Real da Paraíba, Bento Bandeira de Melo, ao rei [D. João V], sobre o pedido de Francisco de Arruda Câmara, para que lhe fossem confirmadas as sesmarias de terras no sertão do Cariri.

AHU_ACL_CU_014, Cx. 12, D. 991.

1743, agosto, 5, Paraíba

CARTA do provedor da Fazenda Real da Paraíba, Bento Bandeira de Melo, ao rei [D. João V], sobre o modo como procedeu à devassa que realizou aos soldados da fortaleza do Cabedelo.

AHU_ACL_CU_014, Cx. 12, D. 997.

1743, agosto, 6, Paraíba

CARTA do provedor da Fazenda Real da Paraíba, Bento Bandeira de Melo, ao rei [D. João V], sobre o modo como se tem procedido à arrematação do contrato dos dízimos na capitania.

Anexo: 3 docs.

AHU_ACL_CU_014, Cx. 12, D. 998

1743, agosto, 21, Lisboa

DESPACHO do Conselho Ultramarino sobre o parecer do procurador da Coroa, a respeito do provedor da Fazenda Real da Paraíba.

AHU ACL CU 014, Cx. 12, D. 1000.

[ant. 1743, setembro, 4, Lisboa]

REQUERIMENTO de Vicente Pereira da Costa, ao rei [D. João V], solicitando a confirmação do lance que fez para arrematar o contrato dos dízimos da cidade da Paraíba.

Anexo: 2 docs.

AHU_ACL_CU_014, Cx. 12, D. 1001.

1743, setembro, 25, Lisboa

CONSULTA do Conselho Ultramarino, ao rei D. João V, sobre o requerimento dos ofíciais da Câmara da Paraíba, solicitando uma remessa de dinheiro de cobre.

Anexo: 6 docs.

AHU_ACL_CU_014, Cx. 12, D. 1002.

1743, novembro, 14, Paraíba

CARTA do provedor da Fazenda Real da Paraíba, Bento Bandeira de Melo, ao rei [D. João V], sobre Salvador Quaresma Dourado e Jorge Salter de Mendonça, provedores da Fazenda Real da Paraíba.

Anexo: 1 doc., m. est.

AHU ACL CU 014, Cx. 12, D. 1007

1743, novembro, 26, Lisboa

CONSULTA do Conselho Ultramarino, ao rei D. João V, sobre as razões prementes para a substituição do capitão-mor da Paraíba, Pedro Monteiro de Macedo.

Anexo: 12 docs.

AHU ACL CU 014, Cx. 12, D. 1009

[ant. 1743, dezembro, 17, Paraíba]

REQUERIMENTO de Jacinto Teixeira Mendes, Manuel Martins Grangeiro e os homens de negócio da cidade da Paraíba, ao rei [D

João V], solicitando para que os produtos que vêm do Reino, não tenham que pagar dois direitos, em duas Alfândegas distintas, na Paraíba e em Pernambuco.

AHU ACL CU 014, Cx. 12, D. 1012.

[ant. 1745, junho, 5, Paraíba]

REQUERIMENTO do capitão Luís Álvares Filgueira do Amaral, ao rei [D. João V], solicitando que este documento deveria ir junto a uma carta do provedor da Fazenda Real da Paraíba, na qual afirmava que os cofres do almoxarifado não estavam na posse do seu responsável.

Anexo: 12 docs.

AHU_ACL_CU_014, Cx. 13, D. 1115.

1744, fevereiro, 4, Lisboa

CARTA de Felix de Azevedo, ao rei [D. João V], sobre o pedido de Vicente Pereira da Costa para que o monarca lhe confirme a arrematação do contrato dos dízimos da Paraíba.

Anexo: 4 docs.

AHU_ACL_CU_014, Cx. 12, D. 1018

1744, fevereiro, 27, Paraíba 
CONSULTA do Conselho Ultramarino, ao rei D. João V, sobre as cartas do capitão-mor da Paraíba, Pedro Monteiro de Macedo, alusivas aos descaminhos da verba para o pagamento da Infantaria, ocorridos na Fazenda Real, na época do provedor Jorge Salter de Mendonça.

Anexo: 52 docs.

AHU_ACL_CU_014, Cx. 12, D. 1021.

1744,setembro, 7, Paraíba

CARTA (cópia) do capitão-mor interino da Paraíba, João Lobo de Lacerda, ao rei [D. João V], em resposta à provisão sobre o modo como guardou as verbas da Real Fazenda, em cofres de três chaves, informando, ainda, que não efetuou o pagamento dos soldados. AHU_ACL_CU_014, Cx. 13, D. 1047.

1744, setembro, 8, Paraíba

CARTA do capitão-mor interino da Paraíba, João Lobo de Lacerda, ao rei [D. João V], em resposta à provisão sobre a demarcação das terras de sesmaria, a serem realizadas pelos provedores.

Anexo: 5 docs.

AHU_ACL_CU_014, Cx. 13, D. 1048.

1744, setembro, 19, Paraíba

CARTA do provedor da Fazenda Real da Paraíba, José Antonio da Cunha, ao rei [D. João V], em resposta à provisão sobre a entrega do sal pelos mestres de navios.

AHU ACL CU 014, Cx. 13, D. 1050.

1744, setembro, 19, Paraíba

CARTA do provedor da Fazenda Real da Paraíba, José Antonio da Cunha, ao rei [D. João V], em resposta à provisão sobre a arrematação do contrato do açúcar.

AHU ACL CU 014, Cx. 13, D. 1051.

1744, setembro, 26, Paraíba

CARTA do provedor da Fazenda Real da Paraíba, José Antonio da Cunha, ao rei [D. João V], sobre o envio da lei de concessão de sesmarias aos oficiais da Câmara da Paraíba e ao procurador da Coroa.

Anexo: 1 doc.

AHU_ACL_CU_014, Cx. 13, D. 1055

1744, setembro, 28, Paraíba

CARTA do capitão-mor interino da Paraíba, João Lobo de Lacerda, ao rei [D. João V], em resposta à provisão sobre a proibição, ao padre Pedro Tavares, de vender carne na rua, em detrimento do contrato das carnes.

AHU ACL CU 014, Cx. 13, D. 1058.

1744, setembro, 29, Paraíba

CARTA do provedor da Fazenda Real da Paraíba, José Antonio da Cunha, ao rei [D. João V], em reposta à provisão sobre a rematação dos bens que dois oficiais devem à Fazenda Real.

Anexo: 2 docs.

AHU ACL CU 014, Cx. 13, D. 1059.

1744, setembro, 29, Paraíba

CARTA do provedor da Fazenda Real da Paraíba, José Antonio da Cunha, ao rei [D. João V], sobre a ordem que recebeu para informar acerca dos trabalhos de talha do altar de São Sebastião da igreja da Paraíba, fonte de Tambiá, cadeia e outras obras.

AHU ACL CU 014, Cx. 13, D. 1060.

1744, setembro, 30, Paraíba

CARTA do provedor da Fazenda Real da Paraíba, José Antonio da Cunha, ao rei [D. João V], sobre o desaparecimento do livro das medições das obras da fortaleza do Cabedelo e da Casa dos Contos da Paraíba.

Anexo: 2 docs.

AHU ACL CU 014, Cx. 13, D. 1061.

1744, outubro, 2, Paraíba

CARTA do provedor da Fazenda Real da Paraíba, José Antonio da Cunha, ao rei [D. João V], em reposta à provisão sobre o pagamento do contrato dos dízimos e subsídio das carnes por José Gomes da Silveira.

Anexo: 1 doc.

AHU_ACL_CU_014, Cx. 13, D. 1064.

1744, outubro, 2, Paraíba

CARTA do provedor da Fazenda Real da Paraíba, José Antonio da Cunha, ao rei [D. João V], sobre a colocação em praça do contrato do subsídio das carnes.

Anexo: 3 docs. 


\section{AHU_ACL_CU_014, Cx. 13, D. 1065.}

1744, outubro, 2, Paraíba

CARTA do provedor da Fazenda Real da Paraíba, José Antonio da Cunha, ao rei [D. João V], sobre arrematação do contrato dos dizímos reais e pela ausência de lances para que o mesmo pudesse ser entregue.

Anexo: 3 docs.

AHU_ACL_CU_014, Cx. 13, D. 1066.

1744, outubro, 3, Paraíba

CARTA do provedor da Fazenda Real da Paraíba, José Antonio da Cunha, ao rei [D. João V], sobre as diligências que efetuou para restaurar a casa da pólvora do Cabedelo, devido ao mau estado de conservação do edifício, bem como do material que nela se encontrava.

Anexo: 1 doc.

AHU_ACL_CU_014, Cx. 13, D. 1067.

1744, outubro, 5, Paraíba

CARTA do provedor da Fazenda Real da Paraíba, José Antonio da Cunha, ao rei [D. João V], sobre as medidas tomadas para reaver o selo da Alfândega que estava em poder de Francisco Pereira das Chagas, quando o mesmo exerceu o ofício de porteiro, guarda-livros da Casa dos Contos e escrivão das Execuções; e dando conta, ainda, da residência que mandou tirar ao ouvidor geral, Inácio de Sousa Jácome Coutinho.

AHU ACL CU_014, Cx. 13, D. 1069.

1744, outubro, 5, Paraíba

CARTA RÉGIA (cópia) de D. João V, aos oficiais da Câmara da Paraíba, sobre os serviços prestados por estes ao capitão-mor, João da Maia da Gama, durante a sublevação de Pernambuco.

AHU ACL CU 014, Cx. 13, D. 1071.

1744, outubro, 5, Paraíba

CARTA dos oficiais da Câmara da Paraíba, ao rei [D. João V], sobre a isenção dos oficiais no pagamento das terças partes dos seus ofícios e em que solicitam só serem destituídos dos seus cargos após um processo judicial que comprove a sua culpa. Anexo: 2 docs

AHU_ACL_CU_014, Cx. 13, D. 1072.

1744, outubro, 7, Paraíba

CARTA do provedor da Fazenda Real da Paraíba, José Antonio da Cunha, ao rei [D. João V], sobre a devassa contra os descaminhos da Fazenda Real e o seqüestro dos bens do capitão-mor, Pedro Monteiro de Macedo, por seu testamenteiro, padre João de Loureiro Viegas, que tentou impedir aquele trabalho.

AHU_ACL_CU_014, Cx. 13, D. 1077.

1744, outubro, 10, Paraíba

CARTA dos oficiais da Câmara da Paraíba, ao rei [D. João V], sobre o governo do capitão-mor da Paraíba, Pedro Monteiro de Macedo, que, levado pelo seu modo de ser, prejudicou alguns habitantes desta capitania e desautorizou alguns oficiais e membros da Justiça.

AHU_ACL_CU_014, Cx. 13, D. 1081.

1744, outubro, 12, Paraíba

CARTA de Bento Bandeira de Melo, ao rei [D. João V], solicitando o arrendamento do seu ofício para que com ele possa sobreviver. AHU ACL CU 014, Cx. 13, D. 1082.

1744, outubro, 14, Paraíba

CARTA do provedor da Fazenda Real da Paraíba, José Antonio da Cunha, ao rei [D. João V], em resposta à provisão sobre o provimento do cargo de escrivão da Abertura, despacho e descarga da Alfândega.

Anexo: 2 docs.

AHU_ACL_CU_014, Cx. 13, D. 1083.

1744, outubro, 15, Paraíba

CARTA dos oficiais da Câmara da Paraíba, ao rei [D. João V], sobre a péssima notícia da Paraíba ficar subordinada à capitania de Pernambuco e as implicações que poderão advir.

AHU ACL CU 014, Cx. 13, D. 1084.

1744, outubro, 15, Paraíba

CARTA dos oficiais da Câmara da Paraíba, ao rei [D. João V], sobre o atraso das obras de decoração em talha dourada do altar de São Sebastião, na igreja matriz da cidade, bem como da cadeia, casa da Câmara e fonte de Tambiá, devido à falta de verbas, cujo pagamento, o provedor da Fazenda Real ainda não efetuou.

AHU ACL CU 014, Cx. 13, D. 1085. 
1744, outubro, 16, Paraíba

CARTA do provedor da Fazenda Real da Paraíba, José Antonio da Cunha, ao rei [D. João V], sobre a invocação de Jesus para protetor e defensor dos oficiais e soldados da capitania e a quantia paga por seus membros à sua irmandade.

AHU_ACL_CU_014, Cx. 13, D. 1086.

1744, outubro, 18, Paraíba

CARTA do provedor da Fazenda Real da Paraíba, José Antonio da Cunha, ao rei [D. João V], sobre o modo como o almoxarife da Fazenda e o tenente mestre-de-campo, Luís Xavier Bernardo, têm agido de modo a prejudicar a sua ação, não podendo ele executar todas as suas tarefas na conformidade da lei.

Anexo: 1 doc.

AHU_ACL_CU_014, Cx. 13, D. 1087.

1744, outubro, 19, Paraíba

CARTA do provedor da Fazenda Real da Paraíba, José Antonio da Cunha, ao rei [D. João V], sobre as interferências do governador interino na sua atividade, nomeadamente no que se refere a uma contenda de terras entre o mestre-de-campo Luís Xavier Bernardo e Tomás Nix da Penha.

Anexo: 1 doc.

AHU_ACL_CU_014, Cx. 13, D. 1088.

1744, outubro, 20, Paraíba

CARTA do provedor da Fazenda Real da Paraíba, José Antonio da Cunha, ao rei [D. João V], em resposta à provisão sobre a letra que foi enviada aos ministros e oficiais do Conselho Ultramarino e recaía sobre a propina do contrato dos dízimos de Vicente Pereira Costa.

AHU_ACL_CU_014, Cx. 13, D. 1089.

1744, outubro, 20, Paraíba

CARTA do provedor da Fazenda Real da Paraíba, José Antonio da Cunha, ao rei [D. João V], sobre o que foi dispendido para recuperar a pólvora que estava arruinada na fortaleza do Cabedelo.

Anexo: 1 doc.

AHU ACL CU 014, Cx. 13, D. 1090.

1744, outubro, 20, Paraíba

CARTA do provedor da Fazenda Real da Paraíba, José Antonio da Cunha, ao rei [D. João V], sobre os livros que foram remetidos à capitania, importando em setenta mil e quatrocentos réis, quantia que deve ser enviada ao Reino.

AHU ACL CU 014, Cx. 13, D. 1091.

1744, outubro, 26, Paraíba

CARTA do procurador da Coroa e Fazenda, Francisco Gaia da Rocha, ao rei [D. João V], sobre a ocupação indevida das terras, porque as mesmas são ocupadas sem serem confirmadas e os ocupantes se expandem em mais de três léguas, contra a lei de concessão de sesmarias.

Anexo: 2 docs.

AHU_ACL_CU_014, Cx. 13, D. 1095.

1744, outubro, 28, Paraíba

CARTA do provedor da Fazenda Real da Paraíba, José Antonio da Cunha, ao rei [D. João V], sobre o modo como tem efetuado o seu trabalho e como alguns habitantes da capitania se expressam acerca dos bons serviços que tem prestado no exercício do referido cargo. Anexo: 15 docs.

AHU_ACL_CU_014, Cx. 13, D. 1098 .

1744, outubro, Paraíba

CARTA do provedor da Fazenda Real da Paraíba, José António da Cunha, ao rei [D. João V], sobre a verba que pediu ao provedor da Fazenda Real de Pernambuco para pagamento das tropas da guarnição e empreiteiros da fortaleza do Cabedelo.

Obs.: m. est.

AHU_ACL_CU_014, Cx. 13, D. 1099.

1745, março, 17, Paraíba

CARTA do provedor da Fazenda Real da Paraíba, José Antonio da Cunha, ao rei [D. João V], sobre as medidas tomadas pelo Bispo de Pernambuco, D. Fr. Luís de Santa Teresa, para demonstrar que ele não desempenha bem as suas tarefas e referindo-se, ainda, à demora do governador da Paraíba, Antonio Borges da Fonseca em assumir o cargo.

Anexo: 6 docs.

AHU_ACL_CU_014, Cx. 13, D. 1111.

1745, março, 17, Paraíba 
CARTA do provedor da Fazenda Real da Paraíba, José Antonio da Cunha, ao rei [D. João V], sobre as averiguações feitas nos livros da Provedoria no intuito de demonstrar a sua inapacidade para o exercício do cargo.

AHU_ACL_CU_014, Cx. 13, D. 1112 .

[ant. 1745, junho, 5, Paraíba]

REQUERIMENTO do capitão Luís Álvares Filgueira do Amaral, ao rei [D. João V], solicitando que este documento deveria ir junto a uma carta do provedor da Fazenda Real da Paraíba, na qual afirmava que os cofres do almoxarifado não estavam na posse do seu responsável.

Anexo: 12 docs.

AHU_ACL_CU_014, Cx. 13, D. 1115.

1745, julho, 3, Lisboa

CONSULTA do Conselho Ultramarino, ao rei D. João V, sobre a suspensão de Francisco Pereira das Chagas do ofício de escrivão das Execuções, selador e guarda-livros da Alfândega, pelo capitão-mor da Paraíba, Pedro Monteiro de Macedo.

Anexo: 33.

AHU_ACL_CU_014, Cx. 13, D. 1118.

1745, julho, 28, Lisboa

CONSULTA do Conselho Ultramarino, ao rei D. João V, sobre a conta do provedor da Fazenda Real da Paraíba, José Antonio da Cunha, dos seqüestros que fez, tendo em vista os descaminhos que se achavam na Fazenda Real.

Anexo: 25 docs.

AHU_ACL_CU_014, Cx. 13, D. 1120.

[ant. 1745, agosto, 17, Paraíba]

REQUERIMENTO do padre Pedro Tavares da Silva, ao rei [D. João V], solicitando autorização para regressar a sua casa no Engenho do Meio, porque é inocente da culpa que lhe atribuem na venda de carnes, que estaria prejudicando os contratadores deste produto.

Anexo: 6 docs.

AHU_ACL_CU_014, Cx. 13, D. 1121 .

1745, setembro, 10, Lisboa

CONSULTA do Conselho Ultramarino, ao rei D. João V, sobre a carta do capitão-mor da Paraíba, Pedro Monteiro de Macedo, sobre os descaminhos que ocorreram quando da introdução dos dez ou doze mil cruzados que deveriam ser encaminhados da capitania de Pernambuco à da Paraíba, para o pagamento da Infantaria.

Anexo: 11 docs.

AHU_ACL_CU_014, Cx. 13, D. 1122.

1745 , outubro, 11, Paraíba

CONSULTA do Conselho Ultramarino, ao rei D. João V, sobre as dúvidas que os oficiais da Câmara da Paraíba tiveram na sucessão do governo da sua capitania, quando do falecimento do capitão-mor, Pedro Monteiro de Macedo.

Anexo: 5 docs.

AHU ACL CU 014, Cx. 13, D. 1123.

1745, outubro, 23, Lisboa

CONSULTA do Conselho Ultramarino, ao rei D. João V, sobre a exoneração de Antonio José da Cunha do cargo de provedor da Fazenda Real da Paraíba, em virtude dos descaminhos verificados na sua instituição, sendo substituído pelo provedor saído da capitania do Rio Grande, Teotônio Fernandes Temudo.

Anexo: 6 docs.

AHU ACL CU 014, Cx. 13, D. 1126.

[ant. 1745, outubro, 26, Lisboa]

REQUERIMENTO de José Ricord e do padre Gonçalves, ao rei [D. João V], solicitando a cobrança e o envio dos bens pertencentes ao ex-capitão-mor da Paraíba, Pedro Monteiro de Macedo, para o Reino.

Anexo: 11 docs.

AHU_ACL_CU_014, Cx. 13, D. 1127.

1746, março, 29, Paraíba

CARTA do [capitão-mor da Paraíba], Antonio Borges da Fonseca, ao rei [D. João V], em resposta à provisão sobre a exoneração de José Antonio da Cunha, do cargo de provedor da Fazenda Real, e sua substituição por Teotônio Fernandes Temudo.

Anexo: 1 doc.

AHU_ACL_CU_014, Cx. 14, D. 1136.

1746, abril, 2, Paraíba

CARTA do [capitão-mor da Paraíba], Antonio Borges da Fonseca, ao rei [D. João V], sobre o envio das listas dos pagamentos da Fazenda Real.

Anexo: 2 docs.

AHU ACL CU 014, Cx. 14, D. 1137. 
1746, abril, 4, Paraíba

CARTA do [capitão-mor da Paraíba], Antonio Borges da Fonseca, ao rei [D. João V], em resposta à provisão sobre o pedido do provedor da Fazenda Real, da botica destinada aos soldados.

Anexo: 1 doc.

AHU_ACL_CU_014, Cx. 14, D. 1141.

1746, abril, 5, Paraíba

CARTA do [capitão-mor da Paraíba], Antonio Borges da Fonseca, ao rei [D. João V], sobre estar enviando em anexo a relação do rendimento e despesa da capitania, de 1744 a 1745.

Anexo: 4 docs.

AHU_ACL_CU_014, Cx. 14, D. 1142.

1746, abril, 5, Paraíba

CARTA do [capitão-mor da Paraíba], Antonio Borges da Fonseca, ao rei [D. João V], informando que os cofres da Fazenda Real se encontram no convento dos padres da Companhia, mas que, em sua opinião, deveriam estar na Casa dos Contos.

Anexo: 8 docs.

AHU ACL CU 014, Cx. 14, D. 1143.

1746, abril, 9, Paraíba

CARTA do [capitão-mor da Paraíba], Antonio Borges da Fonseca, ao rei [D. João V], sobre o requerimento do escrivão do despacho e descarga da Alfândega, José Rodrigues Pires, em que solicita o mesmo ordenado que o escrivão de Pernambuco; e informando, ainda, que, na sua opinião, este soldo não deve ser tão alto, tendo em vista a menor atividade do porto da Paraíba.

Anexo: 11 docs.

AHU_ACL_CU_014, Cx. 14, D. 1144.

1746, abril, 26, Paraíba

CARTA do capitão-mor da Paraíba, Antonio Borges da Fonseca, ao rei [D. João V], sobre a arrematação e orçamento da obra das casas da residência dos governadores da capitania.

AHU ACL CU 014, Cx. 14, D. 1151.

1746, abril, 27, Paraíba

CARTA do provedor da Fazenda Real da Paraíba, Teotônio Fernandes Temudo, ao rei [D. João V], em resposta à provisão sobre o requerimento do alferes José de Melo Moniz, em que solicitava o pagamento do seu soldo dobrado desde o dia em que tomara posse do seu cargo.

Anexo: 2 docs.

AHU_ACL_CU_014, Cx. 14, D. 1154.

1746, abril, 27, Paraíba

CARTA do provedor da Fazenda Real da Paraíba, ao rei [D. João V], em resposta à provisão sobre a criação de alguns ofícios na Alfândega da Paraíba e acerca do pagamento de soldos dos seus funcionários.

Anexo: 3 docs

AHU ACL CU 014, Cx. 14, D. 1155

1746, maio, 2, Paraíba

CARTA do provedor da Fazenda Real da Paraíba, Teotônio Fernandes Temudo, ao rei [D. João V], em resposta à provisão sobre os descaminhos que têm ocorrido nos locais onde são armazenadas as armas e munições e acerca das rendas dos engenhos Podre e Santo André.

AHU ACL CU 014, Cx. 14, D. 1160

1746, maio, 2, Paraíba

CARTA do [capitão-mor da Paraíba], Antonio Borges da Fonseca, ao rei [D. João V], sobre o envio da relação dos rendimentos e despesas da Fazenda Real da Paraíba.

Anexo: 16 docs.

AHU ACL_CU 014, Cx. 14, D. 1161.

1746, maio, 6, Paraíba

CARTA do provedor da Fazenda Real da Paraíba, Teotônio Fernandes Temudo, ao rei [D. João V], em resposta à provisão sobre os impedimentos que o alferes Manuel Gonçalves Ramalho tem para continuar a receber o seu soldo.

Anexo: 1 doc.

AHU ACL CU 014, Cx. 14, D. 1165.

1746, maio, 10, Paraíba

CARTA dos oficiais da Câmara da Paraíba ao rei [D. João V], sobre o provedor da Fazenda Real não querer pagar os direitos das pipas de aguardente entrados no porto da Paraíba, por a corveta que as trazia ter sido confiscada.

Anexo: 9 docs.

AHU_ACL_CU_014, Cx. 14, D. 1166.

1746, maio, 12, Paraíba 
CARTA do provedor da Fazenda Real da Paraíba, Teotônio Fernandes Temudo, ao rei [D. João V], em resposta à provisão sobre o recebimento do cruzado das caixas para efetuar o pagamento de soldos e das fortificações.

AHU_ACL_CU_014, Cx. 14, D. 1168.

1746, outubro, 5 , Lisboa

CONSULTA do Conselho Ultramarino, ao rei D. João V, sobre o requerimento de Bento Bandeira de Melo, solicitando que o seu filho, Hipólito Bandeira de Melo, possa servir o seu cargo, em seu impedimento.

Anexo: 4 docs

AHU_ACL_CU_014, Cx. 14, D. 1180.

1746, novembro, 24, Lisboa

CARTA de Francisco Sales Rodrigues, ao rei [D. João V], sobre a pena a ser aplicada ao ex-provedor da Fazenda Real da Paraíba, Bento Bandeira de Melo, por ter roubado dinheiro da Provedoria.

AHU_ACL_CU_014, Cx. 14, D. 1186

[ant. 1747, fevereiro, 10, Paraíba]

REQUERIMENTO do Solicitador Manuel Borges da Silva, ao rei [D. João V], solicitando ordens para que os provedores da Fazenda Real e Ouvidores Gerais possam cobrar as dívidas da Fazenda Real, como é o caso da Paraíba.

AHU_ACL_CU_014, Cx. 14, D. 1195.

1747, maio, 2, Paraíba

CARTA do [capitão-mor da Paraíba], Antonio Borges da Fonseca, ao rei [D. João V], sobre as listas de pagamentos que mandou o provedor da Fazenda Real executar.

Anexo: 7 docs.

AHU_ACL_CU_014, Cx. 14, D. 1207.

[ant. 1747, março, 3, Paraíba]

REQUERIMENTO do contratador do Contrato da Dízima, Estevão Martins Torres, ao rei [D. João V], solicitando levar em conta a quantia cobrada indevidamente pelos oficiais da Alfândega.

Anexo: 12 docs.

AHU ACL CU 014, Cx. 14, D. 1196.

1747, maio, 5, Paraíba

CARTA do [capitão-mor da Paraíba], Antonio Borges da Fonseca, ao rei [D. João V], sobre a nomeação de Luís Álvares Figueira no cargo de almoxarife.

Anexo: 6 docs.

AHU_ACL_CU_014, Cx. 14, D. 1208.

1747, maio, 31, Paraíba

PORTARIA do provedor da Fazenda Real da Paraíba, Teotônio Fernandes Temudo, ao escrivão Hipólito Bandeira de Melo, mandando passar certidão da primeira condição com que foi arrematado o contrato dos dízimos a Garcia da Ponte Coelho.

AHU_ACL_CU_014, Cx. 14, D. 1211.

1747, junho, 2, Paraíba

CERTIDÃO do escrivão da Fazenda Real, Hipólito Bandeira de Melo, confirmando que o material de guerra proveniente do Reino foi entregue ao almoxarife, Damião de Macedo do Amaral.

AHU ACL CU 014, Cx. 14, D. 1212.

1747, junho, 10, Paraíba

CARTA do provedor da Fazenda Real da Paraíba, Teotônio Fernandes Temudo, ao rei [D. João V], sobre a devassa na qual foi declarado inocente Francisco Pereira das Chagas da culpa de ter feito descaminhos na Alfândega.

AHU ACL CU 014, Cx. 14, D. 1214

1747, junho, 12, Paraíba

CARTA do provedor da Fazenda Real da Paraíba, Teotônio Fernandes Temudo, ao rei [D. João V], sobre a entrega dos direitos do cobre na Provedoria.

AHU_ACL_CU_014, Cx. 14, D. 1216.

1747, junho, 15, Paraíba

CARTA do provedor da Fazenda Real da Paraíba, Teotônio Fernandes Temudo, ao rei [D. João V], sobre o dinheiro de propinas que recebeu para as fardas dos soldados da capitania.

Anexo: 2 docs.

AHU ACL CU 014, Cx. 14, D. 1217. 
1747, junho, 16, Paraíba

CARTA do [capitão-mor da Paraíba], Antonio Borges da Fonseca, ao rei [D. João V], sobre a hipótese de se levantar o sobrado da Casa dos Contos.

Anexo: 9 docs.

AHU_ACL_CU_014, Cx. 14, D. 1218.

1747, junho, 20, Paraíba

CARTA dos oficiais da Câmara, ao rei [D. João V], sobre a dúvida do provedor da Fazenda Real, relativa à regra de precedência numa procissão.

AHU_ACL_CU_014, Cx. 14, D. 1219.

1747, dezembro, 7, Lisboa

CARTA de Antonio Caetano da Silva, ao rei [D. João V], sobre a penhora que os herdeiros de Pedro Monteiro de Macedo terão de fazer para recuperarem os seus bens.

AHU_ACL_CU_014, Cx. 15, D. 1234.

[ant. 1748, fevereiro, 7, Paraíba]

REQUERIMENTO de João Martins Gramacho, ao rei [D. João V], solicitando mandar que a Provedoria da Fazenda Real de Pernambuco pague os atrasados dos vinte mil cruzados anuais que deve à Paraíba e que esta pague a dívida que contraiu com o empreiteiro da fortaleza do Cabedelo, Antonio Afonso de Carvalho.

Anexo: 2 docs.

AHU_ACL_CU_014, Cx. 15, D. 1242.

[ant. 1748, julho, 27, Lisboa]

REQUERIMENTO do procurador, João da Cruz Serra, ao rei [D. João V], solicitando ordens para que o provedor da Fazenda Real da Paraíba levante o seqüestro dos bens de João dos Santos.

AHU_ACL_CU_014, Cx. 15, D. 1249.

[ant. 1748, novembro, 23, Paraíba]

REQUERIMENTO do provedor da Fazenda Real da Paraíba, José Antonio da Cunha, ao rei [D. João V], solicitando as certidões que necessita para dar continuidade ao seu processo no Supremo Tribunal.

AHU ACL CU 014, Cx. 15, D. 1256.

1749, fevereiro, 2, Paraíba

CARTA do [capitão-mor da Paraíba], Antonio Borges da Fonseca, ao rei [D. João V], remetendo a relação do rendimento e despesa da

Paraíba.

Anexo: 7 docs

AHU ACL CU 014, Cx. 15, D. 1258.

1749, fevereiro, 20, Paraíba

CARTA do [capitão-mor da Paraíba], Antonio Borges da Fonseca, ao rei [D. João V], sobre o requerimento de João Martins Gramacho, solicitando o pagamento do dinheiro que lhe deve a Fazenda Real, como herdeiro de Antonio Afonso de Carvalho. Anexo: 2 docs.

AHU ACL CU 014, Cx. 15, D. 1260.

1749, março, 30, Paraíba

CARTA do provedor da Fazenda Real da Paraíba, Teotônio Fernandes Temudo, ao rei [D. João V], sobre as informações de Antonio Gonçalves de Araújo, superintendente e administrador das minas de prata, cobre e outros metais da Serra dos Cocos e Ibiapina, capitania do Ceará, acerca da existência de minas de prata, cobre e outros metais nas capitanias do Norte.

Anexo: 8 docs.

AHU ACL CU 014, Cx. 15, D. 1262

1749, março, 31, Paraíba

CARTA do provedor da Fazenda Real da Paraíba, Teotônio Fernandes Temudo, ao rei [D. João V], sobre as contas do almoxarife da Fazenda Real, Caetano Francisco Gomes.

AHU_ACL_CU_014, Cx. 15, D. 1263.

1749, março, 31, Paraíba

CARTA do provedor da Fazenda Real da Paraíba, Teotônio Fernandes Temudo, ao rei [D. João V], sobre as contas do almoxarife e tesoureiro da Décima, Amaro Velho de Vasconcelos.

AHU_ACL_CU_014, Cx. 15, D. 1264.

1749, março, 31, Paraíba

CARTA do provedor da Fazenda Real da Paraíba, Teotônio Fernandes Temudo, ao rei [D. João V], sobre as contas do almoxarife e tesoureiro da Décima, Luís Alves Filgueira.

AHU ACL CU 014, Cx. 15, D. 1265. 
1749, abril, 10, Paraíba

CARTA do provedor da Fazenda Real da Paraíba, Teotônio Fernandes Temudo, ao rei [D. João V], relatando a forma e condições em que João Henriques Martins arrematou o contrato dos subsídios do açúcar.

Anexo: 5 docs.

AHU_ACL_CU_014, Cx. 15, D. 1266.

1749, abril, 10, Paraíba

CARTA do provedor da Fazenda Real da Paraíba, Teotônio Fernandes Temudo, ao rei [D. João V], informando que Pernambuco atrasou em dois anos o repasse do cobre que deve à Provedoria da Paraíba.

Anexo: 4 docs.

AHU_ACL_CU_014, Cx. 15, D. 1267.

1749, abril, 15, Paraíba

CARTA do [provedor da Fazenda Real da Paraíba], Teotônio Fernandes Temudo, ao governador e mestre-de-campo da Paraíba, [Antonio Borges da Fonseca], informando que a capela da fortaleza do Cabedelo necessita de novos paramentos, sem os quais é impossível rezar missa.

AHU ACL CU 014, Cx. 15, D. 1268.

1749, abril, 15, Paraíba

CARTA do governador e mestre-de-campo da Paraíba, [Antonio Borges da Fonseca], ao rei [D. João V], sobre o requerimento do padre Pedro Tavares da Silva, sacerdote do hábito de São Pedro, solicitando mandar reparar a situação em que se acha sua casa, visto serem falsas as culpas de vender carne publicamente pelas ruas da cidade.

Anexo: 1 doc.

AHU_ACL_CU_014, Cx. 15, D. 1269.

[ant. 1749, outubro, 10, Paraíba]

REQUERIMENTO de João Henriques Martins, arrematador do subsídio do açúcar da Paraíba, ao rei [D. João V], solicitando mandar que o provedor da Fazenda Real da Paraíba cumpra o contrato de arrematação na forma acordada com o Conselho Ultramarino. AHU_ACL_CU_014, Cx. 15, D. 1283.

[ant. 1749, dezembro, 20, Paraíba]

REQUERIMENTO do bacharel Manuel Rodrigues Coelho, ao rei [D. João V], solicitando o posto de provedor da Fazenda Real da Paraíba, ou da cidade de Natal.

Anexo: 7 docs.

AHU_ACL_CU_014, Cx. 15, D. 1286.

[ant. 1749, dezembro, 22, Paraíba]

REQUERIMENTO do bacharel Teotônio Fernandes Temudo, ao rei [D. João V], solicitando nomeação na Provedoria da Fazenda Real de Minas Gerais, ou na Provedoria da Ilha de Santa Catarina, Pará ou Maranhão.

Anexo: 2 docs.

AHU_ACL_CU_014, Cx. 15, D. 1287.

[ant. 1750, fevereiro, 25, Lisboa]

REQUERIMENTO de José Antonio da Cunha, ao rei [D. João V], solicitando mandar entregar ao suplicante umas certidões e outros documentos, das contas que deu, na época que era provedor da Fazenda Real da Paraíba.

Anexo: 1 doc

AHU_ACL_CU_014, Cx. 15, D. 1291.

1750, abril, 13, Lisboa

CONSULTA do Conselho Ultramarino, ao rei D. João V, sobre a nomeação de pessoas para o cargo de provedor da Fazenda Real da Paraíba, por três anos.

Anexo: 3 docs.

AHU_ACL_CU_014, Cx. 15, D. 1295.

1750, junho, 8, Lisboa

DESPACHO do Conselho Ultramarino sobre a forma como o mestre-de-campo da Paraíba, Antonio Borges da Fonseca, encaminhou as propostas dos opositores ao posto de capitão de Auxiliares.

AHU ACL CU 014, Cx. 15, D. 1296.

1750, junho, 28, Paraíba

CARTA do provedor da Fazenda Real da Paraíba, Teotônio Fernandes Temudo, ao rei [D. João V], sobre o traslado dos livros e das despesas do almoxarife da Provedoria da Fazenda Real da Paraíba, Antonio Carneiro de Albuquerque.

AHU_ACL_CU_014, Cx. 15, D. 1297.

1751, março, 24, Paraíba

CARTA do provedor da Fazenda Real da Paraíba, Teotônio Fernandes Temudo, ao rei [D. José], remetendo a certidão com a data em que se dará inicio às arrematações dos contratos que há na capitania da Paraíba. 
Anexo: 1 doc.

AHU_ACL_CU_014, Cx. 16, D. 1303

[ant. 1751, novembro, 12, Paraíba]

REQUERIMENTO do arrematador do contrato dos dízimos do açúcar na Paraíba, João Henriques Martins, ao rei [D. José I], solicitando passar ordem para que não seja alterado o valor da propina na Paraíba.

AHU_ACL_CU_014, Cx. 16, D. 1312 .

[ant. 1751, novembro, 22, Paraíba]

REQUERIMENTO de Antonio Carneiro de Albuquerque, ao rei [D. José I], solicitando a restituição do ofício de escrivão da Abertura da Alfândega da cidade da Paraíba.

AHU ACL CU 014, Cx. 16, D. 1315.

1752, abril, 1, Lisboa

DECRETO do rei D. José I, ordenando que a Provedoria da Paraíba pague a José Antonio da Cunha o tempo em que serviu como Provedor.

AHU_ACL_CU_014, Cx. 16, D. 1323

1752, abril, 10, Paraíba

CERTIDÃO do escrivão da Fazenda Real, Hipólito Bandeira de Melo, comprovando quantos anos se deve de soldo às Companhias da guarnição da Paraíba e fortaleza do Cabedelo.

AHU_ACL_CU_014, Cx. 16, D. 1324.

1752, maio, 7, Paraíba.

CARTA do provedor da Fazenda Real da Paraíba, Teotônio Fernandes Temudo, ao rei [D. José I], sobre não ter executado a sentença contra o padre Matias da Glória, por ter o dito padre pago o que devia da renda do engenho Santo André.

Anexo: 2 docs.

AHU_ACL_CU_014,Cx. 16, D. 1325.

1752, maio, 15, Paraíba

CARTA do ouvidor geral da Paraíba, José Ferreira Gil, ao rei [D. José I], pedindo solução para o fato de que, durante os dois anos que tem servido na Paraíba, apenas recebeu seis meses de ordenado, propinas e aposentadoria, e solicitando que a Câmara lhe pague o que deve.

AHU ACL CU 014, Cx. 16, D. 1326.

1752, maio, 20, Paraíba

REPRESENTAÇÃO dos oficiais da Câmara da Paraíba, ao rei [D. José I], solicitando que defira o requerimento dos moradores da capitania, no qual pedem a abertura do porto para que possam comerciar o que produzem.

AHU ACL CU 014, Cx. 16, D. 1328.

1752, maio, 30, Paraíba

CARTA do provedor da Fazenda Real da Paraíba, Teotônio Fernandes Temudo, ao rei [D. José I], sobre a arrematação do contrato das carnes da Paraíba.

Anexo: 1 doc.

AHU ACL CU 014, Cx. 16, D. 1329

1752 , julho, 6, Paraíba

CARTA do provedor da Fazenda Real da Paraíba, Teotônio Fernandes Temudo, ao rei [D. José I], sobre o envio de um oficial para entregar ao provedor da Fazenda Real de Pernambuco as cartas para fazer a remessa do dinheiro referente aos rendimentos da Dízima. Anexo: 2 docs.

AHU ACL CU 014, Cx. 16, D. 1333.

1752, agosto, 31 , Lisboa

AVISO do [secretário de estado da Marinha e Ultramar] Diogo de Mendonça Corte Real, ao marquês de Penalva, [D. Estevão de Meneses], mandando reformar a consulta sobre as propinas cobradas pelos oficiais da Alfândega da Paraíba, ao contratador do contrato da Dízima da Alfândega de Pernambuco, Estevão Martins Torres.

Anexo: 12 docs.

AHU_ACL_CU_014, Cx. 16, D. 1334

[ant. 1752, outubro, 13, Paraíba]

REQUERIMENTO do capitão José Gomes da Costa e demais homens de negócios da cidade da Paraíba, ao rei [D. José I], solicitando que se recuse o requerimento da Câmara da cidade da Paraíba, o qual propõe que o açúcar produzido na Paraíba embarque por Pernambuco.

Anexo: 1 doc

AHU ACL CU 014, Cx. 16, D. 1337.

[ant. 1752, outubro, 20, Paraíba] 
REQUERIMENTO do capitão da galera Nossa Senhora do Livramento, Santo Antonio e Almas, Antonio Soares Lima, ao rei [D. José I], solicitando que a carga desembarcada no porto da Paraíba tenha como recibo o registo que fez o provedor da Fazenda Real. AHU_ACL_CU_014, Cx. 16, D. 1339

[ant. 1752, novembro, 17, cidade da Paraíba]

REQUERIMENTO de Custódio Martins de Carvalho, ao rei [D. José I], solicitando conceder-lhe a faculdade para nomear no ofício de Meirinho da Correição, Distribuidor, Inquiridor e Contador da cidade da Paraíba, de que é proprietário, na pessoa de sua filha Maria. Anexo: 5 docs.

AHU_ACL_CU_014, Cx. 16, D. 1343.

[ant. 1752, dezembro, 20, Paraíba]

REQUERIMENTO dos herdeiros do capitão Domingos de Cerqueira da Silva e do alcaide-mor Gaspar Acioli de Vasconcelos, ao rei [D. José I], solicitando provisão para o provedor da Fazenda Real da Paraíba levantar o seqüestro dos bens feitos aos pais dos suplicantes.

AHU ACL CU_014, Cx. 16, D. 1348 .

[ant. 1753, agosto, 22, Lisboa]

REQUERIMENTO de Francisco de Sousa Fagundes, ao rei [D. José I], solicitando mandar que o provedor da Fazenda Real da Paraíba restitua ao suplicante, por seus procuradores, a importância da corveta Nossa Senhora da Penha de França, Santa Ana e Almas, e a carga confiscada pelo provedor Teotônio Fernandes Temudo.

AHU ACL CU 014, Cx. 17, D. 1365.

1753, setembro, 17, Lisboa

PROVISÃO do rei D. José I ao governador e coronel da Paraíba, [Luís Antonio de Brito de Lemos], ordenando acabar com as desordens do capitão do Cabedelo, para que não seja prejudicada a Fazenda Real.

Anexo: 6 docs.

AHU_ACL_CU_014, Cx. 17, D. 1369.

1754, março, 4, Bahia

CARTA do vice-rei do Brasil, conde de Atouguia, [D. Luís Pedro Peregrino de Carvalho Menezes e Ataíde], ao rei [D. José I], sobre a representação do provedor da Fazenda Real da Paraíba, a propósito de não ter recebido da Provedoria de Pernambuco os vinte mil cruzados para pagamento dos soldados e obras da fortaleza de Cabedelo.

Anexo: 5 docs.

AHU ACL CU 014, Cx. 17, D. 1379.

1754, março, 16, Paraíba

CARTA do provedor da Fazenda Real da Paraíba, Manuel Rodrigues Coelho, ao rei [D. José I], sobre o padre Matias da Glória não dever nada à Fazenda Real da Paraíba, do arrendamento do Engenho Santo André.

Anexo: 2 docs.

AHU ACL CU 014, Cx. 17, D. 1381

1754, março, 17, Paraíba

CARTA do provedor da Fazenda Real da Paraíba, Manuel Rodrigues Coelho, ao rei [D. José I], sobre a provisão mandando que o provedor da Fazenda Real de Pernambuco faça a remessa dos vinte mil cruzados, de seis em seis meses.

Anexo: 2 docs.

AHU ACL CU 014, Cx. 17, D. 1382

1754, março, 26, Paraíba

OFÍCIO do [governador da Paraíba] coronel Luís António de Lemos de Brito, ao [secretário de estado da Marinha e Ultramar], Diogo de Mendonça Corte Real, sobre ter tomado posse no governo da Paraíba em vinte e um de novembro de 1753; e remetendo a cópia do termo de posse.

Anexo: 5 docs.

AHU_ACL_CU_014, Cx. 17, D. 1383.

1754, abril, 2, Paraíba

CARTA do provedor da Fazenda Real da Paraíba, Manuel Rodrigues Coelho, ao rei [D. José I], sobre não ter tomado as contas dos almoxarifes e Tesoureiros da Décima.

Anexo: 3 docs.

AHU_ACL_CU_014, Cx. 17, D. 1384.

1754, abril, 26, Paraíba

CARTA do provedor da Fazenda Real da Paraíba, Manuel Rodrigues Coelho, ao rei [D. José I], sobre a remessa do tecido para os fardamentos das tropas da Paraíba.

Anexo: 8 docs.

AHU_ACL_CU_014, Cx. 17, D. 1391 . 
1754, abril, 28, Recife

CARTA do juiz de Fora e provedor da Fazenda Real de Pernambuco, João Rodrigues Colaço, ao rei [D. José I], sobre o pagamento da dívida dos vinte mil cruzados que devem ser remetidos anualmente à Paraíba.

Anexo: 3 docs.

AHU_ACL_CU_014, Cx. 17, D. 1392.

1754, abril, 29, Paraíba

OFÍCIO do [governador da Paraíba], coronel Luís António de Lemos de Brito, ao [secretário de estado da Marinha e Ultramar], Diogo de Mendonça Corte Real, agradecendo as gentilezas que tem recebido no exercício do seu governo na capitania.

AHU_ACL_CU_014, Cx. 17, D. 1393.

1754, maio, 8, Recife

CARTA do [governador e capitão-general de Pernambuco], Luís Correia de Sá, ao rei [D. José I], sobre a obrigação que a Provedoria da Fazenda Real da capitania tem de remeter anualmente vinte mil cruzados à Provedoria da Paraíba.

Anexo: 1 doc.

AHU_ACL_CU_014, Cx. 17, D. 1394

1754, maio, 10, Paraíba

CARTA do provedor da Fazenda Real da Paraíba, Manuel Rodrigues Coelho, ao rei [D. José I], sobre a decisão que tomou para requerer da Provedoria da Fazenda Real de Pernambuco os vinte mil cruzados que esta capitania deve remeter anualmente, do rendimento da Dízima, para pagamento das Infantarias, forte do Cabedelo e mais consignações.

Anexo: 15 doc.

AHU_ACL_CU_014, Cx. 17, D. 1395.

1754, maio, 13, Paraíba

CARTA do [governador da Paraíba] coronel Luís Antonio de Lemos de Brito, ao rei [D. José I], sobre a dívida que a Provedoria da Fazenda Real de Pernambuco tem com a da Paraíba, relativa aos rendimentos da Dízima.

Anexo: 8 doc.

AHU_ACL_CU_014, Cx. 17, D. 1396.

1754, maio, 17, Paraíba

CARTA dos oficiais da Câmara da Paraíba, ao rei [D. José I], sobre a petição dos oficiais da Justiça e Fazenda da cidade da Paraíba, solicitando provisão para não pagarem a terça parte dos rendimentos dos seus ofícios.

Anexo: 3 doc.

AHU_ACL_CU_014, Cx. 17, D. 1397.

1754, maio, 20, Paraíba

OFÍCIO do [governador da Paraíba], coronel Luís Antonio de Lemos de Brito, ao [secretário de estado da Marinha e Ultramar], Diogo de Mendonça Corte Real, sobre ter mandando passar precatórios à Provedoria de Pernambuco, para remeter o que deve à Paraíba do produto da arrematação da Dízima das Alfândegas, pertinentes às duas capitanias, arrematadas num só contrato.

Anexo: 23 doc.

AHU_ACL_CU_014, Cx. 17, D. 1398.

[ant. 1754, outubro, 3, Paraíba]

REQUERIMENTO do coronel da Cavalaria, João Peixoto de Vasconcelos, procurador dos herdeiros de José Leitão Freire, ao rei [D. José I], solicitando provisão para que Luís Falcão Freire e Maria Cavalcanti possam arrematar as propriedades, engenhos Santo André e Podre, do alcaide-mor Gaspar Acioli de Vasconcelos, seqüestradas pela Fazenda Real de Paraíba.

Anexo: 13 docs.

AHU_ACL_CU_014, Cx. 17, D. 1404.

1754, novembro, 4, Lisboa

CONSULTA do Conselho Ultramarino, ao rei D. José I, sobre a representação de João Leite Ferreira, morador no Piancó, acerca da utilidade de se arrematarem no sertão os dízimos dos gados, na mesma forma que no Rio Grande e Ceará.

Anexo: 1 doc.

AHU ACL CU 014, Cx. 17, D. 1407

[ant. 1754, novembro, 7, Paraíba]

REQUERIMENTO do alferes Manuel Carneiro de Albuquerque, ao rei [D. José I], solicitando mandar que tome a denúncia do suplicante contra Antonio José de Foios, escrivão do Crime, Ouvidoria, Resíduos e Novos Direitos da cidade da Paraíba, por comerciar publicamente com uma embarcação de escravos chegada da Costa da Mina, e por outras violações das leis.

Anexo: 1 doc.

AHU_ACL_CU_014, Cx. 17, D. 1408.

1754, dezembro, 10, Lisboa

AVISO (cópia) do [secretário de estado dos Negócios da Marinha e Ultramar], Diogo de Mendonça Corte Real, ao provedor da

Fazenda Real da Paraíba, Manuel Rodrigues Coelho, mandando remeter uma relação dos ordenados, propinas e emolumentos dos 
ministros e oficiais da Fazenda Real, para poder fazer os regimentos; e, enviando, em anexo, cópia do Regimento do provedor-mor da Fazenda Real, Antonio Cardoso de Barros, de 9 de novembro de 1722.

Anexo: 4 docs.

AHU ACL CU 014, Cx. 17, D. 1419.

1755, abril, 2, Paraíba

CARTA do [governador da Paraíba], coronel Luís Antonio de Lemos de Brito, ao rei [D. José I], sobre o estado da execução dos engenhos Podre e Santo André, declarando a importância da dívida e os meios de se cobrá-la.

Anexo: 1 doc.

AHU_ACL_CU_014, Cx. 18, D. 1423.

1755, abril, 5, Paraíba

CARTA do [governador da Paraíba], coronel Luís Antonio de Lemos de Brito, ao rei [D. José I], sobre o requerimento do capitão Inácio Pereira da Cunha, solicitando que, ao termo da arrematação que fez o padre Matias da Glória, do engenho de Santo André, seqüestrado pela Fazenda Real, mande entregar o dito engenho ao suplicante.

Anexo: 4 docs.

AHU ACL CU 014, Cx. 18, D. 1424

1755, maio, 4, Paraíba

CARTA do [governador da Paraíba], coronel Luís Antonio de Lemos de Brito, ao rei [D. José I], remetendo a relação da receita e despesa da Fazenda Real, apontando os meios para se tirar alguma utilidade da capitania.

Anexo: 5 docs.

AHU ACL CU 014, Cx. 18, D. 1434.

1755, maio, 9, Paraíba

OFÍCIO do [governador da Paraíba], coronel Luís António de Lemos de Brito, ao [secretário de estado da Marinha e Ultramar], Diogo de Mendonça Corte Real, informando que não tem tido efeito a ordem para o governador de Pernambuco, [Luís Correia de Sá], e o provedor da Fazenda Real, para remeterem à Paraíba a importância de 20 mil cruzados, cada ano, do produto da dízima.

Anexo: 11 docs.

AHU_ACL_CU_014, Cx. 18, D. 1436.

1755, maio, 12, Paraíba

OFÍCIO do [governador da Paraíba], coronel Luís Antonio de Lemos de Brito, ao [secretário de estado da Marinha e Ultramar], Diogo de Mendonça Corte Real, remetendo a relação da receita e despesa da Fazenda Real e as cópias das ordens e suas respostas sobre como tornar útil a capitania.

Anexo: 11 docs.

AHU_ACL_CU_014, Cx. 18, D. 1439

1755, maio, 15, Paraíba

OFÍCIO do provedor da Fazenda Real da Paraíba, Manuel Rodrigues Coelho, ao [secretário de estado da Marinha e Ultramar], Diogo de Mendonça Corte Real, remetendo a relação dos ordenados, propinas e emolumentos que tem lugar na Provedoria da Paraíba, e dos ofícios e ocupações que servem à mesma.

Anexo: 22 docs.

AHU ACL CU 014, Cx. 18, D. 1442

[ant. 1755, agosto, 26, Paraíba]

REQUERIMENTO do Oficial dos Contos da Provedoria da Fazenda Real da Paraíba, Pedro Rique Ferreira, ao rei [D. José I], solicitando provisão vitalícia do ofício que exerce.

Anexo: 7 docs

AHU ACL_CU 014, Cx. 18, D. 1450.

1755, setembro, 11, Lisboa

CONSULTA do Conselho Ultramarino, ao rei D. José I, sobre a carta do governador e coronel da Paraíba, Luís Antonio de Lemos de Brito, a respeito dos provimentos dos oficiais de Justiça e Fazenda, e o que tem ocorrido acerca da matéria nos ofícios de almoxarife e procurador da Fazenda Real e na ocupação de advogados.

Anexo: 5 docs.

AHU_ACL_CU_014, Cx. 18, D. 1451.

1755, setembro, 15 , Lisboa

CONSULTA do Conselho Ultramarino, ao rei D. José I, sobre a carta do provedor da Fazenda Real da Paraíba, Manuel Rodrigues Coelho, a respeito da incapacidade em que se acham as armas e trens dos armazéns da Paraíba.

Anexo: 9 docs.

AHU_ACL_CU_014, Cx. 18, D. 1453.

1755, setembro, 19, Lisboa

CONSULTA do Conselho Ultramarino, ao rei D. José I, sobre a carta do governador e coronel da Paraíba, Luís Antonio de Lemos de Brito, remetendo a receita e despesa da Fazenda Real e apontando os meios de tornar útil a capitania. 
Anexo: 8 docs.

AHU_ACL_CU_014, Cx. 18, D. 1454

1755, setembro, 20, Lisboa

CONSULTA do Conselho Ultramarino, ao rei D. José I, sobre a carta do governador e coronel da Paraíba, Luís Antonio de Lemos de Brito, informando sobre a necessidade que há de capelão, para rezar missa aos presos da cadeia, e como o ordenado do mesmo pode ser pago pelo rendimento dos subsídios administrados pela Provedoria da Fazenda Real.

Anexo: 6 docs

AHU_ACL_CU_014, Cx. 18, D. 1455.

1755, outubro, 1, Lisboa

CONSULTA do Conselho Ultramarino, ao rei D. José I, sobre o requerimento do Provedor e Irmãos da Santa Casa da Misericórdia da Paraíba, solicitando ajuda para a reedificação do hospital, destruído com a invasão holandesa.

Anexo: 8 docs.

AHU_ACL_CU_014, Cx. 18, D. 1456.

1755, outubro, 29, Lisboa

CARTA de Antonio de Barros, ao rei [D. José I], sobre o fardamento remetido à Provedoria da Fazenda Real da Paraíba.

AHU_ACL_CU_014, Cx. 18, D. 1460.

1755, dezembro, 10, Lisboa

CONSULTA do Conselho Ultramarino, ao rei D. José I, sobre a carta do governador e coronel da Paraíba, Luís Antonio de Lemos de Brito, informando que a Provedoria da Fazenda Real de Pernambuco não cumpriu o precatório que passou para remeter os vinte mil cruzados à capitania.

Anexo: 2 docs.

AHU ACL_CU_014, Cx. 18, D. 1462.

1756, abril, 1, Paraíba

INSTRUMENTO DE JUSTIFICAÇ̃̃O do escrivão dos Ausentes, José Cordeiro Max Santos, sobre o teor de uma carta do Senado da Câmara da Paraíba, referente à publicação de um edital acerca da proibição de se vender açúcar pelas portas da cidade.

AHU ACL CU 014, Cx. 19, D. 1467.

1756, maio, 2, Paraíba

CARTA do provedor da Fazenda Real da Paraíba, Manuel Rodrigues Coelho, ao rei [D. José I], remetendo a relação das dívidas que se devem à Fazenda Real da Paraíba.

Anexo: 5 docs

AHU ACL_CU_014, Cx. 19, D. 1473.

1756, maio, 3, Paraíba

CARTA do [governador da Paraíba], coronel Luís Antonio de Lemos de Brito, ao rei [D. José I], sobre a criação da Mesa da Inspeção da Paraíba, independente da de Pernambuco, e os meios de pagamento aos seus oficiais.

Anexo: 1 doc.

AHU ACL CU 014, Cx. 19, D. 1474.

1756, maio, 5, Paraíba

CARTA do provedor da Fazenda Real da Paraíba, Manuel Rodrigues Coelho, ao rei [D. José I], sobre a arrematação e as propinas do contrato do subsídio das carnes.

Anexo: 3 docs.

AHU_ACL_CU_014, Cx. 19, D. 1476.

1756, maio, 10, Paraíba

OFÍCIO do [governador da Paraíba], coronel Luís Antonio de Lemos de Brito, ao [secretário de estado da Marinha e Ultramar], Diogo de Mendonça Corte Real, felicitando-o por ter escapado ao terremoto de Lisboa, e solicitando regressar a sua casa, ou ser provido em um governo geral do Brasil, uma vez que, ao término do seu governo, a capitania será extinta.

Anexo: 1 doc.

AHU ACL_CU_014, Cx. 19, D. 1481

1756, maio, 12, Paraíba

OFÍCIO do [governador da Paraíba], coronel Luís Antonio de Lemos de Brito, ao [secretário de estado da Marinha e Ultramar], Diogo de Mendonça Corte Real, informando ter o cuidado em não esquecer de coisa alguma, para facilitar os ânimos dos moradores em concorrerem com um subsídio de cem mil cruzados em seis anos, para assistirem a Sua Majestade.

Anexo: 1 doc.

AHU_ACL_CU_014, Cx. 19, D. 1483.

1756, maio, 12, Paraíba

CARTA do juiz Inspetor, Domingos Monteiro da Rocha, ao rei [D. José I], sobre a execução da legislação referente aos navios do contrato do sal, que não chegam no tempo devido para receberem a carga existente no porto da Paraíba.

AHU ACL CU 014, Cx. 19, D. 1485. 
1756, maio, 12, Paraíba

CARTA do juiz Inspetor, Domingos Monteiro da Rocha, ao rei [D. José I], sobre o carregamento de açúcar branco e mascavo, couro e sola, nas galeras Santa Ana e Senhor do Bonfim, do capitão Vitorino da Costa, e Santa Ana, Santo Antonio e Almas, do capitão Manuel da Cunha.

Anexo: 1 doc.

AHU_ACL_CU_014, Cx. 19, D. 1486.

1756, maio, 15, Paraíba

CARTA do provedor da Fazenda Real da Paraíba, Manuel Rodrigues Coelho, ao rei [D. José I], sobre a jurisdição das fazendas de gado, chamadas Lages e Bom Sucesso, pertencerem à Paraíba e não ao Rio Grande, como diz o dono delas, Diogo Pereira da Silva, para evitar a cobrança dos dízimos.

Anexo: 5 docs.

AHU_ACL_CU_014, Cx. 19, D. 1487.

1756, maio, 16, Paraíba

CARTA dos oficiais da Câmara da Paraíba, ao rei [D. José I], sobre o terremoto de Lisboa e informando oferecer 100 mil cruzados para ajudar nos estragos.

AHU_ACL_CU_014, Cx. 19, D. 1488.

1756, maio, 17, Paraíba

CARTA do [governador da Paraíba], coronel Luís Antonio de Lemos de Brito, ao rei [D. José I], sobre separar quatro mil cruzados para pagamento da dívida dos dois anos em que não houve dízima; e propondo que o produto das execuções que se fazem aos fiadores dos almoxarifes, se aplique para a mesma dívida.

Anexo: 3 docs.

AHU ACL CU 014, Cx. 19, D. 1489.

1756, maio, 19, Paraíba

OFÍCIO dos oficiais da Câmara da Paraíba, ao [secretário de estado da Marinha e Ultramar], Diogo de Mendonça Corte Real, sobre a extinção do governo da capitania e sua sujeição a Pernambuco; e solicitando que interceda junto ao rei, para que a Paraíba não perca a sua autonomia.

Anexo: 2 docs

AHU_ACL_CU_014, Cx. 19, D. 1494.

1756, maio, 19, Paraíba

CARTA dos oficiais da Câmara da Paraíba, ao rei [D. José I], sobre os motivos pelos quais não deve a capitania da Paraíba ficar sujeita à de Pernambuco, inclusive por possuir renda própria.

AHU ACL CU 014, Cx. 19, D. 1495.

1756, maio, 20, Paraíba

CARTA de Bernardo José dos Santos, ao rei [D. José I], sobre ser o contratador do subsídio do açúcar da cidade da Paraíba e solicitando ordens régias severas para punir aqueles que embarcam o açúcar clandestinamente, sem pagar os subsídios.

Anexo: 1 doc.

AHU ACL CU 014, Cx. 19, D. 1496.

[ant. 1756, outubro, 16, Rio Grande]

REQUERIMENTO do vigário da vara e Cura do Sertão do Açu, padre José de Aranda, ao rei [D. José I], solicitando mandar que a Provedoria da Fazenda Real da Paraíba pague ao suplicante o que deve do tempo que serviu de vigário da vara da cidade da Paraíba; e a Provedoria da Fazenda do Rio Grande, o que lhe deve do posto acima citado.

Anexo: 4 docs.

AHU ACL CU 014, Cx. 19, D. 1505.

1757, fevereiro, 22, Paraíba

CARTA do [governador da Paraíba], coronel Luís Antonio de Lemos de Brito, ao rei [D. José I], sobre averiguar com que ordem a Câmara fez as despesas, quando não havia rendimento destinado para elas, e que necessidade havia de pagar a um procurador na Corte

Anexo: 1 doc.

AHU_ACL_CU_014, Cx. 19, D. 1518 .

1757, março, 8, Paraíba

CARTA do [governador da Paraíba] coronel Luís Antonio de Lemos de Brito, ao rei [D. José I], sobre as ordens de funcionamento da Mesa de Inspeção, que se criou na cidade da Paraíba.

Anexo: 2 docs 
AHU_ACL_CU_014, Cx. 19, D. 1519.

1757, março, 12, Paraíba

CARTA do [governador da Paraíba], coronel Luís Antonio de Lemos de Brito, ao rei [D. José I], sobre propor à Câmara a nomeação de pessoas para o cargo de almoxarife.

Anexo: 3 docs.

AHU_ACL_CU_014, Cx. 19, D. 1521.

1757, março, 14, Paraíba

CARTA do [governador da Paraíba], coronel Luís Antonio de Lemos de Brito, ao rei [D. José I], sobre o decreto referente aos provimentos dos ofícios no Brasil, determinando que os governadores de Estado e capitanias, ao concederem, por se acharem vagos, declarem que os providos deverão pagar, do tempo servido, donativo regulado pelo que tiver pago o serventuário anterior.

Anexo: 1 doc.

AHU_ACL_CU_014, Cx. 19, D. 1522.

1757, março, 23, Paraíba

CARTA do [governador da Paraíba], coronel Luís Antonio de Lemos de Brito, ao rei [D. José I], remetendo a relação da receita e despesa que tem a Fazenda Real da capitania.

Anexo: 6 docs.

AHU_ACL_CU_014, Cx. 19, D. 1524.

1757, março, 29, Paraíba

CARTA do [governador da Paraíba], coronel Luís Antonio de Lemos de Brito, ao rei [D. José I], sobre a falta da remessa dos quatrocentos mil cruzados que a Provedoria da Fazenda Real de Pernambuco deve remeter à da Paraíba, do contrato da dízima para pagamento da tropa.

Anexo: 1 doc.

AHU_ACL_CU_014, Cx. 19, D. 1526.

1757, abril, 16, Paraíba

CARTA do ouvidor geral da Paraíba, Domingos Monteiro da Rocha, ao rei [D. José I], sobre a anexação da capitania da Paraíba à de Pernambuco e solicitando informações sobre as mudanças que ocorreram na Ouvidor Geral.

AHU_ACL_CU_014, Cx. 20, D. 1535.

1757, abril, 20, Paraíba

CARTA do ouvidor geral da Paraíba, Domingos Monteiro da Rocha, ao rei [D. José I], solicitando mandar que o provedor da Fazenda Real e almoxarife, pague o que lhe deve de ordenado.

AHU_ACL_CU_014, Cx. 20, D. 1536.

1757, abril, 24, Paraíba

1757, maio, 13, Paraíba

OFÍCIO dos oficiais da Câmara da Paraíba, ao [secretário de estado da Marinha e Ultramar], Tomé Joaquim da Costa Corte Real, com uma relação de pedidos, figurando, entre outros, o da não sujeição da Paraíba à capitania de Pernambuco.

Anexo: 1 doc.

AHU_ACL_CU_014, Cx. 20, D. 1551.

1757, maio, 31, Paraíba

OFÍCIO do ouvidor-geral da Paraíba, Domingos Monteiro da Rocha, ao [secretário de estado da Marinha e Ultramar], Tomé Joaquim da Costa Corte Real, remetendo a informação de toda a extensão das comarcas, distritos e rios da sua jurisdição, que correspondem à capitania do Rio Grande, Mamanguape, freguesia de Nossa Senhora dos Milagres, distrito da cidade da Paraíba, povoação do Piancó e capitania do Taipu.

Anexo: 6 docs.

AHU_ACL_CU_014, Cx. 20, D. 1564.

[ant. 1757, outubro, 4, Paraíba]

REQUERIMENTO do capitão Inácio Pereira da Cunha, ao rei [D. José I], solicitando que, finda a arrematação dos engenhos de Santo André e Nossa Senhora de Guadalupe, que lhe foram seqüestrados por ordem real, os mesmos sejam entregues pelo mesmo valor do arrendamento.

Anexo: 13 docs.

AHU_ACL_CU_014, Cx. 20, D. 1571.

[ant. 1757, outubro, 20, Paraíba]

REQUERIMENTO de Inácio Pereira da Cunha, ao rei [D. José I], solicitando mandar que o provedor da Fazenda Real da Paraíba dê ao suplicante, e aos demais herdeiros, os rendimentos dos bens seqüestrados deixados pelo pai do mesmo, cuja renda é de cem mil réis por ano.

Anexo: 1 doc.

AHU_ACL_CU_014, Cx. 20, D. 1574. 
1757, novembro, 24, Lisboa

CARTA de Luís Antonio de Lemos de Brito, ao rei [D. José I], sobre a carta dos oficiais da Câmara da Paraíba, solicitando para o porto continuar fechado para evitar que os mantimentos não saiam da capitania, não obstante a ordem em contrário do general de Pernambuco.

Anexo: 6 docs.

AHU_ACL_CU_014, Cx. 20, D. 1578.

1758, janeiro, 7, Lisboa

OFÍCIO ao [secretário de estado da Marinha e Ultramar], Tomé Joaquim da Costa Corte Real, ao [presidente do Conselho Ultramarino], marquês de Penalva, [D. Estevão de Meneses], remetendo a carta do provedor da Fazenda Real da Paraíba, Manuel Rodrigues Coelho, sobre a arrematação dos dízimos da Paraíba.

Anexo: 2 docs.

AHU_ACL_CU_014, Cx. 20, D. 1586.

1759, fevereiro, 20, Paraíba

OFÍCIO do provedor da Fazenda Real da Paraíba, Manuel Rodrigues Coelho, ao [secretário de estado da Marinha e Ultramar], Tomé Joaquim da Costa Corte Real, remetendo a relação dos contratos que existem na capitania, contendo os arrematadores, preço e o tempo que iniciaram e quando finalizaram, e a relação das propinas que se pagam ao governador, provedor e mais oficiais da Fazenda Real.

Anexo: 4 docs.

AHU_ACL_CU_014, Cx. 21, D. 1591

1759, março, 7, Paraíba

CARTA do provedor da Fazenda Real da Paraíba, Manuel Rodrigues Coelho, ao rei [D. José I], sobre a arrematação dos dízimos do gado das Ribeiras do Sertão do Piancó.

Anexo: 3 docs.

AHU_ACL_CU_014, Cx. 21, D. 1593.

1759, março, 9, Paraíba

CARTA do provedor da Fazenda Real da Paraíba, Manuel Rodrigues Coelho, ao rei [D. José I], remetendo a relação das dívidas da Provedoria de Pernambuco e dos herdeiros do alcaide-mor Gaspar Acioli de Vasconcelos, para com a Fazenda Real da Paraíba.

Anexo: 3 docs.

AHU ACL CU 014, Cx. 21, D. 1596.

1759, março, 12, Paraíba

CARTA do [capitão-mor da Paraíba], José Henriques de Carvalho, ao rei [D. José I], remetendo a relação do rendimento e despesa da Fazenda Real da capitania.

Anexo: 3 docs.

AHU_ACL_CU_014, Cx. 21, D. 1603.

1759, março, 16, Paraíba

CARTA do provedor da Fazenda Real da Paraíba, Manuel Rodrigues Coelho, ao rei [D. José I], remetendo a relação do produto dos ofícios da Justiça e Fazenda, arrematados por donativo.

Anexo: 2 docs.

AHU_ACL_CU_014, Cx. 21, D. 1607.

1759, março, 20, Paraíba

CARTA do [capitão-mor da Paraíba], José Henriques de Carvalho, ao rei [D. José I], remetendo as listas das Infantarias pagas que guarnecem a capitania.

Anexo: 8 docs.

AHU_ACL_CU_014, Cx. 21, D. 1610 .

1759, março, 26, Paraíba

CARTA dos oficiais da Câmara da Paraíba, ao rei [D. José I], informando que seus antecessores, para mostrarem fidelidade e obediência de bons vassalos, ofereceram o donativo de cem mil cruzados [para reconstrução de Lisboa] e que, apesar do empenho, vêem a impossibilidade do povo em satisfazer o sobredito donativo, razão pela qual não executaram a cobrança.

Anexo: 1 doc.

AHU_ACL_CU_014, Cx. 21, D. 1612.

1799, janeiro, 9, Paraíba

CARTA do [governador da Paraíba], Fernando Delgado Freire de Castilho, à rainha [D. Maria I], sobre as potencialidades da capitania e das desvantagens para a Fazenda Real da subordinação da Paraíba a Pernambuco; e remetendo mapa da conta corrente do rendimento e despesa da Provedoria da Paraíba, nos anos de 1795 a 1797. 
Anexo: 3 docs.

AHU_ACL_CU_014, Cx. 34, D. 2473.

1799, Janeiro, 24, Queluz

Extin;áo da provedoria

AHU ACL CU_014, Cx. , Doc. 2476 